COPY NUMBER

1

2

3

4

5

$6-7$

8

9

10

11.
DISTRIBUTION

F. K. McCune - Yellow Copy

K. R. Van Tassel

W. E. Johnson

W. K. MacCready

A. B. Greninger

Atomic Energy Commission

Hanford Operations Olf'ice

Attention: J. E. Travis, Manager

Atomic Energy Commission

Hanford Operations Office

Attention: . V. B. Lewis

Atomic Energy Commission

For: B. M. Fry, AEC, Washingtor

700 File

300 File 


\section{TABLE OF CONTENTS}

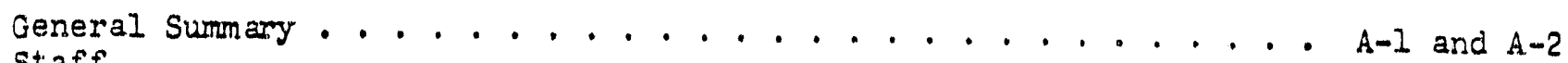
Straff . . . . . . . . . . . . . . . . . . . . . . . B-1 Number of Employees ........................ . C-1

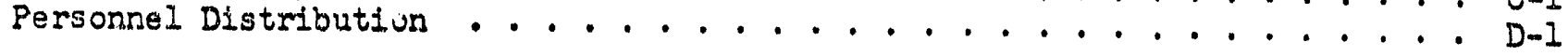

Manufacturing Department ................. E-1 through E-L Monthly Operating keport................. Ea-1 through Ea-7 Metal Preparation Section ............. Eb-1 through Eb-9 Reactor Section .................. Ec-1 through Ec-15 Separations Section ................ Ed-I through Ed-18 Electrical Utilities Section............. Ee-1 through Ee-5 Purchasirg and Stores Section ............ Ef-I through Ef-5 Transportation Section................. Eg-1 through Eg-6

Englneering Department . . . . . . . . . . . . . F-1 through F-4

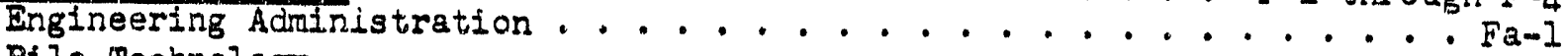
Pile Technologs ............... Fb-1 through $F b-54$ Separations Technology ............. Fc-4 through Fc-56 Design...................... Ff-2 through $5 f-13$ Project ......................... Fg-2 through Fg-18

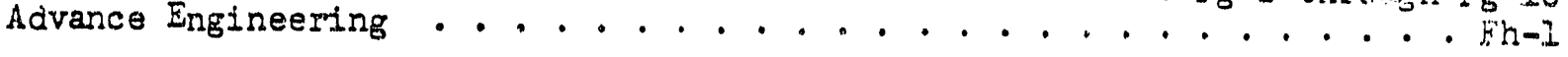

Employee and Public Relations Department .......... G-1 through G-3 Personnel Practices .................. Ga-1 through Ga-12 Employee Conmunications and Public Relations...... Gb-1 thro ugh Gb-15 Union Relations . . . . . . . . . Gc-l through Gc-3 Salary and Wage Administration . . . . . . . . . . . . . . . Gd-I Education and Training............ Ge-i through $\mathrm{Ge}-3$ Health and Saf'ety .................. Gf 1 through $G f-12$

Community Section ...................... . . Gg-I Maintenance Renovation Unit......... Gga-l through Gga-5 Folice Unit . . . . . . . . . . . . . Ggb-1 through Ggb-8 Commercial and Residential Property Unit .... . Ggc-1 through Ggc-8 Fire Unit ................... Ggd-1 and Ggd-2

Community Operations Sub-Section

Electrical Unft................ . Ggf-1 through Ggf-L Engineering Unit . . . . . . . . . . . . Ggg-1 through Ggg-3 Public Works and Recreation Unlt ........ . Ggh-1 through Ggh-5 Water and Sewerage Utillties Unit . . . . . . . Ggi-l. and Ggi-2 Richland Public Library............ . Ggj-1 and Ggj-2

Auxiliary Operations and Plant Protection Section ... . Gh-1 through Gh-28 Radiological Sciences Department ............. H-l through H-IL Financial Department . . . . . . . . . . . . . . I-I through I-LO 


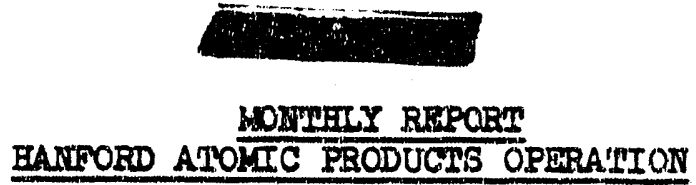

\begin{abstract}
DRCREMRER 2952
GWTARAT SURMARY

ERODUCTION OPERATION

The net production of acceptable canned slugs was 336 tons which was four percent over the official forecast. Of the total, 23 tons were canned using the cored slug material. An increase in the marred surface rejects was experienced during the first week's operation of the n3w finfshing line conveyor systew.
\end{abstract}

The plutontum laput production was 100 percent of the off1cial forecast and e stablished a lecord for monthly production. The eatablishad maximum operating levels, excluding burnout, were increased $222 \mathrm{MW}$ at KGs Renctor and 177 at KW Reactor due to continued gains from cooler inlet water and improved. operating techniques.

There was a total of 39 ruptures, including 35 regular metal pieces. This represents the blghest number of regular metal slug ruptures for a single month in the history of the plant. Outage time for the removel of these ruptures was 314 hours.

The production of low and high ngs plutonilum from the $T$ and Redox Plants was 100 percent and 82 percent of the officlal forecast, respectively.

The Redox Plant rate while operating was about 8 tons per day average as determined by head-end equipment difficulties, dilution of the second plutonium cycle leed, and rework of process wastes bigh in product. Primary feed processing stopped on December 17 for the rest of the month, depletion of the backlog Inventory of bigh MD metal having resulted in a break in production which could advantageously be used for equipment changes.

T Plant plutonium production cont1nued normally throughout the month at a reducei rate as specifled by Comalssion requirements. Special neptunium runs were started on December 27, at Cormission request.

Tue TBP production was 105 percent of the forecast. The plant operated the entire nontb with a minirnum of equipment difficulties. The total outage time for the Plrst and second sycles was 48 and 54 hours, respectively.

The Purex facility continued to process cold runs intermittently, using depleted uranium as feed. A portion of the month was used to replece defective stud bolts on the concentrators, and perform other necessary mintenance work.

\title{
ENGINESRING TECENOLOGY
}

A recent study has shown that the controlling factors in production from Henford reactors after water plant modification will depend upon goal exposure, the status of fuel element rupture resistance, and tube replacement rates. The principal conclusion is that substantial increases in production can be attained by a decrease in go日l exposure before or after Project CG-558. The 
production increase results from a reduction of plutonium burnout acialerable at lower exposure, and the increased powers actulevable at reasonable operational efficlency.

A new atudy of the overall economics of retubing an old reactor with zirconIum tubes Indicates a pay-off period as short as 1.3 to 2.5 years at projected bigher power levels. Because of this favorable pleture, the development of suitable fabrleation technlques for zirconium tubes will be bastened through placement of test orders with mols fabricators.

A revised chewlal Ilowsheet for Redox operation with complete back-cycle and four plutonfun cycles bas been prepared and will be issued for use followlog the equiposent changes to be completed in early January.

Work is in progress on the preparation of advance engineering studies for FY 1958 Plant and Bquipment Budget 1tems. At the end of the month, studies had been started for 46 potential budget items.

Preliminary studies were made of the possibility of accomplishing reactor tube replacement vork during the shutdowns of the reactor modification program, thereby reducing over-all resctor outage time. Construction schedules for reactor modfication work are being adjusted to reflect delays caused by labor problems, slow material deliveries, and adverse weather.

GRITERALI

There were no disebling injuries in Operstions or communty during the month, but nine near serlous accidents were investigated. The disabling injury frequency rate for 1955 was 0.40 and the severity 708 . It was 0.0 For the Community.

Outstanding unaccounted for documents were reduced from 197 to 195 during the ronth. A net reduction of 41 documents was made during the calendar year 1955 .

On Decembex 28, 1955, a law suit was brought by the Hanford Atomic Metal Trades Council agrinst the Company calculated to force arbitration of the establishnent of the new classification of Gauge Worker. The Conrpany's answer to the complaint 1 s due by January 17 .

Seven "live" television program of the GE FANFORD SCIMACE FORUM and THIS WHEK AT HANFORD shows were produced and telecast to regional and local viewers during December by five Eastern Washington televison stations.

A Radiological Defense Handbook was completed and in process of being issued at moath-end.

The Commission and General. Electric resched an agreement in December as to the additional funds to be obligated to take care of operations through June 30,1956 , as well as those needed to complete projects currently in progress and to provide for FI 1956 projects. An amendment to the prime contract will provide for an increase of $\$ 36,000,000$ for BAPO and $\$ 19,500,000$ for KAIL, making the total obligated to date $\$ 1,134,917,000$, of which $\$ 932,833,000$ will be HAPO's portion, and $\$ 202,084,000$ KAYL's portion. 


\section{STAFF}

Vice President and General Manager, Atomic Products Division . . F. K. McCune General Manager, Hanford Atomle Products Operation........ W. E. Johnson Counsel .. . . . . . . . . . . . . . . . E. T. Maher Manager, Finance........................ Johnson Manager, Employee and Public Relations ............. I. L. German Director, Radiological Sciences ................... M. Parker Acting Manager, Engineering ................ o. H. Greager Manager, Manufacturing ... . . . . . . . . . . . . . . K. MacCready Operations Research and Synthesis ............. A. Benrett 
HANFORD ATOMIC PRODUCTS OPERATION NUMBER OF EMPLOYESS

DECEMBER 31, 1955

DEPARTMENT

COONSEL

OPERATTONS RESEARCH STUDY

EMPLOYEE AND PUBLIC REIAATIONS DEPARTMENT

General

Salary and Wage Administration

Personnel Practices

Education and Training

Emp. Comm. and Pub. Rel.

Union Relations

Aux. Oper, and Plant Protection

Community

Health and Safety

ENG INEERTING DEPARTVENT

Engineering Administration

Advance Engineering

Design

Project

Pile Technology

Separations Technology

MANUFACIURINI DEPARTIENT

General

Separations

Metal Preparation

Transportation

Purchasing and Stores

Electrical. Utility

EINANCIAL DEPARTMENT

General

Budgets and Measurements

Contract Cost

General Accounting

Property Accounting

Auditing

SS Accountability

Personnel Accounting

Procedures and Computing

RADIOLOGICAL SCIENCES DEP RTMENT

General

Records and Standards

Biophysics

Biology

Engineering

Adm. and Comm. GAND TOTAL
EXOMPT

$12-31-55 \quad 11-30-55$

OTHER

$12-31-55 \quad 11-30-55$

3
5
9

11

6

10

5
176

76

48

$27 \quad 29$

$\begin{array}{rr}6 & 6 \\ 176 & 1.75\end{array}$

177

228

162

24

345

309

113

44

$6 I$

16

9

7

24

10

17

14

10

9

32

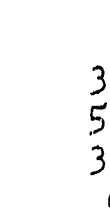

3

2259

$\begin{array}{rrr}3 & 2 & 2 \\ 6 & 1 & 1 \\ 9 & 7 & 7 \\ 11 & 10 & 10 \\ 16 & 39 & 39 \\ 6 & 59 & 63 \\ 10 & 41 & 41 \\ 5 & 1 & 1 \\ 115 & 782 & 780 \\ 76 & 307 & 310 \\ 44 & 174 & 172 \\ & & \\ 29 & 88 & 84 \\ 6 & 1 & 1 \\ 175 & 113 & 110 \\ 175 & 160 & 166 \\ 229 & 175 & 172 \\ 164 & 100 & 98 \\ 24 & & \\ 24 & 13 & 8 \\ 337 & 1508 & 1462 \\ 309 & 1586 & 1609 \\ 113 & 580 & 579 \\ 44 & 4144 & 447 \\ 59 & 226 & 218 \\ 16 & 75 & 75\end{array}$

7

24

11

I7

il

io

9

31

.8

104

60

53

2

36

55

49

3
8
102

102
60

53

2

35

55

49

5

33

55

33

6
2
59

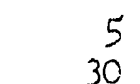

30

33

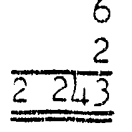

TOTAL $12-31-55 \quad 11-30-55$

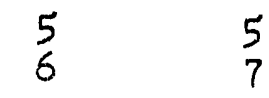

1616

2121

$55 \quad 55$

$65 \quad 69$

$51 \quad 57$

$898 \quad 895$

$383 \quad 386$

$222 \quad 216$

$115 \quad 113$

7 ?

$289 \quad 285$

$337 \quad 341$.

$403 \quad 401$

$262 \quad 262$

8

$\begin{array}{rrr} & 32 & 32 \\ 1853 & 1799 \\ 1895 & 1918 \\ 693 & 692 \\ 488 & 491 \\ 287 & 277 \\ 91 & 91\end{array}$

$12 \quad 12$

15

128

70

70

16

46

6́

81 


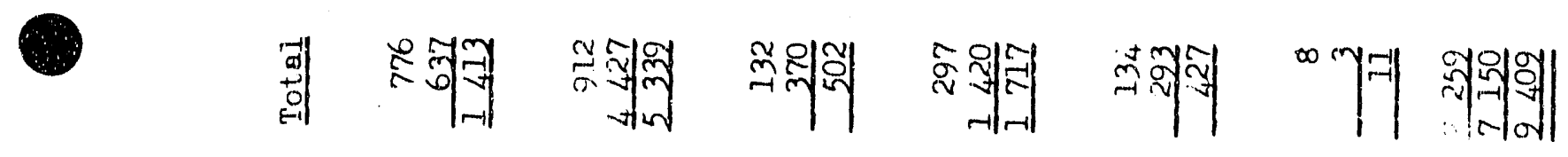

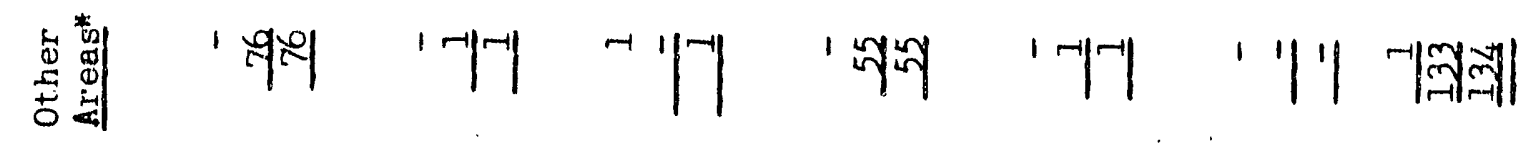

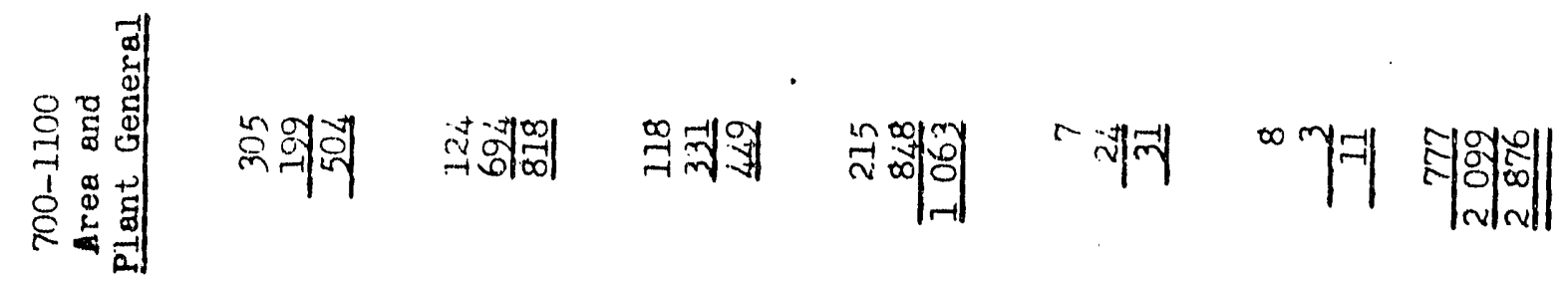

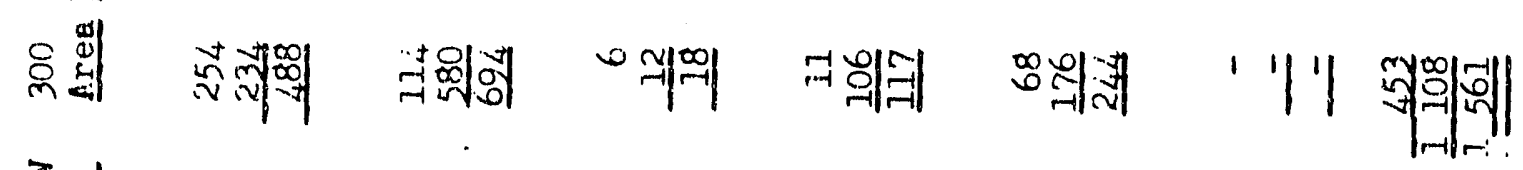

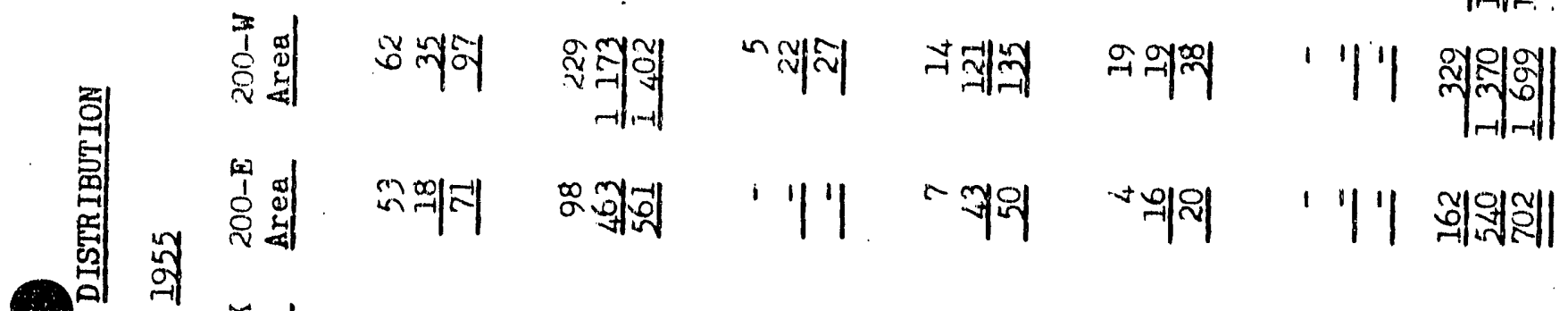

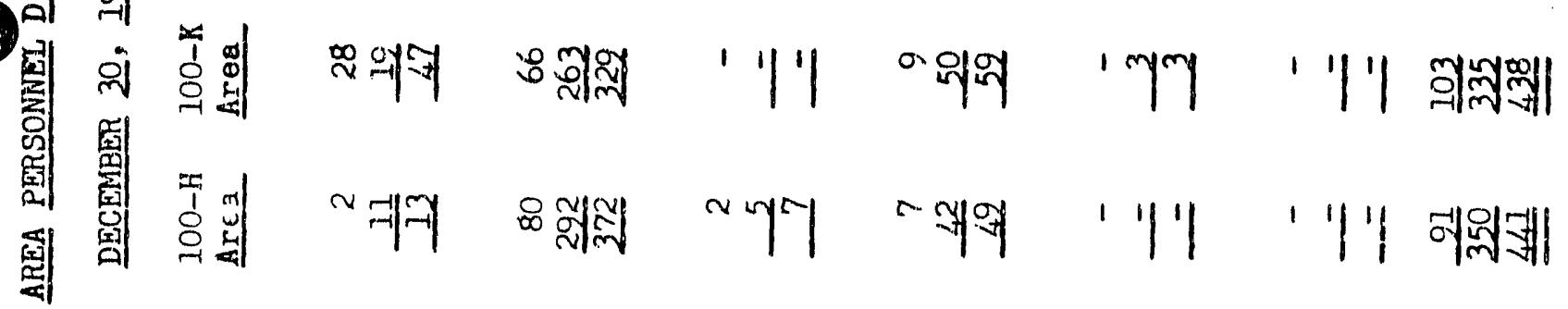

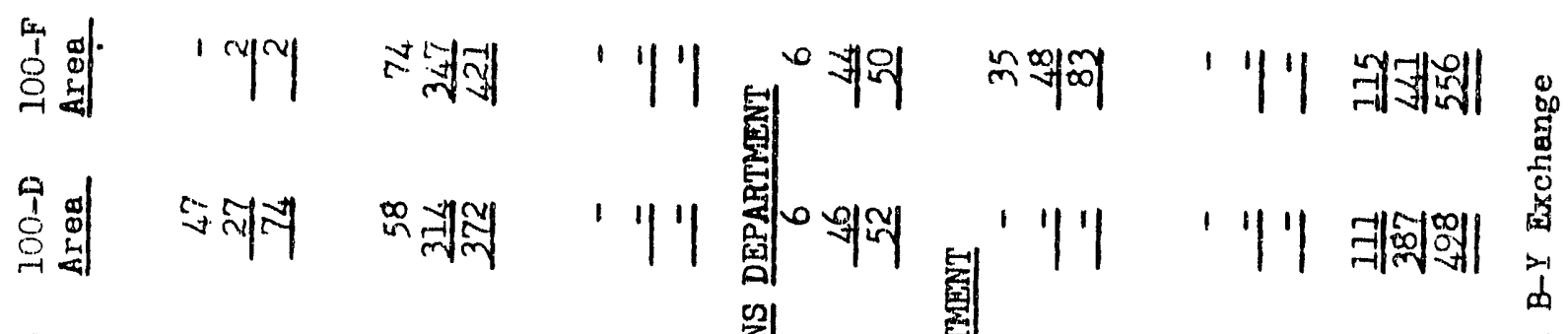

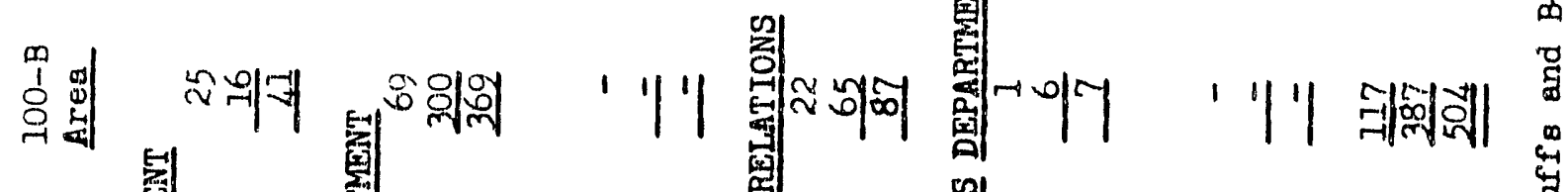

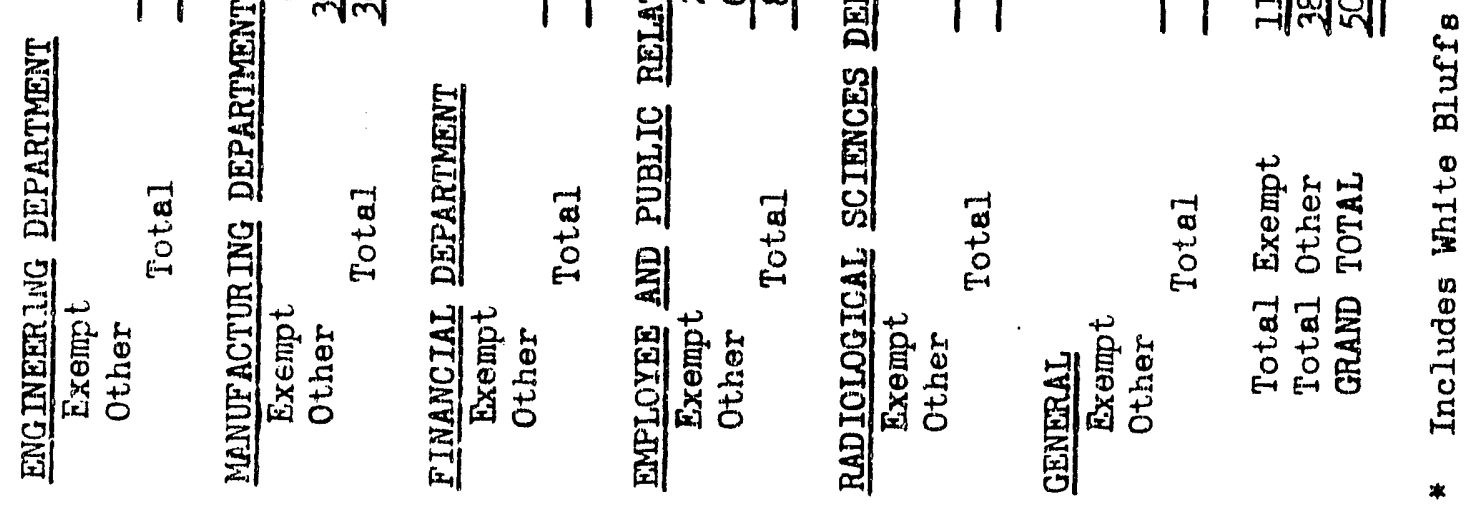




\section{MANUFACTUR ING DFPPARTMEINT}

DECEMBER, 1955

\section{METAL PRFPARATION SECTION}

The net production of acceptable canned slugs was 336 tons which was four percent over the officlal forecast. Of the total, 23 tons were canned using the cored slug material.

The composite cannine yield for the month wes 73 percent, which was five percent iess than the November yleld. An increase in the marred surface rejects was experlenced during the first week's operation of the new flnishing ine conveyor system. Other categories contributing to the month's rejests were frost test, bad welds, and poor bonds.

Through reduced reactor consumption, the inventory of canned slugs had increased to an elght weeks supply at month end. The inventory of bare metal, excluding slugs in process, fluctuated during December from an elght to a three days supply.

No slugs fafled in autoclave testing during the month.

\section{REACTOR SECTION}

The plutonium input production was 100 percent of the offlcial forecast and established a record for monthly production. The record high production of $\mathrm{KE}$ and $\mathrm{KW}$ effectively aided in establishing this production.

The overall reactor time operated efficiency was 7.1.1 percent. Major causes of downtime were chute liner reflacement, rupture removal, tube replacement, and charge-discharge operations.

The established maximum operating levels, excluding burnout, were increased $222 \mathrm{MW}$ at KE Reactor and $117 \mathrm{MW}$ at KW Reactor. These increases are due to continued gains from cooler inlet water and improved operating techniques.

The reactor output production was 67 percent of the forecast. Reduced discharges resulting from cancellation of the low concentration program at the $\mathrm{H}$ and $\mathrm{KW}$ Reactors accounted for the lower output.

There was a total of 39 ruptures, including 35 regular metal pieces. Mis represents the highest number of regular metal slug ruptures for a single month in the history of the plant. Outage time for the removal of these ruptures was 314 hours.

Twenty-tbree reactor scrams occurred, elght of which were caused by normal panellit system variables. Total reastor outage time for all scrams was 261 hours.

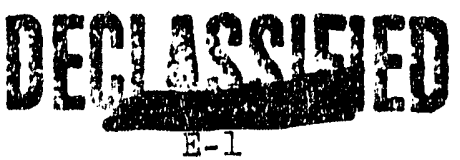




\section{ETW-4+0692}

As a result of continued hfgh water collectlon rates, leak test 1 ng programs were conducted during five outafes at the F Regctor; however, no leaks were found. At month end, a program of 1solating and testing the gais heater and dryer was under way. All tubes were tested during two outages at $\mathrm{H}$, with a total of three leaking tubes being found. $D R$ had two leaks whlch resulted from ruptured slugs.

The fourth shipment of 1rradiated Mirt pieces was made to an offsite recelver. This shipment depletes the inventory of this material.

\section{SEPARATIONS SECTION}

The production of low and hlgh ngs plutonium from the $T$ and Redox Plants was 100 percent and 82 percent of the official forecast, respectively.

The Redox Plant rate whlle operat1ng was about 8 tons per day average as determined by head-end equipment difficulties, dilution of the second plutonium cycle feed, and rework of process wastes high in product. Two shutdowns were required, one for eight hours on December 4 to replace the caustic scrubber.(H-5) reclrculation pump, and one for six and one half hours on December 9 to repair a leak in the product concentrator (L-3). Primary feed processing stopped on December 17 for the rest of the month, depletion of the backlog inventory of hygh MWD metal having resulted in a break in production which could advantageously be used for equipment changes. Principal changes will result in a precycle flowsheet, backcycle of second cycle wastes, and ozone sparging of the final uranium product for ruthenium removal. The facility total outage time for the month was 245 hours, resulting in a 67 percent efficiency.

T Plant plutonium production continued normally throughout the month at a reduced rate as specifled by Comission requirements. Special neptunfum runs were started on December 27, at Comission request.

Iodine emission during the month at the Separations plants was within specification, due principally to the combination of well-aged metal and reduced operating rates.

The TBP production was 105 percent of the forecast. The plant operated the entire month with a minimum of equiprnent difficulties. The total outage time for the first and second cycles was 48 and 54 hours, respectively. Reactivation of Section 6 as an intercycle concentrator, to operate in series with section 8, was essentially completed during the month.

Removal of waste metal from the tank farms was maintained throughout the month at rates sufficient, to insure adequate feed for the TBP plant.

The production of the $\mathrm{UO}_{3}$ plant, although exceeding the official forecast by 18 percent, was limited in feed by the Redox Plant outage from December 17 through the month end.

The Purex facility continued to process cold runs intermittently, using depleted urani'im as feed. A portion of the month was used to replace defective stud bolts on the concentrators, and perform other necessary maintenance work.

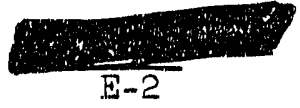


The Isolation factitty continued to process only $10 \mathrm{~g} g / \mathrm{t}$ product from $T$ Plant. Fabrication activities during the wonth were ulrected toward assemblies from high $\mathrm{MWD} / \mathrm{t}$ product. A record production for total welght of shapes fabricated was established.

GERERAL

Personnel.

On Roll December 1, 1955 5300

Net Increase

Total on Roll December 3.1, 1955

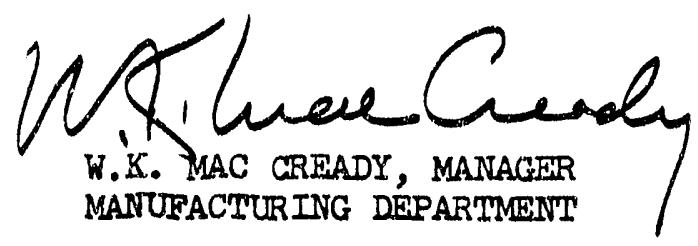


HW-40692 BEL

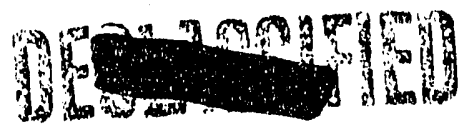

MANUPACTURTIIG DEPARTMETIN

PATHENT FEEPORT SUMMARY

FOR

MONITH OF DECEMBER, 1955

AII persons engaged in work that might reasonably be expected to result in inventions or alscoverfes advise that, to the best of their knowledge and belief, no inventions or discoverfes were made in the course of their work during the period covered by this report except as listed below. Such persons further alvise that, for the perlod therein covered by this report, notebook records, if any, kept in the course of their work have been examined for posstble inventions or discoveries.

\section{INVENTOR}

T.B. Correy
TITLE

Fully Automatic Weldine Machines
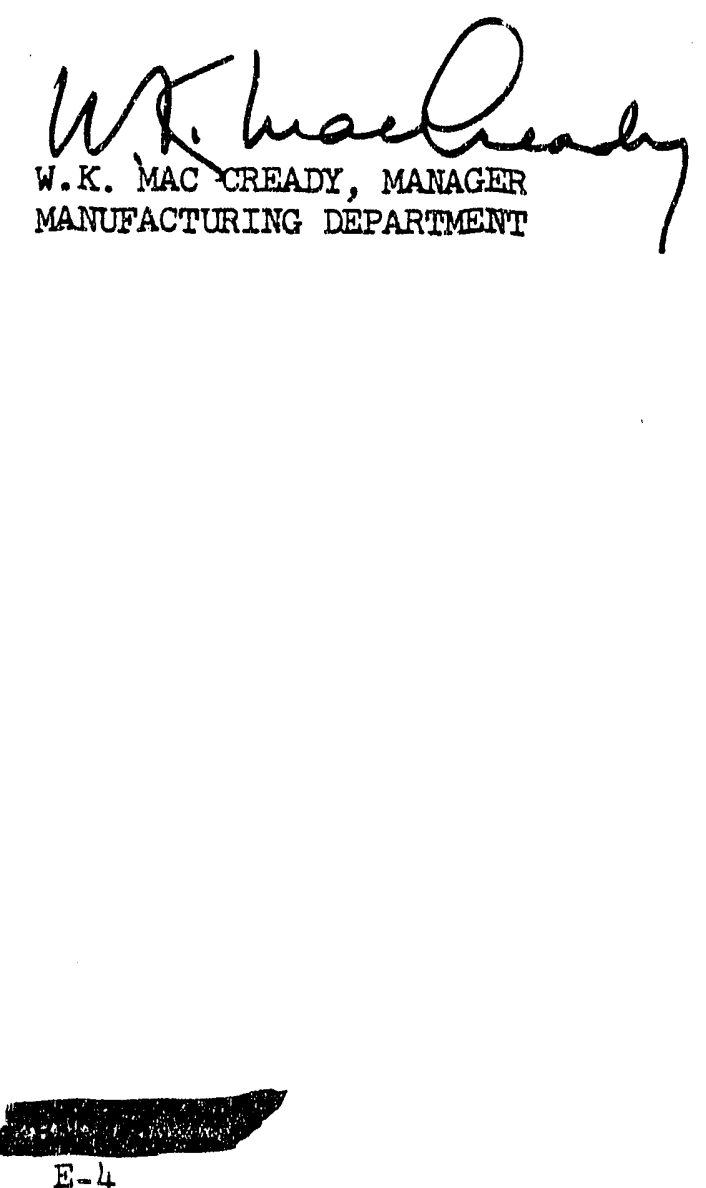

$E-4$ 


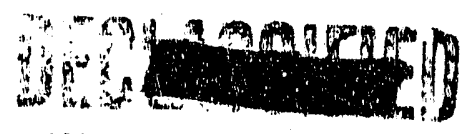

EW $-40692^{-11}$

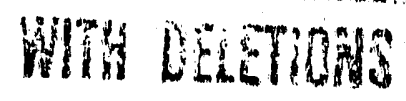

MONIELY OPEILTING REPPORT

DECEMBFA 1955

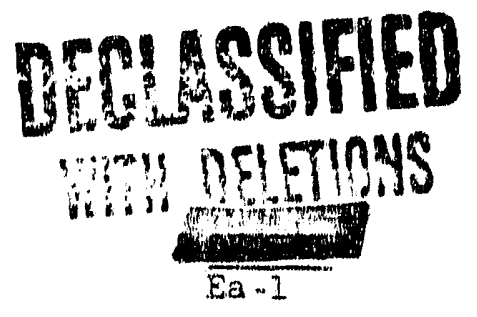




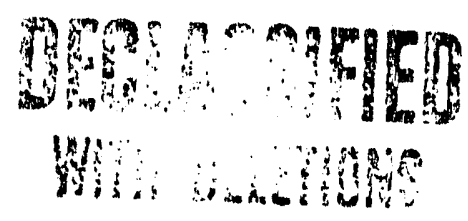

、

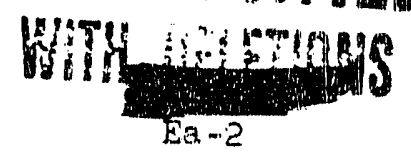




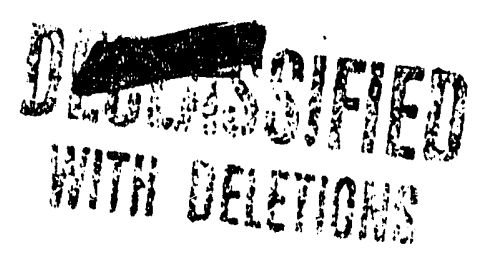

EN-40692 DDE

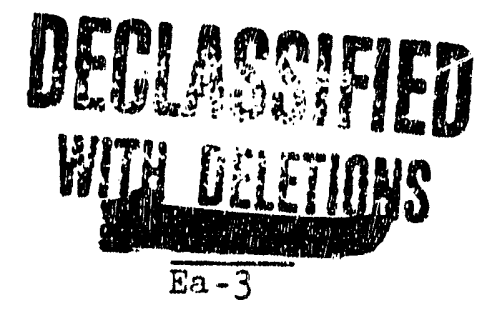




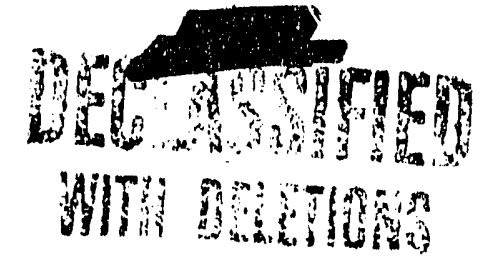

HW -40692 
9xt

BW-40692 DEL

Wha bentera 


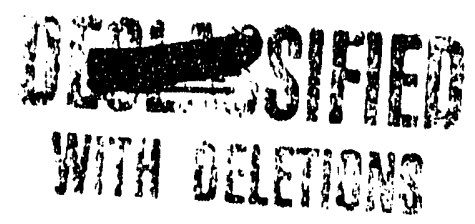

With UEDIS

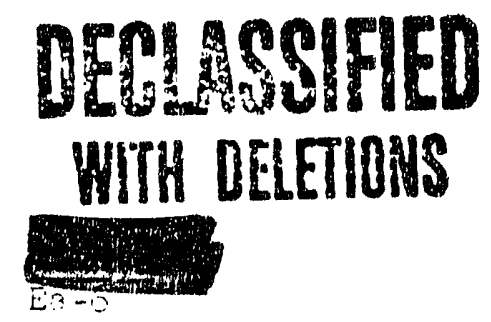




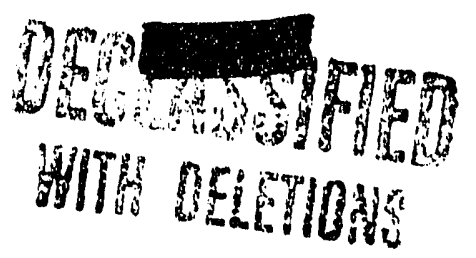

HW-40692

DED

wilin

What ofeic7ons

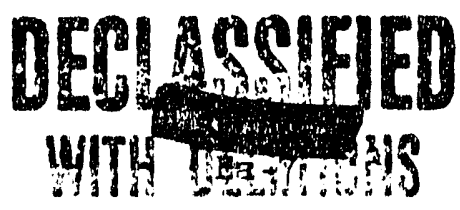




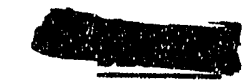

January 9, 1956

MANUFACTURING DEPARTMENT

METAI PREPARATION SECTION

December, 1955

\section{RESPONSIBIIITY}

There was no change in responsiblitity during this period.

II. ACHIEVEMENIS

\section{A. Operating Bxpertence}

1. Statistics

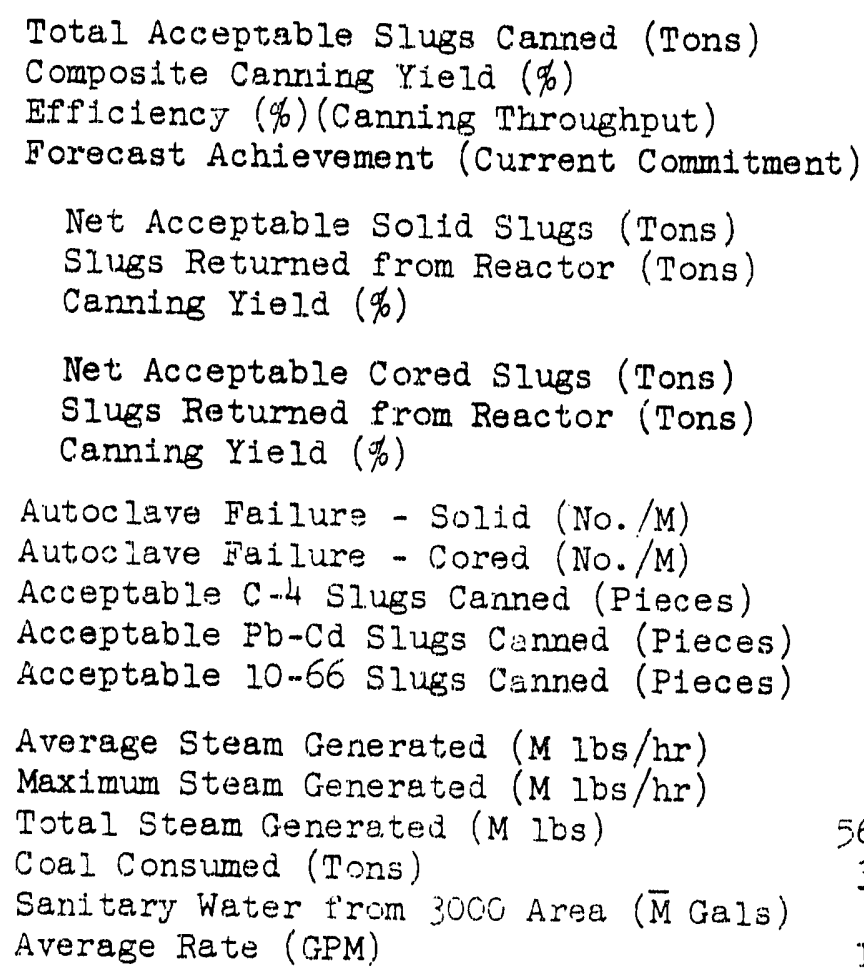

\begin{tabular}{|c|c|c|}
\hline December & November & $\begin{array}{l}\text { Year } \\
\text { to date }\end{array}$ \\
\hline $\begin{array}{r}3.36 \\
73 \\
84 \\
104\end{array}$ & $\begin{array}{r}393 \\
78 \\
95 \\
100\end{array}$ & $\begin{array}{r}4732 \\
76 \\
93 \\
1.02\end{array}$ \\
\hline $\begin{array}{l}313 \\
\frac{1.77}{73}\end{array}$ & $\begin{array}{c}379 \\
1.78 \\
79\end{array}$ & $\begin{array}{c}4334 \\
44.94 \\
76\end{array}$ \\
\hline $\begin{array}{r}23 \\
0 \\
74\end{array}$ & $\begin{array}{r}14 \\
0 \\
72\end{array}$ & $\begin{array}{l}3.98 \\
1.57 \\
73\end{array}$ \\
\hline $\begin{array}{l}.00 \\
.001\end{array}$ & $\begin{array}{l}.00 \\
.001\end{array}$ & $\begin{array}{l}.001 \\
.001\end{array}$ \\
\hline $\begin{array}{r}0 \\
3201 \\
0\end{array}$ & $\begin{array}{r}1262 \\
1355 \\
0\end{array}$ & $\begin{array}{r}7160 \\
13419 \\
3366\end{array}$ \\
\hline $\begin{array}{c}76.3 \\
101.0 \\
6.736 \\
3,537 \\
73.4 \\
1,643\end{array}$ & $\begin{array}{r}69.9 \\
105.0 \\
0,310 \\
3,294 \\
75.7 \\
1,753\end{array}$ & \\
\hline
\end{tabular}

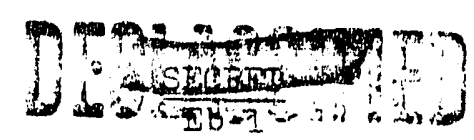




\section{Activities}

A net production of 336 tons of acceptable finished slugs, achieved in 21 working days was essentially $104 \%$ of forecast. Of the 336 ton total, 23 tons were cored slugs. Six canning line shifts per day were operated wh minimum line relief during the month to effectively utlilize the operational manpower.

A composite yleld of $73 \%$ was experlenced in December. Thls is a decrease of $5 \%$ as compared to last month's yield. The major causes for rejection were: marred surfaces, frost test, bad welds and poor bnnds. An increase in marred surface rejection rate occurred during the first week's operation of the flnishing line conveyor. Miscellaneous reject rates were partly due to subsequent rejection of slugs which were transformation tested during the time the tester performance was questionable. Due to reduced reactor consumption during the past two months, the combined Metal Preparation and Reactor canned slug inventory increased to about an eight-weeks' supply at month-end. Forecasted Reactor consumption during the next few months will permit an inventory reduction to an optimum four-weeks' supply.

A reduction in the bare slug shipments from Fernald caused the inventory to remain 10w in the 300 Area. The inventory, excluding slugs in process, fluctuated during the month from an elght to a three-day supply.

The two conveyorized finishing ines were placed in service on a production basis December 1, 1955, changing the finishing process from a batch system to an integrated straight ine system. Consequentiy, the canning Iine efficiency will be influenced by the finishing line efficiency. The finishtng lines experienced significant downtime due to difficulties witb the radiograph and electronic bond and penetration tester.

A new SS Accountability Procedure was successfully placed in effect in order to accommodet, changes in manufacturing arrangements created by the use of an integrated canning and finishing process.

On December 8, a new Metal Preparation Section Official Production Forecast (HW-40361-RD) was issued on the basis of a revised Reactor Section Official Forecast. The new forecast reduced Metal Preparation productivity approximately 575 tons during the period extending from December 1955 through Tune 1956.

No autoclave failures occurred during the month.

Evaluation testing of 3400 caps received from the Hunter Douglas Corporation is in progress, and initial results are encouraging. Extensive testing of the pitting defect in the 4800 cans received from the Harvey Machine Company has shown this to be a fabrication defect. and immediate contact. with the vendor is planned.

Painting of the 321. Bullding caryon was completed with the excention of miscellaneous toush-up and identification work.

The work of cleanlng the north process disposal pond has been stopped to investigate the fensibilit ${ }_{j}$ of reclaiming the uranium which was 
2. Activities - continued

settled out, carrled there by the process sewer. Laboratory analyses have been made of this material and a decision will be made shortly as to the economy of salvaging this material.

3. Special Operations

A total of 666 internally and extermally cooled slugs ( I \& $E$ ) were leat-d1p canned for in-pile testing under PT313-63. Each slug required seven separate faclag steps and three separate welds.

There were 567 small diameter uranium onriched aluminum allny C-4 slugs canned by the hot press method during the month. No slugs were bond tested or traisferred to canned storage. There are approximately 1850 canned slugs ready for bond testing. Appraximately 600 bere C-4 slugs remain to be canned.

During the month $3258 \mathrm{~Pb}$-Cd polson slugs were canned with a yield of 98.3 percent. Three thousand two hundred one slugs were transferred to canned storage.

Two thousand six hundred fifty uranlum dingot llugs were outgassed in the salt bath heat treating facilities during the month.

4. Schedule Variance

Acceptable canned slug production was 104 percent of forecast, based on the December commitment of 322 tons.

B. Equipment Experience

1. Operating Continuity

The canning line "time operated" efficiency was 84 percent which was a decreese of 11 percent from last month. This reduction 1 s primerily due to ifficulties with some of the equipment on the integrated finlshing lines. Finishing line downtime will hereafter directly effect the canning line efficiency.

\section{Inspection, Maintenance and Replacements}

The Productive Maintenance Program for most of the production equipment in the 313 Building has been finalized. It is anticipated that by February this program will be out of the planning stage and work will be done on a routine basis on all major production equipment.

Additional screen guards were installed on the overhead canning supply line conveyor to protect personnel from the possible hazard of dropped sleeves, Additional safety switches were installed to guard against iaming during the operation. It is anticipated that the entire supply line conveyor system will be in service early in January 1956.

Two additional semi-automatic welders were installed in the number three finishing line. Coinpletion of the installation of two additional welders on the number one finishing line is expected during January 1956. Each finishing line will then have sufficient welding capacity to handle the production from three canning lines.

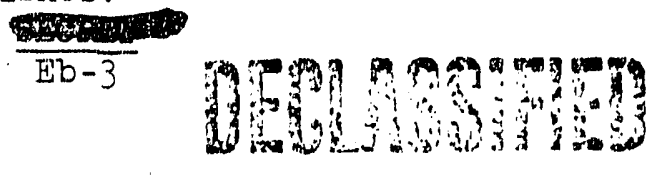


C. Improvement Experience

1. Production Tests

PT-313-47Mr "Cored Slugs from Extruded Blanks and Rolled Rods" EW-33189 Approximately 25 tons of machined eight-inch drilled cored slugs per month are being recelved from Fernald for processing with aluminum end plugs by the load-dip process. During December, a total of 23 tons of finished slugs was produced with a 74 percent yield.

Further investigation of the off-standard aluminum plugs noted last period has indicated the rendor inadvertently mixed 11-S a]loy with the specifled 2-S alloy bar stock from which the plugs were fabricated. About two to three percent of the plugs received in the latter shipments from the vendor contain the foreign alloy and must be rejected. A simple method of sorting was estat_ishod using a weak caustic etch.

PT-3.13-56Mr "Canning of Four Tons of Dingot Uranium for Pile Irradiation" EW-37695

The preparation of dingot uranium slugs for in-pile evaluation as authorized by supplement "A" to this production test was continued. Twenty tons of finished slugs were prepared for low goal exposure. Yields continue to be comparable with standard uranium slugs except for bond porosity which is slightly higher as a reject category.

PT-105-615-A-63MT "Evaluation of I \& E Slugs Canned by the Lead Dip Process" EW-39886-A

A total of 666 elght-inch Internaliy and externally cooled slugs were canned by the lead dip process as authorized. Appraximately 55 percent of the slugs were satisfactorlly assembled using three alumimum components. Only minor difficulty was encountered with biss caps. Finishing and testing changes necessarv for this type production are being expedited for completion earls in January.

Eight tubes of the finished I \& E slugs will be paired with eight tubes of regular solid lead-dip slugs for irradiation. Two out of four tubes of each type of fuel slugs w1ll be exposed to rupture, and the remainder discharged at intermediate exposures for examination.

2. Process Tests and Revisions

A decrease in thin cap rejection of canned uranium slugs resulted from a change of specitication rather than a change in quality level. The cap thickness and non-seat specifications have been replaced with an overall canned slug length specification, which is being administered on a statistical basis. These changes have permitted the discontinuance of the fluoroscope inspection operation.

Concurrent with the adoption of the canned slug length statistical inspection, the slug braze width inspection was changed from a 100 percent inspection to a tight statistical control.

Modffications are being made in the design of the penetration tester head and are expected to markedly reduce the attrition of probes. 
2. Process Tests and Revisions - continued

h new standerd slug has been provided for the bond tester. This slug more accurately defines the limit within whlch the instrument should operate. A significant reduction in bond test reject rate has resulted in a drop from about 17 percent to 4 percent.

The use of the automatic quench machines has resulted in on lmprorement of the Alsi thickness between the cap and slug. The 1mprovement in the monthly average over the past year has been from $27 \mathrm{mils}$ tc $3 \mathrm{mils}$ Als 1 thickness.

Modifications made to the finishing line conveyors including the installation of rubber tubing and padding at the various load and work stations immediately caused the marred surface rejection rate to decreasi from as high as 12 percent to approximately 4.5 to 5 percent.

A new autoclave-type basket in the slug recovery process has increased slug recovery throughput approximately 50 percent. A set of four baskets holds 768 pieces in the tanks at one time.

3. Inventions and Discoveries

Personnel in the Metal Preperation Section engaged in work whlch might be expected to result in inventions or discoveries have reported that no inventions or discoveries wero made during the perlod covered by this report except the following:

T. B. Correy Fully Automatic Welding Machl nes

D. Events Influencing Costs

1. Labor Variance

Direct labor is expected to increase approximately 0.01 per unit over November costs as a result of lower productivity and a decrease of approximately five percent in yield.

\section{Material Variance}

Direct material is expected to increase approximately 0.006 per unit over November costs as a result of an increased consumption in steel sleeves and a drop of approximately five percent in yiela.

3. Other Costs

Unit costs of I.M.E. are expected to increase about 0.03 above November costs due to a production decrease of approximately 16 percent ard carrying excess menpower on the roll as a result of lower production schedules.

E. Plant Expansion

1. Project Status

Project CA-514 - "Expansion of 300 Area Production Facilities" The installation of conveyors through the finfshing area was
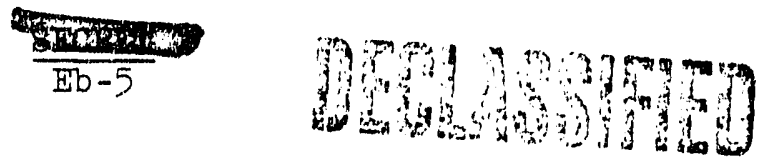
completed December 1, 1955. These conveyors have been used for all production processed since that time.

The installation of slup brushes at the welding stations is completed.

Development work on the stamping machines is being continued by the Fabrication Shops Unit. The recommendations for design changes are expected by January 15 .

The first lot of 120 radiograph wheels with valcanized tires has been recelved from the vendor. Operation with these improved wheels has proven satisfactory and the replacement of tires as a routine maintenance 1 tem w1II be eliminated.

The component parts preparation area conveyor system operated intermittently during the month. Two major modifications neared completion a nonth's end to insure operating dependability. Maintenance persomel met with the conveyor vendor representative to discuss the operation and mintenance of the equiprent.

The cap and can machines have been operating during the month and the production test being conducted by the Process Sub-Section was completed. Preliminary results from the test indicate tiat the machine cleans equaliy as well as the manual method.

A total of 20,000 cans 111 be processed in this test. It is proposed to prevent the methanol svaporation by installing a cover over the top of the tank. The problen of carryover of process solutions is

Project CA-500 "Fiy Ash Colisction Equipment - 384 Building" - Document number HWS-5850 «nt. tiad "Sperit'ication: for Fly Ash Coliection System" was transmitted to tre Atrma Energy Commission on December 19, for use in bid invitations. It was requested that the bidders submit models of the mejor components in order to simplify the bid analyses. The contract is expected to be twarded in approximately one month.

Project CA-бol "Gentral ir iund i Improvement - 300 Area" - The design criteria are current 1 y It is expected that this desigr contract will be let to an ArchitectEngineer by the end of Dinember.

Project CA-614. "Harfirrd 4 F Frogram - 300 Area - Physical completion by work areas as t lisember is 1 is 50 percent complete.

The scheduled crmpletion dat $\rightarrow$ for pifing to the autoclaves is January 29 , 1956. The first wint will bomplete by February 5. Insulation is progressing on sotitule and the installation of all instrumentation will be completed by Fetruary 15, 1956.

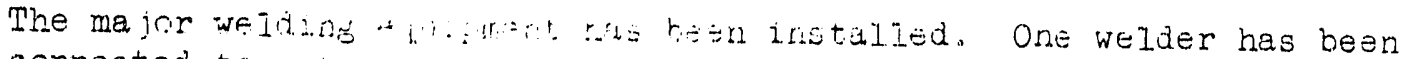
connected to $a+$ rary ary and is being used for production. The expectod onming

The two Ajax furnare installations are complete except for the ventilation and exkitisi durwork. 
1. Project Status - continued

CG-646 - "Modiflcations to P1ckle Mechines - 313 Building" - The revised project proposal requesting a total of $\$ 55,000$ for design, fabrication, and installation of the two imersion units is being routed for departmental approvals. The project was transmitted to the Cormission December 23.

Presently authorized funds allow the procurement of one unt of immersion equipment and a purchase order was issued on December 9, 1955. The estimated schedule for the two plckle machines shows a delivery date of March, 1956 and benef1c1al use dates of April 15, 1956 and June 15, 1956. This schedule was reviewed with operations and it will meet production requirements.

IR-194 - "Central1zed Quality Reporting System" - The last of the equipment components is scheduled to be shipped by January 30 . AlI counters have been equipped with micro-switches. The relay panel w1ll be released from the shop next week for instrument mounting. The cable has been installed and the installation of other components is ready to proceed.

CG-640 - "Nolse Reduction - 300 Area" - The project proposal has been held by the Atomic Energy Comission pending recelpt of an outline of all anticipated noise reduction work at BAPO.

\section{F. Significant Reports Issued}

1. Routine

\begin{tabular}{|c|c|c|}
\hline Number & Author & Date \\
\hline$B W-40200$ & $\begin{array}{l}\text { General Analytical Control Program I, } \\
\text { Uranium Metal - July I to September 30, } \\
\text { 1955. National lead Company } \\
\text { of Ohio PR Anderson }\end{array}$ & $11-30-55$ \\
\hline $\mathrm{EH}-40201$ & $\begin{array}{l}\text { General Analytical Control Program I, } \\
\text { Uranium Metal - July } 1 \text { to September } 30 \text {, } \\
\text { l955. Mallinckrodt Chemical } \\
\text { Works }\end{array}$ & $11-30-55$ \\
\hline EW -40265 & $\begin{array}{l}\text { Monthly Report, Process Sub-Section, } \\
\text { Metal Preparation Section; } \\
\text { November } 1955 \quad \text { KV Stave }\end{array}$ & $12-2-55$ \\
\hline BN -40266 & $\begin{array}{l}\text { Monthly Report, New Fuel Element Production } \\
\text { Program, November } 1955 \quad \text { WA Blanton }\end{array}$ & $12-2-55$ \\
\hline EW -40504 & $\begin{array}{l}\text { Uranium Quality Control Analytical } \\
\text { Results }\end{array}$ & $12-20-55$ \\
\hline EW -40254 & $\begin{array}{l}\text { Monthly Report Operation Sub-Section } \\
\text { Metal Preparation Section, } \\
\text { November } 1955 \quad \text { WW Windsheimer }\end{array}$ & $12-2-55$ \\
\hline $\mathrm{BW}-40350 \mathrm{RD}$ & $\begin{array}{l}\text { Production Report, Metal Preparation } \\
\text { Section Operation Sub-Section, } \\
\text { November } 1955 \\
\qquad \frac{\text { EE Berg }}{\mathrm{Eb}-7}\end{array}$ & $12-8-55$ \\
\hline
\end{tabular}




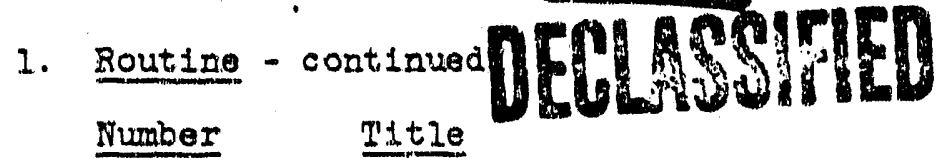 \\ Titie}

Author

Date

None

Monthly Project Status Report

DA. Snyder

$11-21-55$

None

Section Force Report

RెE Ander'son

$12-30-55$

None

General Plant Projects Review FY - 1954 to FY-1958

DA Sayder

$12 \cdot-20-55$

None

Nontbly Roport - Projects \& Personnel Sub-Section, Norember 1955

DW Haught

$12-5-55$

None

Richards-W11cox Z1g-Zae Conveyor

System - 313 Building

(Maintenance Procedures)

JW Nickolaus

$12-2-55$

None

Report of Invention - Fulis Automatic

Welding Machlnes

TB Correy

$12-19-55$

None

Monthly Report - Contact

Engineering Unit

JW Nageley

$12-21-55$

2. Non-Rout1ne

EN-39945 Spontaneous Decomposition of Trichloroe thy lene

GF Yost

$11-15-55$

IIW -40480

High Frequency Induction Hesting of

Can and Sleeve Assemblies

and Caps

VI Herzog

$12-19-55$

ENW -40580

Studies on the Inclusion

Eroticin

RH Iincoln

$12-28-55$

EW-40361 RD Official Froduetion Forecast, Metal. Preparation Secrion, December

1955 through Tune 1956 BE Berg

$12-8-55$

None

MMP 0..0 - Fnsition Description

Audi:ts

WG Hudsor

$12-12-53$

III. PESSONNEI

A. Organization

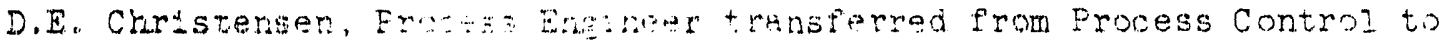

Supertsor, Precess Inspectran.

D.I. Come11, Process Enginer transferred from Process Improvement to Supervisor, 300 Operntistis.

Kirk Drumelier, Sugervisor, 300 Operations, transferred to Manufacturing Englneering Unit.

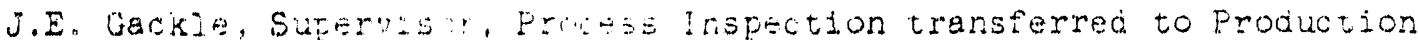

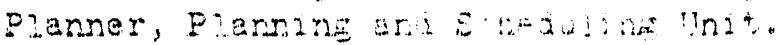

V.L. Berzog, Proces Ertuen ranspredred from Process Improvement to Process Control. 


\section{B. Foree Summary}

Section General
Operations
Power \& Maintenince
Process
Projects \& Perso.meI
Section Totals

Start of Month Eix: N-EX.

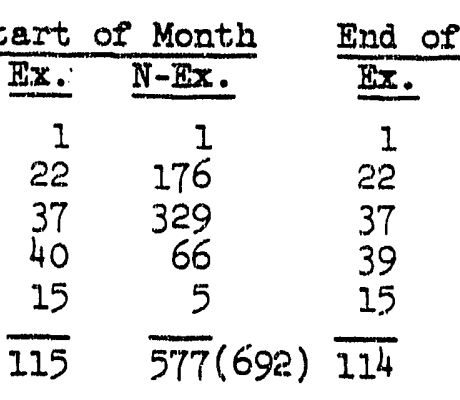

Net Change Ex. $\quad \mathbb{N - E x}$.

1
176
333
65
5
$\frac{580}{5894}$

\begin{tabular}{rr}
0 & 0 \\
0 & 0 \\
0 & +4 \\
-1 & -1 \\
0 & 0 \\
\hline-1 & -3
\end{tabular}

\section{Safety Hxperfence}

There were no major, sub-major or near-serious incidents in December.

\section{Radiation Experience}

No exposures in excess of $200 \mathrm{mrads} /$ week and 16 exposures in excess of 100 mreds/week were reported. The highest exposure reported during the month was 120 mrads. Careful scheduling of personnel and close conformance to operating procedures on bare slugs processing jobs are belleved to be a mejor contributing factors in achleving this exposure record.

\section{E. Personnel Activities.}

\section{V1sits \& Vigitors}

S.M. Gill and R.E. Olson Visited Nationel Lead Company of Ohio to discuss uranium quality control with J.C. Mead.

T.W. Gore attended the second West Coast Noise Symposium held in Los Angeles.

D.W. Haught visited Denver and Tucson doing recruiting at the University of Colorado, Colorado A\&M, Denver University and the University of Arizona.

T.D. Naylor Visited Seattle, Tacoma, Precision Machine Company, Rottler Boring Bar Company and Pacific Oerlikon Company to discuss specifications for steel, sleeves.

H.I. Gustafson, General Superintendent, and R.D. Rowe, Sales Representative of General Machlnery Company, Spokane, Washington visited BAPO to discuss sleeve quality problems.

2. Meetings.

Sixteen round table, 19 infornation meetings and 10 staff meetings were held for Section Personnel.

Seventy-two safety and security meetirgs were held during the month.

There were two Work Simplification Meetings on Paper Work Simplification, one December 13 and one December 20, each lasting two hours with seven participants; one Work Simplification Meeting on December 6 on Layout lasting two hours with seven participants.

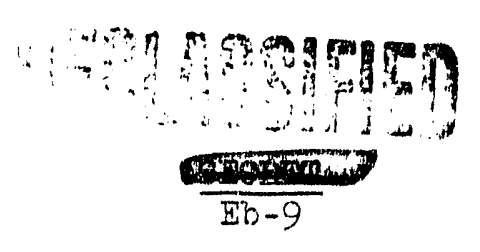




\section{DECLASSFFED}

KANUPACTURTITG DEPARTMEANTS

REACTOR SECTIOT

MONTHLY REPORT

DECEMBER, 1955

\section{RESPONSIBITITIY}

Assigned responsibilities of the Reactor Section remained unchanged during December.

II. ACEIEVERMENTS

A. Operating Experlence

Reactor time operated efflclency was 71.1 per cent which is an increase of slightly more than one per cent over lrovember. Major causes of dowatime were chute Iiner replacement, tube replacement, rupture removul, essentilel maintenance, and charge discharge.

Reactor input production (Pid) for December was 100.4 per cent of forecast. This production is an 911 time hiegh for any month. The November input production was the previous record and was exceeded. by 11.1 per cent. This lncrease is largely due to record high productions at the $\mathrm{KE}$ and $\mathrm{KW}$ Reactors.

Reactor output production was 67.2 per cent of forecast. The discharge of low and high concentration material was 26.9 and 131.4 per crat of forecast, respectively. The low concentration

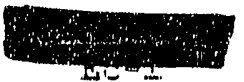




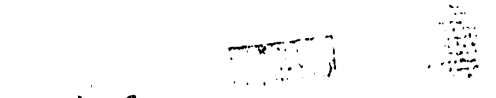

BW- -40692

\section{A. Operating Experience (Continued)}

forecast was not met as a result of the low concentration proGram cancella,tion at H and X Reactors during INovember w1 thout adjustment of the forecast. The high concentration forecast was exceeded due to the lotrering of the goal concentration during Horember.

The established aximu operating levels, excluding burnout, were Increased 223 megawatts at $\mathrm{KIS}$ Beactor and 117 megawatts at KW Reactor. These increases are due to continued gains from cooler inlet water and improved techniques in operation.

There was a total of 39 ruptures, Including 35 regular metal pleces during the month. This represents the highest regular metal rupture frequency yet sustained and exceeds the prevlous blgh of October, 1954, by 52.2 per cent. Resctors sustaining ruptures rexe as follows:

Eight-Inch Regular Elght-Inch. Cored Regular "C" Material Production Test

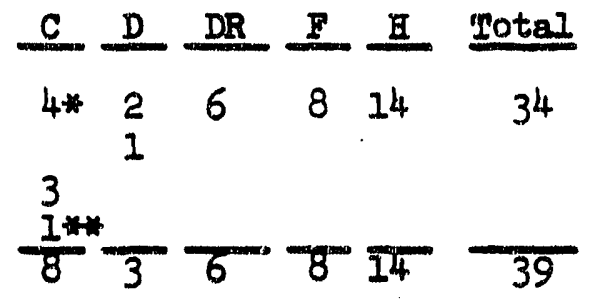

* Includes one regular metal plece charged for PI-105-519-R, "Raising the Permissible outlet Water Temperature of Selected Tubes at $C$ Reactor."

**PT-105-607-A-57-kP, "Irradiat1on of Enriched Cored SIugs With Aluminum End Pluss, Welded Uranium Bad Plugs, and of Two Size Core Diameters."

Reactor outage time for the removal of these ruptures was. 314.1 hours.

1. Stat1st1es

Operating statistics are sumarized in the table shown on Page 3.

2. Actirities

There were forr scheduled and 61 unscheduled outages which resulted in 743.6 and 975.7 hours of outage time, respectively. The $B, D, F$, and $H$ Reactors were each shut down once on schedule. The B Reactor was shut down for chargedischarge and miscellaneous maintenance, D Reactor for the replacement of chute liners and process tubes and for the installation of garma monitor1ng, F Reactor for the replacement of process tubes, and H Reactor for charge-discharge

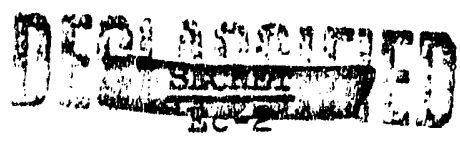




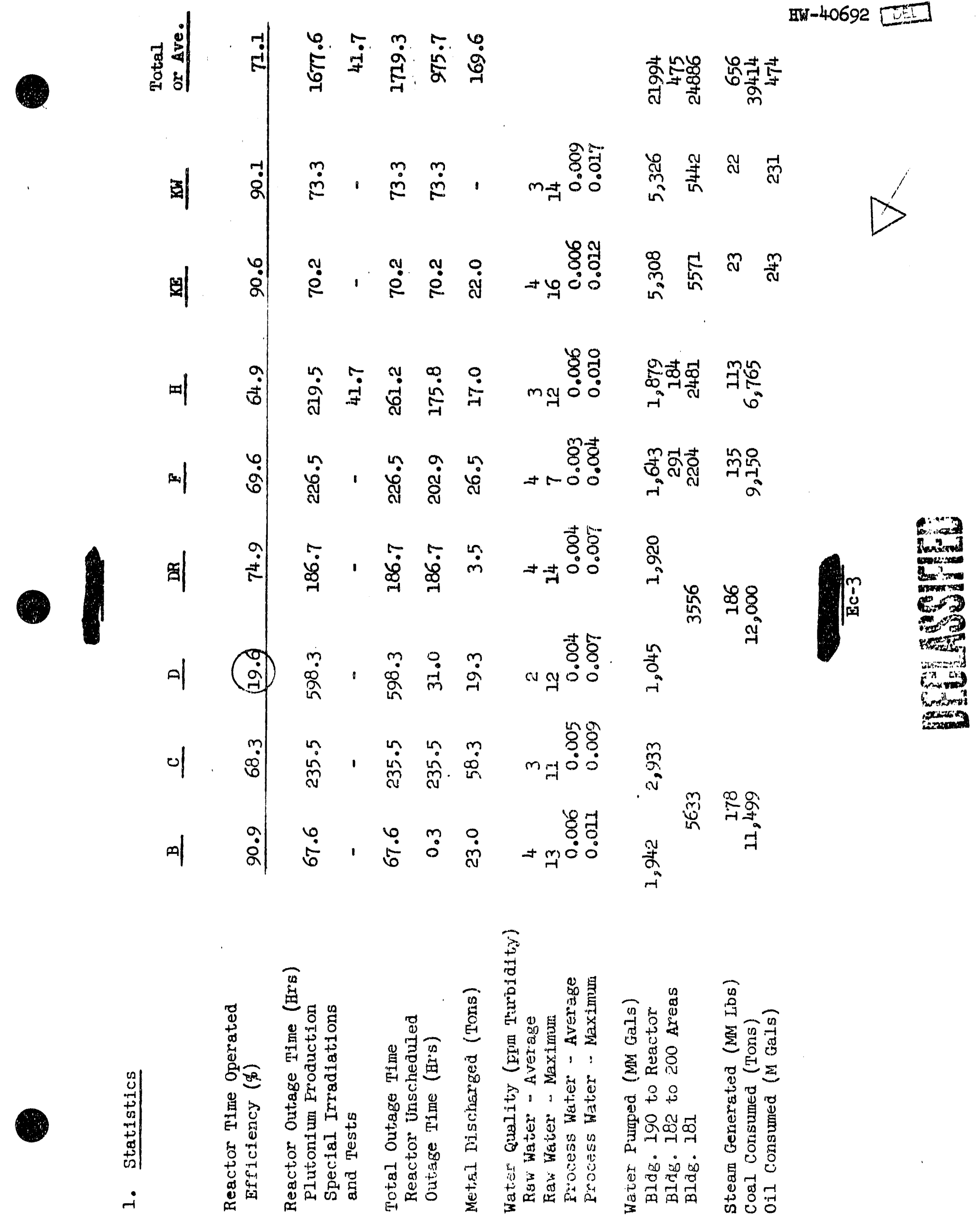




\section{A. Operating Experience}

\section{Activities (Continued)}

and the trial replacement of process tubes.

Prior to the replacement of the chute liners at D Reactor, 34 pieces of elght-inch and three pieces of four-Inch metal were recovered from wader the old Iiners. A document is beling issued requesting the Accountability Section to adjust the 105-D basin book inventory to include this metal.

The following table sumarizes activities during December assoclated with speclal irradilations:

\begin{tabular}{lll} 
Tubes & Tubes & Casks \\
Charged & Discharged \\
\hline
\end{tabular}

\begin{tabular}{|c|c|c|}
\hline $\begin{array}{l}\text { Production Tests } \\
\text { "B" Material } \\
\text { Mint Flattening } \\
\text { Thorium Flattening } \\
\text { "C" Metal }\end{array}$ & $\begin{array}{r}19 \\
0 \\
45 \\
0 \\
24 \\
88\end{array}$ & $\begin{array}{r}5 \\
0 \\
60 \\
2 \\
26 \\
93\end{array}$ \\
\hline
\end{tabular}

B. Equipment Experience

Twenty-three scrams occurred, elght of which were caused by the usual Panellit system variables. Fifteen other scrams occurred from miscellaneous causes as outlined below.

\section{Reactor}

C

$\mathrm{KE}$

$K W$

$\mathrm{KE}$
Reason

Upper limit switch opened on VSR NO. 41.

Improper swltching procedure to restore DC gererators which dropped out due to a surge on BPA system.

Inter-tie scram resulted from above scram at $\mathrm{KE}$.

Panelilt scram due to loss of one pump set tripped out by an over-current relay at Building 165-KE.

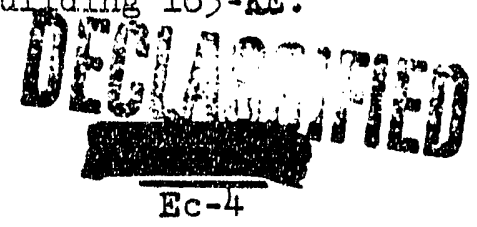


B. Equipment Experience (Continued)

Reactor

KIE

DR

C

$\mathrm{DR}$

C

KST

KNT

C

B

KWH

D $\underline{\text { Reason }}$

Penellit scram due to loss of a pump set caused by improper re-setting of the over-current relay s.t Building 165-80s.

Panellit scram when Ho. 4 bank of Building 190 pumps tripped out by an overload caused by placing an air compressor in servlce.

Manial scram Ior temperature control.

Manual screm due to insufficlent control to accomplish turnaround.

Beckman trip due to by-passing of wrong Beckman.

Beckenan tirlp caused by local unbelance during rod changes to control heat cycling.

Inter-tie caused by above Beckman trip at $\mathrm{KE}$ Resctor.

Manual scram dise to several annunclator alarms when instrument power Palled for an unknown reason.

Panellit trip due to pressure surge from Bullding $190-\mathrm{B}$.

Manual scram to control severe heat cycle.

Panely it trip due to pressure surge caused by maleunction of sutoliatic controller at Bullding 190-D。

Reactor outage time due to a.1 24 scrams totajl.1ed 260.7 hours.

On December 22, a wind storm with gusts up to 80 miles per hour caused extenstre damaxe to the 100 Area installations. Approximately 35,000 squars Itot of roof were damaged to the extent of the concrete blocks toing llown from the roof in some cases. Damage was largely iuncentriated in 100-D and 100-F Areas with no damage reported at 100-K Area and minor damage reported at $B$ and H Areas. Total dimage has been estimated as being approximately $\$ 25,000$. No injurles to personnel resulted.

As a result of contirized high water collection rates, leak testing programs were condurtsd during five outages at F Reactor; however, no leaks were forrin. Minum outages caused by ruptures were utilized for the repstod testing of all tubes. All horizontal

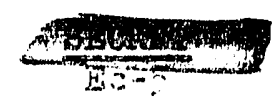




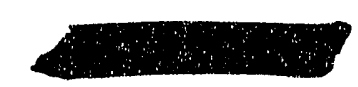

HW -40692

\section{B. Equipment Experience (Continued)}

control rods and two experimental holes were tested with negative results. Current data indicate Building 115-F to be the source of water. A program of isolating and testing each piece of $115-F$ equipment is in progress.

All tubes were leak tested with the hellum facllity at B Reactor an December 4, and again on December 8. One tube (1493). was found leaking and was blanked off as an air tube. Water collection rates have returned to normal following water leaks in rupture tubes Nos. 1072 and 2787.

A total of 273 gallons of water was collected from the DR Reactor as a result of leaks caused by ruptures in tubes Nos. 3285 and 3575 . Water collection rates are normal at month end.

Water collection at $D$ Reactor remained above normal following the start-up from its extended outage. A total of 331 gallons was collected during the last week of the month.

Panellit gage maintenance and replacement during December was as follows:

a. At C Reactor, 41 additional Panellit geges were replaced with the new type for a total of 563 replaced to date. A total of 1441 remains to be replaced.

b. At KI Reactor, 154 gages were found to have separated mercury and were corrected. Four bundred new type switch bottles have been provided by Panellit, Inc, and will be installed for test.

c. A 5 KW Reactor, acheck revealed a total of 171 gages having mercury separation.

The coordinate row and colum lighting feature was activated at KW Reactor on 335 Hamlin type switches as a test on one panel.

d. At $F$ Reactor, nine defective gages were replaced.

e. Reliability checks at $\mathrm{C}$ and $\mathrm{H}$ Reactors disclosed no fault: high or low trips. However, a large number of gages wers observed to have mercury separation at i Reactor.

f. Ati L Reactor, ban fallty trips were found, two due to mercury separation and eight, aue to plugged capillarits.

5. Ait DR Reactor, two faulty trips were found and 15 gacis were replaced due to leaking capillaries.

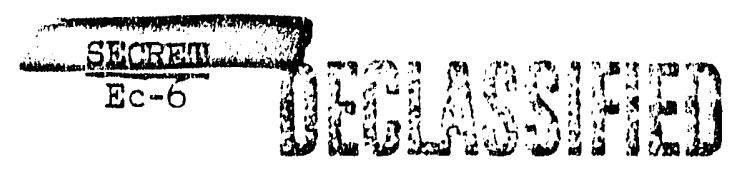




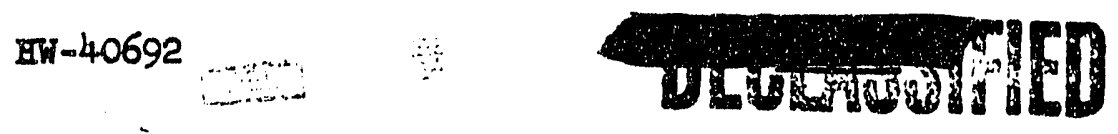

\section{B. Equipment Experience (Continued)}

Maintenance and testing of the BaII $3 X$ systems was as follows:

a. At C Reactor, during a test trip, balls entered channel No. 4 I in a normal manner but falled to pass through the ball valre at the bottom of the reactor. Efforts to dislodge the balls were unsuccessful and they were vacuumed into a collector at the top of the reactor. An obstruction has been located 15 Ieet above the ball-valve which has not yet been dislodged.

b. Examination of the $3 X$ hoppers at $F$ Reactor falled to reveal any molsture on the plastic covers. This is an indication that adding make-ip gas through the hoppers is keeping them dry.

At the $\mathrm{X}$ Reactors, reliabliftio of the latching assemblies continues to be a problem. Iatching difficulties prevented recovery from one seram at $\mathrm{WT}$ Reactor. Difflculties with latching prevented recovery from thrse scrams at $\mathrm{kW}$ Reactor. Interim repairs have been made but continued difficulty in scram recovery is expected until this system can be made reliable. The Process subSection has accepted responsibility for the design of a new latching asserably.

DR Reactor experienced its first alug jacket fallure since the garma monitor placed in service. The sensitivity of the system was demonstrated by the difficulty in detecting the offending tube diring rear face survey sibsequent to shutdown.

At $\mathrm{H}$ Reactor, the ganme nonitor has operated satisfactorily during the month and is oxedited with several rupture removals during the scram recovery time Synchronization dificulties and recorder malfunctions required a significant amount of maintenance.

One temperature mon1tor bulh was replaced at KE Reactor and two at IJ Resctor. Five surams due to temperature monitor malfunctilons would have reaulted at KE Reactor if the temperature monitor had been in tine scrim dircult, At the other reactors, 73 process tube ontet, watsr tamperature thermocouples failed. Of these, 35 were at $H, 19$ ais $D$, nine at $c$, and five each at $B$ and $F$ Reactors.

Three damaged backpash valtes were removed at Building 183-KE and WW filter pianos and replaced during the month. Repairs to a founth valos, which was remowed, will be completed early in January.

Inspection and repuir of the No. 2 thrtine at Building 165-kW was completed aurag rectemb ror limination of erratic governor action. Recompendations of R。C.Fanton, Worthington Corporation representative, were followed to sffert sutisfactory operation of the unit. 
B. Equipment Experience (Continued)

Process pump discharge header screens (12-1nch) in Building 105-B valve pit were cleaned and inspected for excess clearance revealing necessity for correction to stop the by-passing of screens by process water flowing to the reactor. Correction will be accomplished as operating schedules permit.

Excessive clearance at the bottom of the Io. 2, 24-1nch discharge hesder screen at Building 190-c was corrected in December 2. Materials are being pre-fabricated for required alterations on the remalning forr screens.

Satisfactory routine tests simulating BPA power fallure, were conducted at KW and IFe Areas prior to reactor start-up on December 18 and 19, respectively.

Installation of new Plutd drive assemblies in No. 2 and No. II process pum units at Buildiag 190-C completed the program for exchange of all fluld drites.

Repair of No. 3 liquid rheostat at Building 190-KW and Installation of new cells in liquid rheostats Nos. 1 and 2 at Building 190-IKS were completed during December.

Tube replacement programs were conducted at $D$ and $H$ Reactors. During the extended outage at D Reactor during December, 63 tubes were removed, 58 were replaced, and ten were left as air channels. Ten tubes were replaced at H Reactor during a scheduled outage on a trial replacement program.

C. Improvement Experience

The most slenificant Production Tests are reported below, together with other items of improvement significance.

PT-105-506-E (Recirculation Studies)

A new zirconfum tube was installed in channel. 0961-H during the December 8 outage. The tube was recharged and recirculation resuned following the tube replacement outage on December 28. A rupture monitor trip on the No. I safety circuit was installed prior to re-charging the tube. Outage time charged to this test was 25 hours for the month.

PT-105-537-E (Effects of J-Q Pairs on Radiation Damage to Pile Graphite)

The 12 tubes charged with 36 pieces of $\mathrm{J}-\mathrm{Q}$ material were discharged during December at F Reactor.

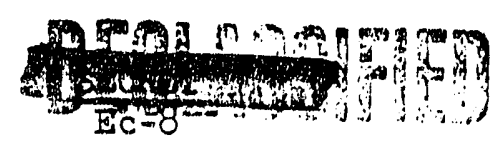




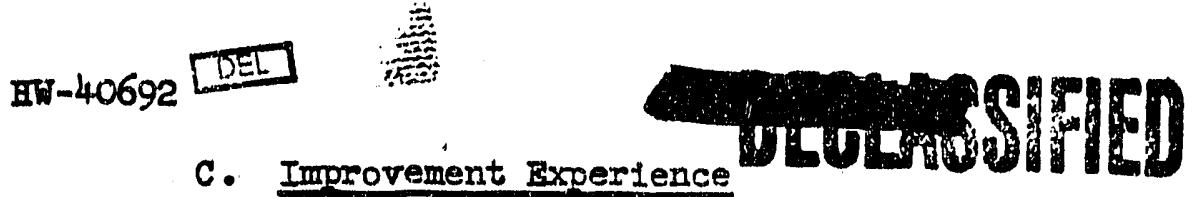

$\mathrm{PT}-105-535-\mathrm{E}$

(HAPO 140 Alternate P1le Atmosphere Study) Tubes Nus. 0776-H and 1282-H were recharged with samples during the December 8 outage. Total outage time charged to this test was 16.7 hours during December.

$P T-M R-105-31$

(Process Thube Sliding Seals)

This test was inftiated to permit installation of " $\mathrm{O}$ " $10 \mathrm{~g}$ in place of rear Van Stone flanges and gaskets on process tubes. Initially, twelve tribss gt the F Reactor will utilize the "O" ring tigo seal.

$P T-105-548-\mathrm{E}$

(C Pile Grsphite Eurnout Experiment) Wine tubes remain charged with $J-Q$ material at C Reactor tor this Production Test.

$P T-105-354-E$

(Evrlustion or $7.0 \mathrm{pH}$ Process Water) Spenlifed $\mathrm{pH}$ wers maintained on a one-hale plant basis without difficulty at $F$ Reactor.

Three revised Process Sturiardis - Resctor, Document HW-33000, were approved and 1ssued. r.be: Standiards and revisions are as follows:

Process Standard B-010, "Gas Coumosition, Pressure, and Flow"

The relationshlp between maximum graphite temperatures and helium concentrations bas been made 2035 restrictive at $C, D R$, and $\mathrm{B}$ Reactors to provide reaser operational plexiblilty.

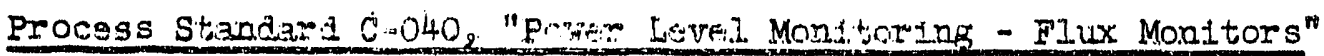

Protistons were made to allo" greater operatonal t'lextbility of the flux monttowitag systoms duw ing shutdown and during the initial operating perfod toiscriats a ould start; -up.

Process Standard $0950_{2}$ "Monhite Turocarature Limits"

Higher graph1te tompuriturso ar: now permittad adjarent to empty

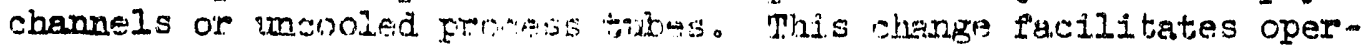

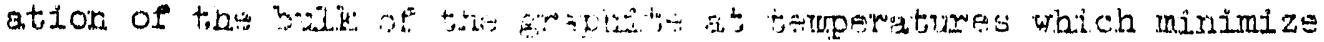
distortion.

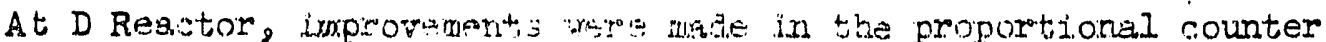
systim by the lristalizition (t) a now chamber and scaler - both of the latest trpe. nhe instrument lo more sensitive, easier to operate, and more positivi in lits responst.

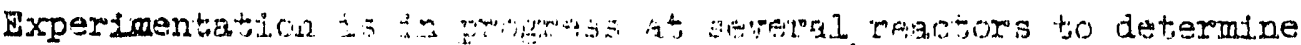

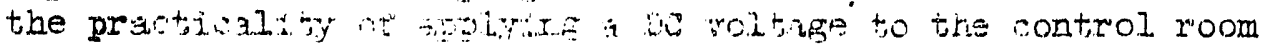

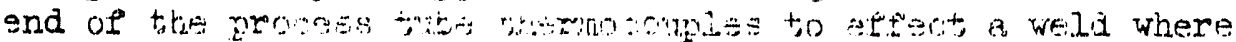

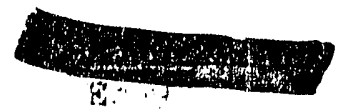




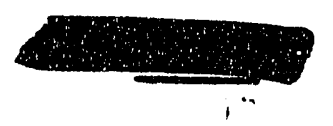

BWW-40692

\section{Improvement Experlence (Continued)}

thermocouples are parifilly open. This can be done during operation and has thus far resulted in restoring several thermocouples to service without waiting for shutdown.

Personnel in the Reactor Section engaged in work which might be expected to result in inventions or discoveries have reported that no furentions or discoverles were made during the perlod covered by this report.

\section{Events Influencing Costs}

It is expected that the unit cost for December will reach an all time low of approximately $\$ 9.98$ per megawatt day. This is approximately nine per cent below November unit cost and results from the record production during December with a relatively small increase in total operating cost. It is gratifying to report that overtime charges took a downward trend in December, partl cularly within the Maintenance Sub-section. This reduction is due to the continued efforts to reduce overtime usage and to the fncrease in personnel on shift coverage. Total costs for applled materials within the Power Sub-Section (the largest consumer) increased two per cent $(\$ 9400)$ over November costs. Whis increase is due to an approximate three per cent increase in water flow to the reactors whth a corresponding increase in fuel costs for steam generation. It is estimated that the unit' cost for January will remain about the same as for December.

E. Plant Development and Expansion

1. Project Status

The most significant Reactor Section project activity is reported below. Further detalls concerning projects may be found in the report, "Status of Reactor Section Projects, Informal Requests, and Budget Items," F.A.R. Stainken to R. S. Bell, dated December 20, 1955.

$C A-431$

100-C Area

Cost estimates based on both total 105-C Reactor horizontal rod replacement ( 15 rods), or a replacement of only five rods, were reviewed. The estimate for replacement of five rods is $\$ 85,000$ with seven days of shutdown, and twice this money and time for all rods. Pile Technology is checkling whether adequate cross-section and rod cooling llow, based on post CG-600 (100-C Area Modifications), can be maintained with the new and present rods.

Funds are not available for completion of 107-c east tank bafile repairs. Repairs to the baffles are now felt to be inopportune since a current

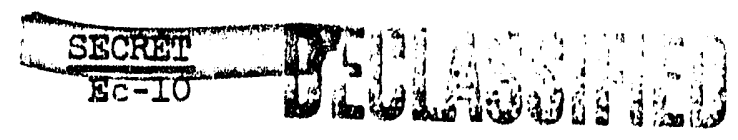


B. Plant Development and Ixpinston

1. Project Status

CA-43I 100-C Area (Continued)

study by Radiologlcal Sclences may result in less. stringent reactor effluent water disposal criteria.

CA-512 100-7i Reactors and Water Plants Plping installation is continuing in all four cells and the make-up room of the 1706-KKMR in-pile reclrculation system building. Equipment foundations are being pouted and formed and assembly of rent fans and casings is in progress. Delivery of the control panels for the four recirculation loops is expected in February. Arrangements have been made to have this rendor's training engtneer conduct a clinfe at BAPO covering the operation, service, and repair of this equipment.

Twenty-four interim resistance bulbs have been replaced, 19 were eventually reinstalled after test and live proved definftely uareliable. Evaluation of these fnterim bulbs w1Il continue.

A $70 / 30$ mixtire of boron balls to plain steel balls has been adopted as a standard to be used throughout the 100 Areas. A total of 37,500 poumds of boron steel balls are now in transit to EAPO. It is expected that they w11l arrive during January.

Stage II of the Fireye system w1Il be included in the groject proposal being prepared which is intended to provide steam auxillaries for back-up of Buflding 165-K steam generating facilities.

A moting was bela on December 28 , between members ot. the Engipleering Department and Manufacturing Department for preliminary discussion of 1 tems which Nanuracturing considers to be in need of correction for satisfactory completion of project CA-512. Minutes of the meering are being prensided. Elither g fitth revision to the CA-512 Frojeat proposal or a new project proposa? will seel AEC authordzation for the expenditure of funds to conplete the corrections required.

CG-558 Resctor Plant Modiflcation for Increased Production constrution in the water plants and reactor areas is progresiating arcording to schedule.

A nagotlated order has been placed with Resistoflex Courpany for approximately 6,000 front face connectors.

\section{Shotenty}




\section{If.: Plant Derelopment and Expansion}

\section{Project Status}

CG-558 Reactor Plant Modiflcation for Increased Production (Con'td.) The remaining connectors will be sent out for bld In an effort to determine whether more than one vendor is capable of producing satisfactory connectors.

An attempt was made, on December 28 , to start the first of the main punp motors in the annex of Building 190-B. A severe voltage depression in other parts of the 100-B Ares resulted and the test was discont1nued. Frrother efforts to start this motor will not be made unt1l a comprehensive revlew of the electrical design has been completed by Design Section.

\section{Plant Engineering}

A number of engtneering and development studies were active in the Section during December. The studies are, in general, almed at decreasing costs and/or increasing production. Detalls are given in Document IIT-40779. Several items of interest are reported below.

Twenty-two tubes were de-filmed at D Reactor during December by purging each tube with a two per cent slurry of super Cel. The contamination level of splitting tools used in these tubes was one-third that of tools used in other tubes. Procedures and methods are being formulated for routine purging of process tubes prior to removal. Detalls of the de-filming test will be reported in a document to be issued in January.

A program was Initiated to determine the cause of eight rear face flexible connector leaks which occurred during the last four months at $\mathrm{H}$ Reactor. Metallographlc examination of two of the fallures to date have revealed radial cracks of the stress corrosion type, three to twelve inches from the header connector end.

The potential merit of Separan, a Dow Chemical Company coagulant, was demonstrated during the month in the experimental filter plant. Less than 0.1 ppm of separan, used in confunction with alum, prevented filter break-through more efficiently than $4.0 \mathrm{ppm}$ of activated silica. A thorough study of Separan is in progress to determine the optimum conditions for 1ts use.

A series of meetings was initiated to acquaint interested groups with the details and the reasons for the proposed modifications of the Ball 3X system at B, D, DR, F, and $E$ Reactors. Supplementary data vere prepared as an aid to interpreting system modifications, and included cost estimates, material and manpower r"equirements, sketches, and justifications. Meetings will continue during January.

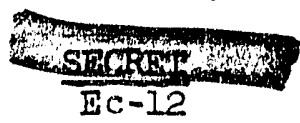


I. S1gmiflcant Reporte

1. Rontine

Montibly operating reports 1ssued for November were:

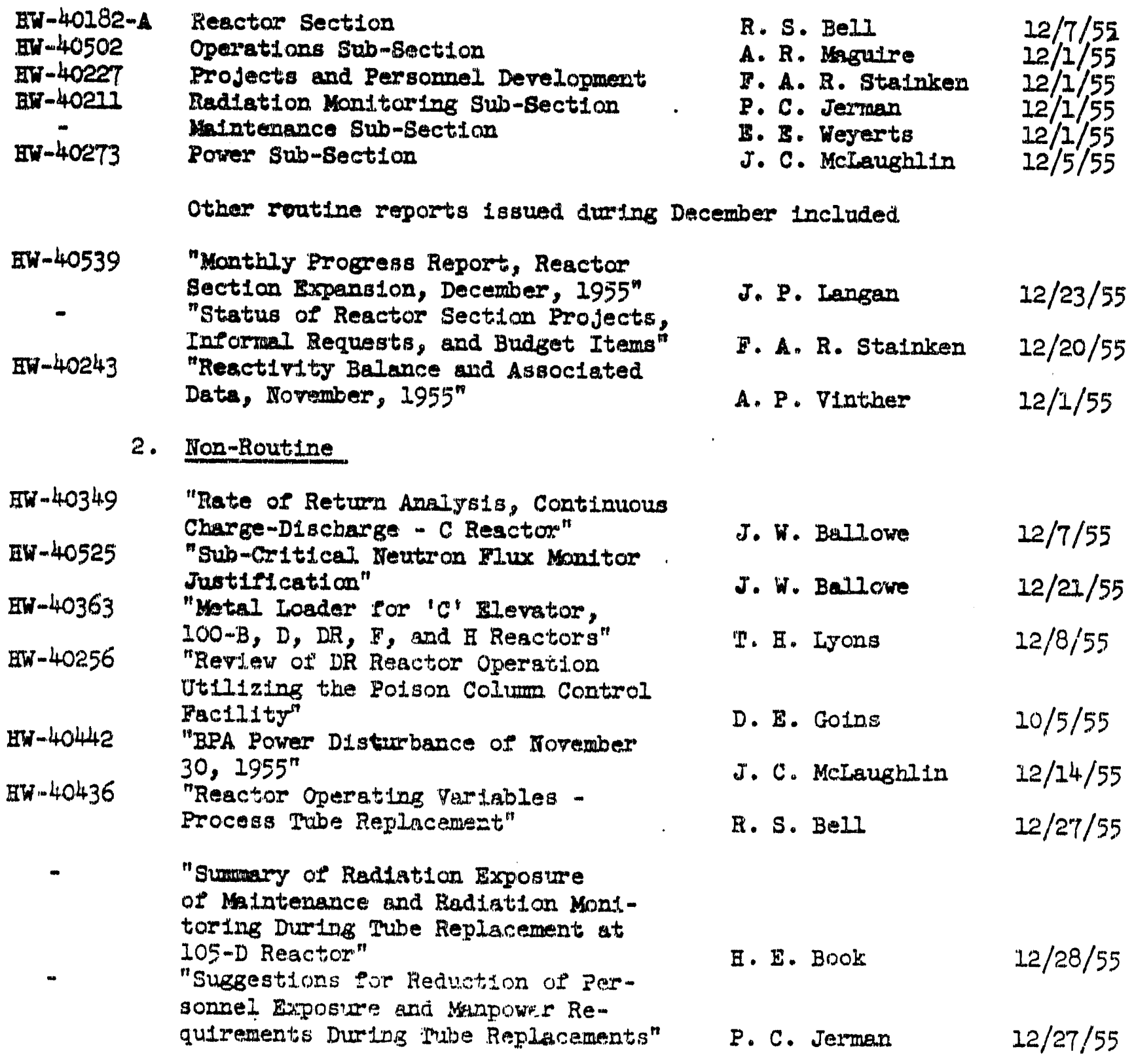

III. FERSONDELI

A. Organization

There were no appointments in the Reactor section dun"1ng December. 
B. Porce Summary

\begin{tabular}{|c|c|c|c|}
\hline & $\begin{array}{l}\text { Beginning } \\
\text { of Month }\end{array}$ & $\begin{array}{l}\text { Fnd of } \\
\text { Month }\end{array}$ & $\begin{array}{l}\text { Net } \\
\text { Change }\end{array}$ \\
\hline $\begin{array}{l}\text { Section General } \\
\text { Operations } \\
\text { Maintenance } \\
\text { Projects and Personnel } \\
\text { Power } \\
\text { Process } \\
\text { Radiation Monitoring }\end{array}$ & $\begin{array}{r}2 \\
388 \\
703 \\
52 \\
488 \\
83 \\
99\end{array}$ & $\begin{array}{r}2 \\
404 \\
722 \\
54 \\
488 \\
87 \\
101\end{array}$ & 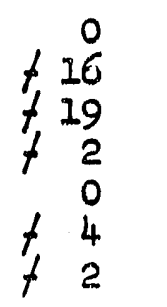 \\
\hline Section Total & 1815 & 1858 & +43 \\
\hline
\end{tabular}

Changes durfing December Included 30 transfers into the Section, one transier out of the Section, 18 new bires, pour terminations, two reactivations, and two desctivations.

\section{c. Sarety Experience}

There were no Nor nor Sub-Major Infurles auring December. There was a total of four Near-Serlous Accldents during the month as follows:

1. A Intenance mochante removed a three-inch pin rom a check valve on a front face riser while the ine was at 75 pounds pressure.

2. ithe Blue Tool Room roof at D Reactor was displaced during tube removal attempts when this roor was used as an anchor.

3. Part of a limit swltch weight fell of the 30-ton crane narrowly missing an operator, during cask transfer operations at $C$ Reactor.

4. A pick-up truck crashed the main gate at 100-H Ares when the arfver fell asleep whtle approsching the area at the end of graveyerd shift.

D. Radiation Experience

There was one Class II and no Class I Radiation Incidents during December.

The Clasa IT Incldent (No. 99-C) occurred at the H Reactor on December 8 , and involved a Chief operator in the operations Sub-Section who recelved localized exposure on the right side of his head in excess of the weekly permissible limit from a radioactive particle. The employee was engaged in rupture removal work in the discharge area and the exact mechamism by Whlch the particle became lodged on his head was not determined. The total dose to the small skJn area, as determined from $\mathrm{fllm}$ 
D. Radiation Experlence (Continued)

studies, was established at 2.5 rads. This Incident 1 s reported separately in Document EW-406I8.

A comprehensive survey of the 111-B Butlding was made during the month to determine the exact extent of contamination and the feasiblilty of decontaminating the bullding for tenancy. Bxtensive contamination was disclosed and a decision has not yet been resched as to what decontamination work may be necessary if occupancy is destred.

A control procedure is being developed to realistically control the contamination which has presented problems during the routine bamalfing of rall road cask cars.

The comprehensive study of exposure problems, assoclated with the tube replacement program, continued during the month.

\section{Personnel Activities}

At month end, 20 employees are receiving on-the-job training for engincering or supervisory assignments in the Section; five of these are on assignment under the rotational training program.

Seren members of the Radiation Monttoring Sub-Section attended the Radiological Sclences Training School for exempt personnel during the month.

Training aids for use in the Radiation Training Jecture Serles have been recelved from the Graphics Unit. The first series of lectures for Radiation Monttoring irrainees is scheduled to start in January.

The secoud of a series of elght sets of training questions were given to Pil- Opers $5=0$ and a training program was inltiated for supervisors below the Unit, Superintendent level and for chlep Operators in the Operations sub-Section.

G. O. Ang and R. I. Thuruer of the Process Sub-Sect1on attended the Nuclear Ingineering and Science Congress, and the International Atomic Bxposition at Cleveland, Ohio, during the week of December $12,1955$.

A three day orientation program was conducted for 12 new craftsmen, and training for four welders was scheduled at the 200-E Area school by the Maintenance Sub-Section.

H. A. Kramer, Maiutenance Sub-Section, was at Oak Ridge, Tennessee for ten days where he particlpated in the ABC Declassification Program. 

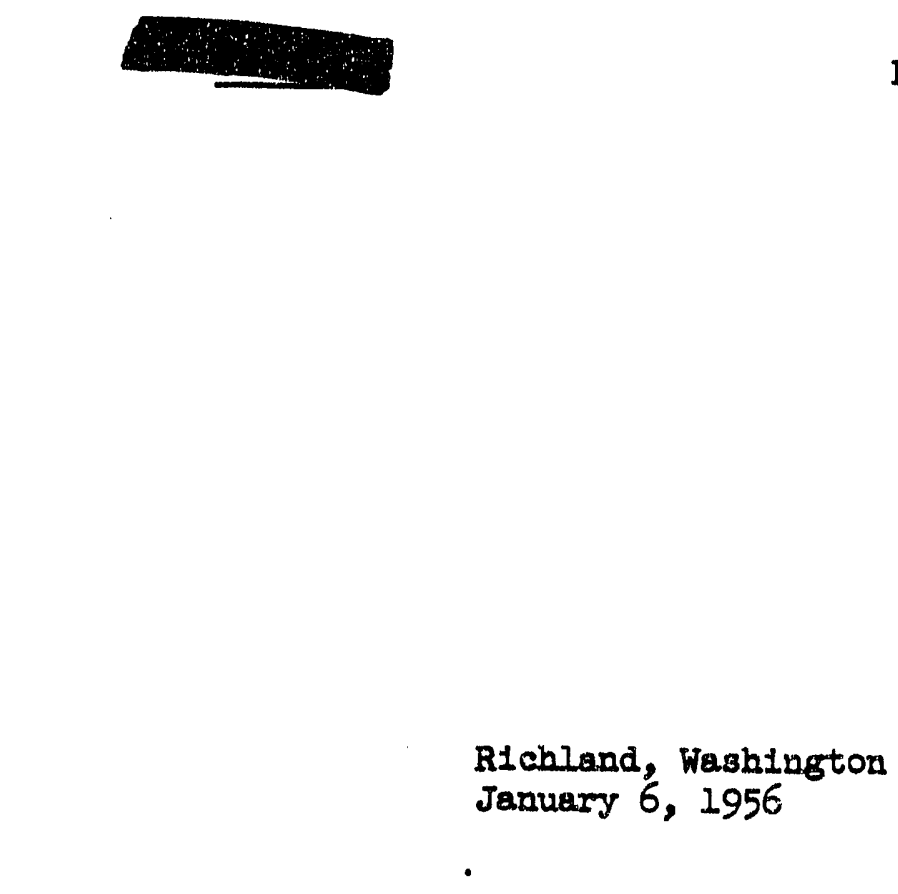

MANUTACIUR.THK DFPARTMEANT

SEPARATIONS SECIION

DECFMMBR, 1955

\section{RESPONBIBTITIY}

Responsibilities of the Separations section were unchanged during the month of December, 1955.

\section{ACHISVETERII}

A. Operating Fxperience

1. Statisties

a. Blsmuth Phosphate Operations

\begin{tabular}{|c|c|c|c|c|}
\hline & \multicolumn{2}{|c|}{ December } & \multicolumn{2}{|c|}{ November } \\
\hline & Normal & $\begin{array}{l}\text { Acid } \\
\text { Wash }\end{array}$ & Normal & $\begin{array}{l}\text { Acid } \\
\text { Wash }\end{array}$ \\
\hline harges started in Canyon Bldgs. & 32 & 2 & 40 & \\
\hline barges completed in Conc. Bldgs. & 40 & 0 & 40 & \\
\hline pectal charges - Conc. Bldgs. & & & & 1 \\
\hline Charges completed-Isolation Bldg. & & & 95 & \\
\hline $\begin{array}{l}\text { Average Waste Losses, } \% \\
\text { Speclal charges - Isolation Bldg. }\end{array}$ & & -1 & & \\
\hline $\begin{array}{l}\text { Materlal bolance, } \phi \\
\text { Yleld through Process, } \phi\end{array}$ & & 2.7 & & $\begin{array}{ll}01.4 \\
98.9\end{array}$ \\
\hline verage cooling time (days) & 13 & & & 15 \\
\hline Minimum cooling time (days) & 12 & & & .00 \\
\hline
\end{tabular}

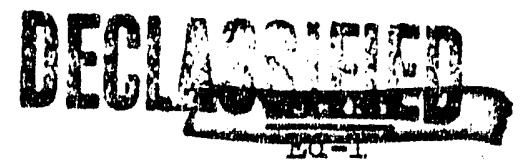


b. Redox Operations

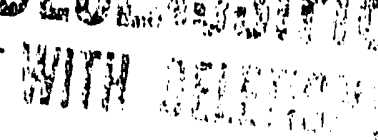

Equivalent charges started

Charges completed

Tons Uranfum delivered to storage

Average Production Rate per Operating day, Tons

Average Da1ly Operating Rate for the month, Tons

Average yleld, $\%$

Urantium

Plutonium

Total Waste Loss, $\%$

Urantum

Plutonium

Averege cooling time, days

Minimum cooling time, days

Percent down time

December

283.6

339.6

153.1

November

*Corrected

c. 231

December November

Batches started

Batches completed

Batches awalting processing

111

$7.4 \quad 9.3$

$4.9 \quad 7.9$

99.2

$101.5 *$

99.1

$98.9 *$

0.87

101.

77

32.9

0.63

1.57

0.92

96

16.8

401.3

373.7

36.9

3

9.9

231

\section{58
6}

December

282

282

183

13.83
November

210

212

96

Waste D1sposal (Untta)

e. UO 3 Operations.

\begin{tabular}{lcccr} 
& Decemer & November & To Dete \\
\cline { 2 - 2 } Urantum drummer, Tons & 370.41 & & 341.94 & $12,171.13$ \\
Uranium shipped, Tons & 389.10 & 324.54 & $12,1.38 .20$ \\
Average cooling time, days & 107 & 163 & \\
Minimum cooling time, days & 83. & 102 & \\
Waste Loss, $\%$ & 0.02 & 0.02 &
\end{tabular}


I. TBP Operations

December November To Date

Tous recelved from Metal Removal.

Tons shipped to $\mathrm{UO}_{3}$ Plant Arerage Production Rate per Operating day, Tons

Average Dally Operating Rate for the Nonth, Tons

Average yleld, \%

Total Waste Loss, $\%$

Ratio Acturl Waste Volume returned to theoretical volume Percent down time

144.38

$147 \cdot 75$

160.88

157.71

$6,356.95$

$6,147.87$

$\begin{array}{rr}4.77 & 5.26 \\ 100.49 & 98.26 \\ 2.59 & 2.19\end{array}$

0.78

7.26

1.01

0

g. Power

Raw water pumped, gpm Filtered water puruped, gpm

Steam generated, lbs/hr

Maximum steam generated, Ibs/hr

Total steam generated, M Ibs.

Coel consumed, tons (est.)

East

200 West

4409

521

114000

235000

85341

4989

$\begin{array}{rr}6 & 577 \\ 1 & 182 \\ 207 & 000 \\ 266 & 000 \\ 1.54 & 333 \\ 9 & 633\end{array}$

b. Waste Storage

Equitralent Tons U Dec. Nov.

Metal Waste reserve storage capacity-I Plant

132

167

lst Cycle reserve storage capacity-T Plant

Metal Waste reserve storage capacity-B Plant

183

685

Ist Cycle reserve storage capaclty-B Plant

74

427

216

685

74

Redox Waste reserve storage capacity

511

2. Activities

a. Redox Processing

During the early part of the month, production rates were held below the 11 tons uranlun per day rate previously proved feasible by the following factors, (1) feed shortages brought about by delays in heed end processing due to tests for leaks in the oxldizer tank (H-4), (2) dilution of the second plutonium cycle feed caused by fet dilutions in the cross-over oxidation step. This necessitated flow sheet changes which restricted

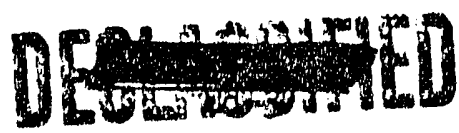




\section{miosese}

\section{a. Redox Processing (Continued)}

$2 B$ colum rates to about 10 tons uranium per day. (3) Rework of waste high in plutonium and uranlum. This waste accurallated from the H cell surps from a leak later proved to be in the H-4 tank shell and from erratic extraction performen in the second plutonfur cycle. An elght hour building shutdown was necessitated on December 4 to replace the caust1c scrubber (H-5) reclrculation pump. Another six and one-half hour shuttown was held on December 9 while a bad leak was repalred in the continuous plutonfum concentrator $(L-3)$ in the 233-S Building. Prinary feed proceseing stopped on December 17 for the rest of the month. Depletion of the backlog lnventory of high MND metal resulted in a break in production which could advantageously be used for equipment repair and replacement. Several rework batches were processed following thls date in an effort to decontaminate the uranium and plutonium product from the last batch processed through the plant. Present plans anticlpate plant startup on January 15.

\section{b. Metal Recovery}

\section{1) TBP Processing}

Good feed supplies were maintalned all month whlch, together with a minimum of equipment troubles, resulted in adequately meeting the conmilment.

Reactivation of Section 6 as an intercycle concentrator to operate in serles with Section 8 was completed except for assembly of the new and converted equipment which will be completed next month.

2) Uo Processing

Production was limited by the feed avallable. The production for this month was achieved essentially by use of the electric pots only as the Luckey gas fired pots were removed from service for replacement on December 4.

The average datly production rate anproached $14.0 \mathrm{~T} / \mathrm{D}$. Several days rates approached $16.0 \mathrm{~T} / \mathrm{D}$. Inproved ganna content, of Redox feed material thls month resulted in lower average carload garma values.

3) Waste Metal Remoral

Puxp failures in both 107-IJ and 101-TX underground storages interrupted siluteing operations during the month and required pump replacements.

Continuols in-tarm scavenging of stored wastes at $R$ frarm was begun teecriber 6 upon cormpletion of installation of $\mathrm{pH}$

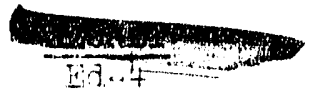


3) Waste Metal Removal (Continued)

control equipment by Minor Construction. In December 109-C tank wes emptied and 101-C tank is being emptied at month-end.

\section{c. T Plant}

The monthily production cormitment was met. On request from the AEC for delivery of neptunlum during February, processing was started on December 27, 1955. On completion of this commitment, I Plant will be cleaned out and placed in standby status.

\section{d. Isolation and Metal Fabrication}

Production in the Isolation Bullaing was confined to the prom cessing of low MWD/T Pu from the T Plant. The material wes loaded fato sample cans as Pu Nitrate and is belng stored temporarily for subsequent processing in the 234-5 Butlding.

Although operations in the 234-5 Bullding progressed satisPactorily, It was necessary to divert the equivalent of 15 Redox runs through the Recuplex facility for further decontamination. These runs contained excessive amounts of flssion products as recelved from the Redox Plant. The Increased radiation level from this materlal decreases the time limits perratssible throughout the fabrication process.

\section{e. Purex}

Cold Run AC-3, which began on November 26 was completed on December 5, 1955. The prime purpose of the run, equilibrium operation at capacity factors of $1.2,1.8$, and 2.4 with $\mathrm{HW}-4$ flowsheet, was accomplished. The major difflculty encountered. was poor interface control on the " $C$ " type and the $2 A$ columns, both utillzing capacitance probes in a side chamber connected to the bottom disengraing section.

Cold Run AC-4 was begun on December 6 and intermupted on December 10, 1955. Using HW-3 f'lowsheet at 1.44 capacity factor, the following studies were conducted: colum flooding frequencies; effect of interface position on "A" column entrainment; uranium breakthrough IBS rate; and effect of intermediate scrub on UX decontamination in $2 A$ colum. Satisfactory laterface control of the $2 \mathrm{~A}$ column was achieved by decreasing the orifice size from one-fourth to one-eighth Inch in the line connecting the colum to the capacitance probe slde chamber.

Startup of the extraction sections, according to run plan AC-5 was begun on December 31. Improper instrument adjustment

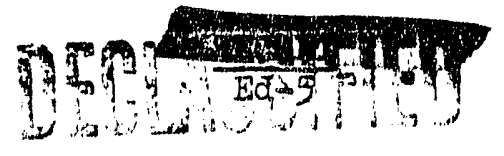


e. Purex (Continued)

on the 1-C colum Interface control resulted in loss of organic out the bottom of the colum to the J8 concentrator. This condition resulted in high waste losses and flooding in the second cycle organic extraction colum TR-2.

AEC and RM approvel wes obtalned to crib depleted UNH solution.

\section{Speclal Operstions}

a. Pu Recovery

Hoods 40 and $4 i$ were utilized in December for the dissolution of high MWD/T scrap metals. The material from Hood 41 served as feed to Tiask I whtle Hood 40 solutions entered the Recuplex feed stream.

The Recuplex sacility which was used for further decontamination of Redox material prlor to RMA IIne processing proved erfective in rewoving excessive beta emitting fission products from the plutonium solution.

During the month, it wes demonstrated that the solvent extraction section could process supernatants at a maximum capacity of 1,200 liters per day and that $s 1 x$ slag and crucible dissolutions could be processed per day.

4. Schedule Varlanae

Redox produrtion exoesded torevest by $1 \%$.

TBP production was 5.5 pexcent; over compltment and the vO, Plant exceeded comitment by 19.5 percent. Ten ars of $\mathrm{UO}_{3}$ were shipped to Paducalh.

I Plant met its production sahedule.

Fabrication actirlties wexe dirented towards producing 130 Model assemblies from high MWD/T Fid. The previous all time high production record for the fingigation forility established in October was exceeded by 3\%. In eddition untabricated production exceeded the previous bigh by $i_{1} 1 / 2 \%$. Eroduction schedules in the 231 Building were also met without dififleulty.

B. Equipment Experience

1. Operating continuity

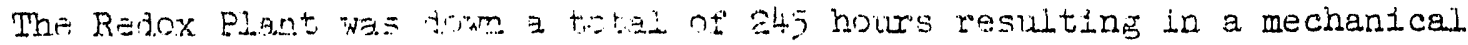
efficleney of 67.1. Er sent ton the month. The primary cause of the downtime was a soheruisid sbutdown for installation of equipment for a 
1. Operating Continuity (Continued)

precycle flowsheet, backcycle of second cycle wastes, and ozone sparging of the final urantium product for removal of ruthentum.

54 hours of lost time of second cycle and 48 hours of f1rst cycle occurred when the 19-7 pump falled and difficulties were exper1enced with the RD extraction colum interface control instrumentation.

No slgnifleant processing time was lost in T Plant.

Performance of the process equipment in the $\mathrm{Z}$ Plant was somewhat more dependable than normal and there were no failures wh1ch advesely Influenced the over-all operating efflelency during the month.

\section{Inspect1on, Malntenance and Replacement}

\section{a. Cell Equipment Replacement - Redox}

Jumpers for trangfer of $D-1$ to $D-9$ were lnstalled during the month. The lnstallation provides storage of reworkable sump material without the necessity of routing it through the waste concentrator and segregating waste batches.

The caustic recirculation pump in $\mathrm{H}-5$ tank was replaced on December 3 when thorough testing Indicated that the shaft was severed. The replacement was made with a Johnson P-lll gas seal puop. The failed untt had been in service since November 15,1954 .

The equipment installation program planned for the extended shutdown was started in E cell on December 24. Cell Installat1ons progressed satisfactorlly during the period with virtual completion of assembly of the ozonizer (E-13), the backeycle concentrator $(D-14)$, the 3-ball waste concentrator $(D-12)$, and the Phase III condenser changes (D-1I, I-3, and $F-6$ ) belng realized. Two fumpers did not fit on $\mathrm{k}-13$; one was rebullt and the other modifled in the remote shop. It was necessary to fabrlcate a replacement P-E-12 power jumper when a connector head screw galled in the open position.

Replacement jumpers were installed for J-2 temperature, H-5 recirculation and $\mathrm{E}-2$ to $\mathrm{E}-3$ jetting. The latter had plugged so solidiy in the jet that aitric acta, introduced through the plpe gallery nozzle, could not dissolve $1 t$.

Replacement of the rebolier section of the contlnuous plutonium concentrator $(L-3)$ was made necessary by leaks which developed as a result of corrosion in this vessel. This was an extremely hazardous malntenance job due to the extremely hlgh levels of plutonium contrmination present and the location of the

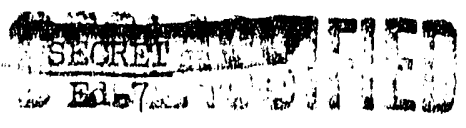


a. Cell Equipment Replacement - Redox (Continued)

equipment in the greenhouse. Most work has to be done by scaffoldlng under numerous layers of SWP clothing. Plastic man techniques were used tbroughout the job, and have been effective in minlmizing contamination spread. Several ruptures in the plastie man occurred, but were repalred without umusual spread of plutonium contamination. By month end, the job is estimated to be 90 percent complete.

A process leak in $\mathrm{H}$ cell was confirmed during the month and resulted in high waste belng reprocessed from the cell flonr sumps. Considerable Inspection effort wes made before the leak was aonm firmed as existing in the shell of the oxidizer pot $(\mathrm{H}-4)$. Inspection was bampered by the insulation around this pot which made detection of a leak in the shell diffleult. This pot will be replaced before startup. Th1s is the first case of a pot shell. leak in a canyon ressel occurring in Separations section history.

Both D-12 tower and D-12 pot were burled under radiation levels heretofore unencountered in burlal operations. The tower bur:ted on December 28 wes measurea at $1 \mathrm{r} / \mathrm{hr}$ at 200 feet, and the pct. $600 \mathrm{mr} / \mathrm{hr}$ at 300 feet. The almost prohibitive time limitis made It necessary to couplete backflling of the pot on a folluwling day when personnel recovered exposire time. Barricades were erected at the road adjacent to the burial ground, where readings were $25 \mathrm{mr} / \mathrm{hr}$, and guards posted until the pot was covered up.

b. 60 Ton Crane - Redox

Prior to starting the cell equipment replacement worts iurirg the shutdown, the crane was sprayed down with perahlorethrlene solirent. to reduce contamination levels and the crane lubricated as far as practiceble with the high radiation levels enscuntiered. A new higher powered opticel head was instialled on the right hand optical mechanian. Early in the month, a spaxe line bonk bad tis be replaced slong with an inpact wrench swivel bar. The lett hand impact wrench was replaced following the deoontamination effort.

c. Stud Replacement - Purex

Inspectirn of two studs sheared from the second awd broptrator (EF-6) tube brale f'lange list month indiceted weskness on the stud where $1 t$ was weliden to the tube bundle flange. In the time available 1 was desided to replace approximately 89 studs con.m sidered most eritical, loceted on the t've wajor consentrator tube bundles, in piplng through conerete, and in major equipment fllanges in $A, B$, and $D$ cells. When the stidd repla ementi program was about fifty persent complete twe of the new studs were broken at the upper threaded section during impating. Examimatifi. of the new studs revealed britt.leness and exsesisve lamdnees. It developed that practioally all of the first shipment of studs

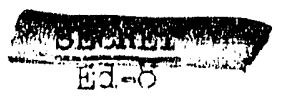


a. Stud Replacement - Purex (Continued)

from one rendor exceeded the hardness spectplcations. Subsequent shlpwents from other vendors were tested and an aceeptable hardness range was establ1shed. At month end all of the IIrst shlpwent of studs have been remored and reploced. Hork remalning to be done consists of replacement of severw studs In A and B cellis.

d. Centrifuge Replacement - Purex

The spare (G4 centrifuge, whlch was installed late last month, falled after less then 24 hours of actual operation. Prior to being placed in service the centrifuge was rum-in for 24 hours at the 272-E shop and 24 hours in G cell during which time the unit was closely inspected. The investigation rerealed fallure of the top drive hesd thrust bearing. The drive head and motor from the original G4 centrifuge was Installed.

C. Inprovement Experience

1. Process Tests and Revisions

a. Iodine Fntssion - Redox

Iodine ofssion durling the first part of the month was not a problem because of the longer age of the metal. However, lodine emission was beginning to appear as a problem at mid-month when the metal age had dropped to $\sim 90$ deys, but wes helted by the start of the scheduled shutdown.

Dhring the shutdown perlod all three silver reactors were regenerated. There was no dissolving during the latter half of the month.

b. Iadine Brission - T Plant

$I^{131}$ emissions at $T$ plant were considerably reduced this month due primarily to the increased age and the amount of motal dissolved. During the period November 22 through December 20, a total of 49.7 tons of metal was dissolved with an average cooling time of lal days. The average daliy Il3l emission during this same period was 0.03 curies.

Collection of calibration data for the new gama scintillation lodine montor contiaued this montio. All of the necessary samples hare now been taken and are currently awalting analytical analyses. It is anticlpated that callbration of the unit will be sompleted by month end.

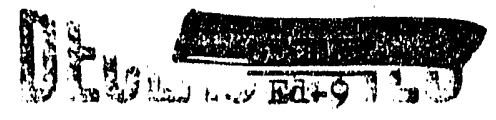


c. Waste Scarenging

The 220d tank of scavenged IBP waste was filled this month. Exceptionally good results have been obtalned on four tapks Iull of TMP scavenged weste in whlch strontium Nitrate was used as a supplenratal additive. Additional supplies of this chemical have been ordered and 1 ts routine use on a flowsheet basis has begun at month end. Consistent improvement in settling of the radioactive strontium in the wastes has occurred.

Upon completion of cribbing of the nineteenth tank of waste, the waste in storage was less than 65 percent of the original HW34t flowsheet.

d. Metal Waste Decontaminatior Test

A plant scale test was made this month to determine the fessibility of decontaminating metal waste solution with a nomal blsmuth phosphate by-product strlke. Data collected from the test indicated the decontamination factors were too low for benefiala 1 use. Further tests were discontinued.

e. Precycle Flowsheet - Redox.

Equipment 18 in the process of belng installed in the canyor which w111 permit going to a precycle flowsheet. This flowsheet will. permit using the sodium dinhromate heed end oxidation step in lien of the present $\mathrm{MNO}_{1}$, process. This Fill eliminate evolution of ruthenlum in the heas end step and reduse contanination fortontind

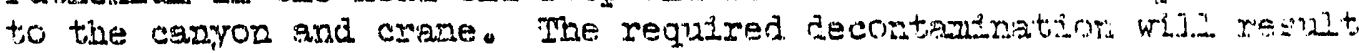

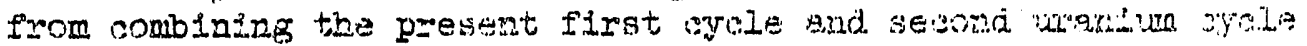

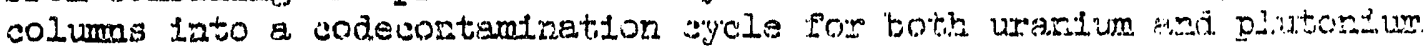
and a second lecontawination, partitionas ayclso Through this

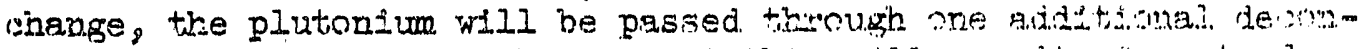

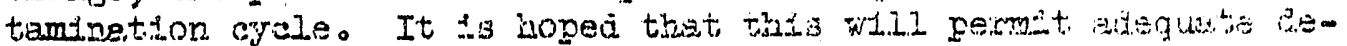
contamination of the plitonium. Equipment for protiding ais orome sparge for the finaz wonfum product to elininate the aldad gmout of mathenturn present under the new fllcwishest hais beam. lastalled.

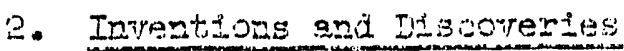

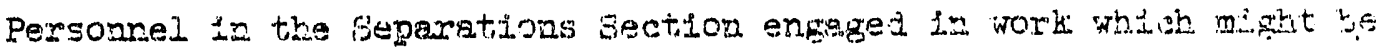
expected to result 12 laventicns or discoveries have reportied that no Inventions or disionveries were made durigg the period oorerod ky this regort.

D. Eventis Influevalng Costs

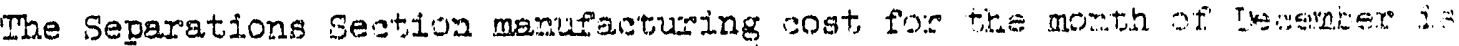
expected to increase approxlmately lo from the Novemicer leven dues,

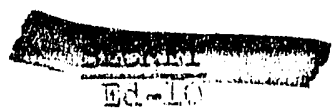


D. Events Torluencing Costa (Contlaued)

primarly, to the 1ncreased salary costs associated with the additional workelng dey in December.

Althoust the maber of Flalshed shapes fabrlcated by the Metal Fabrlcat10n facility In December is $10 \%$ vender the present record production level, the total weight of the shapes fabrieated in December, as well as the cross button production, estrblishes a new high. These record praduction levels are expected to be reflected in new lows in the untt cost of these products.

Bqulpment is beling Installed to permit backcycling the second cycle salt wastes for use in the pre (or f1rst) decontamination cycle. It is hoped that essential material savings in excess of 20 percent can be realized through reduction of Ain use. Waste storage costs should also be lowered to a figure approeching 40 percent of those presently belng experienced.

E. Plant Development and Expanston

1. Project Status

a. $C A-513-A$ - Purex

This project is approximately 99.95 perent complete. Present work consists primarily of startup items and the completion of late authorlized work. All work 1 tems are authorlzed by work orders.

b. $C A-523-E-$ Purex Expanzion

This project is approximately 75 percent complete. Major items in progress are: (1) continuous samplers (work started December 15, 1955): (P) Loatne moltors (work startied November 1, 1955): (3) Installation of probe for the $2 B$ colum Interface control; (it) absorptometer instaliation for the I Cell package.

Work on the 241-A tapk farm circulation fac1lities was started on Noprember 30, 1955, and 1.3 progressing satisfactorily. Con struction 13 erproximatiely 55 percent complete. In-tank installations are couplete.

c. CG-598 - Tacuum Acli Fractionator - Purex

Th1s project is approximately 39 percent complete. All work has beew stonped due to lack of funds. Revistion Ho. 2 of project proposal zequesting 921 1nurease of funds to $\$ 920,000$ is In preparation.

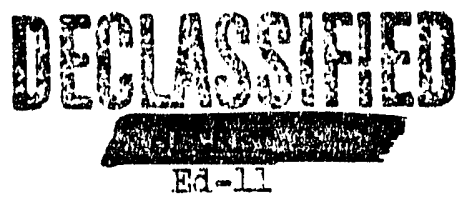


d. $\times-539-$ Addittonal Waste Storage - 24l-5X

This project is essentially cunpiete, except fur tnstrumstation work. Late delivery of the required equipment moves the completion date until Jine 1, 1956. Operational use of needed tanks is $20 \%$ possible at any time by tylng in tempurary alr anci instrumertation as required.

e. $\alpha_{i}-603-4 X$ Program, B1smuth Phosphate Plants

All projesta at 2 Plant under Project $\alpha i-403-4 \mathrm{X}$ Program have now been completed except, for the Lag Metal Storige Fracilitiss. Inds project is essentialiy complete.

The B Plant portion of $\infty-503$ was accepted on 12-23-55, with a few exceptions which wili be completed by Minor Conatriction or work orders after January 1, 1956.

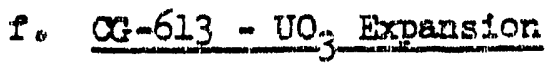

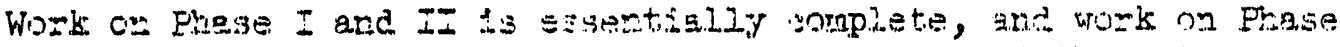

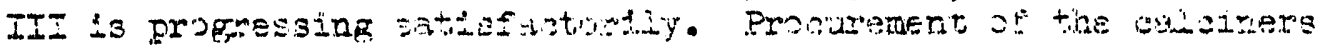

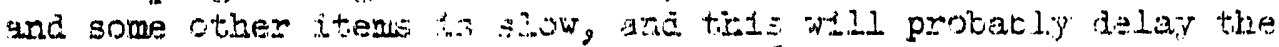

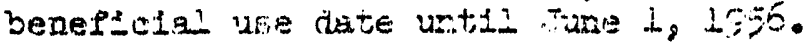

8. $00-621$ - Redox 0oxtamputidor Boptrol

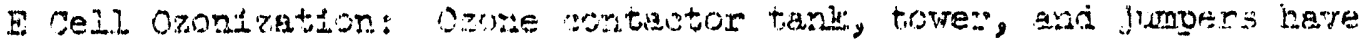

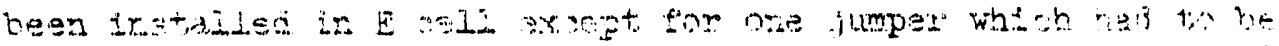

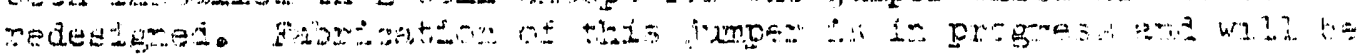

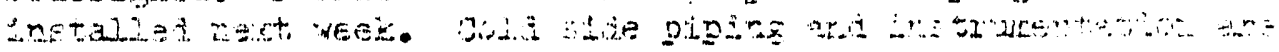

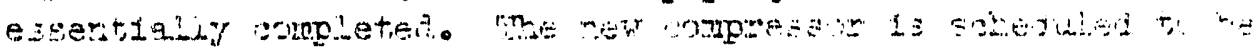

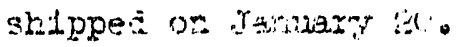

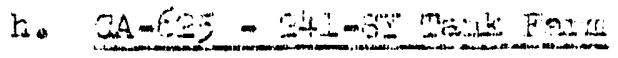

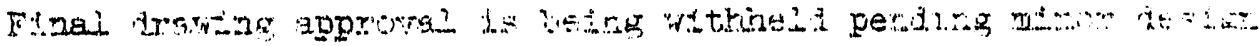
2bartge:.

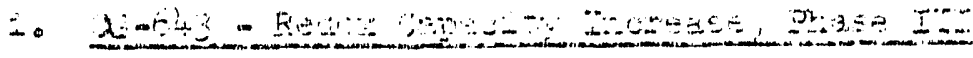

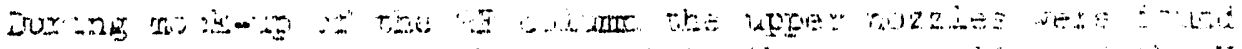

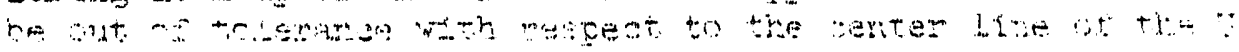

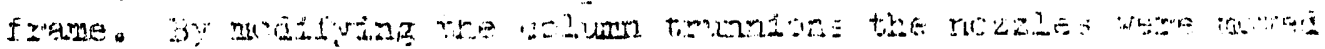

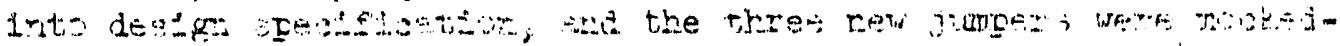

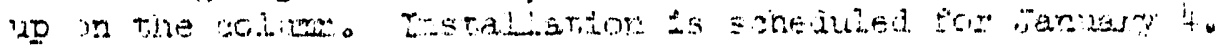

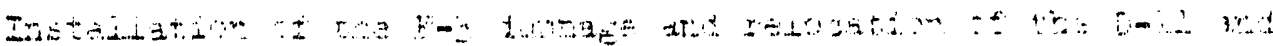

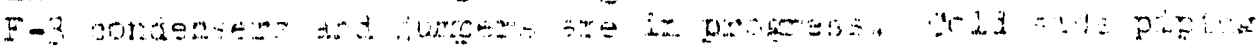
ranges ine $191 \%-2 \%$

2. Elant Enganesing

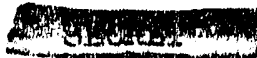


a. Work Stanlif1cation

The class sessions of the fourth Work Simpliflcation series are nearls complete. Twelve proposals have been submitted to date from the 42 operations analyzed for ingrovements.

b. Matenance Productiv1ty

Corrently, three programs are underway in the Separat1ous Section to improve maintenance productivity: 1) Preventive Mintenance; 2) Planning and scheduling; 3) Work sampling. These complement one another, and are deslgned to not oniy measure effect Ireness, but also to provide tools for improvIng this effectiveness.

The Redox preventive maintenance system, established as a model for the Separations Section, is at the present tIme funetioning at a level which is considered excellent for the short time It has been in effect. Systems are being installed In A Plant, 2 Plant and for the Power and Malatenance SubSection wader the gutdence of the Industrial Engineerine Jntt.

c. Cost Reduction - 200-5i Laundry

A layont of the present laundry factlities was developed and a layout of the proposed munttoring chonges is being prepared. Time studies of the present and proposed andoring methods hare been made to establish the possible savinga. The wrik sampliag and time lapse atovles of the washrom operatlons indicate that tie derser types of washing, extracting, and drying cen be Justifided.

d. Malntenance of Standards

A re-englneering of the 334-5 Buflding operations labor standard was started during the nonth. To date, progress has consisted at making time measurements of runctions on the back slde of the RM line, and in the mearanine work area.

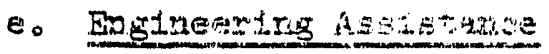

1) Tosise control

Molse control surveys were continued and several locations whilih hate roceltred correctitre measures during the perlod

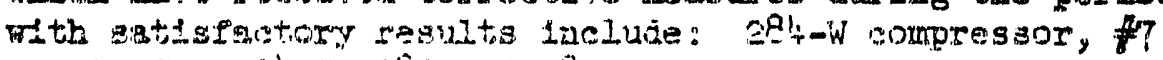
supply for $234-5,253$ and 280 East and Weat yup rooms.

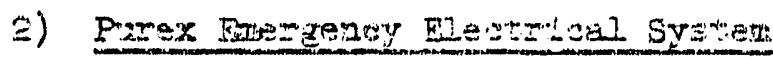

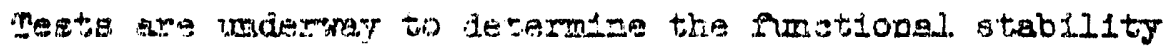

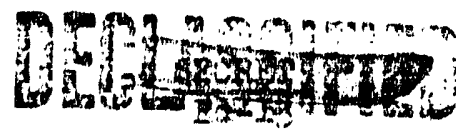


2) Purex Emergency Electrical System (Continued)

of the 200-E Ares emergency power system to sbsorb tine Purex load, and to determine the operating characteristics of the Purex emergency cifcults. Purex switchgear, which falled to operste, in the 11rst test, is curreatly undergoing correction.

\section{3) Purex Crame Bearlags}

Fallure of the origlnally insyalled wheel bearings in the Parex main erane has resulted in an extensire investigation to deteraine the cause, and correct replacement. This Investigation is being carried on in confunction with the manufacturer, the bearing supplier, and the Engineering Dem partaent.

\section{4) Deg1gen and Drafting}

Progress contiunes on the over-all as-bullt drafting program. Items completed during the period include: $T$ and $B$ plants silver-nitrate-reactor shtpping-cepsule, agl tator-assembly reference gulde, 202-S crace auxlliarles, and swivel bar for stid replacement on Purex and Redox vessels.

\section{F. Reports Issued}

1. Routine

Number

Sub jert

Auttor

$E W-40767$

Beperations Section Fedox. Plant Suk-

R.T. Tesser

HW -40805 Sect10a Monthi.y Feport - Decemeer 1355 Separations Section Metal Recovery sub. Section Montidy Report - Irecember 1955

EN- 40793 Separations Soction I Plant subusection Montialy Report, - December 1955

BW- -40744 Separations sectIon Z Plaxt Sub-Serction Monthly Reprot - Decenter 195:

BW -40763

패연 40716

Sepurations Section Radistion Mondtortug

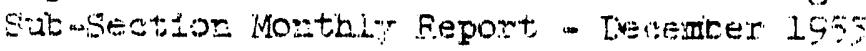

HW $-407 ? 0$ Separattong section Analyt coql Cotrol Sub-3estion Monthiy Report - Eutember 1563 Eeparations Section Projects \&ersomnel Developarert Sub - Bection Monthly Report Decencer 1955

Offlctal Use Only Separations Section Power \& Mainteranoe HW -40768 Sub-Section Monthly Report - Lecember 1955 Eeparations Gection Furex Suc-section Montily report, - Iecender 1955

None Etatue of Erofests, Irformal Requesta. Eizdget Items a [esember 1955

None Space Docupancy heport for 20C Areas recember 1955

T. Frudich

CoTo arsath

W. I. Mnsiey

Á.F. KNesRe

LoM, $K= \pm$ gint $s$

i. is. Snser

CoF, rebeil

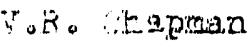

ia Rouse

V.D. Rouse

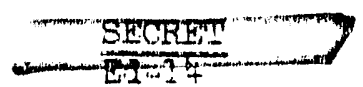


1. Boutine (Coutinued)

Number

Subject

Author

Irone

Sexri-AnnunI Gross Floor Spece Repart -

$\nabla . D$. Rouse

IfI-40eil BD

200 Areas - Januery I, 1956

UW-40e15 BD

202-S Bldgo Prodruetion sehedule for

H.F. Fev

Dacemer 1955

$\mathrm{HW}-40217 \mathrm{RD}$

221-224-In Buflding Production Schedale

H.F. Tew

for December 1955

EW-40217 RD

2 Plast Production Schedule for Decermbe: 1955

BW-40489 RD

Z Plant Procuction Schedule for

H.F. Tew

December 1955

HI) $40216 \mathrm{RD}$

TBF-TO Bldg: Production Schedule

for Deceriter 1.955

HR-40353 BD

Purex Plant Froduction Sehedule for Deceuber 1955

EH-40389 RD

Seren Month roal Foreeast

H.F、Tew

$\mathrm{BH}-40440 \mathrm{RD}$

Orfielal Qu reteriy Forecast, Separation

H.F. Tew

H.F. Ter

B.F. Ter

Sect10n - December 1955 through Jume 1956, Rer. \#2

BI)-40221

Esseitind waterlals Consumtion for T Plsat, Noverber 1955

FIT-40222

Esaential. Materials Consurption for TBSP PLaxt, rofember 1955

giv -40223

Esaential Naterids consumptior for

Redox Elant, Vrreme: 1955

HW-4OE? 4

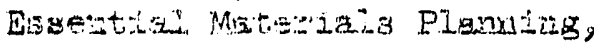

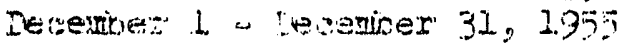

패 -40225

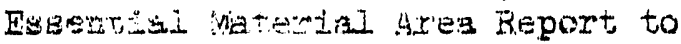

H.R. Tew

Cost, wriz Probising. Norember I

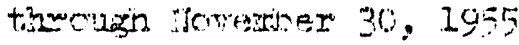

HW-40208

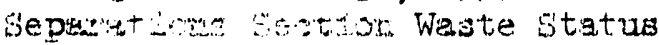

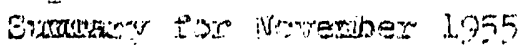

BW- 40573

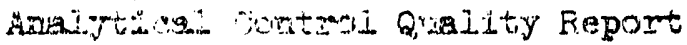

M.A. Thress

MuA. Thresi

MuA, Thress

D.E. Peterson

$M_{*} A$. Thress

D.E. Poterson

BW- 40547

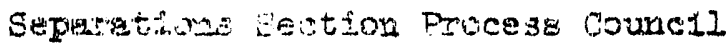
Wentora

A. Brungtad by

G. Co Horigh

C.R. Anderion

2. Mos-Rout1ide

EW 040257

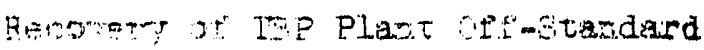

R. I. Lyon

BW -40387 RD

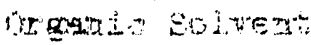

BW -4032

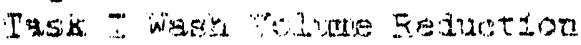

D.M. Rewell

Z Elat Procesen Mproments raaka $I_{0}$

D M. Newe11

BW -40293

BW 40559 $=\pi \quad 5+2 \quad--$

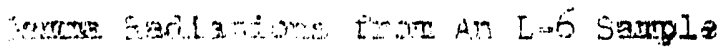

F. R. Helmol2

EW 404047

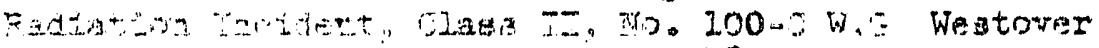

BW 4070764

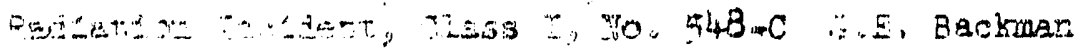

Hector I, Ho, 550-C R No Donelson

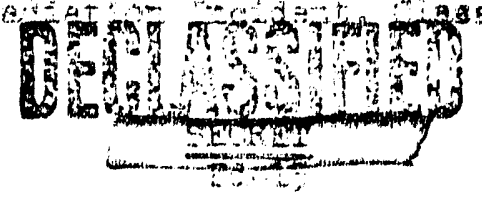


2. Non-Routine (Continued)

\begin{tabular}{|c|c|c|}
\hline Number & Subject & Author \\
\hline $\begin{array}{l}\text { BW-40721 } \\
\text { BW-40765 } \\
\text { None }\end{array}$ & $\begin{array}{l}\text { Radiation Incldent, Class I, No. } 552-R \\
\text { Radiation Inc1dent, Class I, No. } 553-\mathrm{C} \\
\text { Tr1p Report - Manufacturing Time Standards } \\
\text { Conference o Schenectady }\end{array}$ & $\begin{array}{l}\text { NoP. N1sick } \\
\text { G.E. Ba,ckman } \\
\text { R.M. Shervem }\end{array}$ \\
\hline$B W-40447$ & $\begin{array}{l}\text { Study of Froduct and Recycle Can Transporta- } \\
\text { tion }\end{array}$ & V.P. Madsen \\
\hline None & $\begin{array}{l}\text { Redox Plant Essential Materlals Consumption } \\
\text { Study }\end{array}$ & G.K. Carpenter \\
\hline
\end{tabular}

III. PERRSONNEE

A. Foree Stmary

\begin{tabular}{|c|c|c|c|}
\hline & $\begin{array}{l}\text { Start of } \\
\text { Month } \\
\end{array}$ & $\begin{array}{l}\text { End of } \\
\text { Morth }\end{array}$ & $\begin{array}{c}\text { Net } \\
\text { Change }\end{array}$ \\
\hline SectIon General & 1 & 1 & $n$ \\
\hline Redox Plant Sub-Section & 32 & 227 & Sit \\
\hline Metal Recovery Plant SubmSeotion & 242 & $z^{\prime}+1$ & $\therefore 1$ \\
\hline Z Plant Sub-section & $17 ?$ & 180 & a \\
\hline T Plant Sub-Section & 207 & 193 & $=2 \frac{1}{4}$ \\
\hline Purex Flant sub-Section & 28 & $\infty$ & \% \\
\hline Power and Maintenance sub-ïection & 319 & 3 & $i$ \\
\hline Projects \& Personnel Development inosection & 63 & 61 & \\
\hline Anelytareal Control 3ub-osertion & $\because$ & . & 6 \\
\hline Radiation Monitoring sab-jection & 132 & 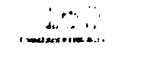 & $\therefore$ \\
\hline Sectzon Total & $1 \%$ & $i i^{2}$ & in \\
\hline
\end{tabular}

B. Safety

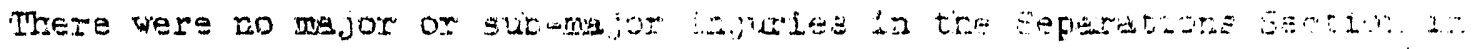

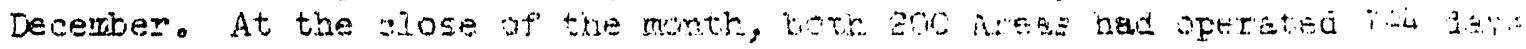

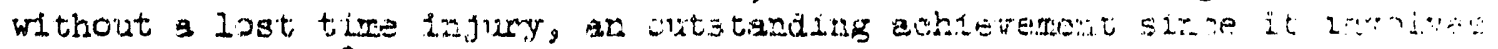
approxinately 9,800, oun exposide nas hour:

O. Fadiation tixpeziense

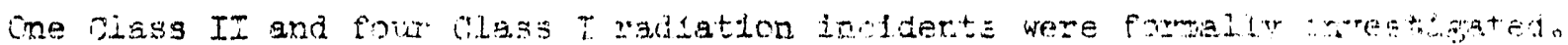

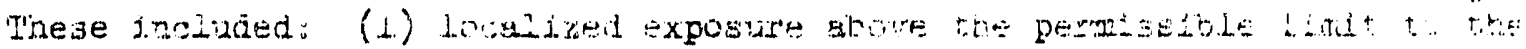
hands of en operator wro resel red spotty ortsoleatson on bis glores durtes

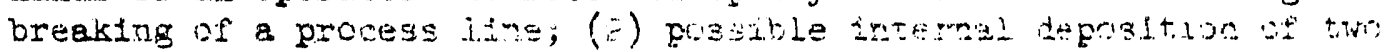

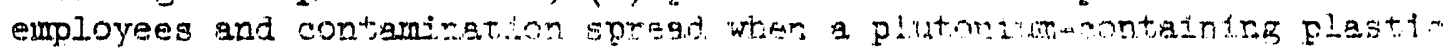

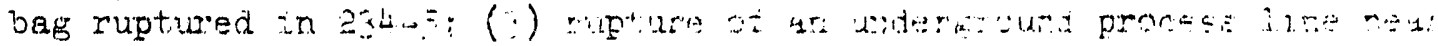

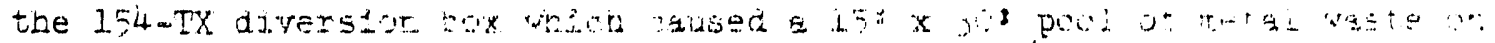

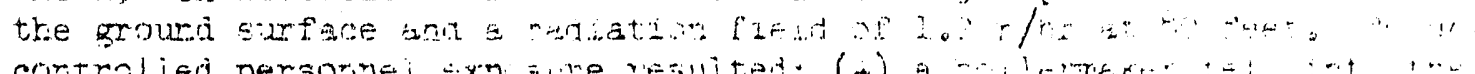

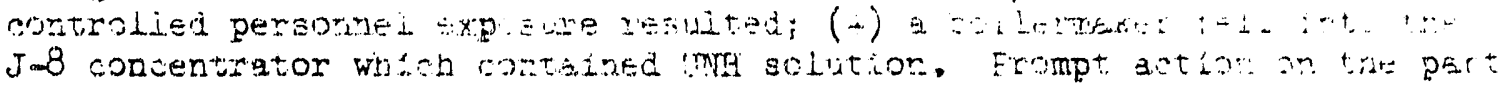


C. Radiation Expertience (Continued)

of nearby employees minlmized 1nternal deposition of uranium which was laftially estimated to be less than 10\% of the MPL; and (5) uncontrolled exposure to an instrment trainee who recelved $110 \mathrm{mr}$ when he unkoorlagly exposed himself to a dose-rate of $18 \mathrm{r} / \mathrm{hr}$ for a Iew seconds during the burlal. of the D-12 tower at the Redox Plant.

Iodine enfission was extremely low as a result of reduced production. Approximately 8 curles of Il3I were emitted; essentialfy all from Bedox.

Studies by Radiation Monftoring Anglysts lndicated higher surface dose rates, from uncoated and coeted plutonlum metal than are currently used in the 234-5 Bufllding. Th13 has developed from Improved instrimeatation and techniques for accurately measuring the surface gamma dose rate. Studies are underway to elininate as much contact handing of metalile plutonium as possible. Several improvements, which are expected to give some relief from contact hand exposures, are the lapping machine just recelved for use in the mating operation and Iead Impregnated plastic gloves which are undergoling tests. The surface dose rates from "normal" metallic plutonlum now are determined to be ca $350 \mathrm{mr} / \mathrm{hr}$ from coated metal and $1700 \mathrm{mr} / \mathrm{hr}$ from uncoated metal -- approxinately a $40 \%$ increase from previously estimated dose rates.

D. Fersonnel Activities

1. Programs

Durlas the month the trafning program activities were as follows:

Program

For Exempt Ro11:

Job Relations Development

For Ton-Exempt Roll:

GE Selection Program

New Joyee arlentation Purex F1] no.

Work simpiffieation

2. V1s1ts

M. J.R. Barber from duPont, Savannah River, Vislted the 2 Flant on December 5 and 6 and reviewed arallable inpopmation on process equipment and time eycles of the fabricstion facility.

H. R. Toczek recrulted technlcal personnel at severen schools In Texas and Bew Mextco during the per1od November 27 through Dersember 7, 1955。

\section{Attendance}

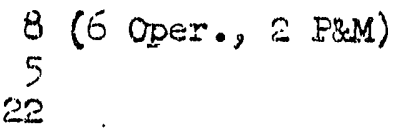

136 


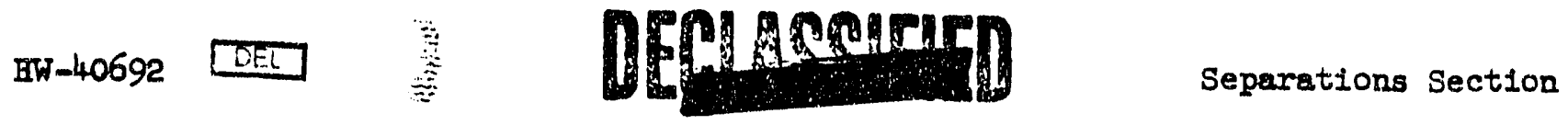

2. V1sits (Cont1nued)

R. B. Abrams and H. F. Soule visited Oak Ridge as members of the document survey team.

L. M. KnIghts attended an AEC Accountability Coumittee Meeting at the Argonne Nat1onal Laboratory on December lst and 2nd. 
Jenuary 10, 1956

HIECTRICAI UIIIITY SECTION

MONTHIY RHPORT

December, 1955

\section{RESPONSIBIITITY}

There were no changes in Section responslbility.

II. ACEIEVAMENTII

A. Operating Hoperience

Power Stat1st1os (Seo last page for detalls)

Plant Contract

Probable time of December Peak . . 2:00 - 2:30 p.m., December 29, 1955

Telometered peat for December. . . . . . . . 178,500 KW

Probable Billing Demand for December . . . . . . 190,000 KWW

Probeble energy consumption for December ....... 112,30I MWH

Actual BPA Metered Demand for Notrember . . . . . 178,676 KW

Actual B1Iling Demand for INotember .......... 185,000 KW

Actual energy consumption for Norember . . . . . . 106,409 MWH Aterage monthly energy consumption-5 months of Flscal

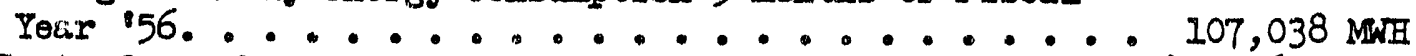

Cost of purchesed electric1ty for Norember ...... $\$ 270,602$

Actual cost of purchased eloctricity for 5 months of

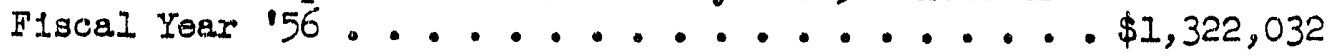

$$
\text { **** }
$$

SyBtem frequency dropped to 59.8 cyclea at $4: 50$ p.m., December 1 , and returned to normal. in two minutes with no effect upon production. The fluctuation was caused by two Mcllary Dam generetors relaylng out.

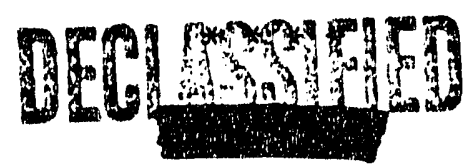

Ex-1 


\section{DEGListomitD}

HW -40692

A surge on the BPA and. EAPO electrical systems occurred at 3:05 a.m., December 8, when 500 My of seneration was lost to two lines feeding from McNary, trigsered by a fault on the Salem-Albany (Oregon) Iine. No effect on production was reported.

$* * * *$

At approrimately 8:30 a.m. on December 12, a service Ine in 200-W waa toin down by a Power and Malntenance motor crane cauging a power outage at the 291-U, 222-U and 2704-U Bulldings. The transformers were re-fused at 9:43 a.m. and Iine repalrs amounted to approximately $\$ 100.00$

At 4:15 a.Ill. on December 16, system Prequency dropped to 59.43 cjcies and returned to normal in three minutes with no adverse effect on HAPO production. The trouble wes due to a BPA transformer f'allure at Albang, Oregon, calasing MoNery to drop 500 MH load.

Mocontary minor surges occurred around 3:10 p.m., December 22, due to BPA troublo on tho WaIla Walla-Colfax Iine and a momentary frequesey drop to $59.7 \mathrm{cjcles}$ occurred later due to a line relaying out at Hungry Horse Dam. There was no effect upon plant operations.

\section{B. Equirment Experience}

Weather conditions provalilng orer the weekend of December 18 caused arcossive leing of the power and control linas bordering the 107 Baslins in 100-B, $H$, and F Argas. Iine crews were callod out on th at:

$$
\text { **** }
$$

Ground Finds which reachad "Tl MPH on the aftemoon of December 22, caused a fite hour outage in white Bluffa and the vicinity of Hariford. Distribution lines bis tagether at three other locations

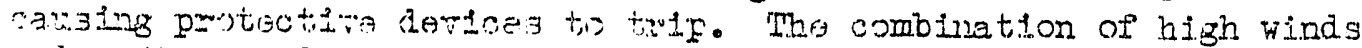

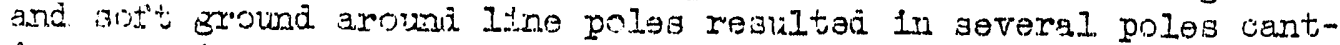
ine, requiring roglimmerst, There were no power Interruptions to production fac1litiss due to the storm, but damage to the electrigal systern is estimated at $\$ 2000$.
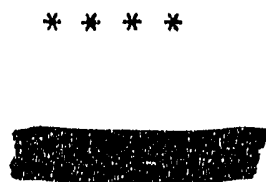

$\operatorname{Eg}-2$ 


\section{Erents Influenclog Costs}

Due to the Increasing vartance between the EAPO actual power demands and the contracted or bliling demands, a reallstic modification of the remeining FY 1956 schedule of contracted demanda w1II be sought in January, 1956. The variance has occurred because expoctod production and construction loads scheduled for thls period have not terlallzed.

Orertime hours expended were appraximately $2.9 \%$ of the total regular hours rorked.

Attendance for the month was $97.89 \%$.

\section{Plant Development and Propangion}

CA-586: Minor Construction forces conpleted the lnstallation of control cables in the 100-K tunnel between the Substation Operating room and the oll circult breaker position. Contractor forces are setting the footings for the 230-KV ateel transmission towers. On Decomber 14, BPA cut-over the Hanford Substation power source from their Mldway Sibstation IIne to a $115 \mathrm{KV}$ IIne feoding from thols Benton swltahing station.

$$
\text { **** }
$$

CG-558: Cable was t1ed in at the 151-B Substation preparatory to testing the first 4500 EP moter. Work continued throughout this month on the molification of the five pair of switch compertments in 151-D which will provide acoommodations for ten single feeders. Section forces ren insulation tests on 1,300 feet of $13.8 \mathrm{KV}$ cable Installed by Minor Construction betwoen 190-B Annex end the 1.51-B Substation.

$$
\text { * * * * }
$$

\section{ORGANIZATION AND PERSONNEI}

A. Organization

No changes in streucture or nomenclatiure.

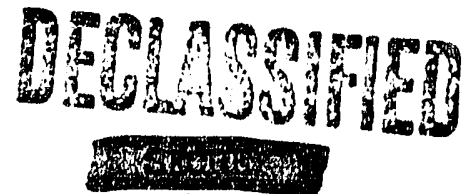

Eө-3 


\section{B. Forse Sumary}

HW-40692.?

$\begin{array}{lccc} & \text { Beginning } & \text { Ending } & \text { Net Change } \\ \text { Trempt Personnel } & 17 & 17 & 0 \\ \text { Dispatchers } & 5 & 5 & 0 \\ \text { Electricions } & 11 & 11 & 0 \\ \text { Iinemen } & 23 & 22 & 1 \\ \text { Substation Operators } & 32 & 32 & 0 \\ \text { Secretary } & 1 & 1 & 0 \\ \text { Stenographer } & 1 & 1 & 0 \\ \text { Clerics } & 2 & 2 & 0 \\ \text { Drafteman } & 1 & 1 & 0 \\ & 93 & 92 & 1\end{array}$

One Ineman was transferred to Substation Operation and one substation operator trengferred. to Rediation Monitorlng during the montus.

\section{Safotr Popertonce}

Two minor Infurles were reported during the month.

D. Radiation Experience

No licldenta were reported during the month.

\#. Porsone? Actirittes

At, the Section monthiy informative meoting, R. S. Bell, Manager 2. Reactor Section, expluired thelr cperational emergeney back-ups

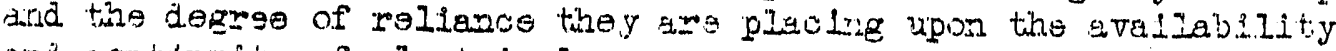
ial ountinufty of electrical power.

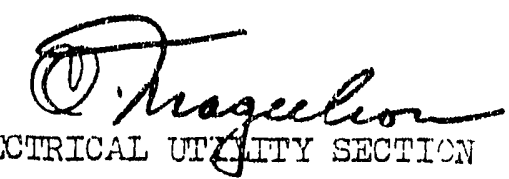

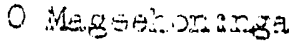

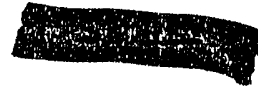

E. $\div$ : 


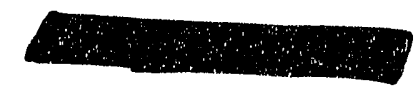

POWHR STATISTICS

HLECTRICAL DWITTTYY SECTION

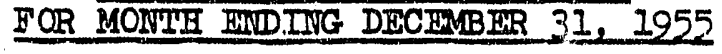

\begin{tabular}{|c|c|c|c|c|c|c|}
\hline & \multicolumn{2}{|c|}{ FINHRGI - MU IIRS. } & \multicolumn{2}{|c|}{ MAITMTM DEMAND-KW } & \multicolumn{2}{|c|}{ IOAD FACTOR-\% } \\
\hline & $\begin{array}{l}\text { Iast } \\
\text { Month }\end{array}$ & $\begin{array}{l}\text { Th1s } \\
\text { Month }\end{array}$ & $\begin{array}{l}\text { Iast } \\
\text { Month }\end{array}$ & $\begin{array}{l}\text { Th1s } \\
\text { Month }\end{array}$ & $\begin{array}{l}\text { Iast } \\
\text { Month }\end{array}$ & $\begin{array}{r}\text { ThIs } \\
\text { Menth }\end{array}$ \\
\hline $230 \mathrm{KV}$ System & & & & & & \\
\hline$A-2$ Out $(100-B)$ & 23390 & 28180 & 46800 & 46800 & 69.4 & 80.9 \\
\hline$A-4$ Out $(100-D)$ & $1+650$ & 12220 & 27000 & 26700 & 75.4 & 61.5 \\
\hline A-5 Out $(100-B)$ & 10710 & 9210 & 17250 & 17000 & 86.2 & 72.8 \\
\hline$A-6$ out $(100-F)$ & 6730 & 8580 & 14200 & 14800 & 65.8 & 77.9 \\
\hline A- 7 Out $(100-E \mathrm{KN})$ & 18528 & 21024 & 32500 & 32500 & 79.2 & 86.9 \\
\hline$A-8$ oxt $(200$ Ares $)$ & 6990 & 7300 & .27400 & 11400 & 85.2 & 86.1 \\
\hline$A-7$ Out $(100-K E)$ & 20172 & 21024 & 33750 & 33000 & 82.8 & 85.6 \\
\hline TCTAR OUT & 101110 & 107538 & $182900 *$ & $182200^{*}$ & -- & $-\infty$ \\
\hline MIDXAY III & 102671 & 109288 & 173600 & 174400 & 82.2 & 84.2 \\
\hline I15 IV Systam (300 Area) & & & & & & \\
\hline $\mathrm{BB} 3-\mathrm{S} 4 \mathrm{Out}$ & 2496 & 2624 & 4720 & 4720 & 73.4 & 74.7 \\
\hline $125-66$ KV Svatom & & & & & & \\
\hline 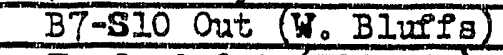 & 300 & 32.4 & 787 & 810 & 54.0 & 53.7 \\
\hline Henford Out $(7200 \mathrm{~V})$. & 51 & 50 & -- & -- & -- & $-\infty$ \\
\hline Hariford In & 350 & 389 & 1000 & 1100 & 48.6 & 47.5 \\
\hline Project Total In & 105517 & 172301 & $179320 *$ & $180220 *$ & $-\infty$ & -- \\
\hline
\end{tabular}

* Dezotea NCn-Colncidental Demend

Average Power Factor - $230 \mathrm{KV}$ Systam 86.3

\section{DECLASSFIED}

ntsing

Ee-5 
MANUFACTURTNG DEPARTMENT

PURCHASING AND STORES SECTION

MONTHLY REPORT DECEMBER, 1955

\section{Responsibility}

With the transfer of patent and contract functions and personnel from Engineering, Purchasing and Stores Section assumed the responsibility for handling all patent and contract activitios for HAPO (excluding the Reime Contract):

II Achievement

\section{STATISTICS}

October November December Average

Purchasing Sub-Section

Emergency requisitions rec'd

Employee \& Public Relations

Engineering

Manufacturing

Medical

Minor Construction

Radiological Sciences

Stores

Total

Average per day

$\begin{array}{rr}32 & 34 \\ 77 & 82 \\ 120 & 116 \\ 6 & 5 \\ 78 & 75 \\ 2 & 1 \\ 130 & 177 \\ \frac{115}{415} & 430 \\ 21.2 & 21.5\end{array}$

22

63

122

2

93

2
173

$\frac{173}{477}$

22.7

19

60

89

4

119

4
178

$\frac{118}{413}$

19.7

Total requisitions

On hand start of month

1,016

Received

2,624

Placed

On hand end of month

2,678

962

* Do not include those assigned to AEC, Viz: $\quad 508$

Number of purchase orders placed

\begin{tabular}{lr}
\hline Ceneral Supplies Unit & $1,53 j$ \\
Process Equipment Unit & 501 \\
Essential Material Unit & 30 \\
Local Purchase & $\frac{95}{2,222}$ \\
&
\end{tabular}

Value of purchase orders placed

General Supplies Unit \$374,753

Process Equipment Unit

Essential Material Unit

Local Purchase

Total
947,709

$1,091,574$

$\$ 2,414,568$

$$
\begin{array}{r}
962 \\
2,738 \\
2,841 \\
859
\end{array}
$$

434

$$
\begin{array}{r}
1,860 \\
602 \\
20 \\
121 \\
\hline 2,603
\end{array}
$$
$\$ 693,510$ 613,607 704,647
$\frac{966}{\$ 2,012,730}$

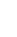

$\$ 474,173$

$38 \$ .705$
700,057

859

2,748

2,602

1,005

$$
\begin{array}{r}
972 \\
2,081 \\
2,696 \\
957
\end{array}
$$

543

432

$\frac{1,384}{\$ 1,501,619}$

\$ 507,546 749,014
705,646

1,689

415
26

524

$\frac{161}{2,147}$

$\frac{99}{2,338}$

$\frac{759}{4,950,965}$

Purchase order alterations

Gromber value

266
$\$ 359,188$

307
$\$ \quad 282,189$

294

$$
E f-1
$$


II Achievement - (Cont.)

Purchasing Sub-Section (Cont.)

Expediting

Orders on hand start of month 2,728

Orders received

Orders completed

Orders on hand end of month 2,718

\begin{tabular}{c} 
October \\
\hline nth $\quad 2,728$ \\
2,154 \\
2,164 \\
2,718
\end{tabular}

Stores Sub-Section

General Supplies

Store orders processed

Value of issues

Iine items in account

Back orders on hand

Out of stock items

Percent of line items qut of stock

29,454
$\$ 379,342$
29,439
534
249
26,553
$\$ 274,915$
31,341
798
350

.8

I.1.

1,826
$\$ 174,152$
30,004
383
264

1,354
$\$ 113,133$
30,152
306
219

36,285
$\$ 357,203$

30,042

908

425

2,947
1,944

2,025

2,666

FI 1956

Average

2,762

2,238

2,261

2,739

Spare Parts

Store orders processed

$\nabla a j u e$ of issues

Iine items in account

Back orders on hand

Out of stock items

1.4

28,890

$\$ 306,401$

30,162

592

251

.8

Percent of line items out of stock

.9

.7

Receiving

Shipments received

Receiving reports issued.

6,508

6,313

4,870

5,709

6,280
6,034

6,132

6,239

Excess Material \& Equipment

Received
Issues to Project
Shipped off-Project
Revenue from scrap and
surplus sales

$\$ 232,564$

$?, 222$

16,539

$\$ 65,782$

16,406

73,953

$\$ 142,366$
1,677
63,430

$\$ 181,02.9$

8,189

50,262

$\$ 55,566$

$\$ 15,717$

$\$ 42,663$

$\$ 30,34$

Requisitions screened

Items screened

Items furnished
2,428
6,424
591

2,529

7,021

778

\section{Traffic}

Savings

Rate reductions

Freight bill audit,

$\begin{array}{ll}4,574 & 6,386 \\ 4,654 & 1,287\end{array}$

$\$ 1,610$

2,437

\$3,766

2,194

Savings since - September 1,1946 to date $\$ 1,987,920$

Money recovered - Claims

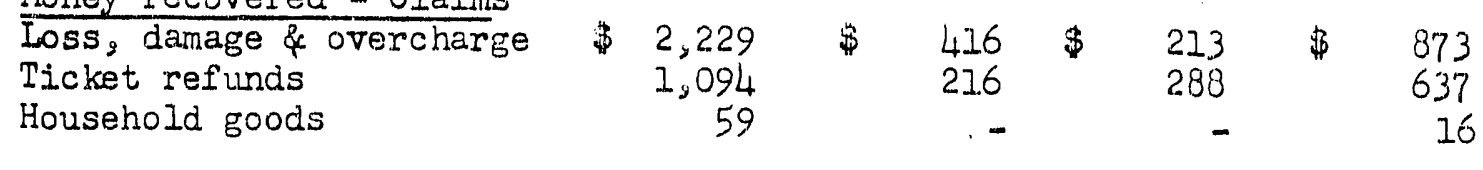

Money recovered - September $1,194,6$ to date $\$ 218,493$

Ef -2 


Cctober. November December Average

\begin{tabular}{|c|c|c|c|c|}
\hline $\begin{array}{l}\text { Work volune } \\
\text { TraveI requests } \\
\text { Reservations mado } \\
\text { Expense accounts checked } \\
\text { Shipmentis traced } \\
\text { Rotations furnished }\end{array}$ & $\begin{array}{l}146 \\
522 \\
182 \\
143\end{array}$ & $\begin{array}{r}184 \\
571 \\
240 \\
98\end{array}$ & $\begin{array}{r}109 \\
294 \\
156 \\
92\end{array}$ & $\begin{array}{l}141 \\
143 \\
193 \\
117\end{array}$ \\
\hline $\begin{array}{l}\text { rates and routes } \\
\text { Froight bills approved } \\
\text { drwounts } \\
\text { Carload shipments received }\end{array}$ & $\begin{array}{r}662 \\
1,591 \\
\$ 303,257 \\
948\end{array}$ & $\begin{array}{r}501 \\
1,546 \\
\$ 294,056 \\
914\end{array}$ & $\begin{array}{r}598 \\
1,714 \\
\$ 293,263 \\
932\end{array}$ & $\begin{array}{r}593 \\
1,527 \\
\$ 280,347 \\
844\end{array}$ \\
\hline $\begin{array}{l}\text { Tonnage Report } \\
\text { Tons received by common ca } \\
\text { Total cost } \\
\text { Average cost per ton }\end{array}$ & $\begin{array}{r}\text { ier59, } 582 \\
\$ 342,388 \\
\$ 5.746\end{array}$ & $\begin{array}{r}57,473 \\
\$ 323,807 \\
\$ 5.634\end{array}$ & $\begin{array}{r}58,715 \\
\$ 318,000 \\
5 \quad .416\end{array}$ & $\begin{array}{r}53,654 \\
\$ 305,421 \\
\$ 5.757\end{array}$ \\
\hline
\end{tabular}

The physical inventory of Automotive Parts held in Stores which was scheduled for December 13 th and 14 th was completed by 10 NM on the 14th. Through advance planning and the cooperation of ali personnel involved some 9000 line items were inventoried in the shortest time to date for this class of material.

The practice of contacting the fleld to determine if substitute material can be used to f1If store orders, which otherwise would be back ordered, is workIng well as approximately $60 \%$ of field contacts have resulted in the acceptance of substitute items.

During the month 60 declarations of excess, consisting of 1,358 items; 36 property disposals covering 1,631. items and six truck loads of scrap were received. In addition 76 shipping documents with a total weight of $1,833,675$ pounds were shipped off the project. The removal of property covered by four surplus and one scrap sale was completed and three surplus sales are currentir open.

The usual year end influx of shipments into Receiving was experienced. Although the Christmas and New Years holidays added to the dffficulties in processing shipments the operation remained current and overtime was not required.

Arrangernents are being made to establish an Excess yard at the 101 Building at Hanford, to handle an estimated 15 to 30 million dollars of excess materials which will be removed during the complotion of Project CG..558. This program is scheduled to start during March and continue throughout 1956.

Foxboro Co. was low biddex on power calculators required by Project $C G-558$ but the quotation was not acceptable from a delivery standpoint. Representatives of Purchasing and Erigineering, by a trip to the Foxboro plant, negotiated a satisfactory delivery schedule and placed an orden for the two additional calculators required.

The vendor for two absorber towers required by Project CG-613 advised that. they could not weet their shipoing promise. In consideration of an extension of slipping schedules, which will still meet construction requirements, the vendor agreed to liquidated damages provision of $\$ 1000$ a day for each day they

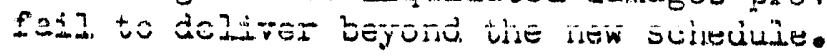




\section{Lehiovanent - (Cont.)}

Hanford stainless steel specifications in the new 8000 series were reviewed during the month by the various sections on the plant, and modifications were agreed to which remored of the objections of the steel mills and warehouses. It is felt that the modifications willl be acceptable to our suppliers, but a few weeks of experience in attenpting to place orders will be neede. before we can state categoricazis that they are acceptable.

An estimated procurement schedule for major process equipment items for Projects CG -647 and 648 , nitric acid recovery and iodine removal for Purex and Redox, was furnlshed to Bnginering during the month. It is apparent from this schedule that oquipwent cannot be procured in time to meet the desired December, 1956 project completion date utilizing established procurement practice. However, thus far wo have not been able to develop backing to request Commission approva]. to utilize procurement practices needed to even approach the required dates.

As a result of the prolonged strike at Westinghouse, two HAPO orders for motor rewinding and control - switchgear and an ABC order for substation equipment, all for CG 558 , are becoming criticaln Although we are informed that skeleton crews are worlding on these orders, progress is very slow.

Negotiations with the three coal suppliers for HAPO, Kenmerer, Republic, and Northwest Inprovement $C_{0}$. on an increase in the price of coal, in accordance with the terms of their respective contracts, were completed. This increase resulted from the recent round of wage increases to coal miners. All suppliers agreed to meet the offer of the lowest bidder, Kemmerer, in terms of BTU per If.

Supplement No. I to Contrast MRO-I was executed. This extends the original BCA Electron Microscope repair and maintenance contract to November 30, 1956.

A swmary of patent activity as of the end of 1955 is detajlod below.

Total invention reports processed through HAFO from June 16, 1947 through December 31, 1955

658

Number of invention reports currently active

Number of applications filed by AEC and awards made to inventors

71

Number of applications to be flled by AEC .. No awards made as yot (in process)

Number of applications returned by $\triangle E C$, Will not patent, nor will GE patent

Number of applications returned by AEC:

Review by $\mathrm{GE}$ pending

Number of applications released to inventors

Adequate maintenance of electric handling equipment has been difficul.t in the past due to la ck of standby equipment to replace that taken out of service for maintenance work. Recently additional equipment became available which, coupled with the transfer of responsibility for mechanical maintenance to the Transportation Section, will permit a reguli r maintenance program without impeding zctivities.

$$
\text { Ef }-4
$$




\section{Schievement - (Cont.)}

in informal request for $\$ 17,000$ covering improvements in the automotive parts room in Building 1771 was completed during the month and is being routed to the AEC for approval.

\section{Organization \& Personnel}

\section{Force Summary}

\begin{tabular}{|c|c|c|c|c|c|c|c|c|c|}
\hline \multirow{7}{*}{\multicolumn{2}{|c|}{$\begin{array}{l}\text { Component } \\
\text { General } \\
\text { Contract Unit } \\
\text { Traffic } \\
\text { Purchasing Sub-Section } \\
\text { Stores Sub-Section }\end{array}$}} & & & \multicolumn{3}{|c|}{$12-31-55$} & \multicolumn{3}{|c|}{ Change } \\
\hline & Ex. & $\bar{N} \cdot \overline{E X}$. & $\bar{T}$ & $\overline{E x}$. & N.Ex. & T & $\overline{E X_{0}}$ & N.EX. & \\
\hline & 3 & 3 & 6 & 2 & 2 & 4 & (I) & (I) & (2) \\
\hline & - & - & - & 2. & 2 & 4 & 2 & 2 & 4 \\
\hline & 3 & 3 & 9 & 3 & 6 & 9 & $=$ & - & - \\
\hline & & 56 & 97 & 42 & 61 & 103 & 1 & 5 & 6 \\
\hline & $\frac{12}{59}$ & $-\frac{153}{218}$ & $\frac{165}{277}$ & $\frac{12}{6.1}$ & $\frac{155}{226}$ & $\frac{167}{287}$ & $\overline{F 2}$ & $\frac{2}{178}$ & $\frac{2}{10}$ \\
\hline
\end{tabular}

Rffective December 1, 1955 a Contract Unit was established. This Unit consists of the former Contracts Analyst - D. S. Cameron, a Contract Engineer - W.C. Poe, transferred from Engineering, and two clerical personnel.

\section{Safety Experience}

Five minor infuries were reported.

Six safety and security meetings were held during the month with a total of 15 ' 8 employees attending.

\section{Radiation Experience}

Some difficulty has been experienced in receiving and storing radioactive shipments. Rays emitted from these shipments have exceeded allowable levels for areas not classified as contaminated areas. Methods of shielding are being investigated which if not satisfactory may lead to the installation of some form of lead shielding. Employees handling these shipments bave been provided with exposure badges and meters. 


\section{DECLASSIFIED \\ TRANSPORTAIIION SECTION \\ MONTELY REPORT \\ December 1955}

Transportation section persannel far ces decreased from 490 to 487 by two transfers in, thre transfers out, one termination, and one deactivation - personal illness.

Transportation Section expenditures for the first fivo months of Fy 1.956 totaled $\$ 1,684,574$ which is an increase of $1.11 \%$ or 18,540 over the same period in FY 1955 . The tncreaso is due to higher salaries of 12,039 , greater material requirements of $\$ 15,285$ primarily for the older bus fleot, and a net reduction of $\$ 8,784$ in overhead accounts. The following indicates comparative costs by major service functions:

Function

Rajilroad

Flant Bus

Heavy Equipment Maintenance

Light Equ ipment Mainteriance

Road Maintenarice
Fy 1956

Ist 5 mos.

$\$ 301,188$

583,554

243,099

252,518

85,229
FY 1955

lst 5 mos.

$\$ 312,896$

548,047

228,258

278,315

59,507
$\%$ of

Variance

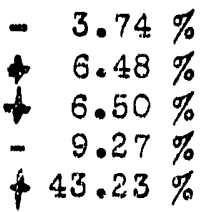

* The increase is mainly due to special work on walkways and parking areas and ice and snow control on primary roads.

Listed below are unit cost statistics for the first five months compared with the performance bogeys for FY 1956 and FY 1955 actuals

Railroad

Cost por car handled - Cominerial Process Average
FY 1956

lst $5 \mathrm{mos}$.

$\$ 30.61$ 237.28 52.28
FY 1956 Bogey

$\$ 29.73$ 232.4 .0 52.34
FY 1955 Actual

$\$ 31.46$ 241.89

52.97

Plant Bus

$$
\begin{aligned}
\text { Cost per mile - } & \text { Operating } \\
& \text { Mai ntenance } \\
& \text { Total }
\end{aligned}
$$

Light Equipment

Cost per mile - Maintenance

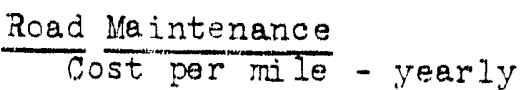

(Primary roads based on 201 roadway seal coating not included)

Seal coating - per sq.ydo for surfaced areas

.4037

.1323

.5360

.0622

288.31

3.7 .74

.0689

.0614

.1281

.5454

.4043

.1268

.5311

.0905

.1108

.11 .34

Track Mairtenance

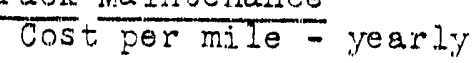

$2,577.18$

$2,698.82$

The INE rate for the Track Maintenance Unit was increased from $65 \%$ to $70 \%$ in December. Liquidation rates for Plant Bus service have been reduced fram $\$ 25$ to 24 for the 100 Areas and from $\$ 20$ to $\$ 19$ for the 20 Areas. 
Transportation Section

Completed reason sheats to provide a Transportation Change House Facility in the 200-West Area and to cover Electric Imnersion Heaters for Asphalt Storage Tanks at Fanford. These proposed projects are being included in the construction Budget at en estimated total cost of $\$ 22,860$. Previously budgeted items for Transportation Facilitios in the 200-East Area, and Widening Stevens Drive - Consolidated Transportation Facilitios and Central stores have been canceled since it is reasonably cortain they will not be required.

Received revised manpower ceilings which are six poople below the FY 1956 Midyear Bidget Review。 The new ceilings allow a maximum of seven additions between Novemior 30, 1955 and June 30, 1956 which wi 11 b e adequate for normal operating requirements. Additiom information has been requested from the Commission on the HOO POOI Program with respect to magnitude and timetablo. Present indications are that this program will necessitate additional manpower and materials when it gets fully under way.

Nineteen units of HO equipment were furnished to the Bichland, Kennewick, and
Pasco post offices for the Christmas Season at the request of the Commission.
These vehicles were supplied without charge inasmac as they were made avail-
able from the pool and did not require special preparatory repairs. All
vehicles were filled with gasoline and returned on the same basis. Maintenance
and service expenses were borne by the respective post offices durinc the loan
period. No visible damages or abnormal wear were detected.

The annual physical 1uventory of Road Materials (0420-930) was conducted on December 29 in cooperation with the Inventory Accounting Unit. This completes the cycle on all material inventories under the custody of the Transportation section. Sevoral procodural and control refinements in inventory administration have been devised during the past yoar.

Two of the thirty White buses being mintained in the HOO Pool for Civil Defense evacuation have been assigned to a construction contractor at the request of the Conmission.

A change in accounting procedures with respect to rental charges to the Light and Heary Equipment Units wi 1.1 result in a reduction of about $\$ 20,000$ per year through the elimination of double charges and a comparable reduction in liquidations.

Further discussions have beon held with Commission personnel regarding the preparation of the AEC Annuel Motor Vehicle Report and taking over the maintenance of associated records. This is a substantial undertaking and qualified personnel are now fully angaged. It may be possible to arrive at a satisfactory solution for the transition after the budget is completed. Commission personnel have agreed to assist in the proparation of the initial report.

Completed an analysis on the over-all utilization of sadans. Total mileage was jow approximately $2 \%$ in FY 1955 and a further reduction of about 9\% is indicated for Fl 1356 due to the restrictive travel between the 1170 outer Area Fool and the Marufacturine Areas. The total reduction in this conrection for a.l1 assigned licht equipment is averaging about $36 \%$.

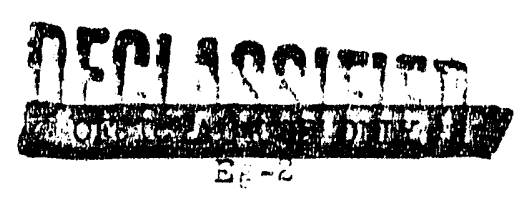


A special study was made on the history of the Ho sedan fleet as to number of units roquired and the attendant conditions. The current inventory has 342 vehiclos after the in-progress reduction of twelve is completed. The matter has been reviewod by the Gonoral Manager and no basic changos aro contemplated in the administration of equipment control activities within this aroa.

Specifications have boen developed and purchase roquisitions written for over 300 units of replacement sedans, pickups, eto. Vehicles scheduled to be replaced are restrioted in maintenance to routine servicing and minor repairs.

Made records available and furnished informational assistance to the Auditing section for an audit of motor pool operations which is performed annually at the direction of the Comission.

The commission has been formally advised that $8.3 \mathrm{mil}$ les of temporary trackage at White Bluffs, Central Mix Plant, and the 3000 Area could be absorbed into tho Plant Railroad system by a transfor of tho property. This action followed numerous discussions relative to the maintenance of this trackage, since the Comission's work orders expired on June $30,1955$.

Continued inclement weather imposed a heavy demand on transportation activities. Rail operations were slowed and track maintenance personnel devotod $36 \%$ of their efforts to snow removal and associated work. Bus operations were reasonably satisfactory under tho vory difficult conditions which caused some lateness in arrivals and doparturos. Equ ipmont Maintenance porsonnel gave spocial attention to buses, snow plows, road sandors, loadors, tire chains, and sorvice calls due to hard starting, etc. Ice and snow control on roadways, walkways, and parking areas required approximately 2,800 man-hours. Traffic accidents were relatively minor without eny serious injuries.

The Biology section is releasing boat $81-4894$ for excess. This unit sank near MC Tary Dam in Novembor while moored off shore. Recovery charges have ap proximated $\$ 1,884$ and an additional $\$ 3,900$ would have been required for reconditioning because of tie water damage.

Commercial rajl. traffic during December decreased $7.68 \%$ over November. The following recapitulation indicates the distribution of commercial cars handled,

$$
\text { Carload Movement - Loads In Empties In Loads Out Empties Out }
$$

\begin{tabular}{|c|c|c|c|c|}
\hline General Electric Company & 95.57 & 19 & 20 & 910 \\
\hline U. S. Army & 37 & 0 & 0 & 38 \\
\hline Farold Kaiser Co. & 1 & 0 & 0 & 1 \\
\hline & 995 & 19 & 20 & 949 \\
\hline
\end{tabular}

Railroad process service during December decreased $26.73 \%$ over November due to the continuatior of production dif'iculties.

Railroad car mrvements consistin;" o' process, ommercial, ard special serrice totaled 2303 in Decemher compared to 2485 in lovember, 2580 in octover, 2282 in September, 2424 in August, 1631 in July, 2673 in June, 2843 in Nay, 2463 in April, 2106 in March, 2354 in Fe'ruary, and 2288 in January. 
Transportation Section

Maintenance of railroad trackage during December was comparatively routine except for weather elements and required 6,502 man-hours.

Locnmotive $39-3719$ f'ailed because of a seized bushing on the main water pump shen.i. A comprehensive inspection disclosed three badly scored liners and pistons. Parts have been ar dered for the necessary reconditioning. This engine has not been overhauled since 1950.

One coal car was rerailed at the 700 Area coal dock on December 23.

New stringers and decking are boing installed on regulated flat cars. This work is veing performed at Riverland because of the contaminat! on factor.

The Plant Bus System transported 2.84 more passengers in Decemver than in November. The following recapitulation indicates the volume of service rendered:

$\begin{array}{lc}\text { Passenger Volume } & 183,538 \\ \text { Revenue - Bus Fares } & 9,176.94 \\ \text { Earnings - Transit Advertising (November) } & 209.26 \\ \text { Bus Trips } & 7,450 \\ \text { Pus Miles - Passenger Carrying } & 207,800 \\ \text { Passenger Miles } & 5,754,536\end{array}$

Recent inspections revealed that 18 buses had been damaged by cutting of upholstery material with a sharp instrument. This appeared to be a premeditated and malicious action which has been reported to GE Security and in turn to the FBI. Pre-trip and post-trip inspections by bus drivers have been intensified. No new outtreaks have been experienced.

The Pzcingre a.s System transported $28.1 \%$ more passengers in December than in Tovemier due $t=$ the severe weather conditions and the christmas shoppins ceason. The collowin recaritulation indicates the rolune of service renderob:

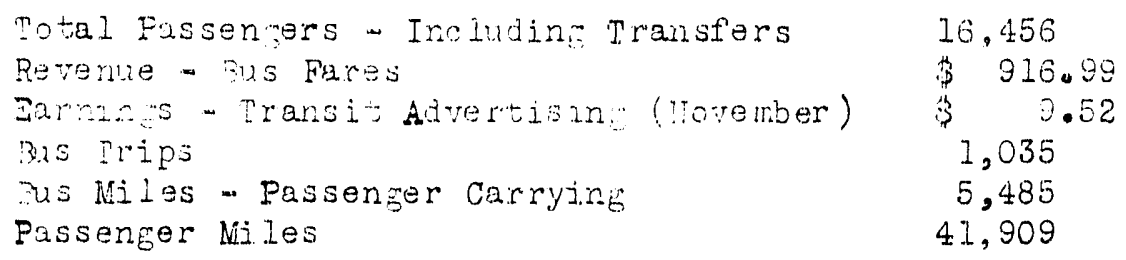

Off Fiant, chauffeured automonile trips (Campary business and/or ofticial.

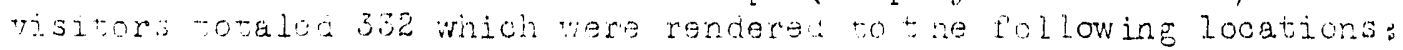

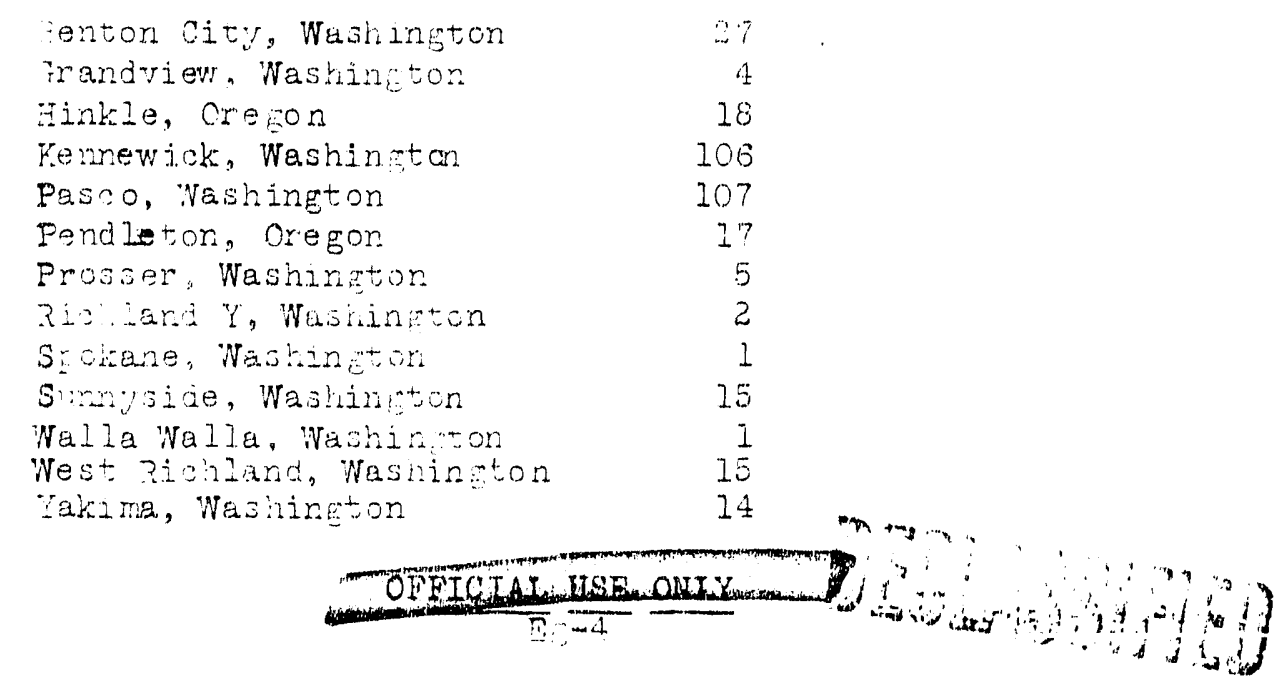


The following tabulation indicates in gallons the volume of fuel distribution during December:

\begin{tabular}{|c|c|c|c|c|c|}
\hline & Gasoline & $\begin{array}{c}\text { Diesel } \\
\text { Fuel } \\
\end{array}$ & $\begin{array}{c}50 \\
\text { Cetane } \\
\end{array}$ & Kerosene & $\begin{array}{c}\text { White } \\
\text { Gas }\end{array}$ \\
\hline $\begin{array}{l}\text { Stock at Start of Month } \\
\text { Received During Month } \\
\text { Disbursed During Month } \\
\text { Stock at Bnd of Month }\end{array}$ & $\begin{array}{r}56,340 \\
107,467 \\
103,532 \\
60,275\end{array}$ & $\begin{array}{l}20,665 \\
24,400 \\
22,885 \\
22,180\end{array}$ & $\begin{array}{r}3,900 \\
46,283 \\
38,733 \\
11,450\end{array}$ & $\begin{array}{l}2,960 \\
4,878 \\
4,193 \\
3,645\end{array}$ & $\begin{array}{r}310 \\
0 \\
16 \\
294\end{array}$ \\
\hline
\end{tabular}

The following tabulation indicates the volume of equipment maintenance activitios during December by types of service and number of jobs:

$\begin{array}{lr}\text { Motor Orerhauls } & 60 \\ \text { Class A Inspections and Repairs } & 97 \\ \text { Class B Inspetions and Lubrications } & 1038 \\ \text { Weokly Inspections - Fuel Trucks and Cff Plant Vehicles } & 107 \\ \text { Semimonthly Inspections - Buses } & 194 \\ \text { Monthly Inspections - Railroad Roliding Stock } & 15 \\ \text { Front End Alignment and Whe l Balance } & 61 \\ \text { Routine Maintenance Repairs and Service Calls } & 2163 \\ \text { Accident Repairs and Paint Jobs } & 49 \\ \text { Tiro Repairs } & 512 \\ \text { Wash Jobs } & 291 \\ & \end{array}$

Completed the modification of turn signals on the 62 older CMC coaches. This is a definite safety improvement in that the signals can now be seen at a greater distance by other traffic.

The following tabulation indicates the number of Ho mi leage vehicles in service during November and the utilization of each type:

\begin{tabular}{|c|c|c|c|}
\hline Code & Type & No. of Units & Total Miloage \\
\hline$I A$ & Sedans & 344 & 465,956 \\
\hline $1 \overline{3}$ & Buses & 137 & 224,730 \\
\hline IC & Pickups & 409 & 237,857 \\
\hline ID & Pane 1, Carryall, Sta.Waron & 157 & 129,629 \\
\hline IG & Joops & 2 & 383 \\
\hline $\mathrm{lH}$ & Power Wagons & 50 & 21,670 \\
\hline \multirow[t]{2}{*}{68 Series } & Trucks & 211 & 96,351 \\
\hline & & 1,310 & $1,176,576$ \\
\hline
\end{tabular}

One additional truck and driver have been stationed in the 200-East Area to serve the 100 Areas with spare parts. 
Transportation Seotion

Maintenance of Plant roads and the production of road aggregate material required 549 man-hours.

The fnllowing tabulation indicates in tons the volume of asphaltic material handled during December for road maintenance:

$\begin{array}{lcc} & \text { MC } 3 & \text { MC } 5 \\ \text { Stock at Start of Month } & 30.48 & 33.39 \\ \text { Recelved During Month } & 0 & 0 \\ \text { Used During Month } & 2 & 0 \\ \text { Stock at End of Month } & 28.48 & 33.39\end{array}$

The following tabulation indicates the volume of mineral aggregate and pro-mix material handled in Docember for road maintenance:

\begin{tabular}{|c|c|c|c|c|c|}
\hline & $\begin{array}{c}3 / 4^{\prime \prime} \text { to } 0 \\
\text { Pre-mix } \\
\text { Tons } \\
\end{array}$ & $\begin{array}{l}\frac{11}{4} \text { to } 0 \\
\text { Pr } \theta-\operatorname{mix} \\
\text { Tons }\end{array}$ & $\begin{array}{r}5 / 8 " \\
\text { Chips } \\
\text { Cu.YQ } \\
\end{array}$ & $\begin{array}{c}1 / 4^{\prime \prime} \\
\text { Crushod } \\
\text { Rock } \\
\text { Cu.Yd. }\end{array}$ & $\begin{array}{l}\text { '3/4" } \\
\text { Crushod } \\
\text { Rock. } \\
\text { Cu.Yd. }\end{array}$ \\
\hline Stock at Start of Month & 309 & 495 & 1,383 & 319 & 2,108 \\
\hline Made During Month & 0 & 0 & 0 & 0 & 0 \\
\hline Used During Month & 309 & 490 & 339 & 16 & 461 \\
\hline Stock at End of Month & 0 & 5 & 1,044 & 303 & 1,647 \\
\hline
\end{tabular}




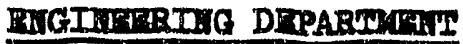

DECTRAR 1955

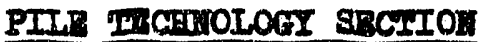

A rocent wtudy has chows that the controling factors in production from Banford reactors after wex plant modifleation w111 deperd upon goal exposure, the status of rual element rupture resistance, and tube replacement rates. The pripcipel conclusion 1 that substantilal 1acreases in production can be attained by a decrease in goal exposure before or after Project CC-558. The production increses semits from a reduction of plutorium burnout schievable at lower exposure, and the Increased powers achievablo at reasonable operational efflelency.

The beta sensitive alug rapture detectors at I, DR, and D P1Les have now been zeplaced with the gam ppectrumster units under Project CG-578. The H PIIe Installation baw the most exporience, havins been inotalled in midAugust, and hows 13 quick dimchargos and scram recover1es in a total of 18 zuptures; of the semaining flve which were stuck, all. but one gave a ruptixe isonal approximately two houx before the plie was ahut down-thus indicating that it har have been posalbie to avold up to 80 percent of the stuck ruptures. Pexpormance thus far demonetrates that (1) censitivity is that predicted-. in several lastances the bete systom would not bave detected the ruptures at the tifme that they were discharged, (2) the grotem hso been reliable and malntenance tree and (3) same monitox are more senaltive than many of the techniques used to conflm the mpture indication.

A new study of the overall economics of retublas an old reactor with z1rconlum tubes 1ndicates a paj-orf persod as short as 1.3 to 2.5 years at prcjected bigher power levela. Because of this favorable picture, the development of suitable fabrication techniques for alrcontum tubes will be hastened through placement of teat orders with retal fabricators.

Four ribbed alugs for use in ribless process tubing were produced successtully by the standard lead dip process. The cans, which were machined from rods, had three ribs of the approximate height and width of the ribs now used in process tubes. Also, for use in rbbless process tubing, aluminum studs were applied to 240 cenned lugn at All using a modified percusaion weldtng techalque.

The tube reduction of two extruded alrealoy-2 proceas tube blanks was attempted by Supers or Tube Company on December 19 and 20 . Two lengths of approximately 33 leet each of einished procens tubing ware formed before a materlal fallure occurred. 


\section{STPABATIONS TMGHTOLOCY SRCHIOI}

A revised chemlcal flowheot for Bedox operation with couplete backcycle and four plutontum cycles has been prepared and will be 1asued for use following the equipmont changes to be completed in early January.

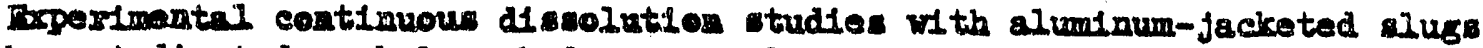
have 1ndicated much less hydrogen erolution than had been predicted from earlier atudies.

Additional trese flering and heat treatment of the prototype continuous calciner trough aseembly by the vendor has oxtended the delivery date into February. Five furnace unita have arrived on alte for use in the prototype and production installations.

\section{DRSIGI SFCYION}

Destgn Section effort on design development programs decreased during the month, primarily because of the increased activity on the preparation of Adrance Ingineering Studies for FY 1958 Plant and Fquipment Budget items. Process Technology effort in support of plant assiatance problems also increased, while desien project activity decressed an presently authorized work on Purex Capacity Increace and the iBesctor Plant Modipl cat1on Program neared completion. Distribution by major components is as pollows:

Percent of rotal Refort

\author{
Der1gn Development Programs \\ Design Section Projects \\ FY 1958 Budget Studies \\ Process Dechnology \\ Cuntomex Work
}

$$
\begin{array}{r}
36.8 \\
34.9 \\
6.1 \\
4.6 \\
17.6 \\
\hline 100.0
\end{array}
$$

Total destga for Project CG-62l, Redax Contamination Control Facllities, advanced to $98 \%$ complete, substantially ahead of schedule. During December, design was completed for Canyon Washdown Facilities and the J-6 Pre-Condenser. Statur on the remaining design 1tems is as follows:
I Cell Ozonization, Phase II
Contaminated Bquipment Removal
$88.8 \%$
$98.0 \%$

Detalled desigm for Project CG-613, Hanford 4X Program - Metal Conversion Plant, 1a 99\% complete. Deslgn asaistance was purni ghed the Struthers Well Corporation to solve weld-cracking problems encountered during fabrication of the calciner troughs.

Work is in progress on the preparation of advance engineering studies for FY 1958 Plant and Equipment Budget items. At the end of the month, studies had been started for 46 potential budget items.

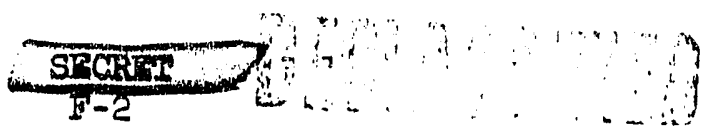


Major reactor design development activity during December Involved studies dealing with a mintmum-completion-schedule plutonium production reactor having a recireulating primaxy cooling system. Other reactor development activity included the issuance of a feasiblilty report for a small demonstration reactor for advanced reactor technology applications.

\section{PROJECT SECTION}

At the end of the month, completion status of major construction was as follows:

Project No.

CA- 512

CA-513-E

CA-539

$\mathrm{CA}-546$

$\mathrm{CG}-558$

$\mathrm{CG}-558$
THtle

1706 KLHR Reclrculation Faclitities

Purex Faclilities, Part \& Additional Waste Storage Facilities Fuel Element P1lot Plant Reactor Plant Modifications, Phase I Reactor Plant Modfflcations, Phase II
Completion Scheduled Actual

$\begin{array}{ll}44 \% & 52 \% \\ 79 \% & 81 \% \\ 44 \% & 44 \% \\ 80 \% & 80 \% \\ 32 \% & 40 \% \\ 3 \% & 4 \%\end{array}$

The continued minor disturbances at the White Bluffs warehouses and storage yards resulted in a relteration of General Rlectric pollcy applicable to Ilxed-price contractors who whthdraw furnished materlals from these locations.

1. Materlals to be withdrawn from White Bluffes warehouses will be set out on the docks, from which the fixed-price contractor's personnel will remove and load the items.

2. Materials to be withdrawn from the White Bluffa storage yards will be handled and loaded by fixed-price contractor's personnel, and a Minor Construction employee will be in attendance.

The manower of the labor service contractor continued to decrease, chiefly among craftsmen, to a total of about 885 employees on the payroll.

Preliminary studies were made of the possibility of accomplishing ret ator tube replacement work during the shutdowns of the reactor modification program, thereby reducing over-all reactor outage time. Construction schedules for reactor modification work are being adjusted to reflect delays caused by labor problems, slow material deliveries, and adverse weather.

\section{ADVANCE EMGINGGHRTING SECTION}

An evaluation study of graphtte and light water moderated boiling reactors was 1ssued as $\mathrm{HW}-40708$. For production reactor use, designs in which each tube is individually accessible were regarded as preferable to "tank-type" desigas.

Studies of the desirability of using uranium oxide fuel elements in present piles and of the use of organic liquids as reactor coolants were initiated during the month.

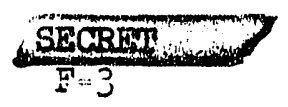


Bngtneering Department

HW -40692

\section{GMGIIIGERING ADMINISTRATION SRCMION}

A review of 1 AAPO Internal reports is belng made at the request of the Atomic forgs Comisaion for possible use in the CIVilian Applications Program.

QRGANIZAMTON AID PERRSOMTIFL
Total on Roll, December 1, 1955
ITet Change
$1,4.15$
Total on Roll, December 31, 1955
1,420

OH Greager

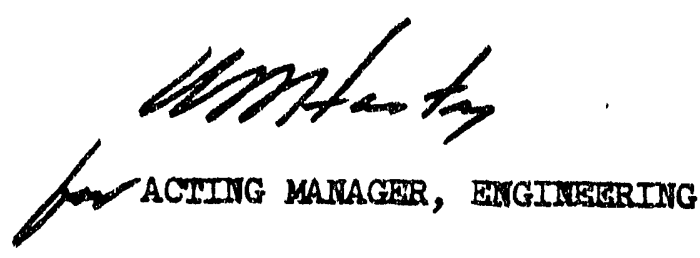




\section{ENGINGHERING ADMINISTRATION SECIION}

DECFMMBER 1955

During December Technlcal Informat1on began a review of all HAPO "Internal" reports to select those of possible usefulness in the ABC CIvilian Applications Program. Technical Information w11l make the intial selection of reports, with 11 nal reviews to be made by Department representat1ves. By December 27, 15,300 of approximately 40,000 documents had been scanned and 2,124 (14\%) selected for flnal Department review. Pertinent reports will be sent to the AEC Technical Information Service, Oak Ridge, for declassification or dowagrading by Declassiflcation Revlew Teams in temporary residence there. All documents provlded for CAP from BAPO WIII bear a spectal disclalmer belng drafted by Counsel.

Providing Oak Ridge with a copy of each approved document has presented a problem, since in many cases only a single copy is available on site. The best move appeared to be to use coples from the Yellow F1le now in Schenectady, slace the file will soon be returned to Banford. Thls procedure has been adopted and the first documents recalled from the Yellow File have been recelved.

The preparation of IBM cards for documents charged to the Yellow File was completed on December 2l. These cards were processed through IBM where they were listed, and a route card prepared. A sopy of the listing $(32,436$ documents) was forwarded to Schenectady.

WM Elarty

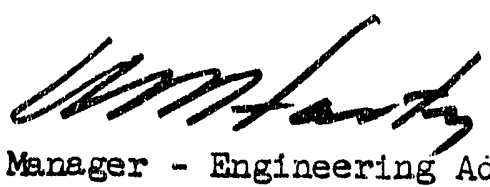

Manager - Engineering Administration MUG INEWERING DERARIMERT 


\section{•}

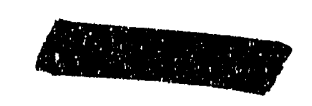

\section{PIEE TECHNOLOGY SECTION}

\section{MONTHLY REPORT}

December, 1955

\section{VISITORS}

N. i. Bleiberg, WAPD, Plttsburgh, visited HAPO on Dec. 21 regarding $x$-ray and trrediation of samples.

W. Crandall, C. Eenry, B. Larsen and M. J. Ryan, UCRL, Iivermore, Calif., visfted BAPO to discuss Hanford assistance to Whitney Project, Dec. $14 \ldots 16$.

T. Dreler and R. H. Simon, KAPL, Schenectady, Visited HAPO to discuss KAPL-120 Loop, Dec. 7-9.

Thomas $R$. Neville, KAPL, d1scussed modiflcations of KAPL-120 Loop at HAPO, Dec. 20-23.

H. Porltsky, GEL, Schenectady, V1sited HAPO for general consulting, Dec.1-2.

I. P. Sharts, L. H. Butcher Company, Seatt].e, Wast., consulted on plating racks at HAPO on Dec. 9.

Mo J. Todd, GE-ANP, Cinclnnat1, V1sited HAPO on Dec. I for "shotting" material discussions.

\section{TRIPS}

W. K. Alexander visited Fhllilps Petroleum, Arco, Idaho, Dec. l-2, to consult on the use of ETR test facllities.

G. S. AJIison and R. K. Koler discussed heat treatment at Oblo Crankshaft, Cleveland, Obio, General Electric, Shelbyvilie, Ind, and Lindberg Ejgineering, Chlcago, I11., Dec. 12-15. They also vis1.ted Axgonne Nat- onel Lab., Lemont, III. on Dec. 16 to discuss induction beating.

R. E. Baars and R. Neidner discussed experimental test programs and facilities (GEH-4), at Philitps Petroleum, Arco, Dec. 15-16.

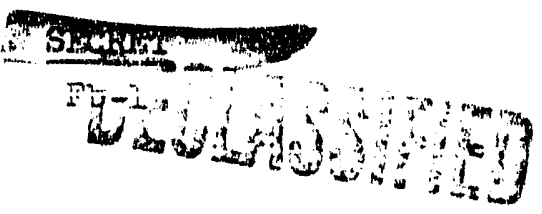


I. P. Bupp spent Dec. 1-2 at Oregon State College, Corvallis, recrulting technicel personnel. Mr. Bupp also attended a meet1ng of Reactor Handbook Chapter Baftors and Fucleer Hogineertag \& Sclences Congress and International. Atomlc Bxposition at Cleveland, Dec. 12-16.

S. H. Bush attended Reactor Handbook Meeting at Battelle Memorlal Inst1tute, Columbers, Oblo, Dec. 7 -9.

3. H. Bush and I. J. Chockle Flsited the Untrersity of Kichlgan, Ann Arbor, for creep consultation on Dec. 9; attended Nuclear Englneering \& Sclences Congreas at Cleveland, Dec. 12-16, and discussed zirconlum fabilication at Trent Tube, East Troy, W18., Dec. 16.

S. H. Bush, L. J. Chockle and W. R. Smlth v1sited Nuclear Metals, Cambridge, Mass., Dec. 5-6, regardins zircontum fabrication and status of uranium alloy work.

I. J. Chockle Fisited Battelle Memorlal Institute, Colurabus, Ob1o, on Dec.9, regarding as81,8tance to HAPO.

J. F. Pletcher spent Dec. 27-31 at Phillips Petroleum, Arco, to observe inotaliation of experiment in Mar.

R. M. Fryar V1sited Phill1ps Petroleum, Arco, to observe MIR experiment, Dec. $27-28$.

N. D. Groves discussed corrosion and welding problems at Crest Reklearch Labs., Seattle, Wash. on Dec. 20.

R. E. Helneman recruited $\mathrm{PhD}$ 's at the Unjversity of Nebraska, Lincoln, Dec. 13, and the Ja1vers1ty of Kanses, Lawrence, Dec. 14-15.

D. E. Jobnson obserted experimental zircontum fabrication processes at

Superior Tube, Norristown, Pa. and Bridgeport Brass, Adrian, M1ch., Dec. 19-21.

N. Ketzlach attended meeting of Nuclear Engineering \& Sciences Congress at Cleveland, Dec. 12-16, and discussed critical mass experiments at Oak. Ridge Nat1onal Labs., Dec. 19-20.

R. K. Marshoi. Inspected customer assembled equipment before shipment st North American Aviation, Dowzey, Calif., Dec. 1-2.

J. T. Mommen visited Argonne National Lab., Lemont, I11., Dec. 14-21, for congultation on welding of studs on F process s.lugss. 
J. F. Music spent Dec. I-2 at Rice Inst1tute, Houston, Texas, recrulting technfcal personnel.

T. C. Nelson spent Dec. 20 at UCRL, L1vermore, Cal1f., discussing plutonium metallurgy and SR 4 strain gage work.

P. G. Pallmer discussed DKm gaging at UCRL, Livermore, Calif., Dec. 19-23.

R. M. Peekema, member or DIV1I1an Application Document Declassification ieam \#2, spent Dec. 12-2l at Oak Ridge for consultations.

J. W. Riches attended meeting of Working Committee for Jranium Quality and Fabrication at Savannah Fiver Plant, Augusita, Georgia, Dec. 5-8.

M. Jo Sanderson attended US-Canadien Reactor meeting at Argonne National Lab., Lemort, Ill., Dec. 5-7, and recruited technicai personnel at State University of Iowe, Iowa City, Dec. 8.

E. A. Silth discussed material quality and testing methods at Savannah River Plikat, Augusta, Georgia, Dec. I2; observed fabrication of fuel elements for HAPO st Sylvania Electric, Hicksvilie, N.Y., Dee. 13-15, and observed stud attachment to fuel Elements at Argonne National Lab., Iemont, Ill., Dec. 16-19.

W. R. Smith and I. $\therefore$. Chockle spent Dec. 7 at Wallingford Steel, Wallingford, Conn., consüting or production of tubing, ard discussed extrusion of precipitation hardening of stainless steeI at Allegheny-Lualum, Waterveliet, N. ${ }_{\text {。 on }}$ Dec. 8.

H. G. Spencer attended Nuclear En\&neering \& Sciences Confress and international Atomic Exposition at Cleveiand, Oh1o, Dec. 12-16.

W. P. Stinson, mernter of CLViLfan Appisotion Dccumeint Declasalfication Team \#2, spent, Dec. 12-21 at Jak R1dge for consiltations and jiscussed experinental reactor physics at ORNL, De-. 22-23. Mr. Stinson attonded meeting of the Amertcan Physical Soctety at Los Angeles, Calit., Dec. 28-30.

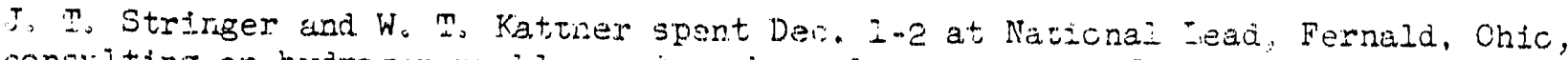
consliting on hydrogen priclem anci vasker sice prog*am. They attended Uranium Quality Meeting and discussed aliumirum at Savanrah Rver Plaut, Augusta, Georgia, Dec. 6-9. L. D. Murner presented film and narration at ASME Iriand Empire Section meeting
at Spokane, Wash. on DE:. 1.

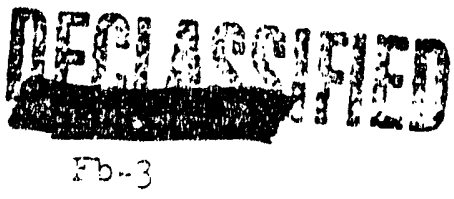




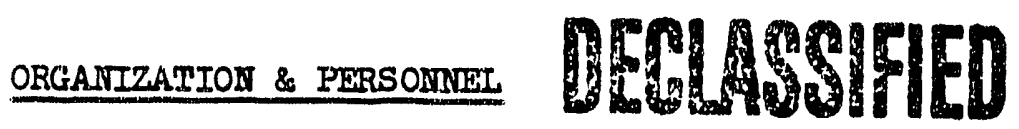

Personnel totals are as follow:

November 30

Administrative
Pile Engineering
Pile Materlals
Fuel Technology
Fhysics Research
Metallurgy Research
Contact Englneering
Technical Administration

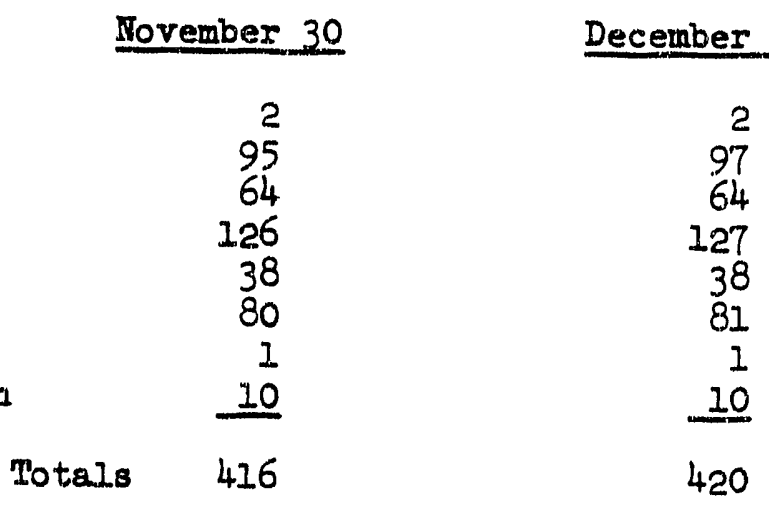

Pile Engineerlng: W. B. Olson, Englneerlng Assistant, transferred in from Separations Section, Dec. I2; M. D. Hannan, Techniclan Trainee, transferred In Prom Comunity Section-I1brary, Dec: 28; P. F. Hayes, Steno-typist, transferred in from Separations Technology, Dec. 19; R. D. Ren, Steno-typlst, transferred in from Office Auxillaries, Dec. 26; C. I. Owen, Engineering Assistant, transferred to Reactor Section, Dec. I; W. K. McJilton, Engineering Assistant, transferred to Separations Technology, Dec. 12; C. E. Welker, Techniclan Trainee, transferred to Fuel Technology, Dec. 14.

Plle Materials: A. B. Balley, Secretary B, was de-activated on Dec, 9.

Fuel Technclogy: A. W. Crosley, Engineering Assistant, transferred in from Metallurgy Research, Dec. 5; C. E. Wallser, Technlcian Trainee, transferred. in Prom Pile Engineering, Dec. 14.

Metallurgy Research: Mary Mourich, Secretary C, was hired on Dec. 29; R. R. Kfng, Jr., Engineerlne Assistant, was remactivated, Dec. 9; A. W. Crosley, Englneering Assistant, transferred to Fuel Technology, Dec. 5; G.W. Riedeman, Engineer II, transferred to Project, Section on Dec. I. 


\section{PIIE ENTGINEERING SIB-SECHION}

\section{PROCESS TIECEIVOLOG:}

\section{Power Level Limitatjons}

The maximum operating porer level, during December 1955, was limited by $105 \mathrm{C}$ tube outlet temperatures at $C, D, D R, F$ and $H$ PIles ard by trip-before-instabllity limts at approximately $100 \mathrm{C}$ outlet at $\mathrm{B}$ PIle. At $\mathrm{K}$. and $\mathrm{KW}$ PIle, levels are being restricted by emergemcy vater supply considerations. The trip-before-instability limits for $B, D, D R, F$ and $B$ Piles were increased $5 \mathrm{C}$ in the Venturi zones for tubes limfted by high pressure trip consjderations. This change is based on a new concept ox adminfstration of trip-before-instability limits.

\section{Process Speciflcation Caunges}

Speciffcation 41.00 - "Temperature of Grephite Modergtor" - The graphite temperature linit wes saised from $500 \approx$ to $560 \mathrm{C}$ for grsphite within one lattice unit of enrichment colums in the I P1le. Temperature limts for uncooled aluminum thimbles were deleted.

Specification 56.00 - "Process Raciation Monitoring Instruments" - Protection during hot stamiups was increased by zequiming trip settings to be lowered by a factor of ten. Requirements were added controlling the design and use of additional intermediaise amplifier ranges, Aliowale trip settlngs were increased for the flrst 1.5 hours of nomal operation after a cold startup. Prevlous close trip settings during this period often required excessive operator attention, thus permitting less than a desirable amount of attention to tube outlet jemperature and temperature contrci. A new section was added to permit and control the taking of all flux-trip devices out of the No. I satety circuit during shutdown when this is necessary for maintenance. This addition wi 1 eiminate the use of temorary relaxations for each instence.

Specification 57.00 - "Power Irve I Measurement" - The reciuirement that the propor. tione - counter shall inficate up to a neutro: power of $0.65 \mathrm{MW}$ was replaced by a requirement that the Indinating range shall extend until the power is indicated by another instmuxent. mafs change will allow a proportional colinter to be more sensitive provided its indicatinn cvenjaps the of a lass sensitive instrument. An increase was made in the mjinim detevtable ririation observable on the Nc. I gelvarometem to ten megaweit, sun the torme:n value of five. Inoreasing power leve..s have made this revision necssay.

\section{Pile Operation}

A totaj of 58 tubes at $D$ P Ile and ten tukes et I Pile weite replacsd during the munth as part of the routine tube ropiecement poogrum. Opsrating efficiency has been reduced durirg tine month prlmaxily by tube replabement at $D$ and $H$ Piles; chute liner replacement at D Ptie, veter leaks at $D$, DR, F and $I$ Piles, and ruptured slugs et

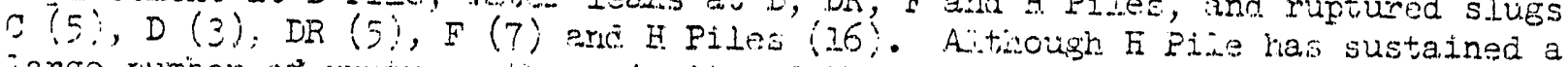
iarge rumber mow rures the wejomlby of thein have bean discharaed during scram
recovery time.

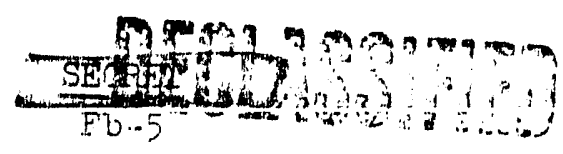




\section{Process Prabe Leaks}

Five pile shutdowns were required due to process tube leaks. Leak testing was done at $F$ on threg other rupture-caused-outages.

\begin{tabular}{llc} 
Wate & Pile & No. Leaking Tubes \\
\cline { 3 - 3 } $12 / 2 / 55$ & F & 0 \\
$12 / 4 / 55$ & H & 0 \\
$12 / 5 / 55$ & DR & 1 \\
$12 / 8 / 55$ & H & 1 \\
$12 / 9 / 55$ & F & 1 \\
$12 / 25 / 55$ & DR & 1
\end{tabular}

\section{Shutdown Flow Shutoff at II P1le}

On December 26, 1955, I P1le shut down to attempt a discharge of a rupture in tube 0769 in scram recovery time. The header valve to the rear riser was closed but the valve to the drain was also inadvertently left closed allowing no exit for water to all tubes on header seven. Rear Pace temperatures on all tubes increased to above the range of the Brown Recorder (120 C). The header remained in this condition for an estimated 13 minutes starting approximately fifteen minutes after shutdown. Slug temperatures were celeulated to be in excess of $170 \mathrm{C}$; however, inspection of metal selectively discharged from the affected area revealed no damage attributable to this event. It was recomenried that the irradiation of the affected metal be continued.

\section{Extrapolation of Rupture Rates}

In the October 1955 Pile Engineering monthly report an equation was given for the extrapolation of the present rupture rate to future conditions. The equation as given was typographically in exror. The correct equation is:

$$
\begin{aligned}
& \text { Rupture Rate }=\mathrm{K} \mathrm{e}^{(.115 \mathrm{X}+0.0092 \mathrm{Y})} \\
& \text { Where } K=\text { Meximum specific power in } K W / \text { ft of } U \text {. } \\
& \text { and } Y=D i s c h a r g e \text { exposure in } M W D / T \text {. }
\end{aligned}
$$

Reactor Operation Afteer Water Plant Modipication

A recent study has shown that controlling factors in production from Hanford Reactors after water piant modification will be larpgely decisions as to goal exposure, the status of fuel element rupture resistance and the tube replacement rates. The foremost conclusion is that substantial increases in proluction can be attained by a decrease in goal exposure before or after Project CG-558. The production increase results Prom:

\footnotetext{
a. Reduction of piuronium burnout achievable at lower exposures.

b. Increased powors actievable at reascnable operational efficiency as permitted by the expcsure reduction.
}

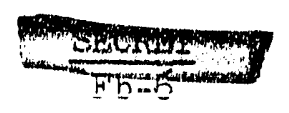


Increased production can be attalned after watex plant modification by reduction of goal exposure even if rupture resistance is increased by a factor of ten.

\section{Ruptured Slugs}

Thirty-six slug fallures occurred during the month. These consisted of thirty-three failures of solid, normal uranlum slugs; one failure of a production test enriched 1.75 v235 urantum $3 / 8$ inch cored slug with aluminum end plugs; one solid uranium slug belng Irradiated at high outlet temperatures for corrosion investigations and one "C" metal piece. The rupture experience for the month of December is sumarized in Table $I$. Included in this tabulation are data for three November fallures which occurred too late to be included in the monthly report for November.

An analysis of the rupture data from $\mathrm{H}$ PIle shows that rupture rate for both the "hot spot" and the "between-the--ibs" fallures are exposure dependent and would reach an Impossible frequency when the major pcrtion of the loading which is now at about $450 \mathrm{MND} / \mathrm{T}$ reaches the present goal exposure of $800 \mathrm{MND} / \mathrm{Ton}$. It appears that a practical imediate solution will be to reduce general goal exposure in one quarter of the pile which is sustaining the major portion of the "between-the-ribs" fallures. A further decrease in goal exposure msy be required. A further study is in progress to determine the exact magnitude of the exposure reductions.

An analysis of the mupture frequency of metal charged as regular production metal but which had sustained various times of exposure to air before quenching after the bete transformation bath, shows it to be more susceptible to "between-the mibs" ruptures under certain present operating couditions than is regular production metal. Studies are underway to determine the advisability of discharging all or part of tils material short of goal exposire.

Production Tests

(See following pages.)

PIIE PEYSICS

\section{Nuclear Safety Studies}

EW-39587, "Nuclear Safety Sumary - Natidral ingnium Losdings", was published during the month; this document presents the best available jata or the Hanford reactor nuclear safety problem in a serles of explazatomy graphs. Wide eirculstion is being given to this document in the Design and Manufacturing organizations and to the Advisory Conmittee on Reactor Safeguands. A companion documert tor locel ise based on the data shown in IW-39587 was 1ssued as HW-4051.9, "Nuclear Safety Objectives Recomended Course of Actinn." Results of recent esiculations designed to estimate the destrable number of fast rods as a function of spesifts fower reve inciuded in the earlier document. 
TABLE I

SLUG RUPTURE EXXFERIEATCE - DECEMBBHR 1955

\begin{tabular}{|c|c|c|c|c|c|}
\hline Tube No. & Fallure Date & Type of & Metal & Exposure & Fa1lure Type \\
\hline $1686-D$ & $11 / 28 / 55$ & 8" Reg. & $I$-Iot & 497 & Unexamlned \\
\hline $1977-\mathrm{H}$ & $11 / 30 / 55$ & $8^{n}$ Reg. & K-Iot & $46 i$ & SIde \\
\hline 2079-H & $11 / 30 / 55$ & $8^{\prime \prime} \operatorname{Reg}$. & $\mathrm{K}$-Iot & 466 & Side \\
\hline $0985-D R$ & $12 / 1 / 55$ & $8^{n}$ Reg. & IJ-Lot & 581 & Side \\
\hline O777-E & $12 / 2 / 55$ & $8^{\circ}$ Reg. & Z-Iot & 469 & Side \\
\hline $3285-D R$ & $12 / 4 / 55$ & 8" $\operatorname{Re}$. & M-Lot & 555 & SIde \\
\hline $1972-F$ & $12 / 4 / 55$ & 8" Reg. & K-Iot & 634 & Cap \\
\hline $2764-\mathrm{H}$ & $12 / 3 / 55$ & 8" Reg. & Z-Iot & 460 & SIde \\
\hline 0661-H & $12 / 5 / 55$ & $8^{n}$ Reg. & & 252 & SIde \\
\hline $2276 .-c$ & $12 / 8 / 55$ & 8" Reg. & PT-105-519-E & 201 & Unexamined \\
\hline $2083-F$ & $12 / 9 / 55$ & 8" Reg. & L-Iot & 577 & Side \\
\hline $3284-D R$ & $12 / 11 / 55$ & 8" Reg. & M-Iot & 555 & Unclassified \\
\hline $2478-c$ & $12 / 11 / 55$ & 8" Reg. & K-Iot & 246 & Split \\
\hline 1072-\# & $12 / 13 / 55$ & 8" Reg. & $\mathbb{N}$-Lot & 458 & side \\
\hline $1983-F$ & $12 / 13 / 55$ & 8" Reg. & L-Iot* & 594 & Side \\
\hline 1776-日 & $12 / 16 / 55$ & 8" Reg. & M-Iot & 455 & Side \\
\hline $1381 \cdots$ & $12 / 17 / 55$ & 8" Reg. & M-Iot & 512 & side \\
\hline $2787-\mathbb{H}$ & $12 / 19 / 55$ & $8^{n} \mathrm{Reg}$. & M-Iot & 482 & Side \\
\hline $228 I-F$ & $12 / 20 / 55$ & 8" Reg. & I-Iot* & 570 & Side \\
\hline $2483-\mathrm{B}$ & $12 / 19 / 55$ & $8^{n} \operatorname{Reg}$. & M-Lot & 478 & Side \\
\hline $1974-D R$ & $12 / 22 / 55$ & 8" Reg. & K-Iot & 375 & S1de \\
\hline $2464-C$ & $12 / 23 / 55$ & 8" Reg. & & 220 & Side \\
\hline 1581-H & $12 / 22 / 55$ & 8" Reg. & M-Iot & 5.18 & Side \\
\hline 1274-B & $12 / 23 / 55$ & 8" Reg. & $M-I 0 t$ & 557 & Cap \\
\hline $3390-F$ & $12 / 22 / 55$ & 8" Reg. & N-Iot & 573 & Split \\
\hline 2063-C & $12 / 25 / 55$ & & PT-105-607 & 313 & Unclassified \\
\hline O876-D & $12 / 24 / 55$ & 8" Reg. & K-Lot & 674 & Unexamined \\
\hline $1473-D$ & $12 / 24 / 55$ & 8" Reg. & D-Iot & 64 & Unexamined \\
\hline $3575-D R$ & $12 / 25 / 55$ & 8" Reg. & M-Lot & 575 & Unexamtned \\
\hline 3290-Z & $12 / 23 / 55$ & 8" Reg. & & 521 & SIde \\
\hline $2667-H$ & $12 / 25 / 55$ & 8" Reg. & & 519 & Unexamined \\
\hline O769-स & $12 / 26 / 55$ & 8" Reg. & & 460 & Side \\
\hline $1781-\mathrm{H}$ & $12 / 26 / 55$ & 8" Reg. & & 537 & Unexamined \\
\hline $0867-\mathrm{H}$ & $12 / 26 / 55$ & 8" Reg. & & & Unclassified \\
\hline 0881-H & $12 / 26 / 55$ & 8" Reg. & & & Unclassified \\
\hline $2783-F$ & $12 / 27 / 55$ & 8" Reg. & L-Lot* & 643 & Side \\
\hline $1683-D$ & $12 / 27 / 55$ & 8" Reg. & L-Lot* & 468 & Unexamined. \\
\hline $0678-F$ & $12 / 29 / 55$ & 8" Reg. & L-Iot & & Cap \\
\hline $1954-C$ & $12 / 27 / 55$ & & " Meta] & 6.41 & tube Unexam \\
\hline
\end{tabular}

* These pieces were normal metal in every respect with the exception that the uranium had cooled in air between the beta-transforming and water quench steps for a period longer than normal. 


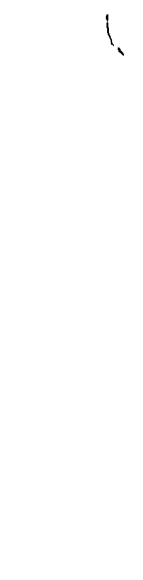

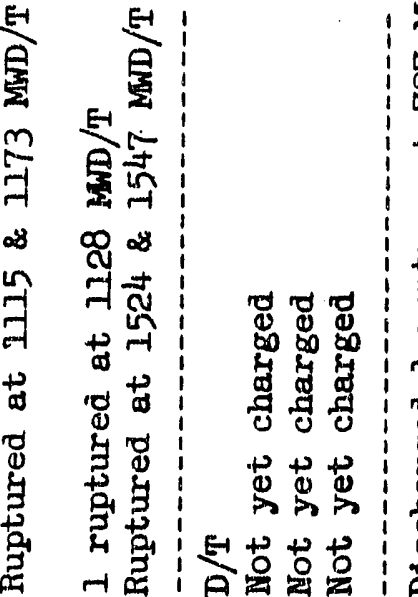
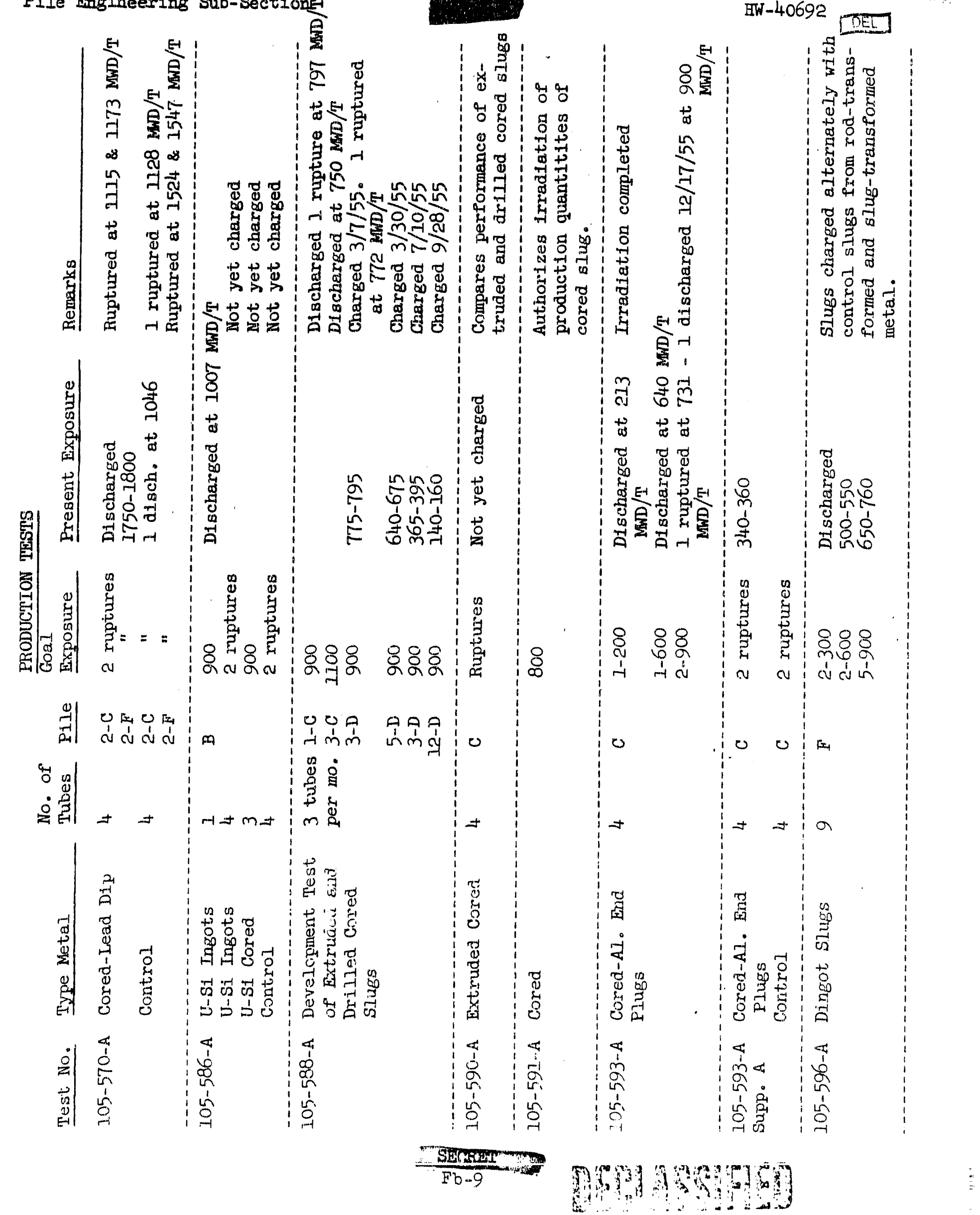

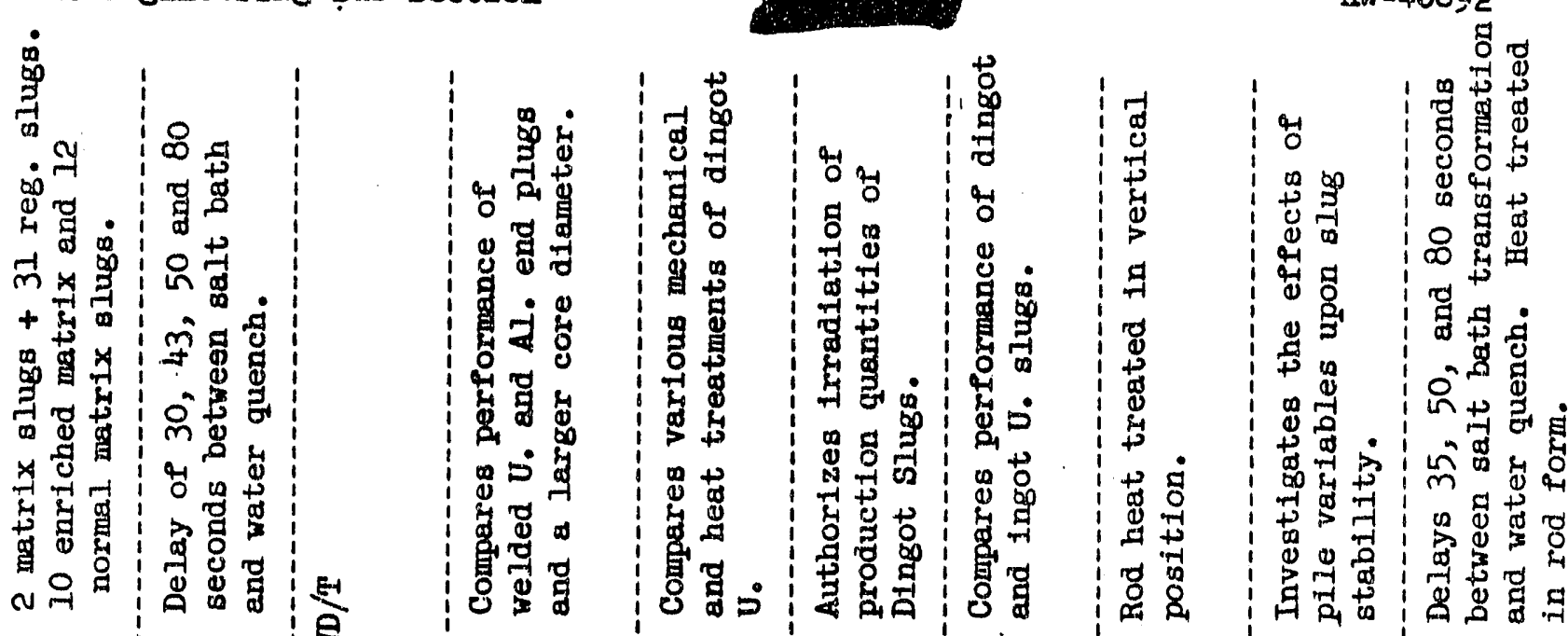

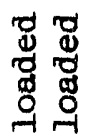

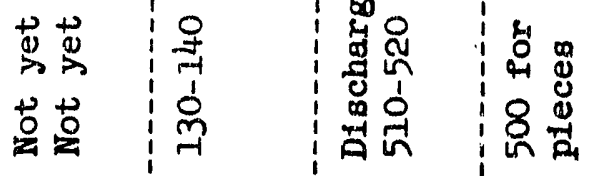

5

I.
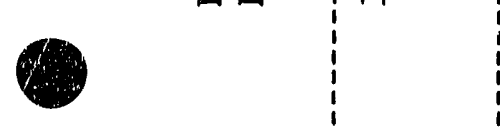

$8: 8 \%$

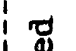

总

$A A$

类

๓⿴囗十丁

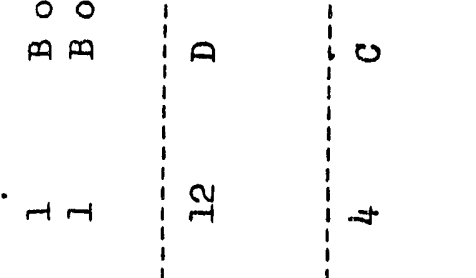

总

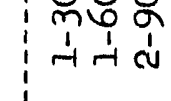

12

$\frac{\mathrm{g}}{\mathrm{g}}$
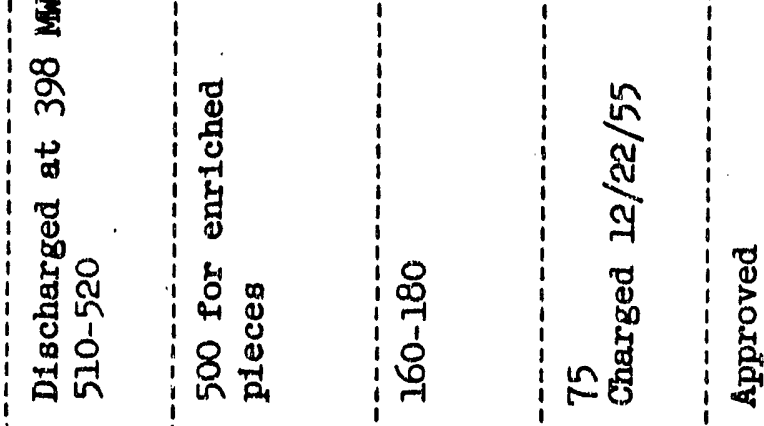

通
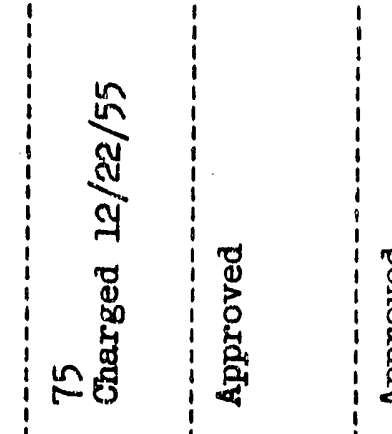

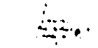




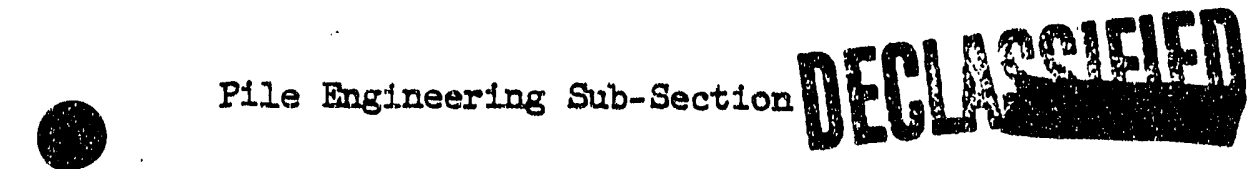

HW-40692

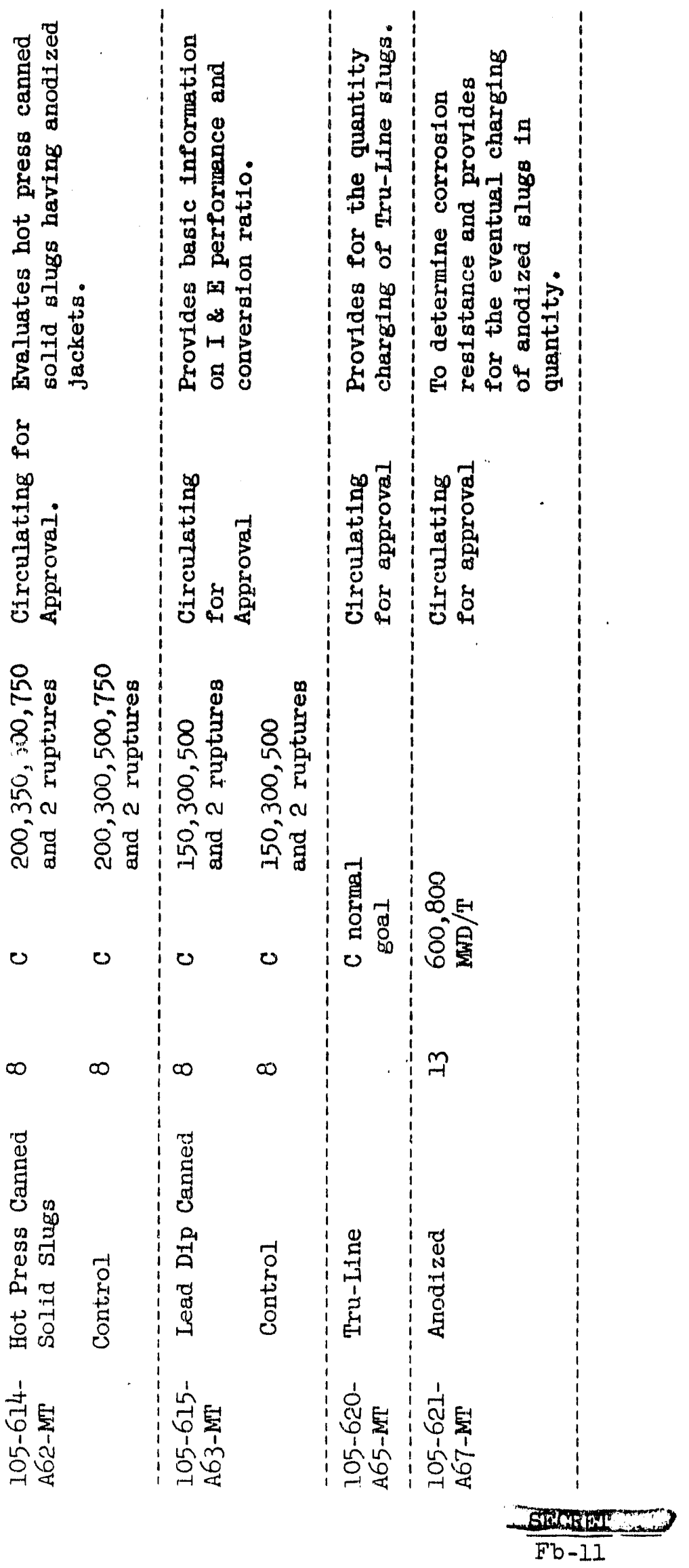


P1le Engineering Sub-section

BW -40692

IIIt:

Measurements of Graphite Coefricient vs. Exposure

The He- $\mathrm{CO}_{2}$ purge test scheduled for December 18, at $\mathrm{KE}$ Plle under PT 105-600-A was cancelled because of a scram shortly beforehand. The seventh purge test graphite coefflclent measurement is presentiy planned for early in January; although a discharge of high exposure materlal has now taken place, it is felt that another measurement in the high-exposure pile will add to the validity of the data already obtained.

The coefficient data taken at Brookhaven during the Thanksgiving weekend graphite annealing test has arrived at Hanford and analysis work has been initiated. The average metal exposure at the time of the test corresponded roughly to $400 \mathrm{MWD} / \mathrm{T}$ Hanford materlal; tube-by-tube welghting of the reactivity effectiveness of the in-pile inventory is belng carried out in the anslysis.

Emriched Loodings

Assistance was given to other groups in providing preliminary evaluations of the conversion ratio and operating characteristics of E-N, J-N, and Wrap-Around loadings for tritium production. Recomendations were forwarded to the Process Technology Unit concerning the planning of E-N and E-for-C production tests.

Calculation was made of the reduction to be expected in rod strength with the $E-N$ load in place of the less-black natural uranium loading. It was concluded that the net effect was relatively small - - of the order of five per cent of the total strength of the safety system; a document has been prepared in rough draft form.

The rough draft was completed of a einal report on PT 105-567-A, "Preliminary Irradiation of J-Q Colums." ORNL separations data on Individual full-tube batches yielded the pollowing overall conversion information:

$$
\text { TEORIUM CONVERSION DATA - PT 105-567-A }
$$

$\begin{array}{llllll}\text { MWD/Col } & 0 & 50 & 100 & 150 & 200 \\ \text { Atams 23/Atoms 25 } & .61 & .59 & .55 & .52 & .48 \\ \text { Grams 23/Col MWD } & .77 & .72 & .67 & .61 & .56\end{array}$
Information was also obtained on the weight percentages of $U^{232}$ and $U^{234}$ in the
recovered $U^{233}$.

\section{Miscellaneous Assignments}

Assistance was provided other groups in estimating the reactivity and operational effects of a full pile loading of $I$ and $E$ siuks in the K Reactors, of short perfs to allow more mixing in the downstream portion of tubes where the ribs are worn, and of water in the large longltudinal test holes of the K Reactors. Discussions were held with Operations Physics of Process Sub-Section regarding K. Pile temperature cycling problems. The PCTR nuclear safety auditing function was carried out, and observations were discussed with Experimental Reactors Unit personne:.

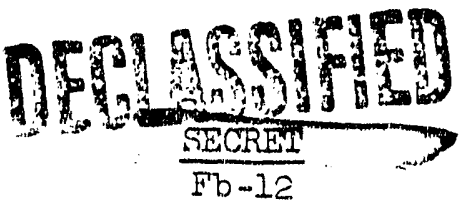


Pile Engineering Sub-Section

Shield Protection by Fringe Poisoning, PI 105-604-A

Economic balance calculations based on test results to date indicate that $U^{233}$ would be 10 to 20 per cent more expensive when produced by this method than if produced in a J-Q loading; the principle difference is caused by a small net loss in plutonium production. Presumably other 1sotopes produced in place of U233 would be more expensive in about the same ratio. Offhand it might appear that shield patching would be cheaper than shield protection which is estimated to cost on the order of $\$ 5,000$ to $\$ 10,000$ per pile face per year. However, initial design scope estimates indicate that shield patching costs might be of the order of a quarter million doliars per pile. Thus, it would appear that there is more incentive to develop fringe poison techniques as an alteratire to shield burnout.

\section{Shield Leakage Detection Studies}

A literature survey is underway on methods of constructing the energy spectrum of the neutrons leaking through the shield. Photographic, instrumentation, and thresbold detector techniques are being surreyed. A request has been given to SS Accountability section to obtain sufficient plutonium for a one-gram foil and to obtain cost and availability information on pure $\mathrm{U}^{230}$, $\mathrm{J}^{235}$, and $\mathrm{Np}^{237}$. Because of a contemplated separations program for Np237 to take place in the near future for limited time only, special study is temporarly focused on the potential benetis and potentlal handicaps from its use. Its one-half MEV fission threshold would appear to provide valuable spectrum 1nformation; however, the material itself would be quite expensive to obtain in poil-size quantities.

\section{PHESICS DEVELOPMENT}

Ruptured Fuel Element Detection

The installation of gamm spectrometer units as replacements for the beta sensitive systems in the slug rupture detection applisation is now accomplished at $H$, $D R$ and $D$ Piles. The $\mathrm{E}$ Pile installation, which was completed in mid-August, has detected eighteen ruptures of which thirteen were rapidly discharged and scram recovery effected. The remining five were stuck and in all but one of these instances a rupture signal persisted for about two hours bafore the pile was shut down and rupture discharge attempted. Emphasis on rapid shutdorn following a rupture signal should substantially reduce the stuck mupture frequency below the wenty-eight per cent observed during the last three montis at I Pile.

The overall performance of the spestrometer urits has bean good. The zensitivity is that whinh was predicted - as a "esult several of the H Dile ruptures were discharged bet"ore they would have been detected on the hetrs systems -- and the sensitivity of the gamm systen exceeds that of some of the rupture "contirmation" tecluniques now in use. Instrument reliability and freedsm from component fajlure has also been good; the electronic component failure rate is iess tinen 0.7 per cent per 1000 hours of operation.

The increased sensitivity of the ganma monitor has resizted in scme difficulty in identifying the tube containing the mpture with unnefined technique. A sensitive, directional detector, the bazooka, was deveioped to complement ojder methods in this appication but it is not yet generaliy emiloyed at the piies.

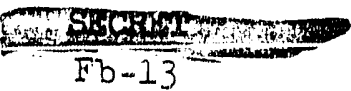


A cooperative program with Radiological Sclences and Radiation Monitoring, Manufacturing, has been established in an attempt to callbrate the response of the gamma monitors to rupture in terms of the resulting fission product concentration in the Columbia River at Pasco.

The major portion of the clrcult design and aystem speclfications for the projected $\mathrm{KE}$ and $\mathrm{KW}$ pile ganme apectrometer Installations is complete.

\section{Reactor Safety - Juclear Instrumentation}

A prototype of the sub-critical pile neutron multiplication detector employing a U-235 fission counter was Installed at D PIle as was improved circuttry for the $\mathrm{BF}_{3}$ neutron proportional counting system. Both systems monitored the D Pile startup; the fisaion counter system gave a useful signal with all control rods in-pile, recorded the increase in neutron multiplication during the approsch to critical, and recorded the post critical power increase to full power. The proportional counter system gave a slight indication at critical and monitored the subsequent power rise over two to three decades but gave no useful sub-critical information.

The major useful data to be obtained from the $D$ Plie test will be an evaluation of the mechanical and electronfe problems associated with a fission counter installation In process tubes. Unavailability for mintenance during reactor operation and subjection to severe vibration make the process tube installation unattractive mechan1cally although it is most attractive nuclear-wise; the alternative is a single installation in a side test hole.

\section{Lattice Heutron Bconomy}

Preparations are being completed for the in-pile conversion ratio determination for an internally and externally cooled uranium slug loading. The measkinements will consist of the following three determinations:

1. Cold, clean conversion ratio as measured in C Pile with neutron detectors with cold graphite.

2. Hot, clean conversion ratio as measured in C Pile with neutron detectors With hot graphite.

3. The hot, dirty conversion ratio as extracted from chemical separation of the plutonium following an accurately measured exposure.

These measurements will serve not only to firm the conversion efficiency, but also to establish the accuracy of the zero power experiments and theoretical methods utilized in internally cooled slug studies. The exposure of selected tubes will be accurately accumulated by the equipment provided for "bluenose" studies and the subsequent product separations periormed by Separations Technology personnel.

Components are being fabricated and experimental techniques developed to permit the measurement of resonance escape probability $(\rho)$ and fast effect $(\varepsilon)$ in lattices utilizing rod clusters, cored, or internaliy and externally cooled fuel elements. A study of the feastbility of employing nuclear emulsion techniques to determine $\rho$ and $\varepsilon$ is also underway.

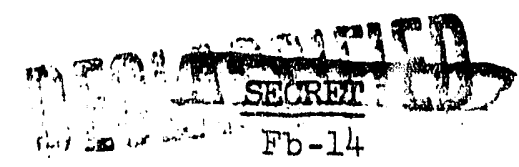


Bj.ght uranium slugs 1rradiated to levels between 43 and 715 MD/T bave been tested In the Teat P11.e to observe the reactivity propertiee of a lattice contraining irradiated thel. The reactivity changes induced by irradiation include the effects of (1) ve35 depletion, (2) pliutonium butldup, and (3) Pission product butidup. The program will continue to inelude appoximately 1rteon additional Irradiated slugs to encompress exposure levels up to $\sim 1600 \mathrm{ND} / \mathrm{T}$.

\section{Plant Assistance}

Some consideration has been given the problem of deterloration of the insulation on the thermocouples on the rear face of the six older reactors; the deterioration has prosressed sufficlently to requtre thermocouple replacement in the near future.

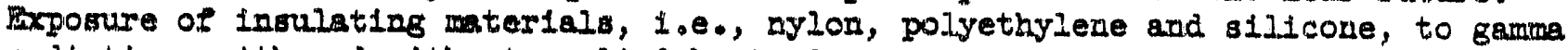
rediation, with and whout applied heat, demonstrates that the deteriorstion results from a combination of radiation and thermal damag. Nylon becomes brittle when Irradiated to $10^{6}$ roentgens at $95 \mathrm{C}$, sillcone and polyetbylene are unaflected for doses under $3.5 \times 107$ roentgens at $95 \mathrm{C}$ and none of the materials are arfected when 1rradiated to $3.5 \times 107$ roentgens at roam teuperature. Hencs, literature values for radiation damge of insulators -- usually based on room temperature irradiations .cannot be validiy extrapolated to even moderate temperature process conditions. This effort to demonstrate long-lived and economical replacement for the present thermocouples is continuting.

\section{Test plle - Rout lase Tests}

Urantum slug testing proceeded routinely. Twenty-six Fernald billet egg lots yielded TDS values ranging from 14 to 20 . Twenty-six Mallfnckrodt biliet egg lots yielded TDS values ranging erom 12 to 19.

Test P1le- Spec1al Tests

Reactivity determinations were made on two SAR prototype fuel assemblies and three Westinghouse fuel elements prior to charglng in the KAPL-.200 100p at H Pile. All elements contain approximately the reported v235 content if the other constituents are correctly reported.

\section{EEAT TRANSFERR}

\section{Instavility Limits}

Using the "generalized" technique, injtability limits were computed for all zones of all piles. The new limits take into account certain secord order effects previously handied by approxinations. The new technique did not prove as general as it pirst appeared and 1 th wecessary at the older piles to calculate correction factors to account for low flow and low power tubes. Analytical work having been completed, data preparation for a complete report on permissibie cutlet temperam tures is nearing completion for publication in piral form.

The low pressure mockup equipment aiterations were not completed as sohediuled. The apparatias was made operable, however, and denonstrated to abcut 60 chi af eperators and shift supervisors on four occasions as a portion of a Manufanturing Department troining program. These personnel. were also given tours of other sites of interest in the 189-D lacoratory.

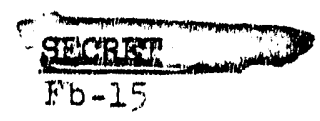




\section{Eyaraulics Studies}

Experimental stuales were infitated to determine the proper oriflce sizings and combinations for Project CG-558. A vide varlety will be studied to provide basic date for possible future changes in orlflce alze.

At the request of Thel Iechnology, calculations for an I \& s.lus for use at K P1le were made. A dip-canned slug 1.498 inches $0 . D$. and 0.360 1nch I.D. Glves these characteriatics: A uranium content decrwase of 3.3 per cent frora present solid slug, tube pressure drop-flow characteristics similar to present solid slugs, and capability at substantial power level with Panellit trip before bolling in elther channel due to selective plugeing.

Calculations of the performance of dip-canned I \& $\mathrm{Z}$ slugs to be charged in a pro. duction test at $C$ Pile in the nea future mere made. Further calculations and final lintt setting $w 11$ be made as soon as slugs are avallable for testing on the Hydraulics Mockup in 189-D.

Calculations were made of the possible flow increases, Post CG-558, by the substitution of thin wall alrcontum tubes.

\section{Cooling by Bolling Equipment Development}

Delivery and installation of a high pressure stralnar are now courplete. A pressure test at 2100 psie was run and completed satisfactionily. Modification of the deaerator tower was necessary to prevent inadvertent llooding of the vacuum pump. Installation of two andistionsl pressure gages and a high speed temperature fecorder (modilied on site) have been completed. It was found necessary that a relief valve be installed on the low pressure side of the loop neer the elow rotameters to protect against rotameter breakage due to shutdown of injection purps before shutdown of recirculating purm. This is nearly completed.

Tests were run to determine the accuracy, within its range, of the Potter flowmeter. Satisfactory accuracy bas been estrolished to permit continuation of initial shakedown runs.

A bigh temperature-high presgure llquid phase run was attempted and a grasket failure at the rear hydrault.c bead at $1300 \mathrm{psig}$ and $250 \mathrm{C}$ caused a stoppage. Repalrs are completed and further testing is continuing.

\section{Analytical Services}

Cooling of 100-C Control Rods - Water flow requirements for both the presert and. new CG-600 Eorizonta] Control Rods were caleulated. It was found that at $2200 \mathrm{MW}$ requirements were $14 \mathrm{gpm}$ for the old rods and $22 \mathrm{gmm}$ for the new ones. In addition, approximately 60 per cent additional flow will be required for the new rods over the old rods at the same reactor power levels due to the increased heat generation of the boron carbide in the new rod as compared to the cadrium of the present rod. 
Sub-Cooled Bumout in VIR - BAPO Irrediation tests at the MIR are expected to be performed at increased power levels in the near future. In connection with this program, calculations vere made to determine the maximum sape operating power level that would not melt the slugs. Theoretically, a power level of $204 \mathrm{kw} / \mathrm{It}$ can be attained. However, due to inherent insccuracies in the calculations, a practical upper limit of $155 \mathrm{kw} / \mathrm{ft}$ bss been recomimended.

Uncooled Control Rod Temperatures - The need for additional reactor control cir. cuits in conjunction with 1038 of control rod cooling water at full power has been investigated analytically. These proposed circuits ward have as separate functions (1) trip of the No. I Safety CIrcuit upon loss of water to any BCR and (2) automatic withdraval of an uncooled rod after a full rod scram. The analysis indicates that, these circusts are not needed provided proper flow monitoring, low flow alarms, and reliable response by operators are obtained.

Shutdown Cooling Studies - A development test was prepared to determine the translent response of the K. FIle water supply to inadvertent opening of the V-T3 valve. other aspects of the K Plie water supply fecilities were studjed, primarily to determine tise extent by which rellablitity of equipment can be assured by periodic proof testing.

Other Studies

Temperature limits were established for a special tube laading of $0861-$ H for use by the Recirculation Technologi Unit. This tube was the 1dentical charge of $0961-\mathrm{H}$ tube ( $\mathrm{E}$ P1le Recircalation Tube) so that accurate tube power of the recirculation tube may be determined by comparison.

Preliminary design speciflcations for increasing generating capacity in 189-D were established. Specifications call for a desired maximum power of $2500 \mathrm{kw}$ with $2000 \mathrm{kw}$ as an acceptable minimum. The heat generating equipment nust be capaile of reducing power continuously or steprise at rates from $25 \mathrm{kw} / \mathrm{second}$ to 560 $\mathrm{kw} / \mathrm{second}$ at adjustable and predetermined times.

The maximum jacket and tube temperatures attained during an unusual occurrence at $\mathrm{H}$ Pile on 12/26/55 were calculated.

\section{MECEAITICAL EQUIPMENTI DEVEROPMERTI}

Graphite Miner

A flexible joint for the graphite miner cutting head was fabricated to allow the head to transverse the graphite channel and make cuts of equal depths at portions of the channel having maximum distortion. Results of preliminary tests on the modified cutter were satisfactory.

Eeliarc Tube Splitter

By using direct instead of alterneting current in a modified beliarc torch, clitting speeds used to split bort sections of process tubes were increased to 70 inches fer minute. Tests to determine graphite damage were made witr the torch held on one spot of the graphita encased aluminum tube for 1.1 seconds. Darkening of the Eraphite was the only observable result. 
P1le Engineering Sub-Section

HWW -40592

DE[

Process Tube Leak Indicator by a Hellum Detection System

The prototype equipment used to find leaking process tubes by means of a helium detection system was succesarully used at $F$ and $E$ P1les during the month. A recent improvialon in the equipment allows leaks in the bellows gae seals to be detected and pinpointed since the system is sensitive to the concentration of helium in air.

\section{High Pressure-Fil gh Pempersture Loop}

Additfonal turns added to the induction heating colls reaulted in an incrased temperature in the loop. Bowever, sufficleilt volume was not avaliable for the resulting increased expansion of the water. A tank is being pabricated to allow for this expansion.

\section{Poison Spline}

Recent flow wock-up tests with central zone BDP conditions show it is not necessary to have a bullet nosed dumay slug at the head of the charge to guilie the spline under the colum. Tests on a chopper to withdray the spline, chop it into short sections, and dispose of the sections in a lead cask were successfilly corpleted.

\section{Process Tube Creep Test}

Three experimental aluminum process tubes installed in the 1706-K out-of-pile loop were charged with a corrosion testing loed and beating water admitted on December 15 , 1955. All strein gages mounted to measure creep are functioning, although readings are questionable in one case.

\section{Slug Sulumn Boring}

Partial column borlng was obtained in a "C" process tube when the end caps of regular metal slugs vere damaged. Tests to induce bowing are continuing.

\section{Sub-Critical Monitor}

The mechanical components for PT 105-589-A were installed in the inlet end of process tube No. 2069, D File, and are operating atisfactorily.

\section{Zircaloy Process Thibes}

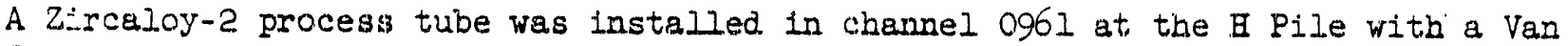
Stone flange on each end. The tube was cut to length, the ends annealed, and one Van Stone fllange was rolled prior to installation. The rear flange was formed with manul rolling tools after installation.

Other Engineering Development Work

A reactor gas-seal cover-boot intended to slip cver the old bellows seal without requiring the removal, of the nozzle or flange has been designed and ordered.

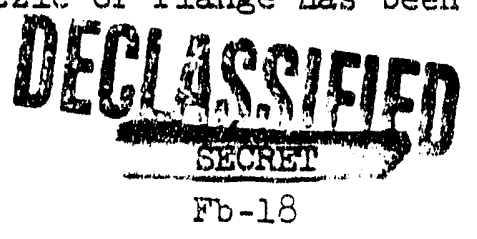


A sow designed to remotely remove stuck mptured slugs from sections of process tubes enclosing them was successtinly tested at the 105-H recirculation facilities on unirradiated ruptures.

A study was begun to determine whether the deflection, caused by glaphite growth, of the top B shield could have damaged the "I" section f1llet welds. If these welds falled 1t would be conceivable that 83 the mosonite deteriorated, the steel plates would settle and possibly cause the VSR's to bind. Preliminary calculations are inconclusive and more detalled investigations are in progress.

A study was de on tube flows which considered flow area above and below a horizontal plane through the center of the process tube. It was determined that unequal arees above and below the center caused by oversized slugs, undersized tube vertical diameter, or over-tolerance rib height could ceuse slugs to flcat because of a differential static pressure between the top and bottom. This study was confirmed by X-ray photographs of an I and $\mathrm{E}$ slug (.040 Inch oversized with central hole plugged) in a "C" tube with $60 \mathrm{gpm}$ Plow, and by X-ray photographs of a bullet nosed slug (.006 inch oversized) in a BDF tube with nommel flow conditions. Both slugs cocked and raised away from the ribs.

\section{SPECIAL IRRADIATIONS}

\section{KAPL-120 Loop}

The first irradiation of KAPL fuel and corrosion test sections were discharged from the KAPL-120 100p on December 5. Additional corrosion and fuel test sections from KAPL were charged for a second irradiation. Test sections from WAPD were found to be incorrectly designed and could not be charged on that date. These test sections were revised and were charged on December 28, 1955. At that time it was necessary to discharge Prom the loop the KAPI out-of-pile reference fuel test section to avoid an excessive pressure drop in the 100p.

Crud formation on the in-pile fuel elements caused a significant increase in the pressure drop across the fuel element test sections of the second irradiation. This crud was successfully removed and the pressure drop reduced by the injection of lithium-hydroxide linto the loop.

The loop operated at specifled conditions during all pile operation during the month. Preparations are in progress to take a Pront to rear flux traverse in the process channel adjacent to the KAPI-120 in-pile tube to obtain additional information on fluxes in the region of the fuel elements in the loop.

In-Pile Irradiation Studies

Work in the support of the evaluation of the use of nitrogen as a pile gas atmosphere (BAPO-140) continue. Two assemblies were charged into H PLIe on December 10, to study the in-pile reaction of nitrogen with aluminum, graphite, and steel. in the preserce of water vapor. 
Four additional experimential assemblies for temperature monftoring I \& E slugs (BAPO-159) are in the process of belag prepared. Fabrication of these assemblies is essentially complete ard testing and caltbration is in progress. Preparations are also being made for additional studies with I \& I slugs scheduled for sometime in Pebruary.

Assembly of the in-plie equipment for the safety fuse experiments was observed at the North American Arlation Iaboratorles. Fram this examination it appears that this equipment should perform satisfactorliy when charged into the pile. Some minor modiflcations are being waie to further ensure satisfactory performance.

\section{Mire Lisison}

The I \& $\mathrm{E}$ wafer slugs bein/ irradiated in the single pass irradiation facility at the MIT have achieved as exposure of $700 \mathrm{MND} / \mathrm{T}$ as of December 27 . It is intended that these w111 be discharged on Januery 16, 1956, at an exposure of about $1000 \mathrm{MWD} / \mathrm{T}$. Average power generation durling this exposure time will have been about $90 \mathrm{kl}$ lowatts peic foot.

The control slug of the insulated slug dimensional stability test which received an elght-hour exposure at maximum power generstion at the Mar bas been examined bere at HAPO. Initial results from this exumination show that the maximum temperature which extsted at the center of this slug was slightly above the melting temperature of uranium metal.

Preliminary plans for the Intentional rupture of an insulated unbonded slug were submitted to the Mar personnel. Pollowing the recelpt of their comments, final. details on the test are being worked out.

Uranium-thorium alloy samples under the GEE-3 program were discharged. Inspection shows that no significant change had taken place in the samples; it is planned that they will be recharged. Uranium alloy tensile specimens were charged as a part of this same program.

Gamma Irrediation Studies

A vertical gama traverse was made in one of the Purex waste tanks. Gama intensities varied over several magaitudes reaching a value of $2 \times 10^{4} \mathrm{r} / \mathrm{hr}$ at the bottom of the tank.

Gama ray intensities have beel successfuldy measured using ferrous-f trric chemical dosimetry. Values obtained from this method have been used to calibrate icnization and calorinetric dosimetry instruments.

The ganma calorineter has been in constant use in the 100-F gamma pit throughout the month. In general, the response and stablilty of the lnstmument has been satisfactory.

The 16 iiter Four Pi ionization chamber has been tested at atmospheric pressure moving air usine a Model $\mathrm{V}$ Beckman in conjunction with the 1orization chamber.

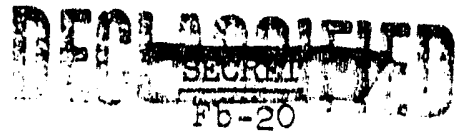


A sensltivity of $0.0847 \mathrm{mr} / \mathrm{hr}$ at one foot in alr/micro-microampere was measured using a National Bureau of Standards Cobalt 60 mource. The chamber also showed less than a 3 per cent rariation of response for a variation 1ri source position over a region eight inches in the sample well.

A 50 cc Ionization chamber has been developed for use in moderate to high radiation elelds. Tests show that the sensitivity of this chamber is $0.36 \mathrm{r} / \mathrm{hr}$ per micro-microampere.

\section{Borescoping and Proversing}

Thube 2266 at B P1le was borescoped December 7, 1955, following the breaking of a process tube and pushing anv1l in the channel. Information obtained from borescoping permitted the clearing of the channel without further difficulty.

Verticel safety rod channel INo. 24 at D P1le was borescoped to a depth of 21 feet on December 9. Fourteen 1nches of liner block were observed to be split at the key slots and short sections of the keys were broken out. No large crecks were observed in the surrounding graphite.

VSR channel No. 34 at F P1le was borescoped December 15 to determine the extent to damage to the liner block. At the depth of 26 seet vertical splits on each side of the block were observed. Two small pieces of the liner block were noted to be 1008 and projecting out Into the channel and blocking passage of the vertical safety rod. The reminder of the liner block appeared to be in good condition. 
PIIE MATERIALS SUB-SECTION

\section{GRAPHITE AND MATIRRIAIS DEVELOPMEWNT}

\section{High Temperature Graphite Irradiations GarH-9}

Under a revised schedule set up at the Materials Testing Reactor, the P1rst GKH -9 Irradiation started December 27. Graphite samples at four values of the neutron flux are being Irradiated at $750 \mathrm{C}$. Thls will be a one-half cycle (about j.0 days) irradiation. The second irradiation, of 2 cycles (40 days) duration, is scheduled to start February 6.

The first GHA-9 thlmble, charged on December 27, was pressure tested by Materials Testing Reactor personnel. While testing the thimble under 80 psig pressure, a few small gas leaks were observed around the electrical and gas lead connectors which had not been observed during previous tests. These leaks were corrected. In addition, pinhole leaks developed in one weld and were corrected.

The fabricated parts for the second GBH- 9 thimble and the graphite samples have not jet been received from the shops. This thimble is scheduled for shipment to the MIR on January 10.

\section{PT 205-535-E, Supplement C, Alternate P1le Atmosphere Study}

On December 10, experimental assemblies were charged into empty process tubes 0776 and 1982 in the $\mathrm{B}$ P1le to determine 19 water-saturated nitrogen and water-saturated helium effect comparable corrosion to sluminum and fron folls and thus whether nitrogen plays an act1ve or passive role in the corrosion mechanism. The ultimate objective of the test is to determine the chemical peasibility of using nitrogen either as a transient polson or a permanent component in the pile gas atmosphere without increasing the corroston of metallic pile components especially in piles with bigh water leakage rates.

The experimental assemblies consist of a central, 0.25 inch aluminum tube through which the pile cooling water passes and to which welghed aluninum and 1ron folls are fastened at regular intervals. Corrosion rates will be detemined by the measurement of foll welght changes. Surrounding the central tube are hollow cylinders of graphite which form a graphlte tube extendi nf along the entire active zone. The graphite tube remalns at the temperature of the plie graphite moderator. The watersaturated nitrogen and water-saturated belium flow through the annular space formed by the inner aluminum cooling tube and the hollow graphite oylinders in process tubes 1982 and 0776 respectively. The gas plow rate in both tubes is about $4 \mathrm{~cm}^{3} /$ minute. As a sidelight, three of the graphite cylinders in each assembly were welghed to determine the order of magnitude of in-pile graphite gasification by water vapor.

\section{High Temperature $X$-Ray Furvace}

An enclosure has been constructed and put into use which allows more convenient determination of crystal lettice constants at temperatures up to 1000 c. Graphite

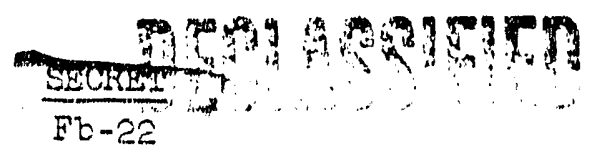


samples are heated, as before, with light from a $750 \mathrm{~W}$. projection lamp. Light is gathered and focused onto the sample with a spherlcal mirror. In the new apparatus samples are placed in a brass cylinder which is closed at the ends and fitted with a pyrex window through which samples are heated. Two openings were made and covered with aluminum foll to act as windows for the X-rays. The enclosure was silver-plated Instde to reduce radiation losses and fittod with copper cooling coils. Dry nitrogen gas is used to provide an lnert atmosphere for the samples.

\section{Thermal Annealing or Irradiated Graphlte}

A thermal pulse method of obtalning rate data on $C_{0}$ annealing of lrradiated graphite has been lavestigated. Within the precision of the method, the results obtained agree w1.th the previous method which was limt.ted to samples having cooled test-hole exposures of less than $1000 \mathrm{MD} / \mathrm{CT}$. However, unless a large number of peak shape measurements are made following each pulse, the precision of this method is not sufficlent to be used in calculating activation energies.

\section{Properties of Irradiated Zircontum}

Standard 1/4 inch A.S.T.M. tensile specimens and hardness testing wafers are being prepared from annealed Zircaloy-2 rods, which have been cold-swaged to area reductions of 30 per cent and 50 per cent. The specimens will be contained in aluminum "perfs" and 1rradiated in a $1.4 \times 1013 \mathrm{nv} 1 \mathrm{lux}$ at water temperatures of $100 \mathrm{C}$ and $200 \mathrm{C}$ in the II P1le recirculation 10op. After an exposure of about $8 \times 10^{19} \mathrm{nvt}$, the samples will be removed and the change in tensile and hardness properties determined. The amount of hydrogen pick-up will also be found.

\section{Qeat Distortion of Tefion}

Heat distortion tests were started on Teflon at $230 \mathrm{C}$ under 225 psi by placing four $1 / 16$ in 2 pieces 0.14 inch in thickness between metal compression sheets and applying static load. Results to date indicate Teflon compresses slightly during prolonged aging, most of the compression or deformation taking place in a relatively few hours. The flrst measurement at 72 bours showed 4.1 per cent compression. Exposure for an additional 360 hours resulted in only 2.8 per cent further compressior.

\section{Ceramic Coating for Graphite}

A preliminary analysis was made of the cost and gains to be made in coating pile graphite witt a ceramic protective layer. New?y reported techniques for performing such an operation appear promising. An estimated annual saving in external corrosion of process tubes could be realized pius, in a new pile, vintual elimination of bigh temperature graphite bumout. Further investigation of the method is auggested in HW $-4047 i$.

\section{Effect of Irradiation on Graphite}

The Texas coke graphite series with density variations acilieved by varying molding pressure has been discharged at $2180 \mathrm{MD} / \mathrm{CT}$ cocled test hole exposure. Theoe semples were prepazed by Bettelle Memorial Institute. Samples alt transverse to the direction

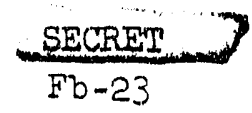


of extrusion show continuing expansion with the maximum expansion occurring at the bighest density under test, $1.83 \mathrm{~g} / \mathrm{cc}$. Samples cut parallel to the direction of extrusion show very little expansion, with two samples, 1.40 and $1.50 \mathrm{~g} / \mathrm{cc}$, exhlbiting a contraction.

\section{Physical Properties Measurements}

Thermal conductivity and electrical resistivity determinations were completed on 37 graphite samples 1rradiated under PF 105-507-E, f1ve unirradiated experinental samples from Battelle being prepared for Irradiation and six CSF samples from a new bar recently cut into standard samples for comparison purposes.

\section{PIIE GRAPHITIE STUDIFS}

Review of Graphite Temperature Distribution

A review of the graphite temperature distribution has been made at all piles. The review Indicates that for the present and future bigh temperature operation, the present instrumentation is 1nedequate at all piles except C PIle and possibly KW Pile. Further, the revlew ind lcates that whlle the "corlng" pattern used at the $K$ Piles has raised fringe zone temperatures to the extent that it is not likely that graphite distortion will be troublesome, the pile is much more sensitive to heat and reactivity cycles and thereby presents difficult control problems. The details and data are sumarlzed in a report to be issued scon.

\section{PT 105-548-E, P1le Graphite Burnout Experiment}

The "follower fumace" has operated satisfactorlly during December, but pile operation has had frequent interruptions. This production test expires soon and preparations are underway for discharging all three process channels and the D test hole bars during next month.

Future use of the follower furnace and the test channels in $C$ has not yet been determined. Further experiments could be conducted at high temperature, but if $c$ returns to $500 \mathrm{C}$ ope:ation, it would probably be desirable to do the tests elsewhere.

Isotoplc purity of plutonium produced by C P1le at $255 \mathrm{MWD} / \mathrm{T}$ exposure is comparable to that of $265 \mathrm{MWD} / \mathrm{T}$ plutonium from the older piles. This indicates that the magnitude of the "neutron temperature effect" on plutonium purity was estimated correctIy, and that an exposure cut should be made to compensate for this effect when graphite tumperature is raised. This will have to be considered when establishing the future operating temperature for C P1Ie.

\section{Grophite Temperature Limits at KE}

The electrical resistance check of $\mathrm{KE}$ thermocouples showed that many are shorted out near the far side of the pile, leaving a large portion of the pile without temperature measurement. The tube biock overboring at $\mathrm{KE}$ makes estimation of temperatures srom the remaining couples very uncertain. A procedure for cbserving the temperature limit. under these circumstances was racomnended in a letter to Manufacturing. (1) The main

(1) "Method of Observing Process Specifications 41.00 and 31.00 at $\mathrm{KE}$ Pile," L.P. Bupp, HW-40324, 12/6/55。

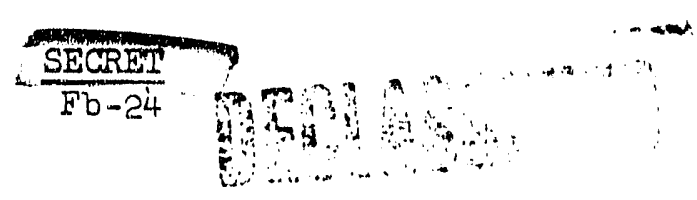


recomendation was the use of a constant gas composition in the range $80-100$ per cent helium regardiess of power level. This skould keep the graphite temperature under $500 \mathrm{C}$ until some thermocouples can be replaced.

\section{Thermocouple Stablifty}

The deleterious effects of carbon dioxfde on bare chromel-alumel thermocouples at $1000 \mathrm{C}$ have been summarlzed in HW-40296. A similar series of muns has been initiated to determine the stability of chromel-alumel thermocouples insulated with nagnesium oxide and sheathed in 304 stalnless steel. A simlar series of thermocouples have been prepered for in-pile testing in eonjunction with the skewed temperature test: PT 105-553-E.

\section{RECIRCUTATION TECENOLOGY}

\section{E-Ioop Recirculation Studies}

Vecontamination of the H-Loop equipment on the - la level was carried out satisiactorily. The general radiation level bas been lowered about ten-fold and is approximately at the levels encountered prior to the incident. Several components which are in stagnant parts of the loops have retained some of the high radiation levels, but are not interferring with operation of the loop. Following installation of a new zircaloy-2 tube in 0961 channel the loop has been operated on recirculation for several weeks with the tube empty. Monltoring the effluent water with delayed neutron detector has not detected any activity increases which can be ascribed to residual particulate matter in the loop from the rupture.

Eraminstion of the zirconium tube discharged in November has been completed, and a hole caused by mechanical damage was found in a blued portion of the tube. The section of tubing evidently has been heated to 300 to $400 \mathrm{C}$ for several minutes to cause this shade of color. The aree surrounding the blue zone was light red due to a rust 11 in.

Partial examination of the slugs discharged in November has been completed and excessive warp has been noted. An extreme warp of 52 mils occurred at the rear end of the tube and 20 to $40 \mathrm{mils}$ warp was noticed in the midale sention of the tube charge. Radiometaliurglcal examination is proceeding. A melted region has been noted on the slug adjacent to the ruptured slug. Warp measurements on these two slugs are being obtained. Also warp examination w:1l be made on 3lugs made from metal of the same lot number and charged in regular tubes.

A tentative explanation of the rupture is hypothesized as fcilows: The metal was prone to warp excessively and a the warping progressed the annulus was reduced with a resultant rise in surface temperature. A failure occurred dile to intergranular attack at these increased surface temperatures and prodiced a flow distortion over the slug downstream of the rupturad slug. This in turn permitted burnout and subsequent melting of the aluminum. The beat caused the zircorium tube to reach a high temperature, and hydrogen relessed by the rupture products caused embrittlement of the tube which was mechanically damaged during the diserarge operation.

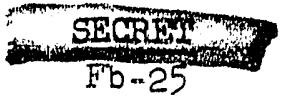


EXMO Loop Development Activities

A Zircaloy-2 tube was installed in ELMO-2 for charging tests and corrosion evaluation

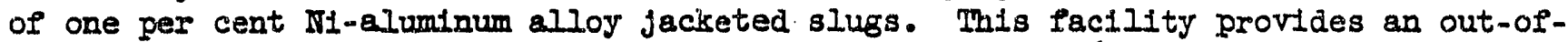
pile correlation with the H-IOOp tests. Delivery of EIMO-6 was obtained and Installation in $1706-\mathrm{KF}$ is proceeding. A revision to the cooling system on BLMO-9 has delayed start-up of the aluminum-zirconium coupon corrosion test until next month. Repeir of the 3 lug rupture test loop, BIMO-4, was begun following dellvery of the necessary parts. Carbon steel loop ElMO-5 was shutdown for addition of a crud probe to aid in the evaluation of the scale-forming tendencies of carbon steel in high temperature water. The project proposal for the component test loop, ELMO-8 was reviewed.

\section{Recirculation Analysis}

A formal report describing the application of ion exchangers in high temperature recirculation systems was issued. Based on the results of the H-Loop rupture and subsequent decontamination, a review of rupture problems in recirculating systems was inftiated, relating to soth the KKR loops and advanced-type Hanford reactors. A draft copy is circulating among finterested parties of the report on economic and technical factors assoclated with conversion of exlsting pliles to recirculation cooling. A document was issued describing the proposed program for the KRR loops and the various supporting facllities.

Materials Braluation

Aluminum coupons are under examination following 52 dajs exposure in H-Loop at $200 \mathrm{C}$ with accumulated fluxes rangirg from $1.3 \times 10^{20}$ nvt to essentially zero. A report was prepared which discusses the application of aluminum in high temperature systems for three uses - fuel element cladding, fuel element spacers (perfs) and process tubes. A review of Hanford and off-site efforts in the fleld of high temperature aluminum development is also presented. Extensive review of currently available information was made in order to arrive at a sound evaluation of the use of carbon steel loop systems for application to advanced-type Hanford reactors. A report is in progress.

\section{Boiling Development Progrem}

The mock-up 1nstallation of the Single Pass Boiling Facility was completed and testing of the equipment is now in progress. The mocis-up was initlally designed to demonstrate the reliability of the equipment prior to in-pile installation. In addition to this function, a method was devised to permit parallel operation of the in and out-of-pile facilities and the necessary equipment was ordered. A report was issued establishing the bases for modification of a KER loop for boiling tests.

\section{KER Activities}

Construction of the KRR Recirculation Test Facility prsoeeded according to schedule. A portion of the cell piping is complete and the ejectrical switchgear has been installed. Continued delay in procurement of zirconium process tubes is being experienced. As an alternate solution to the problem, speciflcations have been prepared for procurement of carbon steel and stainless steel tubes $\rightarrow$ p.m
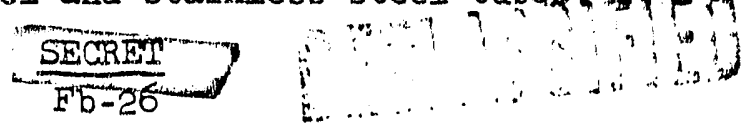
P1le Materials Sub-Section

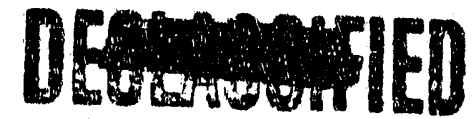

EW - -40692

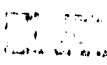

Prellminary scoping design of the side test-hole modification for one KER loop is about two-thirds complete. Design of the charglng-extracting machine is about threeLourtis conplete. This modffeation 1. being negotisted for fnclusion as a FY 1958 budget item.

\section{Operation of 1706-KR Weter Studies Sumi-Works}

Operation of the 1706-10E Sem-Works proceeded swoothly with the exception of one reactor scram caused by lnstrument malfunction. The instrumentation in guestion bas been the subject of an Intengive atudy before and since the scram. Replacement of several crltical parts was effected. A besic difflculty witb the flow cortrol. equipment 1 s the present interjm operation of the reactor process water system at considerably below deslan pressures. Three 1706 fliters vere started up, with the inlt1a], objective of ccorelatfin the pilot scale f1lter with the 183-KE f1lters. An additiona.1 mock-up flow systein was sarted up and 1 operating at a temperature of $155 \mathrm{C}$.

Installation of loop room faclifies and assoclated 1706 work by Minor Construction forces proceeded at a very sat1stactory rate.

\section{PIIE COOLAMT STIDIES}

Production Tegts

The west bale of 105-F Reactor bas opersted for six months, under the proviolons of

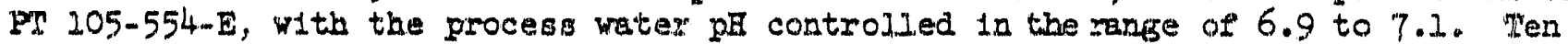
charges of weighed heavy meta. slugs are presentiy being exposed in the reactor. The test has operated whth negliglble water treatment difficulties and with satisfactory in-pile perpormance.

A slug mpture occurred in tube 2276-C, operating under PT 105-519-E, on December 8, 1955. The charge in thls tube conststied of welghed, regular metal pleces and had reached an exposure of $200 \mathrm{MND} / \mathrm{T}$ at the time the rupture occurred. The tulbe outlet temperature was $110 \mathrm{C}$ and the power was $900 \mathrm{~kW}$. The rupture was stuck in tibe tube and bas not been 1nspected. The tube was removed and replesed with a standard "C" annulus tube. The three remaln1ng PT 105-5I9-E tubes are operating satisfactorily at outlet temperatures up to $212 \mathrm{C}$.

\section{File Frocess Tubes}

E1ght process tubes were examined during the month. Examination of the zirconiun tube from 0962-E required week because of the thigh radiation level and the slower slitting speeds. The hole in $0961-\mathrm{H}$ nes not locater, but a possible location was observed adjacent to the gulliotine cut on one seation. No otiner danage or corrosjon attach was sound. Thabes $2,170-\mathrm{B}$ and 0681 H appeared to be severelyr corroded on the Inside near the end of the charge. The $c$ Reacte tubes exantned had no out ide corrosion and vere only slightly corroded on the inside.

Easic temperature data for a more refined calculation of pile proces tube wail thicknesses are veing collected. Tenperature maps since start up of D Reactor have 
been recorded on IEM cards. About three-quarters of the maps from F have been recordea, and tabulation for $\mathrm{B}$ and B Reactors is belng started. It is hoped to have the corroston bistory for and D Resctors computed by the end of the month.

Accelerated corrosion of frocess tubes between the rlbs and corrosion-induced slug Inxptures between the tube Intbs have been attributed to botter water between the ribs as a regult of reduced rib helghts. Theoretical calculations Indicate that insertion of two pleces, whlch result in complete mixing of the water, between slugs of a metal charge In a tube with reduced $\mathrm{rlb}$ helght should lower the local water temperature between the ribs suffucleatly to reduce greatly the incldence of slug ruptures and tube leaks from this cause. A study to develop an insert to 1mprove intermixing 0 : the process water between the two channels bas been inltiated. Preliminary flow laboratory tests, using a giasa tube of process tube dimensions, demonstrated that Interatixine between the two chandels was greatly increased when an elght inch perforated duray was substituted for a solid metal plece in a charge.

Six zirconlun billets vers recelved from the Bureau of Mines by Allegheny-Iudium Corporation for Pabrication lotio six rtbless pile process tubes, 50 feet long. One of the billets 18 1-3/4 inches shorter than the specilled 11 inch length. AlieghenyIudlum has stated that the tuive fabricated from this short blilet w1! be approximately 37 feet long.

\section{Economic Study, Retubing A Reactor with Z1rconlum Tubes}

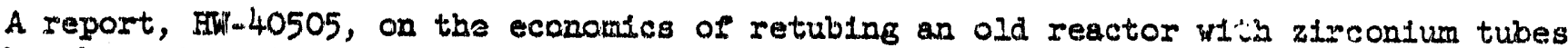
has been 1ssued. An anslysis of production rates and untt costs at outlet temperatures of 120 , 140 , and $160 \mathrm{C}$ comparing zirconiun and aluminum tukes was made. With zirconiun it was possible to use a tube wall thiskness of 34 mils, thereby increasing the annulus and permitting increased Plow after compietion of the CG-558 Project. This increased llow at a glven temperature would permit higher power levels and production.

Considering only increases in 100 Area production and decreases in 100 Area cost and depending upon.the corrosion, and retubing rates obtalned, payofe periods for zirconfum varled between 3.2 and 6 years. When pay-off perlodis were calculated assuring that the added production obtalned with zirconlum tubas was worth $\$ 40 / 8 \mathrm{gm}$, the capital cost of zirconlum tubes could be anortized over perlods of 1.3 to 2.5 years, depending upon corrooton and retubing rates achieved.

In view of the favorable pay-off period it was recomnended that increased efforts be made to demonstrate the fabricability of zirconium tidbes.

\section{Laboratory Corrosion Studies}

The mintube test to determine the corrosion of $2 S$ aluninum in $\mathrm{pH} 6.5$ and 7.0 process water containing $2 \mathrm{ppm}$ sodium dichromete has been completed. The minislug samples are now being cleared of corrosion pioduct. Some difficulty has been encountered in removing the film from the slugs exposer at the bigher teurgeratures.

The full size mock-up portion of the pll 5.5 test was alscontinued because there was insuff-cient pressure from the 1706-KE mock-up pimp to run bcth the mock-up and minitube syotem at the same time. The minitubes are continuing to run at $\mathrm{pH}$ 5.5. The oH 6.5 and 7.0 mock-up testis are also crntinuing.

$$
\frac{\text { SECRES }}{\text { Fb-28 }}
$$


New bourdon tubes were installed in the remainder of the in-plie header pressure controllers so that the pressure control would be less critical. The air operated valve on tube 4963-Ko stily, has a tendency to stlck, which could give a pressure surge during minor pressure adjustments.

Water Treatment Studies

Modiflcations to the Flow Laboratory piping in 189-D are nearly complete. This system $\mathrm{W} 1 \mathrm{II}$ be used in testirg candidate materisls for use in transporting dilute activated silica solutions 18m 183-D to 183-Wand an 183-C to 183-3. Some delay in the plping modiffcation was incurred when a pump casing was broken. The broken pum has been replaced by a spare avallabl.s from 186 storage.

Seven test samples are installed or are avallable for installation. Three more test samples (with promised delivery date of December 15, 1955) have not arrived at Hanford.

The 1706-KR pllot plant p1lters were started on test cunditions on December 12, 1955. Initial results were quite errat1c, as expected, due to dirty lines and operational. problems. By December 17, 1955, fliter data indicated reasonably nornal filter operatiun. Evaluation of the first phase of this program will indicate the degree to which the 1706 e1lters compare with the 183-KS filters as to water quality, operating varlables, and, if possible, in-pile effects. 
BW -40692

\section{FUEL TECENOLOGY SUB-SECTION}

\section{PROCESS TMECENOLOGY}

\section{Untransformed Uranlum}

Approximately 0.5 percent of the current production sol.1d uranium slugs are belag rejected by the ultrasonic (transformation verlflcatior) test at the new test level inftiated in October. To dete no uniransformed metal hes been observed in atatistically chosen samples of the acceptable pleces. The presence of untransformed reject pleces has, in oach case, been' tied to the heat treating parlod that FMPC was off procese. It has been recommended to the Proces: Sub-Section that EAPO lots, from FMPC parent lots heat treated during the off process period and whon the ultrasonic tost at BAPO was inspected at the old low level, be irradiated to low goal exposure only. All reject slugs from the ulitrasonic test station will be re-heat treated at BAPO and returned to the production stream. Investigation of severel remeat treated slugs, some known to have contalned untransformed areas and some known to heve been completely transforned hut fine grained, has showll no evidence that the re-heat treatment has adversely affected the quality of the uranium.

\section{Eydrogen in Urantum}

Process control data recelved from NLO show that the hydrosyl content of the rod heat treating bath remeined below one percent from september 7 through December 2. When the materlal heat treated during this period was canned the frost test plus void reject frequency was an acceptable 3.9 percent.

The equipment for the improved rapid hydrogen method for estimating relative amounts of Burface hydrogen in uranlum cores has been assemblied and is belrg calibrated. Th1s oquipment is being devoloped to aid in establishing a specification for hydrogen and to be used as quality control equipment both at Fernald and Hanford. A group of rods speclalis prepared to provide a wide range of hydrogen values are beling machined for tests leading to the establishment of a hjdrogen specification.

Vacuum outgassing of uranium cores 18 of greater benefit than surface outgassing In a molten selt bath in reducine the unbonded areas in lead dip canned assemblies. Asmrecelved dingot slugs showed an average sonobond count of 1300 . After outgessing in a molten salt bath the average sonobond count for dingot slugs was 342 as compared with an average of 316 for as-recelved ingot siugs. After vacuum outgassing the average sonobond counts were 55 and 68 for eleven dingot and ingot slugs, respectively. The differences between the sonobond counts of slugs subjected to the two outgassins treatments is highly significant. An important secondary conclusion is that, despite reducing the total hydrogen content to less than. $75 \mathrm{ppm}$, significant unbonded areas occur in the lead dip canned assemblies. 


\section{Detection of Bond Defects}

A study of the slug bond defecta detected by the ultrasonic bond test unit was initlated to determine (1) 19 the ultrasonic test should be applied to the entire lengih of the slug or limited to the can area over the core, and (2) whether meaningful, more atringent, acceptance standards could be pui into effect to raise the bond quality of the slugs eccented for shipment as opposed to keeping the ultrasonic reject rate comparable to that of the frost test. About 100 slugs rejected at the current ultrasonlc test level, but which passed the frost test, have been examined to determine the neture and extent of the indicated defects. Nearly all of the slugs in this group were rejected for defective areas under the side wall Indicating that very few slugs are rejected by the ultrasonic unit for defects in the can base or closurs zone (the frost test does not test these portions of the slug).

\section{Canning Cored Slugs with Aluminum End Plugs}

About 46,000 drilled and 9300 extruded cored sluge with 25 aluminum end plugs have been canned and shipped to the 100 Areas to date. Separation of alloy end plugs from 25 aluminum plugs (the aljoy plugs, which have low molting point constituents, were found to be the cause of leaking slug cores last month) is being accomplished during processing by a caustic etching step following degrsasing. The undesirable alloy plugs are stained by action of the caustic and a visual separation can bo mo.

\section{S1licon Content of Al-Si Baths}

The thermal analysis technique, used by Manufacturing to determine the silicon content of the AI-S1 in the canning and duplex baths, was studied. The procedure was then modified to improve both the accuracy and precision of the determination. The data indicate that the expected precision or reprosucibility of the improved thermal analygis 1.11 be within \pm 0.04 percent S1. Prelininary results show what the silicon content as determine $\bar{d}$ by wet chemical analysis differs from the silicon content as deternined by thernal analysis by up to 0.25 percent.

Evaluation of Aluminum Caps and Cans from New Vendors

Frior to using 100,000 caps and cans from each of three new vendors, some in-pila testing must be done to assure that excessive corrosion of these canning componerts will not caluse operational difflculties. Representative fuel elements to be tested will be prepared from the first 4000 caps and cans received at HAPO from each new vendor. (1) The use of the remaining components will je predicated on the r"esults of these tests.

Six control tubes will be required for each type of componert to be evaluated. Test material w1ll be lixeded alternately with standard slugs in each tube. Three tubes will be discherged at. $600 \mathrm{MND} / \mathrm{T}$. The remajning three tubes wiII be discharged at high goal exposure. Control tubes will be charged one month before

(1) BW-4052.7 A, "Production Test 105-66-MT, Evaiuation of Aluminum Caps and Cans frorn New Vendors," W. C RileY and F. W. Vainormer.
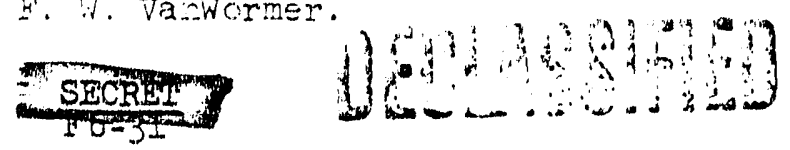
the remainder of the slugs whenever possible. If a corrosion faliure that misht be attributed to new components occurs in those slugs lot charged to high goal, it will be requested that additional tubes be pushed and visually examined.

Brass particles are numerous in the cans recelved from Harvey Aluminum, but are less frequent in the Alco cans. It has been suggested that an investigation be made of the frequency of incidence in Alcos cans and that both rendors be approached with the request that quality control measures be put into effect to assure that the Ianford cans w1ll be free from embedded metallic particles.

\section{Uranium Plckilng}

The production spray plckling machlne in the 313 Bullaling has been modifled by the 1nstallation of new acld spray nozzles and automatic doors to enclose the spray chamber. These modifications should permit reallzation of the benefits observed on the pllot spray apparatus in the 314 Buliding. Proliminary operation has demonstrated thet the doors function properly and that the pickling is satisfactory. Operation on test basis will continue until quantftatfve data are obtained.

\section{PROCESS DEVELOPMENT}

\section{Orantum Processting}

Visual examination of 200 each of dingot and Ingot slugs showed 94.5 percent and 80.5 percent, respectively, to be 71 sually perfect, thus supporting metaliographic observations and chemical analyes that the dingot slugs are freer of striations than slugs from current uranium, cast in seven-inch diameter molds with hot tops. Dingot slugs from Mallinckrodt October and November production were measured and canned for six "pllot" tubes to be irradiated to $900 \mathrm{MWD} / \mathrm{T}$ and four tubes to be 1rradiated to rupture. The Mallinckrodt pilot plant dingot manufacturing and forging operation appears to be well established, and the current practices are expected to be followed at the Weidon Spring piant now under construction.

The thermal fatlgue resistance of beta quenched and beta quenched $620 \mathrm{C}$ vacuum annealed dingot uranlum was determined. A linear relationship was obtained between the temperature difference in the slug and the natural logarithm of the number of cyoles to fallure. For a given number of cjcles to fallure the annealed uranium required a core temperature $50 \mathrm{C}$ lower to prciuce faliure than for beta quenched uranium.

A continuous process for beta heat treating uranium rod by induction heating has been pro osed. The major 1tem of equipment required to accomplish this at HAPO is a device to scan the rod through the induction coll. On the basis of preliminary :ssign studies, a skewed roll conveyor has been selected as the best means of moving the rod through the coil. A search for such a device has revealed that the equipment will cost about $\$ 12,000$. An alternate approach to developing an induction heat treating process is to explore the posaibility of having outside vendors carry out a development program on a contract basis. 
Seven tubes of slugs from supplemental tubes in PT 105-601-A-53-MT (a test of uranium heat treated in slug form with various delays between removal from the transformation salt bath and imersion in the quench brine) have been examined after exposure to $400 \mathrm{MWD} / \mathrm{T}$ in $\mathrm{D}$ p1le. The average warp por the materlal at each deley time was $0.014^{\prime \prime}$ with velues ranging from $0.005^{\prime \prime}$ to $0.025^{\prime \prime}$. The degree of warp observed is characteristic of uranium heat treated in slug form and is less than that experienced with regular production slugs which are machined from heat treated rods. However, no dlametral growth (typlcal of production metal heat treated in slug form without a deley quench) was observed. Ten delay quenched olugs have lalied in the supplemental tubes. These fallures were characterized by penetration of the jacket between rib marks. Examination of the slugs from a tube in which one of these ruptures occurred showed six sluss wh1ch contained severe jacket corrosion. The corroded areas ran the length of the slugs and the width of the area corresponds to the wldth of the ribs in a process tube. These six siugs, according to 1 ilm and weasel data, wero irradiated in the same general area of the process tube (position 3-12). The maximum aluminum 10ss as determined by diameter measurements was 42 mils. The manner of fallure has, in general, been typical of recent side wall ruptures in production metal and indicates that the slug core heat treatment is not a contributing factor. The twelve control tubes, each consecutively charged with $5,35,43,50$, and 80 second delay quenched slugs and production slugs (standards) from heat treated rods have now reached exposure concentrations of approximately $200 \mathrm{MWD} / \mathrm{T}$. Two of the control tubes will be discherged and examined after exposure to $600 \mathrm{MWD} / \mathrm{T}$.

For another production test ( $54 \mathrm{MT}$ ) control tube slugs machined from deiay quench rods have all beer measured and stamped and should be canned and ready for pile charglng by January 15, 1956. Orientation data have been obtained on each siug. Sanples for metal.lographic studies and varicus other laboratcisy teats will be sejected after the material has been lead dip canned ard inspected. Twerty control tubes will. be charged in this test. The remaining 3000 slugs from the heat treated delay quenched rods have been canned and wili be pilie charged to lor goal exposure as lots $\mathrm{C} 88$ and $\mathrm{C} 90$.

Assembly Process Development

A joint design has been developed that appears to prevent excessive weld build-up during the jolning together of two " $C$ " slugs by Fillererc velding. The joint design involves the use of a ore-inch diameter "arc startire wafer" that ia placed between the abutting silig ends.

ADout 250 fuel elements for the hot press sol:al core production test (PT 3.13-59-MT) have been canned. Completion of the canning opergtion has been delayed due to the fialiure of one of the sleeves in the four linit olock. When the sleeve is replaced an additional 200 pieces will be canred to provide the eight tubes of material required for this test.

Approximately 500 fuel elements were produced at Syivania Euectric Projucts by the vacuum hot press technique. These elements will be shipped to BAPO for eraiuation and a possible production test. 
Installation of the Internal worklng mechaniem for vacuum braze ranning has been completed. These mechenf sm, which include the slug suspension and release mechanism, the can elevating system, and the AI-S1 pouring mechanism, heve been tested for operation and perform as intended. The vacuum pumping system is currently under test to ostablish prum speod and uitimate vacuum. Inconsistency between gages has given wide varlation in results. A Plranl gage indicates a pumping rate from atmosphere to 30 microns in 30 seconds and an ultimate vacuum of 24 microns. At the same time an Alphatron gage shows an liltimate vacuum of 7 microns. The above speed and pressure is attalned using only the mechanical pump. When the diffusion pump is in use the preseure indication of the Aiphatron gage is off scale (less than 0.1 micron) at which time the Piranl gage showg 6 microns. Leakage in the system will account for some of these differences.

\section{Post Assembly Processes}

A production test design was prepared which outlines a serles of tests to evaluate the effectiveness of anodizing the surface of canned slugs in reducing the number of jacket fallures resulting from mechanlcal damage and slug misalignment. Slugs with one mil thick anodized coat, formed in axalic acld solution, and sealed in saturated sllicic acid, are to be tested.

In addition to providing improved resistance to mecianical damage, it is belleved that anodizing will reduce slug misaligoment, since the axlal force required to mote a charge along the ribs of a process tube 1s about half that required for regular slugs. This feature reduce the tendency for the slug colum to bow or buckle during charging and during plie startup, when thermel expansion causes a greater lengthening of the slug colum than of the tube.

\section{Tests planned and underway include:}

1. Mechanical and Flow Laboratory Testing. Charging studiss and irvestigation of charge bowling effect shall be conducted, using both regular production and snodized slugs. Current flow laboratory tests will continue in an effort to further define the corrosicn characteristics of aluminum jackets having one mil ticick anodized coats.

2. Irrediation. Determination of the corrosion resistance of anodized slugs:

a. Irradiation of ten tubes composed of aiternated anodized and regular production slugs in about $100 \mathrm{C}$ olitiet tioes. Four tubes are to be discharged at $600 \mathrm{MWD} / \mathrm{T}$ to provide early corrosion data. The remaining six will be discharged at normal high goal exposure.

b. Irradiation of these tubes of alternated anodized and regular production slugs in the higher temperature (about $110 \mathrm{C}$ ) out iet tubes of FT 105-519-E. The results of this test discharged at 400$600 \mathrm{MND} / \mathrm{T}$ will also provide sarly evaluation of corrosion. characteristics.

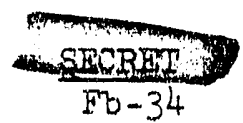


Upon veriflcation that the in-pile corrosion resistance of anodized slugs is equal or superlor to that of regular production slugs, and out-of-pile tests confirm present indications that anodizlng slgnificantly roduces siug misalignment and mechanlcal damege, quantities on the order of several hundred tubes will be irrediated. The number of tubes necessary to establish a flrm fallure rata will depend, of course, on fallure retes prevaling during the perlod of irradiation.

\section{DEVELOPMENT OF NEW FUEL ELEMENTS}

\section{Reactivity and Conversion Ratio}

The phrsics equations for calculating reactivity and initial conversion ratios on the 702 computer have been studied and checked. The constants for 68 cases have been corputed. The programing has been completed and the cases are in the process of being run. The cases under consideration may be divided into three classes: (1) Internal-external, wot and dry, (2) seven element clustor, wet and dry, and (3) solid slug, wot and dry.

The O.D. of the slugs was somewhat larger than the conventional 1.440" being 1.518", $1.550^{\prime \prime}$, and 1.592" for the B-H, $C$, and $K$ plles, respectively. In the same sense the process tube I.D.' $s$ were considered to be $1.676^{\prime \prime}, 1.708^{\prime \prime}$, and $1.750^{\prime \prime}$. In all. cases, the process tubes were zirconlum; whereas the slug jackets were either a luminum, zirconlum, or stainless steel. Four different loadings were considered, namely: (1) 100\% uranium, (2) $55 \% \mathrm{U}$ - 35\% $\mathrm{Mg}$ matre (3) $95 \% \mathrm{UO}_{2}$, and (4) $85 \% \mathrm{0O}_{2}$.

Several cases were fun using a slug with a 2.20" O.D. This would necessitate a process tube with a 2.380" I.D. Conceivably, the present piles would have to be bored out to admit a tube of such dimensione. It may be of interest to add that the proposed 2.20" slug 1s an I \& $E$ Inside of an I \& $E$.

\section{Wafer Fuel Elements}

Two hot dip wafer slugs have accurmulated exposures of about $700 \mathrm{MWD} / \mathrm{T}$ in the Materlals Testing Reactor. The feasibility of fabricatirg wafer (segmented) fuel elements by the lead dip process was investigated. Metallurgical studies show that, if lead does penetrate between the wafers during the preheating cycle, it is displaced almost completely by Al-Si during subsequent canning steps. In several of the slugs examined, very small occlusions of lagd were found between the wafers; in most cases, the leed was surrounded by Al-St which penetrated between the lead and the uranfum. From this work it appears that peretration of the lead between the wafers wili not be a serjcus proilsm. Autociave test: have confirmed previous conclusions that a wafer slug without aluminum spacers, or bulkheads, can be almost completely disintegrated by hot water without seriousiy damaging surrounding process tubisig.

The effects of intemal heating on the corrosion behavior of wafer siugs was investigated. Thirty-two uranium washers $1 / 8$ " thick were assemiled or a bolt $2 / 4$ " in diameter. Steel washers with holes arliled through them were used at each end of the assembly to allow water to run through the center. The slug was placed in

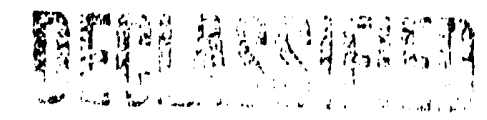


the "woodsplitter" induction heating coll and heated to a maximum temperature of roughly $400 \mathrm{C}$ at polnts midway between the Inside and the outside edges of the wefers. The bulk water temperature was about 18 degrees, the flow rate 15 ft/sec. Two assemblies tested in this mamer broke the bolt in two after eppraximately one hour. The edges of the wafers were darkened by a very thin lajer of oxide. The only appreciable corrosicon occurred at polnts appraximately midway between the Inside and outside odges of tho wafers. Approrimateis 210 pounds was required to break the bolt by a tensile test.

Metallurgical investigations into wafer fabrication procedures revealed that up to 10 percent cold reduction in thicknesa subsequent to bets heat treatment of uranium sheet caused no detectable change in the grain structure. The sheared edges of wafers from this sheet indicated flowed motal and circumferential cracking that increased in severity wlth the amount of cold finishing. The cracking may be eliminated by altering the punch and ale design.

The mufacture of uranium wafers (or washers) was continued in the 306 Bullding pliot plant at a satisfactory rate for canning and severity of fallure investigations. National Lead Compang rolled the first sheet and procured the first set of diss for the production of uranlum washers for the HAPO pile tests, as mentioned in last month's report. It appears, however, that Nat1onal Lead w111 not be able to shlp these washers to arrive at Flanford as soon as they w111 be needed. National. Irad also began to lay plans for making I \& $E$ slugs and wasbers for I \& E wafor slugs from 1.44 percent $U-235$ content uranfum for several pile tegts to explore problems of high power slug irradiation. It appears that these slugs and wafors may not arrive at Earford unt 11 May and June, 1956, respectively.

\section{Interneliy and Externally Cooleć Fuel Elements}

Approximately 650 internally and externally cooled fuel elements were assembled by the lead dip process in the Manufacturing facility (313 Bullding) for pile irradiption (PT 105-615-A-63-MT). A canning jield (through the assembly operation) of about elghty percent was obtained, with the major roject category being cap non-seats. Increased clearance between the tube and cap, and tube and can base hole, resulted in easier assembly than experienced during the inftial run last month. Examination of the initial group of 100 I \& E pleces alp canned last month disclosed the followlng:

1. The outalde jackets of the fuel elements hate a larger grain size ( $\left.\sim .250^{\prime \prime}\right)$ than solfd core production material $\left(\sim .005^{\prime \prime}\right)$. The larger grain size results from the annealing and axpanding operation required to produce the larger I \& $\mathrm{E}$ components.

2. Can-core bonding and can wall penetration were satiseactory.

3. Tube-core bonding and tube wall peretration were satisfactory. Several tubes were bond tested, and the first plece showed circumferential cracking in the compouad leyer when examined metaliographically. However,

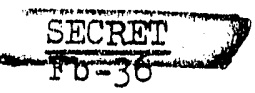


other piecus rejectrad by the tube bond tester have been examined and the cracked condition was not apparent. Three I \& $E$ pieces selected at random and sectloned longltudinalis revealed little or no cracking in the compound Iayer.

4. Metallographic examination of the tube-core braze layer showed that caustic cleaning (as specifled in the" HPA"process) produced more unfform braze layers than the $F$ "process method, though both cleaning methods appeared to permit adequate wetting of the aluminum surfaces.

5. The tube closure on half of the fruel eleme its leaked Al-S1. By spinning the tube closure and superimposing a spot weld on the tip, the leakage rejects dropped from 50 percent, on the inftial canning test, to about 5 percent on the production test run.

6. Many of the furion welds between the tube-cap and tube-can cracked after welding. Widening the braze layer and adjusting the welding conditions reduced the incidence of cracking. Currentiy, the production test pleces are being processed through the varlous pre-pile tests. Elght tubes of material will be selected for irradiation. It is anticipated that the I \& $E$ pieces w1Il be charged in $\mathrm{C}$ pile during January.

A group of 34 hot press I \& $\mathrm{E}$ fuel element assemblies were canned for destructive testing prior to preparing the tube of anodized pieces for in-pile outlet water temperature tests. The destructive tests confirmed the required can, cap, and hot work punch dimension necessary to eliminate the undesirable annular folds occurring near the tube can base area. By controilfng the lubricant application on the pin the graphite entrapment has been considerably raduced also.

\section{Fue]. Elements for Rlbless Process Tubes}

Four ribbed slugs were produced successfuliy by the standard legd dip process. The cans, which were machined from rod, had three full. Iength ribs of approximately the helght and width of the ribs now used in process tubes. Grooved canning sleeves were used to accomodate the rlbs. Three of these ribbed elements were Prost tested and Intentional volds under the ribs, as well as between the ribs, were detected successtulizy.

Approximately 240 aluminum facketed canned uranium siugs have had $1 / 4$ inch diameter studs percussion welded to the can aurtace at ANL. It is pianned that these slugs will be ready for charging into ribless process tibes in January. Development work on alternate methods of affixing supports to the slug jacket is in progress and includes ultrasonic welding and resistance brazing.

\section{Cast Bonded Element}

Eight four-inch uranium cast bonded zirconium jacketed slugs have been received from Ames for evaluation by Fuel Technology. Preliminary observations show that bonding is good although the uranium core contained pipes and appeared dirty. The slugs will be tested to determine bond strength and slug corrosion performance.

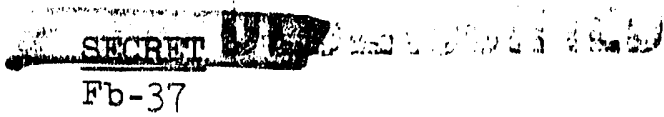


"Tell-Tale" Fuel Element

Twelve "tell-tale" fuel elements, comprised of a nickel plated core encased in a ten mil thick aluminum sleeve and surrounded by a thin (15 mis thlck) nickel plated uranium sleeve (the rapture warning layer), were hot press canned for fallure studies. Four of the fuel elements were subjected to undercutting corrosion testi. Localized swelling occurred at drilied points after approximately ten hours. After approximaielJ 14 hours, the lateral surfaces had swolien to 1.500"-1.525" from the orf.ginal diameter of $1.440^{\prime \prime}$ because of oxide-hydride formation. Dimenalons of the fuel element remalned relatively unchanged from 14 hours to 44 hours at whlch time the teat was discontinued. These tests indicate that impending rupture can be detected by elther radiation measurements or pressure drop meesurements prior to total falluro.

\section{MATERIAIS DEVELOPMEIVT}

\section{Zircontum and Z1rconlum Allors}

Tensile test data have been collected from zircaloy-3 material for cold-worked conditions of from o\% to $80 \%$ reduction in aree. The mechanical properties of the $60 \%$ cold worked material at room temperature were: ultimate strength, 89,750 psi; Jield strength, 81,550 psi; elongation in one inch, 10.5\%; reduction in area, $30.9 \%$.

The tube reduction of two extruded zircaloy-2 process tube blanks was attompted by Superlor Tube Company on December 19 and 20 . Two lengths of approximately 33 feet each of finlshed process tubing was formed before a material failure occurred. The fractures occurred in regions of excessive galling of the tube blank surface, a result of extrusion. On December 21. an attempt was made by Bridgeport Brass Company to extrude one zircaloy-2 bililet. The billet failed to extrude and attemnts to extract the extrusion mandrel from the billet were unsuccessful.

\section{Aluminum and Aluminum Alloys}

Fifty slugs have been canned in M-388 (AI-1\% Ni) components. Twenty-four of these were charged 1nto $\mathrm{H}$ loop on December 28. Additional slugs will be prepared in the next few weeks for a production test and a flow laboratory test of alloy M-388. There has been some difficulty during canning with failure of the cans to wet with AI-SI; however, a minor modification of the canning process variebles should overcome this.

The welding of the $M-388$ alloy appears even better then that of the $M-329$ (present can stock) alloy. There is no superficlal surface cracking in the weld bead or in the weld preheet peth as frequently occurs in $M-329$. There is a gxeater tendency to dimple when the welding arc is shut off, but this can be eliminated, if necessary, by adjusting the variables of the welaing process.

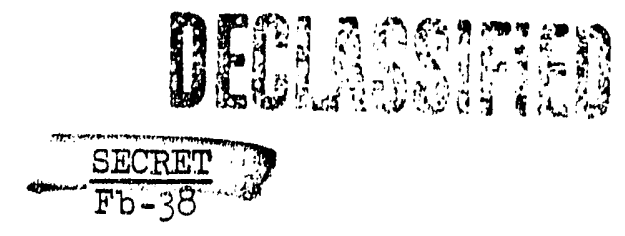




\section{Corrosion of Aluminum and Aluminum Allogs}

Samples of annealed, $99.45 \%$ aluminum were corroded in 300 Area tap water at $90 \mathrm{C}$ and $\mathrm{pH} 8.8$ for 1 to 14 days. Most of the corrosion products went into solution, onls 5-12\% of the alumt num corroded could be recovered from the corrosion product film.

Corrosion rates establlshed over one month exposure in fllowing $350 \mathrm{C}$ delonized water have been calculated for the allogs $\mathrm{M}-388, \mathrm{X}-2219,4032$, and 2018 . A survey corrosion test of some 50 comercial aluminum allogs had indicated these particular alloys are relatively 1mune to lntergranular attack. Current tests are designed to determine accurate corrosion rates over a per1od of $6-12$ months. The results of the first month's *. Jting are shown in Table $I$.

TABIE I

CORROSION RATES FOR SOME ALUMTNOM AILOYS IN 350 C FIOWING DEIONTZED WATER

\begin{tabular}{|c|c|c|c|c|}
\hline AlIOY & Composition & Condition & Total Ex-ogure & $\begin{array}{c}\text { Rate } \\
\text { Mils/Month } \\
\end{array}$ \\
\hline$M-388$ & $1 \% \mathrm{~N} 1,0.5 \% \mathrm{Fe}$ & As rolled & 1 month & 0.86 \\
\hline $7-22.19$ & $\begin{array}{l}6 \% \mathrm{Cu}, 0.3 \% \mathrm{Mn}, 0.1 \% \mathrm{~J}, \\
\mathrm{U} .15 \% \mathrm{zr}\end{array}$ & As rolled & 1 month & 0.84 \\
\hline 4032 & $\begin{array}{l}0.9 \% \mathrm{Cu}, 12.2 \% \mathrm{~S} 1,1.1 \% \\
\mathrm{Mg}, 0.9 \% \mathrm{N1}\end{array}$ & As forged & 1 month & 1.07 \\
\hline 2018 & $4 \% \mathrm{Cu}, 2 \% \mathrm{Ni}, 0.6 \% \mathrm{Mg}$ & As forged & 1 month & 0.85 \\
\hline
\end{tabular}

Bake Test

A bake test at $400 \mathrm{C}$ 1s being conducted to test the effectiveness of various diffusion barriers in preventing aluminum-uranium diffusion at high operating temperatures. Knowledge of an effective diffusion barrler is necessary to establish the f'easiblity of aluminum fuel element fackets for high temperature service.

Reaction of Uranium and Water at Elevated Temperatures

The high pressure loop has continued in operation and data have been obtained for the reaction at lower water temperatures and higher metal temperatures. The rates for bare uranium reacting with $200 \mathrm{C}$ water were found to fit the stralght line relationship ( $1 / T$ VB. $\log$ rate) found by other investigators, thus confirming the data obtained for rates with water at $300 \mathrm{C}$. While uranium preheated to $600 \mathrm{C}$ shows no passivation, there is an indication that a slight passivation may result from preheating to $700 \mathrm{C}$. This will be clarified by varying the reaction time (Iength of test).

Cans have been designed and the components are being fabricated to study the effects of (1) uranium temperature maintained at $700 \mathrm{C}$, and (2) a uranium-nickel-aluminum compound layer between the uranium and the anodized aluminum jacket. 
TESTING METHODS AND EQUIPMENT

\section{Finlshing Iine Test}

The new electronle ualts for the Al-S1 penetration test after a month's operation are proving very satisfactory; however, some trouble is belng encountered with the probe assembly. The chiof source of the difficulty appears to be the mechanism whlch passes a strip of teflon tape between the probe and the slug to prevent destruction of the probe due to wear. It has been agreed that these probe assemblies will be considered st1ll experimental untli the difficulties are corrected.

The machine assembly of the automatic conveyor is complete, and the control and actuator units are being added in the laboratory. The first testing of this equipment should be possible in January..

\section{Bare Slug Test}

Considerable trouble was encountered during the month with the new transformation test units. The trouble has now been traced to defective transducers and has been corrected. The automatic convejors for this location, which were actually designed about two years ago, proved too slow and too unreliable, so they have been replaced with the old ones until better equipment can be developed. The uranium quality testing derice has completed one jot of 2238 blank slugs. The automatic convegor used on this test has also caused a good deal of trouble, so that it is boing deautomated and adapted for hand loading and unloading.

\section{I \& E Slug Tests}

Penetration test equipment for the tube in the I \& $\mathrm{E}$ s.lug has been checked out. Fifteen mil penetrations were readily detected with the probe. Further refinements are necessary and a mechanlcal arrangement must be developed to insert and remove the probe as the slug is being rotated. A "mouse" type of probe for the I \& $E$ bond test has bean bullt which wlll permit holding the two crystals in position in the tube through the I \& E slug. The Al-S1 canned slugs so far tested give rather strong rellections from the aluminum-uranium interface and in all cases the cause for these replections is now evident on destructive examination. The response from the bonding layer of hot pressed slugs is lower than for Al-S1 canred slugs.

\section{Advanced Development}

Fractically all the experimental work on wide band eddy current techniques has been completed. The data are being analyzed and a report is being prepared.

Equipment to make internal friction measurements at high temperatures in vacuo has been received from the shop.

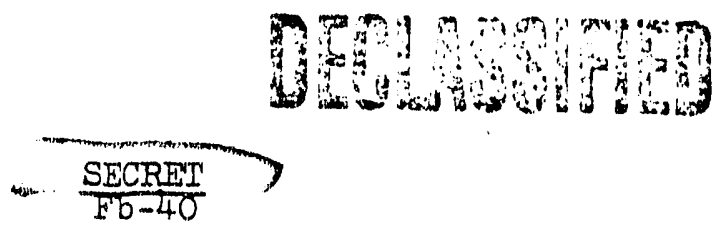




\section{IRRADIATICN BEWAVIOR}

\section{Exemiration of Elugg from the I Ioop}

Sluge from the hIgh temperature loop at I pile ( $200 \mathrm{C}$ out let) were examined after discharge at $250 \mathrm{MND} / \mathrm{T}$ and $470 \mathrm{EW} /$ tube. An averege warp of $18-19 \mathrm{mils}$ was observed on glugs. Irom the May and Nowmber dischargos whlle an average of about 12 mis of warp would be expected of slugs irradiated to a simfler exposure at rormal operating conditions. The maximam warp measured was 52 mils. Arrangements have been made for control tube adjacent to 0961-E which will be oharged and discherged at the same time as the high tomperature tube. Data from these slugs should permit a more valid ovejuatior of the effect of high temperature operation on siug dimensional stablitty and mechenical otrength.

\section{Examination of Cored Sling}

Two tuber of cored sluge were examined th1s month. Thbe 2179-C sustalned a spit rupture at $731 \mathrm{MWD} / \mathrm{T}$ in a cored slug wath aluminum plugs 1rradiated under PT $105-$ 593-A. From slug diameter measurements it was determined tiat, in addition to the rupture, forty percent of the slugs were split longltidingliy inside the cans. This wa expected Prom previous data complied on cored slugs. Stmilarly, fire of the 29 cored sluga with crinped uranium end pluge (PT 603) aplit longltuaineliy lrside the cans without rlpture at an exposure of $400 \mathrm{MWD} / \mathrm{T}$. Three of these slugs broke traneversely at the and plus counterbore when a force wa applied in the silig brealser. Th1s tendency to fracture at the end plug durling the bend test is not as provalent in the cored alugs with aluminum end piugs elther due to the ebsence of the stress et the end during lrradition caused by the heat producine uranlum pide or because of the rounded racher tian aharp coumterbore machined to recesve the plug.

\section{Irrediation of Slugs Heving Tr" Ine Erd Cortours}

Tsing sluge with tiru-line (male and female) contours has beer suggestad as a method cf lasuring slue alignent. Iris method of corraction offers the adventage of economy in that, once productior is estailished, the cost of such a slig is Incroned les than five cents, and, 1t one jacket fallure is avoidea, the production savings would pay for more than alx thougand tube charges haming sucin contrours.

Aa the iocation and degree of misalienment is presimed to be random, no small acaie frrejtatsor of tru-lire can be expected to produce siapificart results. Therefore, a large scale production test (Pr i05-620-A-65-MT, HW-405e6 A) has been destgred. As the feslure is as sumed to bo predondnately porer dependent, $C$ pile offers the advantage of high powers and metai throughput. This test should

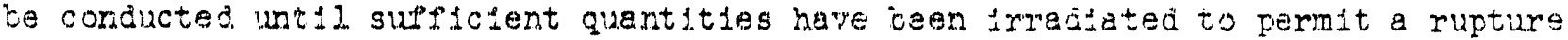
rote antiysts of the effect of tru-lining.

\section{EACIT-TEE AND EGTIDMEIT DEVELCEMENT}

\section{Neldine Iseorstory}

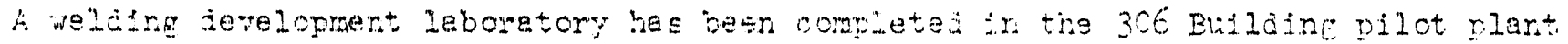

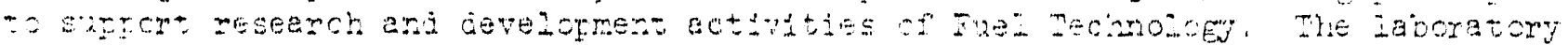


Is oquipped with complete factlities to conduct weld tests on aluminum, zircaloy, and stainless stool shost and plat and jackoted slugs.

\section{Plating and Anodizing Pliot Plant}

Autoclaved and anodized 11.1mb are removed from aluminum by phosphorlc-chromic acta solutions in approximately 20 minutes at $120 \mathrm{C}$. Enthone Compound 89, an alkaline aluninum axlas stripper, was used to remove tho anodized f1lm from threo canned fuel elerents. This Iimited test indicates that this terlal will remove these oxide f1.ms rapldis at room temperature and may be of ralue in proparing fuel elements for reprocessing through the sutsclave or anodizing step.

Enthone Bmilaion Cleaner 75 was tested as a possible replacement for the trichloroethylene degressing operation. This cleaner causes embrittlement of the unfohrome rack couting so 18 not satiafactory for th1s service. Enthol 200, a water soluble detergent type cleaner, is compatible with the rack couting but the degresing was not complete in the preliminary teats.

Zero Mlst, a proprietary compound used to ellminate spray during chromium plating, is being used to oliminate spray from the oxalic acld anodizing and sodium hydroxide etching baths. Almost complete elimination of the lritating mists bas resulted.

\section{5-C Metal Examinat Ion Fac1lity}

Basins I, II, and III were fllled with water and the equipment wes tested as a prelude to maktng the final adjustments necessary for satisfactory operation. The equipment, as a whole, operated very satisfactorily. However, during the testing, several of the hydraulic cylinders falled to function properly. Disassembly of these cylinders revealed furelgn aterial on the inside whlch retarded the cylinder movement. This was attributed to the fallure to flush the lines properly before making the final connection of the plpe Iines to the cylinders. The cylinders were cleaned and replaced. The addition of sler mesh filter screens in the water supply IInes w1Il prevent recurrence of clogged cylinders.

The Installation of four electrical outlets for performing light (bulb) Iffe tests was completed. 


\section{PYYSTCS RESEARCH SITB-SECTION}

\section{Resctor Physics}

During the month of December, work in the ITR consisted of measurements designed to accumulate some basic information needed to urderstand the operation of the reactor. The experiments performed were as follows:

1) Rod-drop measurements: In this type of experiment, a neutron absorber is introduced into the critical pile as rapidly as possible and the resulting decrease in the neutron Plux in the pile is observed. From a study of the flux decay trensient, it is possible, in principle, to state the reactivity erfect of the poison inserted and the lifetime of the neutrons. Stidies of this technique showed that the value of the reactivity strength of the inserice po1son, as determined by this method, depended on the spatial location of the neutron flux detector.

2) Control rod strengths were measured using the "rod-drop technique".

3) A preliminary measurement of the neutron lifetime in the pile was made. The value obtalned was $1.9 \times 10^{-3}$ seconds.

4) The strength of the safety disks was remeasured using the "rod-drop technique".

5) The strength of the safety disks was remeesured using the subcritical measurement technique. Both measurements, 4 and 5 , agreed with the values reported in the previous monthly repoint. These results are puzzling because they give a value for the strength of two front disks $(\$ 5.42)$ which is more then twice tise value of one front disk (\$2.53).

6) The strength of the control rods was measured by critical experiments.

7) Preliminary measurements were made of $F_{L}$ and $F_{H}$ in the center of the pile. $F_{I}$ and $F_{H}$ are, reapectively, the favorableness of low and high energy netutrons toward meinteining the chain reaction.

\section{Nuclear Physics}

The experimental investigetion of the jependence of $v^{4}+9$ on slow neutron energy has been extended to cover the energy leage 0.05 ev to 0.4 ev. $v^{49}$ is the average number of fast neutions emitted De: Blow nextron induced ission of Pu239. The seven relative valueg of 49 obtataed in this regton 9:owed no apperent wrend and agreed with the averege value of $v$ cn tis intervel witi an R.M.S. deviation of 2.5 per cent. These data are 1uteresting 1 I view of the fact that; 7 , the rumber of fast neutrons emfrted ye: slow newann aijorbed, aecresses by about 30 per cent in the neighborhosd of tse 0.3 ev zesnzence.

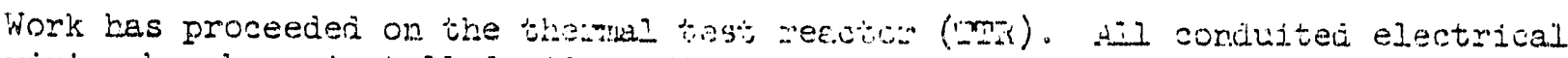
wiring has been installeci, icletstitec, enc comected to approsmiate teminal strips in the control assembly and rescter roms. Cosstruction ef control and Indicating

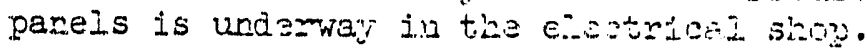

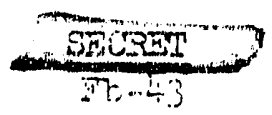


Additional exponential measurements with C-slug lattices during this month have yielded the following buckling values:

\begin{tabular}{lcl} 
Lattice Spacing & \multicolumn{2}{c}{ Bucking } \\
\hline & $\begin{array}{c}\text { (In unts of } \\
\text { Dry }\end{array}$ & Wet \\
$4-3 / 16^{\prime \prime}$ & 1222 & 1572 \\
$5-3 / 16^{\prime \prime}$ & 1134 & \\
$6-3 / 16^{\prime \prime}$ & 1010
\end{tabular}

This completes the serles of buckling measurements with the $\mathrm{C}$ slugs.

The exponential experiments with $1.007 \%$ endiched-uranium rods in light water have now been completed. The buckling value for the 2.7-inch lattice with 1.66-inch diameter rods was deterinined to be $(2213 \pm 100) \times 10-6 \mathrm{~cm}^{-2}$ from a vertical traverse of the neutron density in the lattice. By monitoring the seutron density during the loading, the extrapolated number of rods for critical was determined to be $196 \pm 5$. This gives a buckling of $(2180 \pm 100) \times 10-6 \mathrm{~cm}^{-2}$. which is 1 agreement with the previous value.

Exponential messurements with cluster-type lattices (of interest for dual-purpose reactor use) have coutinued. The buckling of a dry, seven-rod cluster, i.e., seven 0.9e5-inch natural-uranium rods 1r, a 3-inch dianeter tube with a lattice spacing of 14 inches was found to be $90 \times 10-6 \mathrm{~cm}-2$. The $\mathrm{C} / \mathrm{U}$ atom ratio for this lattice is 82.7 , and the $\mathrm{Al} / \mathrm{U}$ atom ration 0.479 . Measurements are now underway on a five-rod cluster in a 14-inch lattice.

Specifications for expertmental quantities of "wrap around" slugs designed for mint production, have been prepared and procurement of these slugs is now being attempted.

A number of exponential experiments (uranium rods with one per cent enrichment, in light water) have been examined in whlch the water-to-uranium-volume ratios ralied from one to four and the rod diameters varled from 0.387 inch to 1.66 inches. The results.of the anslysis indicate that simple diffusion-theoretic methods are sufficient for predicting critlcality hazards for such rods in separations plants.

Physics Problems Connected with Plant Operation

A theoretical analysis of a silver-1odide reactor for lodine removal from dissolver off-gases has been completed. The conclusion is that this type of reactor is

feasibie.

Work has continued on the design of a critical mass laboratory.

Several critical mass and other related problems hare beer. wriked olit for the separations plants.

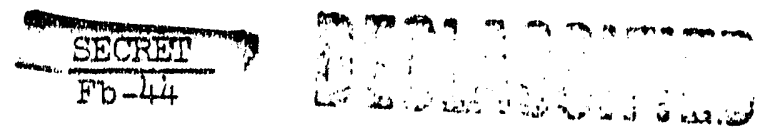


METALLURGY RESEARCH SUB-SECTION

Fundamental Studies

The effect of irradiation on the propertles of uraniurn can be studied by comparing the deformation in microtensile, microbend, and microimpact specimens before and after irradiation. Non-irradiated urantum specimens varying in heat treatments and quality are being studied at room temperature to establish the normal deformation and fracture modes using metallographic and $x$-ray diffraction techniques. Current studies have consisted of motion pictures of a notched sample, 0.015 inch wide at the base of notch, which was stressed to Iracture in tension and a 0.050 inch wide specimen which was subjected to cyclic tension-compression loads. The former study dealt with the progression of a fracture in tension, whereas the latter study established the fact that deformation twins can be un-twinned in sultably oriented grains. The specimen subjected to cyclic stress was not completely fractured and is belng polished to determine the existence and origin of internal cracks in this type specimen.

Initial tests to evaluete the equipment used in the introduction of noble gas into metals and the diffusion or this gas have been completed. A Schiller aischarge tube was prepared this month. Krupton gas was charged into the surface of a hollow silver cathode using the new tube. Six equal pieces of the sllver were cut, and the pieces were fused separately in a vacuum furnace. The gas evolved from the fused silver was collected in quartz ampules, exposed in-pile, transferred to cold ampules. and analyzed with a ganma spectrometer. The analysis falled to definitely indicate the presence of krypton 85 because of a high Compton effect gama ray background. Steps are being taken to eliminate gaseous impurities which are likely to yield high beta activity radioisotopes.

Two U/Zr diffusion couples annealed 336 hours at $450 \mathrm{C}(842 \mathrm{~F})$ did not adhere. Small mounds were observed on the uranium interface, and an attempt is being made to 1dentify these by means of $x$-ray diffraction. The diffusion zone of a $U / \mathrm{Zr}$ couple annealed 77 hours at $695 \mathrm{C}(1283 \mathrm{~F})$ was scratched with a Blerbaum microcharacter hardnes tester to see if there was a difference in hardness across the interface. The results of this hardness study indicate that the visible diffusion zone represents the total extent of penetration of uranium into the zirconium. An $x$-ray diffraction pattern from the diffusion zone of a U/AISI couple, annealed 24 hours at $303 \mathrm{C}(577 \mathrm{~F})$, matched that of a UAI3 standard. Other Iines present have not been identified. A number of minute mounds were found on the uranium interface of a U/Alsi couple annealed 96 hours at $250 \mathrm{C}(482 \mathrm{~F})$. Scrapings of these mounds are being examined by $x$-ray diffraction. Vacuum hot pressing equipment which should provide better interface contact during the diffusion anneal has been compleied. This equipment should provide more uniform, reproducible $\mathrm{J} / \mathrm{AlSi}$ and $\mathrm{J} / \mathrm{Zr}$ diffusion zones than have been obtained previously.

Vacuum cathodic etching has been investigated as a tool for preparing uranium for $x$-ray diffraction studies. Tro factors were examined: (1) the tendency for superficlal annealing of cold worked specimens due to the icnic bombardment, (2) insufficient removal of superficial cold work resulting from mechanical poishing after normal etching periods. Cold worked uranium was used for the first study, and no annealing due to etchine as characterized by $a$ change in diffraction peaks was

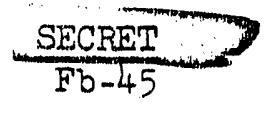




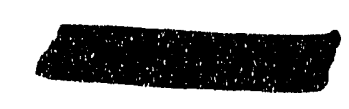

HW-40692 DEL

Metallurgy Research Sub-Sect1on

observed so this is not a limiting factor. Annealed uranium was used in the second case, and it was found necessary to vacuum cathodlc etch for two hours to remove residual cold work due to polishing, resulting in a very rough specimen. A more logical approach appears to be electrolytic polishing followed by vacuum cathodic etching resulting in a specimen sultable for $x$-ray diffraction and metallography as well as belng quite resistant to room temperature oxidation.

Mechanlcal \& Fhysical Properties of Fissionable Materials

After reassembly of the callbrated standard and installation of new thermocouples, it was found that values reproductble to \pm 5 percent could be obtalned with the thermal conductivity unit at temperatures to $200 \mathrm{C}$. With this level of accuracy it wili be possible to measure thermal conductivity values for uranium metal.

Reactor Structural Materials

Testing of zirconium, Zircaloy-2, and Zircaloy -3 specimens in moist air at 500,600 , and $700 \mathrm{C}(930,1110$, and $1290 \mathrm{~F})$ is virtually complete. Results are substantially the same as those found previousily in dry air. Zirconium and Zircaloy-2 show slightly smaller weight gains for a given exposure with the addition of water vapor, while Zircaloy -3 reacts slightly faster; the differences, however, may be within experimental error. The shapes of the curves are the same in both wet and dry air so that the same oxidation mechanisms must exist in the two cases.

Fuel Materials

Further studies have been made of the reaction kinetjcs between hot (200-300 C) water and uranium metal heated 200-500 C above water temperature. After modifying the reaction chamber to permit water expulsion at a predetermined time, a series of reactions detween bare uranium and hot water were run. The principal results are shown in the table below:

\begin{tabular}{|c|c|c|c|}
\hline $\begin{array}{l}\text { Specimen } \\
\text { Temperature }\end{array}$ & $\begin{array}{c}\text { Water } \\
\text { Temperature }\end{array}$ & $\begin{array}{l}\text { Time in } \\
\text { Minutes }\end{array}$ & $\begin{array}{l}\text { Mils/Minute } \\
\text { Penetration }\end{array}$ \\
\hline $\begin{array}{c}\text { Unheated } \\
600 \mathrm{C} \\
700 \\
700\end{array}$ & $\begin{array}{l}300 \mathrm{C} \\
300 \\
300 \\
300\end{array}$ & $\begin{array}{l}20 \\
20 \\
20 \\
40\end{array}$ & $\begin{array}{l}1.5 \\
1.5 \\
1.25 \\
1.55\end{array}$ \\
\hline $\begin{array}{l}\text { Unheated } \\
700\end{array}$ & $\begin{array}{l}200 \\
200\end{array}$ & $\begin{array}{l}200 \\
200\end{array}$ & $\begin{array}{l}0.11 \\
0.095\end{array}$ \\
\hline
\end{tabular}

These results are still preliminary in nature. In the heated specimens, heat was passed through the specimen during the corrosion reaction at a rate of about 69 watts $/ \mathrm{cm}^{2}$ of orlginal specimen surface. This is equivalent to the rate of heat dissipation at the surface of the uranium in a solid Hanford slug operating at $22 \mathrm{kw} / \mathrm{ft}$. This rate of heating could usually be maintained for only $5-12$ minutes of the reaction time. It is interesting to note that this heat at the surface did rot increase corrosion rates in flowing water. The results also indicate an initial. reduction in corrosion rate in the specimens heated to $700 \mathrm{O}$. This effect will be studied further in reactions of shorter duration. Heating canned specimens has to

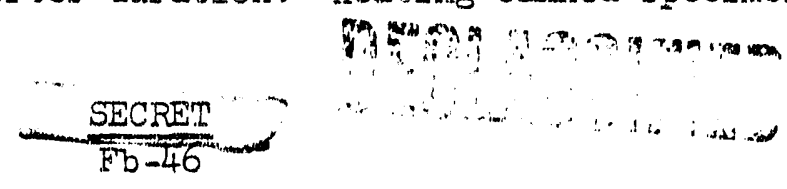


date produced greater penetration than that observed in unheated carned specimens. A canned specimen has been fabricated. which ia insulated by Alsimag and designed to operate at $700 \mathrm{C}$ after admission of water to the chamber. This specimen should indicate whether quite high urantum surface temperatures will serve to reduce or increase reaction rates in a canned specimen.

Nine specimens of U-Mg, prepared by powder metallurgy techniques at KAPL, have been removed from the zixcontum cans. Three of the pleces were broken during this operation, all at the end at which the zirconium cans were closed by fusion welding. There is evidence on the specimens that this breakage may have resulted from a "heat-affected weld zone". Some of the remaining good pieces will be recanned in aluminum for exposure in the MTR. Preliminary canning and autoclaving tests have indicated that this can be done successfully.

The extrusion of Al- $25 \mathrm{w} / 0 \mathrm{U}-235$ alloy sleeves by the Metals and Controls Corporation for duplex slugs and PCTR tests has not been successful. The supplier of these fuel shapes reports that the extrusions were "f'sh scaled" on the $0 . D$., and that they cannot do further work without further expenditures.

Selection and procurement of the necessary laboratory equipment to fabricate ceramic fuel materials on an applied research basis continued. The program will include a study of $\mathrm{UO}_{2}$ starting materials for subsequent extrusion and sintering, a study of the variables encountered in extrusion and sintering, and in-plle evaluation studies of jacketed $\mathrm{UO}_{2}$ elements.

Experiments have been performed to evaluate the use of vibrational energy as an aid in coalescence of metal from oxide reductions. A low frequency, air-driven vibrator operating at 100 cycles per second was coupled to the metal bomb during reduction. Cerium was chosen as a stand-in for plutonium, and calcium was used as reductant. In duplicate charges using $\mathrm{CaCl}_{2}$ as a flux the yield of massive metal was increased from 30 to 43 percent theoretical yield by vibrating. These results are extremely encouraging since in the past all atterpts to prepare massive metal from the oxides in this laboratory have resulted in very poor yields. It is felt that two coalescence mechanisms are taking place during the vibrating operation. First, the energy put in the system may markedly increase the dissolution rate of calcium oxide in the flux forming a solution from which the metal may easily coalesce. Secondly, the vibrational energy may physically breakmp the calcium oxide matrix or the calcium oxide layer around the molten metal spheres which allows them to coalesce. other experiments were performed to prepare metallic pellets from reduction $n$ i the oxides with calcium. Cerium pellets which were grown from fine fowders by vabrating ine bomb during reduction were large enough to be handled and remelted. Remelted pellets from reduction of cerium dioxlde have resulted in yields of over 40 percent as a button of solid metal. Plutonium would be expected to give much better results than cerium in both the direct reduction to massive metal and in the remelt process due to the large density difference. In these exploratory experiments only a low frequency source was used. However, frequencies up to and including ultrasonics may yield far superior results. The use of vibrational energy as an aid in metal coalescence may find application in production of metallic plutonium and uranium rom botin the oxides and the fluorides. In the case of flucride relustions $a$ cleaner metal may result due to evolution of trapped gases including hydrogen.

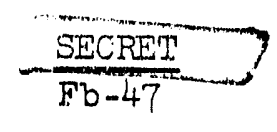


Fuel Element Evaluation

Burnup analysis from two cored insulated slugs 1rradiated at the MIR indicates that the slugs operated at 80-83 kw/ft, 1ncluding gamma heating. This speciflc power is substantially bigher than the orlginal estimate of $65 \mathrm{kw} / \mathrm{ft}$. The second loading of insulated slugs in the fuel element testing facility at the MITR was accordingly discharged after a few hours' 1rradiation to determine the specific power at which they were operating. The burnup analysis of the first loading indicated that the second loading would operate at 107-110 kw/ft total heating since MTR power had increased $1 / 3$ since the flrst insulated slug 1rradiation. This power generation would yield an inftial calculated uranium surface temperature of 500-515 C and maximum temperature of 1160-1190 C. Examination of one slug from the second loading showed that a few drops of molten uranium had collected in the open core and frozen in the bottom of the vertically loaded slug. The observation that some uranium had indeed melted durling operation verifies the higher power figures and, at least qualitatively, the temperature calculations. The diameter of the canned slug had increased from I.439 inches to 1.459-1.46I inches during this short irradiation. This verified the infial assumption that this expansion arises from thermal expansion of the uranium and occurs as soon as the pile goes up to power. The core of the slug appeared unchanged except for the frozen uranium droplets. The unchanged core diameter shows that closing of the core is a time dependent, stress relaxation mechanism and is probably related to buildup of internal. pressure within the metal as gaseous fission products migrate during irrsdiation.

The insulated slug differs from the current HAPO fuel element in two respects: it is unbonded and the urantum surface temperature is higher. Thus, one may expect that the consequences of a fallure of an insulated slug will be different than for a bonded, uninsulated slug. Whether the differences are serious is not known. Experience has shown that fallure of an unbonded slug results in the release of more fission gas than is the case with bonded slugs, presumably because a greater uranium surface area is exposed to corrosive attack by the cooling water when the jacket fails. The existence of higher temperatures in the insulated slug should cause more rapid. corrosion of the uranium. Nothing catastrophic is expected, however, since studies of the rates of aqueous corrosion of uranium at high temperatures indicate that the corrosion reaction, though accelerated at the high temperatures, is not an explosive reaction. Taus, there appears to be no serious hazard associated with the failure of an insulated slug, and the question is one of determining the differences in degree.

An experimental KER size cluster fuel element has been completed. This four rod assembly will be charged in 305 Plle next month t'or irradiation to determine neutron f'lux distribution and other reactor physics data. The assembly consists of four rods, one of which contains flux monitor pins. This rod is sectioned and fits into a can with a removable cap so that the pin may be removed and replaced after subsequent irradiations. The uranlum cores and can caps for in-plle test,s of cluster f'uel elements in the MIR have been machined and will be assembled when the cladding materlal arrives next month.

A direct fabrication method for producing clad $\mathrm{VO}_{2}$ fuel elemerts is being investigated. The technique involves the swaging of a tube containing packed $\mathrm{JO}_{2}$ particles until the final dimensions and the desired densty of the fuel matertal is obtained. For the initial trials, stainless steel tubes filled $\mathrm{wi}_{\mathrm{i}} \div \mathrm{h} \mathrm{UO}_{2}$ have been used. Densi

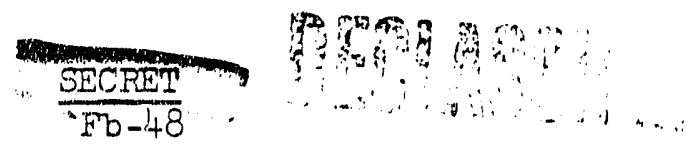


Metallurgy Research Sub-Section

measurements of the first oxide fuel element produced by this technique indicate that $\mathrm{UO}_{2}$ densities approaching that of sintered compacts may be achieved. Swaged elements prepared from fused and ground $\mathrm{UO}_{2}$ powders had a measured density of $9.89 \mathrm{~g} / \mathrm{cc}$ ( $90 \%$ theoretical $\mathrm{UO}_{2}$ density). These studies are being continued to determine whether larger elements with thin walls might be produced by this technique.

Post-irradiation examination of the slugs from MTR irractiation GEH-4-1, which had been irradiated to approximately $700 \mathrm{MWD} / \mathrm{T}$, has been partially completed. After sectioning, the unruptured four-inch AlSi bonded cored slug from this irradiation was found to have split longltudinally. Two radial cracks on opposite sides op the core extended over the full length of the slug. These cracks progressed from the core outward and extended to the outer surface of the uranium except for approximately $1 / 2-1$ inch at each end of the slug where the cracks extended half way from the core to the surface.

\section{Separations Plant Structural Materials}

Since the pulse columns in the solvent extraction separations plant requires periodic flushing to remove "crud" deposits, the effect of the flushing solutions upon the materials of construction was investigated. Based on previous investigations, the normal flushes, which consist of alternate solutions of sodium hydroxide and nitric acid, will have an insigniflcant effect on stainless steel components. Samples of the seal ring material, Graphitor 42 , were exposed to $10 \mathrm{w} / 0 \mathrm{NaOH}, 20 \mathrm{w} / 0 \mathrm{HNO} 3$, and $60 \mathrm{w} / 0 \mathrm{HNO}_{3}$ at $25 \mathrm{C}, 50 \mathrm{C}$, and the boiling temperature for periods of two and 100 hours. Based on these exposures, it $1 \mathrm{~s}$ recomended that the sodium hydroxide flush be no stronger than $10 \mathrm{w} / 0$ at $50 \mathrm{C}$, and the nitric acid flushes be no stronger than $20 \mathrm{w} / \mathrm{O}$ at $50 \mathrm{C}$.

Oxalic acid has been used as a cleaning agent for stainless steel process equipment on some occasions in the past; however, there has been some doubt as to the magnitude of the corrosive damage incurred in the cleaning operation. A cursory investigation was performed, involving the exposure of types $304 \mathrm{~L}$ and 347 stainless steel to 10 and $20 \mathrm{w} / 0$ oxalic acid solutions at $80 \mathrm{C}$ and boiling temperatures. No significant difference in corrosion reststance was observed between type $304 \mathrm{~L}$ and 347 stainless steel, and there appeared to be little or no difference in the comosivity of 10 and $20 \mathrm{w} / 0$ oxallc acid solutions. The increase in temperature from $80 \mathrm{C}$ to boiling resulted in a two to three-fold increase in corrosion rate. It appears that $10 \mathrm{w} / \mathrm{O}$ oxalic acid at $80 \mathrm{C}$ constitutes a satisfactory cleaning agent for stainless steel provided that it is used with caution. However, the corrosion rate under these corditions is of the order of 0.003 inch per minute, and consequently, these materials should not be used as containers for the oxalic acid for prolonged
periods of time.

The effect of carbon content upon the corrosion rate of type 312 stainless steel in nitric acid has been evaluated by static exposures made in thermostated capsules. Samples from flve heats of type 312 stainless steel, with carbon contents from 0.027 to $0.039 \mathrm{w} / 0$, were exposed to solutions of 40 and $65 \mathrm{w} / 0$ nitric acid at temperatures of $80 \mathrm{C}$ to $165 \mathrm{C}$. Carbon content, within the range tested, appeared to have no effect on the corrosion rate of the material.

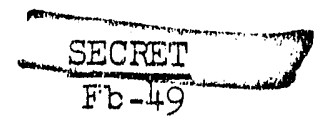


An investigation of the corrosivity of bolling synthetic Purex 2WW waste acid concentrate by quantitative, semiquantitative, and qualitative methods upon selected materials under heat transfer conditions is in progress. The potential. hlgh frequency of replacement of the number two Purex acid concentrator heat exchangers necessitatated such a program which would show the nature and magnitude of the corrosion problem, whlch materials were best sulted for this service, and which would provide operational data to maximize the service life-production efficlency ratio. Additional data heve been collected upon the corrosion behavior of type 347 stainless steel bayonet heat exchangers exposed to bolling synthetic $2 W W$ under beat transfer conditions where the bayonet steam pressures were maintained at equivalent temperatures of $115,125,135,145,155$, and $165 \mathrm{C}$ for 1024 hours. Comparlng these data with simllar type data collected after an exposure of 561 hours shows that in all cases the corrosion rate appears to be constant with t1me for this interval.

The first investigation, involving the use of the pressurized heat transfer unit, to establish the correlation between the corrosion data obtained from the factorially designed static corrosion tests and data obtained from the heat transfer units has been completed. The results indicate that the corrosion of a heat transfer surface is a function of the surface temperature of the metal and is independent of the heat flux through the metal.

\section{Welding Development}

The "Roto Arc" process which consists of a cylindrical electrode within a magnetic coil which controls the arc travel around the electrode is currently being developed and has demonstrated that fuel element can closures can be made without. leaving a crater at the stopping point. Other potential advantages include increased speed, autcmation, and more reproducible welds. Equiprnent has been developed which demonstrates the process and has permitted a cursory investigation of the variables controlling the quality of the welds produced. This process shows constderable potentlal as an automatic welding procedure for maktng fuel element can closures.

A tungsten Inert gas torch has been designed and developed to the point where an aluminum process tube can be slit for extraction from graphite blocks. The torch is water cooled, uses a ceramic shlelding cup and $1 / 8$-inch tungsten in a $60^{\circ}$ head. It operates on direct current, reverse polarity at 410 amperes, $28 \mathrm{l} / 2$ volts, using helium flowing at 40 cubic feet per hour as a shielding gas. With no apparent damage to the graphite block, 1 t, will cut a slot $1 / 16$ inck to $3 / 8$ inch wide the length of the tube at the rate of 60 to 75 inches per minute.

Metallurgical Laboratory Examination

The failure of four (4) remote flange studs in Purex equipment resulted in a decision to replace all tube bundle studs (80) and as many other studs in critical equipment as time would permit with the new Redox "keyed" stili. Previous investigations of stud failures, as reported in HW-36190, indicated these studs are a martensitic chromium stainless steel type 414 or 416 which has been quench hardened and tempered. These studs were welded to the austenitic stainless steel flanges with an austentic stainless steel welding electrode. Faflure occurred in the base metal of the stud in the keat af'fected zone adjacent to the welds. During this
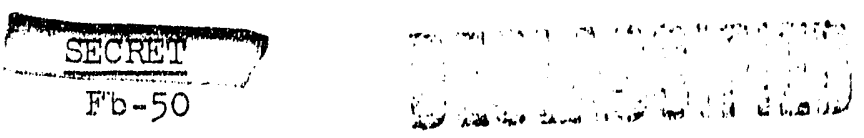
replacement program nineteen (19) studs were selected at random, impacted heavily, and submitted to the Corrosion and Welding Unit and examined for cracks. Of the nineteen studs examined, one (1) was evidently a "dummy" stud wh1ch had not been in service, two (2) were a 300 series stalnless steel and were not cracked, sixteen (16) were a martensit1c chromlum stainless steel, twelve (12) of which were cracked. All of the cracks found were in the base metal of the studs in the heat affected zone adjacent to the welds. A detalled report of these examinations is currently being prepared.

The preciaton mold for the large casting has been fabricated from pile graphite using the new template lathe installed in the 200-W shops. Use of a template lathe is required to produce these molds because of the irregular forms of the experimental castings. The mold is made to postition and support the nickel tube inserts in the casting.

The feaslbility of drilling deep holes in alpha plutonium was demonstrated by arilling a test hole $1 / 16^{\prime \prime}$ in diameter to a depth of 15/16", ustng a single drill. Abili.ty to perform this operation on alpha plutontum is important in the design of parts for many applications.

Various sizes of electroformed nickel tubing has been made for the Experimental Physics Un1t. Three feet of tubing $0.022^{\prime \prime}$ I.D. by $0.025^{\prime \prime}$ O.D., tiwo feet of $0.037 "$ I.D. by $0.040^{\prime \prime}$ O.D., and one foot of $0.035^{\prime \prime}$ I.D. by $0.040^{\prime \prime}$ O.D., was made by plating nickel on dag coated copper wires. The annealed coprer wlye was then rulied on bcth ends to reduce its diameter so that the nickel tuhing could be removed from the whe.

\section{DECISSFFIED \\ ㅂ.}


Some work bas been done on maks!ng a hollow nickel sphere about one Inch in diameter which has two $0.043^{\prime \prime}$ tubes protruaing from elther side. The tubes are an integral part of the sphere and approxtmately 1.-1/2" long. N1ckel is plated on a bismuth-tin or an alumimum mandrel which will be removed either by melting out the alloy or dissolving out the aluminum with caustic. It is difficult to obtain a unfform deposit over the whole surface of the ball and tubes, and some difflculty is being had with pltting on the top half of the hemlsphere. A thin coat is obtained where the tubes join the ball, and a thick coat is obtained on the ends of the tubes. Shielding of various areas has been tried in an attempt to provide a more uniform coat, and some improvements have been made; however, more expertmentation is required. Mechanically brushing the top surface of the ball has reduced the amount of pitting, but some refinements in the technique are necessary.

The entire plating equipment has been moved into a new laboratory in the 231 Building where, In addition to the "all chloride" alckel bath, acid copper, Rochelle salt copper, and rhodium plating facilities are being installed.

Woris in support of fuel element fabrication for the Physlcal Constants Test. Reactor. is continuing. Casting molds have been made and uranium charges obtained. Plutonium for the slugs is scheduled for production early next month. Cans have been machined, and equipment for anodizing them is being assembled. Considerable difficulty has been experlenced with the gas ballast mechantcal pump furnished with vacuum system for the National Research Corporation vacuum furnace. Two additional pumps have been trled with the same poor results. A Kinney pump is now being installed for use whlle difficulties wlth the gas ballast pumps are being corrected.

PJutonium-aluminum alloy for PCTR experiments has been successfully cast in an argon atmosphere at $10 " \mathrm{Hg}$ pressure. The blllets have been partially rolled and samples obtained to determine alloy uniformity. Further work is delayed during painting of the laboratory after decontamination work was completed.

The completion date on Project CG-645 has been extended because of delays In delivery of equiprent. The 440,000-pound capacity untversal testing machine has been received and installed. The $30 \mathrm{KW}$ high vacuum induction melting furnace has been operated and accepted. The hood for the 20 " tracer lathe has been finished and is on hand.

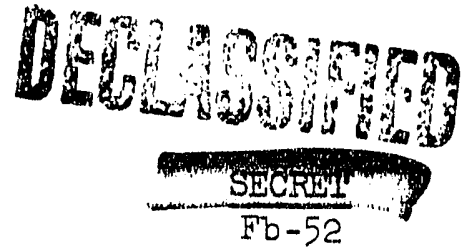




\section{CONIACT BMG INEHERING UNIT}

PROJECT ACTIVITIES

\section{Project CA-512}

The total output of the 165-K pumps 1s being held below desired flows because of inclpient pump cavitation. The present pile flow is only approximately $127,000 \mathrm{gpm}$. To hold these low flows, it has been necessary to run the pumps at reduced speeds by using the liquid rheostats which has resulted in rheostat fallure. The Manufacturing Department feels that the rheostats can be made to function properly if adjusted correctly. No one knows for sure if the inciplent cavitation, which is evidenced by noisy operation, is really harmful to the pumps or not. Three possible methods of increasing the flows to the deslred $140,000 \mathrm{spm}$ level are (1) run all six pumps which would increase flows and pressures and thereby suppress cavitation, (2) speed up the pumps and disregard the possible cavitation damage, (3) turn down the pump impellers so that they can turn faster without cavitation. The last possibility would not, however, give the desired flows but would be an improvement over the present Ilow.

\section{Project CG -558}

The construction of Phase I of this project was $40 \%$ complete as of December 31 . This is $8 \%$ ahead of schedule. Phase II construction was 1 isted as $3 \%$ which was according to schedule. At 100-B Area the 190 annex building is nearing completion and the 4500 hp motors and pumps have been installed. Pump testing is scheduled to start during January. The first major outage will probably occur in June of this year which will be several months ahead of the original schedule.

There were no meetings of the Project Representatives during the month.

\section{Project $C G-600$}

There were no Project Representatives meetings this month. Plans are proceeding for pump replacement but no changes in front face piping will be made.

\section{Project CG-642 (Charge-Discharge)}

One meeting of the Project Representatives was held during December. Three scope drawings were presented for approval but none were approved because the Manufacturing representative was not convinced that the equipment as shown 
would be workable. Manufacturing requested more time to study these scope drawings. Curient estimates indicate that the total cost of this project will be approximately $\$ 3,500,000$. Only $\$ 2,000,000$ is currently budgeted for this project.

\section{E.T.R. Lla1son}

A preliminary scope study, for budgetary use, is being made of this project. Tentative plans call for three loops in the E.T.R. for studying the behavior of varlous types of fuel elements. Two of these loops w1ll operate from a common set of pumps and associated equipment. The third will be totally Independent since it is anticlpated that Pu fuel elements may be tested.

\section{PIIE TEECHNOLOGY SECTION}

\section{INVERTIONS}

All P1le Technology Section personnel engaged in work that might reasonably be expected to result in Inventions or discoveries advise that, to the best of their knowledge and belief, no inventions or discoveries were made in the course of thelr work during December, 1955. Such persons further advise that, for the period therein covered by this report, notebook records, if any, kept in the course of their work have been examined for possible inventions or discovertes.

$\underline{\mathbb{N}} \underline{O} \underline{\mathbb{N}} \underline{\underline{F}}$

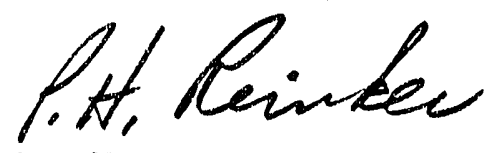

Acting Manager - Pile Technology ENG INFERR ING DEPARTMENT

PH Reinker:cvf 
Separations Technology Section

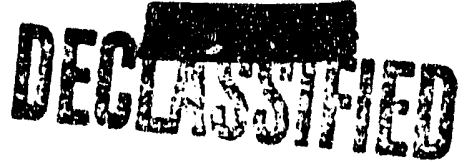

HW -40692 TTEL

\section{VISITORS AND BUSINESS TRIPS}

J. A. Buckham, of the Phillips Petroleum Co., Arco, Idaho visited Hanford on 12-6 and 12-7-55 to tour and 1nspect Purex and the Eot Semt-works and discuss separations processea.

G. I. Booman of the PhIllips Petroleum Co., Arco. Idaho visited Hanford on 12-15 and 12-16-55 to discuss analytical methods, in-ine instrumentation and electroaralytical chemistry and remote instrumentation.

K. W. Calkins and R. W. Hawley, Dow Chemlcal Co., visited Hanford on 12-14 and $12-15-55$ to discuss continuous process equipment under development in $234-5$, and chemical seps:-tions processing and tour the purex. Plant.

J. R. Barber of the E. I. duPont de Nemours, Savannal River PIant, Alken, So. Carolina vistted linford on 12-7, 12-8 and 12-9-55 to discuss the continuous processing equipment.

I. W. Powers, General Electric Co., West Lynn, Mass. Visited Hanford on 12-5 timu 12-20-55 to fnstall a mass-spectrometer.

F. P. Robinson, G. E. Co., Pasco, Washington visited Hanford on 12-5 thru 12-19-55 to 1nstall a mass-spectrometer.

D. G. Milier of Hanford visited E. I. duPont Co. at Augusta, Georgia on 12-3 and 12-9-55 to d1scuss analytical methods and in-line instrumentation; also attended the Nuclear Engineering and Science Conference in Cleveland, Onto on 12-13 thru 12-15-55.

C. B. Barton, of Hanford, Visited KAPL, GE at Schenectady, New York on $12-12$ ani $22-13-55$ to discliss fission product recovery and waste treatment, also attended tiae Nuclear Engineering and Science Conference in Cleveland, Ohio on 12-14 tinru $12-16-55$.

W. R. Reas, of Hanford, visited the lintversity of Nebraska at Lincoln, Neb. on 12-1.2 and 12-13-55 and the University of Kansas, Lavrence, Kansas on $12-14$ and $12-15-55$ for technical recruitment.

$\therefore$. E. Sutin of Janford visited Cak Riage National Laboratory on $12-5$ and $12-6-55$ for consultations on in line instrinentation and separations processes; fuorothene fabrication.

R. E. Tominson and $W$. W. Scinlz of Hantord visjted the U. S. Health Service, Bobert A. Taft Sanfury Zngineering Center, Cincinnati, Onio on 12-6 tiaru $12-8-55$ to present papers.

B. E. Tomirson of Jarford visited the llaticnel Lead Company of Ohio, Fernald, chio on $22-9-55$ for discusstons on oxide processing. 
J. S. Buckingham of Hanford visited Oals Ridge National Laboratory on 12-12 and 12-13-55 for discussions on solvent-extraction problems and ion exchange.

M. J. Stedwell of Hanford visited the National Lead Company, Fernald, Ohio on 11-30 thru 12-2-55 for consultations on uranium refining and $\mathrm{UO}_{3}$ calcination.

E. P. Galbraith of Hanford visited the University of Utah, Salt Lake City, Utah on 12-3 thru 12-7-55 for technical recruitment.

A. E. Smith attended the Chemical Industries Exposition at Philadelphia, Penn. on $12-7$ and $1.2-8-55$.

J. S. Buckingham attended the Nuclear Engineering and Science Congress and the International Atomic Exposition at Cleveland, Ohio on 12-14 thru 12-16-55.

R. E. Tomlinson attended the Northwest Scientific Association, Spokane, Wash. to present a paper on 12-29-55.

R. E. Tomlinson attended the Chemical Industries Exposition at Philadelphia, Penn. on $12-5-55$.

ORGANIZATION AND PERSONNEL

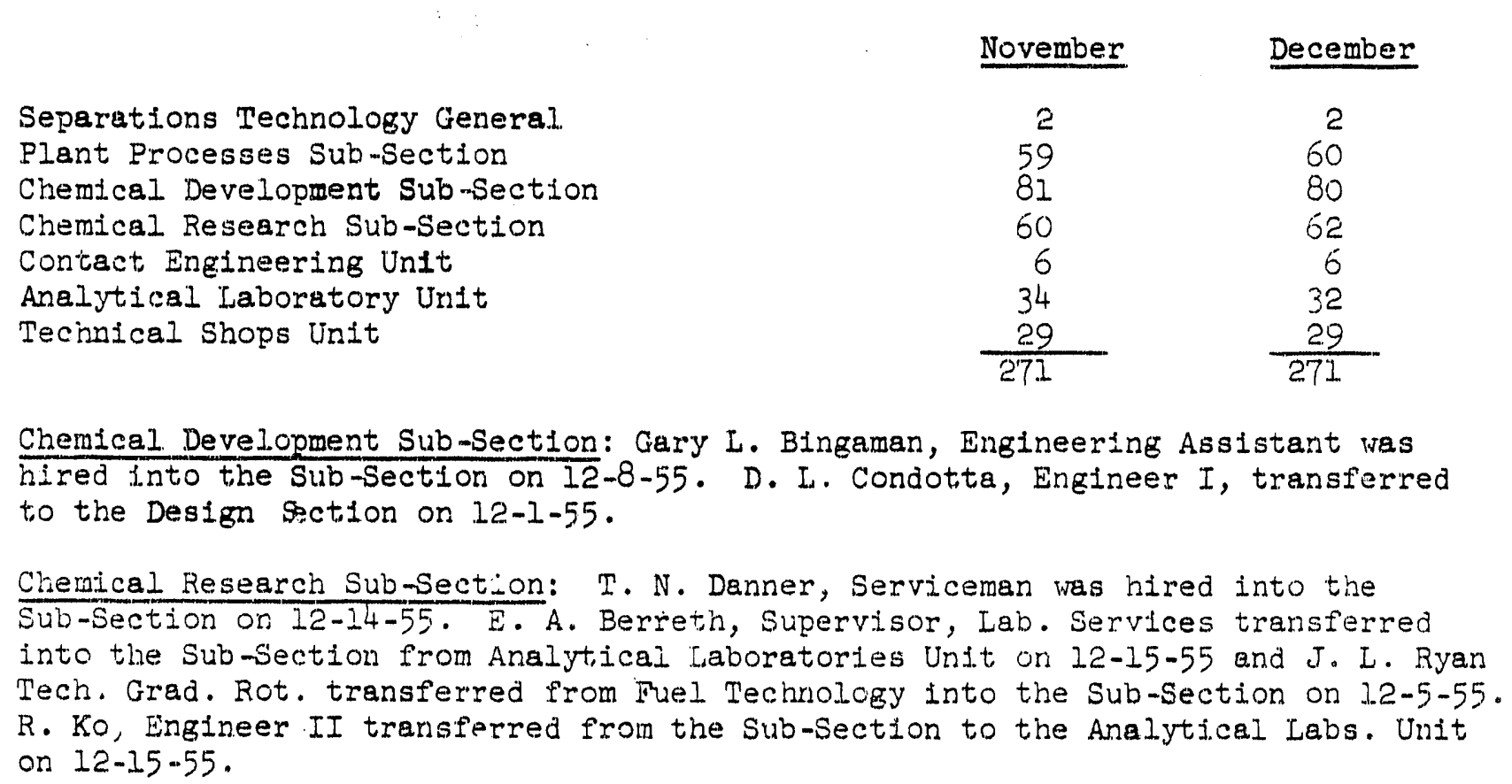

Plant Processes Sub-Section: R. E. Latta, Engineer II transferred into the SubSection from Analytical Labs. Unit on 12-1-55. W. K. MeJilton, Engineering Assistant transferred into the Sub-Section from the Pile Technology section on 12-4-55. P. F. Hayes, Steno-Typist transferred from the Sub-Section to Pile Technology on 12-1.9-55.

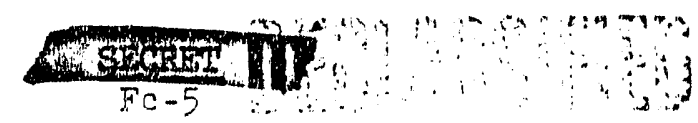


Separations Technology Section

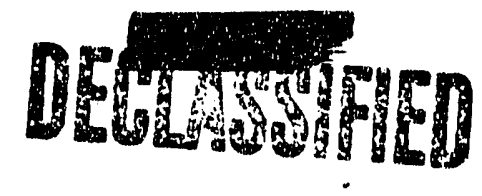

HW -40692

Analytical Laboratory Unit: Roy Ko, Engineer II transferred into the Unit from the Chemical Research Sub-Section on 12-15-55. M. M. Jones, Engineer terminated "to do misslonary work abroad for the Latter Day Saints" on 12-23-55.

R. E. Latta, Englneer II transferred to the Plant Processes Sub-Section on 12-1-55. E. A. Berreth, Engineer II transferred to the Chemical Research Sub-Section on $12-15-55$.

Technical Shops Unit: R. C. Carlson, Design 1, transferred into the Unit from the Design Section on 12-19-55. H. A. Foster, G.lass Technician terminated "R.0.F." on $12-2-55$.

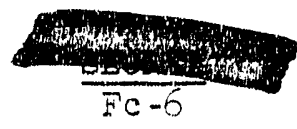


PLANT PROCESSES SUB-SECTION

BEDOX PROCESS TECHNOLOGY

Summary

The precycle flowsheet for startup in January, 1956, has been prepared and is ready for 18suance as EW-40610. Part II of the production test (202-5-2) covering waste storage during initial phases of precycle operation with both single and dual stage waste backeycle 18 currently in preparation, based on production forecasts for the first half of the comfng year.

For about the f1rst three weeks of the report period (November 26 through December 16, 1955), the processing rate averaged 120 per cent of Phase II, and for the first week, both waste losses and decontamination were excellent. However, for the balance of the December operation, waste losaes were high (due to process leaks) and decontamination was poor (due to attempts at waste recovery from cell sump collections), culminating in the necessity for complete rework of both the uranium and plutonium from the final feed batch. Th1s rework operation, which succeeded in decontaminating the plutonium but not the luranium, extended plant operations approximately one week beyond the scheduled shutdown date, with shutdown finally coming simultaneously with the end of the report period.

A test of reduced crossover oxldation time almed at demonstrating the feasibility of bypassing the sampler tank was successfillily completed and, in addition to proving feasibility, also resulted in seduced plucontum loss to the $2 A$ Column raffinatc An attempt to lower crossover oxldation temperatures, however, resulted in a sharp increase in $2 \mathrm{AW}$ loss.

The corrosion leak in the pinal plutonfum concentrator grew worse and was corrected on a temporary basis by rewelding. The unit is to be replaced.

The average exposure of the metal charged to the dissolvers was 912 (712 to 1.060 ) $1 \mathrm{WWD} / \mathrm{T}$, 1ts average cooling time was 1.01 ( 77 to 213) days, and the over-all recoveries of plutonium and uranium were 98.9 and 99.0 per cent, respectively. Concentreted plutonium product ranged from 97.7 to 134.4 grams of plutonium per liter with an average of 1.06 grams per liter.

Feed Preparation

Dissolving proceeded generaliy without incident, but several intermuptions of feed preparation occurred due to such items as (1.) the failure (and replacement) of the caustic recirculation pump in the of' - -gas scrubber, (2) poor vacuum in the oxidizer (and, consequently, inadequate seed concentration) as the result of a leak in the vapor line, (3) rework of material leaked to the cell sunrp (source of leak still unknown but believed to be the oxidizer tank), and (4) tests made in attempting to locate the leak. The caustic recirculation line leaked following the pump replacement, and this is believed to have contributed in large measure to the subsequent decontamination troubles when the cell sump materials were returned to feed preparation and solvent recovery. The process feed solution that was to

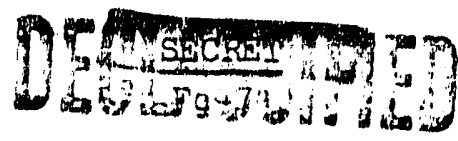


be the final. batch before shutdown contained H Cell sump dralnage, dissolver rinses, plutonium concentration building sump wastes and process recycle, $z$ plant recycle, and dissolver tal heel removal solution. This mixture was oxidized without sparging due to the poor vacuun. Decontamination was wholly inadequate, and both streams were returned to feed preparation where they were re-axidized and reproceroed.

\section{Decontamination}

Up to the point early in December when cell sump collections were added to virgin feed solution for product recovery, decontamination was excellent, averaging overali about 7 and 7.5. (logarithmic) for uranium and plutonium, respectively. From that point on, however, decontamination grew progressively poorer until at the time the last leed batch started to the columns, the dF for uranium had dropped to 6.5 and that for plutonium to 6.9. Analyses showed a steady increase in the ratio of muthenium to zirconium-nioblum in the products during this period. This may have resulted from 1nadequate feed oxidation (due to reducing agents in sump wastes returned to feed preparation), or from ruthenfum introduced to feed preparation With the caustic collected in the sumps (due to the leak in the ruthenium scrubber caustic reclrculation line). The uranfum product during this period was processed through silice gel which provlded enough additional decontamination to permit further processing in the Urantum Oxide plant. The plutonlum product, although not as well decontaminated as usual, was acceptable.

When the last batch was processed, a further drop in decontamination was noted in both products, and over-a.I logarithmic factors of 5.1 and 6.0 were observed for urantum and plutonium, respectlvely. The product streams were recombined, reoxldized, and reprocessed through the entire solvent extraction battery. This delayed the shutdown for a weels but falled to satlsfactorlly decontaminate the uranium. The plutonium decontamination was no more than adequate, and the material was to be further processed in the Recuplex unit in the 234-5 Building. The principal fission product contaminant was zirconium-niobium (about 75 to 80 per cent of the total) and is believed to have been largely the result of polymerization under the basic conditions existing in the sump. A measure of support for this hypothesis was found in the following laboratory data:

(1) Particulate matter was centrifuged from both uranium and plutonium product streams (and subsequent column flushes) giving an arithmetic decontamination factor op abcut two for gross gama.

(2) Sillca gel treatment of the uranium gave very little decontamination in spite of the Greater than normal acid concentration and the large amount of fission product zirconium present in the final uranium. stream.

Solvent Extraction

Tests and changes made in the plutonium cycles consisted of (1) variations in $2 A$ Column aqueous-organic flow ratios to reduce product loss in the raffinate, (2) an increase of 50 per cent in the $3 \mathrm{~A}$ Column scrub stream salt concentration to

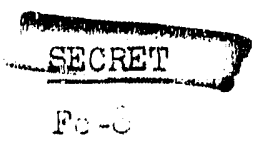


permit comon makeup of $2 A S$ and $3 A S,(3)$ a reduction of the crossover oxidation time by about 40 per cent to prove the feasibllity of bypassing the E-7 sampler tank, and (4) the reduction of the crossover oxidation temperatures in all three tanks (IBP recelver, oxidizer, and $2 A P$ tank). The reduction of temperatures (to 20 to $30 \mathrm{C}$ range from 35 to $60 \mathrm{C}$ ) was trmediately followed by an increase in $2 \mathrm{AW}$ plutonium 10se from a normal 0.1 per cent to over four per cent. The temperatures were restored to their previous values. The reduced oxidation time test was more succesaful, not only demonstrating the feasibility of bypassing the E-7 tank but also reducing the $2 A$ W plutonlum losses by a factor of two to three in the process. This lends encouragement to the ldea of elther cascading IBP solution directly to the $2 A F$ tank or pumping IBP solution from the receiver directly to the $2 A$ column. The whole gexeral subject is under further study.

PIutonium losses from the $2 A$ Column with the "normal" flowsheet were generally erratic, but a definite correlation of high losses with transfers of feed solution into the $2 A F$ tank was observed. Thls resulted from the inordinately large dilution of the feed on jetting, probably causing cyclic reduction of the salting strengtb in the $2 A$ Column. Higher than normal losaes of plutontum in the IA Column raffinate were also experienced, perhaps as the result of inadequate feed oxidation due to impurities in the recycled sump material.

\section{Plutonium Concentration}

The corrosion leak in the concentrator re-boller grew rapialy more severe, reaching the point at which it was necesaary to make temporary repairs by completely rewelding the feed inlet tee. The unit is to be replaced during the shutdown. The flnal two batches of concentrated product contained approximately 40,000 and 60,000 parts of iron per million parts of plutonium, respectively, representing a slight increase over the earlier "norm" of about $35,000 \mathrm{ppm}$. The following equipment drain and flush material, contained in the next batch approximately one-half the normal PR plutonium concentration but had an iron-to-plutonium ratio of 0.95 . Subsequent flushes were even worse, the next one having an iron-to-plutonium ratio greater than three, where the plutonfum concentration was 13 grams per liter.

In terms of volurnes of solution processed through the 233-s Bulliding Plutonium Concentrator since its startup in April of this year, it is interesting to note that a corresponding amount processed through one of the 231 Building product evaporators in the usual manner at the rate of one batch per shift would have represented approximately 60 to 75 years of operation. It is also significant that in the elagsed time of ten years or less each of the product stills in 231 Buliding had to be rewelded frequently and replaced once, all of which indicates that the equipment in 233-S has perhaps g1ven better service than would be apparent if judged solely on its age at the time of fallure.

\section{Iodine-131 Emisaion Problem}

The average age of the metal dissolved decreased to a minimum of 95 to 100 days as the shutdown approached, and an upward trend in the amoint of iodine-131 reaching the stack was observed. Hcwever, the over-all efficiency of the silver reactors remained markably good, exceeding 99.9 per cent through the second week of December.

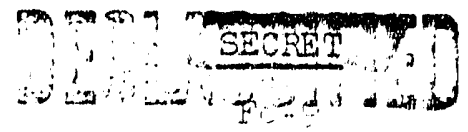


Separations Technology Sect1)

HW -40692 TE

Even toward the end of the metal inventory and the start of heel removal, when all the reactors were overiue for regeneration, the maximum emisgion of fodine-131. did not exceed 0.9 curle per day, and the average was less than 0.5 curie per day. Bach reactor bas since been regenerated in preparation for the coming startup.

\section{PURERX PROCESS TECENOLOGY}

\section{Summary}

The third and fourth cold uranium runs were completed during the month with satisfactory over-all performance obtalned. The third run was made utilizing HW No. 4 Flowsheet at capacity factors of 1.2, 1.8, and 2.4, and demonstrated that the plant and flowsheet are operable at these rates but require close analytical control and flow regulation. The fourth rus was made ut1lizing EW No. 3 Flowsheet at a capac1ty factor of 1.4. During this run, non-equilibrium conditions (e.g., column flooding) were studied in addition to determination of entralment, uranium contamination of plutonium as affected by IBS flow ratio, thorium-234 (UX $X_{1}$ ) decontamination factor, and winor proces variables. Difficulties in controlling the interfaces in HC, IC, $2 E$, and $2 A$ organlc continuous columns continued. The plant was sbut down on December 11 in order to modify the HC, IC, 2E, and $2 \mathrm{~A}$ Column interface detecting systems, change the IC and $2 E$ Colum cartridges from fluorothene to nozzle plates, replace defect1ve remote flange studs, and accomplish much other maintenance work. Decisions for the column modiflcations were based on test work done in the Purex Flant and in the 321 Bullding development columns utilizing synthetic and plant solutions.

\section{Feed Preparation}

No uranium dissolving was performed during the month because the cold, depleted (ca. 0.2 welght per cent U-235) uranium previously dissolved was recycled for plant operation.

The $A I$ and $B I$ filters were inspected following last month's dissolving and were found to have damaged AA Fiberglas packing. Damage resulted because condensate from stean to the vacuum jets leaked backwards into the filter. Although it was believed that this condition had been corrected previously by installation of a cross-tie aspirator, it is apparent that the problem was not adequately resolved. These two filters are to be repacked entirely with 115-K Fiberglas (which is resistant to moisture) as the previously damaged filters have been. This remedial measure does not provide a complete resolution to the problem, and further design effort is planned to provide a more adequate solution.

New deepwell turbine transfer pumps have been installed in the E5 centrifuge catch tank and the E6 HAF makeup tank to reduce dilutions of the HAF which occurred when steam jets were used. This modification is required in order to meet the HW No. 4 Flowsheet HAF specifications.

\section{Solvent Extraction}

The third cold uranium run (AC-3) was started on November 26 and completed on December 5, with the mun history as summerized below:

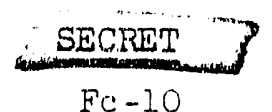




$\begin{array}{lll}\text { November } 26 \text { to December } 2 & 1.2 & \begin{array}{l}\text { Steady-state operation except } \\ \text { for Flnal Plutonium Cycle. }\end{array} \\ \text { December } 2 \text { to December } 4 & 1.8 & \begin{array}{l}\text { Steady-state operation except } \\ \text { for Final Plutonium Cycle. }\end{array} \\ \text { December } 4(0200 \text { to 0650) } & 2.4 & \begin{array}{l}\text { Steady-state operation until } \\ \text { "crash" shutdown. }\end{array} \\ \begin{array}{c}\text { December } 4(1800) \text { to December } \\ 5(1430)\end{array} & 2.4 & \text { Steady-state operation. }\end{array}$

Operation throughout the perlod was similar to previous operation in regard to interface control problems but, in general, the plant ferformed well. During the first two perlods, the Final Plutonlum Cycle was operated under varying conditions to permit evaluation of the 2A Column interface control problem. It was demonstrated that, with the exception of the T-F5 acld fractionator, the plant and flowsheet are operable at these rates, but close analytical control and flow regulation are required. The limiting capacity of the T-F5 acid Practionator has not been determined, but It was exceeded as a fractionator at a capacity factor of 2.4 . Over-all heat transfer coefficients for the uranium concentrators operating at a boilup rate of 30,000 pounds per hour (capacity factor of 2.4 ) were calculated to be ca. 400 units of BTU per hour, per square foot, per degree Fahrenhelt.

The fourth cold uranlum mu (AC-4) was started on December 6 and completed on December 10, being shortened from the planned fifteen to five days in order to provide time for modifications to C-type columns and maintenance work. Also, in order to gain the most information on a conservative startup flowsheet, essentially HW No. 3 Flowsheet was used in lieu of HW No. 4 Flowsheet as originally planned. This run was made at a capacity factor of 1.44 to investigate non-equilibrium conditions at this rate; the major results are sumarized below:

\section{Frequency - Flooding Tests}

\begin{tabular}{|c|c|c|c|}
\hline Column $(a, b)$ & $\begin{array}{l}\text { Frequency Range } \\
\text { Tested }\end{array}$ & $\begin{array}{l}\text { Cyclic Flooding } \\
\text { Frequency }\end{array}$ & $\begin{array}{l}\text { Total Flooding } \\
\text { Frequency }\end{array}$ \\
\hline IO & $71-100$ & 80 & 100 \\
\hline 20 & $85-130$ & No Flood & No Flood \\
\hline HA & $70-105$ & $95-20$ & 105 \\
\hline IA & $70-1.10$ & 95 & 110 \\
\hline $2 \mathrm{D}$ & $70-110$ & 95 & 110 \\
\hline $\begin{array}{c}\text { HC (nozzle } \\
\text { plates) }\end{array}$ & $65-1.30$ & $\ldots$ & 130 \\
\hline $2 \mathrm{E}$ (fluorothene) & $64-90$ & 80 & 90 \\
\hline IES & $46-95$ & 90 & 95 \\
\hline IBX & $59-80$ & (Discontinued at & \\
\hline $2 B$ & $40-100$ & 80 & 100 \\
\hline
\end{tabular}

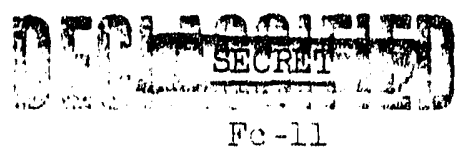


(a) 2A Column tests unsatisfactory because interface was lost; not repeated in order to get $\mathrm{UX}_{1}$ decontamination data.

(b) IC Column (duplicate of $2 \mathbb{E}$ Column) not tested in order to perform simultaneous test.

(c) Or unsatisfactory performance.

Entrainment Tests (HA, IA, 2D, IBX Columns)

Interface Position

Three Inches above bottom dip tube

Six inches above bottiom dip tube

Nine inches above bottom dip tube

IBS Column - Urantum Breakthrough Study

Per Cent Flowsheet

IBS Flow

100

80

60

40
Per Cent U

Loss in IBP

$2.8 \times 10^{-5}$

$3.3 \times 10^{-5}$

$2.2 \times 10^{-4}$

$8.8 \times 10^{-4}$
Description

All samples clear

All samples cloudy

All samples cloudy
Approximate Per

Cent U in $\mathrm{Pu}$

0.11

0.13

0.86

3.5

$\mathrm{UX}_{1}$ Decontamination - $2 \mathrm{~A}$ Column

A test was made of the dual scrub 2 A Column flowsheet utilizing a demineralized water $2 A I S$ stream with a flow equivalent to the $2 A S$. $\mathrm{UX}_{1}$ decontamination for this one test was improved from unity for HW No. 3 Flowsiseet to 30 , about the degree calculated theoretically.

Low Frequency - IC Column Operation

During the flooding tests described above, the IC Column was operated at a frequency of 40 . The condition was characterized by a large variation of uranium losses in the ICW Prom 0.0004 to 0.25 per cent, and interface control was still inferior.

\section{Elimination of Nitric Acid in $2 \mathrm{EX}$}

Nitric acid was not used in the 2EX from December 1 to 8. Uraniurn losses gradually rose over two days' operation from 0.001 to 0.04 per cent, and an excessive amount of water was entrained in the 2EW.

During the month, interface control difficulties continued to plague the operation of several columns (HC, IC, $2 E$, and $2 A$ ) which are organic continuous and have an interface at the bottom of the column. Extensive testing in the plant columns and the 321 Bullding development columns, utilizing synthetic and plant solutions, assisted in defining the modifications which should minimize the interface control problems:

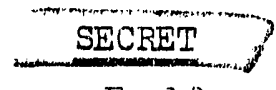


(1) Relocation of the capacitance probes and static pressure dip legs from st1lling chambers to main disengaging sections of the BC, IC, and $2 E$ Columns so that they would "see" the true contents of the disengaging sections.

(2) Installation of a $1 / 8$ inch diameter orifice in place of the former $1 / 4$ inch diameter orlfice in the upper cross-tie line between the 2A Column and the capacitance probe chamber to provide proper hydraulic balance in the system.

(3) Replacement of the fluorothene plate cartridges in the IC and $a E$ Columns with stainless steel nozzle ( 0.036 inch downward protmusion) plates in order to provide for future flexibility in operation of the columns with either top or bottom interfaces. HC Column already has nozzis plates.

A shutdown of the plant was started on December li to make the above column modifications in addition to replacing defective remote flange studs and performing extensive maintenance work.

\section{Waste Concentration and Acid Recovery}

The acid waste concentration and recovery equipment operated to produce approximately a 50 per cent nitric acid product with an iron content on the order of ten parts per million. Recovery efflciencles between 30 and 70 per cent have been realized durln perlods of testing. No recurrence of the white solid formation has been experience Analyses of the white solids obtained from the overflow line of the No. 1 waste concentrator E-FII on November 15 were reported by Chemical Research personnel to be as follows: 1ron - 8.4 per cent; hydrogen - 7.3 per cent ; and carbon - 40.6 per cent. The principal component is an iron complex of dibutyl phosphate.

\section{Organic Treatment}

The G-GH centrifuge was replaced with a spare on November 30 and was put into service on December 3. The original centrifuge was found to have a small leak in the bowl which permitted rapid loss of the aqueous seal.

The uranium distribution coefficients in both organic treatment systems have been ca. 0.02 on an average during the month. Over-all organic losses have continued to average approxinately one per cent of throughput.

\section{URANIUM RECOVERY PROCESS TECHNOLOGY}

\section{Summary}

During the report period, the TBP Plant has processed blends in which 50 per cent of the uranium present was aged approximately 13 months from pile discharge. During steady-state operating periods while processing this f'eed, the product contained fission product activity equivalent to 130 per cent natural uranium gama activity. This activity was half zirconium-niobium and half ruthenium.

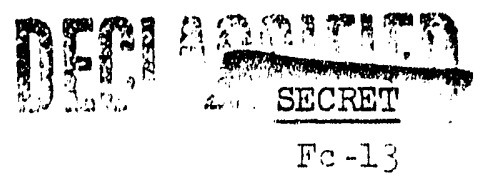


Separations Technology Section

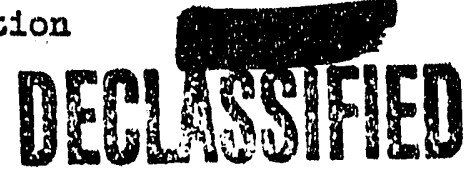

HIN -40692

On some product batches produced during startup and process upset periods, fission product activity as high as 350 per cent aged natural uranium was obtained. Plant combined solvent-extraction losses during the month averaged 1.2 per cent with the RCW contributing 0.8 per cent of the total.

Preparations are currently being made for a plant test prescribed to reduce RCW uranium losses. To alleviate the "pinching" equilibrium and operating conditions existing in the RC Column, a portion (25 to 30 per cent) of the RAU-RCF nitric acid concentration" is to be neutralized before the RCF enters the RC Column.

A new three month test program, document HW-40616, is being 1ssued at month end.

Metal Removal

Removal operations are currently belng conducted on the 17-month minimum aged uranium stored in the 107-U tank and the 13-month old 101-Tx uranium. Each of the operating farms contributed essentially half the uranium shipped to the 22l-U Bullding for processing. All the stored uranium remaining to be processed has recelved an integrated pile exposure of ca. $200 \mathrm{MWD} / \mathrm{T}$ (190 to $250 \mathrm{MWD} / \mathrm{T}$ ).

\section{Solvent Extraction}

The RCW continues to be the major contributor to the over-ali plant solvent extraction 10ss. Durling the month, the RCW loss averaged 0.8 per cent of the feed uranjum, with the RCX flow varled from 75 to 85 per cent of the HW No. 6 Flowsheet value. Laborstory equilibrium studies indicate a "concentrated end pinch" produced by the near crossing of the existing RC Column operating and equilibrium Iines. Increasing the RCX flow would alleviate the "plnch" and reduce RC Column losses, but this is not possible without seriously limiting plant production. Since the RC Column equilibrium is very sensitive to nitric acid concentration, the pinch can be "opened up" by reducing the nftric acid concentration in the RCF. Preparations are currently being made to neutralize a portion of the RCF nitric acid with caustic added through the RCF sampler recently installed on the RC Column.

Pulse loss (e.g०, piston ring failure) has been considered as a possible cause of. the high RC Column losses. Durlns a recent shutdown perlod, the pulse leakage (plus any leakage past the RCU valve) was measured as a normal 0.3 gallons per minute or less at pulse conditions of plant interest.

For two twelve hour periods, the RA Column was operated with no RAIS added to the colurn (RDW pump difficulties). Column uranium ioss and decontamination performancewere essentially unaffected, but the plutonium content of the RCU batches increased approximately eight-foid to approximately 70 parts per billion as expected since no ferrous iron was present in the RA Column; nevertheless, the REU product obtained during this period was w1 thin specification.

Gamma decontamination performance has been consistently good during steady-state periods of operation. Summary data for feeds aged a minimum of 13 to 17 months (the maximum age of any uranium in the tanks processed was 20 months) after pile irradiation to $200 \mathrm{MWD} / \mathrm{T}$ are:

$$
-\frac{\text { SECRET }}{\mathrm{F}-1+}
$$




\begin{tabular}{ll} 
& \multicolumn{2}{c}{ Gross Gamma, } \\
& Per Cent ANV \\
RAF & $1.6 \times 10^{7}$ \\
RCU & $8.3 \times 10^{3}$ \\
REU & $1.1 \times 10^{2}$
\end{tabular}

First Cycle

Second Cycle
Per Cent of Gross Fission Product Gamma

\begin{tabular}{lrll}
\hline $\mathrm{Nb}-\mathrm{Zr}$ & $\mathrm{Ru}$ & $\underline{\mathrm{Cs}}$ & Ce \\
38 & 8 & 33 & 21 \\
70 & 20 & -- & 10 \\
46 & 54 &.- & --
\end{tabular}

Iogarithmic Decontamination Factor

\begin{tabular}{|c|c|c|c|c|}
\hline Gross Gamma & $\sqrt{b-2 r}$ & $\underline{R u}$ & $\mathrm{Cs}$ & $\overline{\mathrm{Ce}}$ \\
\hline $\begin{array}{l}3.3 \\
1.9\end{array}$ & $\begin{array}{l}3.0 \\
2.2\end{array}$ & $\begin{array}{l}2.9 \\
1.6\end{array}$ & $-\ldots$ & \\
\hline
\end{tabular}

\section{Flitration Studies}

Test filters have been installed and operated on varlous process streams. Single element, Glass-wool, "Fulplo" 20 ticron pore size filter units have been installed to permit filtration of a portion of the plant demineralized water, RIOS (three per cent sodium carbonate), and REU. A filter containing 35 micron pore size sintered stainless steel plates has been installed in the RDIS line.

Studies on the RDIS filter have indicated the presence of significant amounts ( 10 to 15 cubic Inches per P1lter plug) of an olly black slime in the RDIS. With an acid resistant felt facing employed over the sintered plates to prolong plate Ife, approximately 4500 galions (a three day plant supply) of RDIS can be processer before plugging of the filter occurs. Backliushing of the filter is unsuccessful in removing the slime from the felt. At month end, preparations are being made to replace the filter with a "Fulflo" unit.

The "Fulf10" demineralized water filter element has processed approximately 60,000 gallons without complete plugging. Some solids pickup has been detected since the pressure drop across the filter has increased from an initial 1.5 pounds per square inch to the present 16 pounds per square inch pressure while the filtration rate decreased over the same period from four to three gallons per minute.

The "Fulf 10" filter element installed on the RIOS plugged after filtering approximately 500 gallons. However, because of limitations within the particular filtration system involved, valid conclusions are not possible concerning this filter without flurther testing.

The REU "Fulflo" filter eiement processed about 13,000 gallons of REU containing 2.5 tons of uranium before plugging. The filtered REU consistently contained fission product gama activity equivalent to 50 to 70 per cent of aged natural uranium gama activity. Arithmetic decontamination factors as high as 2.5 were achieved when the filter feed solution gamma activity reached 160 per cent aged natural uranium activity. The pressure drop across the filter increased from 2.5 to 36 pounds per square inch while the flow rate decreased from 4.0 to 0.2 gallons per minute. After about 0.015 countable ganma curies of muthenium, niobium, and zirconium were removed by the filter, the exposure rate two inches from the filter body was 200 milliroentgens per kour. The filter was backflushed with 50 gallons of water but no significant improvement in filter performance resulted.

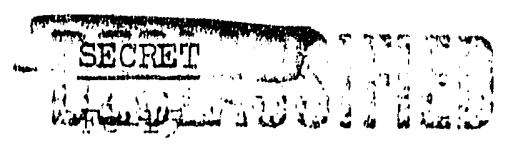




\section{Waste Scavenging}

N1ckel ferrocyanide scavenging supplemented by the addition of strontium nitrate to concurrently precipitate strontium phosphate along with the aickel ferrocyanide has proved to be the most effective procedure yet tested in the scavenging program. The average residual strontium-90 concentration in the scavenged vaste supernatant of the four tanks scavenged to date has been three-fold lower than obtained while using. supplemental calcium phosphate scavenglag.

For comparison purposes, strontium-90 concentrations achieved employing different scavenging techaiques in the ITBP Plant are listed below:

Method

Nlckel ferrocyantde scavenged - waste concentrated

Nickel ferrocyandde scavenged - no waste concentration

Nickel ferrocyanlde plus calcium phosphate scavenged - waste concentrated

Nickel ferrocyanide plus inert strontiura phosphate scavenged - no waste concentration sr90 Conc., microcuries per $\mathrm{ml}$ of supermatant

The residual cesium-137 concentrations have been essentially unchanged (less than 0.1 microcurie per milililter) for the above four procedures. The present alckel. ferrocyanide-supplemental strontium phosphate procedure requires only 50 per cent as much nickel sulfate and sodium ferrocyanide as was used by any of the previous procedures. Thus about a 50 per cent reduction in scavenging chemical consumption has been achieved. To date, about $9,000,000$ gallons of scavenged waste have been discharged to cribs.

Scavenging of the first tank of stored UR Plant waste in the CR "in-farm scavenging" facility was completed during the month. Analysis of grab samples obtained during the processing of this waste gave 0.03 and 0.1 microcurie per ml of strontium-90

and cesium-137, respectively.

\section{Intercycle Concentration}

The modifications required to permit operation of Section 8 and section 6 in series are nearing completion. With the modifications completed, the intercycle capacity bind will be eliminated. A recommendation has been made to lower the feed point two plates on the Section 8 stripping tower during the coming shutdown for the final changes required to permit series intercycle concentration. With the feed point changes, stripping losses should be reduced two or three-fold to 0.1 to 0.2 per cent.

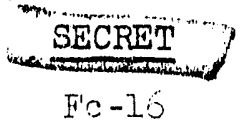


RCU Gamma Monttor

The new "current measuring" type RCU garana monitor was installed in the 16.6 sampler pit. It measures the RCU act1vity as it is transferred from the RCU pump-out tank to the 16-6 recelver tank. Although some minor refinements are still required on the unit, it is operating in good agreement with RCU laboratory analyoes.

\section{URANIUM CONVERSION PROCESS TECHNOLOGY}

\section{Product Quality}

The fission product garma activity of $\mathrm{UO}_{3}$, as determined by Hanford analytical methods, exceeded the specification of 100 per cent aged natural uranium during the month. The last ten carload block shipment fission product activity averaged 104 per cent aged natural uranium ganmactivity. Processing non-standard UNF solution, with activity primarily contributed by zirconium and niobium which are not volatilized during calcination, resulted in cars 344,345 , and 353 having abnormelly bigh f1ssion product gactivities of 154, 145, and 141 per cent of aged natural uranium, respectively. Iot 4333 was 1.5 per cent below the uranium purity specifications. The lot contained abnormally high nitric acid and water concentrations of 3.21 and 2.72 per cent, respectively. The lot was shipped on the basis of a walver by the customer. Total metallic inpurities averaged 112 parts per million parts of uranium. Average reactivity was 1.12, using nominal 0.05 welght per cent sulfamic acid as a pot additive.

\section{Corrosion Detecting Instrument}

A probolog instrument orlginally developed by the Shell Development Company and presently used 10 the pile areas to determine the thickness of pile tubes is being evaluated for use as a tool for determining the extent of corrosion of heat exchanger tubes in the varlous separations facilities. The probe proper includes two electric coils which are connected to a Wheatstone-bridge circuit. In passing through the tube, variations in the tube wall. introduce eddy current variations which, in turn, produce an unbalanced bridge circuit. Preliminary testing employlng a one inch schedule 80 tube with synthetic flaws "machined in" indicated the instrument can pick up minor variations in wall thickness (a machined ring on the external tube surface 0.017 inch wide and 0.005 inch deep was distinguishable)。The instrument has been referred to Chemical Development for further evaluation.

\section{Equipment}

Replacement of Luckey pot kettles and agltators is in progress. Three feed ports are being installed in Pot 1.9 lids so that the "Sern-Contlnuous Luckey Pot Calcination Test" can be made shortly after the pots are returned to service.

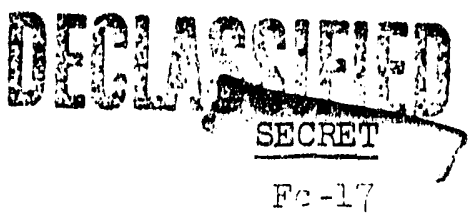


Z PLANT (ISOLATION, PURIFICATION, AND FABRICATION) PROCESS TECHNOLOGY

Metal Reduction (Task III)

Three more test runs were wade with unground, unreilned (Nelco) eslclum. Plutonium metal of sat1afactory purity was produced, with ylelds of $97.7,97.0$, and 95.9 per cent.

The rupture disc was blow off the mixer as a result of the Introduction of a $\mathrm{PuF}_{4}$ charge which presumbly contalned adsorbed $\mathrm{HF}$ and $\mathrm{H}_{2} \mathrm{O}$. Included in the PuF, was part of a powder batch which bad been left in a Taak II furnace after it cooled, with resultant exposure to $\mathrm{HF}$ when a leak developed.

\section{RECUPIEX DEVELOPMENFI}

The Recuplex solvent extraction system was operated 291 bours during the report persod (Novewber 26 to December 26) for an on-stream efficiency of 62 per cent. Major causes of the abnornal down time were the repeated fallure of the stripping agent feed pump and a bellows rupture in extraction colum pulse generator. The feed input consisted primarily of Task I supermatants and dissolved skulls, reduction-crucibles, and fluoride powders. Approximately 87 per cent of the plutonium lnput was v1rgin to the facility, and 13 per cent was recycled from w1thin the system. Cribbed waste losaes represented 0.7 per cent of the total. plutonium input. In addition to the product transferred directly to Task I, five equivalent Task I batches were loaded out 1nto sample cans; tbe purity of the latter, after steam strlpping and evaporation to $37.5 \mathrm{~g} / \mathrm{l}$ plutonfum, was 96.6 per cent.

\section{Dissolver Corrosion}

Preliminary examiation (by personnel in the Corrosion and Welding Unit) of corrosion coupons suspended in one of the slag-and-crucible dissolvers incilcated severe pinpoint pit corrosion of the Type 309 SCb stajnless steel and preferential area attack of the Type 347 material. The welded Type 347 coupons showed evidence of knjfe-ine attack and crater corrosion. Intergranular corrosion was not directly evident on coupons of elther material.

It was recomnended to the Manufacturing Departinent that the spare dissolvers be constructed of Type $304 \mathrm{~L}$ stainless steel, welded with Type $30 \mathrm{~L}$ rod (corrosionpassed).

\section{Flowsheet Studies}

Studies were made of a low acld flowsheet (2-2.5 $\mathrm{MNO}_{3}$ and $1 \mathrm{M} \mathrm{Al}\left(\mathrm{NO}_{3}\right)_{3}$ or equivalent in the feed) and of the effect of adding nitrite to the feed (enough to give a concentration of $0.04 \mathrm{M}$ for the elimination of plutonium(III) in the extraction columns). The reduction in acidity hed no detrimental effect upon the waste losses during the short time ic was tested, and it j.s hoped that a reduction in waste losses will eventually be denonstrated since laboratory data

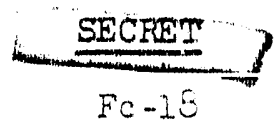


have polpted to improved extraction of plutonium(VI) at the lower acidity. The use of nitrite in the feed is belleved to have caused the variations from normal conditions described below:

(1) The rate of solvent degradation was three to six times greater than normel.

(2) Although the aqueous waste losses increased with the increase in plutoulum content of the recycled organic stream, the unexplained large variations observed in the past did not occur.

(3) While procesaing supernatants from Task I mans which had contained higher than normal fission product activity levels, the radiation levels around the solvent extraction hood, and especially around the product recelver tank, rose sharply. Fission product analyses showed that ruthentum decontamination had been good (DF 90) but that $\mathrm{Zr}-\mathrm{Nb}$ activity had leaked through into the product (DF $\sim 8)$.

\section{Plant Capacity Studies}

Plant capacity studies were made for the following operating conditions:

(1) Seven day, 24 bour operations.

(2) An on-stream efflclency of 90 per cent for the SC Process Hood, with a 15 hour dissolver cycle.

(3) An on-stream efficiency of 80 per cent for the solvent extraction system, with an extraction column volume velocity of 900 gallons/ (bour $x$ foot $^{2}$ ) (sum of both phases) and an aqueous-to-organic phase flow ratio of 2.0 .

The throughput capacity for processing only the solid wastes from Tasks II and III is limited by the dissolver cycle to 140 per cent of the design basis for capacity.

The capacity for processing combined liquid and solld wostes from Tasks I, II, and III is dependent upon the final flowsheet adopted and the operation of the solvent extraction system. For feeds prepared to medium acid and salt concentrations (as enrployed during July and August for plutonium(IV) solutions), the throughput capacity is 105 per cent of the design basis. For feeds prepared to high acid and salt concentrations (as employed during September, October, and November for plutonium(IV) and (VI) sulutions), the throughput capacity is 68 per cent of the design requirement. For feeds prepared to low acid and high salt concentrations (employed during this report period for plutonium(IV) and (VI) solutions), the throughput capacity is 108 per cent of the design basis.

\section{Column Performance Studies}

The physical stability of the solvent extraction system was demonstrated during the month for instantaneous throughput rates equal to and greater than those requided to achieve the above capacities. The extraction columns were operated at

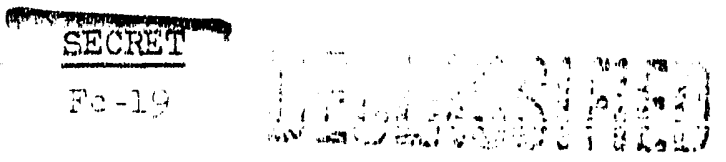


volume velocities up to 1000 gallons/(hour $x$ foot ${ }^{2}$ ) with an $\mathrm{L} / \mathrm{V}$ ratio of 1.9 , and the stripping colum up to $435 \mathrm{galloms} /\left(\right.$ hour $x$ foot ${ }^{2}$ ) with an I/V ratio of 0.3 . Pulse frequencies were 50 cycles per minte for the two extraction colcmas and 90 cycles per minute $f \circ r$ the stripping colum. At the upper rates, control. of the feed specific gravity to 1.30 or less was necessary to prevent flooding.

\section{Equipment Maintenance}

The forward unt of the two teflon bellows comprising the H-1 extraction column pulse generator failed completely at both end junctions between the bellows and the holding flanges. There was no evidence of fallure of the backup bellows. Since the bellows alarm was lnoperative due to corrosion, the pallure was not noticed until an appreciable leak had developed at the flange between the two bellows. Both bellows were replaced, requiring a 74 hour shutdown. At the time of the shutdown, the extraction colum pulse generators had operated $9.6 \times 10^{6}$ cycles at approximately 60 cycles per minute and one ipch colam amplitude, whlle the stripping column unt had operated $14.3 \times 10^{6}$ cycles at 90 cycles $6^{p e r}$ minute and one inch column amplitude. This compares with a life of $10 \times 10^{6}$ cycles estimated from life testa performed by Chemical Development.

The Roth submerged regenerative turbine pump employed a.s the stripping agent feed punp failed three times during the month -- once due to mechantcel failure of the labyrinth seal and twlce due to dissolution of the key holding the shaft to the impeller. Although the passivating properties of the stripping agent $(0.2 \mathrm{M}$ nitric ac1d, $0.01 \mathrm{M}$ sulfuric acid) are borderline for stainless steels, i: $1 \mathrm{~s}$ bejleved the corrosion fallures experienced with the solution are due to incorrect parts material:.

Redegign of the $G$. W. Dahl diaphragm-sealed valves to provide satisfactory service under column pump pressures has proven ineffectual. Three of the specially fabricated stainless steel diaphragms installed in five valves failed, while the use of two types of increasingly stronger springs has not prevented valve leakage against pump backpressure. Fifteen alr operated valves (Aveco) employing a packing gland rather than a diaphragm for the stem seal were, therefore, procured as substitutes for valves subjected to pump pressures.

\section{4-5 DEVELOPMENT}

Continuous Task I

Two runs have demonstrated the operation of prototype equipment for continuous plutionium oxalate precipitation, filtration, and calcination. Using Recuplex product as feed, the throughput rate was approximately $0.5 \mathrm{Kg}$ of plutonium per hour, and the product losses in the first run were about four per cent with indivldual, samples ruming as low as one per cent, comparable to losses obtained in the RMA Task I equipment. Nearly one-half of the first run was comFleted before an adherent cxilate cake was obtained on the filter drum. The period of operation with little or no "cake" coincides with the period of high plutonium loss to the Piltrate, indicating some filter cake is necessary to

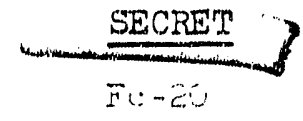


retain fines on the filter and keep losses down. In the second run, satisfactory filter cake formation was obtained from the start by using a greater vacuum on the P1lter drum.

The knife blade removed the filter cake from the drum satisfactorily, and two passes of the oxalate through the drier-calciner gave an acceptable plutontum oxide. The oxIde will be processed through the continuous bydrofluorinator and reduced to the metal to prove its acceptabllity.

Continuous Task II

Further experience with the continuous Task II reactor has borne out the usefulness of this equipment. About 3.8 kflograms of the plutonfum oxide was processed through the continuous hydrofluorinator at an average rate of $0.4 \mathrm{kllograms}$ per hour. Aralysis of the product showed a composition of PuF 3.72 . Reduction of a portion of this material in the ine gave a satisfactory 98.6 per cent yleld.

\section{Oxidation of Calcium Metal}

A method is sought to safely oxidize the calcium in unreacted plutonium fluoridecalciummixtures to avold hazardous hydrogen evolution during the dissolution of these powders. The most rapid method is to convert the calcium to calcium hydroxide by heating at approximately $100 \mathrm{C}$ in a molst atmosphere for approximstely 12 hours. Conversion was also achleved after elther 18 days' exposure to room alr at room temperature or after 14 deys" exposure in a water saturated atmosphere at room temperature, Conversion in room als at $170 \mathrm{C}$ did not appear to be any betiter than at room temperature.

Dissolution of Turnings

Foaming during the dissolution of alpha phase plutonium turnings has plugged process equipment necessitating considerable maintenance. Two additives were tested in an attempt to alleviate this problem: "Dow Anti-Foam" and a strong oxldizing agent, potassium permanganate. Neitber additive appreclably decreased foam formation. Controlled oxidation of the turnings to the oxide followed by hydrofluorination or dissolution is still the best method found for recovery of this type of metal.

\section{Dissolution of Nickel Coats}

Enstrip "S" has been tested for stripping nickel from reject plutonium shapes in the search for a solvent which would dissolve the nickel coat more rapidy than concentrated nitric acid without dissolving the plutonium. Two re ject shapes were stripped, one at a time and one following the other, in one liter or the a.jkaline solution containing 90 grams of sodium cyanide and 60 grams of Enstrip "S" at a temperature of 65 to $70 \mathrm{C}$. The first stripping required one hour and 40 minutes, and the second three bours and 40 minutes, comparing favorably with that experienced with nitric acid dissolution. Approximately 0.16 grams of plutonium were lost during the treatment of the filrst piece and 0.08 grams with

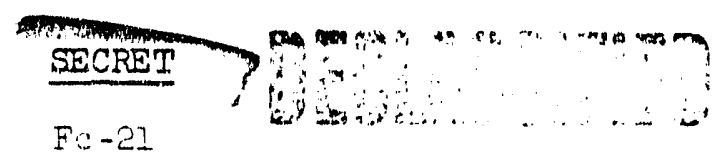




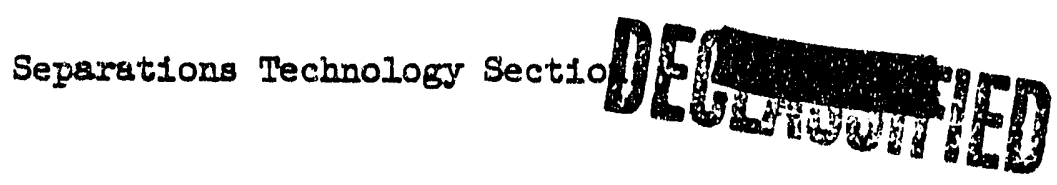

the second, as compared to an average 0.6 gram per piece loss by stripping with nitric acid. In addition to dissolving less plutonium, the Enstrip "S" treatment requires less operator attention and costs only $1 / 6$ as mucb as fuming nitric acid. 
CHEMICAL DEVELOPMENT SUB-SECTION

HOT SEMIWORKS PUREX STUDIES

Hot Semfworks setivities during the month Included the completion of equipment revisions in B Cell and necessary repalrs to A Cell equipment. When decontamination efforts in $A$ Cell reached the point of dimluishing returns, hot spots on the floor and equipment were shlelded with lead to reduce the radiation readings. Working time limits ranged from 2 to 10 minutes in the cell. Malntenance work completed included: (a) replacement of numerous process jet line flange gaskets which had been damaged by heat and radiation, (b) replacement of several grounded thermohres, (c) rerouting the drain IIne from the downdraft condenser back to the dissolver to eliminate "slugging" during dissolution, and (a) Instaliation of a recirculation jet in the service concentrator to replace a damaged agitator.

Irradiated slugs were charged on 12/22/55. After jacket removal and dissolution, HAF was prepared for Run PX.-10 whlch is currently in progress. Detalled data w1II be reported next month.

The Waste Self-Concentrator which duplicates the height of the "A" Farm tanks but has $1 / 500$ the capacity, is now approximately $2 / 3$ full of neutralized Purex IWW, having been self-concentrated by about 17 per cent over a period of three months. Approximately forty "bumps" occurred during the month of October, producing

pressures up to 17 inches of water. Peak condensation rates of about $125 \mathrm{ml} . / \mathrm{mln}$. were observed when the tank was vented through the $1 / 2$-inch vent. Only two bumps have been observed in the past two months, and the contents are now selfconcentrating at about $12 \mathrm{ml} . / \mathrm{min}$. A radiation proflle of the tank was obtained by lowering an ionization chamber into the capped pipe extending vertically through the tank contents. Th1s profile, tabulated below, indicates a sludge layer about four-peet deep, with a supernatant liquid containing gamna emitters at a concentration about one-tenth that of the sludge layer.

GAMMA RADIATION VS. HEIGHT FOR THE BOT SEMIWORKS WASTE SELF-CONCENTRATOR TANK

Hright from Bottom of Tarik, Ft.

0
3.5
6
$7-1 / 2$ to 20
25 to $36 *$

Gamma Radiation Intensity, R/Hr.

$$
\begin{aligned}
2 & \times 10^{4} \\
1.5 & \times 10^{4} \\
2 & \times 10^{3} \\
1-1 . / 2 & \text { to } 2 \times 10^{3}
\end{aligned}
$$

Drops rapidly toward 0

(*) Tank filled to about 21 feet.

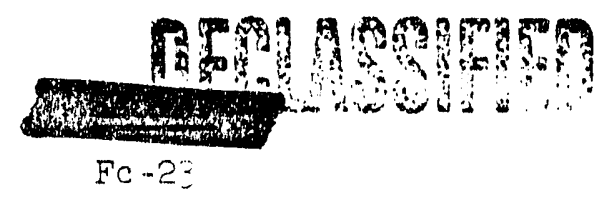


Separations Equipment Development

Piston-Bellows Pulse Unit. A piston-bellows pulser (Dwg. SK-2-6586) has been placed on test, pulsing water in a 4-inch test column. A 3.875-inch-diameter by 6-inch-long pile graphite plug reciprocates in a stainless steel cylinder to pulse the coluran liquid. A 4-inch Teflon bellows seals the shaft. Air is introduced between the bellows and the piston to prevent the Teflon bellows from contacting the process solution thereby minimizing the effect of radiation on the longevity of the bellows.

Telion Bellows Frequency - Amplitude Calibration. The 3 and 4-inch U-type Tefion bellows (J. L. Dore Company Type E-8A) were tested to determine pulse volumes as a function of bellows stroke, pulse frequency and column static head. Pulse volumes of the 3-inch bellows were found to be a linear function of the stroke, but the pulse volume ( $V$, cubic inches) of. the 4-1nch bellows was found to be $a$ function of bellows stroke ( $S$, Inches) pulse frequency ( $F$, cycles/min.) and the static head (H, feet of water). The equation:

$$
V=4.0716\left[-1+5.61 S+\frac{F}{10^{2}}\left(2.965-\frac{2.08}{10^{2}} F\right)+\frac{1.024 \mathrm{H}^{2}}{10^{3}}\right]
$$

is the best statistical fit for the curve.

\section{PUREX DEVELOFMENT}

\section{Process Chemistry}

Solid Material in Waste Concentrator. A grey, greasy-appearing soild material removed from the F-ll Waste Concentrator was found to react rapidiy with $1 \mathrm{M} \mathrm{NeOH}$ to form a fluid dark brown slurry. High concentrations of caustic produced a dark brown precipitate and an olly organic phase. Analyses conducted by the Chemical Research Sub-Section indicate the solid to be a ferric-dibutyl phosphate compound. When the ferric dibutyl phosphate compound was preclpitated at $90^{\circ} \mathrm{C}$. in a solution $8 \mathrm{M}$ in $\mathrm{HNO}_{3}, 0.1 \mathrm{M}$ in $\mathrm{UNH}$ and $4 \times 10^{-5} \mathrm{M}$ in Pu (simlated evaporator bottoms), about $\overline{9} 8$ per cent of the plutonium and 12 per cent of the uranium were carried. Several other combinations of solutions expected at various points in the Purex Plant, where partition of uranium and plutonium might occur through precipitation or solvent extraction, are under study to determine if criticality hazards may exist.

Waste Rework. Waste rework in the Purex Plant will involve addition of offstandard waste concentrator bottoms to dissolver solution in lieu of recovered acid to adjust to HAF acidity. Further digestion of waste concentrator bottoms to destroy TBP hydrolysis products can be done in plant equipment if necessary. The effect of additional digestion (at reflux) of a sample of plant IWW on F.P. decontamination and retention of $\mathrm{Pu}$ in the organic phase was determined by batch contacts simulating the HA and HC Columns and using, as feed, synthetic dissolver solution spiked with Redox dissolver solution and adjusted to HAF

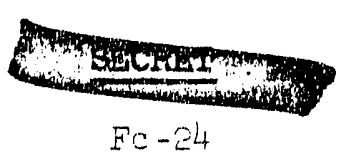


acidity with the digested IWW. C.P. nitrlc acid was used for acldity adjustment in a control run. HA extraction gross gamma D.F.'s (arithmetic) of 450, 310, (190), 290 and 390 were obtalned for C.P. $\mathrm{HNO}_{3}$ and $0,8,32$ and 1.04 hours refluxed IWW, respectively. However, after the organic was scrubbed twice and stripped once, the corresponding D.F.'s were $3040,3890,(1330), 4510$, and 3330 . Plutonium retention in the organic after stripping (HCW) was essentially the same in all cases. These data indicate that, for the rework sample studied, the normal residence of waste in the concentrator represents adequate digestion and that additional reflux is not necessary.

\section{Chem1cal Engineer1ng Development}

Pulse Column Studies. Twenty-seven runs were made during the month in the 3-inchdiameter Demonstration Unit C-type column. The study was carried out to compare the flooding characterlstics of stainless steel nozzle plates having nozzle depths of 0.06 and 0.036 Inch and to determine extraction effectiveness of nozzle plates having 0.036 - inch-deep nozzles with both top and bottom interface position. The plates having 0.06 -inch-deep nozzles had been shown to have satisfactory capacity and efficiency characteristics in both a 3-inch-diameter column and the 27-inch-diameter prototype column. The plates having 0.036-inch-deep nozzles are ldentical with those recently installed in the Purex Plant IC and $2 E$ Columns. The runs were made under the conditions of Purex HW \#3 Flowsheet. Complete data from the flooding runs are included in Table $I$, and preliminary efficiency data are given in Table II. The waste loss values in Table II are useful as a comparative indication of extraction efficiency but should not be construed to be indicative of losses to be expected in columns of different helghts. H.T.U. values will be calculated as soon as analytical data are completed.

Highlights of the flooding data are included in the following table: C-TYPE COLUMN FLOODING FREQUENCY FOR NOZZLE PLATES

\begin{tabular}{|c|c|c|c|c|c|}
\hline \multirow{2}{*}{$\begin{array}{l}\text { Nozzle } \\
\text { Depth }\end{array}$} & Inte & \multicolumn{2}{|c|}{$\begin{array}{l}\text { Flooding Frequency } \\
\text { at } 10 \text { T'ons U/Day* }\end{array}$} & \multicolumn{2}{|c|}{$\begin{array}{l}\text { Flooding Frequency } \\
\text { at } 20 \text { Tors U/Day* }\end{array}$} \\
\hline & Position & yclic Local & Complete & Cyclic Locel & Complete \\
\hline & & & & None & 125 \\
\hline & To & $85 \pm 5$ & $125 \pm 5$ & $75 \pm 5$ & 95 \\
\hline & Bottom & None & $135 \pm 5$ & None & $105 \pm$ \\
\hline 0.036 & Top & $95 \pm 5$ & $125 \pm 5$ & $65 \pm 5$ & $105 \pm$ \\
\hline
\end{tabular}

(*) Equivalent volume veloctty in the Purex Plant columns based on HW No. 3 Flowsheet.

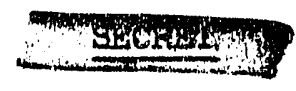

F心 -25

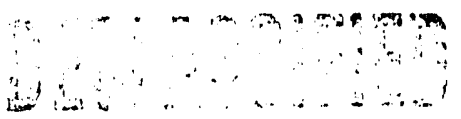


It can be concluded that there is no significant difference between the flooding frequencles obtained with plates having 0.06 -inch and 0.036 -inch deep nozzles. Moving the interface position from the bottom to the top of the column appears to decrease the flooding frequency up to 30 cycles/minute. With the interface at the bottom no cyclic local flooding was observed below the frequency which produced a complete flood. With the interface at the top, however, cyclic coalescence occurred at 20 to 40 cycles/minute below the complete flooding frequency.

It appears that satisfactory extraction performance can be obtained for rates up to 20 tons U/day with interface at elther the top or the bottom in spite of cyclic coalescence with the top interface position. Operation under conditions of Purex HW NO. 4 Flowsheet (heated HCX and lower $I / V$ ) produced lower waste losses than comparable EW No. 3 conditions. The extraction efficlency was shown to be sharply sensltive to frequency for both top and bottom interface positions.

Thermal Efficlency Studies. To determine whether 1 it is feasible to employ heat transfer as an analogy to mass transfer in pulse column, thereby having an additional tool for efficlency studies, temperature measurements were taken on a 9-ft.-high C-type column operating under Purex conditions at a rate of 10 tons U/day. Equilibrium temperatures were as follows:

$\begin{array}{cc}\text { Stream } & \text { Temp. }{ }^{\circ} \mathrm{C} . \\ \text { HCX } & 54 \\ \text { HCW } & 51 \\ \text { HCF } & 30 \\ \text { HCP } & 42\end{array}$

These temperature differences appear large enough to warrant further investigation of the technique.

\section{Process Planning}

Total Dissolution. A study was initiated to determine the process and economic feasibilities of substituting total dissolution techniques in the Purex Plant for the two-step (Jacket removal, uranium dissolution) dissolution incorporated in the HW No. 4 Flowsheet. Preliminary results indicote that a total dissolution flowsheet may produce appreciable increases (ca. 5 tons $U$ per day) in the dissolution and acld recovery capacities of the Purex Plant. Only the solvent extraction columns would need be replaced to achieve a capacity factor of 3 . Assuming the wastes are allowed to self-concentrate to about $8 \mathrm{M}$ sodiun ion, the total dissolution flowsheet is about $\$ 15$ per ton of uranium processed more expensive than the HW No. 4 Flowsheet. The successful development and inauguration of the coating waste cribbing program now under study would increase this differential to perhaps $\$ 45$ per ton. 
The flowsheet poses several unknowns of undetermined magnitude, e.g. hydrogen evolution during alssolution, effective "salting" strength of ANN in the $\mathrm{HA}$ Column, and vapor-liquid equilibria in $\mathrm{HNO}_{3}-\mathrm{ANN}-\mathrm{H}_{2} \mathrm{O}$ systems. These areas will require experimental development before plant tests are conducted.

\section{REDOX DEVELOPMENT}

Process Chemistry

Rework of Redox Uranium and Plutonlum. When processing sump and recycle material blended with the final head-end batch prior to the scheduled December shutdown, uranlum and plutonium products having gama ratios 100 to 1000 times higher than specifications were obtained. Reworking the plutonium through the second and third plutonium cycles did not bring it within specleications; consequently, the plutoniurn and uranium were returned to the $H-4$ oxidizer to be glven a second head-end treatment. In the laboratory, samples of the uranium and plutonlum product were combined, concentrated to IAF composition, given a head-end treatment, and treated by batch contacts.simulating the IA, IB, and IC Columns. Although the gross gamma D.F. (arithmetical) for the head end was only 1.1, over-a.ll gross gamma D.F.'s (arithmetical) from IAF to ICU and IAF to IBP were 115 and 141 , respectively. These data indicated that adequate decontamination of the rework uranium and plutonium could be obtalned with head-end and the first cycle treatment.

\section{URANIUM RECOVERY DEVELOPMENT}

Process Chemistry

Ozonization of Uranium Recovery Product Solution. In studies simulating the processing of Uranium kecovery Plant product solution through the proposed Redox ozonization equipment for additional Ru decontamination, four different samples of RDF solution were maintalined at $90^{\circ} \mathrm{C}$. and spraged with two per cent ozone in air at a rate of one $\mathrm{ml}$. of spargent per $\mathrm{ml}$. Of solution. No induction period was noted in any case. Approximately 60 and 85 per cent RU removal was attaned in four hours and eight hours, respectively. The 1ritial solutions contalned about $5 \times 10^{5}$ gammas $/ \mathrm{min}$. $/ \mathrm{ml}$. (gamma scan) with ruthenium contributing about 40 per cent of the total radioactivity. Two of the samples contained Ru adsorbed on the finely divided black solids frequently present in Urantum Recovery Plant solutions. No impairment in Ru decontamination was noted for these solutions. No adverse effect was noted when an RDF solution was sniked to contain 0.01 . v0l. Fer cent Uranium Recovery Plant solvent. However, when the solvent concentration was increased to 0.025 vol. per cent, an induction period of about two hours was observed.

RDF rather than REU was used in these studies because of the present low Ru content of the latter. Concentration and stripping facilities for the RCU and REU streams are 1dentical; therefore, no difference in the behavior of these streams toward ozonization is to be expected.

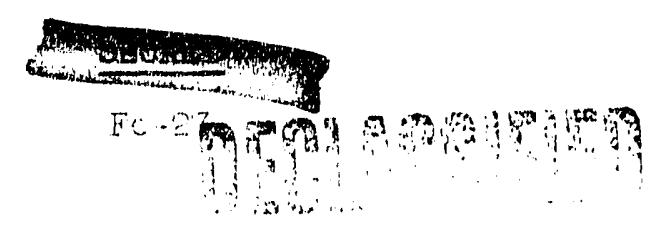


Use of $\mathrm{PO}_{4}$ to Improve $\mathrm{Zr}-\mathrm{No}$ Decontamination. Possible processing of very young ieeds (aged as little as s1x months) through the Uranlum Recovery Plant (current average age is 11 months) prompted an Investigation of the use of phosphate in the second uranium cycle as. a means of lmproving $\mathrm{Zr}-\mathrm{Nb}$ decontamination. In a serles of minlature pulse column runs made with plant solutions and slmulating RD Column operation, the scrub solution was splked with $\mathrm{H}_{3} \mathrm{PO}_{4}$ in amounts varying from 0.0 to $0.1 \mathrm{M}$. Arialytical difficulty due to the very low radioactive content of the product solutions caused some scattering of the data. However, a scrub solution containing $0.2 \mathrm{M} \mathrm{PO}_{4}$ (no increase in actdity) produced abolat a two-fold increase in gross gemme decontamination (compared to no $\mathrm{PO}_{4}$ in the scrub) with no significant increase in uranium waste losses. In a second series of runs made with a feed 20-fold bigher in activity (Plant RDF splked with Redox H-7 solution), a 2.2-101.d Increase in gross gamms decontamination was observed with $0.1 \mathrm{M} \mathrm{PO} 4$ in the scrub. Uranium waste losses to the RDW Increased from about 0.3 to 0.6 per cent as the $\mathrm{PO}_{4}$ concentration in the scrub was increased from 0.0 to $0.1 \mathrm{M}$.

Chalk River Uranium. It has been proposed that approximately 40 tons of depleted uranium, partially decontaminated from plutonium and fission products in the Chalk RIver separations faclilty, be processed through the Uranium Recovery Plant. A sample of the solution recelved from Chalk River contalned $1.92 \mathrm{M} \mathrm{U}$ (0.648 per cent $\mathrm{U}^{235}$ ), $0.26 \mathrm{M} \mathrm{HNO}_{3}, 2.07 \mathrm{mg}$. Pu/ $/ ., 3.55 \times 10^{3}$ gamma c./m./ml. (40 per cent $\mathrm{Zr}-\mathrm{Nb}-60$ per ceñt $\mathrm{Ru})^{\prime}, 4.97 \times 10^{4}$ beta $\mathrm{c} . / \mathrm{m} . / \mathrm{ml}$., and 0.4 vol. per cent of a heavy oil phase. On the basis of uranium distribution ratios, dispersion and disengaging times, flssion product decontamination in laboratory batch tests, effect on solvent quality, and behavior in pulse columns, no adverse effects on Uranium Recovery Plant performance is to be expected as a result of processing this feed material. Unless unusual problems are encountered in transferring the material from the shipping containers to plant tankage, processing costs should be nearly identical with current TBP Plant processing costs.

Continuous Calcination. Equipment modifications were made to permit the use of a more highly concentrated feed in the three-inch-dlameter continuous calciner. An electrically heated pot was placed above the calciner which allows the concentrated feed to be added above the $\mathrm{UO}_{3}$ bed. One run has been completed to date, in which the average feed corresponded to $\mathrm{UO}_{2}\left(\mathrm{NO}_{3}\right)_{2}, 4 \mathrm{H}_{2} \mathrm{O}$, with no improvement noted in the quality of the $\mathrm{UO}_{3}$ produced. These studies are being continued.

A smali scale semi-continuous calciner has been fabricated and put into operation. Preliminary tests indicate that a product characterlstic of continuous calciner operation (long reduction time and low reactivity) is formed. The calcination cycle for this equipment is 1.5 to 2 hours and will allow the survey of a large number of additives with a minimum of effort.

The furnace controller used in the reactivity apparatus has been modified to permit reactivity determinations at the temperature recommended by $\mathrm{K}-25$, i.e., reduction for two hours at $925^{\circ} \mathrm{C}$., and a three-hour hydrofluorination at $560^{\circ} \mathrm{C}$.

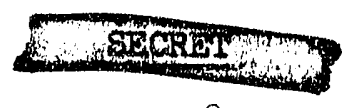

Fc -28 
Reactivity determinations were made on $\mathrm{JO}_{3}$ produced in the 321 Building prototype calciner during Run S-4. For th1s run a baffle was installed to 1solate the feed polnt and flnishing sections; the feed point temperature was maintained at $300^{\circ} \mathrm{C}$. while water was added in the finfshing section to maintaln the exit powder temperature at $127^{\circ} \mathrm{C}$. A reactivity ratio or about 0.75 was found under both "standard conditions" (two-hour reduct1on at $590^{\circ} \mathrm{C}$. and 0.5 -hour hydrofluorination at $410^{\circ} \mathrm{C}$. ), and at a hlgh (two hours at $800^{\circ} \mathrm{C}$.) reduction temperature followed by a standard hydrofluorination period. Two intermediate samples taken before water was added to the finishing section exhlbited reactivity ratios of about 0.95 at $590^{\circ}-410^{\circ}$ and about 0.80 at $800^{\circ}-410^{\circ}$.

\section{Chemical Englneering Development}

Continuous Calcination. Six 8-hour scouting runs were made in the 16-1nch-diameter semiplant-scale continuous calciner to test the operabllity of the reactor with the newly Installed baffle plate. Thls baffle, installed between the calcination section and the finishing section, was designed to minimize mixing of the finished and reacting products. Operability was good with temperatures in excess of $400^{\circ} \mathrm{C}$. attainable in the finlshing section when the calcining section was operating at $230^{\circ} \mathrm{C}$. Three of the runs were made with water added to the finishing section near the discharge weir in an attempt to hydrate the product. Although operability was good, a water addition rate of 16 to 20 welght per cent of the product rate was required to lower the finlshing section temperature to $127^{\circ} \mathrm{C}$. (calcining section temperature $=260^{\circ}$ to $300^{\circ} \mathrm{C}$.). The product under these conditions contained about 2 per cent water. The runs were made with only a fraction (approximately 1/3) of a through-put produced, and longer runs will be required to establish product qualities.

\section{WASTE TREATMENT}

\section{Process Chemistry}

Ceslum and Strontium Scavenging. Scavenging procedures have been established for the first four tanks scheduled for in-farm scavenging in the $200 \mathrm{~W}$ Area. For three of these tanks $0.005 \mathrm{M} \mathrm{Ni}_{2} \mathrm{Fe}(\mathrm{CN})_{6}$, alone, was sufficient for adequate cesium and strontium decontamination. The fourth tank required the addition of $0.01 \mathrm{M}$ calclum to remove strontium to cribbable limits.

Of a number of solid absorbents (Kaolin, Superfiltrol, Fuller's Earth, and Attaclay) and preclpltants (nlckel ferrocyanide, silicotungstic acld, zirconyl phosphate and sodium tetraphenyl boron), examined for the removal of cesium and strontium from coating removal waste, only Fuller's Earth, Attaclay and sodium tetraphenyl

boron were significantly effective. The latter was the most effective of the three; concentrations as $10 \mathrm{w}$ as $0.0003 \mathrm{M}$ gave strontium and cesium decontamination factors of 40 and 110 , respectively. It has the disadvantages that the settling properties of the precipitates formed are sometimes poor, and that the present cost of the reagent is high. It was also found that cesium can be extracted from aqeuous solutions with sodium tetraphenyl boron in an organic solvent.

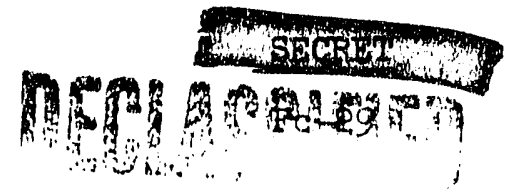




\section{DECLSPETER}

Chemical Engineering Development

Silver Reactor Studies. The degree of wetting of the packing during silver reactor regeneration, the accumulative effect of successive regenerations, and the effect of rate of addition of the regenerant solution were investigated in a series of experiments in the 4-inch-diameter by 8-ft.-high column packed with 1/2-1nch saddles. Regenerant solution was poured over the top of the packing, and the volume of leak-through measured. Representative results are listed below:

$$
\begin{gathered}
\text { Volume 7-Molal } \mathrm{AgNO}_{3} \\
\text { Applied to Top of Packing } \\
\text { MI. }
\end{gathered}
$$

200

300 (Plant ratio)

400

200 (After 3 previous regenerations)

300 (Applied rapidly to uncoated packing)

300 (Applied slowly to uncoated packing)

300 (lst regeneration)

300 ( 7 th regeneration)

\begin{tabular}{r} 
Volume \\
Leak - Th \\
MI \\
\hline 7 \\
75 \\
75 \\
0 \\
40 \\
20 \\
40 \\
3
\end{tabular}

$300 \mathrm{ml}$. of solution were poured rapidly over uncoated packing. The packing was drled and samples of the packing from various levels were analyzed for $\mathrm{AgNO}_{3}$. Thls experiment was repeated except that the solution was applied slowly (to simulate plant practice). After 6 additional regeneration cycles, $300 \mathrm{ml}$. of dye-colored solution were poured over the packing. The packing was dried, and samples of the packing were exanined to determine the fraction of the surface

\begin{tabular}{|c|c|c|c|}
\hline $\begin{array}{c}\text { Vertical Location, } \\
\text { Ft. from Top } \\
\text { of Bed }\end{array}$ & $\begin{array}{l}\mathrm{AgNO}_{3} \\
\text { on Pack } \\
\text { Rap1d } \\
\text { Add1tion }\end{array}$ & $\begin{array}{l}\frac{\text { tained }}{3, \text { Wt. } \%} \\
\text { SIow } \\
\text { Addition }\end{array}$ & $\begin{array}{l}\text { \% of Packing Surface } \\
\text { Wet by Dye-Colored } \\
\text { Regenerant Solution }\end{array}$ \\
\hline$O$ (TOP) & 0.80 & 0.84 & 80 \\
\hline 2 & 2.15 & 2.14 & 90 \\
\hline 4 & 2.42 & 2.17 & 90 \\
\hline 6 & 1.74 & 1.54 & 80 \\
\hline 7 & -- & - & 60 \\
\hline 8 & 0.30 & 0.56 & $100 *$ \\
\hline
\end{tabular}
that had been wet by the regenerant solution. The results of these experiments are given in the following table:

(*) Saddles in contact with packing support grid.

On the basis of these tests, it appears that present silver reactor regeneration practice in the Redox Plant is proper for maximum efficiency.

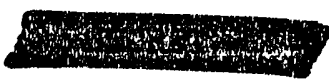

$$
F:-30
$$


Separations Equipment Development

Pump-Agitator. A Johnston three-stage TBS deepwell turbine pump has been equipped with a 20 -horsepower, $3450 \mathrm{rpm}$. motor. The unit is installed in the $A Q-7$ Tank, where it is operating as an agitator pumping 150 GPM through a throttled discharge p1pe. The unit draws 15 horsepower, and develops a 250-ft. head. The same unit equipped with a 3-horsepower, $1750 \mathrm{rpm}$. motor delivered about 150 GPM at a $35-\mathrm{ft}$. maximum head.

Interface Control. A Taylor D/P transmitter 1nstalled across the bottom 15 inches of a one-1nch glass pulse column equipped with a 15-ft. "standard" cartridge was successfully used for control of a bottom interface. Purex organic and water were used for column solutions and the pulse rate was varled from 30 to 120 cycles per minute. The $D / P$ transmitter impulse lines were fllled with the heavy column liquid and the instrument was connected to a recorder controller which controlled a diaphragm operated valve on the bottom outlet of the column. The system was not sensitive to pulse frequency and controlled over a wide range of water flow rates.

This equipment was installed on the prototype $2 \mathrm{~A}$ Column where it was used to record 1nterface position during test runs made to check the capacitance probe interface control. It is now concluded that this type system can be used for interface control. should other systems fall to perform satisfactorliy. Before such a system could be installed in the plants, however, a sultable $D / P$ transmitter having a full scale range of 6-1n. of water should be developed and the system should be made sultable for remote maintenance.

Titanium Studies. An experiment designed to explore the conditions that govern titanium-nitric acid explosions was started. To date, samples of sheet titanium $(A-55)$ and sponge titanium have been exposed to 92 per cent nitric acid for a one-month period. The samples were alternately heated to $50^{\circ} \mathrm{C}$. and cooled to ambient temperature; also, they were alternately made anodic and cathodic by an 11 volt potent1al to induce chemical reaction and depassivate the metal. One sample was electrolytically plckled in dilute sulfurlc acid to encourage hydrogen occlusion prior to the exposure to 92 per cent nitric acid. In no case did an explosion occur; in fact, little if any chemical reaction was realized during the test period.

Recent investigations ( 1 ) conducted at the Wright Field Jet Propulsion Laboratory indicate that ignition of titanium in nitric acid is dependent on (1) there being 10 to 20 welght per cent $\mathrm{NO}_{2}$ and (2) less than 1.5 welght per cent water in the acid. The acld used in the tests described above contained seven weight per cent, water.

(1) Progress Report No. 26-1, "Corrosion and Ignition of T1tanium Alloys in Fuming Nitric Acid," Jet Propulsion Laboratory, California Institute of Technology, September 1955.

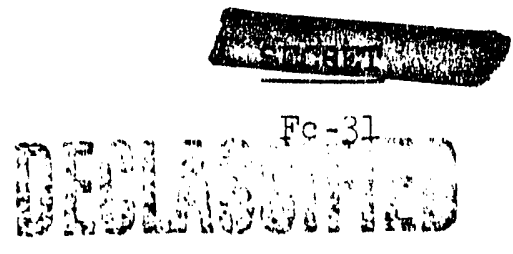


These data plus the fact that t1tanium has been successfully used for 60 per cent nitric acld service in manufacturing plants (du Pont's Chamber Works) encourage further development of this material for application in H.A.P.O. Separations Plarts.

Titanium is now in good supply and the Pabrication cost is about equal to that of stainless steel. The material cost per unit velght is about ten times that of stalaless steel, but 1ts lower density and higher resistance to corrosion by nitric acld permits equipment fabricated from titanjum to be less massive than equivalent stainless steel equipment. It is estimated that titanium equipment wili cost three to f1ve times more then stalnless equipment but, ff applied properly, the longer iffe of titanium equipment will probably justify the higher Initial cost.

Materials Testing. Super Dylon (a new process polyethylene) manufactured by the Koppers Company was tested by static 1mersion at room temperature in 1.0 per cent nitric acid, 60 per cent nitric acid, 50 per cent caustic soda, carbon tetrachloride, tributyl-phosphate, Purex organic (30 per cent TBP-kerosene) saturated with nitric acfd, and $100^{\circ} \mathrm{C}$. alr. The samples 1umersed in solutions showed no visible change after 84 days. The material in $100^{\circ} \mathrm{C}$. air softened slightly and adhered to the watch glass it rested on after 17 days exposure.

\section{In-Line Chemical Instrumentation}

pH Flow Cells. Final design of the pH flow cell was completed (Dwg. H-2-3139) and Technjcal Shops heve fabrlcated elght cells for plant application. Two of the elght cells were tested in the cold semlworks where they perpormed satisiactorily. Th1s design will replace all pH flow celis now ingtalled, permitting standardization throughout the separations plants. A double junction, permanentily sealed calomel electrode (Beckman, Catalog No. 4970-6) is employed in this cell. The electrode was test-operated under is inches of mercury vacuum for 22 days and did not show anj losa of junction liquid nor change in operating characteristics. other electrodes tested required refilling with junction liquid and were not sultable for plant application.

Purex Plant In-Line Konftors. The P1rst draft of the Operations and Maintenance Maidul is about 90 per cent complete. A working copy of this manual will be avallable to plant personnel in Janusry.

Sampling pump. An alr-operated samping pump designed to fit the standard 2 in. remote tank nozzles has operated 370 hours pumping $90^{\circ} \mathrm{C}$. water. This unit was designed for sampling thermally hot, corrosive, high density, radioective aqueous or organic solutions and is described in Drawing SK-3-6566. The jet samplers usually employed will not function on thermaly hot streams and wil not provide continuous samples on high density streams, such as purex $2 E U$.

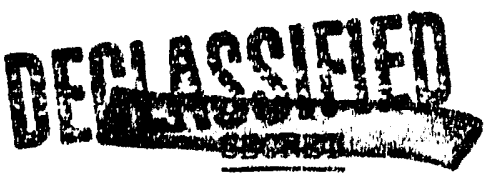

$$
B-3 c
$$


Chemical Engtneering Development

\section{DECASSFIED}

Continuous Dissolution. Two runs were made in the 2-inchmdiameter by 9-ft.-high tower-type dissolvex during the month. The pirst run using bare uranium slugs was made to establish nitric acld and urania concentration gradients in the tower. The results using a 60 per cent altric acld feed indlcate that oriy slight concentracion gradients exist.

The second run using aluminum-jacketed slags (standard 8-in. long) was carrled cut using 60 per cent altric acid containing $0.005 \mathrm{M} \mathrm{B}_{8}\left(\mathrm{NO}_{3}\right)_{2} \cdot \mathrm{H}_{2} \mathrm{O}$ as the feed solution. A uranlum dissolution rate of $1.7 \mathrm{~kg} / \mathrm{hr}$. was achleved with a feed rate of $5.51 . / \mathrm{hr}$. The product composition is campared with that from a dissolut1.on of bare slugs in the following table:

\begin{tabular}{lcr} 
& \multicolumn{2}{c}{ Composition, G/I. } \\
\cline { 2 - 3 } Component & Bare Slugs & Jacketed \\
\cline { 2 - 3 } Oranium & 407 & 402 \\
Nitric Acid & 257 & 252 \\
Aluminum & -- & II
\end{tabular}

The dsta Indicate little effect of aluminum on dissolution rate or product composition.

Eydrogen was evolved at a rate of less than 0.4 std.cu.ft./hr. which is apprectably less than the $2.2 \mathrm{std} . \mathrm{cu} . \mathrm{ft} . / \mathrm{hr}$. predicted if the aluminum dissolved according to the equation:

$$
\mathrm{Al}+3 \mathrm{ENO}_{3} \longrightarrow \mathrm{Al}\left(\mathrm{NOO}_{3}\right)_{3}+3 / 2 \mathrm{H}_{2}
$$

Further exploration of the extent of hydrogen evclution is planned.

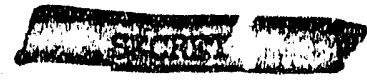

FC -33 


\section{TABLE I}

\section{PUREX HC COLIMN FLOODING STUDIES}

Flowsheet: Purex HW No. $3^{(\mathrm{a})}$ Pu and F.P.'s omitted. ShelI E-2342 diluent. Equiprent: 3-in, precision bore glass column; cartridge: see notes. Pulse Amplitude: $0.60 \mathrm{~m}$.

\begin{tabular}{|c|c|c|c|c|c|}
\hline \multirow[b]{2}{*}{ Run No. } & \multirow{2}{*}{ Cartridge $^{(b)}$} & \multirow{2}{*}{$\begin{array}{l}\text { Interface } \\
\text { Position } \\
\end{array}$} & \multirow{2}{*}{$\begin{array}{l}\text { Equivalent } \\
\text { Processing Rate, } \\
\text { Tons U/Day }(c) \\
\end{array}$} & \multicolumn{2}{|c|}{$\begin{array}{c}\text { Frequency Flooding } \\
\text { Thresholds }\end{array}$} \\
\hline & & & & Cyclic Iocal & Complete \\
\hline $\begin{array}{l}3-247-\mathrm{CH} \\
3-248-\mathrm{CH} \\
3-249 \mathrm{~b}-\mathrm{CH} \\
3-250-\mathrm{CH} \\
3-251-\mathrm{CH}\end{array}$ & $\begin{array}{l}A \\
A \\
A \\
A \\
A\end{array}$ & $\begin{array}{l}\text { Bottom } \\
\text { Bottom } \\
\text { Bottom } \\
\text { Bottom } \\
\text { Top }\end{array}$ & $\begin{array}{l}10 \\
15 \\
20 \\
25 \\
10\end{array}$ & $\begin{array}{l}\text { None } \\
\text { None } \\
\text { None } \\
\text { None } \\
85 \pm 5\end{array}$ & $\begin{array}{l}>120 \\
>120 \\
125 \pm 5 \\
115 \pm 5 \\
125 \pm 5\end{array}$ \\
\hline $\begin{array}{l}3-252-\mathrm{CH} \\
3-253 \mathrm{~b}-\mathrm{CH} \\
3-254-\mathrm{CH} \\
3-247-\mathrm{CH} \\
3-249 \mathrm{c}-\mathrm{CH}\end{array}$ & $\begin{array}{l}\text { A } \\
\text { A } \\
\text { A } \\
\text { B } \\
\text { B }\end{array}$ & $\begin{array}{c}\text { Top } \\
\text { Top } \\
\text { Top } \\
\text { Bottom } \\
\text { Bottom }\end{array}$ & $\begin{array}{l}15 \\
20 \\
25 \\
10 \\
20\end{array}$ & $\begin{array}{l}75 \pm 5 \\
75 \pm 5 \\
45 \pm 5 \\
\text { None } \\
\text { None }\end{array}$ & $\begin{array}{r}1.5 \pm 5 \\
95 \pm 5 \\
75 \pm 5 \\
135 \pm 5 \\
105 \pm 5\end{array}$ \\
\hline $\begin{array}{l}3-251 c-\mathrm{CH} \\
3-253 c-\mathrm{CH} \\
3-255-\mathrm{CH} \\
3-256-\mathrm{CH}\end{array}$ & $\begin{array}{l}\text { B } \\
B \\
B \\
B\end{array}$ & $\begin{array}{l}\text { Top } \\
\text { Top } \\
\text { Top } \\
\text { Top }\end{array}$ & $\begin{array}{l}10 \\
20 \\
10 \\
20\end{array}$ & $\begin{array}{r}95 \pm 5 \\
65 \pm 5 \\
95 \pm 5 \\
>70\end{array}$ & $\begin{array}{l}125 \pm 5 \\
105 \pm 5 \\
115 \pm 5 \\
95 \pm 5\end{array}$ \\
\hline
\end{tabular}

Notes:

(a) The same batch of HCF was used for all muns except 3-255-CH and 3-356-CH. The composition of this feed was $76 \mathrm{~g} . \mathrm{U} / \mathrm{L}$. and $11.9 \mathrm{~g}$. KNO / / . The composition of the HCF for Runs $3-255-\mathrm{CH}$ and $3-256-\mathrm{CH}$ was $35.6^{\mathrm{j}} \mathrm{g}$. U/L. and $11.6 \mathrm{~g} . \mathrm{HNO}_{3} / \mathrm{I}$.

(b) Cartriage A

9 feet of 2.98 in.-diameter stajnless steel nozzle plates with $1 / 3 \mathrm{in}$. holes, $10 \%$ free area on 4-n. plate spacing. Nozzle depth was 0.06 in. and noziles pointed down.

Cartridge $B$

Identical with Cartridge A except nozzle depth was 0.036 in.

(c) Jranium processing rate based on Purex Plant-size columns.

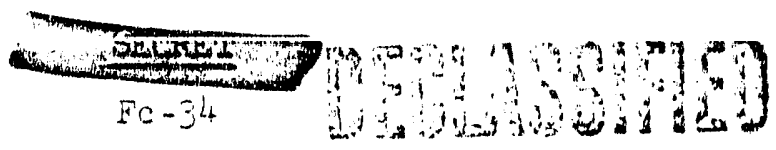




\section{TABIE II}

\section{FUREX HC COLUMN HTU STUDIES}

Flowsheet: Purex EN No. $3^{(a)}$ Pu and F.P.'s omitted. Shell E-2342 diluent.

Equipment: 3.00-in. precision bore glass colum; Cartridge: $9 \mathrm{ft}$. of 2.98-in. diameter stainless steel nozzle plates, 1/8-in. holes, $10 \%$ free area, and 4-1n. plate spacing. Nozzle depth $=0.036$ in. and nozzles are pointed down.

Pulse Amplitude: 0.60 in.

\begin{tabular}{|c|c|c|c|c|c|}
\hline Run No. & $\begin{array}{l}\text { Pulse } \\
\text { Frequency, } \\
\text { Cyc./Min. }\end{array}$ & $\begin{array}{l}\text { Interface } \\
\text { Position }\end{array}$ & $\begin{array}{c}\text { Equivalent } \\
\text { Processing Rate, } \\
\text { Tons U/Day (b) } \\
\end{array}$ & $\begin{array}{l}I / V \text {, } \\
\text { Aqueous to } \\
\text { Organic } \\
\text { Flow Ratio }\end{array}$ & $\begin{array}{lr}\% & U \\
\text { Loss }\end{array}$ \\
\hline $\begin{array}{l}3-257-\mathrm{CH} \\
3-258-\mathrm{CH} \\
3-259-\mathrm{CH} \\
3-260-\mathrm{CH} \\
3-261-\mathrm{CH}\end{array}$ & $\begin{array}{r}70 \\
80 \\
100 \\
40 \\
50\end{array}$ & $\begin{array}{l}\text { Top } \\
\text { Top } \\
\text { Top } \\
\text { Top } \\
\text { Top }\end{array}$ & $\begin{array}{l}10.1 \\
10.3 \\
10.2 \\
19.1 \\
19.4\end{array}$ & $\begin{array}{l}1.73 \\
1.69 \\
1.77 \\
1.71 \\
1.76\end{array}$ & $\begin{array}{c}0.38 \\
0.013 \\
0.0029 \\
17.3 \\
4.5\end{array}$ \\
\hline $\begin{array}{l}3-262-\mathrm{CH} \\
3-263-\mathrm{CH} \\
3-264-\mathrm{CH} \\
3-265-\mathrm{CH} \\
3-266-\mathrm{CH}\end{array}$ & $\begin{array}{r}80 \\
90 \\
110 \\
60 \\
80\end{array}$ & $\begin{array}{l}\text { Top } \\
\text { Bottom } \\
\text { Bottom } \\
\text { Bottom } \\
\text { Bottom }\end{array}$ & $\begin{array}{l}18.0 \\
10.1 \\
10.1 \\
18.0 \\
18.5\end{array}$ & $\begin{array}{l}2.04 \\
1.56 \\
1.69 \\
1.49 \\
1.93\end{array}$ & $\begin{array}{l}0.058 \\
0.14 \\
0.0029 \\
19.3 \\
3.7\end{array}$ \\
\hline $\begin{array}{l}3-267-\mathrm{CH} \\
3-268-\mathrm{CH} \\
3-271-\mathrm{CH}\end{array}(\mathrm{c})$ & $\begin{array}{l}80 \\
80 \\
60\end{array}$ & $\begin{array}{l}\text { Top } \\
\text { Top } \\
\text { Top }\end{array}$ & $\begin{array}{l}10.3 \\
19.5 \\
20.2\end{array}$ & $\begin{array}{l}1.23 \\
1.24 \\
1.74\end{array}$ & $\begin{array}{l}.003^{(a} \\
.002^{(a} \\
0.57\end{array}$ \\
\hline
\end{tabular}

Notes:

(a) HCF composition was $35.6 \mathrm{~g} . \mathrm{U} / \mathrm{L}$. and $11.6 \mathrm{~g} \cdot \mathrm{HNO}_{3} / \mathrm{L}$.

(b) Uranium processing rate based on a Purex Plant-size column.

(c) HCX was heated to $450^{\circ} \mathrm{C}$.

(d) Waste losses based on final sample only.

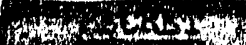


CHEMICAI, RESEARCH SUB-SECTION,

PUREX

\section{Solvent Studies}

As reported last month, an unidentified phosphorous compound capable of enhancing. zirconium-nloblum extraction in Purex systems was 1solated by chromatograph1c analys1s of recycled Hot Sem1-Works solvent ( 30 percent TBP - Soltrol 170 uged in ESW Run PX-6). This terial is insoluble in nonpolar solvents (carbon tetrachloride, pertane, chloroform, diethylether) but is soluble in vater or equeous three percent sodium carbonate. Addition of nitric acld to water solution of this materlal results in mild gas evolution and formotion of a yellow o11, soluble in carbon tetrachloride. The oll phase has been 1dentifled by infrared examination as dibutyl phosphate contaminated with minor amounts of diluent degradation products.

In further efforts to trace the source of this compound, the chromatographic separation technique wes applied to "as recelved" TBP from the Comercial Solvents Corporation. A fraction which, on the basis of infrared examination and its effect un zirconium-niobium extraction, appears to be identical with the material obtalned from recyclea Hot Seml-Works solvent was also obtained from this unused solvent! Experiments are currently in progress to ascertain if this material acturily exists en impurity in the tributyl phosphete or if it is formed in the course of the chromatographic analysis.

Samples of solvent obtained from the Purex plent after cold runs $A C-1, A C-2$, $A C-3$, and $A C-4$ have been examined. No glenificant decline in quality has been observed in solvent samples from the No. 2 solvent system through these runs. Signiflcant changes have been noted in the samples from the No. 1 solvent system, however. These data are sumarized in Table I.

\section{TABLE I}

\section{CHARACTERIZATION OF PUREX PLANT SOLVENT}

\begin{tabular}{|c|c|c|c|c|c|}
\hline Run & Stream & $\begin{array}{l}\text { "C" Contact } \\
\mathrm{EQ}(\mathrm{U}) \\
\text { (as received } \\
\text { solvent) }\end{array}$ & $\begin{array}{c}\text { "C" Contact } \\
\text { EQ (U) } \\
\text { (carbonate-washed } \\
\text { solvent) } \\
\end{array}$ & $\begin{array}{r}\text { Optical } \\
\text { Density } \\
\text { at } 330 \text { mu* } \\
\end{array}$ & $\begin{array}{l}\text { Scrub } \\
\mathrm{E}^{\text {Sc }}(\mathrm{Zr}-\mathrm{Nb}) * *\end{array}$ \\
\hline \multirow[t]{2}{*}{$A C-1$} & $\mathrm{HCW}$ & 0.016 & 0.010 & 2.4 & 0.01 \\
\hline & 100 & 0.011 & 0.010 & 2.5 & \\
\hline \multirow{2}{*}{$A C-2$} & HCW & 0.11 & 0.013 & 4.0 & 0.02 \\
\hline & 100 & 0.010 & 0.013 & 4.2 & \\
\hline \multirow[t]{2}{*}{$A C-3$} & HCW & 0.096 & 0.011 & 5.5 & 0.03 \\
\hline & 100 & 0.012 & 0.010 & 5.8 & 0.03 \\
\hline \multirow[t]{2}{*}{$A C-4$} & BCW & 0.080 & 0.010 & 5.3 & 0.04 \\
\hline & 100 & 0.013 & 0010 & 60 & 0.04 \\
\hline
\end{tabular}

* Optical density measured after exhaustive carbonate washing of solvent.

**ER ( $\mathrm{Zr}-\mathrm{Nb})$ in first scrub stage of batch extraction-scrub operation simulating

HA column. Measurements made after exhaustive carbonate washing of solvent.

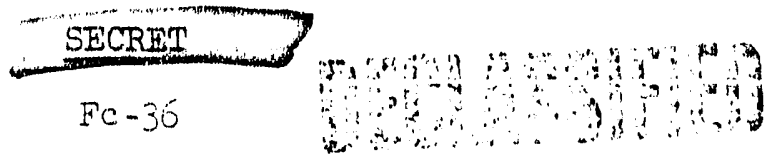


Separations Technology Section

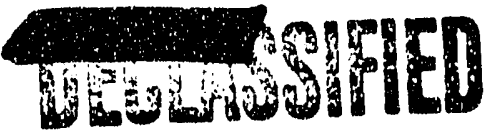

It will be noted that whereas no change has occurred in the "C" contact values during these runs a perceptible change has been observed in the color of the solvent and in the scrub distribution ratio for zirconium and niobium. For comparison, the recycled TBP-Soltrol 170 solvent used in Hot Semi-Works Run PX-6 gave in this test acrut distribution ratio for zirconium-niobium of 0.02 . The plant solvent regenexation system appears to be functioning properly since the quality of Purex plant 100 is not improved significantly by further carbonate washing in the laboratory.

The decontamination potentlal of Purex plant 100 froin Run AC -4 was tested also in a Purex EA Minl run. Only fragmentary data are available as yet but these Indicate no difference in the decontamination with Purex 1.00 (Run AC-4) and with laboratory solvent prepared from vacuum-distilled TBP. Using feed prepared in the laboratory grose ganma decontamination factors from HAF to BAP were 640 for the Purex plant 100 and 660 for laboratory-grade solvent. However, it should be noted that gross gama decontamination in both these runs was significantiy worse than in previous runs employing feed obtained from the Hot Semi-Works.

Some effort has been expended in examination of solids removed from the Purex plant No. I AC1d Concentrator on November 21, 1955. Infrared examination and quantitative analysis for iron, carbon, and hydrogen indicate this material to be principaliy ferric dibutyl phosphate. The carbon, hydrogen, and iron contents were, respectively, 3.5 percent lower, 7.6 percent lower, and 3.2 percent higher then the values for pure ferric dibutyl phosphate. These deviationg are only slightly greater than the analytical error and are in the direction to be expected if the sample contains some ferric monobutyl phosphate in addition to the ferric dibutyl phosphate.

It has been found that elimination of nitrous acid (by addition of urea) reduces very markedly the rate of attack of Purex solvent by aqueous nitric acid solutions. This may be seen from the data of Table II.

These data indicate that if provision is made to excluce nitrous acid from all aqueous phases with which the solvent comes in contact, present Purex solvents should be more than adequately stable.

Chemistry of $\mathrm{Zr}-\mathrm{Nb}$ in Purex Systems

The diffuston coefficients of zirconium have been measured in Purex HAF and in aquecus phases appearing at various stages in a batch extraction-scrub study simulating the operation of the Purex HA column. The HAF solution employed for the diffusion coefficient measurement was prepared by diluting Bot Semi-Works BAF solution (obtained during HSW Run PX-7) one-hundred fold with cold BAF

$\left(1.35 \mathrm{MU}, 2 \mathrm{M} \mathrm{HNO}_{3}\right)$. The full-level BAF solution was used as feed for a batch extraction scrub study simulating the operation of the HA column and the diffusion coefficient of zirconium measured in the aqueous resulting from the second scrub

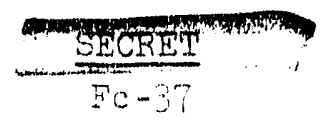


TABIE II

EFEECT OF UREA IN SUPFRESS ING CHEMICAL ATTACK OF PUREX SOLVENT

\section{Solvent Elstory}

Fresh

Erposed $1 \mathrm{hr}$. to $6 \mathrm{M} \mathrm{HWO}_{3}-0.1 \mathrm{M}$ No $\overline{2}$ at $70 \mathrm{C}$

Exposed $24 \mathrm{hrs}$ to $6 \mathrm{M} \mathrm{IINO}_{3}-0.1 \mathrm{M} \mathrm{NO}_{2}^{-}$ at $70 \mathrm{C}$

Exposed 43 hrs to

$6 \mathrm{M} \mathrm{HNO}_{3}-0.2 \mathrm{M}$

$\mathrm{NH}_{2} \mathrm{CONH}$ at $70 \overline{\mathrm{C}}$

Exposed 7l: hrs to $6 \mathrm{M} \mathrm{HNO}_{3}-0.2 \mathrm{M}$ $\mathrm{NH}_{2} \mathrm{CONH}_{2}$ at $70 \overline{\mathrm{C}}$

$$
\begin{aligned}
& \mathrm{Zr}-\mathrm{ND} \mathrm{DF} \\
& \mathrm{HAF} / \mathrm{EAPb} \\
& \hline
\end{aligned}
$$

10,000

200

17

21,000

$1.2,000$
$Z x-N D D F$
HAF $/$ HCPC

12,500

550

60

1.6

a. Initiel solvent 30 percent vacuum-distilled TBP in Shell E-2342 diluent. Weshed three times with two volumes of 3 percent $\mathrm{Na}_{2} \mathrm{CO}_{3}$ prlor to use.

b. Decontamination factors measured after one batch extraction, 3 batch. scrubs simulating HA colum operation. All contacts 5 minutes.

c. Decontamination factors and $\mathrm{Pu} 10 \mathrm{ss}$ measured after one batch extraction, 3 batch scrubs simulating HA colum operation and 5 batch strips simulating BC colum operation. All contacts 5 minutes.

operation. The measured diffusion coefficients for zirconium were $3.5 \pm 0.3 \times 10^{-6}$ $\mathrm{cm}^{2} / \mathrm{sec}$ in the EAF solution and $1.6 \pm 0.3 \times 10^{-5} \mathrm{~cm}^{2} / \mathrm{sec}$ in the aqueous from the second scrub stage. From these values, it is estimated that the average mass of the zirconium species present in the BAF is approximately twenty times that of the species present in the aqueous phase in the second scrub stage.

\section{Zirconium Dibutyl Phosphate Complexes}

Studies are in progress to characterize the organlc-soluble complex(es) formed. between zirconium and di-n-butyl phosphate. The partition of radiozirconium between aqueous nitric acid solutions and iso-actane is currentiy being studied

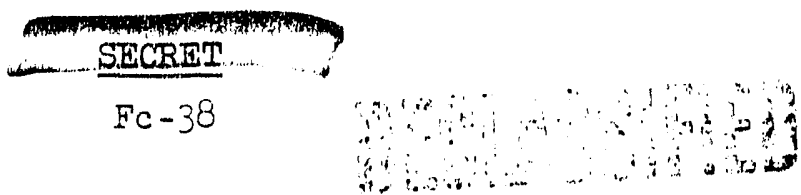


as a function of the dibutyl phosphate concentration and other pertinent concentration variables. Results obtained to date may be sumerized as follows:

(1) The partition coefflclent for radiozirconlum between $10 \mathrm{M} \mathrm{ENO}_{3}$ and isooctane varies as the square of the dibutyl phosphate concentration and is independent of zirconium concentration.

(2) At an lonic strength of ten and for nitrate concentrations of four molar and greater, the partition coefficient for zirconium into iso-octane out of aqueous solutions contaliing $0.034 \mathrm{~g} / \mathrm{I}$ DBP varies inversely as the square of the nitrate concentration.

\section{WEW PROCESSES}

\section{HC1 - TBP Solvent Extraction Sygtem}

Earlier studies with tracer solutions prepared from nitratedissolver solutions indicated a posslbility of decontaminating uranium by proferentially extracting certain of the troublesome flesion products (nioblum, zirconium, antimony, etc.) away from uranium(IV) chloride. Current experiments are testing this operation with full-level feeds. Feed for these experiments wes prepared by dissolving irradiated uranium metal in a solution of hydrogen chloride in methanol. The methanol solution was then diluted two-fold with aqueous $12 \mathrm{M} \mathrm{HCl,} \mathrm{and} \mathrm{the}$ resultant solution contacted with 30 percent TBP in carbon tetrachloride. The organic extract was then stripped with water to provide an aqueous uranium(IV) chloride leed solution for the present study.

Aqueous feed prepared in this fashion was adjusted to 5.4 molar chloride and contacted with eight equal-volume portions of 30 percent ITBP - CCI . Under these conditions uranium(IV) favors the aqueous phase (EQ ca. 0.03). Following these extractions the uranium was oxldized to the hexavalent state with hydrogen perozide, the hydrochloric acid concentration adjusted to six molar (ca. $7.1 \mathrm{M}$ chloride), and the solution contacted with a volume of 30 percent TBP $-\mathrm{CCI}_{4}$ sufficient to yield an organic extract $0.35 \mathrm{M}$ in uranium. The organic phase was then scrubbed three times with $7 \mathrm{M}$ BCI and sitripped with $0.1 \mathrm{M} \mathrm{BCI}$.

Analytical data are not yet avaliable, but the indication from survey meter readings is that the extraction of fission products away from uranium(IV) chloride was far less efflcient than had been expected on the basis of the earlier tracerlevel work.

\section{Chemical Effects of Ultrasonics}

An acceleration of the rate of dissolution of nickel in nitric acid has been reported by Wirta and Smith (HW-39080) when the reaction is carried out in a $300 \mathrm{kilocycle}$ ultrasonic field. The equipment used by these investigators has been obtained on a loon basis and scouting experiments performed with fuel

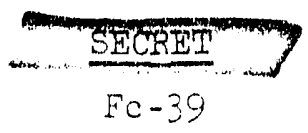


element materials. The effect on nickel was verified in preliminary experiments, and similar meesurements vere then made vith thorium and uranium. Over the temperature range (25 C to $65 \mathrm{c}$ ) permissible with this apparatus, the penetration rate of metallic thorlum by $10 \mathrm{M} \mathrm{HNO}_{3}-0.01 \mathrm{M} \mathrm{HF}$ was increaged by a maximum factor of 2.3 by ultrasonic irradiation. The digsolution rate of metallic uranidum in concentrated nitric acld was decreased by ultrasonic irradiation, however. The observed effects on both thorium and uranium were largely duplicated by extremely vigorous motor stirring, suggesting that the observed effects are largely mechanical in nature.

Processing of Alternate Reactor Fuels

$\mathrm{HMO}_{3}$ - HF - $\mathrm{H}_{2} \mathrm{O}$ I1quid Vapor Equilibrla

Since several proposed reactor ruel elements will require the use of a fluoride catalyst to accomplish their dissolution in nitric acld, the effects of fluoride on the acld recovery system must be eveluated before consldering processing such fuel elements in the Purex plant. Accordingly, experiments have been initiated to evaluate the vapor-liquid equilibria for the system $\mathrm{HNO}_{3}$ - HF - $\mathrm{H}_{2} \mathrm{O}$. Several experiments have been performed w1th a $309 \mathrm{SCb}$ Othmer-type equilibrtum st1ll, but, as yet, analytical data are avallable for only one composition, $4 \mathrm{M}^{\mathbb{N N O}_{3}}$. For this system a distribution coefficient (concentration in condensete7 concentration in st11l bottoms) of 0.28 was obtained for fluoride compared with a coeficient of 0.6 for nitric acid.

WASTE TREATMENT

Cegium Removal from Purex Waste

Analysis of the Mini-produced Purex HAW used in cesium recovery experiments reported last month showed $2.9 \mathrm{M}_{\mathrm{HNO}}$ and $0.15 \mathrm{M}$ UNH instead of the nominal ralues $2.2 \mathrm{M}$ and $0.002 \mathrm{M}$, respectively. Previously reported experiments with synthet1c $\overline{B A}$ indicated that the increased nitric acid concentration does not affect cesium scavenging, but the very high uranium concentration reduces scavenging markedly, thus accounting for the unexpectedly poor cesium recovery results. Therefore, further full activity level scavenging studies have been deferred until more representative BAW can be obtained.

Meanwhile, alternate methods for recovering cetium from the ferrocyanide precipitates are being investigated. Since the calcination-leaching process is In the course of engineering development at Arco, emphasis here has been placed on wet processing, specifically alkaline metathesis, or simple drying.

Metathesis of ferric and nickel ferrocyanide by sodium hydroxide to the respective hydrous oxides with concomitant relesse of cesium to solution was studied as a function of amount and concentration of caustic and temperature. The standard metathesis procedure consisted of stirring a water-

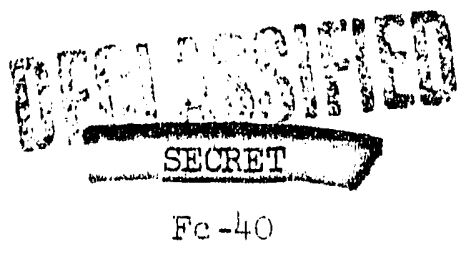




\section{Separations Technology Section HW $40692 \cdot$ DEL}

washed ferrocyanide precipitate containing scavenged cesium with calatic (equivalent per wesh to $60 \mathrm{gel} /$ ton $U$ ) for flfteen minutes, and determining the ceslum removal on three successive treatments of this type. With ferric ferrocyanide, $2 \mathrm{M} \mathrm{NaOH}$ was very effective in removing ceslum at elther room temperature or $95 \mathrm{C}$ ( $80 \%$ removal per caustic wash). Results with $0.5 \mathrm{M} \mathrm{NaOH}$ were much poorer ( $0.1 \%$ and $55 \%$ in the flrst and second washes). With Fickel Perrocyanide, cesium removal wes satisfactory with $2 \mathrm{M} \mathrm{NaOH}$ at $95 \mathrm{C}$ (75\% per wash) but wes poor at room temperature (20\% per wash) and totally unsatislactory with $0.5 \mathrm{M} \mathrm{NaOH}$ even at $95 \mathrm{C}(0.1 \%$ and $5 \%$ in the first and second vashes).

Radio-purity of the cesium-untaining metathesis solution is very good. The orlginal ferrocyanide precipitates contain about five percent of the total zirconium-niobium present in the BAW, two percent of the cerium-praseodymium, and one percent of the ruthenium-rhodium. The water wash removes about ten percent of the scavenged $\mathrm{Zr}-\mathrm{Nb}, 30$ percent of the $\mathrm{Ce}-\mathrm{Pr}$, and $\mathrm{all}$ of the Ru-Rh. Most of the residual $\mathrm{Zr}-\mathrm{Nb}$ and $\mathrm{Ce}-\mathrm{Pr}$ remain with the hydrous oxide on metathesis leaving the product cesium solution containing no other gamma emitters detectable on the game spectrometer ( $<5 \%$ gama impurity).

Radiation sources could be prepared directly from the ferrocyanide precipitates merely by heating them to dryness provided low specific activities are acceptable, as may well be the case for some purposes. The magnitude of specific activities attainable in this way was determined by measurement of the volume and bulk density of ferric and nickel ferrocyanide after centrifugation and after heating to constant weight at $105 \mathrm{C}$. The results may be translated into specific activities attainable by precipitation of $0.005 \mathrm{M}$ ferrocyanide in HAW from processing $600 \mathrm{MWD} / \mathrm{T}$ uranium ( 1800 curies $\mathrm{C} 3-1377$ ton $U$ ) according to the $\mathrm{BW}-3$ flowsheet.

\section{Cs-137 SPECIFIC ACTIVITY IN FERROCYANIDE PRECIPITATES}

$\begin{array}{rcc} & \begin{array}{c}\text { Cravimetric } \\ \text { curies/gram }\end{array} & \begin{array}{c}\text { Volumetric } \\ \text { curies/liter }\end{array} \\ \text { Ferric - vet } & 0.03 & 30 \\ \text { dry } & 0.15 & 250 \\ \text { Nickel - wet } & 0.04 & 4.5 \\ \text { dry } & 0.2 & 300\end{array}$

These vaiues may be compared with $90 \mathrm{c} / 8$ for pure metallic Cs-137 (unattainable because of isotopic dilution by $\mathrm{Cs}-133$ and -135) and "in excess of $10 \mathrm{c} / \mathrm{g}^{\prime \prime}$ quoted by Arco for their caicination-leaching process.

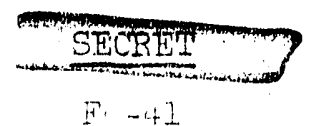




\section{Cesium Removal from Redox Waste}

The scavenging of cesium from simulated Redox D-13 waste (pooled, unconcentrated, ingle back-cycle) by nickel ferrocyanlde has been determined as a function of nickel to ferrocyanide mole rat1o. With considerable excess of elther ion, significant reduction in cesium decontamination occurs, especially with ferrocyanide 10n. For example, wherees addition of $0.01 \mathrm{M}$ ferrocyanide and $0.02 \mathrm{M}$ nickel (stoichiometric for $\mathrm{Ni}_{2} \mathrm{Fe}(\mathrm{CN})_{6}$ ) gives a cesium decontamination factor of I25, addition of a ten-fold excess of nickel gives a factor of 54 and addition of but a four-fold excess of ferrocyanide reduces the decontamination factor to 5. Althoush it was hoped that ceslum decontamination might be improved with slight excess of either nickel or ferrocyanide lon, no such effect was found. Thus in th1s D-13 system at least, cesium decontamination passes through a rather flat maximum when the precipitating lons are added in stoichiometric proportion.

\section{Silver Reactor}

Iodine removal from a silver reactor by a mixture of air and nitrogen dioxide has been shown to increase rapldiy with decreasing temperature, as predicted thermodynamicaliz. For air containing 10 percent nitrogen dioxide flowing with a residence time of 1.4 minutes, messured lodine concentrations were $0.014,0.78,60$ and $580 \mathrm{ug} / \mathrm{cublc}$ loot at $216,187,160$, and $140 \mathrm{C}$, respectively. The calculated lodine concentration for 1 curle/day emission at Hanford is $0.027 \mathrm{ug} / \mathrm{cub1c}$ foot, assuming 5 reactors operating $24 \mathrm{hr} /$ day at $250 \mathrm{cfm}$ air fllow processing $600 \mathrm{MWD} / \mathrm{T}$ metal irradiated at $3 \mathrm{MW} / \mathrm{T}$ and cooled 90 days. Attainment of this "tolerance" conceritration would require reactor operation above silver nitrate's melting point ( $212 \mathrm{C})$ if the gas stream contained 10 percent or more nitrogen dloxide.

No further experimental work on this problem is planned except for brief testing of a silver lodide isotoplc exchanger on a portion of the effluent of a Redox silver nitrate reactor.

\section{$\underline{\text { RADIOCBEMISTRY }}$}

\section{Fission Counter}

Gas acintillation fission counter parameters affecting precision counting continued under Invegtigation with the following results:

Chamber gas - The amplitude of fission pulses obtalned with argon-nitrogen mixtures (0.5 to $3 \%$ nitrogen) is approximately twice that observed with heliumnitrogen mixtures. The argon-nitrogen system thus requires only half the electronic amplification needed for the helium-nitrogen system.

Chamber depth - Since precise determination of plutonium $239 / 240$ isotope ratios will require counting a sample for several days, minimum slope in a counter's fission plategu is desired so that slight drift in electronics with time will not

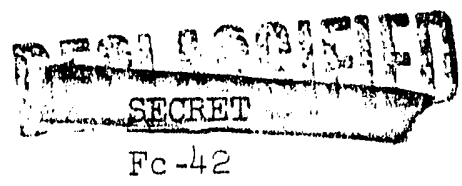


affect counting efficlency. Accordingly, fission plateaus (counting rate versus discrimination level) have been determlned as a function of chamber depth with both helium-nitrogen and argon-nltrogen mixtures. With helium - 0.1 percent nitrogen, operating plateus with slope $0.5 \pm 0.3$ percent ( 95 percent limits) per volt over a ten volt region were obtalned with chamber depths from $3 / 4$ to $33 / 4$ ". With argon - I percent nitrogen, similar operating plateaus were obtalned with chambers $3 / 16$ to $3 / 18$ " deep. Less setisfactory plateaus resulted with greater chamber depths. The foregolng operating plateaus are defined as that portion of the counting platea where the counting rate due to alpha plle-up is less than $0.01 \mathrm{c} / \mathrm{m}$, the maximum permisatble for precise isotopic ratio determinations. Since the plateau in the $0.01-1 \mathrm{c} / \mathrm{m}$ alpha pile-up region is nearly lat, electronles improvement is being sought to reduce the amplitude of alphe pileup pulses thus giving an operating platesu of less slope.

Photomultiplier Tube - No improvement in pulse-height was achleved on substituting a quartz window tube having a spectral response in the ultra-violet for a glass window tube. Apparently nitrogen is gufficiently effective in shifting the scintillation wave length to the vigible region.

On substitution of a three-inch diameter tube for the standard 2-inch tube sat1sfactory operation was observed but no improvement in the plateau was noted with $1-1 / 8$ inch diameter source. Larger sources may, however, require larger tubes.

\section{URANIUM PROCESSING}

\section{Uranium Reduction}

The principel problem to be solved in the successful reduction of urantum or plutonium oxides to masive metal by calcium or magnesium is the removal of the protective coeting of the oxide of the reductant which surrounds the uranium globules and prevents coalescence. Partial success in removing this oxide barrier has been accomplished by utilizing reaction heat sufficiently great to partially fuse the oxide and hence permit aggregation of the uranium droplets (HW-39751-H, HW-40182-H). A second approach to the removal of this oxide film is also being investigated. Th1s approach seeks to convert the very refractory calcium or magnesium oxide to the relatively low melting chloride by reacting it with lithium chloride. The driving force of this reaction is the formation of lithium oxide which has an appreciable sublimation pressure in the neighb rhood of $850 \mathrm{C}$. Preliminary experiments in the system $\mathrm{LiCl}-\mathrm{Mg}_{\mathrm{g}} \mathrm{UO}_{2}$ resulted in the production of uranium powders but very littie collescence. These disappointing results, it is believed, were due to mechanical difficulties rather than failure of the chemistry. Retention of the lithium chloride in the reaction zone is very difficult with the present equipment since its high mobility in the fused state enables it to readily flow through the crucible.

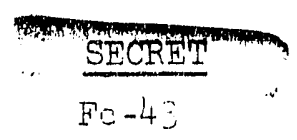


Chemical Preparation of Uranium(IV) Fluorides

The invegtigation of the removal of iron from uranium(IV) fluorides produced by 1 ron(II) reduction of urenyl compounds in the presence of fluoride ion has been continued in order to determine the effect of the mode of re-precipitation on the fron content of the final product.

A stock solution of Uranfum(IV) sulfate was prepared using essentially the procedure previously reported (HW-40182-H). It contained 80 to $85 \mathrm{~g} / \mathrm{I}$ uranium and about 0.2 percent iron based on the uranium content. Sodium uranic fluoride was precipltated by the concurrent addition of an aliquot of this solution and a 2.7 molar hydrofluoric ac 1 d solution into stirred 0.3 molar sodium sulfate. When the precipitation was done at 50 to $60 \mathrm{C}$, the product contained 0.015 percent iron (based on the uranium), but when done at room temperature only 0.0054 percent fron was found. Tap densities were $0.63 \mathrm{~g} / \mathrm{cc}$ and $0.87 \mathrm{~g} / \mathrm{cc}$ respectively.

In another experiment sodium sulfate wes added to an aliquot of the stock solution to make a sodium concentration of 0.9 molar. This solution was then added concurrently with 2.7 molar hydrofluoric acld to water vigorously stirred at 50 to $60 \mathrm{C}$. A similar precipitation was made at room temperature except that 0.1 molar nj.tric acid replaced the water. In both cases the iron content of the product ( $\mathrm{NaUF}_{5}$ ) was 0.01 percent and the respective tap densities were 0.44 and $0.71 \mathrm{~g} / \mathrm{cc}$.

The above procedure deviates from conventional precipitation procedures in that only very low concentrations of uranium and fluoride ion are ever permitted in the precipitation medium. The decontamination factors for iron are considerably improved over those previously reported; $13,20,20$ and 35 vs. 8 (obtained by precipitation from boiling solution, of. HW-40182-H). It has not yet been established whether this improved decontamination is due to the temperature or the mode of precipitation. The above procedure, however, does result in a product displaying excellent handling characteristics. It also appears capable of greater production rates than conventional precipitation methods particularly at lower temperatures.

\section{Flurex Frocess}

Data from the Flurex run whlch used stripped Redox IBU as a feed has been completely evaluated. After correcting for the growth of uranium daughters and the decay of fission products, the gross gama activity of the product $\mathbb{N a U F}_{5}$ at the time of precipitation was established as 85 percent of the gamma activity of aged natural uranium. The beta activity for a $200 \mathrm{mg}$ sample of the product was no different from an identical sample of NaUF 5 containing aged natural uranium. Because of the extremely low fission product content, it was not considered feasible to analyze for the flssion product(s) responsible for the activity; however, the lack of beta activity implies the absence of ruthenium and suggests that the fission products present may be zirconium or niobium or both.

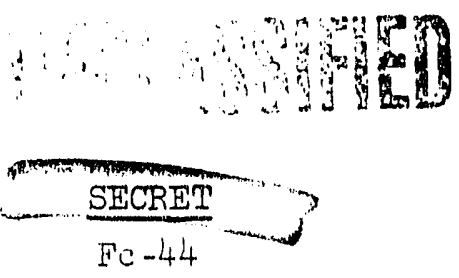




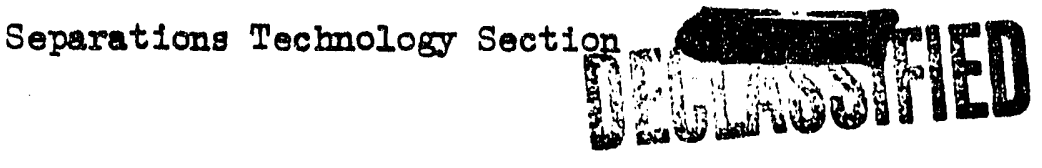

HW -40692

\section{Preparation of Uranium Hexafluoride}

Fending completion of the fluorination facility, some effort has been expended in examining the reaction of uranlum tetrafluoride in the presence of oxygen.

$$
2 \mathrm{UF}_{4}+\mathrm{O}_{2} \rightarrow \mathrm{UF}_{6}+\mathrm{UO}_{2} \mathrm{~F}_{2}
$$

Although only preliminary experiments have been performed to date, uranium tetrafluoride derlved from ammonium uranic fluorlde (by vacuum sublimation of ammonium fluoride) was found to be much more reactive than the same salt prepared in other ways. Wherees Oak Ridge personnel report $740 \mathrm{C}$ as the minimum reaction temperature and $800 \mathrm{C}$ a practical resction tempereture ( $\mathrm{K}-567)$ in this study trace of $\mathrm{UF}_{6}$ was formed $3 \mathrm{t} 600 \mathrm{C}$ and complete reaction of a five gram sample occurred in less than three hours at $675 \mathrm{C}$. This finding is of considerable slgniflcance since the lower temperature grsatly reduces the side reactions which, in other studies, hare resulted in yields much less than the theoretical yleld (K-567, ABRE $C / R$ 863). In the above described small-scale experiment 44 percent of the theoretical yield of UF 6 was obtained.

\section{ISOTOPE SEPARATION}

\section{Thermal Diffusion}

A thermal diffusion experiment using uranyl nitrate-TBP wes run for 26 days. This run was Intended as a check of one wade in November. For comparison, the conditions and data for both of these runs as well as those for a previous "standard" run are shown in Table III.

Inspection of the deta discloses grossly different behavior in the December run as compared to the other two in which expected agreement is found. The reason for this anomaly is not clear, although it may be associated with the one of the following factors that were peculiar to the run. Very little excess IBP was present in the charge since the concentration dropped only slightly during the course of the run as compared to previous runs. It is not, however, belleved that the isotopic separation is dependent upon the separation of excess solvent. Since the uranium concentration remained high, the average daily take-off rate for the firgt 19 days was roughly three times greater than in the other runs. This increased take off could result in the reduced steady state value for the enrichment observed; however, reduction of the take-off rate to a value comparable to the other runs did not raise the steady state enrichment value.

Another difference which could conceivably account for the poorer separation was a change in mechanical linkage of the apparatus which increased vibration. Without further experimental evidence, neither of the above explanations is satisfactory to explain this enomalous behavior.

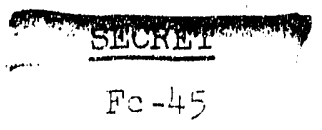




\section{TABIE III}

SEPARATION OF URANIUM ISOTOPES BY THERRMAI DIFHUSION URAWI NITRATE - TRIBOTIL PHOSPHATE SYSTEM

\section{Cond1tions:}

$\begin{array}{ll}\text { Run Designation } & \text { November } \\ \text { Columi annulus - } & 0.25 \\ \text { Steam temp. - C } & 116 \\ \text { Coolast } & \text { glycol - Ho } \\ \text { Coolant temp. (av.) - C } & -15 \\ \text { Heat Consumption - cal/min } & 1.25 \times 105 \\ \text { Telse Off Rete - mi/day } & 1\end{array}$

$\begin{array}{ll}\text { December } & \text { "Standard" } \\ 0.25 & 0.25 \\ 119 & 116 \\ \text { BI.ycol- } \mathrm{H}_{2} \mathrm{O} & \mathrm{H}_{2} \mathrm{O} \\ -10 & 23 \\ 1.43 \times 10^{5} & 1.17 \times 10^{5} \\ 1 \text { (to } 19 \mathrm{th} \text { day) } & 1 \\ 0.35 \text { (19th day } & \\ \text { to 26th day) } & \end{array}$

Enrichment Data

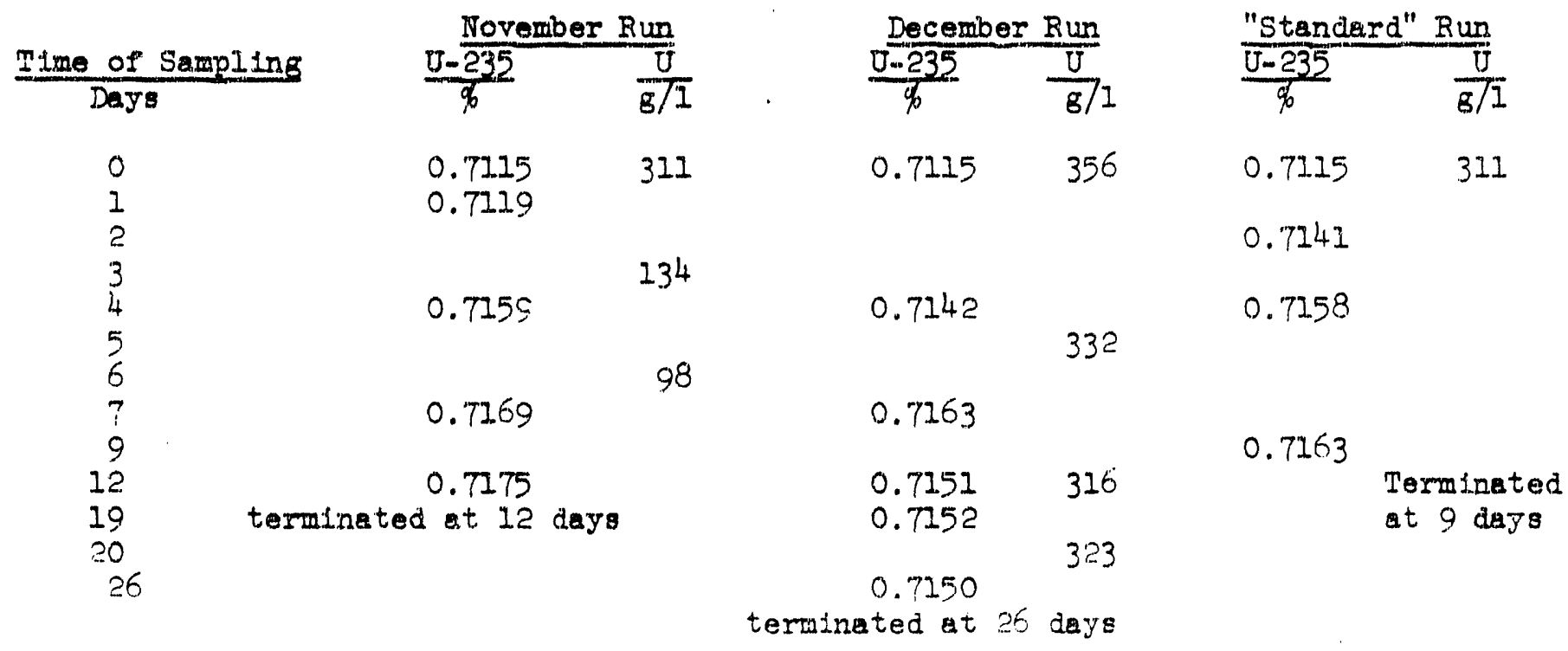

\section{Fused Salt Electromigration}

Because of the difficulty in maintaining a prolonged electrolysis in fused piutonium balides, re-examinetion of the syetem for possible causes of difficulties and their remedies has been de.

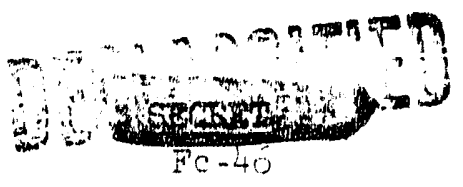


Electrolysis falls principally because of gas formation. Since the presence of molsture, possibly introduced in the highly hygroscopic lithium chloride, could be responsible for gessing, the further use of this salt was abandoned in favor of an equimolar mixture of sodium chloride and potassium chloride (m.p. $660 \mathrm{C}$ ).

Difflculty in proparing plutonium chlorlde free from oxide and its affinfty for water during handling prompted the attempted preparation of $\mathrm{PuCl}_{3}$ from the metal by introducing the metal into the molten salt bath in contact with the graphite anode. The formation of the chlorlde was found to proceed very smooth.ly and at a readily controllable rate resulting in a salt of good appearance which displaced the alkali halide vith a sharp interface. A bromide of plutonilum was prepared in similar manner by using potassium bromide as the backing alt and sunplying bromine vapor carried in a stream of argon to the cathode. Again, a well-defined interface was established between the light-blue plutonium tribromide and the colorless potaselum bromide. It was noted thet plutonium(III) bromide hed a much lower conductance then plutonium(III) chloride.

Graphlte electrodes are apparently a source of the gas bubbles which cause frequent interruption of current passage. The use of Inconel or nickel electrodes resulted In a steedy current. However, corrosion of both anode end cathode was severe in either the chloride or bromide system, resulting in contamination of the fused salt by alckel hallds. Degersing of the graphlte electrodes to remove adsorbed alr was tried with partial success, and this approach will be pursued further.

\section{Electromigration in Aqueous Systems}

Two six-day electromigration runs on the uranyl sulfosalicylate system have been completed. Isotopic analysis of a samp...e isolatad irom the cathode and containing 2.7 percent of the charge was 0.7123 percent U-235. A sample from the anode end containing 8.3 percent of the charge contained 0.7112 percent U-235. Although barely in the range of validity, intervening samples of intermediate values, substantiate the separations as reaj.

\section{$\mathrm{DO}_{3}$ STUDIES}

Surface areas of soveral uranium oxide samples have been messured by the nitrogen adsorption (BET) method. These data are tabulated in Table IV. Good agreement on re-runs was obtained. Sample outgassing times ( $150 \mathrm{C}$ under high vacuum) of about four hours are required for hydrated samples whereas other samples require only two hours. Ionger outgassing periods have no appreclable effect. Most residual nitrate and water is removed from the sample by the outgassing treatment.

Hydration of $\mathrm{UO}_{3}$ appears to increase its surface area, as does conversion to $\mathrm{UO}_{2}$. Sample 7 has a larger surface area than expected, although it was an old sample and hydration may have occurred in the laboratory since the water determination reported was made. Sample 14 has a higher surface area than sample 13, which was

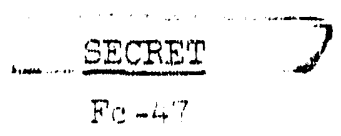




\section{TABLE IV}

SURFACE AREAS OF

SET ECTED URANIUM OXIDES

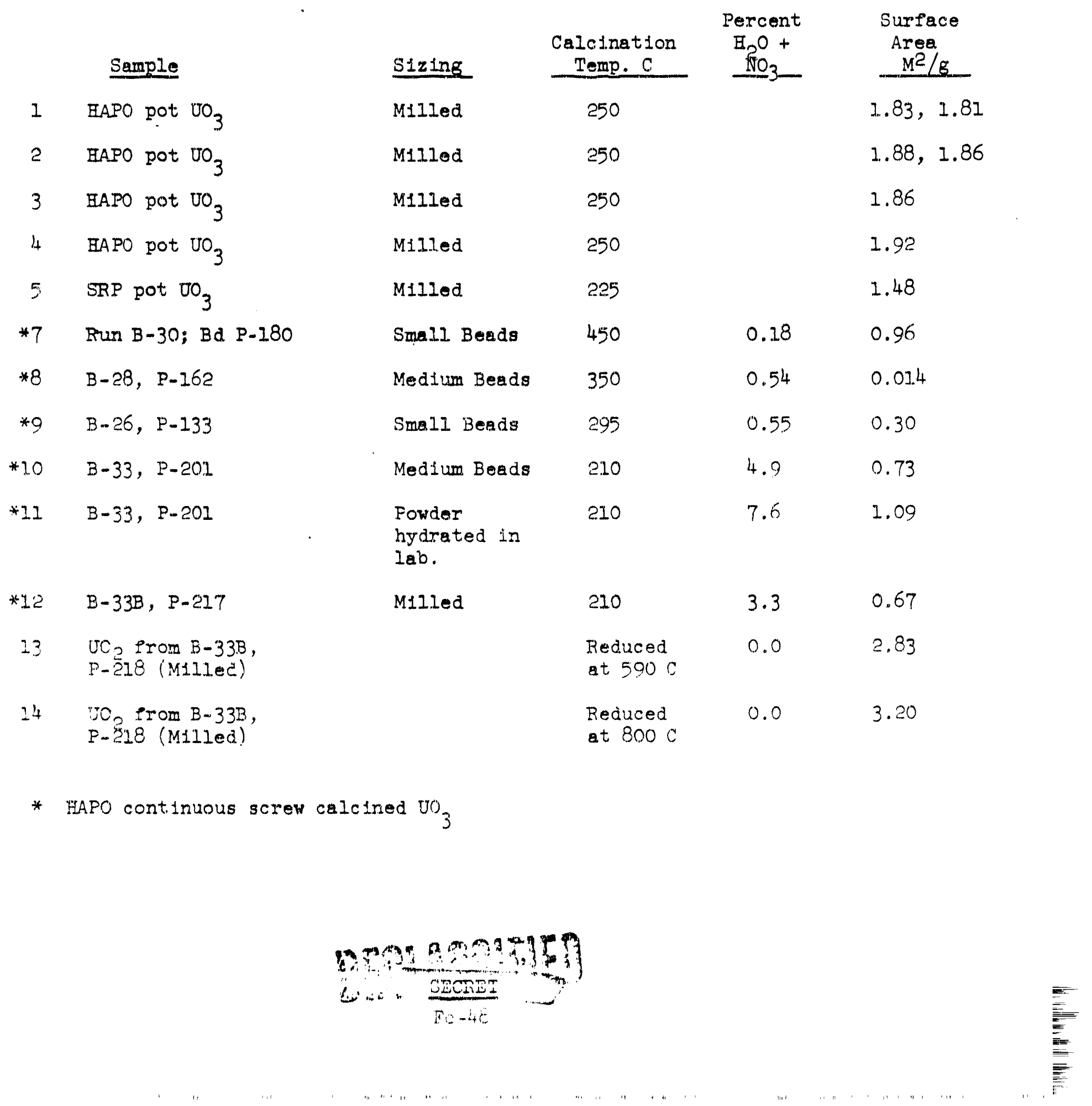


reduced at the lower temprature. This is contrary to information from $\mathrm{K}-25$ that hlgher temperature reductions reduce the surface area of the continuous screw calcined powder.

In comparing surface areas of these materlais, the state of subdivision of the materlal hes a surprisingly small effect on area as compared with the porosity of the particles. This is predicted by the fact that calculated areas of spheres 1.s very much smaller than the observed surface areas of $\mathrm{UO}_{3}$. The surface area of a apherical $\mathrm{UO}_{3}$ perticle of I mn diameter would be ebout $0.0004 \mathrm{M} / \mathrm{g}$ while that for a 25 micron particle would be abolit $0.016 \mathrm{~m} 2 / \mathrm{g}$. These particle sizes compare roughly with the unmilled and milled beads of the continuous calcined powiders.

An attempt was mode to prepare a form of urany nitrate which can be calcined to $\mathrm{UO}_{3}$ without the formation of an Intermediate Ilquid phase. Samples of UNH were partially denydrated to varying degrees by heating at sub-meiting temperatures or up to $126 \mathrm{C}$ under vacuum and up to $190 \mathrm{C}$ in alr. It was found that to obtain a nonmelting solid, nearly all of the hydrate water and some nitrate must be removed.

\section{ANAEYTICAL IEVELCPMENT}

The direct reading adapter for the JACO spectrograph with two photomultiplier receivers was assembled and tested using gas discharge lamps and hollow cathode uranium discharge as sources. The adapter, although not yet in final form, appears to meet design requirements. The slits can be positioned within $0.5 \mathrm{~A}$ and scannirg can be accomplished without loss of alimment. Baciground noise, using the uranium excitation, became significant at a reiative line intensity of about five or a current of 10-10 amperes. The electronic stability may be inadequate for better sensitivity, but solirce fluctiations are likely to be a more important variable. The direct reader is being used at present as a valiable ald in further stlidying the holiow cathode excitaticn technique.

Stidives of methods for separating ritinenilu from cesium in the analysis of plant.scavenged waste supernates have continued. The lise of periodate for the volatilization of ruthenturn from a neutraified metei recovery plart waste stresm has been satisfactorily cemonstrated. The sampie la asidiflei with nitric acid, icdis acid is added, and the sciution is bolied in an appropriate distillation apcaratus for fifreen minites, Ne carzier ruthenium is recessary. It was found that the temperature is a crittcal parameter in this roiatizizatior method. Haticg the solution in the rande 90 to 35 a for one hoir frodiced a decontamination factor of about io, while bolilng at approximate 3.200 C for 25 minutes produced a decontamination factor greater than 20 . The rlithenilum remeining after treatment of the wate samples vised in these experiments was not detectable using a standard ganma scintizlation epectrometer. After this compiete removal of ruthenium, the cesium-137 consent of these samphes colida be detemined using the standard sizicoturifstate tecmique. This mithendum viatidization nethod 
offers no analytical advantages over the perchloric acid method now being used in the 200 Area Control Laboratorles, but it avoids the posible hazards of the perchloric acid evaporation.

Studies of the coulometric titration of plutonlum yielded promising results v.sing the corlc oxidation method in chloride-bromide system. A precision of about \pm 0.3 percent $(\hat{\sigma})$ was demonetrated in titrating a cerium stock solution, and a plutonfum standard wes analyzed vith an accuracy ithin this precision. More data with standards of various histories are being gathered. The pertinent parameters studied in order to establish the proper oxidation and titration coraltions were the effect, of the concentrations of cerlc oxidant, the various acid anions, the acldity, and the times for oxidation and reduction.

A study of the circultry of the EAPO standard alphe counter (ASP and ASVP) was begun in order to redesign and modernizo it es well as to develop an eifective malntenance procedure. Interim circuitry alterations for the presently used counters were recomended to the Separations Control Laboratory personnel, and the future program will be almed at reducing maintenance, reducing $\beta$ pile up, reducing coincidence loss, and increasing instrumental stability.

A GE IOn Resonance Masa Spectrometer wes received and Installed by the vendor's representative. Acceptance tests of resolution, stablilty, and accuracy on known gas somples were run. The instrument is smali ( 24 by 30 by 70 inches), simple, and designed for light gas analyo13. Inftially, the application of the instrument for automatic, in-Iine gas analysis will be otudied.

Miscellaneous activitieg included development of a technique for making thyrite resistore (impedance varies inversely with applied voltage) for high impedance circuitry in the $1012 \mathrm{ohm}$ range, a study of the use of a crystal diode as a prediscriminator for a Plssion counter (similar to an application at Argonne), and aligning a new spectrographic plate densitometer for the Analytical Laboratories Unit. Anelytical method asistance for the Separations Control Laboratories included supplying procedures for the acid deficiency of aluminum nitrate solutions (changlng from the pH method to a fluoride complexing method), providing a colorimetric procedure for purex solvent quality testing, and making three gtandard uran1um solutions for the Analytical Laboratory Unit.

IN-IINE ANAIYSIS

The new controller and sensing unit for the first, Model III uranium photometer which incorporates a cadmium sulfide cell, interference filter optics, and automatic atandardization were debugged and installed in the Hot Semf-Works. Operation was satisfactory during plant start-up at the end of the month. The sensing unit is about twice as sensitive for uranium as the previous units, slightly lesg sensitive to organic color interference and virtually unaffected by sample turbidity. The unit standardizes automaticalif once a day by admitting standard solution and automaticaliy adjusting light intensity till the output

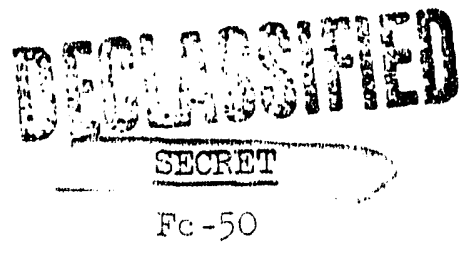


Separationg Technology Section

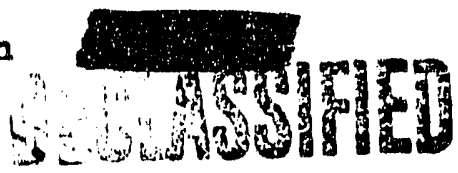

HW -40692

sigral matches a standard voltage obtalned from the Brown recorder. A feedback circuit and Brown Amplifier-motor combination operate the light adjusting potentiometor.

A method Ita qutomatic in-Iine monltoring of dichromete concentrations in Redox process strans (IAFS, EAIS, and 2AF) is being studied. A simple photometer system looks promising, but many design detalls are not yet firm. Another problem under study is that of determining nitrite in-line (primarily for Purex $2 A F)$. The methods now being considered involvo colorimetry, pFI meesurement, methyl nitrite distillation and polarography or electroda potential measurement. The potential of a dropping mercury electrode is proportional to the nitrite concentration in altric acld solution. Iron and plutonium ary interfere (depending on concentration and valence state), but the nitrite can be readily sparged from the sample and collected in a separate cell where the potential meesurement is made.

Studies of uranfum polarography at intermediate scanning rates (about one scan per second) were made using an amalgamated gold electrode. While results vere not different from those obtained with droppling mercury electrode, the sensitivity of the amalgamated gold electrode is prone to drift and the electrode life is short, perticularly in solutions containing nitrite. Although the electrode may be useful for polarography of nitrite-free solutions, frequent standardization is necessary, and any advantage over the presently used system is doubtrul.

The RCU garme monitor in the U-plent was callbrated and installed with a siliconeoil treated glass cell, but cell background bulld-up is being observed. A fluorothene-coated cell which has proved very good for Purex Hot Semi-Works streams will be substituted.

Work on the Tellon-covered ZnS scintallation screens for liquid-contact alphe counting has been continlied, and hot-molded screen (described last month) has been shown to give reproducible results with liquid samples. Its sensitivity (using a cell heving about $3 \mathrm{~cm}^{2}$ surface) has been found to be obout $200 \mathrm{c} / \mathrm{m}$ per mg/I Pu concentration, with a rinsed-cell reading equivalent to about $100 \mathrm{mg} / 1 \pm 5 \mathrm{mg} / 1$. Both the full-cell (390 mg/I) and the rinsed-cell reading are reproducible to with in less than Plve percen with only $5 \mathrm{ml}$ sample flow following change of sampie concentration from $390 \mathrm{mg} / \mathrm{l}$ to zero to 390 , etc. A counter for low activity solutions would requile a much larger screen areo, and the rinsed-cell or background problem may be serious.

Some other methods of screen fabrication have been tried, but without jmproved performance or a markedly simplifled procedure. Co-sedimentation of Kel-F dispersion with $\mathrm{ZnS}$ appears to yield ael-F laver over the $\mathrm{ZnS}$, resulting in rediced light jield, without improving the bond to the Terlon film. The use of a Kel-F backing plate, in place of Kel-F-coated glass, was considered, but it was found that $1 / 8-$ inch $\mathrm{Kel}-\mathrm{F}$ has only about 40 percent transmission at $4400^{\circ}$

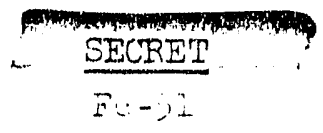


Angstrom. Most of this loss is not due to absorption, however, but to scattering.

A discugsion of analytical problems and in-Iine instrumentation with Savannah PIver Laboratory personnel at SRP has been sumearized in report $\mathrm{BW}-40607$.

\section{IABORATORY SERVICES}

Activities for Laboratory Services may be sunmerlzed as follows: 80,000 gallons of critb level waste were transported to 200 West Aree for disposal. Average plutoniun analysis was $1.2 \times 10^{-4} \mathrm{uc} / \mathrm{ml}$. Average grogs beta analys is was 5.1 $\times 10^{-2}$ uc/ml.

Approximately 3,000,000 gallons of retention level waste wes discharged to the 300 Area pond. Average alphe analysis was less than $4.5 \times 10-7 \mathrm{uc} / \mathrm{ml}$. Average beta analysis was less than $8 \times 10^{-7} \mathrm{uc} / \mathrm{ml}$.

Work was started the 300 North Burial Ground to cover radioactive waste in the pit with about elghteen inches of dirt, and to stabilize the bank with additional fill. High radiation readings at the edge of the pit and potential fire hazards made this operation necessary.

All other bullding services, laundry and waste disposal functions were accomplished. in a routine manner.

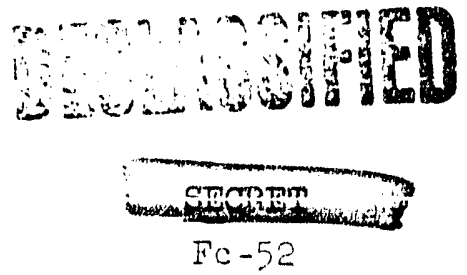




\section{ANALYIICAL IABORATORIES UNIT}

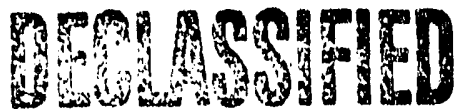

\section{General Chemical Laboratory}

Laboratory work in support of Chemlcal Development "scrub-section" studies wes completed and control of Purex " $C "$ Column studies for the same group was begun.

A relatively large portion of the Laboratories mork load consisted of shortterm Investigations conducted on samples recelved from the Chemical Research Sub-Section. Tro (2) radiation-chemical assay studies involved analysis for ai-butyl phosphate, chloride and oxidation states of iron as a monitor of exposure. Several solvent quality tests were made on degraded plant-type solvents. The aqueous-vapor phase acid concentration ratios were determined on mult1-ac1d systems, and composition analyses were made on Purex metal-organic "crua" samples.

\section{Rad lochemical Laboratory}

Mejor effort of the month wes applied to measuring individuel fission products on laboratory scale chloride separation process streams.

During the month, chloride assays were performed on varlous streams arising from laboratory scale chloride separation process studies. The Volhard method wes adepted for handing the radioactive samples satisfactorily.

Contamination control in connection with distribution studies made on carbon tetrachloride solutions presented a problem. Creeping, during the extraction process, was satisfactorily controlled after dry filming the containers used in the experiments.

S1x more specimens were received from the ANPD, Idaho Falls facilities for uranium burn-up measurements. At months end, two (2) of the samples were nearly completed.

The apparatus is now complete for utilizing vacuum fusion as a means of removIng geseous inpurities from plutonium metal--a step preliminary to evaluation of the gases on the mass spectrometer. The apparatus performed smoothly with stand-in zirconium.

\section{Spectrochemical Laboratory}

A standard curve has been prepared allowing a quant1tative determination of nickel, in the range of one per cent concentration, in aluminum.

Plutonium samples are now being analyzed quantitatively by emission spectrographic methods.

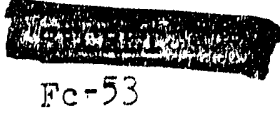




\section{Mass Spectrometry Laboratory}

Individual automat1c liquid nitrogen dispensing systems were installed on the General Electric analytical instrument and on the new General Electric Ion Resonance Mass Spectrometer. These installations make it possible to leave all liquid nitrogen traps on the mass spectrometer unattended for from four to six days.

Assistance was rendered during the installation of the new General Electric Ion Resonance Mass Spectrometer. The instrument is now undergoing check-out prior to rout ine operation.

The General Electric analytical mass spectrometer was out of service for a week during the month to allow regreasing of the manifold system and cleaning of the molecular leak whlch had become partially plugged following.gellium chloride examination.

\section{Water Quel1ty Laboratory}

The sample work load of the Water Quality Laboratory showed an approximate 40 per cent increase again. this month due to continued activity at the 1706-KE semi-works. All operations were of a routine nature.

Work volume statistles for the Analytical Laboratories Unit are as follows:

\begin{tabular}{l}
$\frac{\text { NOVEMEER }}{\text { No. of }}$ No. of \\
Samples \\
\hline
\end{tabular}

$\frac{\text { DECEMBER }}{\text { No. of }}$ No. of
Samples Determinations

Research and Deve lopment

\begin{tabular}{|c|c|c|c|}
\hline $\begin{array}{l}\text { Metaliurgy Research } \\
\text { File EngIneering } \\
\text { Pile Materlals } \\
\text { F.del Technclogy }\end{array}$ & $\begin{array}{r}63 \\
2 \\
20 ? \\
37\end{array}$ & $\begin{array}{r}221 \\
7 \\
957 \\
538\end{array}$ & $\begin{array}{r}70 \\
8 \\
289 \\
19\end{array}$ \\
\hline $\begin{array}{l}\text { Eefarations Tachrology } \\
\text { ChemicaI Resear uh } \\
\text { Chemical Derelopnent } \\
\text { Piant Processes }\end{array}$ & $\begin{array}{l}076 \\
722 \\
108\end{array}$ & $\begin{array}{r}1453 \\
1575 \\
124\end{array}$ & $\begin{array}{r}599 \\
262 \\
48\end{array}$ \\
\hline Process Technology & 460 & 24.76 & 314 \\
\hline cther Customer & 73 & 400 & 57 \\
\hline Tota: & -343 & 个要 & $10 ? 6$ \\
\hline
\end{tabular}


TECHAICAL SHOPS UNITS

Mechantcal Shops

The work load during the month remined at a high level recessitating 1721 hours of overtime work lo complete the nore urgent projects. One craftsman was added to the work force bringing the total force to yithin one man of the desired complement. The backlog of work has been reduced from 10,000 hours to approximately 8000 .

An andt of the overtime adminlstration for the shops was completed by the Flancial Department durling the month. The report issued by the auditor recumends some minow changes be made in the method of reporting the backlog but in general recormends that aurent procedures be costinued. The report also rocngnizes the inadvisability of establisining an arbitrary overtime level for the skops and recomends thet the shop nagement gear the overtime to meet project dearlines so specifled by techaical personal.

\section{Buizäings and Grounds}

Project CG-576, Genersl Improvements to Irboratory Area Buildings, ras completed at month's end with three exceptions in 327 Building, numely, the joor signal system, the panle bardware, and the tensile testex shieldios cell. The latter Fas receited with aumerous surface flaws which had to be refinished. At month's ond it is undergolng radiation tests.

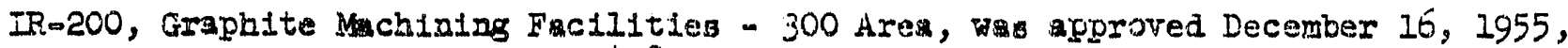
ith total authorleed funds of $\$ 18,700$.

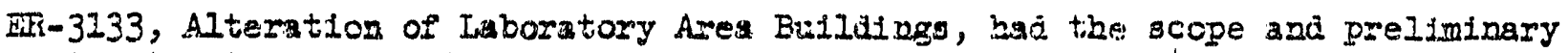
cost estimate completed this mokith. This estimate was for $\$ 23,000$.

D.0. 100963 , Floor joadizs Stress Surrey - 326 Butiding, was completed. The findings were sumared in a sketch which jaidastes the permissible loads in verious areas of the buliaing.

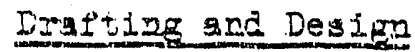

The total productlye man kours for the nontin jeme 2940 laciuding 88 hours of overtime. This included the productire time of two men on loan from the Graphics

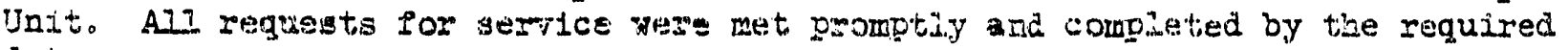
date.

\section{gaes Shop}

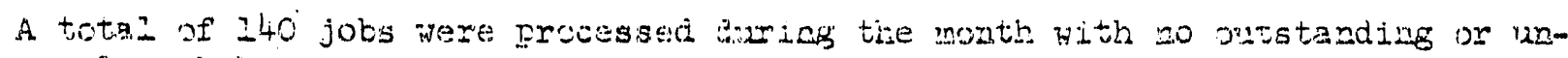

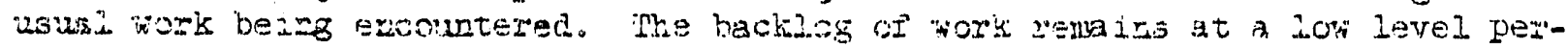

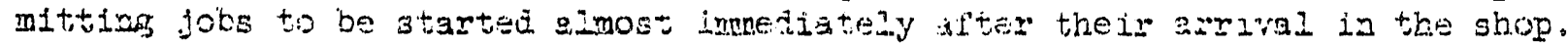

Mettcds are being investigated to roduce the notso devel. which resilts from the

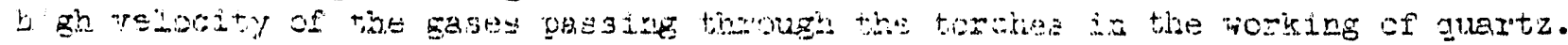

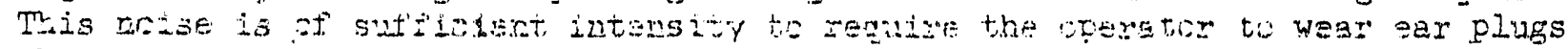
Fked gerking in the guartz shre.

\section{Proto inabratory}

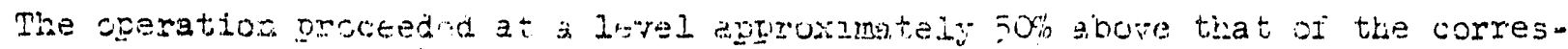

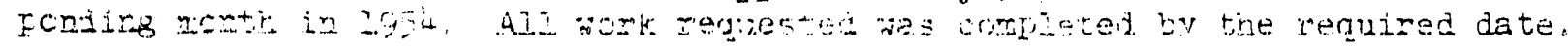




\section{CONTACT ENGINEERING UNTT}

Additional stress relleving and heat treatment of the prototype continious calciner trough assembly by the vendor has extended the delivery date into February. Five furnace units have arrived on site and are in receiving inspection pending release to the project and prototype installation.

Puxex Plant run plan AC-5 (HW-40171) which provides for operation under spiked plutonium conditions was lssued as part of the cold uranium shakedown program.

Separations Technology developmental contributions were complled and submitter to the Manufacturing Department for incorporation into the "1955 At Hanford" annual report.

\section{INVENTIONS}

All Separations Technology Section personnel engaged in work that might reasonably be expected to result in inventions or discoveries advise that, to the best of their knowledge and bellef, no inventions or discoveries were made in the course of thelr work during December, 1955 except as listed below. Such persons further advise that, for the period therein covered by this report, notebook records, if any, kept in the course of their work have been examined for possible inventions or discoveries.

\section{Inventor(s)}

E. J. Wheelwright

R. W. Wirta \& R. C. Smith
Title

"Removal of Iron from Uranium(IV) Fluoride Sa]ts"

"Chemical Processing; namely, the Utilization of UItrasonic Energy to Accelerate and to Further the Dissolution of Nickel in Nitric Acid"

RB RIchards:khs

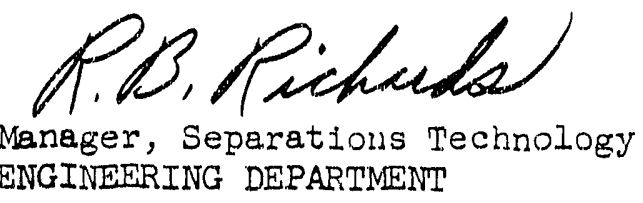

Manager, Separations Technology

ENGINEERING DEPARTMENT 
MONTHLY REPORT

DESIGN SECTION

VISTTORS AND BUSINESS TRIPS

C. J. MeVey of the Thomas A. Ed1son Company, Chicago, Illinols Visited Hanford December 5th through December 7 th for consultation on the prototype cell temperature monitor system for Project CG-558.

J. J. Dietz of the Thomas A. Edison Company, Chlcago, Illinois visited Hanford December 5 th through December 6th for consultation on the prototype cell temperature monitor system for Project CG-558.

E. J. Barrett visited the Bonneville Power Administration, Portland, Oregon December lst for conferences on scheduling of work at the Midway Substation.

C. S. Bucholz visited the University of Illinols, Champaign, Illinois December 5 th through December 9th to attend a course on Cathodic Protection.

․ D. Switters visited the Allegheny Iudlum Steel Corporation, Watervliet, New York and Brackenridge, Pennsylvania, Fansteel Metallurgical Corporation, North Chicago, Illinois, Struthers Wells Corporation, Warren, Pennsylvania, Merck and Company, Rahway, New Jersey December 6th through December 27th to discuss metallurglcal problems assoclated w1th continuous calcination and use of tantalum and titanium heat exchangers.

H. J. Bellarts visited the Monarch Machine Tool Cormany, Sidney, Oh1o, International Tool Company, Dayton, Oh1o, Sheffleld Corporation, Dayton, Ohio December 6th through December 9 th for consultation on special lathe design prior to possible procurement; and to obtain information for design spectfications for gages under consideration for the $234-5$ building.

J. R. Carrell visited the University of Idaho, Moscow, Idaho December 7 th to deliver a lecture to the student branch of ASME.

M. W. Cook and R. T. Jaske visited the National Carbon Company, Oak Ridge, Tennessee December 8th through December 9th for consultation on homogeneous reactor design, processing of homogeneous reactor fuels and other separations problems.

L. M. Finch visited the Struthers Wells Corporation, Warren, Pennsylvania December 9 th through December 20th for inspection and design liaison for continuous calciners.

R. I. Grenda visited the Nuclear Engineering and Science Congress and Exposition, Cleviland, Oh1o, and Panellit, Incorporated, Skokie, Illinols December 10th through December 17th to present a paper "Hanford Reactor Instrumentation" by E. See Day, Jr., before the Congress and to observe tests on mercury switches at Panellit, Incorporated.

H. S. Davis visited the Nuclear Ingineerling and Science Congress and Exposition, Cleveland, Ohio December 10th through 18th, and attended a meeting of Chapter editors for Reactor Handbook. 
J. C. W1111 visited the Nuclear Englneering and Sclence Congress and Exposition, Cleveland, Ohio December 12th through 18th.

M. W. Cook visited the Nuclear Engineering and Science Congress and Exposition, Cleveland, Oh10 December 12th through 16th.

C. R. Bergdahl visited the General Electric Company, Cleveland, Oh1o December 12th through 16 th as a representative on recruitment.

H. R. Hughes visited Washington State College, Puljman, Wasilington December 15 th to deliver a lecture to englneering students on power reactors.

I. E. Foster visited the General Electric Company, San Jose, California December 18 th through 20 th to discuss recent developments in reactor cooling by boiling water.

E. R. Astley attended the Winter meeting of the Amerlcan Physical Soclety at the University of Southern Callfornia, Los Angeles, California December 28th through December 30 th.

ORGANIZATION AND PERSONNEL

Personnel Statistics:

Design Management

Process Engineering Sub-Section

Design Planning Unit

Design Engineering Sub-Section

Design Drafting Unit

Total Section Personnel

Rotational. Technical Graduates Total.

Accessions - 5

Separations - 3

$\frac{\text { November } 30}{\text { Non- }}$

\begin{tabular}{rr}
2 & 1 \\
70 & 12 \\
18 & 13 \\
79 & 10 \\
7 & 76 \\
\hline
\end{tabular}

176

$\overline{176}$

$\begin{array}{r}3 \\ 82 \\ 31 \\ 89 \\ 83 \\ \hline\end{array}$

238

112 $\frac{3}{115}$
December 31
Non- Non-
Exempt Exempt Total

\begin{tabular}{rrr}
2 & 1 & 3 \\
72 & 12 & 84 \\
17 & 14 & 31 \\
79 & 11 & 90 \\
7 & 16 & 83 \\
\hline 177 & 114 & 291
\end{tabular}

$\frac{-}{177} \quad \frac{2}{116}$

\section{GENERAL}

Design Section engineering and drafting effort on design development programs decreased during December, due primarily to increased activity on the preparation of advanced engineering studies for potential FY 1958 Plant and Equipment Budget items (at the end of the month, studies had been started for 4.6 potential budget 1tems). Process Technology effort in support of plant assistance problems also increased, while design project activity decreased as presently authorized work on Purex Capacity Increase and the Reactor Plant Modification program neared conpletion. Distribution by major components 
Design Section

1s as follows:

\begin{tabular}{|c|c|c|c|}
\hline & $\begin{array}{l}\text { Englneering Man } \\
\text { Months Expended }\end{array}$ & $\begin{array}{l}\text { Drafting Man } \\
\text { Months Expended } \\
\end{array}$ & $\begin{array}{l}\% \text { of Section } \\
\text { Eefort }\end{array}$ \\
\hline $\begin{array}{l}\text { Design Development Programs } \\
\text { Design Section Projects } \\
\text { FY } 1958 \text { Budget Studies } \\
\text { Process Technology } \\
\text { Customer Work }\end{array}$ & $\begin{array}{r}63.4 \\
54.5 \\
14.6 \\
8.5 \\
15.7 \\
\end{array}$ & $\begin{array}{r}21.8 \\
31.9 \\
3.2 \\
1.9 \\
22.0 \\
\end{array}$ & $\begin{array}{r}36.8 \\
34.9 \\
6.1 \\
4.6 \\
17.6 \\
\end{array}$ \\
\hline Total & $156.7^{*}$ & $80.8 *$ & 100.0 \\
\hline
\end{tabular}

* Equivalent man months expended 1ncluded 294 hours of engineering and 286 hours of drafting overtime, which represents $1.2 \%$ of the Section based on the total avallable hours for a normal 40 hour week.

The Design Drafting Unit production for December was 237 new drawings and 317 drawlng revisions for an equivalent of 4.8 man days per drawing.

\section{DES IGN DEVELOPMENT}

The total number of engineering and drafting man months applied to design development actlvitles for December were as follows:

\section{Engineering}

Man Months of of Total

\section{Man Months of of Total}

0.2

12.5

5.8

49.2

32.2

20.4

$$
1.7
$$

2.0

2.7

$\underline{3.1}$

63.4
1.9

1.4

21.8
0.9

57.3

26.6

8.7

6.5

100.0

\section{Metallurgical Design Development}

Major metallurgical design development effort during December involved pre-scope studies dealing with production facilities for an internally and externally cooled diffusion-bonded fuel element. Estimates were prepared ind Icating those 1tems which would require major development activity prior to scoping of the conversion of present fuel element production facilities to the proposed new process. Estimates of the engineering manpower that would be required for total design of the proposed new process were also prepared. 
Reactor Des1gn Developmeat

Major reactor design development activity during the month involved studies for a supplementary plutoniu production reactor having a recirculating primary cooling system. Since the scope criteria calis for a minimun dealon completion schedule, It is antlclpated that this reactor would be essentially a copy of the K reactors, wth the modifications neceasary to incorporate a recirculating cooling system and only those other improvements which could be obtained without extending the over-all. 7 completion schedule. Preliminary bullding layout studies indicate that the recireulation feature will result in major buflding modifications from the kr reactor design.

Studies have been started to determine the optimum water annulus and necessary process tube dlameter for a larger dlameter fuel element whlch is under conslderation. Other development studies which will be inftiated in support of the desien of the supplementary production reactor include radiation studies to determine anticipated front face activity resulting from process tube cooling water recirculation, investigation of the effect of higher tempereture water on renctor instrumentation, and development of a radiation-resistant high-tenperature process tube connector for both front and rear face application.

A feaslbility report was completed and issued during the month covering a small demonstration reactor for advanced reactor technology appilcations. The major items inciuded in this report are: description of the proposed reactor, its operating characterlstics and its demonstration capabilities; an estimate of the minimum time schedule on which the fecility could be built; a aumary of the development work which would be required in support of the design and construction of this fac1litiy; a discussion of how such a. Incllity would be ut1lized and how 1ts development, design and operation would affact existing manpower and paciilty requirements. The estimated total cost of the proposed demonstration reactor and its auxiliaries is $\$ 3,000,000$.

Separations Design Development

Development work continued on the preparation of flow diagrams and equipment and bujiding arrangements for a tew separations plant utilizing a simplified Redox process. A remote slug charging machine capable of charging individual slugs to the continuous dissolvers has been developed and incorporated in the study to minimize hydrogen evolution peaks anticlpated with the use of a batch charging system.

In anticipation of future requirements for cooling water conservation at the Redox Plant, a study of possible routings for reclrculated cooline water was completed during the montis. it was recomended that the exfsting raw water header be used for recirculated water and that a smaller new headex be provfded for those services requiring fresh raw water.

Separations program mechanlcal development activity during Deceraber included studies of In-line monitoring instruments for the Redox and Purex Plants, and of agitators for separations process tanks.

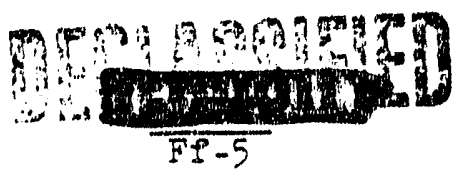


Chemical Processing and Reduction Design Development

Investigation continued during the month of several alternate methods of converting Task I from a batch to a continuous pluorination process. In conjunction with the studies of a continuous Task I process, consideration is being given to development of a combined Task I - Task II process.

Coments were recelved from operating and malntenance personnel on equipment arrangement draw1ngs show Ing three different methods of 1nstaling a new RM line in the RG line area, and agreement was reached as to whlch alternate would be used for cost estinating purposes in confunction with an advanced engineering study for a potential FY 195$\}$ Plant and Equipment Budget 1tem.

Studies for Installing the Task I process in the Redox and Purex Plants continued through the month. $\$ 1 x$ drawlngs have been completed to date illustrating potential instailation of continuous Task I equipment in these plants.

\section{4-5 Des 1gn Development}

Drawings showing two different methods for loading of permanent mold castings into the Task IV furnaces were completed and 1ssued for coment during December.

Studies were continued of methods for Improving and mechanizing the Task $V$ remote final shape machlaing process. Discussions were held with potential fabricators of a special automatic lathe for finol shape machining and scope drawings and specteications were revised as considered necessary on the basis of the technical coments received.

\section{Engineering Standards and Materials Development}

The status of progress on standards during December is as follows:

a. Fourteen new standards were completed, including:

HWS-8002-S, Standard Specification for Thernoplast1c Insulated Wire and Cable, 600 Volt. HWS-8003-S and HWS-8006-S, Standard Speciflcations for Polychloroprene Jacketed Cable, 600 Volt and 5 and $15 \mathrm{KV}$.

b. HWS-8066-S, Standard Specification for Wrought Austenltic Stainless Steel Fittings - 30\% complete. HWS-8001-S, Standard Specification for Metal-Clad Switchgear, 600 Volt - 90\% complete. HWS-8005-S, Standard Specification for Metal-Clad Switchgear, 4.16 and $13.8 \mathrm{KV}$ - $80 \%$ complete.

c. DG-301-W, Design Gulde for Welded Jolnts (orlginally planned as an addendum to $D G-300-W)$ - $80 \%$ complete.

d. Standard instrument drawings for Five-Fold Hand and Foot Counters - $80 \%$ complete. 
DESIGN PROJECTS

Statistics

Englneering and drafting effort of the Section on profect activity for the month of December was as follows:

$\mathrm{UO}_{3}$ Plant Expansion

Reactor Plant Modifications for Increased Production

Purex Capacity Increase

100 K Renctor Plants

Purex Radiolodine Removal Facility

Other Design Projects

Process Technology and Customer

Work

Total
Engineering

Man Months क Of Total

$$
4.5
$$

11.4

4.2

9.6

5.5

19.3

$\frac{24.2}{78.7}$
14.5

5.3

1.2 .2

7.0

24.5

$\frac{30.8}{100} \cdot \frac{8}{0}$

$\frac{\text { Drafting }}{\text { Man Months कo of Total }}$

0.8

1.4

3.5

3.5

8.7

3.1

12.3

6.3

6.3

15.6

5.6

22.0

$\frac{23.9}{55.8}$

\section{CA-512 - 100-K Area Facilities}

Work continued during December on CA-512, Revision 4, which covers the modification, correction, and installation of varlous eystems for the satisfactory completion or' the 100-K Area facilities. The design work covered by this revision is estimated at a.pproximately $\$ 85,000$ and includes design for the following major 1tems: Gama MonftorIne System - 105-K, Ac1d Add1tion Facilities - 183-K, 107-K Retention Basin Foundations and Effluent Sampling and Monitoring, and Ventilation System Corrections - 1720 and $1704-\mathrm{K}$.

\section{CA-513 - Purex Separations Facility}

Deslgn for the currently approved major phases of Project CA-513-E, Purex Plant Modif1catIons, was completed during December with the completion of detalled designs for Iodine Monitoring Facilities and Continuous Sampling Facilities. Funds have been requested but not yet authorized for the provision of an additional Purex crane.

\section{CA-514 - 300 Area Expans1on}

Design was coupleted during the month for an explosion-proof methanol probe housing for the cap and can cleaning machine in the 313 bullding.

\section{CA-539-Add1tional Waste Storage Facilitles - Redox}

Detalled design o1 Phase II facllities was completed during November. Deslgn field liaison work continued during December. Assistance was given to fleld forces for install.. Ing temporary hook-ups until permenent instrumentation arrires on plant-site. Vendor drawings for the motor contrul center were reviewed and approved during the month.

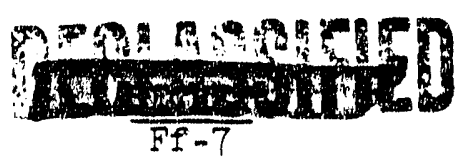


CA-546 - Fuel Element P1lot Planti

Over-all design advanced to $98 \%$ complete during December. All drawings for the new anodialng equipment have been issued for coment, and revisions to electrical drawings are In progress as required by changes in the anodizing area.

\section{CG-558 - Reactor Plant Mod1f1cat1ons for Increased Productilon}

Total design for CG-558 advanced to $98.5 \%$ complete (excludig zone temperature monitoring facilities). Provision of a zone temperature monitoring system for 105-B, C, D, DR, $F$ and $\mathrm{H}$ buildings was approved as a part of the scope of th1s project and detalled desigri of these facilities was started during the month.

CG-600 - 100-C Alterations

Design completion status remains at $96 \%$ at the end of December. Additional design for Installation of the new 190-C process pumps $w 11$ be accomplished upon recelpt of necessary information from the pum vendor. Preparation of acceptance test procedures for the new process pumps was started during the month.

\section{CG-613 .. Hanford 4-X Frogram - Metal Conversion Plant}

Letalled design for the addition to the $\mathrm{UD}_{3}$ Plant is $99 \%$ complete. Preparation of necessary drawing revisions and acceptance test procedures continued during Decernber. Deslon assistance was furnished to the Struthers Wells Corporation to solve weld-cracking problems encountered during fabrication of the calciner troughs.

CG-616 - Installation of Acld Feed Equipment - 100-B, C, D, LR, F and H Areas .

Detailed design for this project advanced to $96 \%$ complete during the month.

CG-621 - Redox Contamination Control Facilities

Total design for Pro, ect CG. 621 , Redox Contamination Control Facilities advanced to $98 \%$ complete during the month. Design was completed for Canyon Washdown facilities and the. J-6 Pre-ciondenser. Status on the remalning deslon 1tems is as follows:

$\begin{array}{ll}\text { E Cell Ozonization, Phase II } & 88.8 \% \\ \text { Contamirated Equipment Removal } & 98.0 \%\end{array}$

CG-625 - Additionaj Waste Disposal Facilities - 200 Area

Detailed design for Phase I of this project remained at $80 \%$ complete at the end of Deceruber. The revised scope for the recirculation facilitles has been completed but no additional detailed design was done. Design for the Phase II tank farm addition was $4 \%$ complete at month's end and the overall compietion status of Project CG-625 was 39.4\%. 
Design Section

CG-635 - Redox Stack Particulate Sampler

Detalled design for this profect was completed during Deceraber with the approval of the five required drawings.

CG-638 - Alum-Act1vated S111ca Water Treatment Fac1lit1es - Phase II

Status of design for the provision of additional activated slilca water treatment facilities in the 100-B, D, DR, F and $\mathrm{B}$ Areas was $27.7 \%$ at the end of the month.

CG-642 - Design of Continuous Charge-Discharge Equipment - C Reactor

Work continued durling December on the preparation of desien scope for full-scale continuous cherge-discharge equipment for C Reactor.

CG-643 - Redox Capac1ty Increase - Phase III

Status of detalled design for the first phase of this project, whlch consists of removal of equipment limitations whlch will be imposed by process changes to be made in conjunction with Froject CG-621, Redox Contamination Control Facilities, was as follows at the end of December:

$\begin{array}{ll}2-\text { E Colum Modiflcations } & 92.9 \% \\ \text { F-3 and F-6 Condenser Modifications } & 90.0 \%\end{array}$

Work is in progress on the compliation of data on ralves, orifices, etc., which wil. affected by proposed changes in flows, pressures and tenperatures assoclated with the Phase III capacity rate.

CG-644 - Silica Gel Tail-End Treatment Facilitles - Purex

A preliminary project proposal requesting $\$ 60,000$ for initiation of design os silic" gel tail-end treatment facilities for the Purex Plant was approved during the mont"r. Detailed design of these facilities will be performed by an architect-engineer under technical direction of the General Electric Company.

\section{CG-646 - Modifications to Plckl1ng Mach1nes - 313 Bu1laing}

Specifications were completed during December for a dip tank and necessary machine components required to convert 300 Area Metal Preparation plckling machines from a spray process to an immerston-dip process. Two drawings covering installation of the new equipment remain to be completed.

CG-64t - Beck-Up Rad 1010dine Removal Facilit1es - Redox

Detalled des1gn was started during the month for back-up radiolodine removal facilities for the Purex Plant, and was 5\% coraplete at month's end.

CG-648 - Aux111ary Rad1010dine Removal and Nitric Ac1d Recovery Fac1lities - Redox

Detalled design was started, and advanced to $8 \%$ complete, during December for the provision of auxiliary radiolodine remrval and nitric acid recovery faclilties for the Redox Plant.

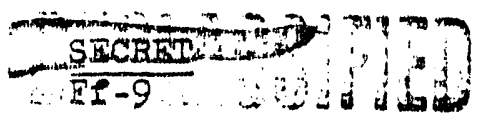


D.0. 101398 - Feasibility Study - Dumy Decontamination Facilities - 100 Areas

Comments recelved during the month from the Manufacturing Depariment on a rough draft report sumarfing the economies and feasibility of alterrate methods of decontamination of aluminum dumies used in the 105 bulldings are belng evaluated prior to issuance of a final recomendation report.

\section{D.0.A-00104 - Sub-Cr1t1cal Neutron Flux Mon1tors - 100 Areas - Project Proposal}

Work continued during December on a project proposal for the provision of sub-critical neutron flux monitors for the 105 bullaings in all the 100 Areas.

\section{D.0. A-00164 - Flow Loop, 314 Bullding - Project Proposal}

Work continued during the month on the preparation of a profect proposal for the installation in the 314 Bullding, 300 Area, of a test loop for simulating reactor flow conditions. The scope or work covered by this proposal has been expanded to include the provision of associated service connections.

$\frac{\text { D.0. A.-00174 - Installation of Beta Monitors on Retention Basin Effluent Iines - 100-B, }}{\text { C, D, DR. F and H Areas - Project Proposal }}$

Project proposal preparation continued during December for the installation of beta monitors on retention basin effluent lines in $100-B, C, D, D R, F$ and. H Areas.

D.0. A-00176 - Water Plant Camponent Test Loop - Project Proposal

A project proposal for the installation of a water plant component test 100p in the 1706 . KE building was completed during the month and routed for Management approval.

D.0. A-00179 - Steam Driven Auxiliaries for 165-K Buildings - Project Proposal

Work continued during December on the preparation of a project proposal for the provision of steam-driven auxiliaries for steam generators in the 165-KE and $165-\mathrm{KW}$ buildings.

D.0. A-00188 - Redox Plant Ventilation System Improvements - Project Proposal

A project proposal, completed in November, requesting $\$ 205,000$ for design; fabrication and installation of equipment for the correction of deficiencies in the Redox Plant ventilation system was awaiting Management approval at the end of December.

A-00218 - SWP Service Facilities, Redox - Project Proposal.

Work continued during the month on a project proposal covering expansion of SWP service facilities in the Redox Plant.

D.0. A-00226 - Process Technology - Inproved Purex Plant Silver Reactor

Design work continued during December for a prototype two-stage reactor to be used as a replacement for one of the existing in-canyon silver reactors in the Purex Plant.

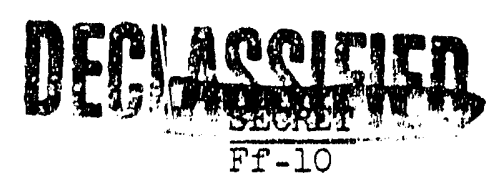


D.0. A-00228 - Metal Load Ing Faellities - 100-B, D, DR, F and H Areas - Project Proposal

A draft project proposal for the provision of metal loading facllities for the 100-B, D, $D R, F$ and $B$ Areas was completed and routed for coment during the month. Issuance of the final proposal is scheduled for mid-January.

D.0. A-00273 - Alterat1ons to Ninor Construction Shops - White Bluefs (CG-630)

Design of miscellaneous alterations to Minor Construction Shops, White Bluffs, was $25 \%$ complete at the end of December.

\section{D.0. A-00280 - Relocation of Purex Cooling Water Swamp - Project Proposal}

Work was started during December on a project proposal for the relocation of the Purex cooling water swamp from the present area east of the 202-A building to a natural depressed area south of Gable Mountain.

\section{D.0. A-00283 - Monochromatic Neutron Beam Fac1lity - Froject Proposal}

Project proposal preperation was started during the month for design and procurement of a monochromatic neutron beam facility for installation in a test hole in one of the $105-\mathrm{K}$ reactors.

D.0. A-00284 - Additional Heat Generation Facility, 189-D Building - Project Proposal

A draft project proposal for an adaitional heat generation facility for the 189-D buildinc was completed and routed for coment during December.

D.0. A-00285 - High Level Metallurglcal Examinat1on Cell, 327 Bullding - Project Proposal

Work was sterted during the month on a preliminary project proposal for the installation of a high level metaliurgical examination cell in the Radiometaliurgy Bullding in the 300 Area.

D.0. A-12884 - Purex Plant - Prototype In-Iine Alpha Monitor

The Design Section is directing the procurement for and fabrication of a prototype alpha monitir, which is to be installed on the 2AW stream 1n the Purex Plant. At the end of December, fabrication of the prototype was $90 \%$ complete.

D.0. C-47050 - Structura.1 Analysis for 300 Area Coal Shake-Out Installation

Structural analysis and design for the installation of a coal shake-out at the 384 building, 300 Area was $25 \%$ complete at the end of the month.

D.0. C-79326 - Underwater Cutting and Etching Equipment - 105-C Metal Examination Fac1lity

Preparation of a scope study of equipment for underwater cutting and etching of irradlated fuel elements in the 105-C Metal Examination Facillty advanced to $95 \%$ complete during December.

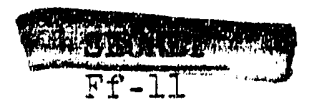


Design Section

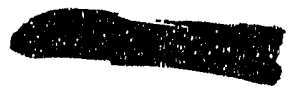

EWW -40692

$-$

Design Work Completed During December

D.0. 100599 - As-Built Drawings (CA-431-B)

D.0. 101362 - Fower Factor Study of Electrical System

D.0. 101367 - 100 Areas - Relocation of Grove Valve Irpulse IInes

D.0. A-00165 - Prototype Calciner Installation - 224-U

D.0. A-00168 - New VSR Tower (CA-548)

D.0. A-00180 - Pole Figure Mechan1sm for X-Ray Diffractionator

D.0.A-00197 - Fly Ash Collection System - 384 Bullding (CA-590)

D.0. A-6544 - Fagineering Services - Thibe Removel Development Program

D.0. A-12502 - Door for Column Carrler Outlet Opening - 202-S

D.0. A-12582 - Redox Plant - Vapor Line Connectors

D.0. A-12920 - U Plant - Jumper Design

D.0. A-13531 - Redox Plant - Redesign of Rec1rculating Boller Section

D.0. C-96846 - Isolation Process - 224-T Building

D.0. C-98574 - Eaglneering Study of Construct1on Budget Items - 300 Area

INVENTIONS

AlI persons engaged in work that night reasonably be expected to result in inventions or discoverles advise that, to the best of their knowledge and bellef, no inventions or discoverles were made in the course of their work during the period covered by this report except as listed below. Such persons further advise that, for the period theretn covered by this report, notebook record.s, $11^{\prime \prime}$ any, kept in the course of their work have been examined for possible inventions or discoveries.

Inventor

H. R. Hughes

H. R. Hughes
Subject

Heat transfer from a nuclear reactor by a radiant energy method.

A method for the removal of radloactive substances from metals and other materials by the application of the principles of electrolysis.

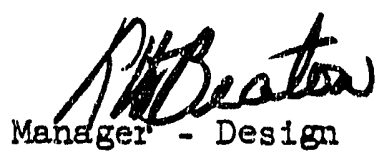

ENGINEERING DEPARTMENTT

RH Beaton:HDT:rd

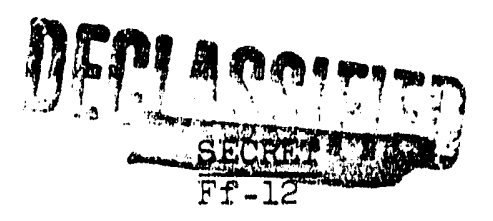




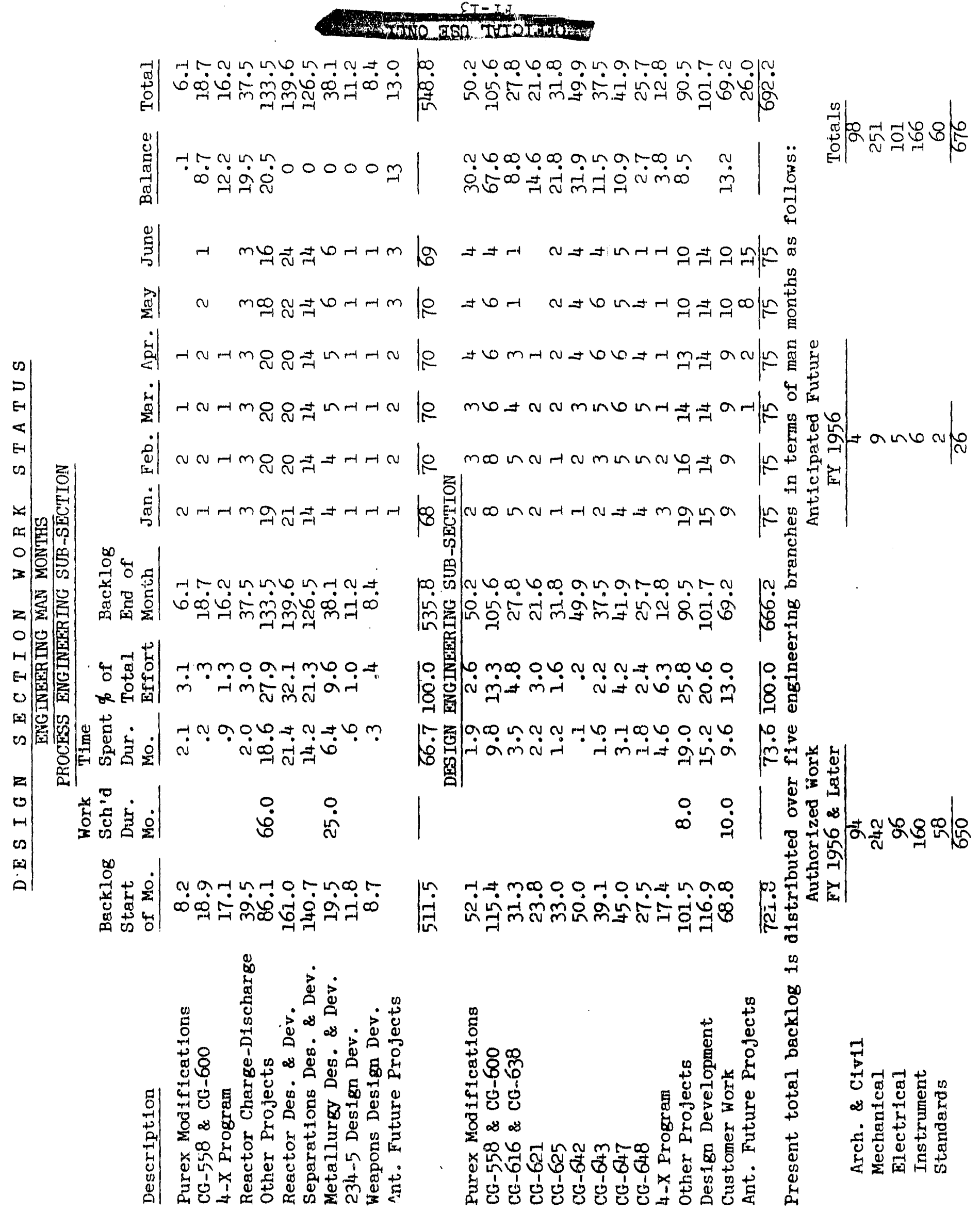


I. SUMMARY

\section{A. Organization and Personnel}

Following is a sumary of personnel changes in Project Section during the month:

November 30, 1955 December 31, 1255 Net Change

Employees on payroll Technical Graduates, Rotational
342
340

6
$-2$

The end-of-month status involved these changes:

\section{Project Section}

Payroll additions
Payroll removals
Transfers into Section
Transfers from Section
Transfers within Section

Teshnical Graduate: Rotational

At the end of the month there were positions open for 13 exempt and three nonexempt exployees. Six exempt persons are being prosessed for addition to the payroll.

\section{B. Scope of Activities}

At the end of the month, completion status of mor construction was as follows:

Project No.

CA -512

CA. -512

CA $-513-A$

CA $-513-E$

CA- 539

CA -546

CG -558

CG -558

CG -603
Tit.le

100-K Area Fecilities

1706 KFR Recirculation Farilities

Purex Facilities, Part A

Purex Frcilities, Part E

Additional Waste Storage Facilities

Fuel Element Pllot Plant

Reactor Plant Modifications, Phase I

Reactor Plant Modifications, Fhase II

Hanford 4X Program, Bismuth Phosphate Plants $\frac{\text { Complstior }}{\text { Scheduled Actidit }}$

$100 \% \quad 1000 \%$

$44 \% \quad 5 \%$

$1.00 \% 100 \%$

$790^{\circ} \quad 8 \mathrm{i} ; 0$

$14 \%$

$80 \% \quad 80 \%$

$320 \% \quad 40 \%$

$3 \%$

$100 \%$

\section{Craft Labor}

Because of continued minor disturbances at the White Bluffs warehouses and storage yards, a reiteration of General Electric policy has been necessary to f'ixed-price contractors who witharaw finished materials from tiese locations. The basic statements were:

a Complete except for start-up and scheduled design changes.

b Completion percentage is based on work now approved.

c General Electric portion of Phase II work.

d Completed on December 30, 1955, with exceptjons.

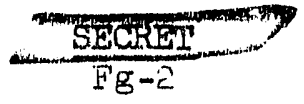


1. Matexials to be withdram from Whito Bluffs warehouses will be set out on the docks, from which the flred-price contractor's personnel w1I.I remove and load the Items.

2. Naterials to be withdrawn from the White Blurfs storage yards w1II be handled and loaded by Ilred-price contractor'a personnel, and a Minor Construction exployee w11 be in attendance.

\section{Sarety and Security}

Serron regular meeting for dlscusslons of safety, security, and health toplcs were attended by about 190.Project Section employees. In addition, safety meetings were conducted by the I1ve Off-site Inspection Un1ta. Four mass meetings were held in the fleld for service contractor personnel, and information on radiation hazards and work procedure was dispensed throughout the construction areas. In cooperation with the current emphasis an safety, all Sub-Sectlons have reviewed work assignments in preparation for job bazard ... Ijses. This roview has been extended to off-site inspectors wo are working in ven. ars". plants.

\section{E. R1ghIIghts}

Inspection Sub-Section

The total rorkloed of arderes requiring 17apection decreased 45 to a total of 649 , of which 618 have been aselened to inspoctors. Responsibllity for inspection of the assigned orders ras divided as fullorr: off-site inspectors, 501; on-site" Inspectors, 102; and goverument agency, 15. An increase of the on-site assignments has necesaitated additional inspection facilities at Hanford. The Corrosfon Testing Program workload remalned about level, with 242 corrosion tests, 76 micro and macro testa, and 94 chemical determinations being performed at the industrial laboratories. Generaliy, the inspection assignments concermed major work being performed on calciners and other equipment for the $\mathrm{JO}_{3}$ plant, piping and risers for reactor plant modiflcation, Resistoflex connectors, and process water pumps. This latter order has been rewoved from the crltical list since the first commitment of 24 pumps has been shlpped from the foundry, and ten finished pumps have been shipped by the vendor.

\section{Minor Construction Sub-Section}

The manpower of the labor service contractor continued to decrease, chiefly among craftamen, to a total of about 885 employees on the payroll. According to manpower distribution, the primary efforts were directed toward tbo Reactor Plant Modification, Blomuth Phosphate Plants, Metal. Converalon Plant, 300 Area Production Facilities, weste disposal feclilties, and the Fuel Element Pliot Flant. Minor ConstructIon work was essent1alij completed on the B1smuth Phosphate Plants and 24 alscellaneous work orders. New vork was accepted on three projects and 48 work orders. The total amount authorized to Minor Construct Ion was $\$ 16,107,435$, of which $\$ 8,271,975$ was not expended or committed. The u.pgrading pxogrem for equipment progressed to the stage of leaving only ten items to be processed for sale. Inventoriss were made of all stores in Warehouse \#I and of all clothing items. Kardex files and stock lovels were established for expendable tools in Warehouse \#2.

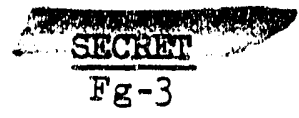




\section{Project Ingineering Sub-Section}

The remaining project assigaments and functions of the Separations Projects SubSection vere assimilated during the month, and the title of the Purex Construction Undt was changed to Construction Inspection Unit. Thus, the Project Ingineering workelaed ves increased b5 these projects, plus projects for modiflcation of Kadlec Hospital and valte houses in the 100 Arees, and elght engineering requests. Work ansignments were completed on two englneering requssts and three projects, CG-603, B1sututh Phosphate Planta; CG-576, General Improvements to 300 Area Laboratory; and

$\nabla$ CG-572, Particlo Problon Aatmal Exposuro Equipment. Prelimtnary study and planning on the problen of reactar tube replacement were coordinated with Minor Construction. and the Menufacturing Dopartment to include the posalbility of effecting the maximum utilization of the mojor shutdowns and Minor Construction forces during the Reactor Modification project, and the possibility of changing methods of work. 0ther projects that required intensive engineering work were the Metal Conversion Plant, Reactor Plant Modification, and waste disposal facilities. Construction schedules for reactor modiflcation work are being adjusted to reflect delays caused by labor problems, olow materlal dellverles, and adverse weather.

\section{Project Auriliaries Sub-Suction}

Plans were completed to redesignate this component as the Project Service Sub-Section, effectivo January 1, 1956. Actlons were cont Inued to obtain personnel for current vacancies. Project administration functions were realigned for more precise controls and presentation of construction data. Project Cost Control continued 1ts routine functions and also assisted with inrentorles, appraisals, and speclal reports. Reproduction output was 323,795 square loet, a substantlal lecrease from the peak production during Iovember 1955. Dlatrlbution by Engineering F1les also dropped to a total of 156,778 prints, of which about 1800 were classified 1tems. The largest single order was 13,574 prints for Reactior Plant Modlfication. Fleld Surveys performed additional work on the survey of Richland, Washington, and also provided routine services for establishing control points, graphite inventory, and other survey sesvices. Estimating workload continued 1ts increase to a total of 83, of which 29 were completed during the month.

\section{F. Monthly Report of Inventions and Discoveries}

All persons in Project Sectlon engaged in work that might reasonably be expected to regult in inventions or discoveries adrise that, to the best of their knowledge and bellef, no inventions or discoveries were made in the couree of the ir work during the period covered by this report except as listed below. Such persons further advise that for the period therein covered by this report, notebook records, if any, kept in the course of their work have been examined for possible inventions or discoveries.

None.

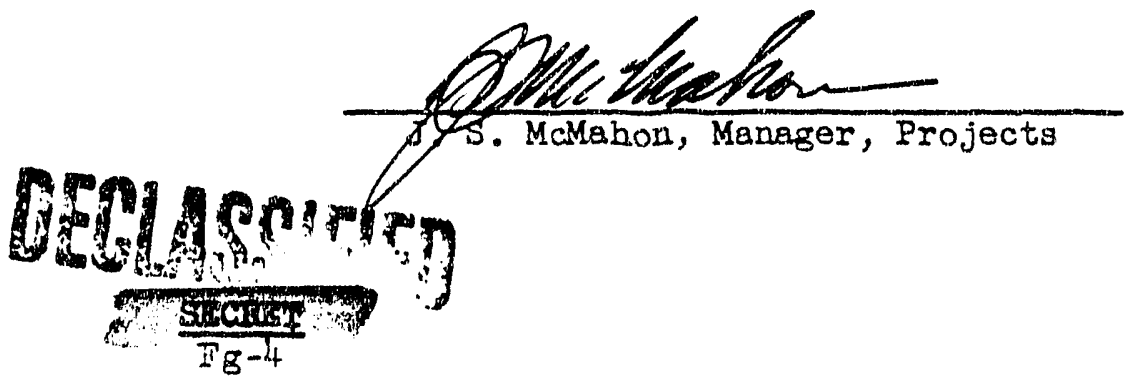


II. STATISTICAL AND GINYRAL

\section{ULLASOSFIED}

A. S1gnil leant Assigonents

1. Inftial Reporting

CG-647, Beck-up Radiolodine Removal Fac1l1t1es, Purex

Detalled design is the responsiblilty of Destin section, and the rough draft of Revision No. I to the project proposal ls being clrculated for coments. Worls was proceeding on an interiso autiorization.

ER 1231, Installat1on of Soundproop1ng Fac1lit1es 12 1706-KE Bulla1ng

With prelininary desibn complete, an informal request is being prepared on the basis of a cailed ertimate.

EFf 2772 , Improvements to Rudox Plant Ventilation

Preparation of the profect proposal is a Design Section responsibility, wad the proposal is belng routed for General Electric approvals.

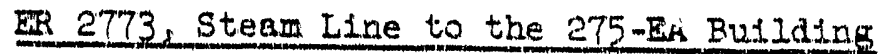

The 1aformal request was transmtited to ABC for authorization.

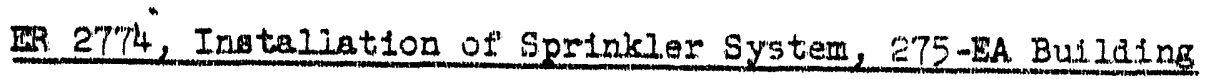

The project proposal is being prepared.

ER 3137 Evacuat10n Warndag System, 360 Area

W1th scoping 60 per cent complete, the Comission has requested the fnclusion of

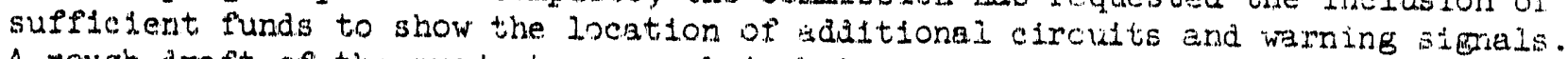
A rough draft of the project proposal is being prepared.

ER 3138, Installation of Frotecttve Canopy crer Loading Dork, 313 Butiding

Information for the project proposal. is being assembied.

ER 3139,011, Paint, and Solvent Storage Farility, 300 Area

Information for the project proposal. fo betng assemblea.

III 3140, Add1tion to EY Thelephone Exchangs

A work order for $\$ 150$ was recelved from the Telephone Sut mection to prepare an estimate for construction. Two design drawings for tise proposed teel building accompanied the work order. 


\section{ER 3I41, Replacement of Obsolete Radio Commicstion Equipment}

A work order for $\$ 1,000$ was recelved from the Telephone Sub-Section for preparation cf the project proposal. The proposed work includes a remote control system to the equipment on Rettlesmake Mountaln, the replacement of radios and moblis and sitaionary uafts, and the reworal of equipment from the Gablo Butte station.

\section{Plinal Reporting}

\section{Ca-572, Particle Problem Antmal Exposure Equipment}

Work on both phases was completed with exceptions.

GG-576, Ganeral Improvements to Inboratory Area, 300 Area

Coustruction prosressed 19 per cent to completion as of Decomber 30, 1955, with the folloring exceptions: door slenal system, panic hardware in 327 Building, and ahleloling for the tensile machine. These exceptlons have been assigned on work orders to plarit forces.

\section{CG-603, Hanford 4X Program, B1smuth Phosphate PIantig}

Construction progressed two per cent to completion as of Decewber 30, 1955. Whe remaining vork has been assigned on vork orders to Minor Congtruetion and to plant forces. The repalr work on 22lw Bullaing is to be accouplished when weather permits.

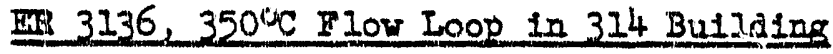

This requast was closed out when Information was transmitted to Design Section for use in the project propossl.

\section{Current Projects}

\section{CA-512, 100 m Keact or Fac111t1e日}

Although the over-all project was consldered couplete, the work on repalrs and mod1ficstions about 49 per cont complote. This completion was appraximately on schedule for work now known.

Tests are still being conducted on the Hamiln 3D model. switones for the pressure monitor system. Panelift switches of simijar dessen wili be tested in January.

Repair work was completed on nine of the 22 bsckwesh valvas to be rapaired in the Pliter planta, and modiflcation work was continued on about ten other service and control syetems. At a meeting on December 16, 1955, w1.th Manufacturing Department representat1ves, the following future work was discussed: activated silica piping, gema monitoring, pressure monftoring, and cross-urder drain instrumentation.

The scheduling of future work is being based upon approved work for back-up facilithes, the steam-driven auriliary equipment, and related modjications.

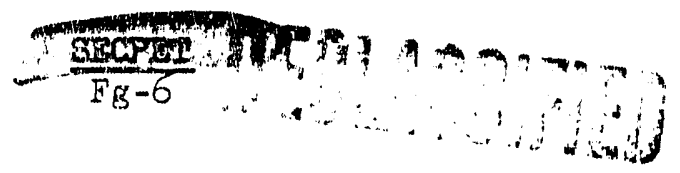




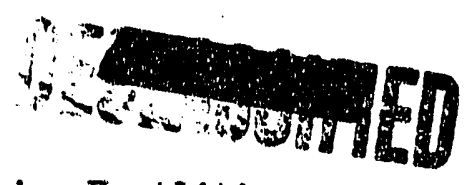

$\mathrm{HW}-40692$ TE:]

\section{CA-512, 1706 Reciren Recution Facilities}

Over-all construction progressed nine per cent to a total of 52 per cent. A fixedprice contractor proceeded with fabrication of plping, placement of pump foundations, electrical services within the bullaing, and process plping in the north tunnel. Service piping in 1706-5I has been completed, and plping in the south corrfdor was practlcally complete. Fabrication work has been started on valve and stralner asemblies for the front face, wirlne trays, sheotwetal ducts, and control systems. Installation of plping assembiles in the Ball $3 \mathrm{X}$ room of $105-\mathrm{KR}$ h $\mathrm{ks}$ been started.

Late deliveries of critlcal materlals hove jeopardized schedules for the fixedprice contractor, as well as Minor Construction.

\section{CA-5.13-A, Purex Facility}

The over-all project continued with the completion status of 100 per cent.

The lixed-price contractor for the Purer Disposal Tunnel proceeded with final struc.tural work and backfliling. Inis portion of the project was essentially completed.

Excaration for the Purex Burlal Garden was started on December 27, 1955.

Other activitles were directed towerd the hot start-up scheduled for January 16, 1956. The fallure of studs on some of the plant equipment has resulted in substitution of keyed-and-screw type atuda. Other changes are being made to the capac1tance probes and the in crane wheels.

\section{CA-5I3-E, Expansion of 200 Area Fac1lities}

Construction remalned at 81 per cent complete, and this completion is based on work now approved. Detalled design for the Purex lodine monitor and the continuous sampler was completed.

Revision No. 5 to the project proposal, which requests $\$ 1,600,000$ additional funds and Includes a second remote crave, is still awalting action by AEC in Washington.

Equipment modipicationg are 98 per cent complete and will remain so until delivery of spare equipment which has beon purchased. This delivery is not expected until after July 1, 1956.

Work on the 241-A Tank Farm Circulation Facilities was started on November 30, 1955, and has progressed satisfactorliy toward the scheduled completion date of February 10 ,
1956.

Equipnent installation progressed on the continuous samplers, lodine monitors, metal solution tub pumps, the $I$ cell absorptometer, and waste tank clrculation Pacllities.

\section{CA-532, Additionel Waste Storage Facilities for Redox}

Construction on the General Electric portion of the work was 44 per cent complete; however, the over-all completion was 53 per cent.

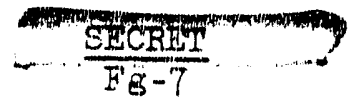


Design is eseentialiy crupleto on sil phases. Dravings submitted by the vendor of the motor control cr ater were revlewed and approved. Sketches were provided the fleld forces for the texporary hook-ups of Instrumentation unt 11 permanent equipwent 18 recelved from tile vendars.

During the flrst half of December, tide entlre 24-inch rapor manifold system was placed in operatilon. On December 27, the valved mantfold furmpers in Diversion Bax 241-SX-151 woro installed.

Delivery of the instrument panel. for the circulators has been promised for orid-Mag 1956 Instend of March 23. Efforts are belnit made to improve this delitery.

CA-546, Pnel Flement Pllot Plant

Over-all constructlon prosaressed 11 per cent to a tatel. of 86 per cent; the General Electrife portion was 80 per cent complete. Dealgn work on rerisions to the anodizing Pacilities completed except for the electrical phases. The contractor's shop draulage on partitlong and miscellaneous stesl for the second floor offlces were revlewed.

The Ifed-price contractor was delayed a few days by laci os structural steel, but the erection work is now progressing.

Bquipant Installation Included the waln exiaust beader, fume separator, the twoton crane, power supply, and plping in the plating room. Instaliation work is belng delayed by slow delivery of engineered equipment, but delivery je expected In oarly January 1956.

\section{CG-558, Reactor Plant Modiflcation for Increased Production, Phase I}

Construction progressed $81 x$ per cent to a total of 40 per cent.

Electrical data is being obtalned in proparation for the first 4500 HP motor test. AII ATP'B have been 1ssued for comment. Design was inftiated on Zono Temperature Monitoring which was approved as an addition to the scope of the project..

Procurement of process pumps has improved to the degree that a backlog exists at both the rendor's machine shop and the Instailation site. Shipments are now befng made in palrs, and the last two pumps for 190-B wero shipped on December 12. They arrived t Hanford on December 27, 1955, and on the same date the vendor shipped fos. 9 and 10 for use in another area.

Installation of equipment in 100-B was continued, Including the new bowl and Impeliers for the B-8 position of 181-B, the second proces pump at 183-B, process pumplng equipment In 190-B, and portlons of reloceted switchgear. The fixed-price contractor continued with grouting and equipment alignment in 190-B Annex, and the contract completion date has beon extended to Apr11 27, 1956.

Excavation Por the 100-B raw water line was essentialiy completed. About 1200 feet of plpe was lald and welded, and anpther 500 peet was tack welded.

Scheduling of work is being arranged according to reactor outages in order to mininize downtime of the roactors. Th1s scheduled coordination includes equipwent

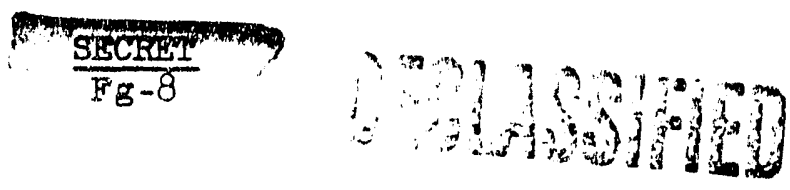




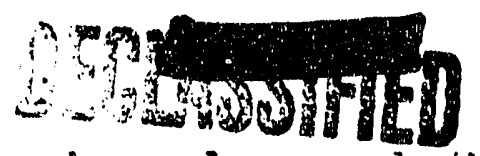

HW-40692

testing, installation of poison columa, and other items of work which can be accomplished at any tim without interfering with production.

CG-558, Bosctor Plant Modification for Increased Production, Phase II

Construction proeressed one per cent to a total of four per cont. Specifications for the raw vater lino in 100-Z and the offluent systein in 100-F have been conpleted.

Site proparation at 100-E was essentially comploivd. Structural ateel and aiding were orected for the 151-H switch house addition. Temporary swltchgear was belng Installed for the high tank pump at 183.H. Other work conslsted of rolocating lines and fabrication of piping.

At 100- $\mathbb{P}$, excarations were made for the 190-F Annex and the process sewer. Installation of equipment included the temporary arltchgear at 183-F, and the stear injection system at $182-F$

Minor Construction flold work at 100-F and H Areas has boen essentially stopped to avalt deliveries of material and equipment.

CA-586, Irst Capac1ty Increase, 230-KV System

The over-all completion of the worls was about 12 per cent and the General Electric portion wes 30 per cent complete.

Tendor' drawings on the duplex board were reviewed and approved. Minor Construction work has been stopped to avalt recelpt of control cable and the duplex board. The cable was shipped from New Fork on December 22, 1955, and the duplex board has been achodulod for delfvery by March I, 1956. Preliminary inspection of the cable tray between $165-\mathrm{KLE}-\mathrm{EW}$ was held.

The fixed-price contractor has completed the footing for tower \#5, and the subcontractor has begun erection of the tower. Other footing locaticns have been surreyed.

CG-613, Hanford 4X Program, Metal Conversion Plant

Over-all construction progreased nine per cent to a total of 23 per cent. The General Eloctrlc portion of work was 15.7 per cent completo.

An AEC dfrective dated December 2, 1955, Increased funds from $\$ 3,000,000$ to $\$ 4,000,000$ and authorlzed the following changes in scope of work: (1) facilitles for using fiveton shipping containers in place of the presently utilized 30-gallon drums, (2) a chemlcal additive systen for the calciner feed material, (3) a maintenance facility to serve the Metal Conversion Plant and equipment, and (4) a shlelding wall for isolating tro uranium lag storage fanks.

Minor revialons were made to 14 drawing including the bag filter platform. The operations and capacity test procedure is appraximately 50 per cent complete. Assistance was furiaished the Struthers Wells Corporation to solve the weld cracking problem encountered during the fabrication of the calciner troughs. Redesign of the corner jolnts was done to reduce stresses. The prototype and first production unit are to be shipped without purtiher heat treatment.

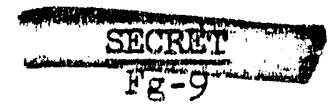


Procurement of major equipment continued as the major problem, particulerly concerning process bag filters, calciners, the absorber tower, and control valves. A penalty agreement amounting to $\$ 1,000$ per day after February 5, 1956, has been made with the absorber tower vendor.

Equipment recelpts durlag the month included flve calciner furnaces, the surge tenk, and Instrument panels. Minor Construction completed new. Ilds for the Luckey pots, and proceeded with installation of the purge tank, the surge tank, and acid pump in "B." and "D" Cells.

Completion of the 224-JA Butlaing structure, partlcularly the built-up roofing, was prevented by adverse weather. In preparstion for installations of process equipment, work was continued on electrical services, process water plping, and service piping. Electrlcal work in the cells was completed, and "G". Cell was palnted.

Bids for Phase IV, the raliroad car loading factlit, ars scheduled for opening on January $5,1956$.

\section{B. Other Asg Ignments}

\section{CA-548, Reactivated Project Proposal for New VSR Teat Tower}

The AEC decided that detalled design is to be done by an architect-engineer. A contractor was selected during the month, and the design criterla and scope drawling have been issued to him. Completion of detailed design is anticipated by Aprii ${ }_{\text {, }}$ 1956.

\section{CA-555, Graphite Eot Shop and Storafe Building}

Over-all completion of construction was about 94 per cent. Congtruction of the hot shop portion of this project was completed by the contractor on December 8, 1955. Installation of services was completed, and the hot shop was accepted by PIle Technology on December 22, 1955.

Minor Construction continued installation of service headers in the cold shop. Iate delivery of material is expected to delay compietion of ingtaliation until late January 1956.

CG-578, Effluent Water Monftoring Improvements, 100-B, D, F, DR, and H Areas

Construction was 72 per cent complete at the end of the month, and this conforms approximately to the new schedule which has been submitted to the AEC. The revised project proposal requests an extension of the physical completion date to July 1 , 1956.

The gamm monftoring syatem in 105-D was completed with minor exceptions. BenePiclal use of the corresponding system in 105-B is anticipated during January 1956. Rotameter rack assemblies for $105-F$ are being fabricated in the shop.

CG-579, Effluent Water Monitoring Improvements, 100-c Area

A revised project proposal requesting extension of time and additional funds has been returned to Project Section for re-eraluation of the completion date. A study

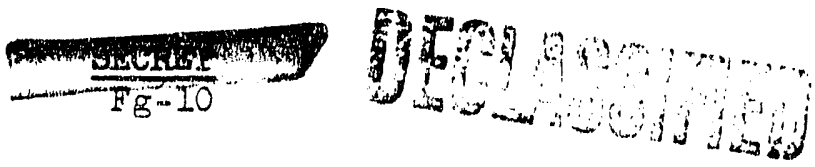




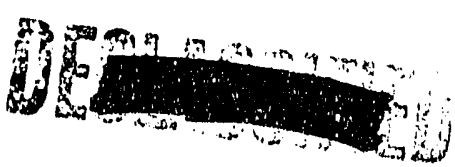

HW-4CE92

is being made of the shutdown schedule and of a tentative method of installation which has been devised with the cooperation of Manufacturing Department.

\section{CG-587, TBP Waste Scevenglag}

C nstructian progressed three per cent to a total of 91 per cent. The make-up tank has been set and the plping is bolng installed. The one requitred jumper has been fabricated. Delivery of this control ralve and agltator was expected durling oarly January 1956.

CA-590, FIY Ash Colloction Equipment, Butlaing 384

The speciflcations for work to be performed under this project were transmitted to AEC on December 19, 1955, for rovier.

\section{CG-598, Purex Acld Frectlonator}

The revised project proposal requesting an increase of funds from $\$ 590,000$ to $\$ 920,000$ and an extension of completion date from December 1, 1955, to September 1956 wes forwarded to AEC on December 29. The englneering review of bids was 85 per cent complote, and 65 per cent of the vendor's certified dats bas been approved. The construction completion status remained at 39 par cent, following the issue of a stop charge notice on December 1, 1955.

Ca $-600,100-C$ Alterations

Completion atatus remained at design 96 per cent, construction .3 per cent.

Two drawings were added for the installation of the 190-C process water pumps. Final completion was held up until vendor information is received. A'TP's for the new pumps in the 190-C and 183-C Butldings were started.

Procurement was progressing. The Byron Jackson Company subintted the low bid for the vertical turbine pump and hollow shaft motor unit. If this bla is accepted, the new and existing units will be interchangeatle.

\section{CA-60I, 300 Arse Generel Improvement Progran}

With preliminary design completed, the design criteria were transmitted to AEC for bld purposes, and the AEC is now consulting with architect-engineer firms.

CG-614, Hanford 4X Program, 300 Aree

Construction progressed 11 per cent to a total of 54 per cent. Production sarvice was obtained during the month fron weldins machines in iine \#3 and a portion of the conveyor system. All autoclave control valves have been received, and work was continued on installation of plping and insulation. Preliminary work was completed for new exhaust ducts from the east line of the welding booths and for the argon piplng. A small amount of work vas performed on the furance inductor cofl exhaust and supply ventilation in the recovery area.

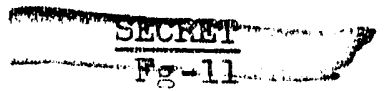


CA-615, MochanlceI Malntenance Shop Centralizat1on, 100 Areas

Since the AEC in Washington withhold approval of this project, additionel justif1cation has been forwarded by the Hanford Operations Offlce.

CQ-616, Installation of Acid Foed Equipment, 100-B, C, D, DR, F, and E Areas

The declsion was made to combine this project with CG-638, Alum-activated Silica Facilfties, Phase II. Althourch the start of fleld work on CG-616 may be delayed about two months, the comblnstion of projects should reduce over-aIl deslgn and construction costa. It is proposed that acid unloading and storage facillties in $100-B$ and $D$ be kept at orly one of the 183 Buildings and that the acid be pumped to the other 183 Bullding. Deslgn Section 1s evaluating these proposed changes.

\section{CG-618, Replacement of Steam Iline Support Poles}

Construction remained at 32 per cent complete,. while the revised project proposal was belag routed for approvals. Manulacturing Department bas requested a revis1on so that work may be coupleted as originaliy scoped.

\section{CG-620, Malt Plant Modif1cationg, 314 Butlding}

A study of requirements for thla facility has resulted in a project proposal revision requesting funds for lnstallation of a packaged furnace unit. This proposal is now being prepared.

\section{CQ-621, Redox Contamination Control Facilitles}

Design progressed 13 per cent to a total of $98^{\circ}$ per cent. Over-all construction was 34 per cent complete.

During the month design was completed on the Canyon Washdown and J-6 Precondenser. Removal of contaminated equipment is to be completed 1n January. E-Cell, Phase II drewligs are complete and awalting Manufacturing Department approval.

Requisitions for spare roplacement vessels were complete. Delivery of the H-6 heat exchanger has been promised by July 1, 1956. Purchase orders are being placed for the $\mathrm{H}-4$ tank and tube bundle and the $\mathrm{H}-5$ tower.

A.1 "E" Cell Ozonlzation work was completed except prociurament of spare equipment and installation of the ruthenium monitoring system.

Bids for the J-6 pre-condenser were opened on December 21, and the vendor has promised delivery in ten weeks. One jumpex has been fabricated, and the others are Bcheduled for Januart 1956.

CG-624, Redax Ra1lroad Tunnel Vent1lat1on Barrier

An official construction schedule is being prepared for submittal to the AEC during early January 1956. The vendor of the sliding door has been informed of all changes and comments so that fabrication can be started. Minor Construction has scheduled the start of electrical work during early January 1956.

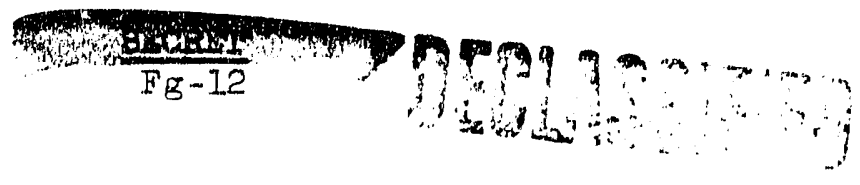




\section{CA-625, Add1tional Waste Disposal Fac1lities, 200 Area}

The completion status of design was revised downward to 39 per cent because of additions to thi circulators which required drawing changes. Design study for roinforcling the tanks 18 belng made. Completion of design is being planned in time to award a flred-price contract by August 1956.

\section{CG-626. Alterations to Bedor Inert Gaa Vent Syatems}

Construction to be performed by General Flectric progressed 47 per cent to a total of 97 per cont complete. Fabrication work which was scheduled for completion during December 1955 was suspended for higher priortty work in the 202-S Bullding. The completion of the ressel assembly in the shop is to be accomplished after the operational start-up.

\section{CG-630, Minor Construction Fabrleation Shops Modifications}

Minor Construction work was started on December 1, 1955, and progressed to about two per cent complete. This work consisted of relocating equipment and preparing bufldinge for the flred-price contractor. Detalled design work began on December 5, 1955.

\section{CG-631, Crtb Beplacement Fac1lities, 241-T Tank Farm}

Construction progressed 15 per cent to a total of 90 per cent. Fabrication of the liquid lovel roel ras started. Installation of pumps was scheduled ofter the expected recelpt of equipment in January 1956. Work has been completed sufficlently to permit use of the facility by the operating department.

CA-633, Remodeling of Facilities, Kadlec Hospltal

Revision No. I to the project proposal has been approved locally, and it is being transmitted to the AEC in Washington for authorization.

CG-634, Replacement of Redor 216-S-1 and 2 Cribs

Over-all construction progressed 63 per cent to a total of 79 per cent. The firedprice contractor completed instaliation of the crib $f 111$ and the pipe work as scheduled on December 31, 1955. Minor Construction has completed Its assigned work except for removel of temporary construction.

The U.S. Geological Survey crew was 75 per cent compiete on the first of three test wello.

\section{CG-635, Redox Stack Particulate Sampler}

After review of the comment drawligg, they are being changed accordingly. A revised estimate based on Plnal design is scheduled for completion during early January 1956. Construction work is being delayed until the sufficlency of authorized funds is determined.

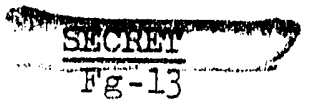




\section{CG-636, Redar Service Facilities Impansion}

The project proposal which is now being revised by Design Section for reduction of scope is to be completed in late January 1956. The proposed scope includes an SWP sorvice faclilty as a bullding addition.

CG-637, IBBP Product Tail-end Prestment Pacilities

A review by Manufacturine Department has revealed that the facility is no longer required, princlpally because of changes in the $4 \mathrm{X}$ Program requirements. AccordIngly, the processing of the project proposal has been stopped.

CG-638, Alum-activated Silica Water Treatment Facility, Phase II

Por the reasons noted under Project CG-616, these projects are being combined. Authorization has been recelved Prom AEC for the following work: instrument checks and Rotameter relocation by plant forces, site decontamination and tie-ins by Minor Construction, and the remaining project work by a ilxed-price contractor.

CA-639, Palnting Water Plant Structures, 100-DR Area

With scoping coupleted, a design order for $\$ 500$ was written for preparation of specifications for uso by a flred-price contractor.

CG-642, Continuous Charge-discharge Fac1lity at 105-C

Detalled design including procurement of equipment components for testing purposes Is the responsbility of Design Section. Some dravings have been issued for colment. Project comittee meetings were suspended during December 1.955.

CG-643, Redox Capacity Increase, Phase III

Construction work was about 54 per cent complete at the end of the month, and a construction achedule is being circulated for approvals.

Minor Construction completed modification of D-11 Alunnage and 2-E column and delivered them to the 200-W shop for mock-up. Work has been started on mock-up of modifled ressels and jumpers. The Redox shutdown was temporarily postponed because of operating difficulties.

CG-645, Plutonium Fabrication Laboratory

Over-all construction progressed 14 per cent to a total of 98 per cent. All gerVice piping, ventilation, and laboratory equipment has been fabricated and installed. Minor painting and electrical items are being completed.

CG-646, Modiplcation to P1ckling Machines, 313 Bullding

The revised project proposal requesting a total of $\$ 55,000$ for installation and the balance of design and procurement funds is befng clrculated for approvals. Bids are being received for the required equipment.

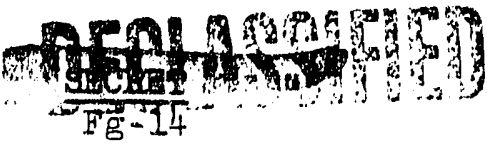


CG-648, Aux1liary Radiolodine Remoral and N1tr1c Ac1d Recovery, Redax

The proliminary profect proposal requesting design funds was authorlzed by

Diroctive HW-367 dated November 23, 1955. The project proposal requesting conatruction funds is being routed for approvals.

CG-649, FY-1.955 Weter Tank Replacements, 100-200 Aross

The profect proposal, wilch was transmitted to AEC on November 17, 1955, is st1II araiting authorization.

CG-650, Replacement, Repair, and/or Removal of Valve Houser, 100-B, D, and F Areas

The project proposal requesting $\$ 65,00$ w was transmitted to AEC at the end of November 1055. An AEC representative has ruflewed the fleld work requested for the project.

\section{IR-191, 321 Bullding FIre Protection and Staging Study}

Over-all construction was 19 per cent complete. Installation of the fire protection system was begun on December 1, 1955. The installations included electrical conduit and boxes in the basement, main Ploor, and canyon areas.

\section{IR-198, Redax Stack Sprax Piplng Modification}

Construction work progressed to about 60 per cent complete. Installation of piping modifications within the atack has been completed. The other work consistings of Installation and tie-in of the pump and removal of a temporary ladder within the stack is to be performed after delivery of the pump in January 1956.

IR-200, Graphite Machining Facilities, 300 Area

The informal request was approved by AEC on December 16, 1955. A total of $\$ 4,850$ was authorized General Electric Company for design and engineering functions.

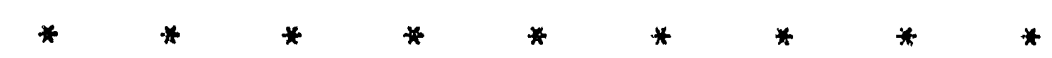

The following studies and Engineering Requests, Involving preparatory work and scoping of future projects, were active during the month:

ER A-1219, 105-KW Laboratory

The deciaion was made to have this work performed by a fixed-price contractor. The project proposal has been revised accordingly and is being circulated for General Electric approvals.

HR A-1227, Provide Additional Storage and Shop Space in the 105-B, $D$, and I Bulldings

The project proposal, was returned with coments by Manufacturing Department, and these coments are belng incorporated in a linal draft. The method of performing design is also being re-evaluated.

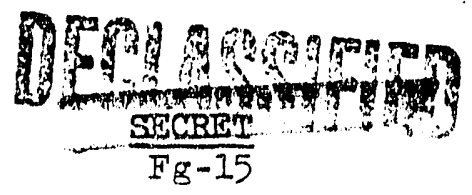




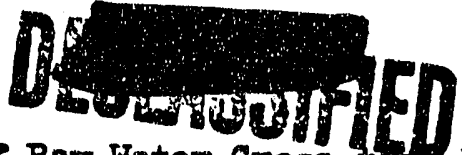

HWT -40692

IAR A-1229, Installation of Raw Hater Cross-tie, 105-C

The project proposal is belng routed for General Electric approvals.

ERR 2764, 2101 Bullaling Converalon

The project proposal is being routed for General rlectric approvals.

IER 2767, Additional Redox Ilguld Cooling Waste Cribs

The project proposal was transmitted to ABC on December 20, 1955, for authorization.

FRP A-3122, Beplacemont of Steam Plant, Deaerator, 384 Bullding

The Manufacturing Dopartment is studying the reaults of tosts made during cold weather periods.

Hin 3125, Roof Repairs, Central Storea

A work arder has been recelved authurelzing $\$ 400$ additfonal funds for preparation of the project proposal.

HAR 3127, Painting of Two High Tanks at 105-C Area

Work was suspended unt1l further notice because of adverse weather conditions.

IR 3128, Decontamination Facilities, 100-H, 200-W, and 300 Areas

The project proposal is being routed for General Electric approvals.

ERR 3131, Shlolded Personnel Monitoring Station, 747 Building Addition

The project proposal is being routed for General Electric approvals.

FR 3132 , Equipment Installation in the 314 Building

Rough draft coples of the project proposal have been distributed for comments. The work has been classifled as a major process plant 1marovement project with 20 per cent of the cost to be charged to Cost Accounts and 80 per cent to Capital Accountz.

ER 3133, Alteration of Laboratory Area Bulldings

The project propasal is being prepared, and the costs are to be charged to Capital Accounts.

ER 3134, General Improvements, Central Stores

The informal request for lighting improvements in the 1171 builaing is being routed for General Electric approvals. The project proposal for improvements to storage yard \#I and the parking lot is in rough draft. 
ER 3135, OPfice Addition to $141-M$ Buflding

The project proposal is being delayed pending a dectsion of the Radiological Sciences Department on the question of proceeding at a roduced cost.

\section{Related Functions}

The workload of orders requiring inspection decreased both in number and in dollar valus. Of the 649 orders requiring inspection, 618 have been assigsed as follows: off-site, 501; on-site, 102; government agency, 15. The total money value of ass igned orders was $\$ 10,88 \mathrm{C}, 000$. The workload for the Corrosion Testing Program remained approximaty level, with 242 corrosion tests, 76 macro and micro tests, and 94 chemical determinations. To accommodate the increasing workload for on-site inspection, additional facilfties have been made avallable at Hanford.

Followin is a resumd of inspection activities during the month:

\begin{tabular}{lcr} 
Items & Number & Value \\
\hline Iew orders recelved during the month & 105 & \\
Total arders for Items requiring inspection & 647 & \\
Cumulative orders ass igned to inspectors & 618 & $\$ 10,880,974$ \\
Orders assigned to inspectors this month & 127 & 548,444 \\
Orders completed during the month & 199 & 856,716
\end{tabular}

The emphasis of work ior off-site inspectors continued to be on calciners, reactor compoivstas, and process water pumps.

The workload for Reproduction and Engtneering Files Units decreased sharply in comparison with the high production for November 1955. The reproduction output was 323,795 square feet, and the distribution by Ensineering Files was 156,778 prints. The largest single order was 13,574 prints for Reactor Plant Modification.

Estimating Onit workload increased by about ten per cent to 83 , of which 29 were completed. The completed estimates included the following: study, 13; project proposal, eight; construction, four; fair cost, three.

Fleld Surveys performed additlonal work on the aurvey of Ricnland, Washington, consisting of subdivialons and lot divisiops. This Unit also provided routine services including control points, topographical surveys, and volume measurements of graphite.

Project cost control and administrative punctions were realigned for more precise controls and presentation of construction data. Property evaluation was being made on nine projects, and three of these were completed during the month. Other assistance was given with inventories, appraisals, statistical reports, and speciai project reports.

\section{Orapt Labor}

See Summary above.

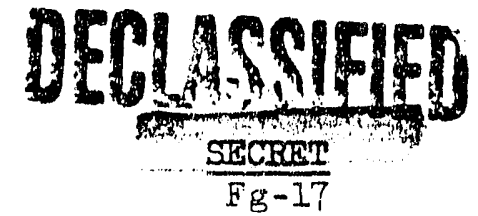




\section{A. To Hanford, Decembor 1955}

N. A. Basmusaen, Pryer-Knowles, Seattle, Washington, visited R. M. Griffith on December 1 to assist with adjustment of equipment for $300 \mathrm{Area}$.

C.S. Slenning, Minneapolla-Honeywell, Minnespolls, Minnesota, Visited E. S. Bell on December 19 to assist with ventilation balancing in the $141-F$ Building.

B. To Other Installations, December 1955

G. I. Swezea visited the Bonneville Power Administration, Portland, Cregon, on December 1 to pertorm design Ilaison on the $230 \mathrm{KV}$ transmission line.

H. H. Hubble Visited DeLaval Steam Turbine Company, Trenton, New Jersey, on December 1 Por englneering consultation with the vendor inspector.

W. D. Richmond risited the Foxboro Company, Boston, Massachusetts, on December 14 to place the order and arrange for fabrication of calculators for 100-DR Area.

W. W. McIntosh visited points in M1ssour f from December 4 to 18 to recruit engineering and technical personnel. 


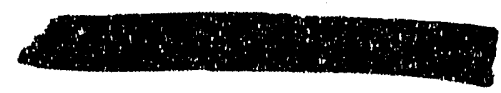

EW-40692, ?

\section{ADVANCE ENG DVEERIVG SECTION \\ MONTHLY REPORT \\ DECEMBER 1955}

An evaluation study of graphite and light water moderated bolling reactors was issued as HW-40708. For production reactor use, designs in which each tube is individually accessible were regarded as preferable to "tank-type" designs.

Studies of the desirablitty of using uranium oxide fuel elements in present piles and of the use of organic liquids as reactor coclarts we lnitiated during the month.

$$
\text { 7.w. Albaugh }
$$

Manager, Advance Engineering

FW Albaugh:pik EMTGIJVERTINC DEPARTMENT

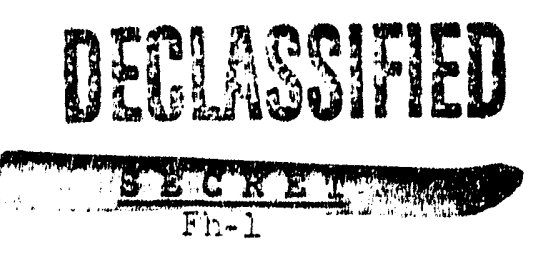


FERSONREI PRACTICES SECTIOI!

The number of applicants interviewed in December wa 1331 as compared with 1.550 for November. In addition, 69 new applicants applied by ma1l. Open, nonexempt, nontechnical requisitions decressed from 167 at the beginning of the month to 85 at month end. Ninety-elght exployees were added to the roll and 44 removed during the month. The separation rate for fiscal month of December was .61\% and for fiscal. month of Hovember. $51 \%$. These rates when converted to annual rates are $6.36 \%$ and $6.65 \%$ respectively. During December 184 new requests for transfer to other type of work were recelved by Bngloyment and 19 transfers were effected. Attendance recognition awards were distributed to 241 employees in December, including 30 who qualified for five year awards.

There were no deaths during the month of December. One hundred and sixteen visits were made to employees confined to Kadlec Hospital, and 14 checks were delivered. to employees coufined at the hospital or at bome. At month end, participation in the Pension Plan was $98.7 \%$, in the Insurance Plan $99.6 \%$, and the pmployees Savings and Stock Bonus PIan 53.2\%. At month end there were 638 non veterans registered under Selectlve Service and 709 military reservists were on the roll. Since August 1, 1950, 427 employees have terminated to enter military service, of which 170 have returned, 55 have not claimed remployment rights, leaving 202 still in military-leave status.

One hundred and twenty $81 x$ adopted suggestions were spproved for awards in December resulting in cash awards totaling $\$ 2,265$ with a total net savings of $\$ 13,375.26$.

Since the beginning of the 1955-56 season, 74 offers have been extended to BS/MS graduates for the Personnel. Development Program. There have been 7 acceptances to date. Acceptances have been received from 22 experienced candidates. To date $4.34 \mathrm{PhD}$ cases have been considered, 80 have been invited to visit and 29 have accepted invitations to visit.

\section{EMPIOYEE COMMUNICATIONS AND PUBLIC RELATIONS}

The Press Relations Unit issued 53 releases during the month, 10 of which were especially planned for national publicity purposes and were sent to the Schenectady Press Relatioris section. Elebt manuscripts were approved for publication, and nire technizal papers receired all required approvals. Arrangements were made for three speeches to be delivered before public groups. The Community Newsletter was written and distributed to community lesders in Pasco, Kennewick, and Richland. Five Management NEWS Bulletins were produced and distributed to all exempt personnel during the month.

Hanford laundry plctures appeared in the THIS WHEK section of the New York HERAID TRIBUNE - circulation 528,000.

Three booklets were completed and delivered to plant "customers" during the month; copy for three booklets was prepared and submitted to "customers" for approval; and preparation of copy for two booklets was begun.

$$
\text { G- } 1
$$


Fifteet radio programs of the INSIDE HANFORD and GE HANFORD SCIENCE FORUM shows were produced and broadcast regionally during December by affiliate stations of the Eastern Washington network.

Seven "live" television programs of the GE HANFORD SCIENCE FORUM and THIS WEEK AT HANFORD shows were produced and telecast to regional and local. viewers during December by five Eastem Washington television stations.

Graphics work on the "1955 at Hanford" annual report is progressing on schedule. The first rough draft is being edited and consolidated.

A total of 367 photographic assignments were covered for the month of December, and 13,940 prints were produced.

\section{UNION RELATIONS}

On December 28, 1955, a law suit was brought by the Hanford Atomic Metal Trades Council against the Company calculated to force arbitration of the establishment of the new classification of Gauge Worker. The Company's answer to the complaint is due by January 17 .

Retroactive pay adjustments to 110 employees who had been improperly paid under the double-time pay provisions of the 1954 HAMTC-GE Agreement were made during the month.

To date some 20 area meetings with supervision have been held to discuss contract revisions and interpretations. A step up in meetings is scheduled for January folicwing distribution of Agreement booklets.

Receipt of HAMTC and HGU Agreement booklets from the printer is expected the first wesk in January, at which time distribution will be made to all exempt exri-ress on the addressograph list and to the employees through the unions.

Sime 20 : $\therefore$ f negotiations were satisfactorily resolved during December.

\section{SAIAF: AND NACE ADMINISTRATION}

[r.t.s the moth plans were completed for conducting the annual exert employae arpresa: Salary \& Wage Auministration Advice No. 6, containing the instruction:

fr. ini. program was issued and all preliminary work required of this seotion was

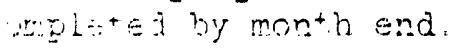

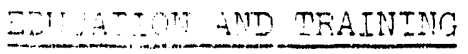

Di the original registration in the School of Nuclear Engineering- jas, the a actively pursuing their course work. This compares very favorably to the expertence in frevious terms. Twenty graduate courses and nineteen college-level and vo:stidura.h courses have been planned for the Spring semester. Five of these are new courses.

\section{VEFETES AND SAEETY}

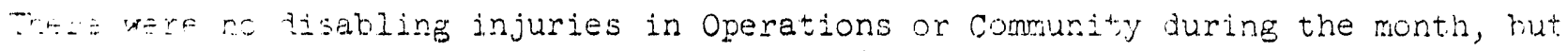
$\because \therefore$ aear serzous accidents were investigated. The dzsabiing injury frequency rate $\therefore$ : 2955 wa: 0 40 and the severity 708. It was 0 o for the Commurity.

$$
G-2
$$


The average dally adult census decreased from 49.2 to 43.6 as compared w1th 60.6 a year ago. The average dally new born census was about the same at 8.8 . This is a continuation of the low census figures which resulted in a $20 \%$ decrease for 1955 as compared w1th 1954.

An "Institute on Human Relations" for sanitarians in southeastern Washington was presented in Richland by Dr. Ted Barnowe, University of Washington, and Mr. Dan Prosser, State Department of Health consultant in mental health.

\section{AUXIIIARY OPERATIONS AND PLANY PROTIECTION}

Bids were recelved from two directory publishing companies for three annually speced editions of the RIchland Telephone Directory. A high bid of $\$ 36,000$ was sibmittad by General Telephone Directory Company of Des Plaines, Illinois. This bid wili produce $\$ 1,000$ per year more than any previous editions.

Outstanding unaccounted for documents were reduced from 197 to 195 during the month. A net reduction of 41 documents was made during the calendar year 1955.

\section{COMMUNITY}

Effective December 12 the normal force of the Richland Police Department was reduced from 40 to 38 employees.

On S-D Day, December I, Richland experienced only six reportable accidents with damages estimated at $\$ 755.00$. There were no injuries reported in any of the accidents. On S-D Day a year ago, December 15, 1954, Richland experienced only one traffic accident and no infuries. However, a year ago there was no snow and ice on the roads.

LLCerman/jak

$1, / 20 / 56$ 
Employee and Public Relations

PERSONNER PRACTICES

Employment

November, 1255 December, 1955

Applicants Interviewed

1,550

1,331

238 of the applicants Interviewed during December were Individuals who applied for.employment with the Company for the first time. In addition, 69 applications were recelved through the mail.

November, 1955 December, 1955

Open requisitions

Exempt Nonexempts

Of the 167 open, nonsxempt, nontechnical requisitions at the beginning of the month, 92 were covered by interim commitments. Of the 85 open, nonexempt, nontechnical requisitions at month end, 51 were covered by interim commitments. During December, 69 new requisitions were received requesting the employment of 83 nonexempt, nontechnical employees.

November, 1955 December, 1955

Employees added to the rolls

Employees removed from the rolls

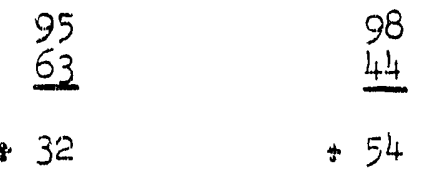

NET LOSS OR GAIN

$+32$

Fiscal Month Fiscal Month

November, 1955 December, 1955
Male Female Male F'emale

Separation Rate:

$.31 \% \quad 1.144 \% \quad .37 \% \quad 1.71 \%$

Fiscal Month Fiscal Morth

Norember, 1.955 December.. 1.955

Over-a.1. Separation Rate:

$$
.52 \%
$$

During December, 9 employees left voluntarily to accept other employment and 2 left. for business for self. 
Employee and Public Relations

PERSONIEEX PRACTICES

Transfer Data

Accumulative total of requests for transfer recelved stnce l-I-55

Number of requests for transfer recelved during December

Number Intervlewed in December, Including promotional transfers

Transfers effected in December, Including promotional transfers

Transfers effected since 1-1-55, including promotional transfers

Transfers effected in December for employees being laid off

Number of stenographers transferred out of steno pool in December

493

Transfer requests active at month end

ADDITIONS TO THE ROIIS

Exempt Nonexempt Comunity Firemen Total

New Hires

Re-engaged

Reactivates

Transfers

Total Additions

\begin{tabular}{rr}
6 & 71 \\
- & 2 \\
2 & 15 \\
2 & $=$ \\
\hline
\end{tabular}

$-\cdots$

$--$

77

2

17

$\underline{2}$

10

88

$\underline{-=}$

98

TERMINATIONS FROM TEEE ROIIS

Exempt Nonexempt Community F'semen Totia

Actusi Terminations

Reriorals from rolls (deactivates)

Transfers

3

14

17

$\begin{array}{r}2 \\ 1 \\ \hline\end{array}$

$2 \quad 23$

$\begin{array}{r}23 \\ 1 \\ \hline\end{array}$

25

6

38

$\underline{-\infty}$

2

Totial Terminations

GENERAI

$\begin{array}{lcc} & 11-1955 & 12-1955 \\ \text { Phctiographs taken } & & \\ \text { Fingerprint impressions } & 163 & 150 \\ 88 & 32\end{array}$

PERSONREL SECUR ITY QUESTIONNA IRES PROCESSED

\begin{tabular}{|c|c|c|c|}
\hline & & $11-1955$ & $12-1955$ \\
\hline $\begin{array}{l}\text { General Electric Cases } \\
\text { Facility Cases }\end{array}$ & & $\begin{array}{l}1.35 \\
18 \\
\end{array}$ & $\begin{array}{r}88 \\
9 \\
\end{array}$ \\
\hline & Total & 153 & 97 \\
\hline
\end{tabular}




\section{Employee and Public Relations}

\section{PERSONNEU PRACTICES}

As a result of the publicity regarding the impending force reduction in the Separations Section, 134 Requests for Transfer have been recelved from Separations Ut1lity Operators. Sixty-elght of these employees have been intervlewed to date and arrangements were completed during the month to transfer 35 of these people to other positions in the Plant. In addition, to this number arrangements were made to transfer five Plumber Steampitter Journeymen, one Millwright Journeyman and two Instrument Trainees. Offers were made to another 20 Utillty Operators who rejected the job of fered. So far, two Separations personnel have been transferred with the bulk of the transfers arranged to take place in January.

In an effort to establish more contacts for stenographlc personnel the following schools have been contacted: Sunnyside High School, Grandview High School, Prosser High School, Toppenish H1gh School, St. Patrick High School, Touchet High School, Walla Walla Business College, Walla Walla College, Walla Walla High School, Whitman College, Riverview H1gh School, Yak1ma Senior E1gh School, St. Joseph Academy, Moxee High School, Yakjma Valley Junior College, West Valley High School, Selah High School, Highland Figh School, Yakima Business College, and Columbia H1gh School.

Personnel Records and Investigations

\section{INVESTIGATION STATISTICS}

Cases received during the month

Cases closed

Cases found satisfactory for employment

Cases found unsatisfactory for employment

Cases closed before investigation completed

Special investigation conducted

PERFEC'I ATTENDANCE RECOGNITION AWARDS

Tothl one-year gwards to date since January 1, 1950

One-year awards made in December for those qualifying in November

Total two-year awards to date since January 1, 1950

Two-year awards made in December for those qualifying in November Total three-year awards to date

Trreewyear awards made in Decerber for those qual.ifying in November

Total four-year awards to date

Folu-year awards made in December for those qualifying in November

Total five-year awards to date

Five-year awards made in December for those qualifying in November 
Employee and Public Relations

PERSONNEL PRACTICES

SERVICE RECONITION

Total Service Recognition Pins presented to date

Five-year Service Recognition Pins presented during December to Exempt pers onnel

5491

Five-year Service Recognition Pins presented during December to Non-exempt personnel

During December, 16 people whose continuity of service was broken while in an inactive status were so informed by letter.

\section{Employee Services}

The following contacts were made with employees during the month:

Employee contacts made at Kadlec Hospital

Salary checks delivered to employees at Kadlec Hospital

Salary checks delivered to employees at home

At the end of the month, participation in the Benefit Plans was as follows as compared with last month's participation:

\begin{tabular}{|c|c|c|}
\hline & NOVENBER & DECEMBER \\
\hline $\begin{array}{l}\text { Pension Plan } \\
\text { Insurance Plan } \\
\text { Saving \& Stock Bonus Plan } \\
\text { Good Neighbor Fund }\end{array}$ & $\begin{array}{l}98.6 \% \\
99.6 \% \\
53.4 \% \\
70.2 \%\end{array}$ & $\begin{array}{l}98.7 \% \\
99.6 \% \\
53.2 \% \\
70.0 \%\end{array}$ \\
\hline
\end{tabular}

There were no deaths during the month of December, therefore the number of life insurance clairns remain at 184 totaling $\$ 1,269,776.66$.

There were no employees to retire during the month of December.

A total of 79 new employees attended Orientation Programs given by members of this group during the month of December. "97\% have signed up to participate in the Insurance Plan, 100\% have signed up to participate in the Pension Plan, and 96,0 have signed up to participate in the Good Neighbor Fund.

Twenty letters were written in regard to matters concerning deceased employees and their families during December regarding payment of monies from the Company, and general information.

* One wajer was received because this employee is covered under Dependent Insurance of spouse. 
Employee and Public Relations

PERSONNEL FRACTICES

Military Reserve and Selective Service

Total number of non-veteran employees subject to military service training through Selective Service System

$\begin{array}{lr}\text { Number Classifled IA } & 152 \\ \text { Number Classified IAO } & 1 \\ \text { Number Classified ID } & 54 \\ \text { Number Classified 2A } & 110 \\ \text { Number Classified } 3 \mathrm{~A} & 233 \\ \text { Number Classified } 4 \mathrm{~A} & 3 \\ \text { Number Classified } 4 \mathrm{~F} & 83 \\ \text { Number Classified 2S } & \frac{2}{638}\end{array}$

Number of Technically Trained \& Engineering Personnel for whom deferments are currently being requested

Number of Non-Technically Trained \& Engineering Personnel for whom deferments are being requested Total $\frac{6}{12 I}$

Accumulated total of deferments requested 1583

Ac:umulated total of deferments granted 1277

Current number of deferment requests pending

Curont number of deferment requests denied

Current number of deferment requests granted

\section{During Month of December}

Number of deferment, requests pending at Local Board Leve.].

Number of deferment requests pending at Appeal Board Level

Number of deferment requests pending at Presidential Appeal Level Total $\quad \frac{1}{26}$.

Number of deferment requests denied by Local Boards

Number of deferment requests denied by State Appeal Boards

Number of defarment requests denied by Presidential Appeal Boand

Total 
Number of deferments granted by Local. Boards

Number of deferments granted by State Appeal Boards

Number of deferments granted by Presidential Appeal Board

Total $\quad \frac{0}{12}$

Number of Technica.ly Trained \& Engineering Personnel denied, or requesting no further apeal, now pending induction

Number of Technical Graduates with over two years of deferments

Number of Selective Service vulnerable Technical Graduates Enlisted

Number of Selective Service vulnerable Technical Graduates Drafted

Number of Technical Graduates called to active duty under R.O.T.C. .

Reservists Data - Total Number of Reservists on Roll

Number of Active Reservists

Number of Inactive Reservists

Number of employees in the National Guard

Reservists and National Guard members subject to drills, tours of ditiy, Cruises, Sumer Camp and/or Weekly or Monthly meetings

Military Service Leaves of Absence - August 1, 1950 thru Dec.31, 1955

Reserrists

Selectivs Service System

Female Employees Enlist,ed

Total number returned to roll

$\begin{array}{lr}\text { Reservist.s } & 72 \\ \text { Sel.Serv.Sys. } & \frac{98}{170}\end{array}$

Known number not claiming reemployment rights

Number of employees.still on military leaves 
Suggestion Plan

Suggestions Received

Acknowledgements to Suggesters

Suggestions Pending Acknowledgement

Suggestions Referred to Departments for Investigation

Suggestions Pending Referral to Departments

Investigations Completed and Suggestions Closed

Suggestions Adopted - No Award

Adoptsed Suggestions Approved by Board for Award

Total Net Cash Savings

Total Cash Awards

Total Number Suggestions Outstanding to Departments

\begin{tabular}{|c|c|c|}
\hline November & December & $\begin{array}{l}\text { Totial since } \\
7-15-47 \\
\end{array}$ \\
\hline 275 & 244 & 18483 \\
\hline 238 & 250 & \\
\hline 56 & 50 & \\
\hline 290 & 289 & \\
\hline 58 & 55 & \\
\hline 238 & 274 & \\
\hline 1 & 0 & \\
\hline 67 & 126 & \\
\hline$\$ 11,985.58$ & $\$ 13,375.26$ & \\
\hline$\$ 1,885.00$ & $\$ 2,265 . n 0$ & \\
\hline 513 & 4 & \\
\hline
\end{tabular}

Cumulative suggestion statistics for the year 1955, compared with 1.95\%, are:

\begin{tabular}{|c|c|c|c|}
\hline & 1.955 & 1954 & Increase \\
\hline $\begin{array}{l}\text { Received } \\
\text { Adnpted } \\
\text { \% of Adoption }\end{array}$ & $\begin{array}{r}2,862 \\
1,073 \\
37.5 \% \\
\end{array}$ & $\begin{array}{r}2,579 \\
763 \\
29.6 \%\end{array}$ & $\begin{array}{l}1.1 .1 \% \\
40.6 \% \\
25.7 \%\end{array}$ \\
\hline Awarda & $\$ 23,684$ & $\$ 16,665$ & $42.1 \%$ \\
\hline Savingis & $\$ 172,189$ & $\$ 124,487$ & $38.3 \%$ \\
\hline Avgrd/Savings & $13.8 \%$ & $1.3 .4 \%$ & $2.9 \%$ \\
\hline
\end{tabular}

The propoed OPG regarding decentrallzation was distributed to department; managers for theiz revatis.

\section{Iife Irexance}

Tintoty-jo requets for code information were reseived fum irsumarce omparie ard in-

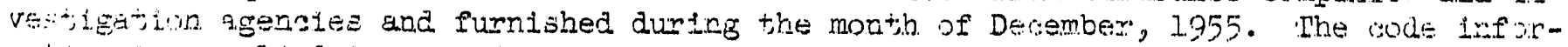

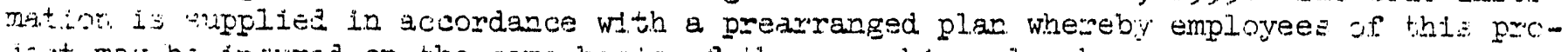
feot, may he insured or the same basis of those working elsewhere.

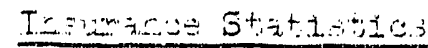

Qizime renonterd to

Department of Labor

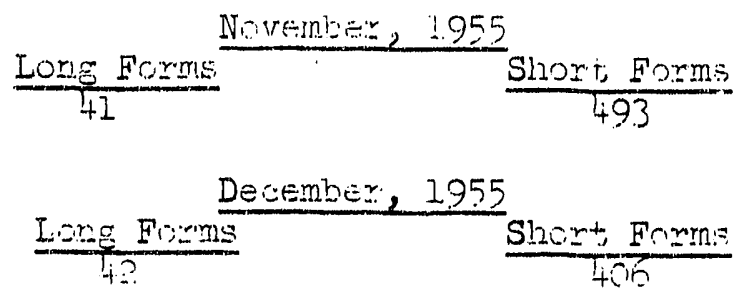

Tral arot Septemer, $1946-30,535$ 
EMPLOYEE AND PUBLIC RELATIONS DEPARIMEHTI

WORKMEN'S COMPENSATION AND SUGGESTION PIAN

In ulrarce Statistics, Continued

Claims reported to

* Of these claims 12 were property damage and 1 bodily injury.

Tctal Since September, $1946-1,044$

\section{Wortuen i Compensation}

¿. Wo:dror W. Mortgomery, 8001879 -- Date of Injuny: 6-4-54; Employter: General Elertute Company; Nature of Infury: Contuzion of retk

Mw. Montgmery, a fireman, sustained a contus ton of the neck while riding a fins twuk in the course of his employment. His clatm wa: allowel by the Dinisment if Labor and Industries and is open at the present time. In oc:-sher of $1.954 \mathrm{Mr}$. Montgomery filed a summone and complaint against the Bl-w Krox Compary alleging that they had regligently failed to provide didequate barricades and lights, etc. for an ob:tructinn in the road and that is: $a$ vesult Mn. Montgomery sustained serious lniuries. Recentiy, Mv. Charles Pourell, the defendant':s attorney, proposed that onnadideration be:

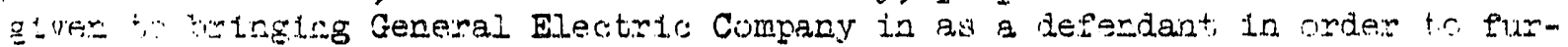

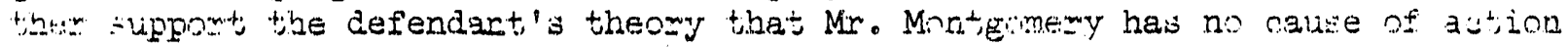

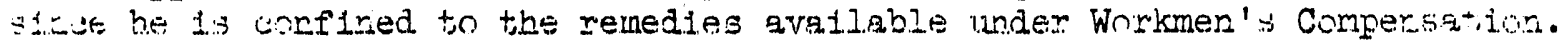
I: 1.4 olm understanding that rothing deflutte has beer wore along those lines I. A that the proposal is merely being anc:idered. It is our opinion that the

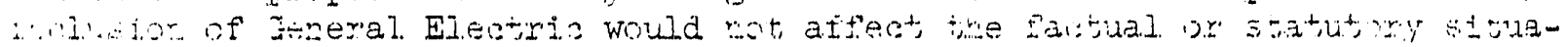

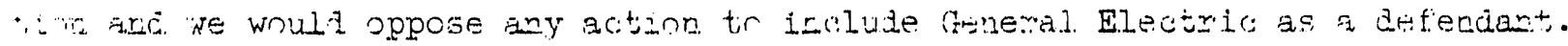

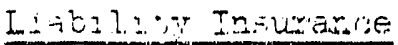

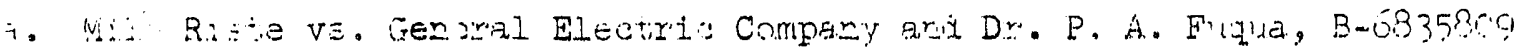

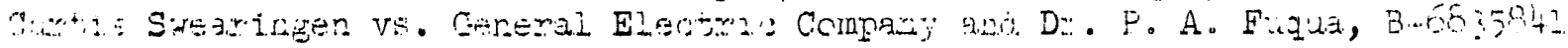

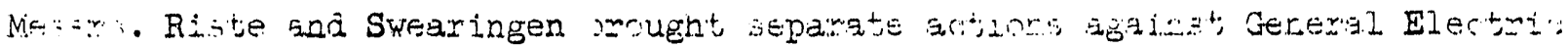

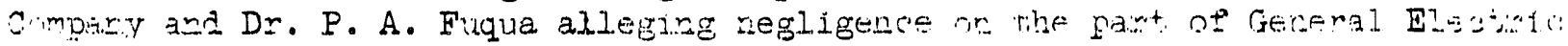

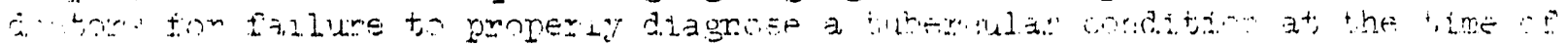

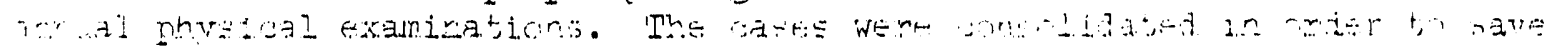

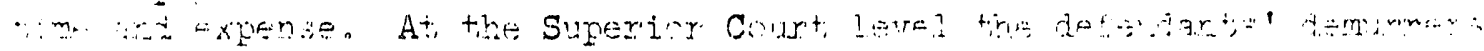

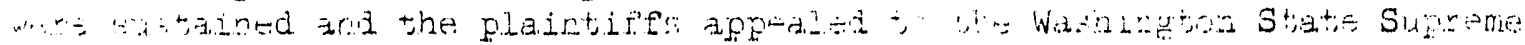

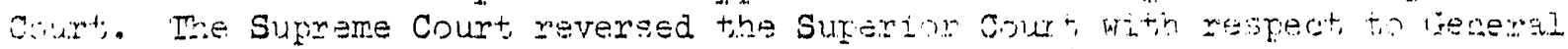

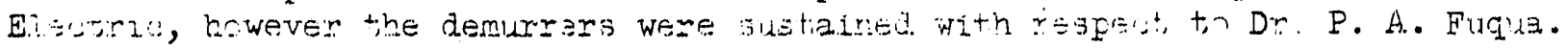

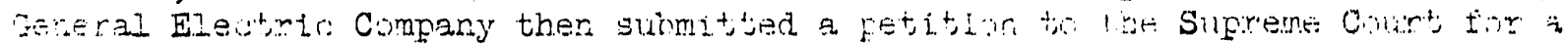
rehearing ard the Supreme Court has asked the plairtiffi' attorney to arswer

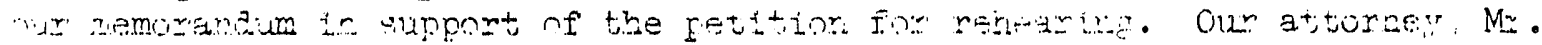

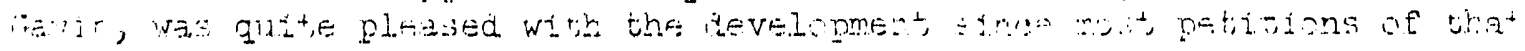

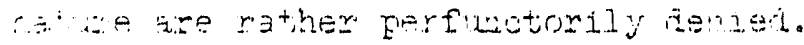

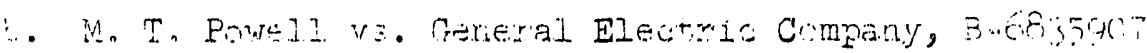

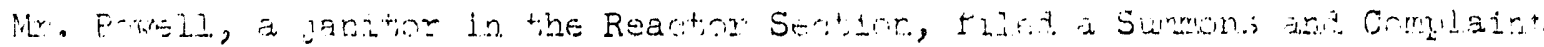


EMPLOYEE AND PUBLIC RELATIONS DELAIITMENTI

\section{WORIMEN'S COMPENSATION AND SUGGESTION PLAN}

Lirability Insurance, Continued

alleging loss of vision in his right eye as a result of an infury allegedly sustalned when he was struck by an ash tiay thrown by a fellow workman. The Complaint alleged damages in the amount of $\$ 25,000$. The case was set for trial on December 28 in Yak1ma in the U. S. District Court for Southeastern Washington. At that tirne the plalntiff's attorrey asked for a continuance or a Dismissal Without Prefudice. The continuarce was denied, however it wa a areed to stipulate to a Dismissal Without Prejudice and with impnsi.. tion of costs. The plaintiff's attorney advised that a new action may be expscted very shortly setting out the same allegations as containe? in the previnus Summons and Complaint. They have until rext August to enter the rew Complaint. 


\section{Techrical Personnel Placement}

\section{Personnel Development Program}

Four recruiters attended 12 colleges and universities in Regions 5 and 6 during the month. This completed the fall recruiting with a total of 14 Hanford representatives attending 33 schools resulting in 74 program offers to date and 23 offers to be made.

The current status of the Personnel Development Program may be summarized as follows:

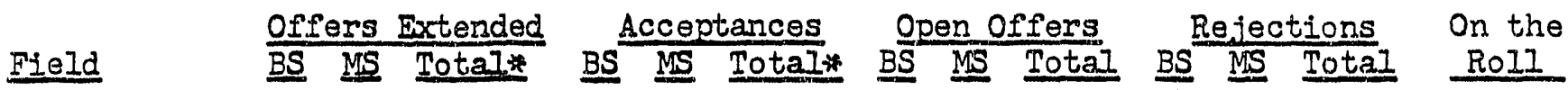

\section{Engineering:}

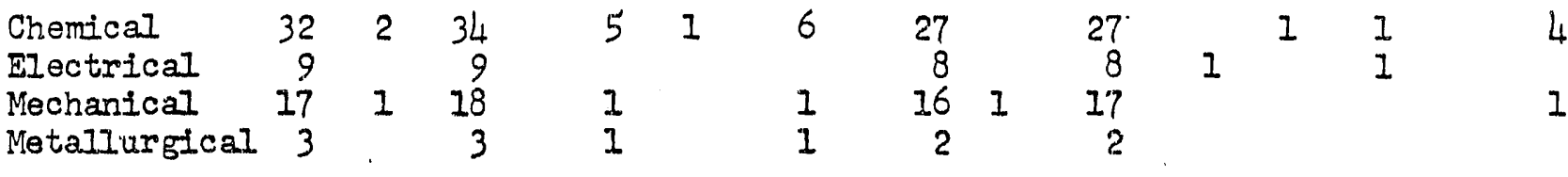

Science

$\begin{array}{lccccccccccccc}\text { Chemistry } & 5 & 3 & 8 & 2 & 1 & 3 & 3 & 1 & 4 & 1 & 1 & 2 \\ \text { Physics } & 1 & 3 & 4 & 1 & 2 & 3 & & 1 & 1 & & & 1 \\ \text { Other } & 7 & - & 7 & 1 & - & 1 & -6 & - & -6 & - & - & - & - \\ \text { TOTAIs } & 74 & 9 & 83 & 11 & 4 & 15 & 62 & 3 & 65 & 1 & 2 & 3 . & 8\end{array}$

*Offers and acceptances totals include 9 carry-over offers from the 1954-55 season of which 8 were acceptances not on the roll as of $9 / 1 / 55$.

Experienced BS/MS Recruiting

Fiftywight exrerienced BS/MS applicants were considered during the month. Twentyeight candidates were invited to visit, 16 visited, 8 offers were extended, 8 candidates accepted and 5 reported on the roll. 


\section{BS/MS Experfenced Recraiting - Continued}

The following table sumarizes the Experienced BS/MS recruiting to date:

Engineering:

Chemical.

Mlectrical

Mechanical

Industrial

Metallurgical

Civil

Ceological

\section{Casas} Considered
INVITATIONS

Tisited Tisit Open

OFFERS

\section{Science:}

\begin{tabular}{|c|c|c|c|c|c|c|c|c|}
\hline $\begin{array}{l}\text { Chemistry } \\
\text { Physics } \\
\text { Math-Statistics }\end{array}$ & $\begin{array}{l}26 \\
28 \\
25\end{array}$ & $\begin{array}{l}5 \\
5 \\
5\end{array}$ & $\begin{array}{l}3 \\
2 \\
1\end{array}$ & 1 & $\begin{array}{l}1 \\
4 \\
1\end{array}$ & $\begin{array}{r}10 \\
3 \\
3\end{array}$ & $\begin{array}{l}9 \\
2 \\
2\end{array}$ & \\
\hline Other: & $\underline{84}$ & 7 & 5 & - & - & 13 & 1 & $I$ \\
\hline TOTALS: & 269 & 60 & 30 & 12 & 12 & 57 & 42 & 1 \\
\hline
\end{tabular}

*offer totals include 24 carry-overg from the $1954 / 55$ season of which 20 were acceptances not on the roll as of $9 / 1755$, and 4 were open offers at that time.

\section{FHD Recruiting}

The fall. PhD campus visits have been ccinpleted wh th 22 Hanford representatives cartisipating in coordinated Company-wide PhD interviewing at 37 colleges and universities. About 50 J.S. campuses were visited by Company PhD teams this past fill compared with about 35 schools in previous years, the additional schools keing largely covered by single individuals since the number of randidates trailable at each was small. In previous years Hanford has participated in only 20 to 28 FhD canpus visits. 
PhD Recruiting - continued

The following tabulation sumarizes HAPO action since September I, 1955 on PhD candidates contacted during the current season:

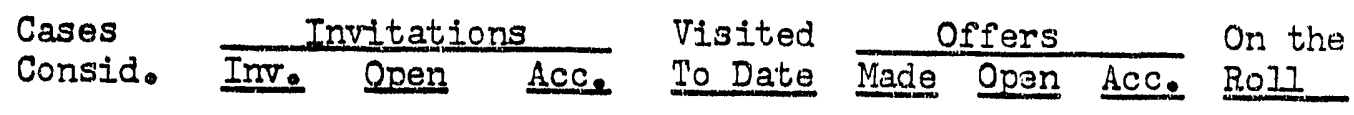

$\begin{array}{llllllllll}\text { New PhD's } & 447 & 110 & 40 & 56 & 32 & 2.1 & 5 & 10 & 4\end{array}$

Exper. $\quad 37 \quad 11 \quad 2 \quad \underline{6} \quad 6 \quad 2 \quad-$

$\begin{array}{lllllll}\text { Sub-totals } & 478 & 121 & 62 & 38 & 23 & 10\end{array}$

$1954-55$

$\begin{array}{llllllllll}\text { Carry-overs } & 44 & 41 & 5 & 32 & 20 & 13 & 5 & 7 & 0 \\ 55 / 56 \text { Totals } & 434 & 80 & 42 & 29 & 18 & 10 & 7 & 3 & 4\end{array}$

$12 / 31 / 54$

Totals excl.

$\begin{array}{llllllllll}\text { of carry-overs } & 358 & 7 & 1 & 6 & 5 & 5 & 2 & 3 & \text { - }\end{array}$

Terminations

During December there were 4 terminations of technical or major exempt employees. One left because of illness in his family, one for another job, one to go into business for himself and one transferred to New York. 


\section{Eroloyee and Pablic Relations Department}

\section{EMPLOYEE COMMUNICATIONS \& PUBLIC RELATIONS}

During the month, Press Relations issued 53 releases. The breakdown by category distribution and content was as follows:

Subject

Pey and Benefl.ts
Eumloyment Serrices
Good Will
Technolog and Research
Utilitios \& Public Works
Safoty, Fire
Administration and Legal
Richlanduanford Protection
Education and Iibrary
Health and Medicine
Plant Services
Organization Changes

7
5
5
24
1
5
2
2
2
3
3
4

Distribution

\begin{tabular}{lr} 
Hanford Area & 40 \\
West Coast Area & 3 \\
National. & 9 \\
Other Special & 1 \\
& \\
Content & \\
\hline Information & 7 \\
Plctures & 1 \\
Short & 47 \\
Long & 1 \\
Feature & 3
\end{tabular}

National publicity releases sent to Schenectady Press Relations with carbon copies to B. A. Beaudoin included: a feature story with photos on the Banford railroad; the final approved version of a story with pictures of an "atomic sasen used at Hanford for storing and studying radioactively hot materials; a set of photos for possible placement in a large pleture magasine, the plctures included two very unusual extreme close-up photos of a shoep's eye, and an additional picture showing how these were taken; three papers presented by kanford employees at the Nuclear Engineering and Sclence Congress in Cleveland were described; story on time study motion pictures used at Hanford to study phases of operation in atomic reactors; finally-approved story on closed circuit color IV in use at Hanford; and finally-approved story on the uses of water in the operation of an atom plant.

Robert Schulman, Bureau Chief for TIME and IIFE at Seattle, called to express interest in a story on the G. E. School of Nhuclear Engineering for IIFE. The story was "sold" to LIFE in New Iork. Information and photos were sent to Mr. Schviman.

Hanford laundry pictures appeared in the "IHIS WEEk" section of the New York HERAID TRIBUNE - eirculation 528,000.

Story sent to the science-engineering list announced the appointment of Dr. Carl A. Bennett as manager of the operations research section at Hanford.

Release forwarded to the sclenomengineering list announced that Dr. A. B. Greninger had been selected to attend the advanced management course at Crotonville, N. I.

B. F. Butler's transfer from Hanford to New York was announced in a release distributed to the daily Iist. 
EMPLONES COMUNICATIONS \& PUBLIC RELATIONS

Local releases covered the lollowing storles:

J. R. Carrell's talk at the University of Idaho Dec. 7 on MEssential Differences Between Nhclear and Correntional Power Plants".

Telerision prealere of "Hanford Salence Form". Plctures of participants wero sent to several local papers.

I. I. Ceman's talk at a moeting of the American Institute of Chemical Engineers on "Relation of the Individual to Himself, Co-Workers and Management."

Change in Rlchland air rald warning sirons.

Allocation of the Mucleonfes Employees Good Noighbor Fund at Hanford.

Raise of room and service rates at Kadlec hospital.

Transfer of John W. Hall to Schenectady.

Story on Christruas holiday schedule for plant and community services.

Adrance notice of a talk to be giren by R. E. Rose at the Walla Walla, Wash., Rotary Club. Followmup story was forwarded to be distributed after presentation of the talk.

Stories of plant suggestion winners, retirements, gervice enlistees, promotions.

Story on men tho transferred from Hanford to the Conmonwealth Edison project at San Jose, Calif., was prepared for the Progress Edition of the Walla Walla UNION BULIETIN; also, a covering stary on the Geneva "Atoms for Peace" Conference, a story on the White Blutis fire department, and other previously-issued stories and photos were forwarded.

COLUNBIA BASIN NEWS reporter requested and was furnished further information on Kadlec hospital's raise in rates.

TRImCITY HERATD reporter asked for detalls of injuries to man caused by high winds at Hanford; also requested other information covering wind damage to buildings.

A story was released to the two local papers when a Hanford worker fell into a large tank contajning uranium nitrate.

Local papers were notified of damages sustained by a pick-up truck when it skidded and slid into a roadside ditch.

A release about the water treatment laboratory in use at Hanford was given to two local papers and the GE NENS.

COLIMBIA BASDN NEWS reporter requested and was furnished with information about advertising in plant buses. 
EMPLOTES COMUNICATIONS \& PJBLIC RELATIONS

TRI-CIII HERAID reporter inguired whother recent cold weather had "frozen" bus engines. Be was told that no buses froze up and there was no engine block damage.

The General Manager's New Iear's message was given to the two loc al papers.

COLDIBIA BASIN NEWS reporter Inquired whether Kadlec hospital would flle an application for Ford Foundation funds, and what funds would be used for. He was told that the ATC was looktag into the mattor.

COLUMBIA BASIN NEWS reporter inquired whother lot being cleared near administration buflding was to be used for parking. He was told that it would be.

Six requests from students and teachers for Information on atomic energ were answered.

At the request of the OFFICE magazine, New York, we forwarded to them a picture and story on the temperature-taking typenriter used at Hanford to make temperature maps of reactors.

The following manuscripts received all required approvals during the month:

Bergene Kawin, "Esflects of Cortisone Acetate Upon Distribution and Excretion of Radioyttrium," for submission to SCIENCE for passible publication.

R. D. Cilbert, "Paper Work Simplification by Manufacturing Engineering," for submission to a trade magazine.

R. C. Thompson, "Further Studies on the Gastro-Intestival Absorption of Plutonium," for resubmission to RADIATION RESEARCH.

R. D. Gilbert, "Work Measurement of Maintenance Supervision." This abstract was submitted as a possible signed article to Schenectady.

D. A. Sryder, "The Presentation of Labor" Variance Analyses." This outline was written far publication in a trade magazine and has been sent to Schenectady.

W. R。 DeHollander, "The Melting of Small Pieces of Uranium Metal," for distaribution under TID 4500 .

Roy Ko, nThe Quantitative Electrodeposition of Micro Amounts of Anericium," for submission to NUCLEONICS.

W. G. Spear, "A Single Transistor High Voltage Supplyg" writtion as an unclassified informal report.

An outline approved earlier, "Paper Work Simplification by Manufacturing Engineering," by R. D. Gilbert, was also submitted to Schenectady during the month. 
The authors' proof's for the Belllarts-Spencer-Peterson article were received during the month from NUCIEONICS magazine. Corrections were made and the proofs returned.

At his request, a copy of M. B. B. Socky's paper, "The Role of Nondestructive Testing at Hanford," sent to Mr. J. J. Timmer, Editor of WISTERN INDUSTRY.

A status report of the Signed Article program at Hanford was completed and distributed during the weok.

The following papers recelted all required approvals during the month:

S. H. Bush, "Application of Zirconium to Nuclear Reactors," for presentation at the ASM meeting on Norember 29, 1955.

J. F. Cline, "The Use of Atomic Energy in Agriculture -a Present and Future," for presentation at a meeting of the Sunnyside Rotary Club on Norember 28, 1955.

W. J. Dowls, "The Atointc Age," for presentation at the 4-H Club Leaders' nquet in Astoria, Oregon on November 30, 1955.

R. E. Brown, M. W. McContga and P. P. Rowe, "Geologlial and Hydrological Aspects of the Disposal of Ilquid Radioactive Winstes," for presentation at the Sanitary Engineering Conference in Cincinnati on December 6, $1955^{\circ}$

J. R. Mchenry, D. W. Rhodes, and P. P. Rowe, "Chemical and Physlcal Reactions of Radioactive liquid wastes with Soils," for presentation at the Sanitary Engineering Conference in Cincinnati on December 6, 1955.

J. F. Fletcher, "Irradiation Damage to Graphite," for presentation at a meeting of the Richland Naval Reserre Unit, on December 13, 1955.

D. W. McLenegan, "Professional Development -- The Importance of Early Planning," for presentation at an ASME regional meeting in Portland, Oregon, sometime in March 1956.

W. C. Roesch, "A Neutron Dosimeter Hating Uniform Sensitivity trom 0.1 to $5.1 \mathrm{Mev}, "$ for presentation at a meeting of the American Physical Sociaty, December 28-30, 1955.

W. C. Hanson, "Canada Goose Nesting Studies at HAPO," for presentation $a$ the Wildilife Society, Northwest Section, meeting in Spokane, Washington December 28-29, 1955.

Twenty-one of twenty-three slides for 0 . H. Pilkey's talk or Hanford tank farms were approved this month by Washington AEC office. Approval of these slides was not granted on two prerrious occasions.

$$
a b-4
$$




\section{EMPLOTYE COMMUNICATIONS \& PUELIC RELATIONS}

Two nembers of the Unit met with Mr. I. B. Mackey, Patent Counsel, Atomic Products Division, and local. Patent people during the month and succeeded in clarifying and simplifying patent clearance of papers and speeches.

Blographies of J. F. Fletcher and I. W. Iang, Engineering, were furnished to Iloyd Wejr. The two men w1II be guest speakers at the December 13, 1955 meeting of tho Rlchland Naval Reserve.

The following speeches were arranged during the month:

Presentation or Submission Date

Subject and Organization or Publication

Author.

December 7。 1955

"Some Interesting Facts About Hanford," and show the movie, "A Is for Atom," before the

O. C. Schroeder

January 17, 1956 "The Atomic Age," before the Rotary Club in Toppenish Chamber of Commerce. Eugene, Oregon

W. J. Dowis

Jamuary 17, 1956

"The Atomic Age," before the Electric League in Eugene, Oregon

W. J. Dowis

A Community Newsletter was prepared and distributed to community leaders in the Tri-City area. Fifty new pexsons were added to the list with this mailing, and each receired a letter signed by the Section Manager explaining the reasons for the Newsletter and other spocial mailings they will be receiving from time to time.

Copies of the November atomic power issue of the GE REVIEW were sent to the community leaders in the Tri-city area.

At his request, ten additional copies of this issus were furmished to $R_{0}$ K. Hermich of the Science Department at Columbia High School.

A Community Relations ad with a Christmas message was prepared and placed in the GE NEWS on December 23, in the COLUMBIA BASIN NEWS on Decomber 24 and in the IRI-CITY HERATD on December 25.

A conference was held with W. A. Halteman and Muriel Fulmer concerning production of motion plctures for use by IV as part of the HAPO public relations programs and recommendations were sent to Mr. Halteman in a letter.

A GE 1956 diary was sent to the principal of a Richland junior high school at his request.

Arrangement, 3 were made for cold lunches from the Desert Inn to be served to three Company lawyers from the East and four local people during an area tour.

Arrangements for refreshmentis for a Company dinner of 16 wers made during the month. 


\section{EMPIOTEE COMPONICATIONS \& PUBTIC REIATIONS}

A schedule for Ronald Reagan's visit on February $I$ and 2 was prepared. It was approved by the Section Manager and sent to D. W. Burke, R. W. Jackson and I. I. German.

Sereral booklets on the nation's atomic energy program were sent to Nr. T. A. Purton of Seattlo at his request.

Six copies of the speech, "The Middlemen in Management," by I. I. German were sent to the Personnel Manager of the Weyerimaeuser Tinber Company at his request.

A request was recelved for material which could be included in a monograph publication prepared by the National Bureau of Standards which will discuss various types of recorders. A copy of the November issue of the GERERAL EIECTRIC REVIEW which contained the article, "Data Processing in the Atomic Industry," by E. B. Montgonery was sent since this article is the only unclassified material available.

Eight GE booklets, discussing electricity, electrical engineering and electronics, were furnished to the local AEC office for transmission to a requesting student.

Fire copies of the Notember GE REVIEW were given to a HAPO scientist for transinssion to sereral high schools in California be had taught at in previous years.

A proposed communty relations program for HAPO for 1956 was comploted and submitted to the Section Manager.

F:ary Management NEWS Bulletins were produced and distrubuted during the month.

Three booklets were completed and del.ivered to Plant "customers". These Included "Air Iight," and "Radiological Defense Handbook, both for Radiological Seienses Department; and the BAMTC-GE and HGO-GE Agroement booklets, both $\because$ gususted by Union Relations.

The 36-page Technical Recruiting booklet, "Horizons at Hantord," was placed in product:on with the Walla Walla UNION BULlETIN at the reques? of Personnel Prantices Section. Proofs were read and corrected, and delivery of 2500 copies wili be made on January 6 .

Copg tor three booklets was. prepared and submitted to isistomers"s for appworal during the morth. These included "Radiation Protection for You," a handibook for a.1. emploryees, and "Double Check," which concerns the Bloassay Program, both requested by Radiological Sciences Department; and "Just. for Protestiong" $a$ radiation information booklet concerning the proper use of radiation zone boundary tape, requested by Separations Radiation Monitoring.

Preparation of copy was begun for two booklets: "Hanford's Metallurgy Building," requested by Engineering Department, and "1955 Hantord iatoty Report, "sequested by Health and Safety Section.

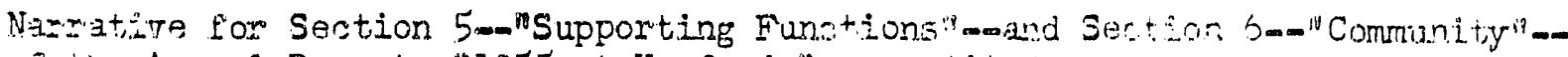
of the Annual Report., "I955 at Hanford," was edited.

$$
\text { Ghom }
$$




\section{BHPIONTE COMRONICATIONS \& PUBLIC RELATIONS}

A Communications Program concerning the 50th annitersary of the GE Suggestion $\mathrm{Plan}_{2}$ prepared by the Now York of 1 ce and adapted for Mlocalized" application, was bogun.

Distribution through Section Managenent of CE 1956 calendaris, diarles and logbooks was coordinated.

Holiday notice concerning the Christmas and New Years holidays was prepared for the signature of the Manager-Enmloyree and Public Relations, for bulletin board posting and publication in the CES NEWS.

The December safety topic, the December health bulletin, and December issue of "Your Mamulacturing Month" were completed and distruibuted.

Work was begun on communications concerning the General Manager's Report to Employees. Tlckets were ordered and completed through Printing. A letter to Section Management concerning ticket distribution was prepared and approved.

A letter to all employees of employee Commications and Public Relations Section, concerring the Section's absenteeism record, was prepared for the signature of the Section Manager.

Frection of poster frames in badge houses throughout 100 and 200 areas was complsted during the month.

The 5 OE NEWS Issues during December gave increased empasis to Safety, featuring a total of 19 safety articles.

A sommunications series of weekly "messages from the General Manager" was initiated during the month. Topics discussed by the General Manager in the series to date included Safety, Hunan Relations, a Christmas Message and a New Iears Message.

Extorts were Increased during the month to "localize" syndicated news and feature matiexial wherevex" possible. These efforts were reflected principally in the figrst staries of the New York-originated communications program concerning the $50 t$ h anniversary of the Suggestion PIan, and in President Cordinex's review of outstanding Company accomplishments in 1955.

Negotiations ar'e underway between representative of the GE NEWS, the TRI-CIIY HERAID, Pwochasing and Kennewick Engravers to arrite at a new solution to a vurrent problent of unsatisfactory engraving service. The present engraving prosedure, which is on a trial basis, involves the shipment of photo prints by rail to the Kennewick Engravers' office in Bremerton. It has proved incompatible with GE NEWS production deadlines.

Artwork completed during the month by the commerical artist included: a fullpage and one double-page GE NEWS photo layout; final layout and artwork for the 36-page recrusting booklet "Horizons at Hanford"; final. artwork for a poster concerning Audio Tisual Communications Unit radio and.TV programs arot and layout for the 1956 course catalog of personnel development courses of fered by Education and Training Section; a $4{ }^{\prime} \times 8{ }^{\prime}$ mural for use as a backdrop on the "Hantord 


\section{ENPLOYHE COMMONICATIONS \& PUBLIC RELATIONS}

Science Form" mo shows layout and artwork for a Community Relations advertisement in the TRI-CITI HERALD, GE NEWS, and COLOMBIA BASIN NEWS; layout for artwork for the Jamuary health bulloting layout and artwork for a "Public Health Newsletter" letterhead; and sketches for projection slides to be used by the General Manager during his Report to loyers.

The film, "Productirlty: Key to Plenty," selected by Imployee Communications for showings to employees as part of efforts to increase employee understanding and appreciation of sound economic principles, was shown 15 times to a total of nearly 350 ermloyees during the month by Technical Information Unit.

Fifteen radio programs of the IISIDE HANFORD and G-E HANFORD SCIENCE FORUM shows were produced and broadcast regionally during December by affiliate stations of the Eastern Washington network.

Final selection of master film footage for the AEC motion picture THE HANFORD REACTOR EXPANSIUNi PROCRAM will be made next week preparatory to sending the film to the studio for completion.

Progress was made on the production of the motion pictiure CEANNEL 4669, and all indications point to lts completion next month.

With the announcement by one of our Specialists, Audio-Visual Productions, (R. K. Maurer) of his voluntary termination January 31 (going into business for self), we are faced with the problem of replacement. Prelininary consideration to the matter suggests moving our Publicity Writer (Pat MacKelvie) in to understudy Maurer during Jamary. If he shows aptitude for this type of work it is planned that a replacement be obtained for MacKelvie to handle radio progranming, audio installations and film editing.

SAren "Ii"Te" television programs of the G-E HANFORD SCIENCE FORUM and IIIS WEEK AT HANFORD shows were produced and telecast to regional and local viewer:s during Dacember by five Eastern Washington television stations.

The two "Iive" telecasts of GuE HANFORD SCIENCE FOROM received enthusiastilo priaise from both viewers and executives of all stations. It was alis suggested that consideration be given to a Kinescope recording of the program and making the $f^{\circ} 1 \mathrm{~m}$ available to regional or national audiences.

Conferences are being held between W. A. Watto, Muriel Fulmer and W. A. Halteman conerning the latter's proposal for production of ten television features on Hanford activities. Finm footage, in color, to be derived from filming of two feature-lerigth recruitment motion pictures for Tachnical Personnel Recruitment. A wesume of the conclusions will be submitted to the Section Manager as soon as completed.

The second "Iive" telerision show, THIS WEEK AT HANFORD, also receivsd its premiens telecast this month on RTTC, Richland. Jack Quinn, Manager, and other station executisres were well satisfied with the progroam.

Thiis is atrictly a "proving ground" arrangement to develop a new Community and Public Relations outlet for programs developed by the Sestion. The "employee

$$
G b-8
$$




\section{EMPLOTEE COMMONICATIONS \& PUBLIC REIATIONS}

relations" value of this medium will be derited from the features where GE employees participate. When a satisfactory format is finally developed, it is planned to make the program araflable to a reglonal television outlet for greater corerage.

The Audio-Tisual Communications Unit Supervisor showed the HAPO produced film HERE'S HANFORD to 150 members of the Coilumbia Basin Shrine Club, their wires and families at an annual Christmas party Saturday, December 17. A total of 310 persons view the film. It was particularly well received, with generous applause.

As a community serrice, a member of this Unit (Frank Losch) served as judge for the Richland Junior Chamber of Comerce "Voice of Democracy" contest.

Harry Kramer, a member of HAPO's Declassiflcation Team attending meetings in Oak Ridge, Tennessee, showed the BAPO produced motion picture HFRE'S HANFORD to community groups in Muncie, Indiana. Groups which viewed the film were the Muncle Senior High School sclence clisses, Ball State College Science majors (thrse showings), a group of businessmen' and engineers, and three showings to the A.G.\&E., an Indiana and Michigan employment group. Also, the local television station in that city provided a feature spot for the film and it was telecast for riewers in that area.

Furth rehabilitation and remodeling of 723 Building is now under way. When cormleted, the functions of this Unft will be placed back lnto normal operating sonditlon.

Distwibution of Graphics December Assigrments

Gengroyl Adminiztrative (Including Operations Research)

$\frac{\text { Pevent }}{2}$

Employee and Public Relations

Engizeering

Manuf's turi.ing

Finguarial

Radiological ScLences

Asomic Energy Commission

Total assignments rompleted Total assignments backlog

Gxaphios Statistisal Summary

Report Material (Includes Technical Prublications)

Terhnical or Scientific Ilustrations

Mechanial Art (Flow charts, schematios, maps, etc. - not for publication)

Lecturo Matarial (Includes plates for silide:3)

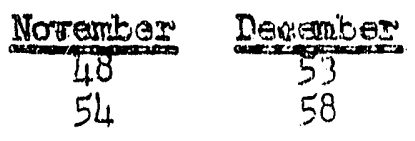

$100^{\circ}$

\section{Charts or}

Graphs Ilustrations Others

$\begin{array}{rrr}59 & - & 11 \\ 5 & 9 & - \\ 72 & 9 & 49 \\ 13 & 15 & \end{array}$




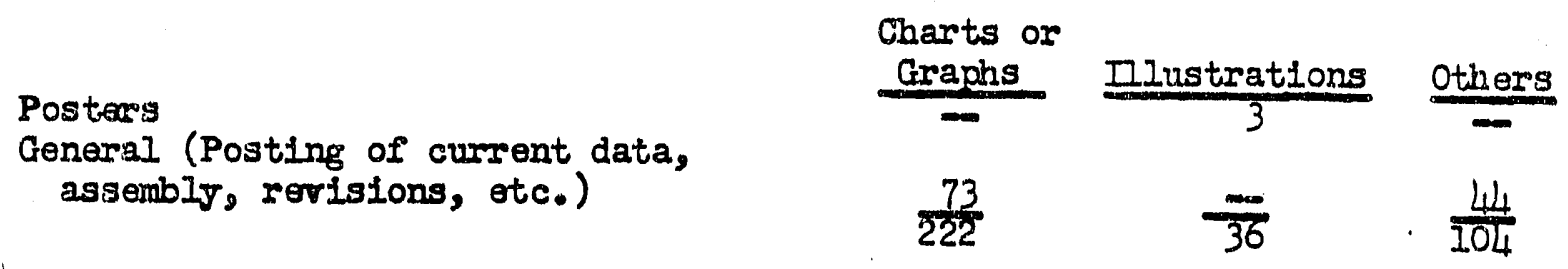

Sotal plates completed - 362

A request wes submitted from the HOO for four sets of maps of the Hanford Prom ject for use by the Washington, D. C. AEC office in connection with defense activities. Each set was to include separate area maps of the 100, 200 and 300 production areas. The existing bat obsolete plate masters of maps previously published were revised and brought up-to-date. Nine plates were submitted to the Printing Unit for reproduction on December 29, 1955 with a scheduled date for copy assembly of January 9, 1956.

All visual aids required for the Separations Technology Section Business Review of Desember 7, 1955 were completed on schedule. Visual aids were also completed for the Pile Technology review of January 4, 1956. Other reviews for which material is presently being prepared are the Project Section and Trans. portation Section Businss Reviews.

Twenty-three visual alds were prepared for representatives of the Mampfacturing Department Radiation Monitoring Unit to use for training purposes. In addition to the above orcier, a second series is being prepared and scheduled for como plotion on January 12, 1956.

Frur cut-a-way perspective illustrations showing various types of fuel elements regre pwapared for the Metallurgy Research and Pile Materital Sub-Sections. The ilyustwions were required for fileld work, howevor, they will also be used in the Gesarial Manager's Anmal. Meeting.

A Mata Bock" is being prepared for the Generol Managgr at, the request of the Finanolal Department. Many of the ariginal plate masters used in the HoO Marageris Data Book were made available for this assignment saving considerable nostis of new drawings. Approvals of both GE and AEC Security were required in oxder to obtain the abore release of plates.

Wrik on the "1955 at Hanford" anmal report is progwsing on schedule. The tirist draft is being edited and consolidated.

Twanty-aix plate masters for the "HAPO Cost Chanta" report were posted and submitted to Printing on schedule.

The KAPI-120 Project Scale Model was completed this month. Delivery has not yet been made as arrangements were being set to harre the Audio-Tisual Unit wse the model ir a training movie. The Model Shop had two risitors from the Knolls Atomic Power Iaboratory this month to Tiew this model.

Eight plates for slides were prepared for a representrative of" the Radiological Scienres Department to use in a lecture to the Wildilfe Soriety at Seattle.

$$
\mathrm{Gb}-10
$$


Six plates for slides were prepared for a representative of the Engineering Department to use in a presentation at the A.E. Congress in Cleveland, Ohio.

Material prepared for famal docments included the following: Three flgures for document EN-38780 BIS titled "Statistical Analysis of Run to Rupture Tests Irrolving Mare then Two Metal Types"; serven figrares for document $\mathrm{HW}-\mathrm{L}_{6} 0 \mathrm{Jl} 2$ titled "Promotion of Chemical Reaction of Pile Badiation"; eleven plates for document EW-39969; twelre flgures for document HW-39927 titled, "study. of Process Tube Conditions - Iffe and Replacement"; ten figures for kW-38776 titled "Production Tests"; and miscellaneous plates for documents HW-39649, 39539, rolor, 37158 and 36788 .

All requests for photography were normel for the month of December except for one order for the Financial Department. A large number of prints were requested. Serenty-one ( 7$)$ charts wera copied and a total of one-thousand, sixty-five (1065), Bin X IIn prints were produced. Several orders for threehundred (300) to seven-hundred (700) prints were produced for Technical Publications, Engineering Department.

A total of 367 photographic assigrments were covered for the month of December, 1955. 13,940 prints were produced of which 5,662 were identification; 8,278 were area and news. 1,005 negatives were exposed.

For additional information see attach statistical report. 


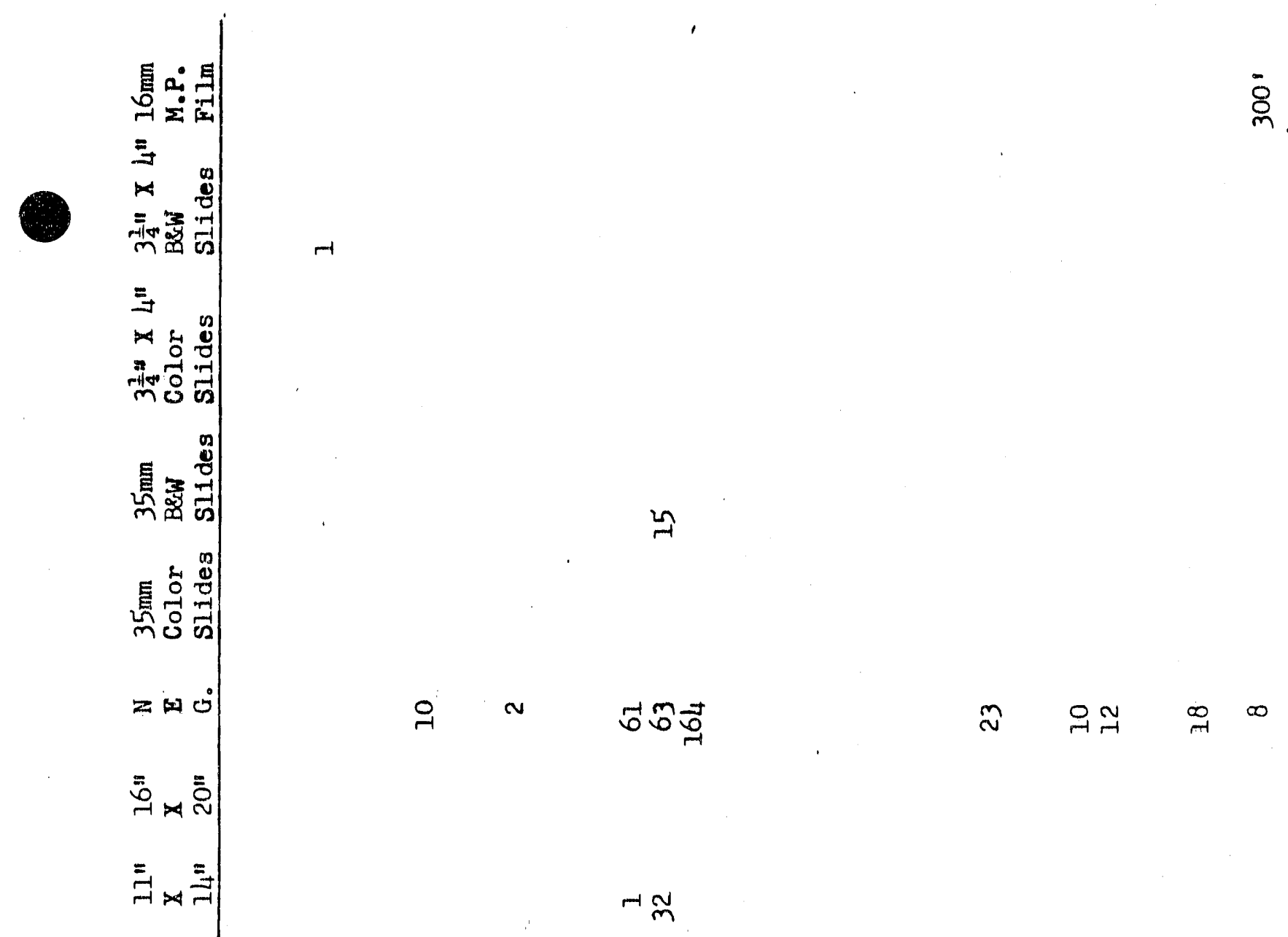

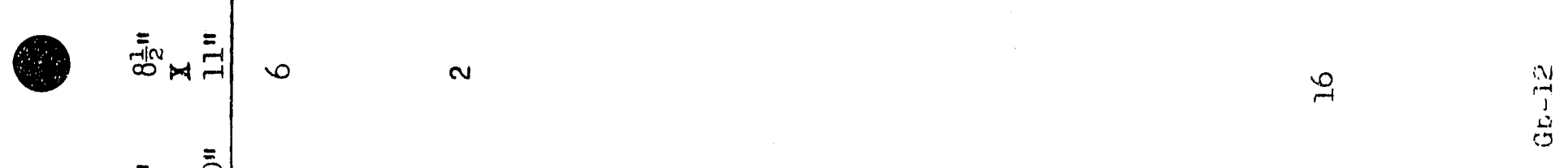

\begin{tabular}{|c|c|c|c|c|c|c|c|c|}
\hline 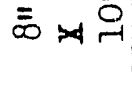 & in & 0 & $m$ & $\underset{\vec{F}}{m} \tilde{i n}$ & $\stackrel{\infty}{r}$ & $\vec{\sim} \cong$ & 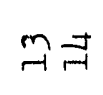 & $\stackrel{\infty}{9}$ \\
\hline & & & & $+\infty$ & & & $\stackrel{m}{v}$ & \\
\hline
\end{tabular}

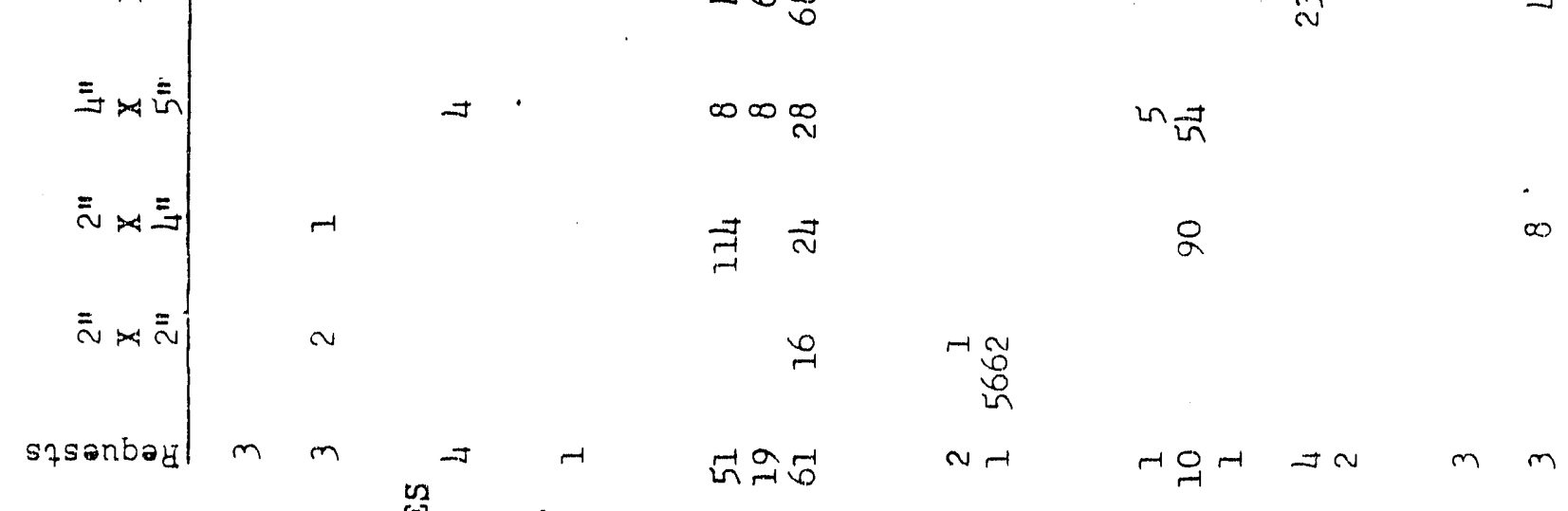

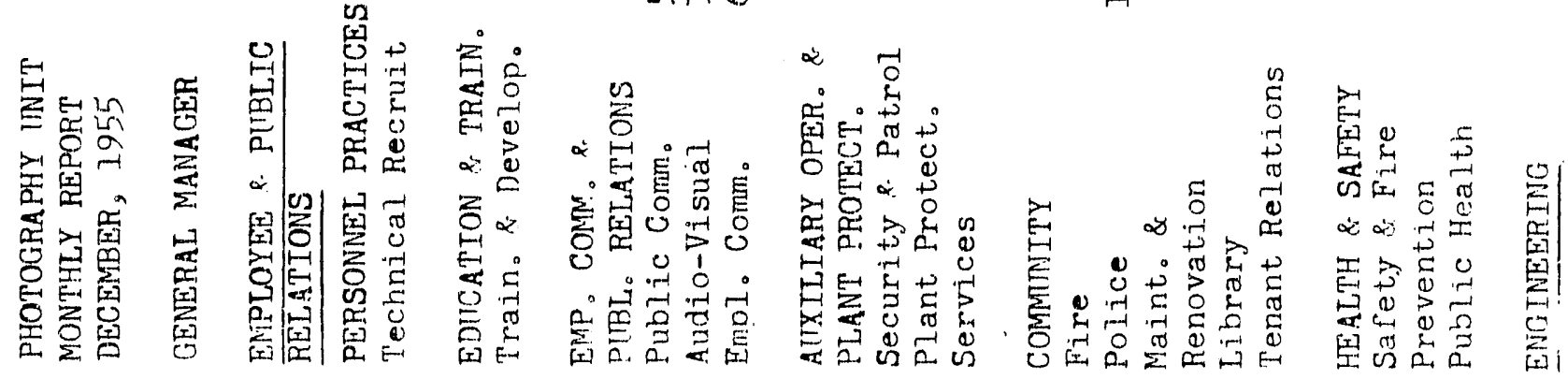




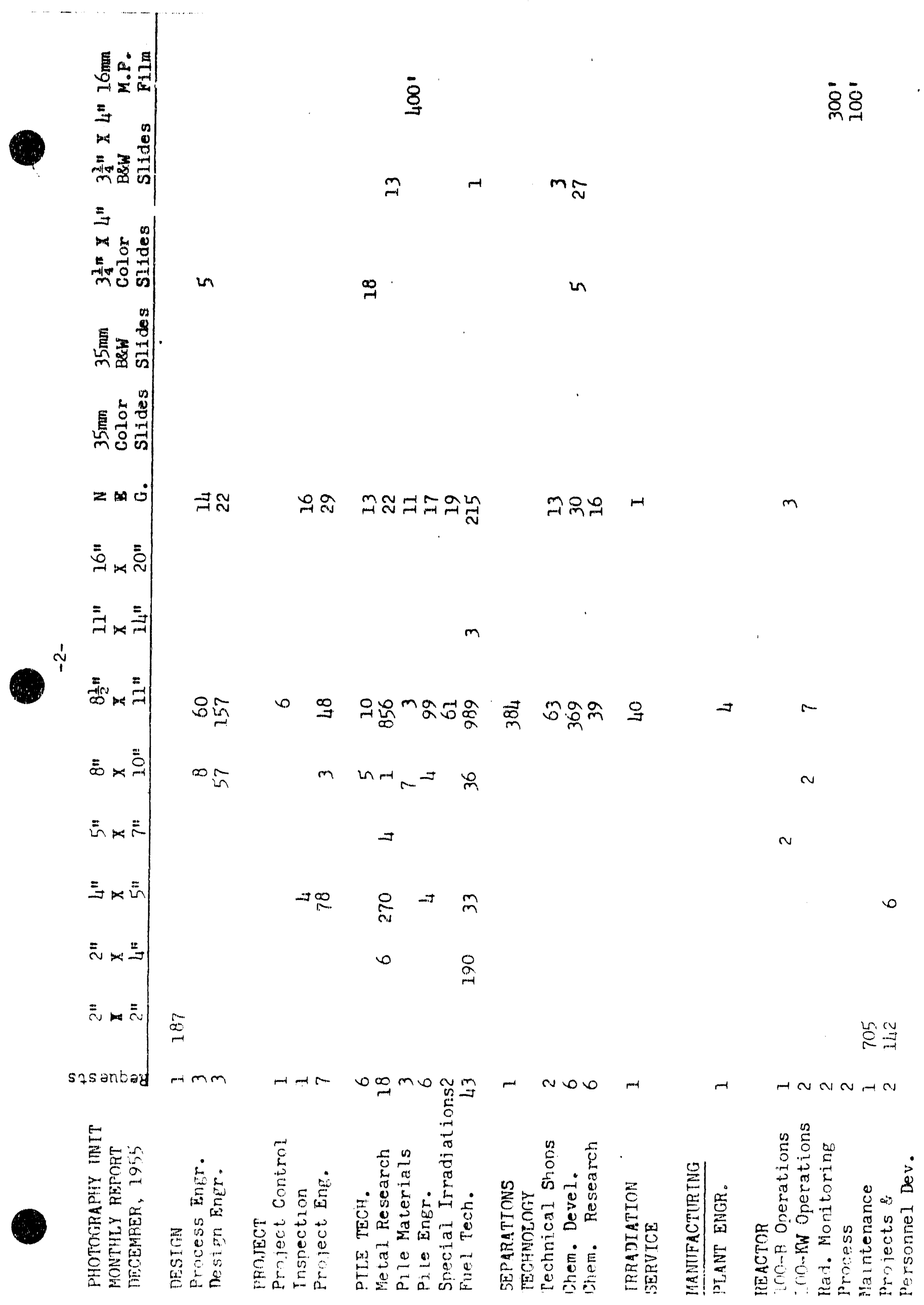




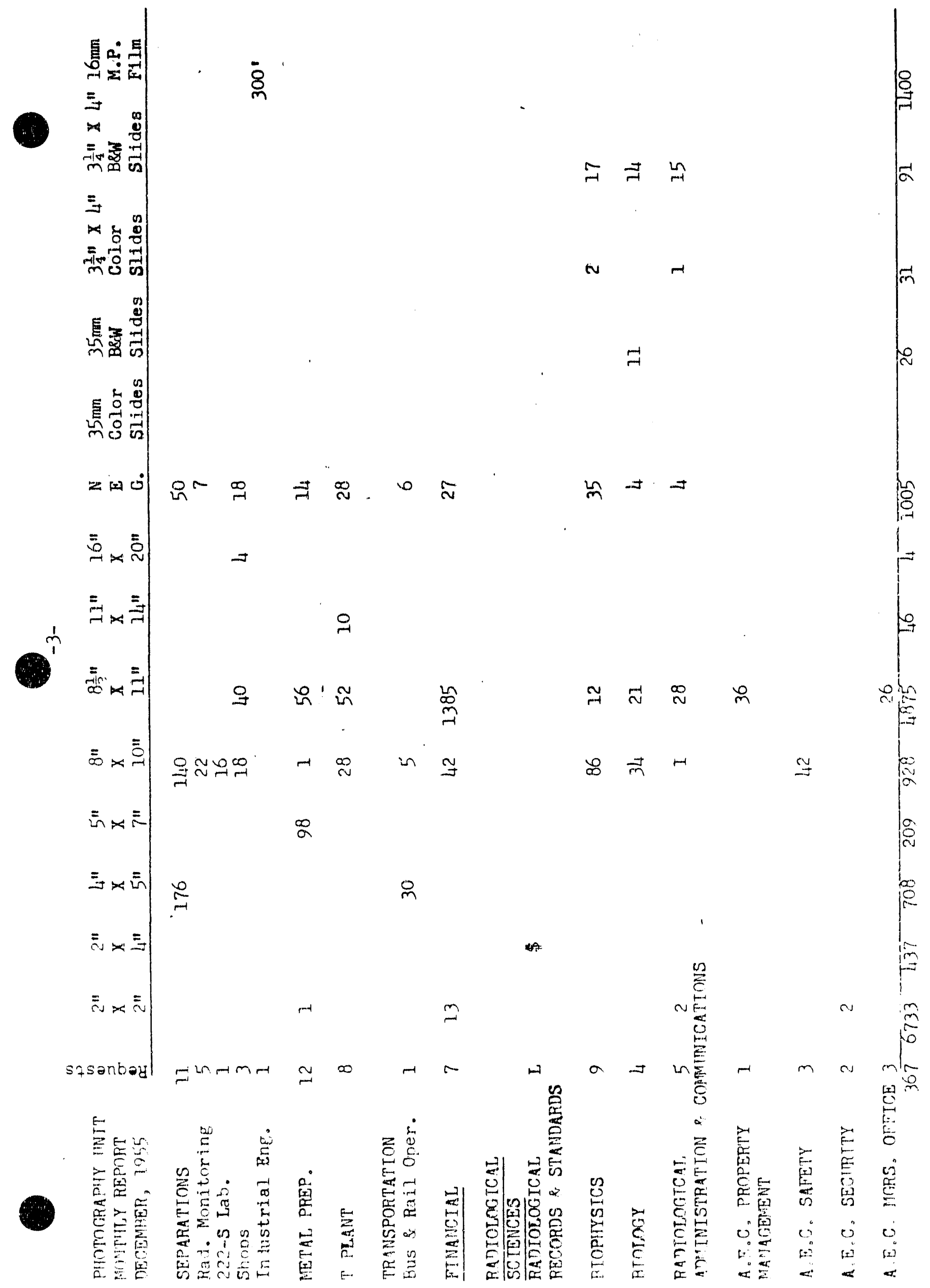




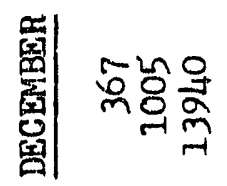

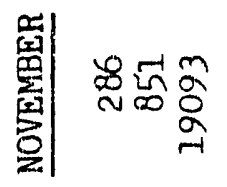

a $\frac{1}{1}$

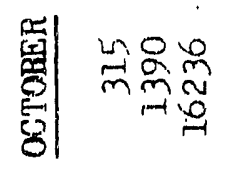

$\frac{n}{1}$

翼留 


\section{UNION REIATIONS}

On December 28, 1955, in response to our refusal to arbitrate a dispute concerning the establishment of the new classiflcation of Gauge Worker, a lawsult was brought by the Hanford Atomlc Metal Trades Council against the Company calculated to force arbitration of this 1ssue. Outs1de counsel has been retalned. The Company's answer to the complaint is due by January 17.

Agreement was reached on December 9, 1955 with the Eanford Atomic Metal Trades Counc1l which resulted in a settlement payment amount1ng to $\$ 1,118.25$ in retroactive pay to 110 euployees who had been improperly paid under the double-time pay provisions of the 1954 EAMCC-GE Agreement.

Area meetings with supervision to discuss contract revisions and interpretations continued during the month. To date some 20 such meetings have been held covering approxinately 700 exempt people. A step up in meetings is scheduled for January followling the holldays and the distribution of Agreement booklets.

The Hanford Atomle Metal Trades Counc1l and the Hanford Guards Union Agreement booklets are expected from the printers during the flrst week in January. Distribution wilj. bo made to all exempt enployees on the addressograph list and to the employees through the unions. Additionel copies will become stores stock 1tems.

A backlog of some 20 Stop II grievances whlch had accumulated during a three months' perlod of contract negotlations were sat1sfactorliy resolved during Desember.

Grievance Statistics:

A total of fifty-four (54) grievances were received and four (4) Step II grisvance meetlngs were held durlng the month. A breakdown of the grievences recelved and processed follows:

\section{ALI DEPARTMENTS}

$\begin{array}{lccccccc} & \text { HAMPC } & \text { HGU } & \text { BSEIU } & \text { Unit } & \text { Nonunit } & \text { Total } \\ \text { Received this montb } & 51 & 2 & 0 & 53 & 1 & 54 \\ \text { Reselved this year } & 476 & 8 & 2 & 486 & 18 & 504\end{array}$


Thployeo and Public Relations

UNION REIATIONS

Grievance Stat1st1cs:

AII DEPARTMEMS (Cont'd.)

EAMTC EGU BSEIU Unit Nonunit Total

\section{Step I}

Pending November 30

Settled this month*

Settled thls year

Pending December 31

$S t \in p I I$

Pending November 30

Settled th1s month**

Settled this year

Pending December 31

$\begin{array}{rrrrrr}0 & 0 & 0 & 0 & 0 & \\ 38 & 0 & 1 & 39 & 0 & 39 \\ 339 & 3 & 1 & 343 & 7 & 350 \\ 0 & 0 & 0 & 0 & 0 & \end{array}$

Arb1trat1on

Pending November 30

Settled this month

Settled this year

Pending December 31

Total settled this month

Total settled this jear

$\begin{array}{rrrrrr}60 & 1 & 1 & 62 & 0 & \\ 11 & 1 & 0 & 12 & 0 & 12 \\ 120 & 4 & 0 & 124 & 10 & 134 \\ 64 & 2 & 0 & 66 & 1 & \end{array}$

$\begin{array}{rrrrrr}0 & 0 & 0 & 0 & 0 & \\ 0 & 0 & 0 & 0 & 0 & 0 \\ 0 & 1 & 0 & 1 & 0 & 1 \\ 0 & 0 & 0 & 0 & 0 & \\ 49 & 1 & 1 & 51 & 0 & .51 \\ 459 & 8 & 1 & 468 & 17 & 485\end{array}$

\section{BI DEPARTMENTS}

$\begin{array}{lll}\frac{\text { Recelved }}{\text { Th1s Th1s }} & \frac{\text { Settled Step I* }}{\text { Th1s This }} & \frac{\text { Settled Step II** }}{\text { ThIs This }} \\ \text { Mo. Yeer } & \text { Mo. Yeer } & \text { Mo Year }\end{array}$

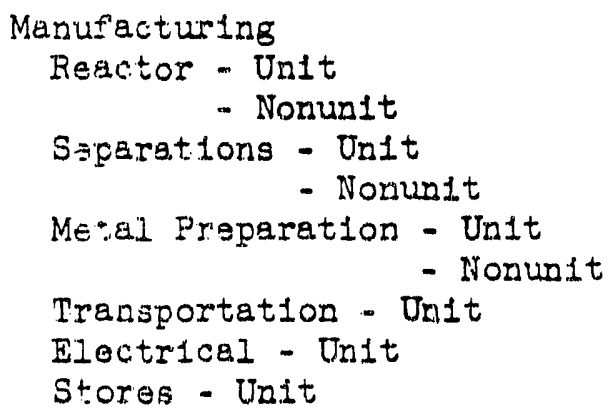

$\begin{array}{rrrrrr}26 & 217 & 22 & 155 & 5 & 53 \\ 0 & 1 & 0 & 1 & 0 & 0 \\ 16 & 135 & 7 & 103 & 3 & 23 \\ 1 & 10 & 0 & 4 & 0 & 9 \\ 3 & 52 & 6 & 36 & 0 & 12 \\ 0 & 1 & 0 & 0 & 0 & 1 \\ 3 & 23 & 1 & 12 & 2 & 11 \\ 0 & 5 & 0 & 2 & 0 & 2 \\ 0 & 5 & 0 & 4 & 0 & 4\end{array}$

* Grietances brought to Step II prior to October 1, 1955 but never processed by the union are, for the purpose of this report, considere settled at Step I.

* Gristanes which the union formally ladicated their intention to sumit to arbitretion but bave taken no further action since october 1 , 1955 are, for the purpcse of this report, considered settled at Step II.

$$
\text { Gc- }-2
$$




\section{Theroyee and Public Relations}

\section{ONION RELATIONS}

\section{BY DEPARTMENTS (Cont'd.)}

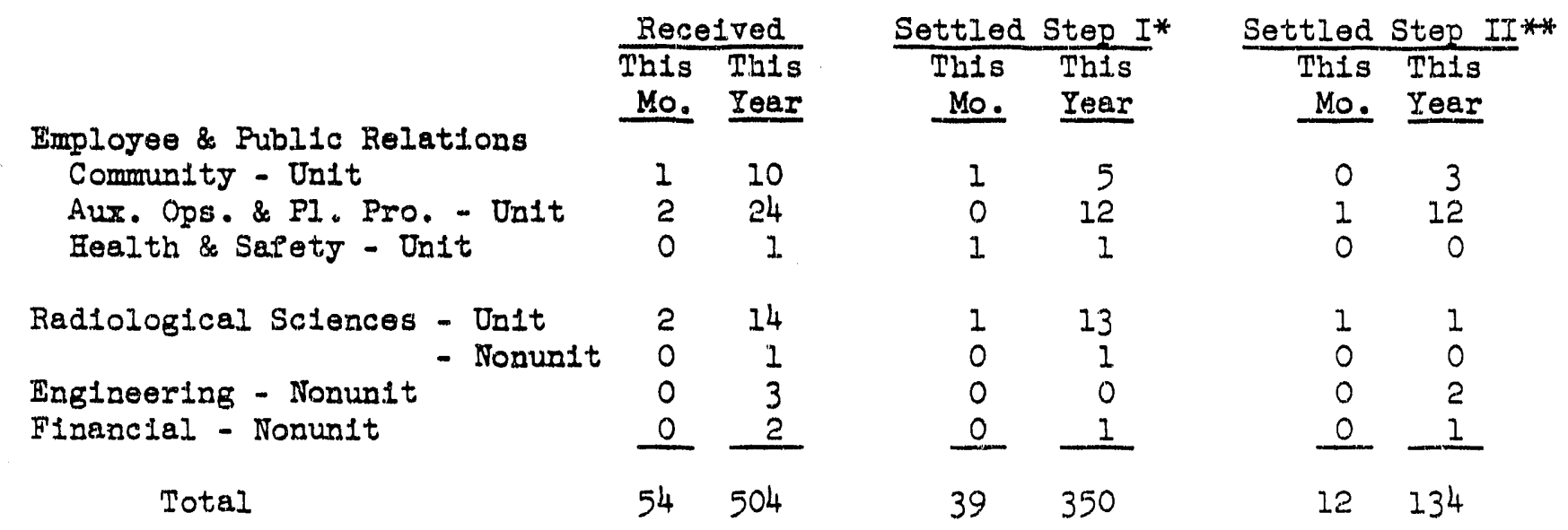

* Grievances brought to Step II prior to October 1, 1955 but never processed by the union ere, for the purpose of this report, consldered settled at Step I.

* Grievances which the union formally indicated their intention to submit to arbitration but have taken no further action since october 1 , 1955 are, for the purpose of this report, consldered settled at Step II.

\section{BY SUBJECTS}

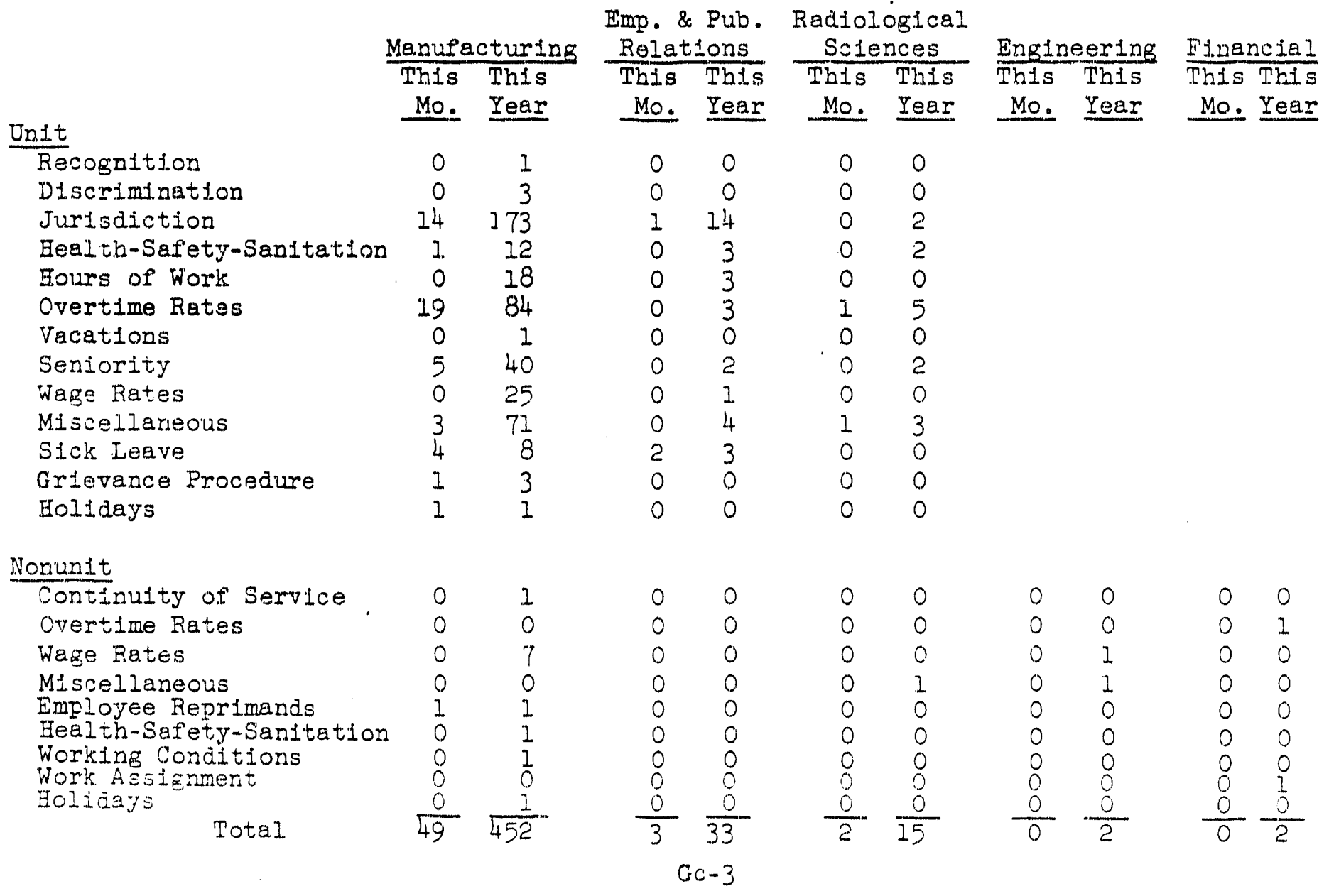




\section{SALARY \& WAGE ADMINISIIRAUIION}

In addition to the normal flow of routine work In Salary \& Wage Administration, the following work was conducted during December:

1. During the month plans were completed for conducting the annual exempt employee appraisals. Salary \& Wage Administration Advice No. 6, containing instructions for this program, was issued and all prellminary work required of this Section was completed by month end.

2. Spectal studies in progress and thelr status at month end are:

a) First-line supervisory differential study -- Collecting and analysis of pertinent data continues.

b) Wage Rates study -- Ranklngs of Clerlcal-Functional jobs by supervisors and Section personnel were coupared with rankings made separately by Section personnel and discrepancies between the two are under study. Alternative pricing structures for these jobs and for the Sem1-Technical jobs are also under study.

c) Secretarial and stenographic study -- Further study of the evaluation of these jobs is planned. An evaluation plan specificalily designed for these jobs will be developed and used on a representative sampling, and the results obtained wll be compared with the resulto obtalned using the paired comparison method.

3. Work continued on revlaions to the Salary Administration Manual made necessary by recent changes in pay structure and policles, organization nomenclature, and adminlstrative procedures.

4. A report was 1ssued to appropriate local and off-site Company personnel which contained a current listing of HAPO Representative Positions and analyses of current coverage of these positions.

5. Information was submitted to two other A.EC contractors in connection with wage and benerit studies being conducted by them.

6. Four organization changes were processed during the month. Three of these consisted primarliy of changes in organization nomenclature. The other was a major change involving reorganization of the Reactor Maintenance Sub-Section of the Manufacturing Department.

7. Salary survey data are now avallable on radiographers. Thirty organizations were contacted and information bas been recelved from 16. 
EMPIOYEE AND PUBLIC REIATIONS DEPARTMENT

Education and Training Section

NONTHLY REPORT FOR DECEMBER 1955

PERSONNEL DEVELOPMENI PROGRAM FOR NUCLEAR ENERGI

I. Prosent Assignments

Department

Iast Month

Engineering

Pile Technology

Separations Technology

Design

Project

Eng Ineering Administration

$\begin{array}{rr}12 & 14 \\ 8 & 8 \\ 3 & 2 \\ 4 & 6 \\ 1 & 1\end{array}$

Man ufacturing

Metal Proparation

Separations

Reactor

Eleotric Utility

$\begin{array}{rr}1 & 1 \\ 10 & 10 \\ 9 & 5 \\ 0 & 1\end{array}$

Radiological Sciences

Biomphysics

Records \& Standards

Radiological Engineering

$\begin{array}{ll}0 & 1 \\ 1 & 0 \\ 1 & 1\end{array}$

Financial

Procedures \& Computing

$\frac{2}{52} \quad \frac{1}{51}$

II. Permanent Placements

There were two placements off the program as follows:

Reactor

2

Ge-1 
EMPLOYEE AND PUBLIC REILATIONS DEPARTMEMVII

Education and Training Section

III. Additions

There was one addition to the program during the month of December; namely, a University of California graduate with a degree of MS in chemistry.

IV. Selective Serv1ce

There were no losges of technically trained men to milltary service.

Two letters were sent during the month to all of the 66 men in the military service who have entered due to selective service motivation. One of these letters was to request the assistance of these men in locating promising scientists and englneers to help Hanford 1111 its requirements for fiscal year 1956 and 1957. The other letter was to forward to the men a copy of the GE Pocket Dlary. A few names of frlends and acquaintances who are scheduled to leave the military servlce have been passed along to us by our former employees. However, we hope that this letter will bring additional nemes and, as they are recelved, they will be called to the attention of the Technical Recmiling Unit. It is believed that the sending of the "Works News" and the "G.E. Revlew" to our former employees is worthwhile as one of the means of keeping them interested in returning to Hanford and as a means of Interesting others in the armed services in applying to Hanford for work upon discharge. These publications are sent regularly to all the former Hanford employees now in the armed forces.

TEECENICIAN TRAINING PROGRAM

It is planned to add three new members to the Technician Training Program starting January 30. Two of these additions are students who were considered for employment last sumer, but were not employed because they were only 17 years of age. The other is a new person not previously considered.

UNIVERSITY RETATIONS

We continue to have excellent response from univergities requesting talks by Hanford personnel on technical subjects. To date flve talks have been presented and seven talks are scheduled for future presentation.

Copjes of the Pocket Diary, Log Book and. Wall Calendars were sent to each of the seven professors who were on the summer 1955 Professor Program.

PERSONNEL DEVELOPNENT COURSES

\section{Course}

New Exempt and Supervisors Orlentation

Conference Leading

Secretarial-Stenographic

Labor Managenent Relations

Principles and Methods of Supervision

Job Instruction Training

Job Relations Development

Responsibility of a Supervisor ("McGregor")
Number of Times Presented

$\begin{array}{rr}1 & 21 \\ 3 & 24 \\ 1 & 8 \\ 1 & 17 \\ 1 & 11 \\ 3 & 11 \\ 1 & 13 \\ 1 & 13\end{array}$


EMPLOXES AND PUBCIC RETATIONS DEPARTMIHVIT

Bducation and Training Section

Participants in recent Principles and Methods of Supervision courses were honored at a completion dinner. There were 58 present, including guests. First quarter (1956) plans, indicating dates on which regularly scheduled courses will be presented, have been malled to correspondents. The 1956 Personnel Development Courses booklet has had I1nal approval. It will be distributed in January. SCHOOL OF NUCLFAR EMIGINEHERING

Out of the original reglstration of 525, 472 are actively pursuing their course work. This compares very favorably to the experience in previous terms.

Oregon State College and the University of Washington have approved all graduate courses for the fall semester. The University of Idaho approves new courses after the term ends, with all previous approvals carrying over as long as they are offered. Washington State College has not indlcated whether any courses have been approved or not.

During November and December, D. S. Roberts and H. C. Mayer visited with a number of faculty members at each of the four cooperating colleges and universities. These visits enabled Mr. Roberts to meet the Graduate Deans and gave us time to discuss numerous items in our working relationship.

On December 1.3, Dr. S. E. Hazlet, Dean of the Graduate School at Washlington State College Visited RIchland to talk with twelve W.S.C. afflliates about their graduate study programs.

On December 20, Dr. R. W. Moultion and Dr. A. I. Babb, both from the University of Washington Chemical Engineerlng Department, visited Richland to talk with the students interested in taking graduate work with the University.

With the above visits each of the four affliated schools has sent representatives to Richland this term to talk with their interested students.

Twenty graduate courses and nineteen college-level and vocational courses have been planned for the Spring Semester. Five of these are new courses. 
ENPLOYEE \& PUBLIC RELATIUNS DEPARTMENT

HEALTH \& SAFETY SECTION

DECEMBER 1955

General

Personnel Changes

Seven additions and one deletion resulted in an increase to 222.

Imoloyee Rielations

Employee attendance at 37 meetings was 296.

Visits

Mir. McKinnon and Mr. Goslin attended the General Electric regional safety vorkshop at Berkeley, California, December 4-10.

$\mathrm{Mr}$. Branchini attended a conference of siate health educators at the State Department of Health offices and an executive committee meeting of the Viashingtion State Public Health Association.

Dr. T. Barnore, University of Washington, and Mr. D. Prosser, State Department of Health consultant in mental health, visited the Public Health Unit.

Industrial Medicine

Dispensary visits increased from 5161 to 5407 while medical examinations decreased from 912 to 800 .

Absenteeism Statistics

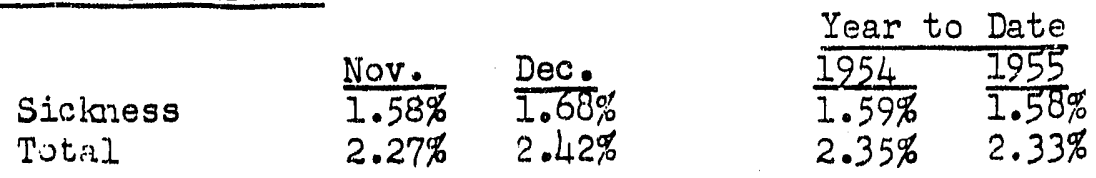

Safety \& Fire Prevention

While there were no disabling injuries in (jperations and Community, nine near serious accidents were investigated.

The disabling injury frequency rate for $1955 \mathrm{ras} 0.40$ and the severity 703 .

It has 0.0 for the Community.

Kadlec iospit 1

The averace daily adult census decreased fron 49.2 to 43.6 as compared itn 60.6 a year $3 g \circ$. The average daily newborn census was about the same at 3.8 . This is a continuation of the low census figures which resulted in a $20 \%$ decrease for 1955 as compared with 1954.

Fublic Health

Commulicable diseases increased by $21 \%$ to 0 . An 'Institute on Human Relations" for sanitarians in southeastern Washington vas presented in Richland by $\nu \mathrm{r}$.

Ted Barnowe, University of Washington, and Mr. Dan Prosser, State Depar ment of Public Health consultant in mental health.

High bacterial counts in pasteurized cream from one pasteurization plant

necessitated recnecks. 
Industrial Medical Servioes

Dispensary visits increased from 5161 to 5407 . The December total for 1954 was 484. The total visits during 1955 were 67,733 as compared to the total 1954 visits of 55,653 , or an increase of 11,980. There were no disabling injuries to either General Electric or contractor employees.

The total number of physical examinations was 800 as compared to 912 in November. The 1955 total was 11,373 .

There was one information meeting for industricl. physicians.

A tape recording was made for general public information on HAPO Industrial Medical services to be used on the radio program, Inside Hanford. Information has also been collected for a series of articles on noise control at. HAPO for the Works News. The purpose of these articles is to inform employees exactly what has been done to contrul noise.

A series of seminars conducted by a local psychiatrist on the subject of "Human Understanding" for top level management awaits approval.

Preparations for summarizing and storing industrial medical records $h^{\text {n }}$ e been completed and will begin January 3, 1956. This will permit reorganization of file content and allow for adequate file space.

The Health Activities Committee met on December 15 and the health topic on packed lunches was presented. Information on this subject was prepared for distribution to all employees. Sickness absenteeism for November was $1.58 \%$ and the year to date figure was $1.97 \%$. Total absenteeism was $2.32 \%$ for the year to date, just under the 1954 year to date figure of $2.36 \%$.

ivet costs for the month of November increased approximately $\$ 2,000$ over Uctober costs due mainly to a small increase in salary costs booked and to decreased expense credits in connection with physical examinations. No significant fluctuations occurred in Other costs. On a year to date basis a budget underrur of $\$ 1,000$ exists a ter five months of operation.

\section{Costs-Operations}

Selaries

Continuity of Service

Laundry

Utilities, Transportation, Maintenance

Supplies and Other

Total Gross Costs

Less: Revenue

Expense Credits

Net Cost of Operation

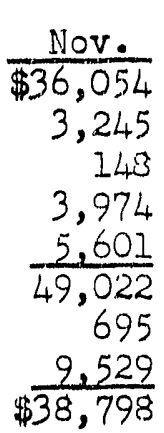

Increase

(Decrease)

Oct.
$\$ 35,269$
3,174
172
4,372
$\frac{5,312}{48,299}$
987
10,473
$\$ 36,839$
$\$ 785$

71

(24)

(39i)

$\frac{289}{723}$

272

$\frac{944}{\$ 1,959}$ 
Industrial Medical Services (Contirued)

\section{Finysical Evaninations}

Operations

Pro-employment . . . . . . . . . . . .

Rehire... . . . . . . . . . . . . .

Annual . . . . . . . . . . . . . . . .

Interim . . . . . . . . . . . . . . .

․․… . . . . . . . . . . . . . . .

ke-examination and recheck . . . . . . . .

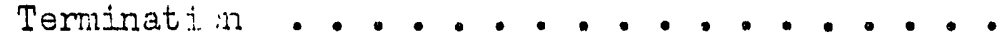

Sub-totil

Contracturs

AnnudLo ., . . . . . . . . . . ....

Pre-emplupnent . . . . . . . . . . . . .

Recheck . . . . . . . . . . . . . . .

Re-examinations . . . . . . . . . . . .

Termination ind Tralisfer . . . . . . . .

Interim . . . . . . . . . . . . . . .

Sub-totel . . . . . . . . . . . . .

Total Physian Examinations . . . . . . . .

Laborat.ory Fuaninations-olinical

\section{Operations}

Government . . . . . . . . . . . . .

Pre-amploynent, Terminatim, Transfer $\bullet^{-} \cdot \bullet^{-} \cdot$.

Airnual . . . . . . . . . . . . . . .

Recheol: (Aren) . . . . . . . . . . . .

First At , . . . . . . . . . . . . .

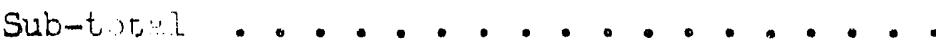

Coitract:one

Pre-emplor lent, Ternination, l'runsfer • • • • 1135

Total Clini aul Laboratory Fra Lnations • . • L186

$X-R a Y$

operations

Guvernment

Premernmt

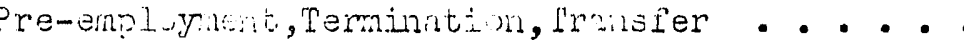

Allull . . , . . . . . . . . . . . . .

First Aid . . . . . . . . . . . . . . . .

Sub-tot al

Contractors

Pre-empl bynent, Termination, Transfer . . . . .

First Aid . . . . . . . . . . . . . . .

Sub-total . . . . . . . . . . . . . .

Total $\mathrm{s-litay}$. . . . . . . . . . . . .

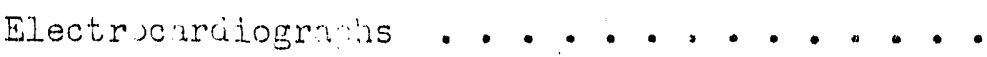

Physical Tharazy Jases Referrad
November:

83

13

335

35

30

130

45

671

3

44

14

112

60

241

912

128

861

1878

154

30

3051

.297

$\frac{121}{636}$

1399

111

45

2312

1297

3609

16

107

4.09

35

567

129

1.1

1.40

797

13 ?

31.
7602

50096

Year

to Date

1376

168

2884

442

316

1701

101.1

$7890^{\circ}$

1535

470

1
235

407

3475

11373

1258

234,07

$15 \% \%$

$23: 3$

232

433.4

143

32.1

372

300

3112

123

909

b].

90

134

90

Intit?

237 


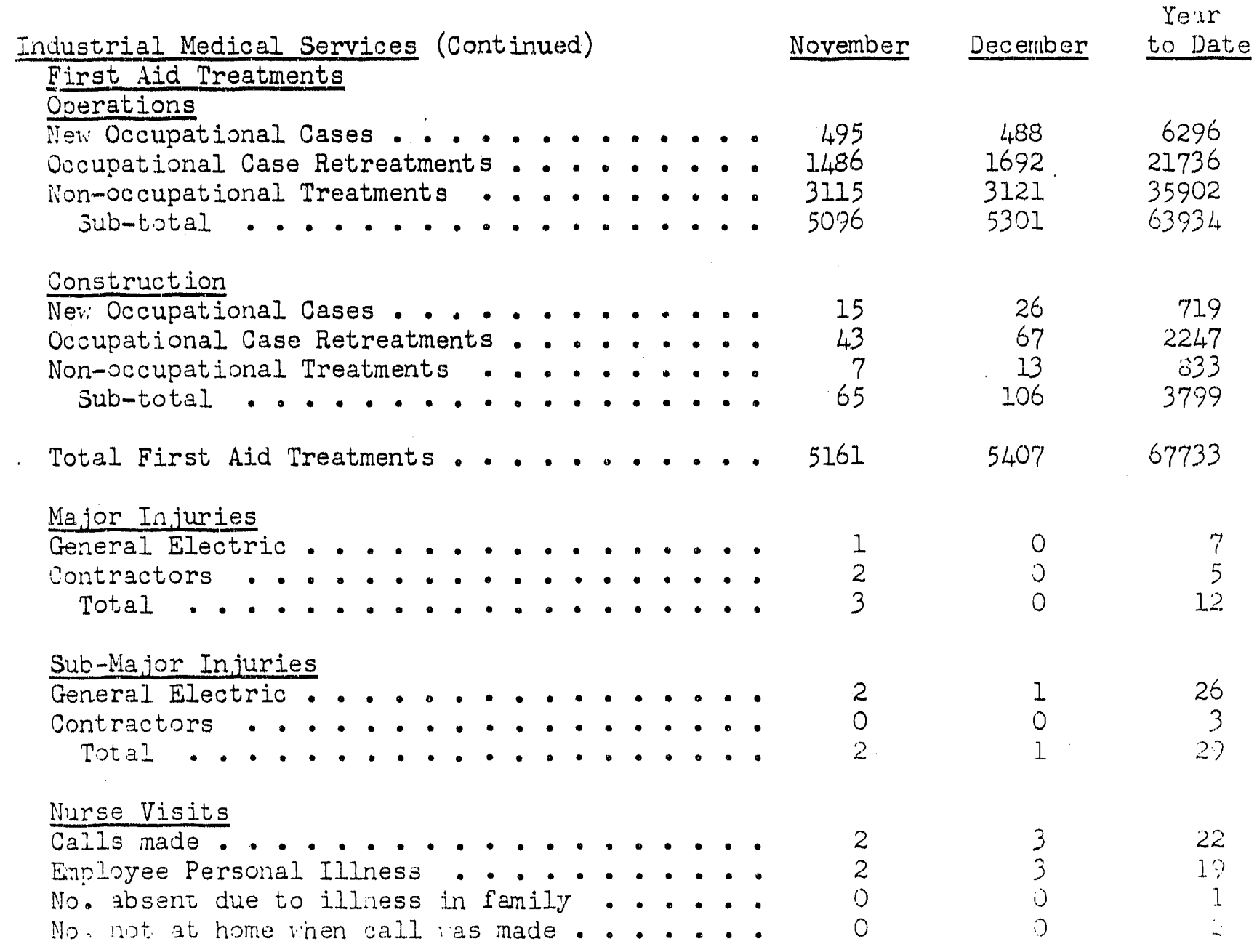


Kadlec Hosuitel

The average daily adult census decreased from 49.2 to 43.6 as compared vith 60.6 a year ago. This represents an occupancy percentage of 40.0 broken down as follows: Mixed Service (Medical, Surgical, Pediatrics) 38.3; Obstetrical Service 47.1. A furtiner breakdown of the Mixed Service show's an occupancy percentage of 20.5 un Medical, 49.4 on Surgical and 42.6 for Pediatrics.

The minimum and maxinum daily census ranged as follows:

\begin{tabular}{|c|c|c|}
\hline & Minimum & Marimun \\
\hline Mixed Service & 19 & 56 \\
\hline Onstetrical Service & 5 & 15 \\
\hline Total Adult & 26 & 71 \\
\hline
\end{tabular}

The average daily newborn census increased from 8.6 to 3.8 as compared ith 12.0 a year ago.

Nurstng hours per patient per diay:

$\begin{array}{ll}\text { Medical, Surgical, Pediatrics } & 4.80 \\ \text { Obstetrisai } & 5.63 \\ \text { Newborm } & 4.05\end{array}$

The nursing hours on sbstetriad service and in newbom nursery vere reduced from last month as a result of an increase in the number of births as conpared to Novenoer and the policy of utilizing nurses from obstetrics on other services when they could be spared.

The ratio of inpatient hospital employees to patients (e.cluding nevbom) for

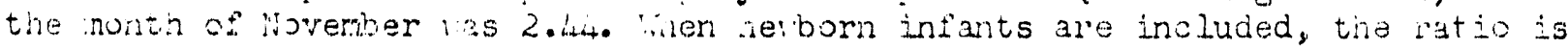
2.2.

The ret expense for the oeration of Kadlec iospital for Livemoer as $\$ 27,3,3$ as compared ita 19269 ior Oetober. jumary is as follons:

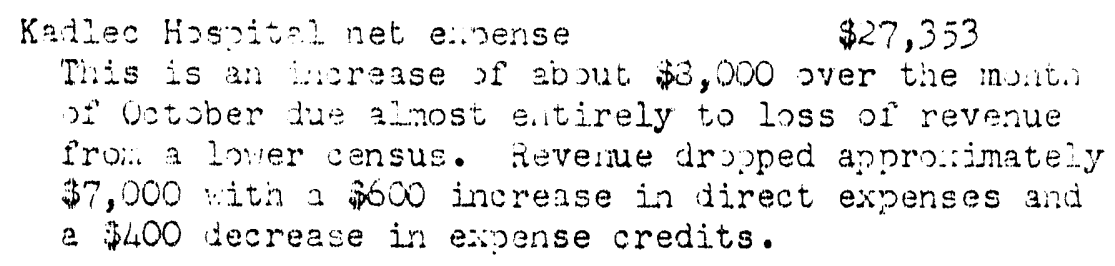

To combat to some extent this arst and revenue problem, additional reductions in erol syees nave been alade. Ho ever, since Jaunnry, February and kiarch are normaliy the hospital's biggest nonths as to patient census, no large anoult 0 : reduct ions have been posstible.

$$
G \mathrm{f}-5
$$




\section{HEALTH \& SAFETY SECTION}

\section{DECENBER 1955}

Kadlec Hospital (Continued)

Approval was received from the Atomic Energy Commission for an increase in rates at Kadlec Hospital. for room, board and nursing service to be effective January l, 1956. This increase was necessary in order to keep Kadlec rates in line : ith other Wasinington hospitals which had recently increased their rates.

Following is a sumary of employee relations meetings held in the Health and Safety Section during the month of December.

Hospital

Industrial Medicine

Public Health

Safety \& Fire Prevention

General

$\begin{array}{cc}\frac{\text { Meetings }}{26} & \text { Attendaice } \\ 2 & 228 \\ 7 & 11 \\ 1 & 40 \\ \frac{1}{37} & 11 \\ & 296\end{array}$


Hospital Unit (Continued)

Kadilec Hospital

Average Daily Adult Census .......... liedical ................. jurgical. . . . . . . . . . . . . Pediatrics ................. Hixed . . . . . . . . . . . . . Obstetrical .............. Average Daily Newborn Census . . . . . . . Maximun Daily Census:

Nired Services ... . . . . . . . Obstetrical ............... Total Adult Census ............ Minimum Daily Census:

Mined Services . . . . . . . . . . Obstetrical Service ........... Total Adult Census ........... Adnissions: Adult . . . . . . . . . Discharges: Adult ............ Medical ................. Surgizal . . . . . . . . . . . . Pediatrics . . . . . . . . . . . . Mired . . . . . . . . . . . . . Obstetrical ............... Nevbori . . . . . . . . . . . . .

P.tient Days; Adult ............ Medical . . . . . . . . . . . . Surgical . . . . . . . . . . . . jediatrics . . . . . . . . . . . ined . . . . . . . . . . . . obstetricul . . . . . . . . . . Ne:born . . . . . . . ........ Average Length of Stay: Acults ........ Viedicl . . . . . . . . . . . . Surgical . . . . . . . . . . . . Pediotries . . . . . . . . . . . 壬.................. vbstetriel . . . . . . . . . . .

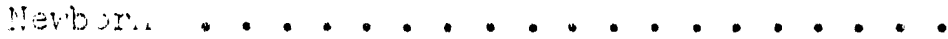

Occupancy Percentage: Adults . . . . . . . liedical ................ Surgical ............... Pediatrics ............... Yined . . . . . . . . . . . . . Gbstetrical . . . . . . . . . . Vienorn . . . . . . . . . . . . (Covupancy Percent-ge beseri on 109 adult beds and 26 bassinets.)

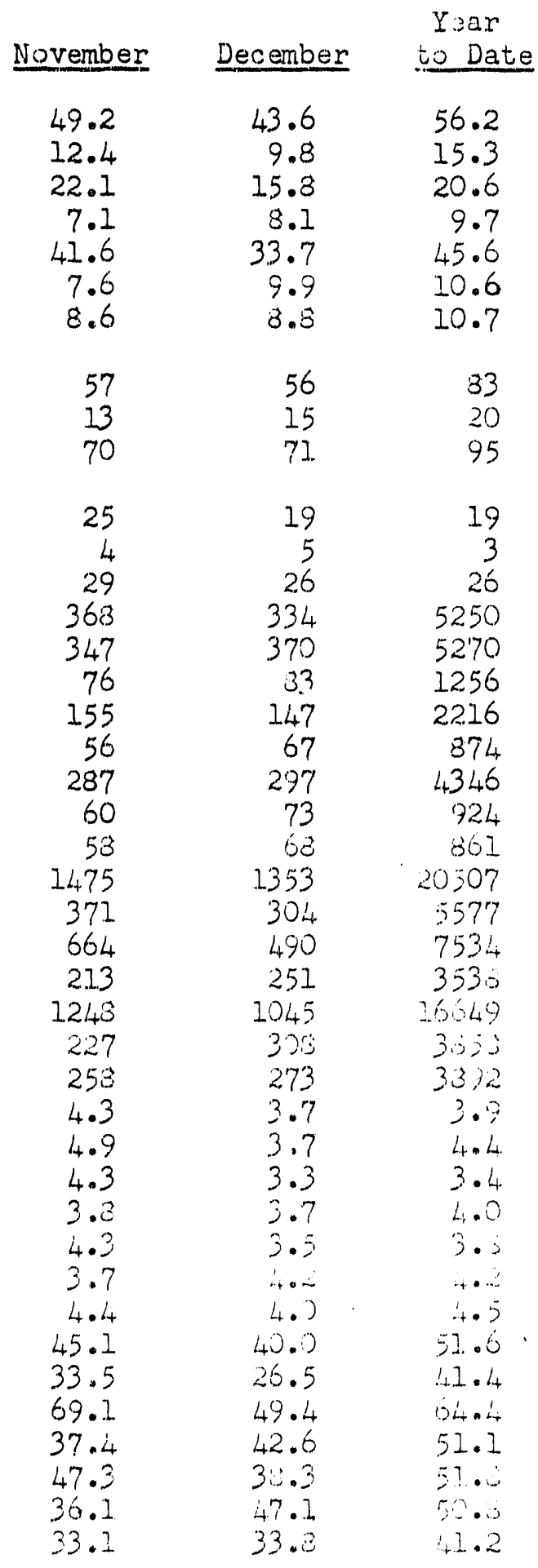




\section{HEALTH \& SAFETY SECTION}

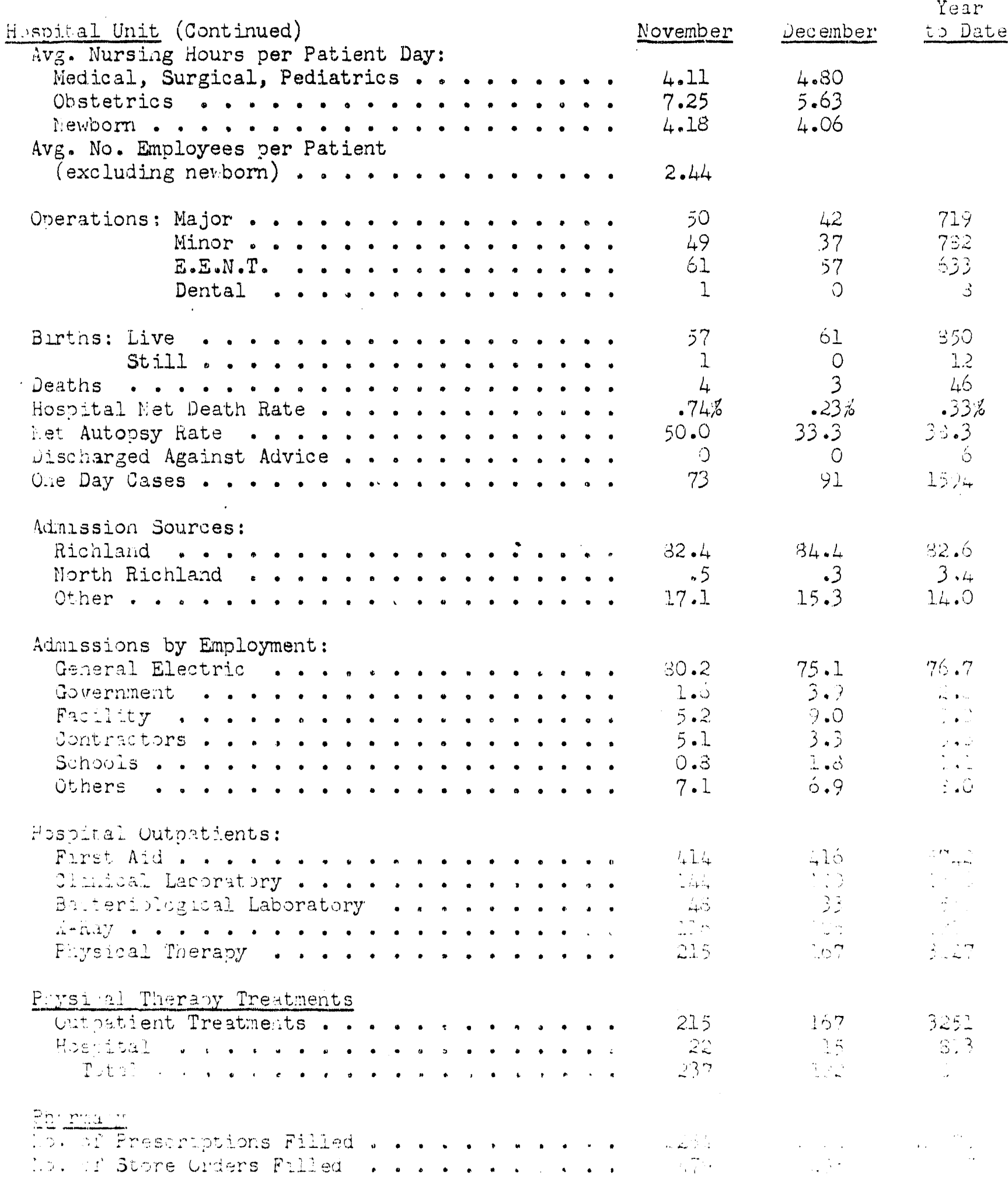


Hospital Unit (Continued)

Kadlec Hospital (Continued)

C.linical Laboratory Examinations

Outpatient Examinations ............ 381

Hospital . . . . . . . . . . . . . 2986

Public Health . . . . . . . . . . . . .

Total.....................

X-Ray Examinations

Outpatient Examinations . . . . . . . . . 122

Hospital . . . . . . . . . . . . . . .

Prbilc Health....................

Total................ . . . .

Electrocardiographs

Outpatient Examinations .............

Hospital . . . . . . . . . . . . . .

Total . . . . . . . . . . . . . .

\section{Bacteriological Laboratory}

Treated Water Samples ............. 198

Milk Samples (Inc.Cream \& Ice Cream) . . . . .

Cther Bacteriological Tests ..........

Total .....................

Patient lieals

Regulars . . . . . . . . . . . . . 2311

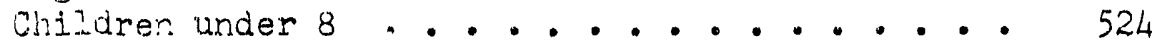

Specials . . . . . . . . . . . . . . 474

Softs.................. 591

Tonsil and Adenoid . . . . . . . . . 105

Liquids . . . . . . . . . ...... 135

Surgical Liquids .... . . . . . . . . 46

Total................. 4186

Cafeteria Meals

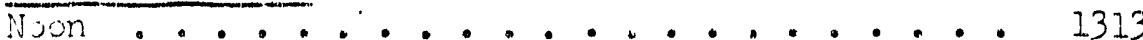

Night................... 233

Total.................. 1546
Year

December to Date

485

2803

3288

4.653

39925

1

L4.579

$11.4 \quad 1387$

$190 \quad 2442$

$3 \quad 8$

44.24

1.5

285

300

2398

454

5197

8049

1947

503

615

406

116

107

41

3735

31603

738 i

2253

6372

$6 \%$

1ólco

sec

57140

1345

2738

2.45

3300

1590 
There is no pg.10 


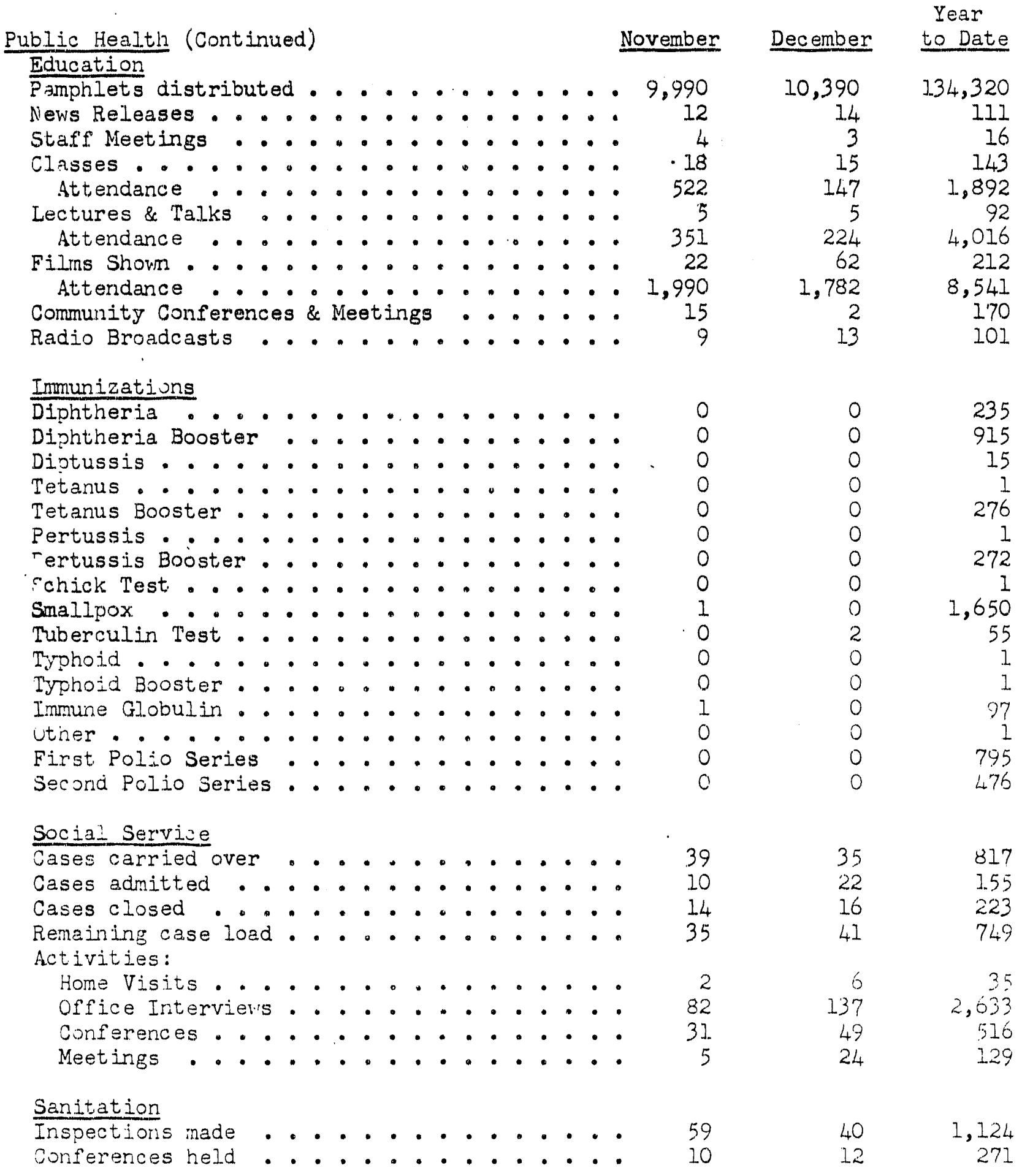


Public Health (Continued) Communicable Diseases

Chickenpox . . . . . . . . . . . .

Erysidelas . . . . . . . . . . . . .

Food Poisoning . . . . . . . . . . .

German Measles .. . . . . . . . . .

Impetigo . . . . . . . . . . . . . .

Influenza (J.R.I..) . . . . . . . . . .

Infectious Mononucleosis . . . . . . .

Infectious Hepatitis . . . . . . . . .

Measles ..... . . . . . . . . .

Meningitis . . . . . . . . . . . .

Munps . . . . . . . . . . . . . .

Pinkeye . . . . . . . . . . . . . .

Pneumonia . . . . . . . . . . . . . .

Poliomyelitis . . . . . . . . . . .

Rheumatic Fever . . . . . . . . . .

Ringworm . . . . . . . . . . . .

Roseola . . . . . . . . . . . . . .

Salmonellosis . . . . . . . . . . .

Scarlet Fever . . . . . . . . . . .

Strep. Infection (Throat) . . . . . . .

Tuberculosis . . . . . . . . . . . .

Whooping Cough ... . . . . . . . . .

Total ..................

Total To. Nursing Field Visits . . . . .

Total $\mathrm{N}$. Nursing Office Visits . . . . .

\section{November}

18

0

0

6

2

0

0

0

o

13

3
Year

to Late

19

276

$\frac{1}{5}$

81

13

4

17

35

2

$-73$

12

1

8

2

47

34

133

49

7

21

1,234

4.197 
COMMUNITY SECTION

DECEMBER 1955

ORGANIZATION AND PERSONNEI:

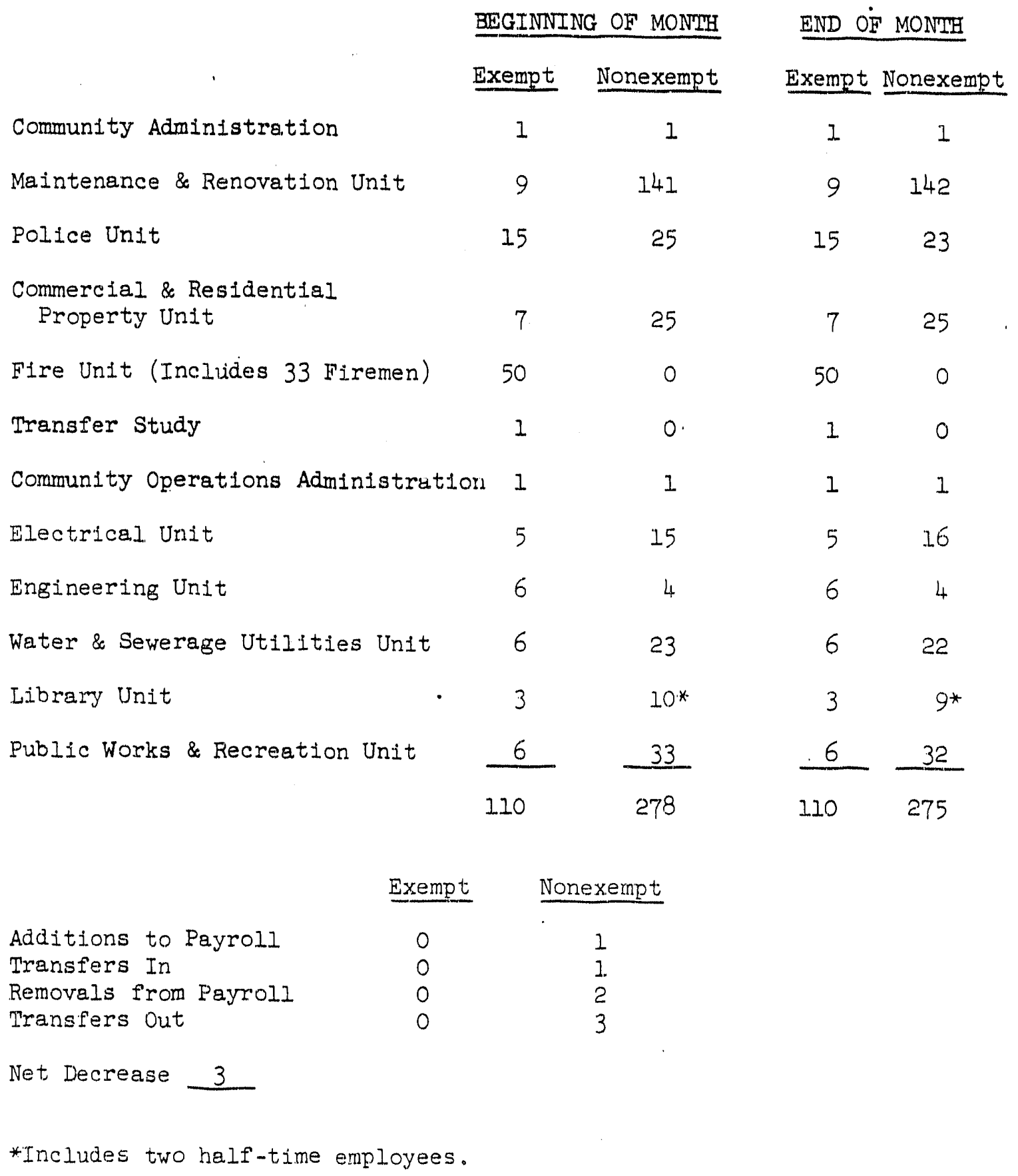




\section{MAINTENANCE AND RENOVATION UNIT}

$$
\text { December, } 1955
$$

Exempt

$$
\begin{gathered}
\text { Employees - Beginning of month } \\
\text { New hires }
\end{gathered}
$$

Employees - End of month
9

0

9
Nonexempt

142

1

142

Gga-I 
December, 1955

FOREMEN: R. A. CHAMBLISS; D. W. LUKINS; M. E. TAPPAN

TYPE NO. UNITS ' COMPLETED COMPLETED BALANCE TO

UNIT SCHEDULED $\quad$ THIS MONTH $\quad$ TO DATE

\begin{tabular}{|c|c|c|c|c|}
\hline A & 405 & 21 & 93 & 312 \\
\hline B & 348 & 26 & 111. & 237 \\
\hline C & 160 & 39 & 81 & 79 \\
\hline D & 2 & 0 & 1 & 1 \\
\hline$E$ & 23 & 1 & 7 & 16 \\
\hline$F$ & 64 & 4 & 21 & 43 \\
\hline$G$ & 5 & 0 & 1 & 4 \\
\hline $\mathrm{H}$ & 68 & 4 & 26 & 42 \\
\hline $\mathrm{K}$ & 57 & 20 & 31 & 26 \\
\hline I & 37 & 2 & 2 & 35 \\
\hline M & 7 & 0 & 0 & 7 \\
\hline Q & 28 & 1 & 3 & 25 \\
\hline $\mathrm{R}$ & 23 & 2. & 2 & 21 \\
\hline $\mathrm{S}$ & 5 & 0 & 0 & 5 \\
\hline$T$ & 0 & & & \\
\hline U & 77 & 1 & 2 & 75 \\
\hline V & 183 & 2 & 12 & 171 \\
\hline$Y$ & 17 & 1 & 13 & 4 \\
\hline Z & 2 & 0 & 0 & 2 \\
\hline IBP & 9 & 2 & 7 & 2 \\
\hline $2 \mathrm{BP}$ & 29 & 7 & 23 & 6 \\
\hline $3 B P$ & 8 & 1 & 6 & 2 \\
\hline Tract & 19 & 1 & 2 & 17 \\
\hline IBR Apt. & 27 & 1 & 1 & 26 \\
\hline 2BR Apt. & 69 & 2 & 1.4 & 55 \\
\hline Dormitories & 5 & 0 & 0 & 5 \\
\hline TOTAL & 1677 & 138 & 459 & 1218 \\
\hline
\end{tabular}

11 Units added

Est. MH B. F.

Est. MH This Month

Total Est. MH

$\begin{array}{r}16,395 \\ 7,500 \\ \hline 23,895\end{array}$

Actual MH B. F.

Actual MH This Month

Total Actual MH
16,712

7,820

24,532 


\section{PLUMBING SHOP}

December, 1955

FOREMAN: F. L. EISENSOHN

Electric water heaters replaced Laundry trays replaced

Miscellaneous plumbing work orders completed 15

Miscellaneous steam work orders completed 20

Plumbing for floor and sink linoleum 87

Plumbing for shower stall replacement

Radiators completely overhauled in dormitories and the hospital

Cleared major sewer stoppages caused by tree roots 81

Cleared major sewer stoppages in main sewers for Public Works

Plumbing and steam repairs in the hospital and Public Health buildings

Worked on plumbing service orders

Loaned truck driver and serviceman to Public Works for sanding streets and operator to blade snow

Loaned plumber to Public Works

Shoveled snow off steps and walks at domitories

Furnished men to help repair two broken water mains for Public Works

Furnished serviceman to Renovation crew

Broke up foundation, filled and leveled ground at 1019 Lee Blvd.

Made routine steam inspection once each week in Government owned commercial facilities, dormitories, and apartments.

Excavated with backhoe machine and handwork for the cleanout of roots in sewer lines, and to repair all leaking and broken underground piping, and backfilled.

\section{SERVICE ORDER CREW}

FOREMAN: L. F. CARPENTER

A. Service orders on hand at beginning of month 1601

B. Received during the month 2121

C. Completed during the month 2251

D. On harld at end of month 1471

E. A total of 123 manhours were expended on work orders.

F. Backlog of service orders by craft:

\begin{tabular}{lr} 
Plumbing & 728 \\
Electrical & 721 \\
Carpentry & 22 \\
\hline & \\
Total & 1471
\end{tabular}




\section{RENOVATION AND LABOR CREW}

December, 1955

FOREMAN: B. C. BAIN

Houses renovated 34

Minor carpenter repairs to renovated houses 23 .

Trash pickups 21

Minor repairs to dormitories 11

Renovation minor paint jobs 26

Houses sprayed for insect control 2

Renovation houses deodorized. 1

Floors cleaned and sealed in renovation houses 5

Provided weekly service of delivering linens and janitorial supplies to occupied dormitories.

Provided weekly pickup and delivery of laundry from various General Electric Company units to Richland Laundry and Dry. Cleaners.

\section{MECHANICAL SHOP}

FOREMAN: Z.H. MAYBERRY

A. Millwright Crew:

Routine furnace inspections $\quad 180$

Furnace service orders $\quad 291$

Routine work performed at Kadlec Hospital by 1 man.

B. SheetmetaI Crew:

Shower stalls installed 12

Installed coal hatch flashings 44

Installed rain gutters 29

Installed flashings 9

Smoke pipes replaced 10

C. Service Crew:

Tree removal orders completed 52

Top soil delivered 4

Snow was removed from steps and sidewalks at all dormitories after every snow fall.

Two days were spent hauling and sanding icy streets. 
December, 1955

\section{FOREMAN: R. M. MARTIN}

Replaced bath wall tile

Repaired bath wall tile

Resealed wall tile - dormitories

Replaced bath floor linoleum

Repaired bath floor linoleum

Replaced kitchen floor linoleum

Repaired kitchen floor linoleum

Replaced bedroom floor linoleum

Repaired bedroom floor linoleum

Replaced utility room floor linoleum

Replaced utility room tileboard

Replaced living room floor linoleum

Repaired living room floor linoleum

Replaced hall Itnoleum

Replaced steps and landing linoleum

Replaced sink top linoleum

Repaired sink top linoleum

Replaced cupboard top linoleum

Replaced work bench linoleum

Replaced kj.tchen sinks

Chempoints

Paint touch ups

Repaired ranch house ladders

Repaired porches

Jack \& shim

Repaired thresholds

Exterior doors repaired

Interior doors repaired

Interior house repairs

Repaired siding

Repaired roofs

Replaced ranch window screens

8

3

Replaced screen doors

Repaired screen doors

Repaired walls

Repaired ceilings

Replaced floor boards

Repaired basement stairs 


\section{COMMUNITY SECTION \\ RICHLAND POLICE DEPARTMENT \\ MONTHLY REPORT \\ DECENBER 1955}

ORGANIZATION

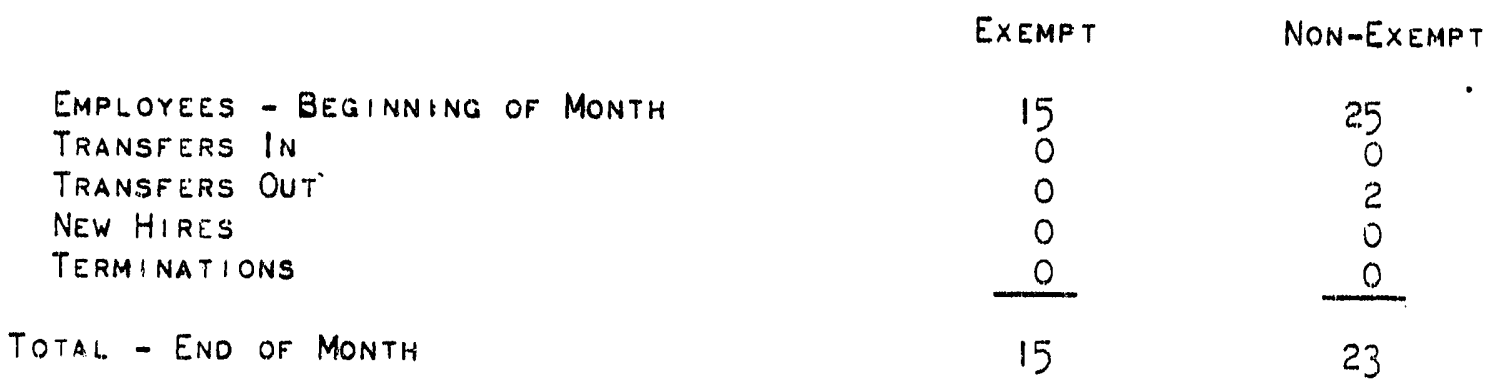

GENERAL

Effective December 12, the normal force of the Richland Pol ice Department was REDUCED FROM 40 TO 38 EMPLOYEES.

A TEMPORARY STRAIGHT SWING SHIFT SCHEDULE HAS BEEN ADOPTED TO PROVIDE DESIRED COVERAGE DURING THE HOURS OF 2:00 PM TO 10:00 PM. THIS BECAME NECESSARY DUE TO THE TRANSFER OF tWO PATROLMEN TO THE SECURITY PATROL AND WILL PROBABLY BE NECESSARY UNTIL REPLACEMENTS ARE RECEIVEO.

ON S-D Day, December 1, RICHLand Experienced only 6 Reportable accidenis, With DAMAGES ESTIMATED AT \$755.00. THERE WERE NO INJURIES REPORTED IN ANY OF THE

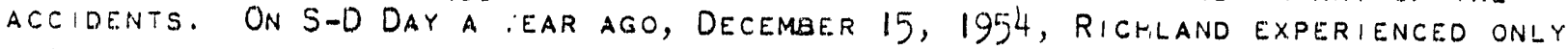
ONE TRAFFIC ACCIDENT aNo NO INJURIES. HOWEVER, a yEAR ago there WAS NO ICE AND SNOW ON THE ROADS ON S-D DAY.

On December 21 the anivul school boy Patrol christmas party was held at the COMMUNITY HOUSE WITH MORE THAN 500 Patrol bOYS and Patrol. GIRLS IN atTENOANCE. THE PARTY IS SPONSORED EACH year by the RICHLAND POLICE athletic League and IS AN AWARD FOR SERVICES RENOERED TO THE COMMUNITY IN THE PERFORMANCE OF SCHOOL PATROL DUTIES OURING THE YEAR.

Caft. W. A. Ziegler ano lt. E. E. Miller made two television appearances this MONIH IN CONJUNCTION WITH TRAFFIC SAFETY PROGRAMS.

The Richland police department was featured in tha december issue of the pacific

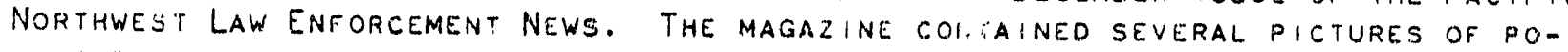
L. CE FERSONNEL aLONG WITH a STORY about the DEPARTMENT.

Members of the traffic Control section conducted 5 traffic safety meEtings this MONTH.

TWO GROUPS OF CUB SCOUTS WERE EgCORTED ON TOUR OF POLICE HE, DQQUARTERS DURING THE MONTH. 
TRAFF IC

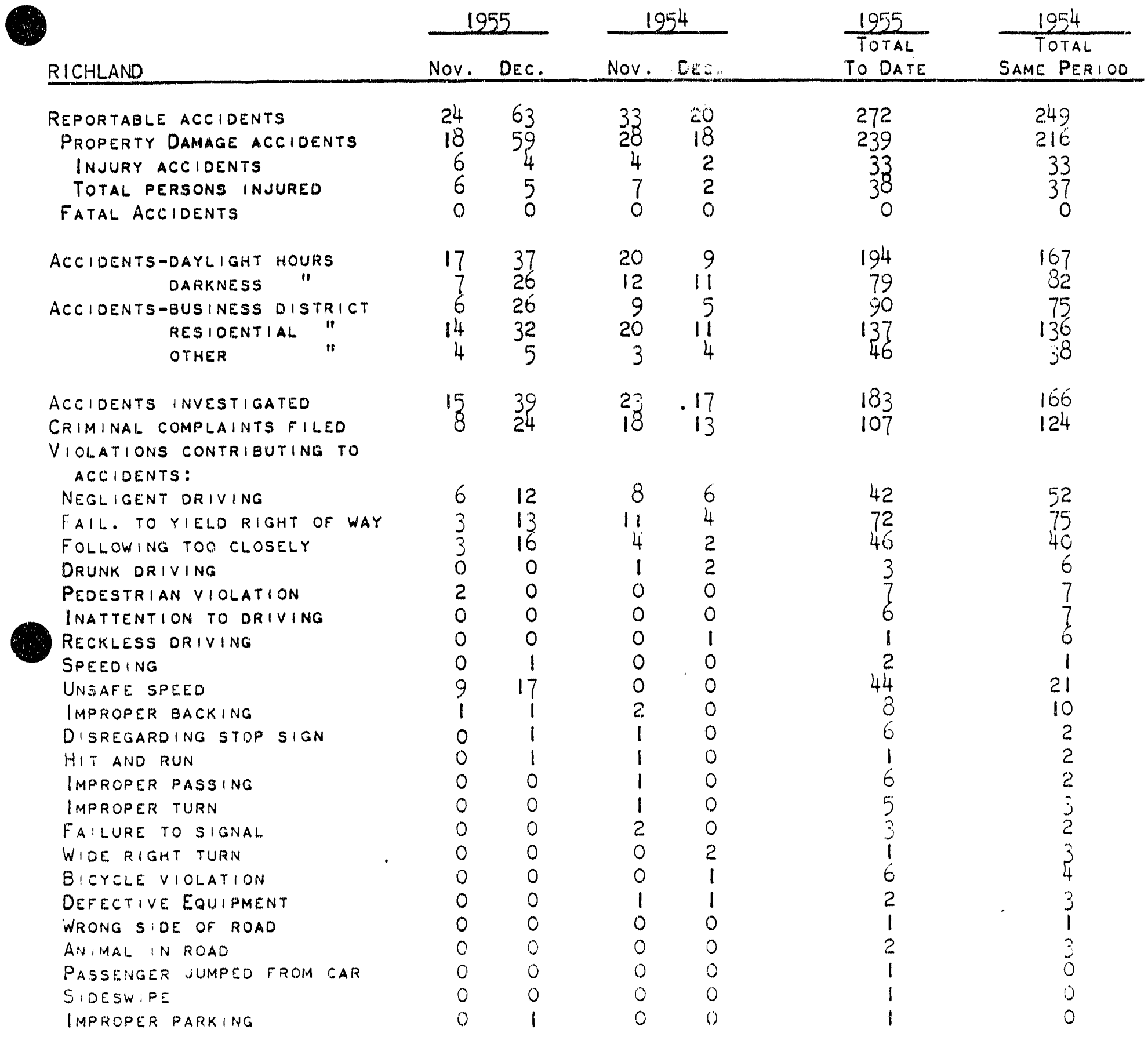

\begin{tabular}{|c|c|c|c|c|c|c|}
\hline \multirow[b]{2}{*}{ Z:CHLANO } & \multicolumn{2}{|c|}{1955} & \multicolumn{2}{|c|}{$\begin{array}{l}\text { AVE. PER ACCIDENT } \\
1955\end{array}$} & \multicolumn{2}{|c|}{$\begin{array}{c}\text { AYE. PER ACC IDENT } \\
1954\end{array}$} \\
\hline & Nov. & DEC. & Nov. & DEC. & Nov. & DEC. \\
\hline
\end{tabular}




\section{TRAINING}

Advance training fí Richland Police members at the small. Arms inange for the PERIOD IN FIELD INSTRUCTION WAS AS FOLLOWS:

RIOT GUN ANO MACHINE GUN TOTAL NUMBER OF MEN REPORTING AT THE RANGE NUMBER OF MEN FIRED OVEA THE ARMY -L COURSE

$\frac{1}{2}$ HOUR

11

THIS FIRING WAS FOR PRACTICE AND NO SCORES WERE TAKEN.

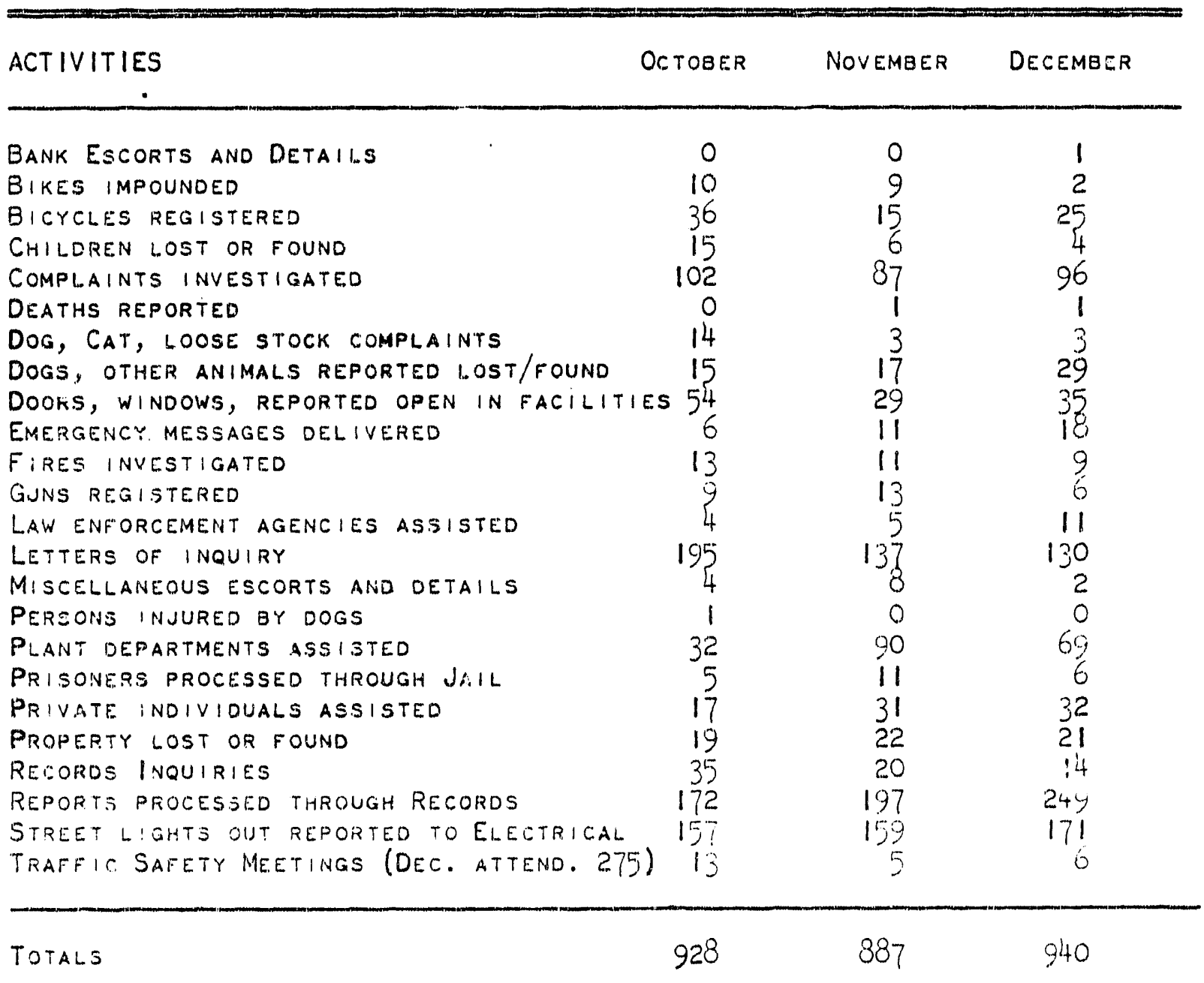




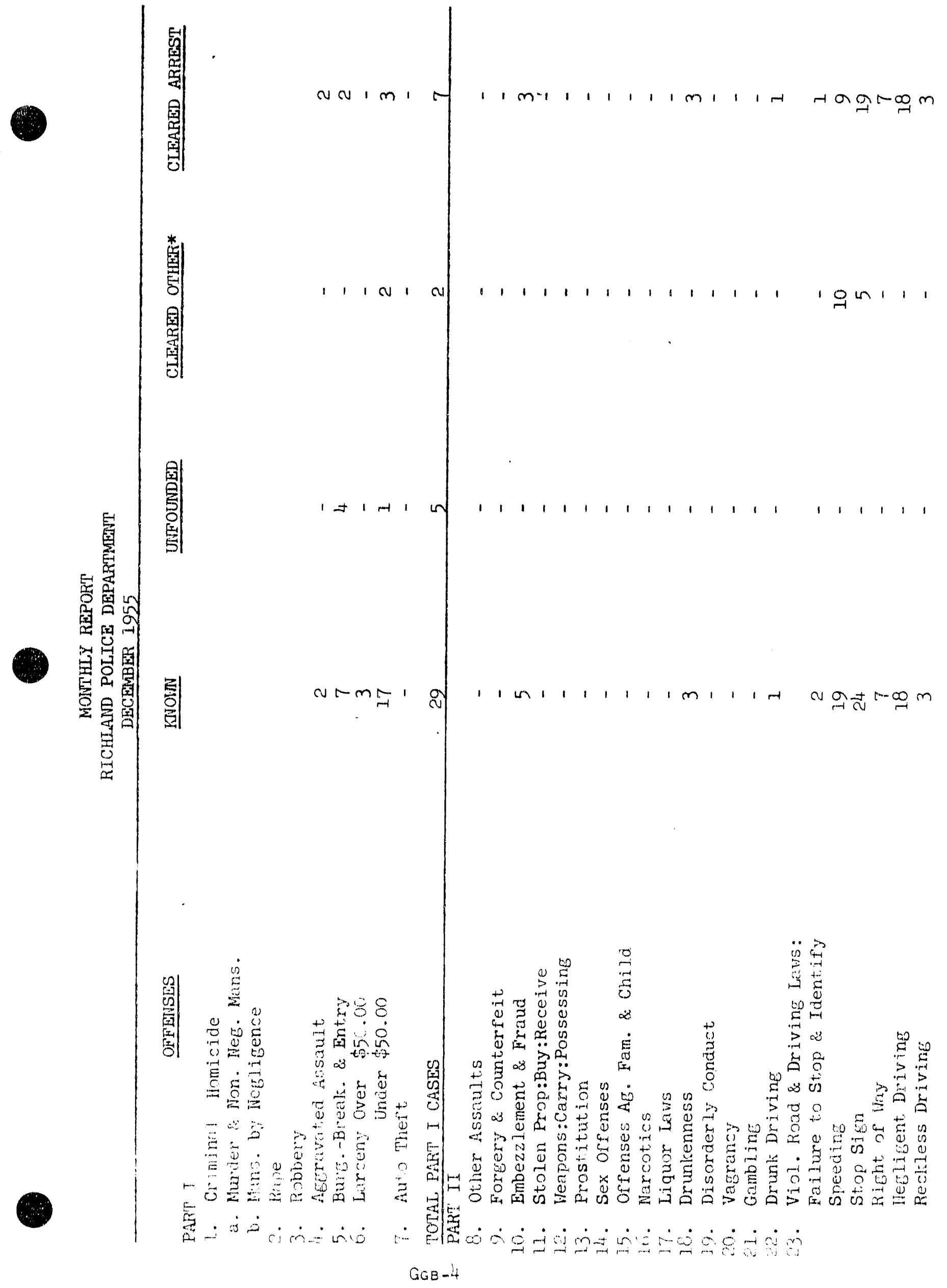




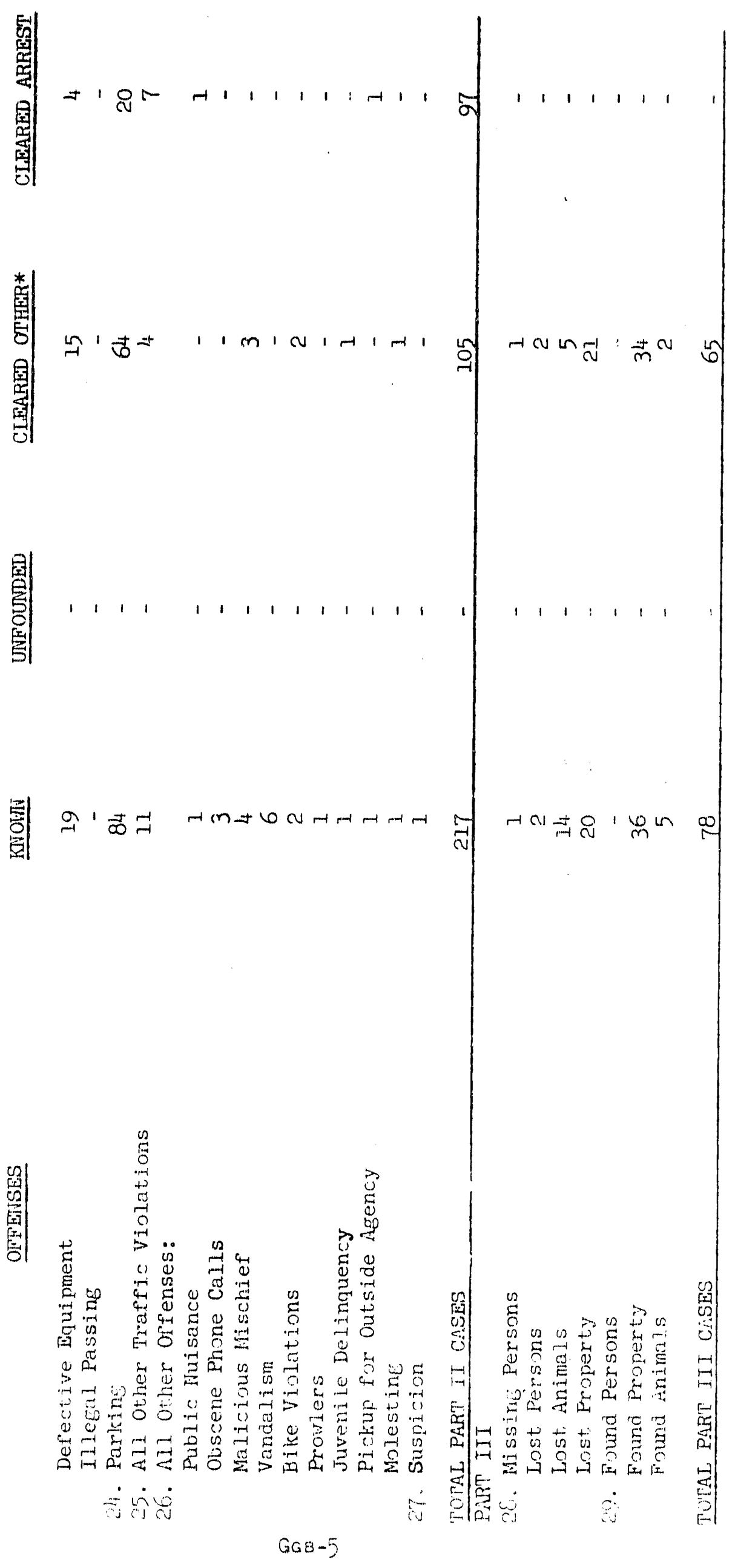



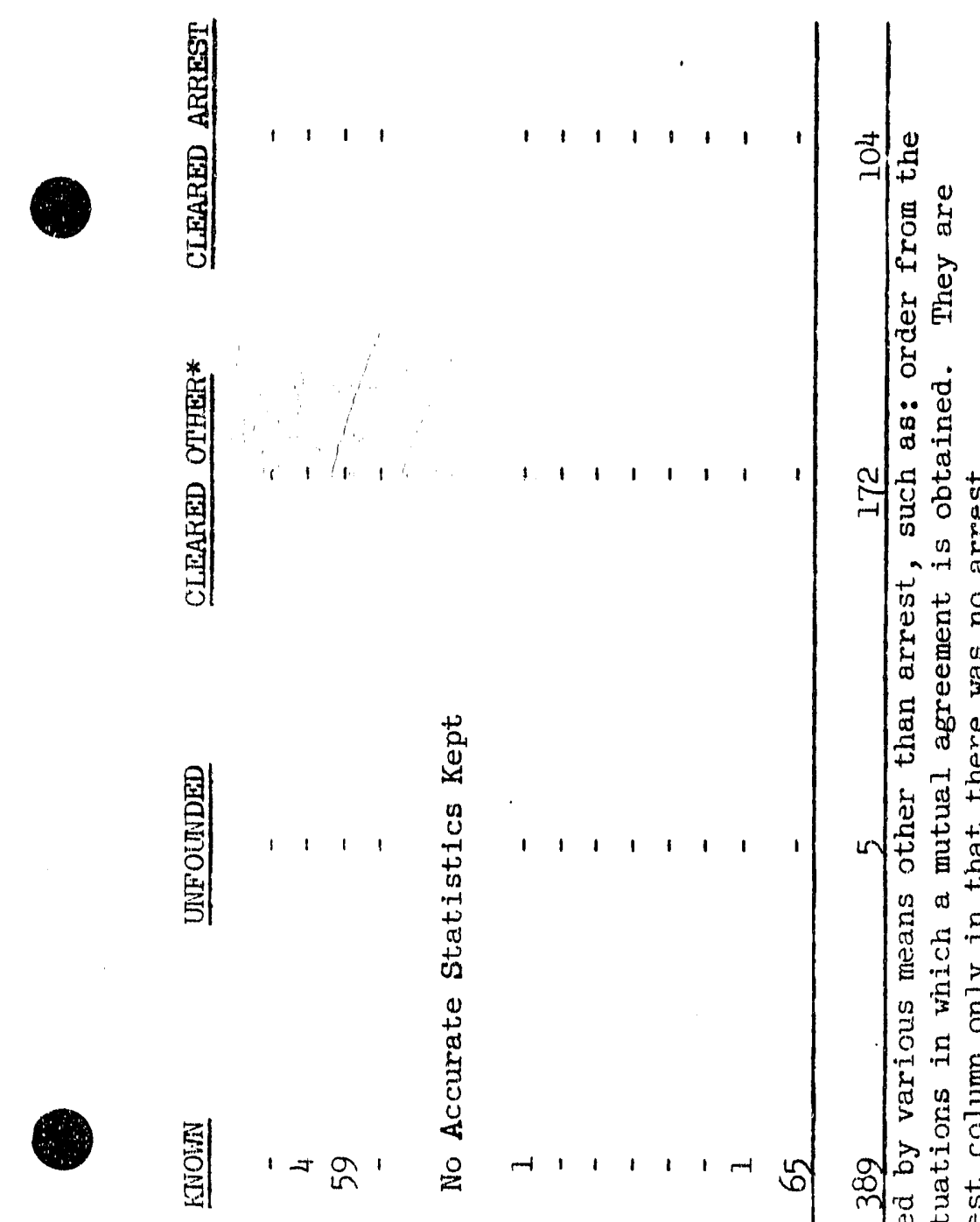

vis

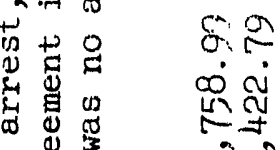

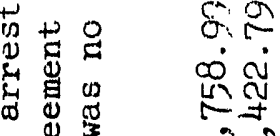

द्व क्षी

엻

$\sqrt{2}$

녹

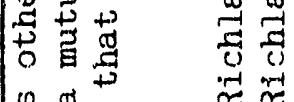

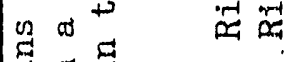

중

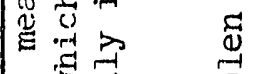

उू

.

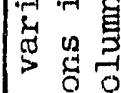

व.

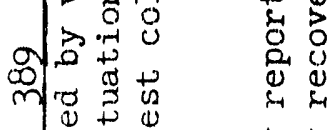

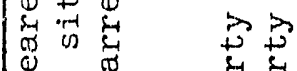

0

ऊ) क्ष

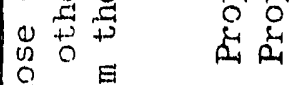

至界

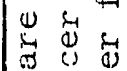

路

\begin{tabular}{l}
$\dot{d}$ \\
\cline { 1 - 1 } \\
$y$
\end{tabular}

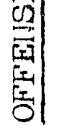

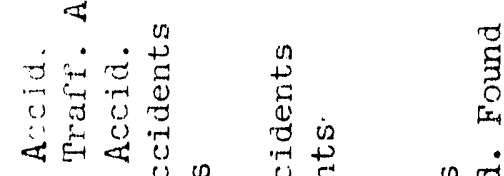

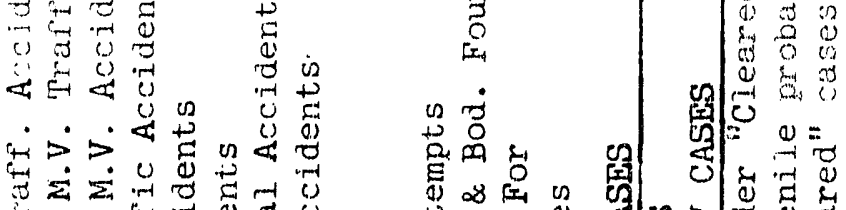

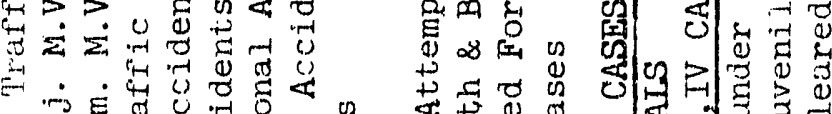

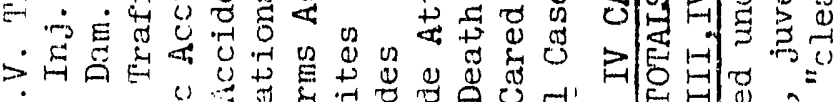

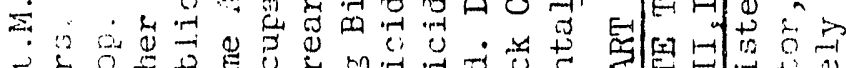

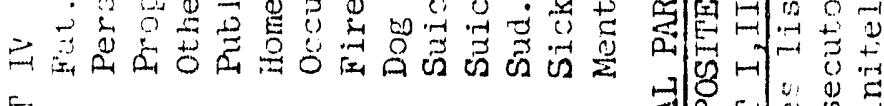

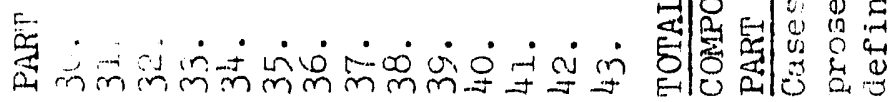

$6 c 0-6$ 


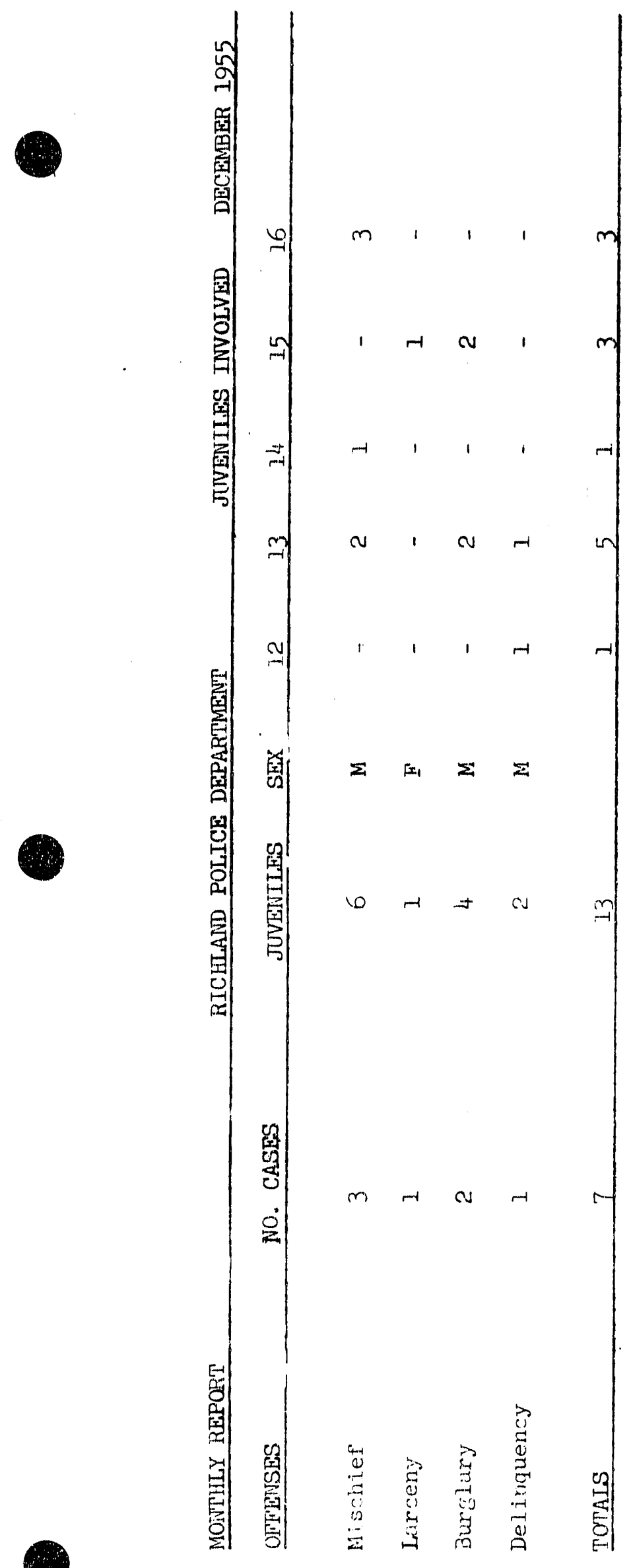

GGB-7

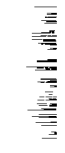




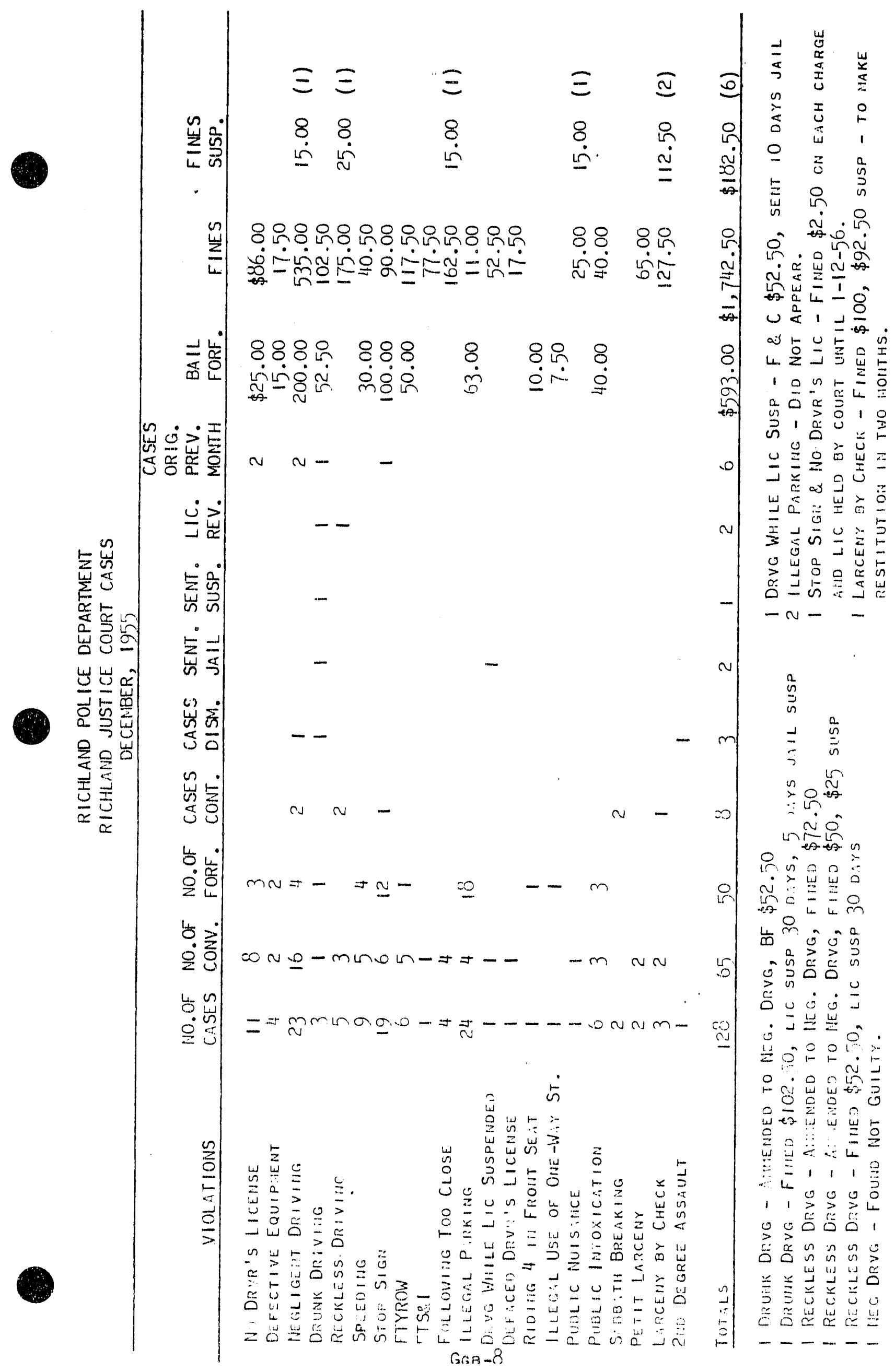


PERSONNEL - COMMERCIAI AND RESIDENTIAL PROPERTY UNIT:

Exempt Non-Exempt

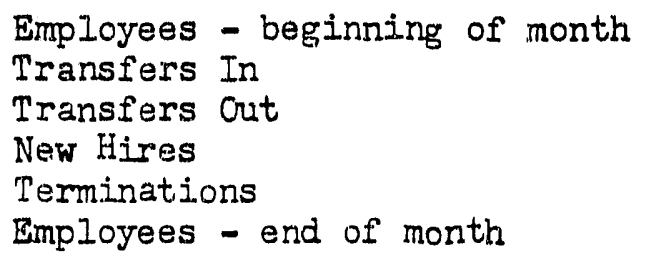

\begin{tabular}{ll}
7 & 25 \\
0 & 0 \\
0 & 0 \\
0 & 0 \\
0 & 0 \\
\hline 7 & $\frac{0}{25}$
\end{tabular}

PERSONNEL - COMMERCIAI AND NONCOMMERCIAI FACILITIES:

Commercial Noncommercial Total

November 1,603 99 1,702

December 1,597

$\underline{94}$ $\underline{1,691}$

Net Change $-6$

SUMMARY OF ROUTINE ITEMS PROCESSED:

Commercial Noncommercial Total

Work Orders 50 11

Back Charges

1

FY Work Orders

214 25 239

FY Back Charges 8 2

\section{CONTRACTS AND NEGOTIATIONS:}

A. Commercial

1. Supplemental. Agreements:

a. Anderso: 1 Motors - to provide for new rent, separate payment for utilities and services, and certain other changes in connection with lease renegotiation and arbitration. 
b. Colin Bleiler - to provide for subleasing office space.

2. Business Development:

Three bids received were opened and read in connection with leasing the Government-owned 1125 Warehouse.

B. Non-Commercial

1. Lease:

Richland Riders Club - a new lease to supersede a lease which had expired. GENERAL:

A. Conmercial

1. Ed Hollenbeck, 24 Flavors Ice Cream, terminated his sublease in the C. D. Joseph building.

2. Walston and Co. terminated their sublease in the Richland Development Co. building.

3. Davis Furniture Co. terminated their lease on the 1125-4 Warehouse.

4. Richland Printers closed business, but retain the lease on the building.

5. Morrison-Knutson subleased space in the Automatic Laundry Co. building.

6. True's Oil Co. No. 2 started construction of a service station on George Washington Way, south of Kni ght Street.

7. 123 brochures were prepared and submitted to the Commission for use by appraisers in connection with disposal legislation.

B. Non-Commercial

1. The inventory of govermment-owned equipment in connection with the North Richland Tavern formerly operated by Mr. R. Bruce Johnson was processed and distributed.

2. At the request of the Atomic Energy Commission, officials of the local church groups were informed that it may be possible to purchase their respective leased or otherwise allocated sites under an existing delegation of authority or at a later date when such sales would be made under the provisions of Public Law'221, 84th Congress. Following receipt of information indicating their decisions, it is anticipated that additional church sales may be consummated.

3. Twent,j-one brochures were prepared and suomitted to the Commission ror. use by appraisers in connection with disposal legislation.

$$
\text { Gre-2 }
$$


4. One pasture permit was issued.

5. Two boat moorage site permits were issued.

\section{COMMERCIAL PROSPECTS:}

Inquiries were received during the month conceming the establishment of the following types of enterprises in Richland:

\section{Equipment Bental Drive-In Restaurant \\ Industrial Spray Painting}

\section{SUMMARY OF OCCUTPANCY AND EXPANSION STATUS:}

A. Conmercial

NOVEMBER DECEMBER

1. Number of Government-Owned Buildings

a. Number of Businesses operated by Prime Lessees

(I) Number opened

(2) Number closed

b. Number of Businesses operated by Sublessees

(1.) Number opened

(2) Number closed

Total Busineeses in Government--Owned Buildings

2. Doctors and Dentists in Private Practice

3. Number of Privately Owned Buildings

a. Number of Businesses operated by Frime Lessees

(I) Number opened

(2) Number closed

b. Number of Businesses operated by Sublessees

(1) Number opened

(2) Number closed

Total Businesses in Privately Owned Buildings

4. Privately Owned Buildings under Construction

5. Total Number of Businesses in Operation

a. Total openings

6. Totals for calendar year 1955

Businesses beginning of year

Leases executed

Supplemental agreements executed

Bid awards

Private building construction started

Arbitrations

Businesses opened

Businesses closed

Businesses closed - North Richland
41

41

36

0

2

$2 I$

0

0

57

31

31

81

82

49

49

0

120 
B. Noncommercial:

1. Government-Owned Buildings

a. Churches

b. Clubs and Organizations

c. Government Agencies

\section{Total}

2. Privately Owned Buildings

a. Completed and in Use

b. Under Construction

3. Church Plots and Buildings in Private Ownership

4. Pasture Land Permits

5. Private Boat Moorage Permits
NOVEMBER DECEMBER

\begin{tabular}{ll}
$\frac{1}{5}$ & 7 \\
2 & 5 \\
\hline 8 & $\frac{2}{8}$
\end{tabular}

13

13

6

6

100

101

74

76 
PROGRESS REPORT

$\begin{array}{lcc} & \text { Orders incomplete as } & \text { Orders 1ssued } \\ & \text { of November 30, 1955 } & 11-30 \text { to } 12-30 \\ \text { Service orders } & 1854 & 2416 \\ \text { Work orders } & 1438 & 779 \\ \text { Service charges } & & 238\end{array}$

Total orders Incomplete as of December 30, 1955 1553 1534

Princlpal work order loads

Kitchen cabinet linoleum

Incomplete as of
November 30,1955
187
114
31
10
76

Incomplete as of December 30; 1955 247
125
47
10
85

184 alteration permits were issued as compared to 177 issued in November.

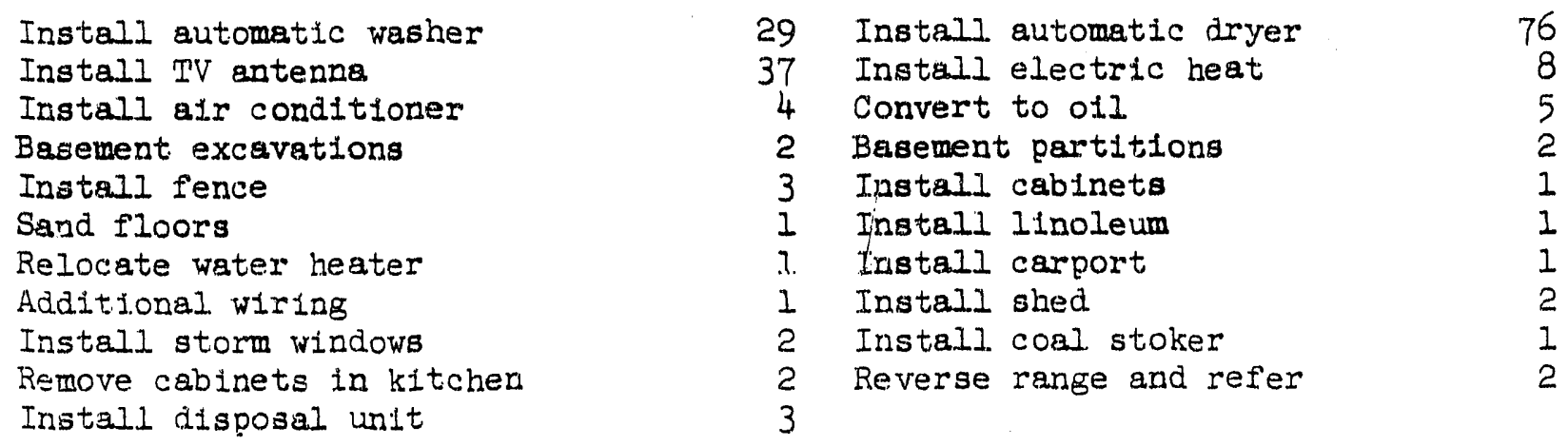

1029 inspections were made, as compared to $\underline{1458}$ in November.

$\begin{array}{lrlr}\text { Alteration permits } & 240 & \text { Basements } & 15 \\ \text { Bathroom } & 11 & \text { Ceilings } & 15 \\ \text { Doors } & 10 & \text { Floors } & 11 \\ \text { Laundry trays } & 16 & \text { Linoleum } & 2.14 \\ \text { Lot lines } & 5 & \text { Paint } & 11 \\ \text { Eorch } & 3 & \text { Range \& refer recal1 } & 17 \\ \text { Steps \& walks } & 2 & \text { Sink } & 18 \\ \text { Shower stall } & 10 & \text { Toilet seat } & 2 \\ \text { Trees } & 7 & \text { Walls } & 28 \\ \text { Windows } & 4 & \text { Yard } & 7 \\ \text { Miscellaneous } & 12 & \text { Renovations rechecks } \\ \text { Dormi toris } & 149 & \text { Renovations } & 41 \\ \text { Cancelilations } & 58 & \text { Shows (new tenants) } & 57 \\ & & & 66\end{array}$


TENANT STORES

Merchandise Issued

Shades
Reflectors
Ice cube trays
Meat tender
Drip tray
Hydrator glass
Hydrator brackets
Door stops
Cooker pot \& cover
Refer parts
Range parts
Furniture recall
Furniture delivery
Space heaters, recall
Space heaters, delivery

Total Amount

511
14
20
4
12
5
2
5
3
1
3
21
18
26
10

RECAIL AND DELIVERY OF RANGES AND REIFRIGERATORS -- MONTH OF DECEMBER

$$
\begin{array}{ccc}
\multicolumn{2}{c}{\text { DELIVERY }} & \multicolumn{2}{c}{\text { RECALI }} \\
\text { RANGGES } & \text { REFHERS } & \text { RANGES REFERS }
\end{array}
$$

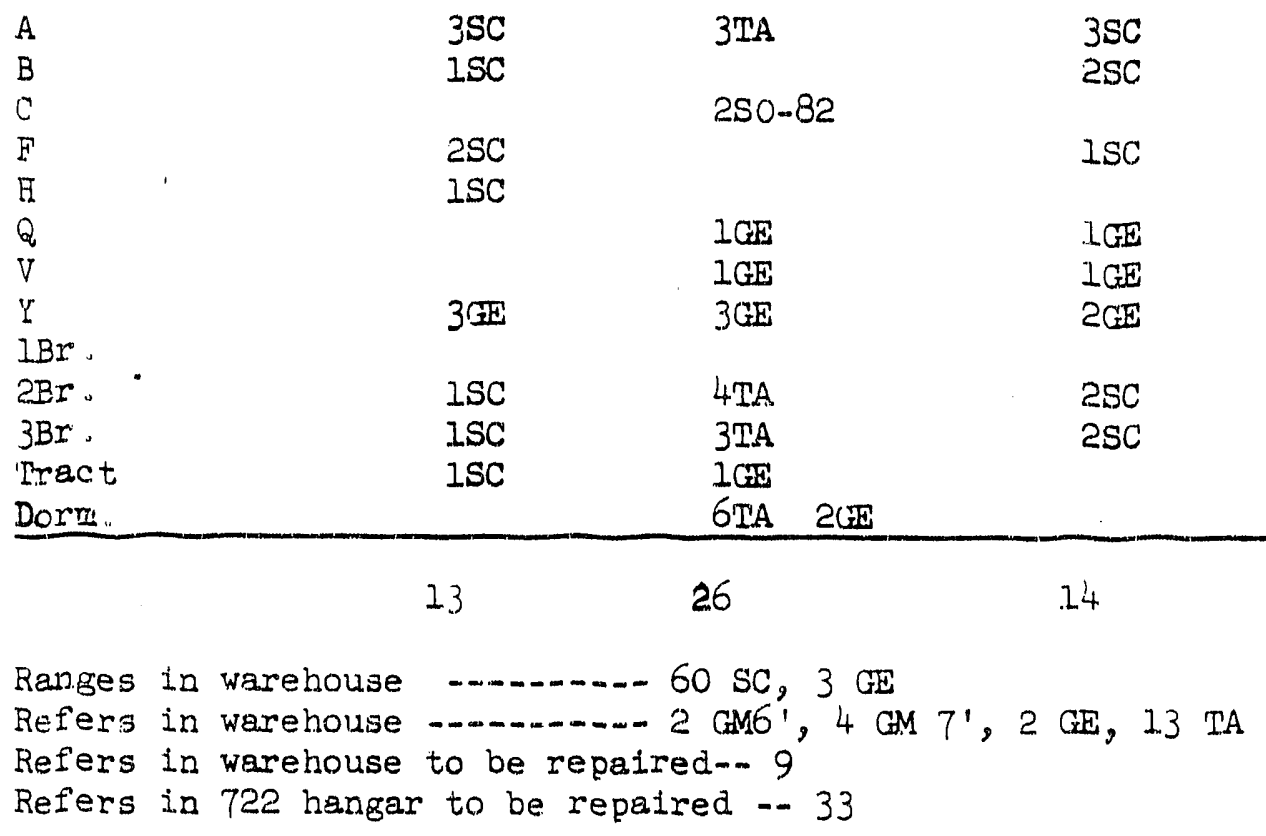


COMMERCIAL \& RESIDENTIAL PROPERTY UNIT

RES DDENTIAL LEASES

DECEMBER 1955

DORMITORY REPORT

Men

Women

Beds Avallable Vacant Beds Occupied Beds

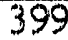

$\frac{305 *}{704 *}$

\section{5}

$\frac{54 * *}{1.19 * *}$
334

$\frac{251 *}{585 *}$

Iotal

*This Includes 2 beda used for Dormitory Offices

* This Includes 7 beds vacant in Dormitory $M-13$

Haiting list

Men

Women

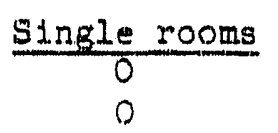

$\frac{\text { Double rooms }}{0}$

The following Dormitorles are in stand-by condition:

W 1138 beds W $1.5 \quad 50$ beds M 639 beds

$W 12 \quad 38$ beds W 16 50 beds M? 39 beds

M 839 beds

Total beds 293

Dormitories released for temporary use:

it 2150 beds if 1750 beds

Total beds 100

\section{CAINELIATIONS}

RES IDENTIAL LEASIIFG

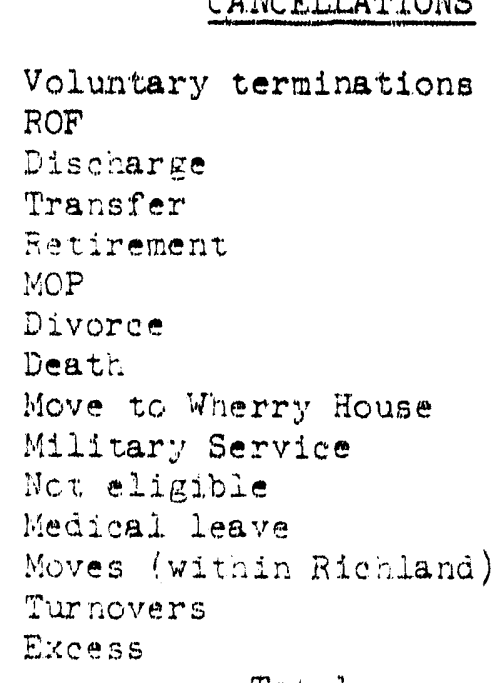

Total

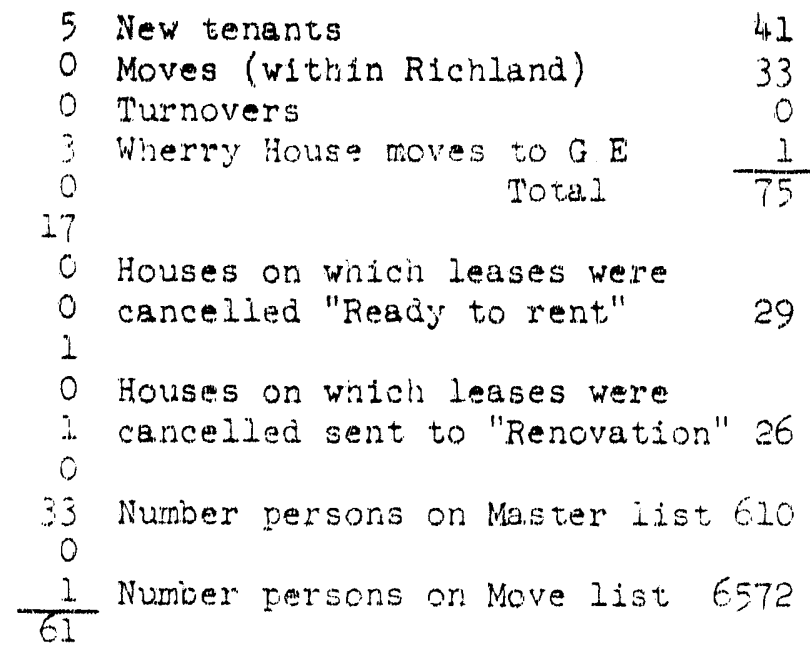

0 Houses on which leases were

o cancelied "Ready to rent" cancelled sent to "Renovation" 26

33 Number persons on Master inst 610

$\frac{1}{61}$ Numider prsons on Move list 6572

ALIOCATIONS

17

1

0 
RICEILAND HOUSING

HOUSING UMIIIZATION AS OF MONTH ENDING DECEMBER 31, 1955

HOUSES OCCUP IIDD BY FAMITYY GROUPS

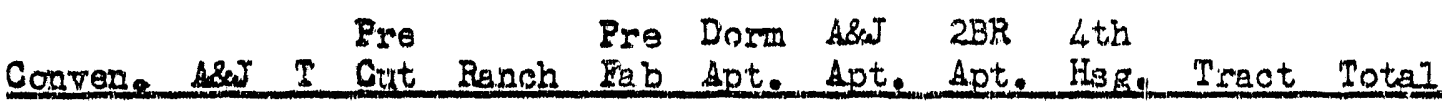

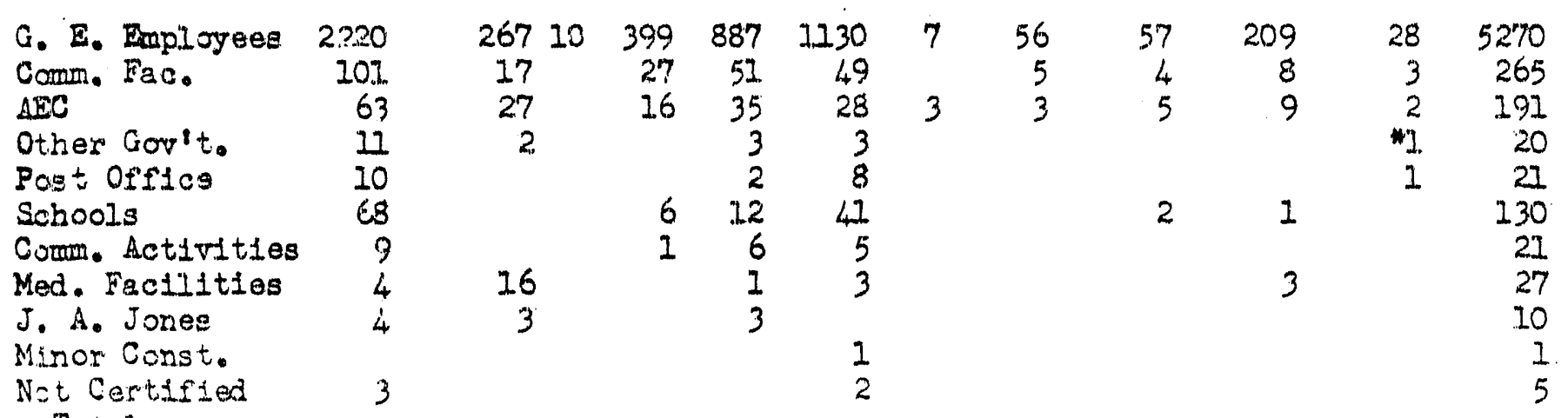

Ready to Rent In Renovation

\begin{tabular}{|c|c|c|c|c|c|c|c|c|c|}
\hline $\begin{array}{r}2493 \\
1 \\
6\end{array}$ & $\begin{array}{c}33210 \\
1\end{array}$ & $\begin{array}{c}4491000 \\
1\end{array}$ & $\begin{array}{r}1270 \\
2 \\
4 \\
4\end{array}$ & 10 & 64 & $\begin{array}{l}68 \\
2\end{array}$ & 230 & $\begin{array}{r}35 \\
1\end{array}$ & $\begin{array}{r}5967 \\
5 \\
13\end{array}$ \\
\hline$\overline{2500}$ & 33310 & 4501000 & 1.76 & 10 & 64 & 70 & 230 & 36 & 5979 \\
\hline
\end{tabular}

Begin Month Moved In Moved Out End of Month Difference

\begin{tabular}{|c|c|c|c|c|c|}
\hline Conventional Type & 2486 & +214 & -17 & 2493 & +7 \\
\hline $\begin{array}{l}\text { ART Type } \\
\text { HTn Type }\end{array}$ & 337 & +5 & $=4$ & 332 & $4 \quad I$ \\
\hline Precut Type & 446 & +6 & $=3$ & $\begin{array}{l}10 \\
49\end{array}$ & $?$ \\
\hline Rarch Type & 999 & +7 & -6 & 1000 & +1 \\
\hline Prefab Type & 1246 & +25 & -19 & 1270 & +6 \\
\hline Dorm Apts. & 10 & +0 & -0 & 10 & 0 \\
\hline Asct Apts. & 64 & +1 & -1 & $6 L$ & 0 \\
\hline $2 B R$ Apts. & 70 & +1 & -3 & 68 & -2 \\
\hline Fourth Housing & 227 & +5 & -2 & 230 & +3 \\
\hline Tracta & 35 & +0 & -1 & 32 & -1 \\
\hline TotaI & 5943 & $7 / 4$ & 56 & 5961 & +18 \\
\hline
\end{tabular}

"JI-ób4 Vernita show on Dally Housing report on December 14, 1955, under

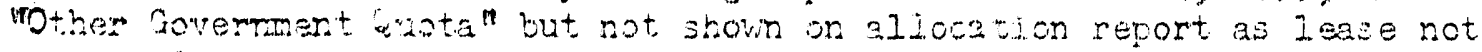
received. 


\section{ORGANIZATION \& PERSONNEL}

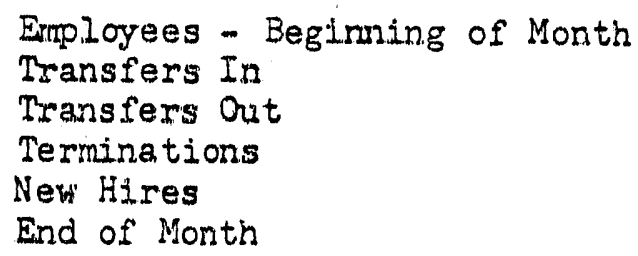

\section{ETRE PROTECTION}
Fire Loss (Estimated) - Govermment Personal December Total 1955 Total

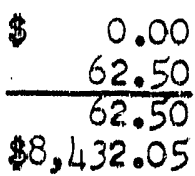

Kesponse to Alarms

Investigation of Minor Fires \& Incidents

Outside Drills

Safaty Meetirgs

Security Meetings

Eight Explorer Scouts were given a first aid review on Dtcember 8 , by the Duty Captain at No. 2 Station.

Elght off-shift members of the Fire Department semed as judges of first aid and other contests at the Blue Mountain Council Boy Scout skill-raliy rela the evening of December 8 in Columbia High School.

The Duty Captain at the Central Fire Station gave instruction on December 30 to five members of the Police Department in the use of all-service gas masks.

\section{FIRE MARSHAL'S MONNILY REPORT}

A total of 467 buildings were inspected, resulting in 216 hazard reports being submitted. A total of 398 fire extinguishers were inspected, 14 installed, 10 removed, 5 repaired, 61 weighed and 18 winterized. In 


\section{Fire Marshal's Report Continued}

addition, 71 fire hose standplpes and 7 fire hose boxes were inspected, and serriced.

A total of 39 sprinkler system inspections were made, pressur'a boosted on three systems and timing device raised on one system to prevent false alarms. Arranged overhaul schedule for five systems in 700 Area. Approved and assisted with piping changes in one of Kadlec Hospital systems. Approved AEC's plans for five new systerns in High School.

Tested six building fire alarm systems and promoted the rewiring of a complete school fire alarm system and enlargement; of another school system. Contracts were awarded and work commenced on both systems during month.

Requested appointment of new fire wardens and revisions in evacuation procedures for all major 700 Area Buildings.

Completed special Christmas inspections of all comercial buildings and asked the cooperation of all owners and linagers to be extra cautious of fire hazards during the season.

Planned Fire safety publicity for the Holiday season and assisted the Jaycees with plans for their amnal "Operations Torch" project, which rids our city of the hazards of discarded Xmas Trees.. 
ORGANIZATION AND PFERSONNEI

Employees Beginning of Nonth

Transteres In

Transfers Out

Terminations

Total Errd of Month
Exempt Non-Exempt

5

\section{SYSTEM MATNTENANICE AND OPERATION}

Outside Iines:

Poles set

Poles transferred

Anchors installed

Guys installed

Street lights installed

Mast arms installed

Street lights relamped - 1100 Area

Street lights relamped - 700 Ares

Flood lights relamped - 1100 Area

Flood lights relamped - 700 Area

Stack lights relamped - 700 Area

Traffic signals relanped

Primary line footage added

Primary line footage removed

Traneformer KVA adderi

Transformer KVA renoved

New services installed

Services removed

Scheduled outages

Unscheduled outages

Trees tr.inmed

Stand by and Escort

\section{TRAFFIC SIGNALS}

Operational failures

2

Installations

Removals

Routine check Railroad signal at Van Gilesen

Total signals in operation - automatic

Total sigrals in operation - manual auxiliary

Total Eignals in operation - flasher 
PUBLIC WORKS ETECTRICAI MAINTENANCS

Electrical motors checked and serviced - irrigation 0

Electrical motors checked and serviced - water 116

Blectrical motors checked and serviced - sewage 104

FIRE DEPARTMENT TEST AND MATNTENANCE

Inside circuit and equipment checks 8

Outside circuit checks 10

Inside faults repaired 2

New circuits placed in operation 0

Outside faults repaired

New boxes placed in operation 0

\section{SUBSTATIONS}

Main feeder and tie breaker checks - BELSI

Main feeder and tie breaker checks - BBLS2 5

Secondary and pad located stations - checked jumpers, 26

cutouts, grounds and general condition

IETERING - OPERATION, MAINTENANCE, CONSUMPTION AND REVENUE

Voltage and load checks

10

ileters tested - customer's requests

New meters shop tested

16

Fault.y meters replaced or repaired

Damaged meters and covers

Residential read-ins

Residential read-outs

Rosidential disconnects

Residential reconnects

Radio literferace chacks

Ovirloaded meters changed out

liont ins meter tests

Rétidsotial - Schedule 1

6.972

Commerciel - Schedule 2

$5,230,111$

$\$ 54,048.12$

$2,557,376 \quad \$ 28,847064$

Total 7,384

$8,787,487$

$\$ 82,895076$ 


\section{COMMENTS:}

\section{STBRET LIGHTING}

Performed routine relamping and triming of trees from circuits. Two street light poles, damaged by vehicles, were straightened and repaired.

\section{TRAFFIC SIGNAL SYSTEM}

Performed routine maintenance and cleared two cases of trouble. Difficulty has been experienced in the past in maintaining batteries at the railroad crossing signal. It is believed that this difficulty will be cleared when the Transportation Section completes the welding of all electrical bonds in the controlled section of track.

\section{FIRE PROTECTION SYSTEM}

Relocated conduit and wiring to battery charger at Central Fire Station. Auxiliary fire alarm loop at Chief Joseph School has been removed from sorvice 30 as to allow contractor to rewire the entire loop. Installed new cells in battery bank No. 3 at Central Fire Station. Performed routine check and maintenance on all boxes, circuits, and main board. Performed routine tests on auxiliary circuits at men's and women's dornitories, Desert Inn and Medical-Dental Building.

\section{WATER SYSTEM}

Performed weokly routine maintenance and servicing of electrical in3tallations at domestic wells. Overhauled pump motor at No. 5 water well and installed new bearlngs. Installed drain and filler tubes on domestic water wells 30 as to facilitate oiling the motors.

\section{SEWAGE TREATMENT AND DISPOSAL SYSTEM}

Fonformed weekly routine maintenance and servicing of all electrical iristaliations. Removed pump motor from No. 2 plant pump house so as to $r \in$ place bad bearing.

\section{GENERAI COMMINITTY MAINTENANCE}

Inisected and repaired where necessary the electrical system and replaced electrical range in tract house at Horn Rapids Dam.

\section{STBSTATION AND MELER MAINTENANCE}

$F=-10 m: d$ routine tranzformer and substation maintenance as required. Discornected and reconnected three residential customers for delinquent bill Ing. Made 10 voltage and load checks with all voltage checks found to be satisfactory. Twenty-seven disconrects were made to houses so as to allow tenant to install electric heat. 
Made field inspection of proposed Benton-Richland $115 \mathrm{KV}$ transmission Iine relocation along Thayer Drive and relocated stakes so as to permit the transfer of our circuits at minimum cost.

Transmitted to Community Division of AEC our easement requirements for all constant current street light stations.

Removed pole line feeding tract house at 3415 Davison because the Army has taken over tract house and will supply it with electricity. Accepted operation and maintenance of tio switch between Army and Richland Electrical systems on George Washington Way.

Straightened pole damaged by bus in line feeding gas plant on Saint Road. Submitted pole contact applications on BPA transmission line through Richland to AEC for forwarding to Bonneville Power Administration. Have surveyed $20 \%$ of town for trimming and removal of trees for the winter program.

Brought up to date the system maps. Repaired 4 service drops damaged by falling trees. Replaced 14 transformers with transformers of a higher capacity and added 2 transformers because of new electric heat installations. Provided escort for one crane from excess yard to 300 area.

\section{CALI OUTS}

Seven weekly men and four monthly men were called out during the month on four cases of trouble. 


\section{COMMUNITY OPERATIONS SUIB-SECTION \\ ENGINEERING UNIT \\ MONTHLY REPORT \\ DECEMBER 1955}

$\begin{array}{lccc}\text { PERSONNEL } & \text { Exermpt } & \text { Non-Exempt } & \text { Total } \\ \text { Eimployees Beginning of Month } & 6 & .4 & 10 \\ \text { Transfers Out } & 0 & 0 & 0 \\ \text { Transfers In } & 0 & 0 & 0 \\ \text { Terminations } & 0 & 0 & 0 \\ \text { Total End of Month } & 6 & 4 & 10\end{array}$

BUIIDING FERMITS ISSUED IN DECEMBERR

1. Parker A. Hansen - 1317 Cottonwood Drive - Store Building

2. True's Oil Company - $750 \mathrm{Geo}$. Wash. Way - Service Station

3. Robert H. Ver Steeg - 1302 Roberdeau St. - Anateur Radio Tower

4. I Sign Permit

NEW MUNICIPAL CONSTRUCTION STARTED IN DECEMBER

NONE

NEW PRI VA'TE CONSTRUCTI ON STARTED IN DECEMBER

Parker A. Hansen - 1317 Cottonwood Drive - Store Building

True's Oil Company - 750 Geo. Wash. Way - Service Station

Robert H. Ver Steeg - 1302 Roberdeal St. - Amatour Radio Tower

PRI VATE CONSTRUSTION COMPLETED IN DECEIMER, OR ON WITCH FINAL INSPECTION LAADE

Davis Furniture Company Addition

ENGINEERING JOBS COMPLETED IN DECEMBER

NONE

STATUS OF ENGINEERING UNIT PROJECTS

G-01018 - Relocation of $20 "$ Meter at 300-F Well - Construction 95\% complete. Awaiting improved weather conditions to complete.

G-02171 - Automatic Bar Screens, Sewage Iift Station - 85\% complete. Contracton working on final phase of work. 
G-02197 - Water Meter Installation for 300 Area Supply Lines - 95\% complete. Awaj,ting improved weather conditions to complete.

G-03629 - Replacement of Thir Wall Steel Water Lines (FY 1955) - 98\% complete. Awaiting improved weather conditions to complete.

G-0364l - Harris Avenue, Gaillard Place \& Hains Aveme Extension - Design materially complete. Awaiting A.E.C. approval.

\section{STATUS OF ACTI VE ENGINEERING WORK ORDERS}

C-0572 - Study of Drainage Ditch from Swift Blvd. to Origin on Wellsian Way 80\% conplete. Design delayed for higher priority work.

C-0580 - Design \& Installation Water, Sewer on Wellsian Way - Scoping and project proposal complete.

C-058? - Extending Side Easements to Property Lines - 75\% complete. Work progressing rapidly.

A-5108 - Furnish Plat and Legal Description for 1125 Warehouse - 50\% complete.

C-91455 - Retirement of Imigation Canal - 75\% complete. Delayed for higher prioxity work.

Com 945 - Retirement of Separate Irrigation System - Drawings \& specifications materially complete.

C-II460 - Plat and Legal Description, Christian Science Society - 90\% complete.

- -11461 - Revise Legal Description of 11 Churches - 81\% complete.

C-1 1483 - Plat and Legal Description - Trinity U.P. Church - 75\% complete.

C-11486 - Plat and Legal Description "Jewish Congregation" .. 50\% complete.

5. 81020 - "As Builts" - Phase III - Final detajils are being completed.

C-81578 - Basin Located West of No. Richland Recharge Basin - Design 100\% complete. Plans \& specifications to A.E.C. November 14, $1955^{\prime}$

C-8176.7 - Dispcsa1 - Streets, Estimate of Cost - Scoping 50\% complete.

D-95450 - Replace Lot Line Corner Stakes - an open active file. Work being performed as requssted.

C.-98020 - Plat and Legal Description, Vacant Lot So of Horgan's Warehouse $90 \%$ complete.

C-98054 - Legal Description "Rose Garden" - 90\% complete. 
Plans, Specs., Inspections, All Saints Episcopal Addition - 93\% complete. Work held up pending arrival of windows.

First Baptist Church (Richmond \& Raleigh Sts.) - 92\% complete. No progress this month.

Plans, Specs., Inspections, Christ of King (Catholic) - Construction materially complete and building occupied.

Plans, Specs., Inspections, L. G. Cook Bldg. - 99\% complete. Work progressing slowly. Minor addition being completed.

Plans, Specs., Inspections, Johnny's Drive-In Farmers Market - $98 \%$ complete. Work progressing slowly.

Plans, Specs., Inspections, Parker Hansen Bldg - Construction $45 \%$ complete. Work progressing slowly。

Plans, Specs., Inspections, Moore's Service Station - 50\% complete. No progress this month. Work has been stopped for some time.

Plans, Specs., Inspections, Parcell's Bulk Station, Well sian Way - 80\% completed. Work progressing on schectule.

Plans, Specs., Inspections, True's Oil Company (Old "Rose Garden" site) Constmaction $15 \%$ complete. Work progressing on schedule. 


\begin{tabular}{l} 
COMMUNITY OPFRATIONS SUB-SECTION \\
PUBIIC WORKS AND RECRPATION UNIT \\
MONIHLY REPORT \\
DECEMBER I955 \\
\hline
\end{tabular}

ORGANIZATION AND PERSONNHL

Troployees Beglnning of Month
Transfers out
Transfers In
New Bmployees
Terminations

Exempt $\quad$ Non-Exempt

Total End of Month

$\begin{array}{ll}6 & 33 \\ 0 & \\ 0 & \\ 0 & \\ 0 & \end{array}$

33

2.

1

0

632

\section{ROADS AND STREETS}

Snow and ice control on the city streets required the full time of the roads and itreets crew, except for part of one week, when the weather moderated slificlently to do other work.

A total of 952 regular shfft manhours were used directly. for sanding of streets during the month and 172 manhours of overtime wexe used for this same work. 483 cubic yards of sand was spread on streets during the month and $468 \mathrm{c}$. y. was hauled in to the stock plie from the sand pit west of North Richland. At the end of the month the reserve of sand for sanding of streets was depieted.

On December 27-22 a Chinook caused rapld run-off and drying of the street suriaces. Temperatures were above 50 degrees and the asphalt surfacing on stweets of temporary construction began to break up requiring barricading of these jtreets. The straetis showing the most severe damage were:

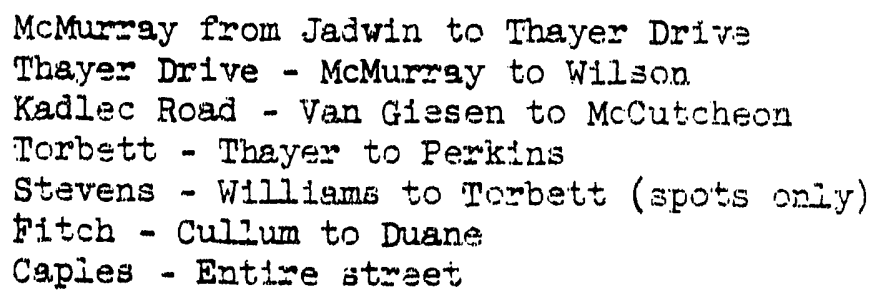

During the week pwor to Christmas, December 19-23, the roads and streets crew Was lissd to hall rock for stabilizlng the waterfront from Bralisy Road north to th jersioped parik at Riversi.je Park. During this same week work was $5^{4}$ arted to comect a safety hazard along the sast shoulder of George Washington Way from the intersection of the By-pass highway to the Yaklme Fiver bridge, created by an old imlgation ditch.

One dump track was out of service all month walting for engine repair by the Tranafortation Section. One Motor Patrol (Gellion No. 33-5992) recently assigned to this Unit was out of service for minor zepali several times during the month. This equipment is not piovine to be a satisfactory replacement for the caterpiliar No. 12 Motor Patrols uperadej by the Transportation Section.

Except for occastonal minor repales, wl other equipment is in operating condition. 
Die to the heary use of all equipment for snow and lce control, bafety has been stressed and a full comlement of lights and other safety equipment fnisilled on all equipwent used for this work.

\title{
SANITATION
}

Due to the Inclement westhex plus the heavy run of trash and garbage durlag the hollday season, extra belp was required for the saturday plok-up and on occasion durlag the veek for the entire month. This extra belp was furnished from the Parks and Public Grounds crews. Futra crews required for garbage and tresh collection followlng the Chrlstmen hollday period of December $24-25-26$ were also furnished by the Parkis and Public Grounds crews.

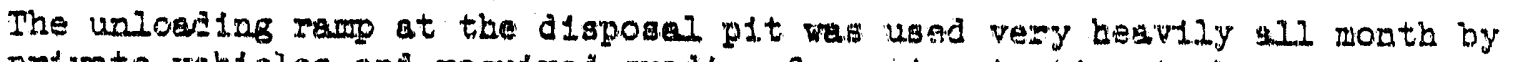
private vebtclos and required grading from time to time to keep private cars from getting stuck in the mud wile unioring.

The aId buralug pits ware filled to a rolat where new burning pita had to be construct,ad and this vas done during tho month. A new service road was also conatizucted to these new burging plts all surtace with base rock for wll weather travel.

A.i santition equipment vas kept in operating condition during the month whth oniy mincr repglis required.

Total weight of garbage and trash collected and disposed of auring the montit was:

\begin{tabular}{|c|c|}
\hline $\begin{array}{l}\text { Realdential } \\
\text { Comerctal } \\
\text { Trash Wagons }\end{array}$ & $\begin{array}{l}876 \text { Tons } \\
234 \text { Ton. } \\
242 \text { Ton }\end{array}$ \\
\hline & \\
\hline
\end{tabular}

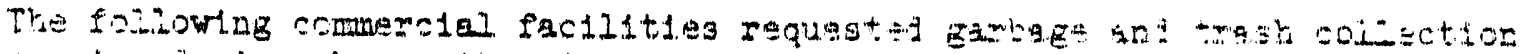

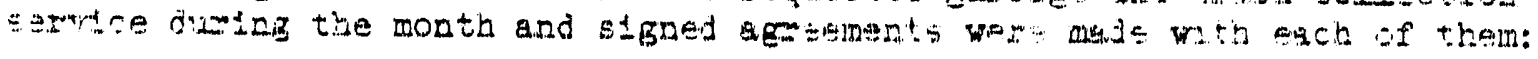

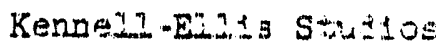 \\ Stantileli Filorigt. \\ Goody $y$ Good Bak $=$ wy \\ Kalisars Mariket.
}

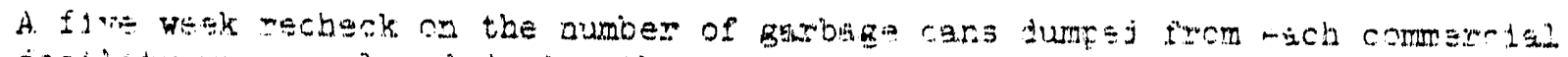

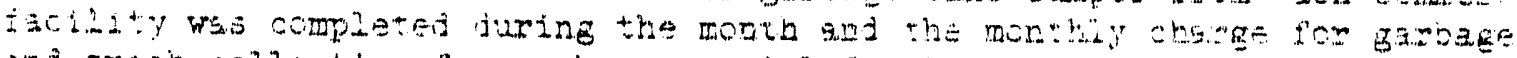

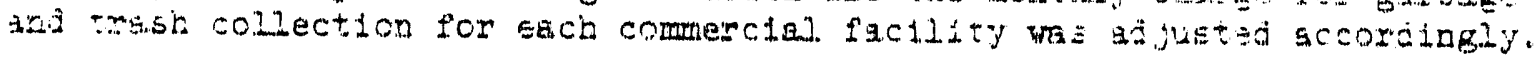

FAFKS AND FUBIIC GROUNDS

KElisf crows for snow and lce control and santation wer a furnibled from the Parka and Public Ground erews during the ent1wo month. This resilted in

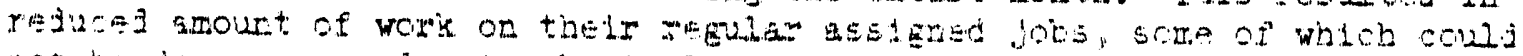

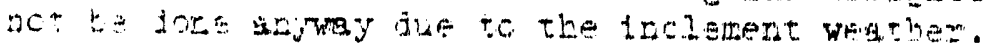


PARKS ANTD PUBIIC GROUNDS (COnt'd )

Snow and 1ce control on all public walks was continued during the month whenever mappower was arailable to do $1 t$.

Durling the one week when burning was posstble genergl clean-up of open areas was continued.

Clean-up along the R1verslde Park waterfront was concentrated in the area south of Bradley Road to expedite the moring of clubs and organizations to new locations in this area.

Due to the hesvy undergrowth in the shelterbelts work was started to plow a flrebreak between the shelterbelt and the abutting residentiai properties. Th1: work w1ll be rushed as soon as weather permits.

One serviceman was uperaded to grounduan in the R1chland Electrical Unit during the moth. Thls vacancy has not been flligd to date.

A review of the squipment and matertal needs for the coming malntenance season was started.

A codprebenglipe sepcrt wa made to the Rlchiand Park Board at their December meetirg on the fast years operation of the Rickland Park systan by M. K. J. Furchen. Foremar. Capital improvements to the parks were also reported on it this meting.

\section{RECREATION}

In aldition to the zegrlar fali and winter program, christmas parties were heid In the Colmonity House by varlous organiagtions. These included the slemertizy and fludor square Jap"e group, Frojecteers and Ji". Chamber of Cimmon, Columbla HI.gh School Malc Department and Hispot. The Richlend Fol1:e vit also held thelr annuel christmas party for all the youngsters in the Sciopl Boy Patwol. with about 500 attending. Other party groups rarled f.r.m 200 - 300 . 2il rather lange Ecups. The American Lagion Auxillary beld

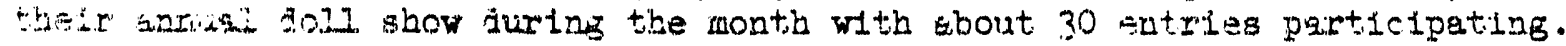

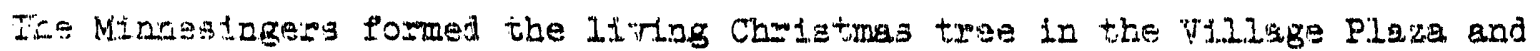

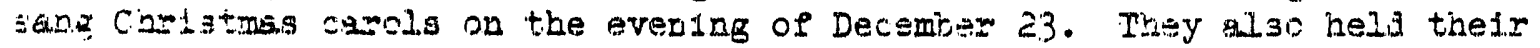
pirty. in the Comunlty Holdse earlier in the week.

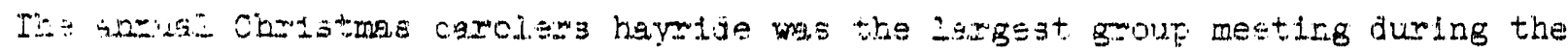

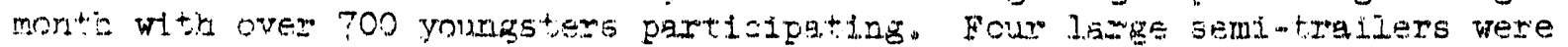

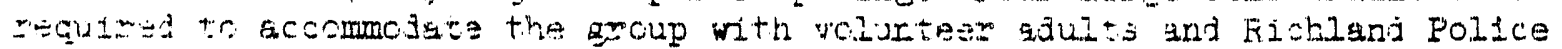
ic tirg as chaperons for the ride.

Ins R1chland Youth Council held the annual. election meeting aluring the month ard the folicwing members comprias talo bonxd for the coming year:

M. Gruham PEt

Mrs. H. B. DeVlne

M. George Gililett
Cooratinatox

$A \equiv s^{\prime} t$ Cocringtor

O.d member 
RECREATION (COnt'd)

RIchland Youth Counc1l board members - (Cont'd)

\begin{tabular}{|c|c|}
\hline $\begin{array}{l}\text { Mr. Joward Chitty } \\
\text { Mr. A. C. Christis }\end{array}$ & Old member \\
\hline $\begin{array}{l}\text { Mrs. T. D. Gibbs } \\
\text { Mr. Ed. Wood }\end{array}$ & New membe \\
\hline $\begin{array}{l}\text { Mr. George Fulilmer } \\
\text { Mr. J. McGulfe }\end{array}$ & " \\
\hline
\end{tabular}

The Youth Archery Instruction program at the Columbia High School completed their conxse for the year.

Outdcor actifities during the month were limited and consisted primarily of bok-slodding on the hills at the school grounds, and Plshing. In spite of the weather, the boat ranps were used nearly every day by a few haidy fishermen out after Steelhead and Whitefish.

Attendance Statistics - December 1955

No. or

Sessions

Youth

Sub

Total

\section{A. Community House}

American Leg1on Aux. Unit 71 American Red Cross

Art.a \& Crafts

Boy Scouts

Cunptire Girls

Ceritral Mail Room Christmas Party

Christma Carolers Party

Ciry Councid

Columbia Basin News

Columbia Bi Music Christmes Party

Dol. Show

E.ism. \& $\mathrm{Jr}$. Square Dancing

Q.1ementary Movies

Fericing

Games Room

H. Spint

irjeptrdent Basketball AEsoc.

Internetional Folk Dancers

hinior Crapt. Desert Ski Club

Juniow Sportsmen

Thyces is Christmas Party

Mannesinger's Program \& Party

Projecteer's Chriatmas Party

Friblic Eeglth Meeting

Talnbow Girls

Fac-A-Teers

Richland Basketball Assoc.

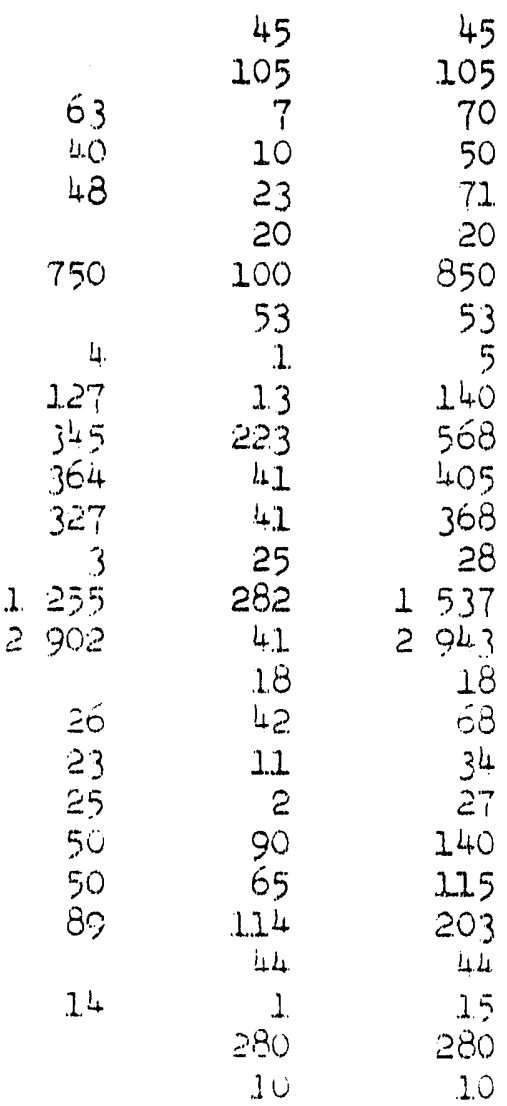


Attendance Statistics - December 1955 (Cont'd)

\begin{tabular}{|c|c|c|c|c|}
\hline & $\begin{array}{l}\text { No. of } \\
\text { Sessions }\end{array}$ & Youth & Adults & $\begin{array}{l}\text { Sub } \\
\text { Total }\end{array}$ \\
\hline Richland Rod \& Gun Club & 2 & 12 & 79 & 91 \\
\hline Richland Women's CIub & 1 & & 21 & 21 \\
\hline Richland Youth Counc1]. & 1 & & 15 & 15 \\
\hline $\begin{array}{l}\text { School Girl \& Boy Patiol Christmas } \\
\text { Social Security } \\
\text { Stamp Clubs } \\
\text { Tumbling }\end{array}$ & $\begin{array}{l}1 \\
2 \\
1 \\
3\end{array}$ & 108 & $\begin{array}{l}34 \\
54 \\
16 \\
34\end{array}$ & $\begin{array}{r}561 \\
54 \\
16 \\
142\end{array}$ \\
\hline \multirow[t]{2}{*}{ Total Community House } & 89 & 7152 & 1960 & 9112 \\
\hline & $\begin{array}{l}\text { No. of } \\
\text { Sessions }\end{array}$ & Youth & Adults & $\begin{array}{l}\text { Sub } \\
\text { Total }\end{array}$ \\
\hline
\end{tabular}

B. Parks and Playgrounds

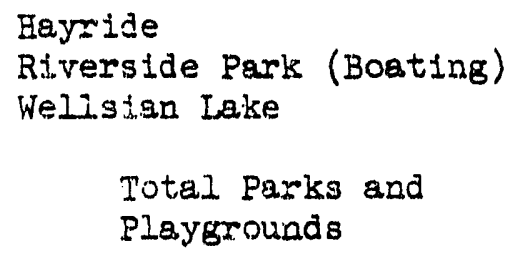

C. Summary

Community House and

Parks and Playegrounds

total for December 1955

$\underline{126} \underline{2857} \underline{\underline{330220}}$


COMAONITY OPERA TIONS SUB-SECTION

WA TER AID SEWHRAGE UTIIITIIES UNIT

MONTHIT REPORT

DEVEMIBER 1955

ORGANTZA TION AND FERSONNEE

$\begin{array}{lcc} & \text { Exempt } & \text { Non-Exempt } \\ \text { Employees Beginning of Month } & 6 & 23 \\ \text { Transfers Out } & 0 & 0 \\ \text { Transfers In } & 0 & 0 \\ \text { New Employees } & 0 & 0 \\ \text { Terminations } & 0 & 0 \\ \text { Employees on leave of Absence } & 0 & 1 \\ \text { Total End of Month } & 6 & 22\end{array}$

DOMESTIC WA THR

Nomal operations and routine maintenance were continued throughout the month.

On December 10th a I1re hydrant in the 400 block on Duane was broken off by an eutomobile. Temporary repalrs were made by removing fire hydrant from the water maln. Permanent repalrs are awaiting delivery of some dresser couplings that were temporarily out of stock. On December 20 th a $6^{\prime \prime}$ water main break occured in a cement asbertos water main in the Richland Village apartment area north of the Public Health buliding. This break was repaired by the Richland village maintenance crew.

DOMESTIC WATER DATA

Well Prouuction Av. Da. Prod. Total Consumpt. Av. Da. Cons.

\begin{tabular}{|c|c|c|c|c|}
\hline $\begin{array}{l}\text { Richiand } \\
\text { North Riohiand } \\
\text { Solumbia Fiedd } \\
300 \text { Area }\end{array}$ & $\begin{array}{l}58,570,000 \\
78,490,000 \\
60,777,600\end{array}$ & $\begin{array}{l}1,889,300 \\
2,531,900 \\
1,960,500\end{array}$ & $\begin{array}{l}92,312,200 \\
32,288,000 \\
73,390,000\end{array}$ & $\begin{array}{l}2,977,800 \\
1,041,500 \\
2,367,401 \\
\end{array}$ \\
\hline 4. & $7,837,600$ & $6,381,700$ & 197,990 & $6,386,70$ \\
\hline
\end{tabular}

Maximum daily production 7,625,800 gallons on December 7, 1955

Maximum dailu consumption 7,285,000 exallons on December 22, 1955

SEWERAGE SYSTEM

Maintenance painting at the number 2 Sewage Treatment Plant was completed and the plent was returned to service on December 12th. Flow at the Sewage ifit Station is still being diverted to permit installation of barminutor unit in the north inlet. This work is about 90 percent corrplete. 
Frogramed fluahing of the sewage collectlon system was commenced and the section of sewers that directs flow through the south trunk sewer line has been completel. The program is at a stand still awaiting completion of con. struction work at the sewage lift atation.

Some difficulty has been encountered in maintaining adequate temperature in the digestor at the sewage treatment plant.

\section{SEWHRAGE DATA}

Plant No. I Total Flow

Plant No. 2 Total Flow

Total Flow
$57,540,000$

$40,676,000$

$98,216,000$
Average Datly Flow $1,856,1,00$

Average Daily Flow $1,312,100$

$3,168,200$

\section{IRRICA IION SYSTEMS}

Winterization of the 1rrigation pumping and aistribution systems was compieted during the month. Because of adverse weather conditions the canal sleening program has been discontinued.

Water was run through the canal system to the 3000 area percolation basin December 8 th through December 14 th. 
COMMUNITY OPERATIONS SUB-SDCITION

RICHIAND PUBLIC IIERRARY

MONTHLY REPORT

DECEMBER 1955

ORGANIZATION AND PERSONNET

Employees beginning of month
Transfers in
Transfers out
New hires
Terminations
End of month

\section{GENERAI}

\section{Circulation}

Books
Magazines
Pamphlets
Records
Inter-library loans
$\quad$ Grand total

Current Bcok St,ock

- Books added this month

Books withdrawn this month

$$
\text { Grand total }
$$

Vi"umes of bound magazines added

Registration added

$$
\begin{aligned}
& \text { Adult } \\
& \text { Jurenises }
\end{aligned}
$$

\section{Reglitration aropped}

$$
\begin{aligned}
& \text { Greniz } \\
& \text { Grand toval }
\end{aligned}
$$

Tctal registered borrowers

Meetings in North Hal?

Chilaren's $\equiv$ tory hour atterdanoe

\section{EDEMPT $\quad$ NON-EXEMPT}

$\begin{array}{ll}3 & 9 \\ 0 & 0 \\ 0 & 0 \\ 0 & 0 \\ 0 & 1 \\ 3 & 8\end{array}$

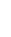

0

0

8

1

14,575

387

77

1,211

16,620 
Special Christmas activities at the Richland Public Library included the following:

Ninety children attended the special Christmas story hour for elementary school age children on December 19 and two hundred and seventeen premschool children attended the Christmas story hours on December 20 and 2l. The Christmas candy and films, presented at these story hours were financially sponsored by the Richland Chapter of the American Association of University Women as a part of their sponsorship of the children's special activities program.

The Eagle Scouts furnished the Christmas tree for the Children's Room. The tree was decorated December 17 by one hundred and fifty Cub Scouts who individually hung their hand made ornaments on the tree.

Miss Marie Golubski, Children's Librarian had a children's Christmas story hour over Radio Station KWIE on December 23 as well as telling Christmas stories over television RTVC during Christmas week.

The Richland Chapter of Knights of Columbus furnished their Eeautiful Christmas Nativity figures for the library's

Crristmas window.

The AIlfed Arts Association displayed $p=1$ nting from the Columbia Park Art Competition in North Hall this month. 


\section{MONTHIY REPORT -DECEMBER 1955}

ORGANIZATION AND PERSONNEL

Number of employees on payroll:

Beginning End of

of Month Month Increase Decrease

Staff

2

2

Administration Area Maintenance

103

104

$1(a)$

Security and Patrol

465

467

2(b)

Fire Protection

130

130

Office Auxiliaries

113

112

1 (c)

Telephone

82

81

1 (d)

TOTALS

895

896

$\overline{3}$

2

NET INCREASE: 1

(a) - Administration Area Maintenance

1 Reactivated

(b) - Security and Patrol

2 New Hires

2 Transferred in

2 Reactivated

1 Transferred out

3 Deactivated

(c) - Oifice Auxiliaries

13 New Hires

4 Deactivated

9 Transferred out

1. Termination

(d) - Telephone

I New Hire

1 Reactivated

1 Deactivated

2 Terminations 
FIRE PROTECTION UNIT

Fire Responses

$\begin{array}{lrrr}\text { U. S. ANMS } & 1 & \text { Loss } & \$ 50.00 \\ \text { HAPO } & 4 & \text { Loss } & 0 \\ \text { TOTAL } & 5 & & \$ 50.00\end{array}$

Description of Fires

Engineering-Separations Technology \& Chemical Research-Special Process 300 Area - Time 1:29 PM - 12/1/55

Transformer burned out on water control unit in Building 325 due to normal wear. On arrival found that the unlt had been disconnected and cooled with a five-pound $\mathrm{CO}_{2}$ by an employee. No.10ss.

Manufacturing - Separations - Operations

200-W Area - Time 10:16 AM - 12/7/55

Employees of 224-T Building unsuccessfully attempted extinguishment of a small fire in a lug loader outside the building with a water pump can. On arrival the fire was extinguished with a booster line from a fire department pumper. No loss.

Engineering - Technical - Fuel Assembly

300 Area - Time 1:46 PM - 12/12/55

On arrival found that box 52, 306 Building had tripped due to a nearby door closing with sufficient force to jar the wall behind the box. Identical alarm received on $12 / 24 / 55$ at $8: 33 \mathrm{AM}$.

U. S. Army - Post Engineers

Hanford Area - Time 2:17 PM - 12/16/55

Responded to an Army bus fire in the Hanford Area. Fire had been extinguished by the driver and two patrolmeil before fire department arrived. On arrival the fire department smoved hot debris and stood by until the danger of rekindle was past. Approximately $\$ 50.00$ damage to wiring, radiator hose and air filter on carburetor of Army bus No. 20932937.

Engineering - Minor Construction - Construction Facilitieg White Bluff's - Time 9:06 AM - 12/22/55

On arrival found that sprinkler head had fused and actuated box 31] at the Pipe Shop due to heat from defective oil burning torch. Replaced head, reset sprinkler system and alarm box.

Drills Held During December

Outside drills 25

Inside drills 204

4,350 feet of fire hose were used for drill purposes during December. 
Fire Protection Unit (Contin)

The Fire Chief and Administrative officer attended a Central Washington Firemen's Association meeting in Pasco, Washington, December 11, 1955.

One staff meeting was held December 1, 1955 with the shift captains, drillmaster, Chief and Administrative officer attending.

Fire Protection officerg held three classes on fire extinguishers with 39 Manufacturing and Power employees in attendance.

Fire Extinguishers

$\begin{array}{lr}\text { Inspected } & 1,530 \\ \text { Installed } & 6 \\ \text { Delivered to new locations } & 3 \\ \text { Seals Broken } & 30 \\ \text { Serviced } & 334 \\ \text { Weighed } & 667\end{array}$

Gas Masks

Inspected 54

Serviced 15

Hand lines inspected 61

Hose Boxes inspected 11

\section{OFFICE AUXILIARIES SUE-SECTION}

Plant Mail Unit

Mail activity in both weight and volume was quite heavy during the juriod. Cut-off dates do not permit showing this in the statistical portion of the report. The annual distribution of log books, calendars, diaries, etc. added to the usual Christmas volume increased activities to about the maximum that could be handled with available space, personnel, and equipment.

Addressograph work also continued to increase, but due to technical difficulties encountered on the collator, the actual work volume is not reflected on the numerical count since several partial assignments were finished with hand collating. The difficulties have been resolved and the collating operation should be fully utilized during the month of January.

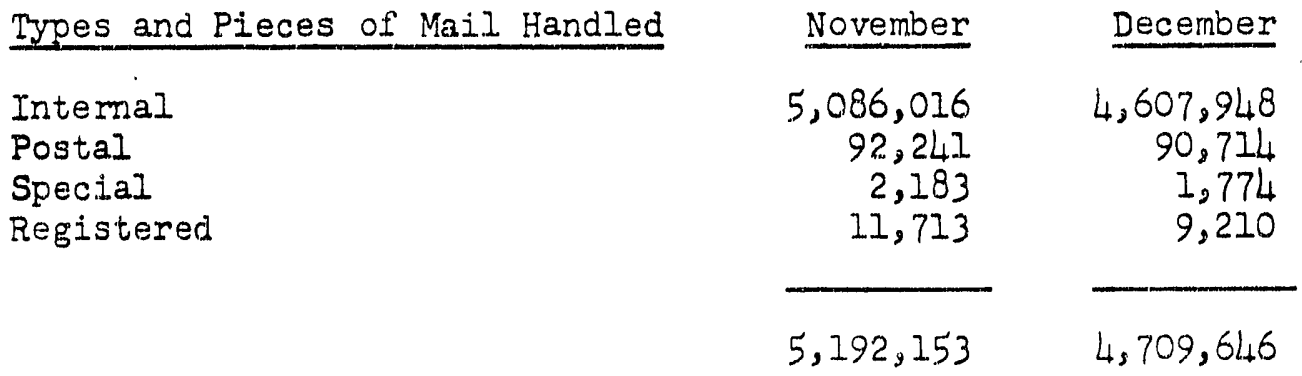


Plant Mail Unit (Cont1n)

\begin{tabular}{|c|c|c|c|c|}
\hline \multirow{3}{*}{$\begin{array}{l}\text { Total postage used } \\
\text { Total teletypes handled } \\
\text { Total store orders handled } \\
\text { Addressograph }\end{array}$} & \multirow[b]{3}{*}{$\begin{array}{l}\text { Numbers } \\
\text { of Runs }\end{array}$} & \multirow{2}{*}{$\begin{array}{r}\text { Norember } \\
\begin{array}{r}\$ 303.68 \\
3,053 \\
615\end{array}\end{array}$} & \multicolumn{2}{|c|}{ December } \\
\hline & & & \multicolumn{2}{|c|}{$\begin{array}{r}\$ 3,145.04 \\
3,084 \\
605\end{array}$} \\
\hline & & $\begin{array}{l}\text { Total } \\
\text { Copies }\end{array}$ & $\begin{array}{l}\text { Number } \\
\text { of Runs }\end{array}$ & $\begin{array}{l}\text { Total } \\
\text { Copies }\end{array}$ \\
\hline $\begin{array}{l}\text { Plate name list } \\
\text { Housing list } \\
\text { Payroll list }\end{array}$ & $\begin{array}{r}122 \\
17 \\
75\end{array}$ & $\begin{array}{r}184,927 \\
49,185 \\
31,465\end{array}$ & $\begin{array}{r}122 \\
17 \\
15\end{array}$ & $\begin{array}{r}183,005 \\
50,361 \\
36,153\end{array}$ \\
\hline \multirow[t]{2}{*}{$\begin{array}{l}\text { Total new plates } \\
\text { Total corrected plates }\end{array}$} & \multicolumn{2}{|c|}{$\begin{array}{l}5,221 \\
4,165\end{array}$} & \multicolumn{2}{|c|}{$\begin{array}{l}6,191 \\
5,136\end{array}$} \\
\hline & \multicolumn{2}{|c|}{9,386} & \multicolumn{2}{|c|}{11,327} \\
\hline Machine Collating (sheets) & \multicolumn{2}{|c|}{80,000} & \multicolumn{2}{|c|}{43,182} \\
\hline
\end{tabular}

Printing Unit

In order to reduce the heavy backlog of printing orders, the Print Shop personnel worked a total of 155.3 overtime hours during the month.

The backlog of routine orders was created due to the great demand for priority requests, illness absences, vacations and equipment breakdown. The following are some of the priority jobs completed:

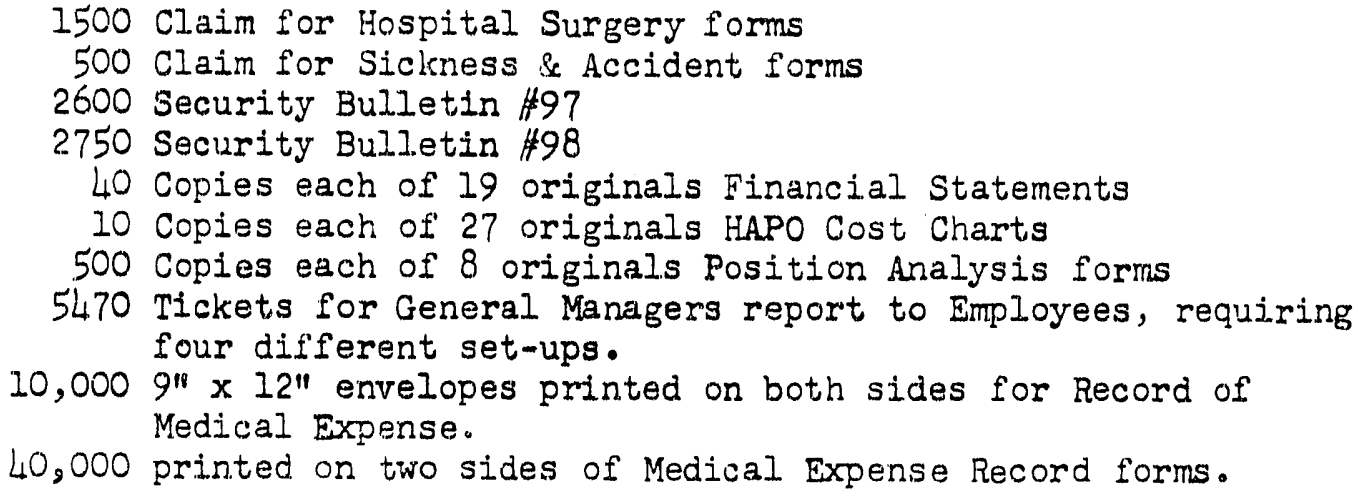

While the number of orders handled was less than the previous month, the number of printed copies show an increase in December by 648,596 over November.

Fewer requests for formal reports were received, making it possible to concentrate on orders of a routine nature.

Statis electricity has been a source of concern in our plant operation during the winter months, so that it seriously interfered with production and calised heavy paper waste. To correct this condition, steam escape valves were installed in the shop. 
Printing Unit (Contin.)

\begin{tabular}{lcc} 
& November & December \\
\cline { 2 - 3 } Orders received & 464 & 378 \\
Orders completed & 427 & 392 \\
Average orders on hand & 89.6 & 102.7 \\
Copies printed & $1,239,418$ & $1,888,074$ \\
Vacuum frame plated masked & 547 & 486 \\
Negatives processed & 743 & 556 \\
Photo Copy prepared & 353 & 310 \\
Litho plates processed & 730 & 662
\end{tabular}

Stenographic Unit

Six stenographers and two stenographer-typiest were assigned to the Stenographic Unit in December, all highly qualified for their classifications. Nine permanent transfers were made to other plant offices. Due to unusual heavy December vacation relief loan requests, reduced number of personnel, and heavy work load in the Unit office. It was impossible to fill all loan requests, however, twenty temporary assignments were made throughout the month.

Heavier assignments included 55.5 hours preparation of Good Neighbor Fund mailing for Employee Services, 90.5 hours duplimat typing of Excess Property Lists for Stores, 231.5 hours typing of special and year's end reports for Budgets and Measurements Section, 35 hours duplimat typing for General Accounting in connection with the prime contract, 67 hours setting up insurance file for Benefit Plans Accounting Unit, 55 hours miscellaneous and duplimat typing for Radiological Standards Unit, and 49.5 hours typing for Instrument Development Unit. Work is current at month's end.

\begin{tabular}{lcc} 
& November & December \\
\cline { 2 - 3 } Total Production Hours & $2,081.5$ & 1,869 \\
Training Hours & 501.5 & 197 \\
Urassigned Hours & 91 & 68.5 \\
Holiday Hours & -21 & 208 \\
Meeting Hours & 6 & \\
& 2,695 & $2,348.5$
\end{tabular}

Duplicating Unit

Work loads on Research and Development Reports has increased to a point making it necessary to handle a large portion of such orders on an overtime basis. Presently, there are eleven Research and Development Reports on hand, and in various stages of completion. However, due to the overtime worked, all of the reports on hand are either current or have been delayed due to reasons beyond duplicating control such as text changes, etc.

A revised system of handling orders which require drilling has made it possible to excess one Challenge Rotery Paper drill. Stores Stock Requests for three hole and five hole pre-drililed No. 4 sulphite bond have been issued; and in the f'uture, requests for drilling will be handled by running the work on pre-drilled stock. This new procedure will reduce mail handling previously necessary on paper stock which was drilled in Central Duplicating and mailed out to outer area duplicating offices. 
Duplicating Unit (Contin.)

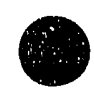

$\begin{array}{lrr} & \text { November } & \text { December } \\ \text { Orders received } & 3,806 & 3,488 \\ \text { Orders completed } & 3,777 & 3,400 \\ \text { Orders on hand } & 189 & 136 \\ \text { Offset plates } & 16,412 & 13,831 \\ \text { Offset copies } & 1,034,358 & 1,027,159 \\ \text { Verifax masters } & 3,117 & 2,563 \\ \text { Verifax copies } & 10,614 & 8,262 \\ \text { Ditto masters } & 573 & 273 \\ \text { Ditto copies } & 7,543 & 5,182 \\ \text { Zerox Plates } & 2,098 & 1,622 \\ \text { Ozalid masters } & 35 & 20 \\ \text { Ozalid copies } & 196 & 89 \\ \text { Embosograf orders } & 24 & 48 \\ \text { Embosograf copies } & 167 & 134 \\ \text { Number of copies duplicated } & 1,052,878 & 1,040,826\end{array}$

Office Equipment Unit

\section{Office Furniture}

The expendable office furniture inventory account 93 was valued at $\$ 11,248.00$ on November 30,1955 , or an average of 2.9 months supply on hand. Withdrawals for the month were $\$ 1,535.00$ and receipts were $\$ 3,428.00$.

The following is a detailed list of pieces of furniture handled during the month:

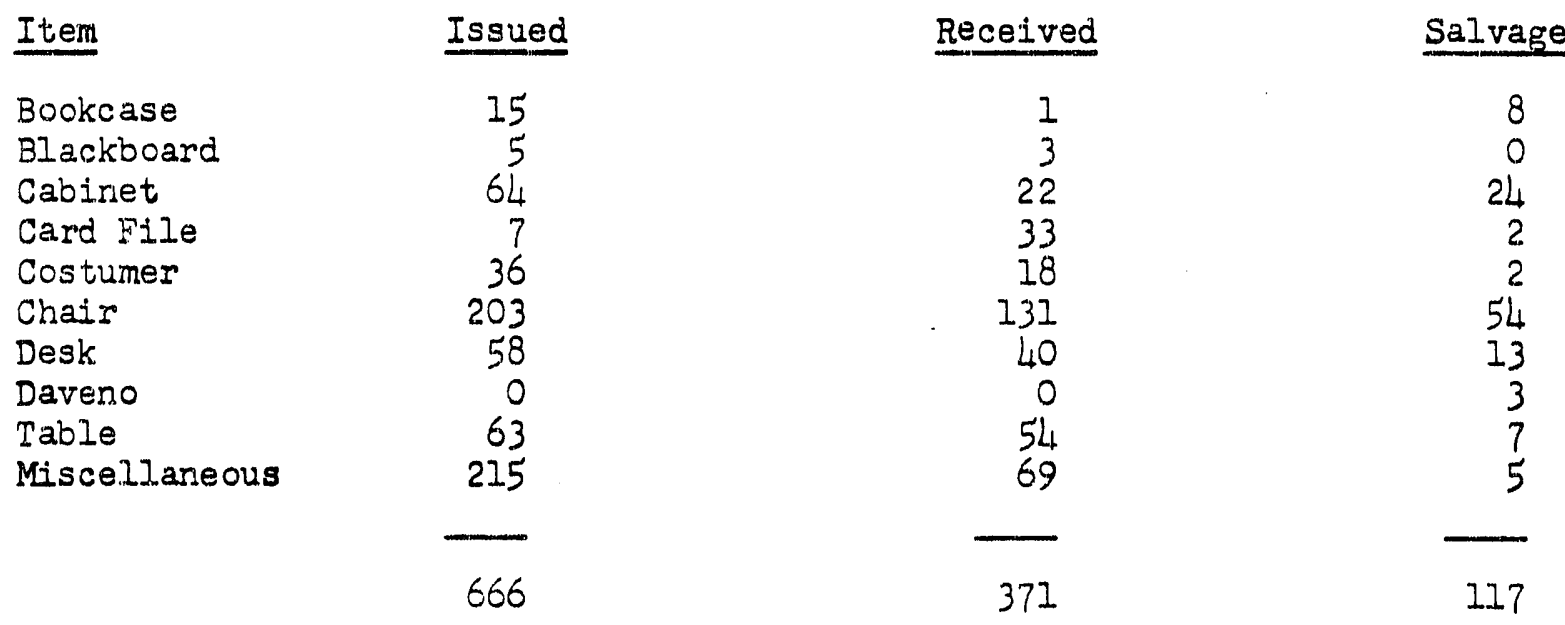

A total of 70 service orders were issued to repair oflice furniture and locks which were in need of minor repair. Ten work orders were issued for special types of raintenance repairs.

There were 503 debit and credit store orders processed during the month or an average of 26 per working day.

The total number of office machines in service and stock as of December 20, 1955, was 4215 or a net decrease of 65 machines over previous month. 


\section{Office Mechine Repair Unit}

During the month of December, Inventory was completed on all Multilith parts. This completes the inventory of all of fice machine spare parts. The parts will. be placed in an inventory account in January, 1956.

During the month, tratning was given all employees in methods we will use in accounting for all repair parts used.

A representative of the Auto-Typist Compang, was braught on the plant for two days to glve majntenance and operating instmetion to offic Machine Ropair personnel and Tschnical Recrulting personnel. The operating instruction was requested by the Employment Unit aid Technical Recruitment Unit.

During the month seventeen and one-balf hours were spent on special service calls on Flexowriters; of this time, four and one-half was on an overtime basis.

Instmunent work during the month wes of routine nature with the exception of reconditioning 10 wall clocks (office type).

Repair tilckets processed: November Decomber

$785 \quad 433$

\section{ADMCNISTRATION AREA MAINTENANCE SUB-SECTION}

Following conferences whth Commisston personnel and representatives of the Seattie Reglonal office of General Sertices Administration, work was started on complation of data required in connection with submission of a proposal for a new Admindstration Buliding. It is anticipated that this information will be completed in January.

A total of 52 office moves were made during December.

Through matual agreemert, Northwest Ut1lities group was moved to 701-B, after Audio-71sual Unj.t was movec to 723 Building where more space will be provided for their activitieg.

Complation of semi-annual Domestic Manufacturing Plants report for the entire plant was prefared for submission to Manufacturing Services Division.

Froperty Unit control cards on load-lugger trash containers have been ficed under the new control system.

Shell measurements of all Administration Area buildings aro practically completed.

As-built drawings of Admintstration Area bujldings are in current status, with exception $0:$ a jew minor changes resulting from the recent mass move.

Subnissior. of project proposal on roads and walks has been temporarily withheld, awaitins more defintte information in connection with AEC-GSA action on new office building.

Shipmert of 985 lineal feet of movable partitioning was received on December 14 . Apprcxtmately 500 feet has already beer. released for installation and the remainder is acmmitied. Requisition for approximately 390 additional feet has been placed and shipmeri is expected in seven to eight weeks. 
Administration Area Maintenance (Contin.)

Continued emphasts is being placed on safety. Inspection of craft shops and power flant was made in December by Section Maneger and Sub-Section Superintendent.

\section{Building and Equipment Maintenance}

All work in connection with alterations to office space to provide for relocation of $A E C$ and GE personnel has been completed or is now in process. Included in this work completed on this progran during December are the following:

$\begin{array}{ll}\text { Building 703: } & \text { Installation of } 64 \text { lineal feet of Hauserman partition } \\ & \text { top f1ller and removal of a } 161 \text { frame partition; applicat } \\ & \text { of } 128 \text { square feet of acoustic tile; installation of two } \\ & \text { doors, } 18 \text { buzer circuits and } 12 \text { light circuits. } \\ \text { Building 705: } & \text { Installation of } 54 \text { lineal feet of Hauserman partition } \\ & \text { with top filler and } 10 \text { lineal feet of frame partition, } \\ & 3 \text { doors and } 576 \text { square feet of acoustic tile; removal } \\ & \text { of } 20 \text { lineal feet of Hauserman and closing of one door } \\ & \text { opening. }\end{array}$

Building 713: Installation of 100 lineal feet of Hauserman in Auditing Section.

Building 761: Removal of 15 lineal feet of Hauserman; installation of one new door and 6 radiators.

Building 762: Relocation of 10 lineal feet of Hauserman.

Central Stores: Application of 1,200 square feet of acoustic tile in Traffic and Stores offices.

Work is now in process at Building 723 to provide space for Audio-Visual Unit and Building Service group.

Three carpenters and two painters who have been assigned to swing-shift since October 10, 1955, were retumed to day shift on December 27, 1955.

The main corridor ceiling and walks of Building 721, which were damaged by the rupture of an attic water line in November, were repaired and repainted. Damaged wall board which had been used to form an air duct above the ceiling was replaced with sheet metal.

Painting completed during the month included complete repainting of 20 rooms in $703,705,760$ and 761 Buildings, and a considerable amount of plastering and touch *up painting where partitions were relocated or removed in connection with office moves.

Additional support was placed under the new AIC law library in 703 Building to provide for heavier floor loading. All book shelves which have been delivered to date have been assernbled.

The sign painter was assigned to a job of approximately three weeks duration in the 100-K Area beginning December 27, 1955. 
Administration Area Maintenance (Contin)

Iffective December 1, 1955, all 115V. convenience outlets installed in the 700 Area were of the new ASA standard type, and-during the month 35 were installed in 703, 30 in 760 , two in 761, and two in 770-A. At the time each installation was made all equipment used on the outlets was also changed to new ASA standard caps (plugs.)

All convenience outlets at Transportation Shops are being charged to ASA standard and this conversion is now $80 \%$ complete.

Other work completed in the Transportation area includes: repair of 12 Kemstart circuits and installation of eight Kemstarts in recently procured busses; installation of electrical oil heating tanks for heating of fumace oil when steam boiler is inoperative; Installation of time switches on furnaces to re-cycle the furnaces every 30 minutes and pick up any burners that have ceased firing; repair of two battery chargers; relamping of all buildings; repair of gas purm motor; installation of two circuits for space heaters; and inspection and repair of 25 portable electrical tools.

Semi-weekly tests of air raid sirens were conducted and all tests were satisfactory except the test of December 30, 1955. On this date, following completion of satisfactory tests of No。 3 and No. 2 sirens, the electrician was at No. 1 siren and asked the Airport radio operator to start No. I. Nothing happened at No. 1 siren and it was found that No. 3 siren sounded for about six seconds, then shut down, and No. I started. Although the Airport operator feels certain that he closed the switches to No. 1, an investigation revealed that the only possible means of causing such a situation would have been an error in switching. Complete testing later on the same dey indicated all controls were in satisfactory condition.

Miscellaneous work completed in 700 Area included: cleaning and protective painting of evaporative cooler pans in 702, 703 and 712 Buildings; relocation of one unit heater in 744 and one in 760 ; installation of drinking f'ountain in fifth wing of 703; replacement of approximately $70^{\prime}$ of $2^{\text {"1 }}$ steam lateral serving 761, which was damaged by unknown truck hitt1ng support pole; adjustment of operating sections of all windows in fifth wing, 703, which were binding because of building settlement; laying of 192 square feet of f'loor tile; installation of new non rings in three refrigeration compressors at Building 713; fabrication and installation of five stainless steel sink liners at 747; fabrication of six mail carry boxes; repair of six pilot valves and two main valves for steam pressure reducing stations; machining and installation of two bearings for seven HP air conditioning motor in 712 ; installation of eight light fixtures and five steam radiators in 723; replacement of two exhaust fans in 722- A; installation of time clock circuit in 760; replacement of coa.l crusher hammers and installation of new motor on coal conveyor in 784 .

Work completed for Central Stores included 100 manhours of labor utilized in crating excess material for shipment; overhaul of electrical parts of two lift trucks; and relamping of all buildings.

Routine seasonal maintenance on buildings and equifment was continued in the 600 and 700 Areas. Central Stores and Transportation shops; and locksmith and glazier service was fumished to all areas. 


\section{Building Service}

Floor seal was applied to wooden floors in 43 rooms of Building 760 , the area being west wing and central section, and concrete color seal was applied to fluoors of three rooms in Building 707 .

Effective December 12, 1955, a supervisor was appointed to direct day building service employees formerly assigned to two craft foremen, to handle material procurement for day and night shift janitors, and to act as liaison between building tenants and night janitorial foremen. The effectiveness of this position is already apparent and efficiency of day fanitors and satisfaction of tenants is improving.

Routine fanitorial service was continued in all buildings according to schecule.

\section{Steam Operation}

Nos. 1,3 and 4 boilers were in service at the beginning of the month, with No. 2 in reserve.

On December 6, No. 2 boiler was placed in service and No. 1 boiler removed from the line for several minor repairs and also to permit better access to the heat exchanger for cleaning this piece of equipment.

At the close of the month, Nos. 2, 3 and 4 boilers were in service, with No. 1 in reserve.

The quantity of steam generated at 784 plant was 8.46 greater than for the same period of the previous year.

Two loads of sulphuric acid were sent to 384 Power house and one load to 200-E Area during the month.

Operations at Central Stores heating plant were normal throughout the month.

Coal consumed: $2,120.10$ net tons.

Steam generated:

Steam leaving plant:

Steam delivered:

Total water softened:

Total soft water sent to Kadlec Hospital:

Total soft water sent to 784 heating plant:
$30,698.9$ M. Ibs. $26,690.3$ M. Ibs. $24,309.5$ M. Ibs.

$3,768,700$ gallons 43,170 gallons

$3,725,530$ gallons

\section{TELEPHONE SUB-SECTION}

A new edition of the Plant Telephone Directory was distributed on December 1.7 .

Bids were received from two directory publishing companies for publishing three annually spaced editions of the Richland Directory. A high bid of $\$ 36,000$ was submitited by the General Telephone Directory Company of DesPlaines, Iliinois, publisher of the last four editions of the Richland Directory. "The Thomhill Publishing Company of Everett, Washington, submitted an offer of $\$ 18,000$. 


\section{Telephone Sub-Section (Contin.)}

Authorization was received from the Hanford Operations Office on December 22 to have evaluation appraisals made on the Hanford Plarid and Richland Community Telephone Systems. Ebasco Services, Incorporated, of Portland, Oregon, were contacted regarding possibility of their undertaking the appraisal. At least two other appraisal firms are to be contacted before a selection is made.

A proposed PABX Service Application form was submitted to the Hanford Operations Ot'fice for approval.

\section{Plant Telephone Operations}

A]I work in the 300 Area exchange necessary to increase its line capacity from 500 to 600 lines was completed on December 17 and the additional unit was placied in service.

Completed cable balancing work necessary before transferring all I-l trunk cable circuits to a single 102 -quad cable in the George Washington Way underground.

The alarm enunciator to Indicate start-up of the emergency generator in the 700 area exchange was changed to register as an emergency alarm on the switchboard instead of non-emergency.

Installed guard rails on the main and intermediate distributing frames in the 700 Area exchange. These additions were made for the purpose of reducing saf'ety hazards to Maintenance personnel and to provide mechanical protection for distributing frame terminal strips from possible damage by rolling ladders.

Modified line lock-out alarm equipment in the 700 area exchange so that no alarm will be actuated until five lines are affected. This feature is intended for use during hours when the exchange is unattended by Maintenance personnel.

Installed ó jack circuits on the 700 area exchange test board to provide better testing facilities for teletypewriter and other similar circuits.

Located and cleared a moisture fault in a 51-pair cable serving in the 100-K area exchange. The fault was caused by water entering a detective splicing sleeve and resulted in completely in errupted dial telephone service to the 100-KW Plant for approximately 13 hours.

Several spans of trunk cable between the BY and Whi.te Bluffs exchanges were relashed to replace broken lashing wire.

Maintenance of PAX and PBX systems serving the 202-A, 271-T and 234-5 buildings required 80 manhours.

Prepared Job Specification P-56-15 to cover the procurement and erection of a small metal storage building at BI Telephone Exchange.

Issued a Purchase Requisition for two 50 ampere selenium type rectifiers to replace motor generator charging sets in the 200-EN and White Bluffs Telephone exchanges. It is estimated that these replacements will be made by April 30, 1956.

Began preparation of an annual report of telephones and other miscellaneous capital equipment which were purchased by the Telephone Sub-Section during the calendar year 1955.

$$
\mathrm{Ch}-\mathrm{II}
$$




\section{Commercial Telephone Operations}

Reconnected the Pasco and Kennewick long distance trunks and the trunks to the 700 Area $P_{7}$ ant Exchange to improve traffic distribution.

Modified fire reporting trunks so that operation of answering key at the Fire Station will make trunk busy to selectors in the exchange.

Placed in service approximately 400 feet of number 26-pair cable and three new terminals in the 300 block on Thayer Drive to replace old cable dismantled because of pole relocations.

Installed five new cable terminals in the Southwest section of Richland preparatory to transferring service drops from cable plant being replaced because of Richland Electrical unit pole replacement and relocation program.

Located and repaired a cracked splicing sleeve on cable No. 2 near Williams and Mahar streets.

Installed seven additional pressure-test valves in the Richland-Kennwick trunk cable. Completely rewired and recabled the key telephone installations at Kortens Music Store and at the Uptown Furniture Store.

Prepared six Engineering Job Specifications covering outside Plant expansion and improvement.

Prepared Property Disposal and Excess papers for approximately 20 items of Telephone material.

Radio System Operations

Shop-serviced 36 mobile receivers, 33 mobile transmitters, one fixed-station transmitter, one fixed-station receiver, five intercom units, three record changes, 10 pack-type transmitter-receiver units, two tape recorders and one cable testing set.

Field serviced 64 miblie transmitter-receiver sets and six fixed-station sets. Installed six mobile transmitter-receiver units and associated auxiliary items. Removed four mobile transmitter-receiver units and associated auxiliary items Recorded Science Forum Programs on December 7, 14, 21 and 28.

Rebuilt a pack-type radio transmitter-receiver set that had been submerged in the river at McNary Dam for approximately one week. This set was a part of the equipment in a Radiological Sciences boat that accidentally sank and was later recovered.

Overhauled 12 intercom master stations in the 760 building.

One service outage occurred during the month. Station KKE 624, No. 8, (200-E Area) was out of service on December 13 from 5:00 A.M. to 9:05 A.M. due to a defective microphone.

Converted 10 pack-type transmitter-receivers used in conjunction with Civil. Def'ense from wet battery operation to dry battery operation. This change will eliminate considerable maintenance costs on these items.

$$
\operatorname{cin}-12
$$




\begin{tabular}{|c|c|c|c|}
\hline & $\begin{array}{l}\text { At } 20 \text { th of } \\
\text { December }\end{array}$ & $\begin{array}{l}\text { Change from } \\
\text { Previous Month }\end{array}$ & $\begin{array}{l}\text { Change from } \\
\text { Year Ago } \\
\end{array}$ \\
\hline $\begin{array}{l}\text { Paystations, North Richland } \\
\text { Residential Subscribers } \\
\text { Business Subscribers } \\
\text { Paystation Telephones } \\
\text { Official Subscribers }\end{array}$ & $\begin{array}{r}16 \\
6124 \\
466 \\
47\end{array}$ & $\begin{array}{rr}-1 & 2 \\
t & 66 \\
t & 1 \\
t & 3\end{array}$ & $\begin{array}{r}9 \\
6 \quad 70 \\
6 \\
6 \quad 19\end{array}$ \\
\hline $\begin{array}{l}\text { Richland Exchange } \\
700-1100 \text { Areas } \\
\text { Process Areas Exchanges }\end{array}$ & $\begin{array}{r}233 \\
906 \\
1661\end{array}$ & $\cdot \begin{array}{l}15 \\
+17 \\
+16\end{array}$ & $\begin{array}{l}-760 \\
+906 \\
-223\end{array}$ \\
\hline & & +86 & $t$ \\
\hline
\end{tabular}

New Service Requests received during the Month:

For residential service

For business service

110

8

TOTAL

118

Backlog of Service Requests:

For new residential telephones

For new business telephones

For residential outside moves

For business outside moves

55

1

16

1

TOTAL

Service orders processed:

In connection with business \& residential service

In connection with plant service 332

TOTAL

742

Telephone Facilities - Installed, In Service and Available

\begin{tabular}{|c|c|c|c|c|}
\hline & & xchange Line & & Party Lines \\
\hline & Installed & In Service & Available & Available \\
\hline $\begin{array}{l}\text { North Richland } \\
\text { Richland Community } \\
700-1100 \text { Areas } \\
\text { Process Areas }\end{array}$ & $\begin{array}{l}600 \\
4000 \\
1230 \\
2050\end{array}$ & $\begin{array}{r}26 \\
3684 \\
887 \\
1653\end{array}$ & $\begin{array}{l}316 \\
343 \\
397\end{array}$ & 914 \\
\hline & 7880 & 6250 & 1056 & 914 \\
\hline
\end{tabular}


Radio Stations - In Service

\begin{tabular}{|c|c|c|c|}
\hline & $\begin{array}{l}\text { At } 20 t h \text { of } \\
\text { December }\end{array}$ & $\begin{array}{l}\text { Change from } \\
\text { Previous Month }\end{array}$ & $\begin{array}{l}\text { Change from } \\
\text { Year Ago }\end{array}$ \\
\hline $\begin{array}{l}\text { Fixed Stations } \\
\text { Mobile Stations }\end{array}$ & $\begin{array}{r}34 \\
156\end{array}$ & $\begin{array}{l}0 \\
0\end{array}$ & -1 \\
\hline & 190 & 0 & 0 \\
\hline
\end{tabular}

SECURITY AND PATROL SUB-SECTION

Document Report

Number of classified documents and prints unaccounted for as of December 1: (101 of the above 297 documents are chargeable to du Pont Company)

Number of classified documents and prints reported as unaccounted for

during December:

Number of classified documents and prints either recovered or downgraded in classification during December:

(This document is not chargeable to du Pont Company, and it is

downgraded in security classification)

Number of classified documents and prints remaining unaccounted for as of January 1,1956 :

( 101 of the above 296 documents are chargeable to du Pont Company)

The Non-Technical Document Review Board held one meeting during December and reviewed a total of 42 documents. Of this number -

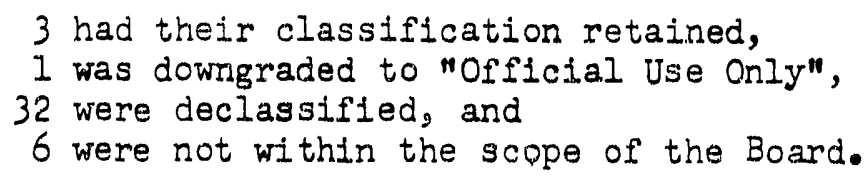

\section{Security Education}

Nine security items appeared in the GE NEWS during the month.

There were 337 security meetings held and attended by 4,806 Hanford Atomic Products Operation personnel. A representative of the Plant Protection Services Uni.t showed one of the security films at some of these meetings as indicated below:

\begin{tabular}{lccc} 
Film Tital & $\begin{array}{c}\text { Number of } \\
\text { Meetings }\end{array}$ & $\begin{array}{c}\text { Average At,tendance } \\
\text { per Meeting }\end{array}$ & Total \\
\cline { 2 - 3 } & 24 & 26 & 624 \\
"The Living Contract" & 2 & 29 & 58
\end{tabular}




\section{Security Education (Contin.)}

One hundred copies of the poster with the slogan "TIme Is on Our Side", which were furnished by the Department of Defense, Washington, D. C., were posted in the plant areas.

1,100 leaflets with the same security slogan as the poster, "Time Is on Our Side", were distributed to employees.

2,000 copies of the "A-B-C" securlty pamphlet with the slogan "Personnel Changes Mean Combination Changes, Too....Combinations to classified file cabinets must be changed when personnel terminate or transfer" were distributed employees of the Company during December.

The following GE Security Bulletins were issued:

Bulletin No. 97 "It's Amazing", dated December 2, 1955

Bulletin No. 98 "Modem Day'Braddocks'", dated December 1.5, 1955

The following organization and Policy Guides were issued:

No. 15.4 "Non-Defense Information", dated November 21 , 1955, is a new policy directive.

No. 15.1.3 "Security Clearances and Identification", dated December 1 , 1955, was a revision of a previously issued instruction.

The following items of security interest appeared in Management News Bulletins during the month:

December 7 "Photo Identification Passes should be shown to the bus driver by each employee when boarding area busses at the bus terminal..."

December 7 "All present security clearances to the 108-B Building, 100-B Area, will be cancelled effective December 12 because the building has been placed on a standby status..."

December 28"Each employee responsible for classifying information should be fiamiliar with the provisions of the recent Organization and Policy Guide 15.4, urges Security...."

Ninety-five employees of the General Electric Company received a "Q" Security orientation talk from either a representative of the Plant Protection Services Unit or a Patrol Supervisor, and 19 employees received the "L" security orientation lecture during the reporting period.

Statistical Report of Patrol Activities

\begin{tabular}{|c|c|c|c|c|c|c|c|c|}
\hline & $100-B$ & $100-D$ & $200-F$ & $200-\mathrm{H}$ & $100-\mathrm{K}$ & $200-E$ & $200-W$ & 300 \\
\hline Pat Searches & 90 & 90 & 60 & 30 & 90 & 0 & 0 & 0 \\
\hline Escorts & 14 & 9 & 16 & 31 & 57 & 12 & 23 & 10 \\
\hline Ambulance runs & 2 & 2 & 4 & 4 & 1. & 1 & 1 & 8 \\
\hline Passes issued: & & & & & & & & \\
\hline One day temporary & 29 & 13 & 11 & 7 & 11 & 13 & 39 & 50 \\
\hline Travel & 2 & 0 & 0 & 0 & 0 & 0 & 0 & 160 \\
\hline Red Tag & 61. & 78 & 36 & 14 & 21 & 191 & 348 & 85 \\
\hline Telechonic & 0 & 0 & 0 & 1 & 0 & 0 & 0 & 10 \\
\hline Supervisors'Post Contacts & 426 & .284 & 175 & 128 & 371 & 285 & 433 & 239 \\
\hline & & & Gh -15 & & & & & \\
\hline
\end{tabular}


Other Patrol Activities (Computed by Hours)

\begin{tabular}{|c|c|c|c|c|c|c|c|}
\hline $100-B$ & $100-D$ & $100-F$ & $100-\mathrm{H}$ & $100-\mathrm{K}$ & $200-E$ & $200-W$ & 700 \\
\hline $\begin{array}{l}190 \\
322\end{array}$ & 231. & $\begin{array}{l}220 \\
261\end{array}$ & $\begin{array}{r}495 \\
1,062\end{array}$ & $\begin{array}{l}334 \\
334\end{array}$ & & $\begin{array}{l}276 \\
276\end{array}$ & $\begin{array}{r}2,22 \\
72\end{array}$ \\
\hline
\end{tabular}

File Check

Building Check

322

55

Number of

Cont. Cases

Cases

Arrest Report

Violations Violations from Nor.

Cleare

\section{Drunken Driving \\ Illegal Parking \\ Negligent Driving \\ No Valid Driver's \\ License on Person \\ Public Intoxication \\ Reckless Driving \\ Speeding}

TOTALS

\begin{tabular}{l}
1 \\
2 \\
1 \\
1 \\
1 \\
1 \\
\hline \\
8
\end{tabular}

0
2
0

0
2
0

Pending

Fined Jailed

Citation tickets issued:

Warming tickets issued:

Verbal warnings:

0
0
0
0
-2

\begin{tabular}{ll}
1 & 0 \\
1 & 0 \\
1 & 0 \\
1 & 0 \\
\hline & 4
\end{tabular}

$\begin{array}{lll}1 & 0 & 1 \\ 2 & 2 & 0 \\ 1 & 0 & 0\end{array}$

\section{Patrol Training Activities}

402 Patrolmen attended classroom instruction during the reporting period.

170 Patrolmen attended Firearns training during the same period.

General

During the visit of the Cole Committee, Washington, D.C., the Security Audit and Investigation Unit escorted an area tour of the 100-D, 100-H, 200-W, and 300 Areas on December 16 and 17 .

Since the second cycle concerning the audit and inspection of custodians of classified material was started September 1, 1955, our Security Audit and Investigation Unit has completed 190 audits.

\section{Security Administration}

$\begin{array}{lr}\text { Daily Badge Log entires } & 2,855 \\ \text { "Q" Clearances } & 95 \\ \text { "L" Clearances } & 19 \\ \text { Formal. "P" Clearnances issued } & 31 \\ \text { "P" Approval clearances issued } & 21 \\ \text { Category access granted } & 61 \\ \text { Category access withdrawn } & 41 \\ \text { Category access revised } & 34 \\ \text { Number of photos for "A" badges } & 65 \text { (Total of } 812 \text { for year 1955) } \\ \text { Number of photos for "B" badges } & 279 \text { (Total of 3,765 for year 1955) } \\ \text { Number of persons re-photographed } & 33\end{array}$




\section{Security Administration (Contin.)}

Total of 377 photo identification passes were lamirated and issued.

Total of 814 "A" badges were assembled and distributed to the areas.

Total of 511 "A" badges were received from the areas.

Total of 59 "A" badges were received from the areas for repair.

Top Secret Clearances

Clearances cancelled during December:

13

Clearances requested:

Clearances granted:

53

54 


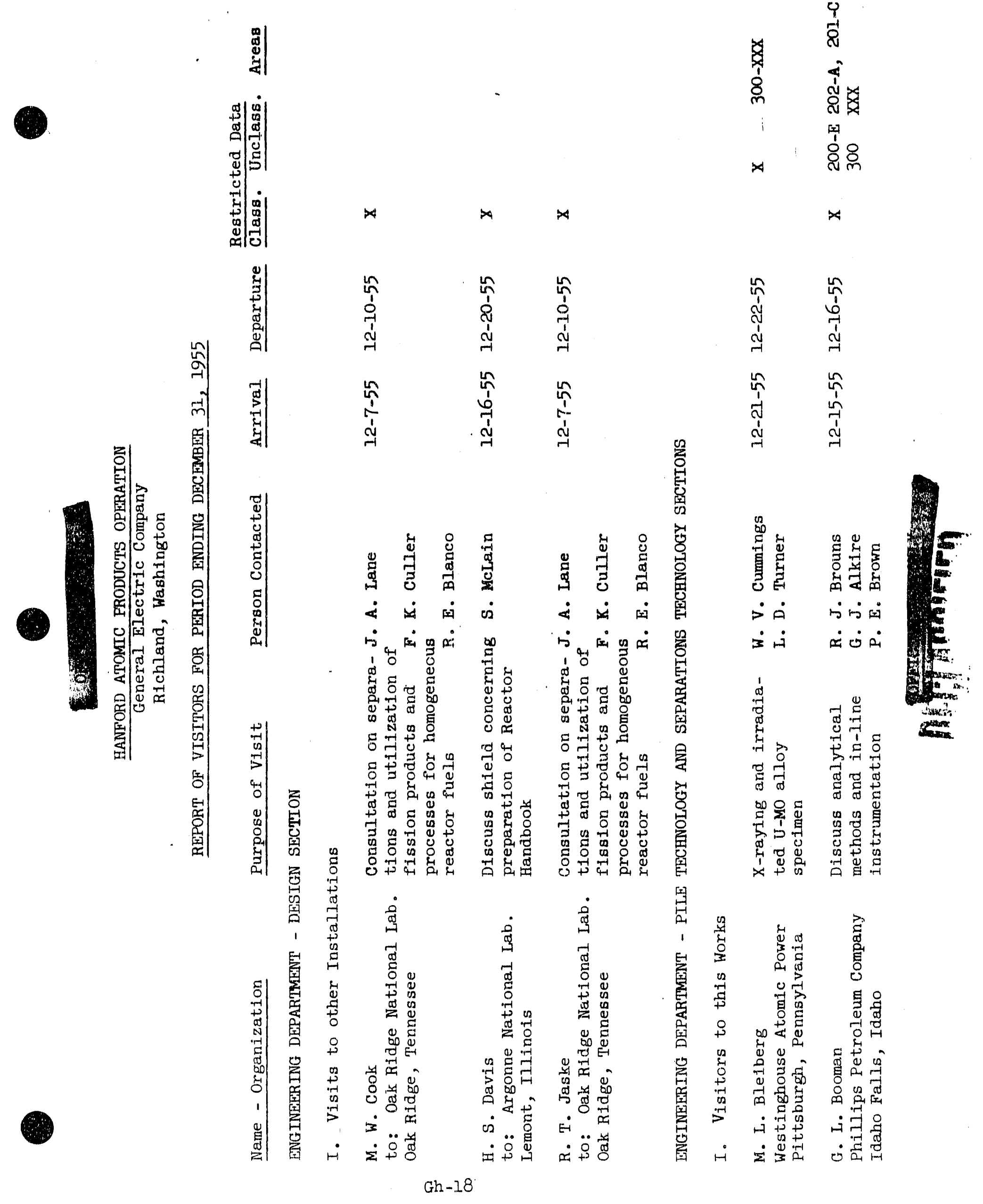




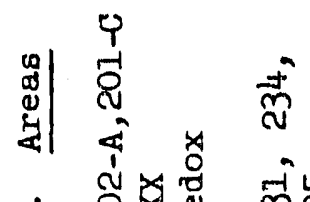

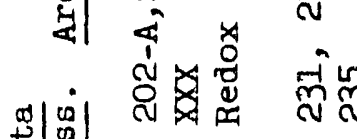

年

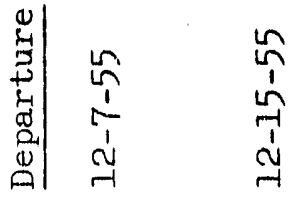

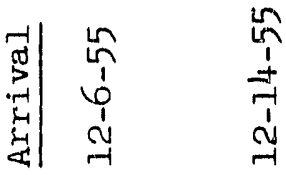

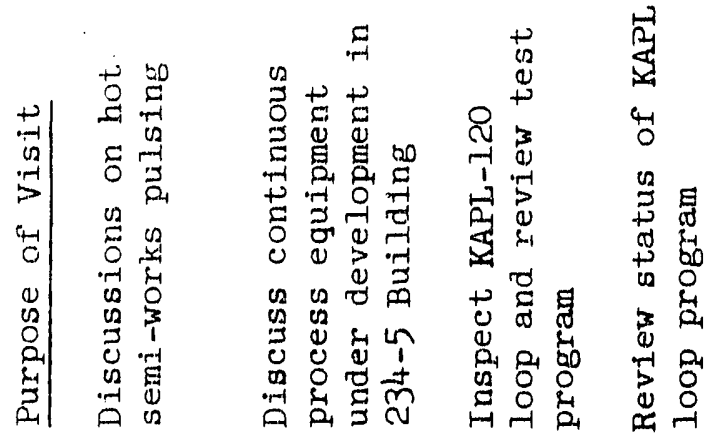

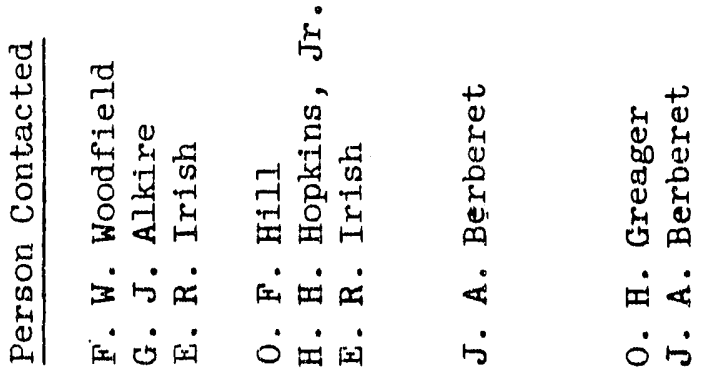

ले

象 8

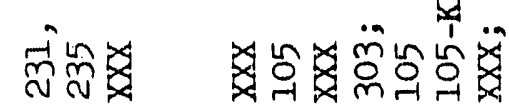

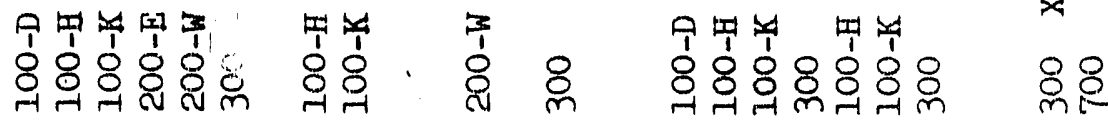

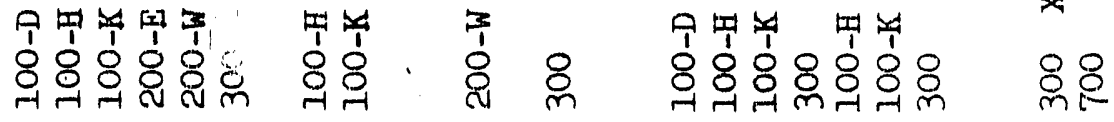

$\times$

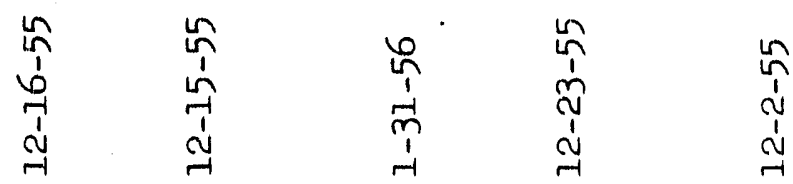

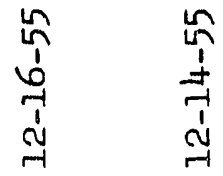

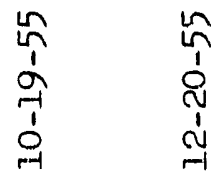

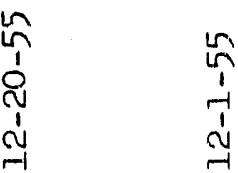

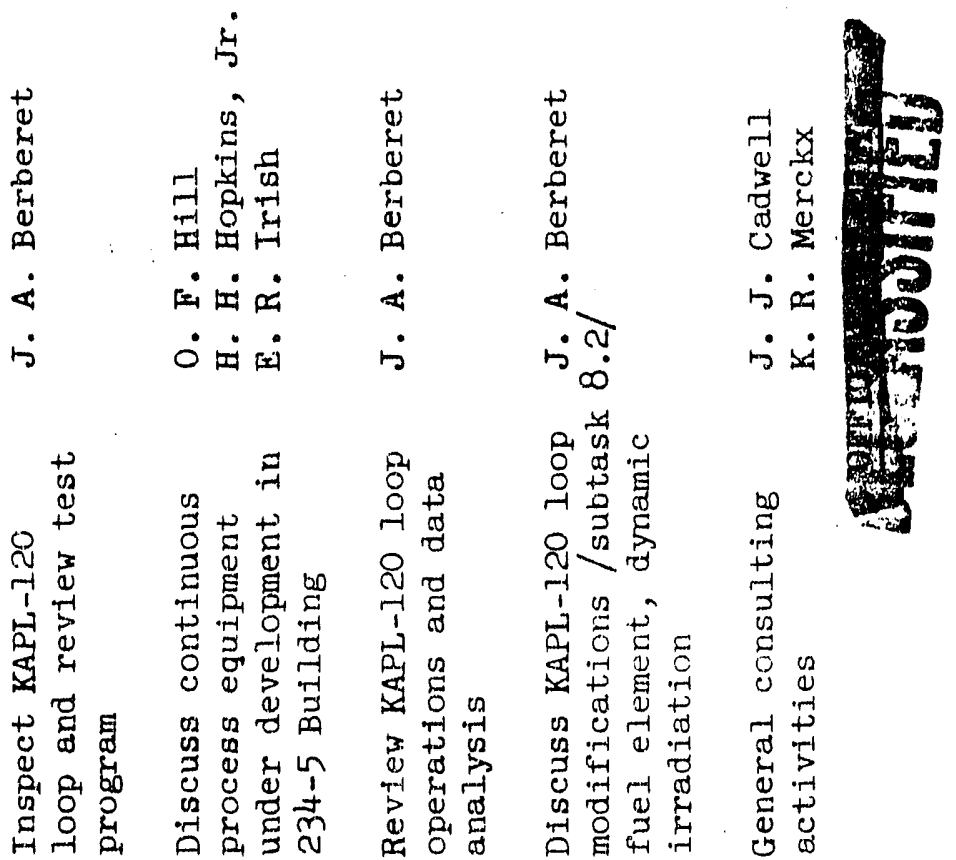

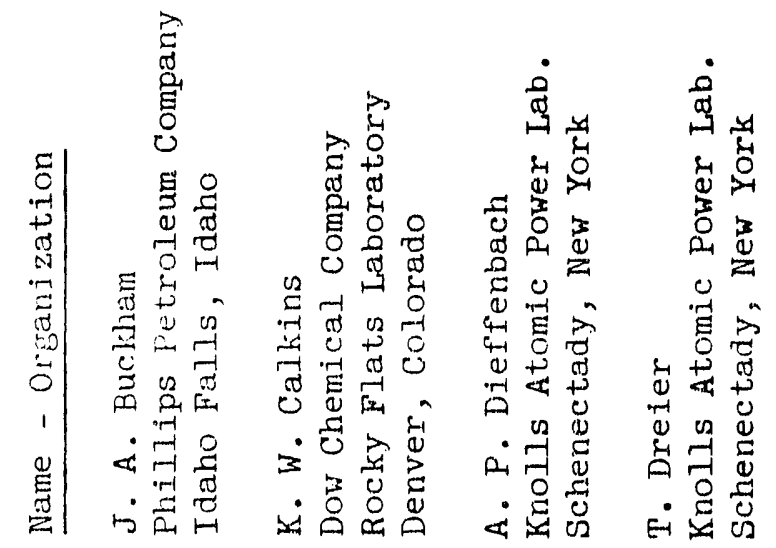
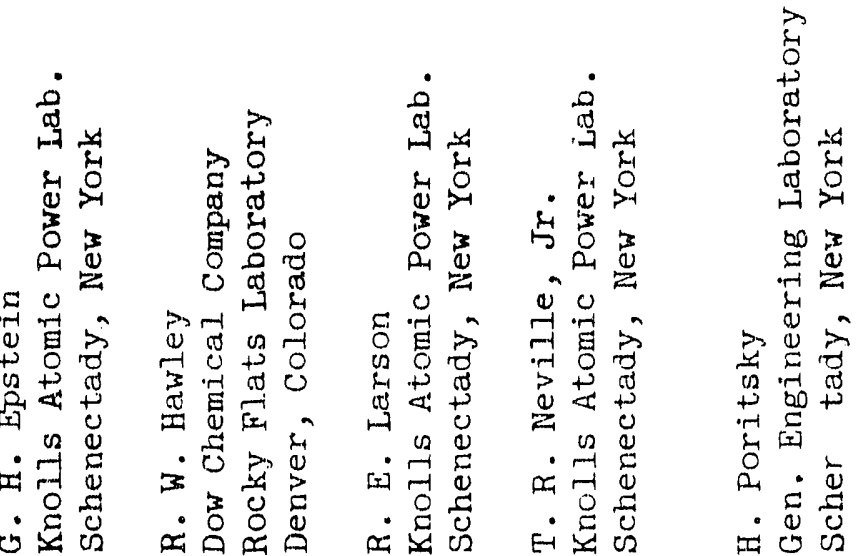
ำ

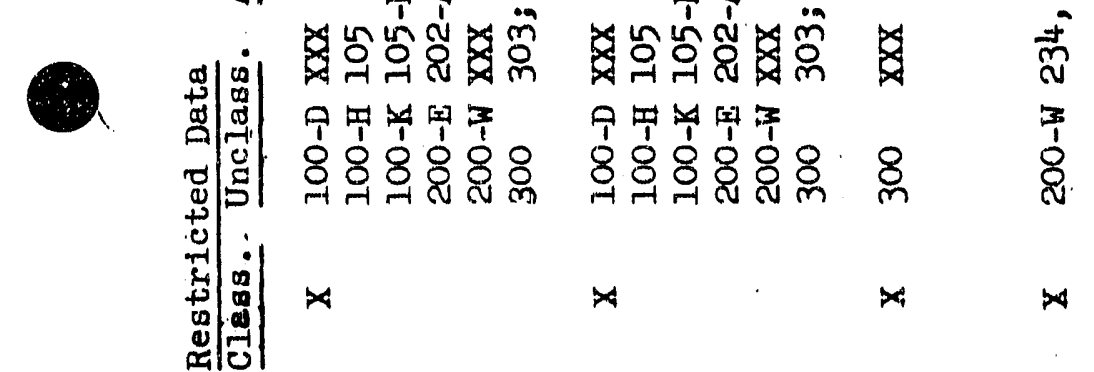

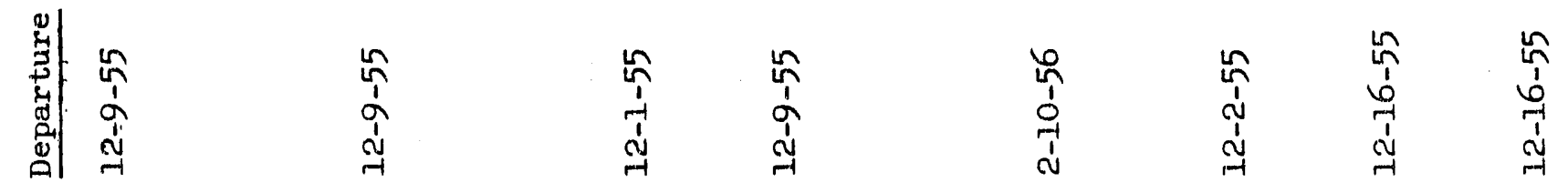

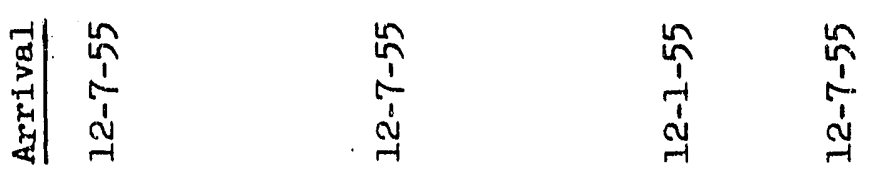

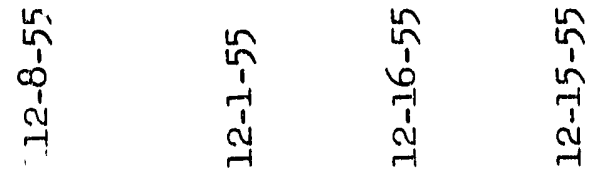

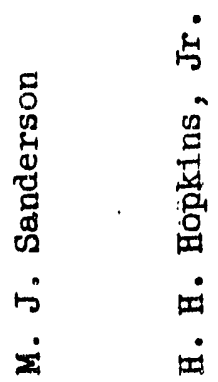

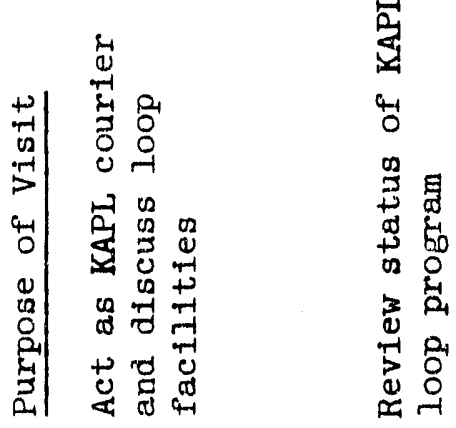

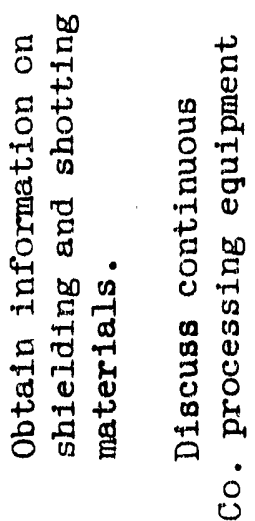

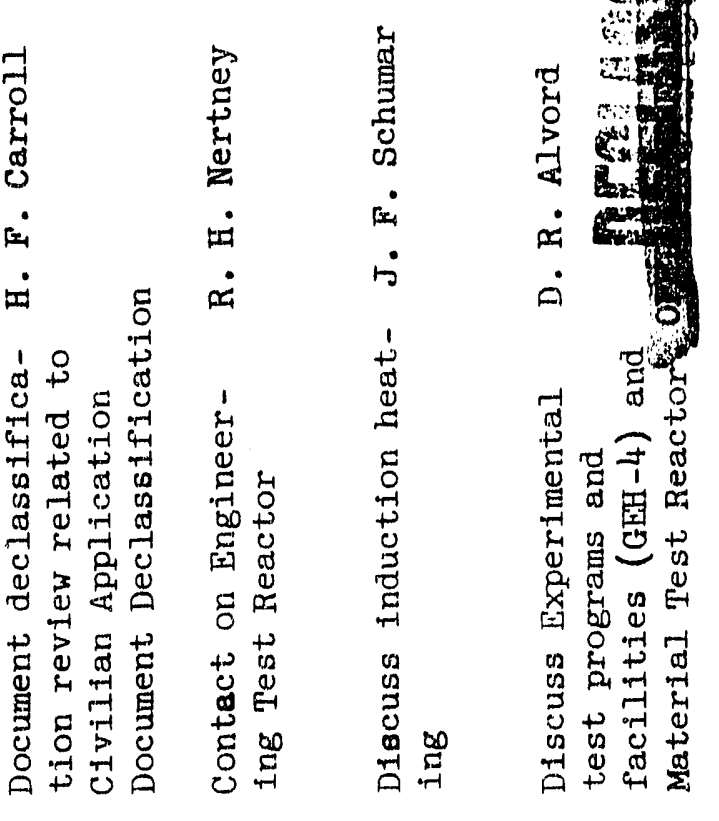

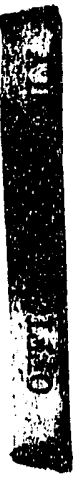

离这

$\dot{1 \dot{4}}$

or

ह $\infty$

$\begin{array}{ll} & \\ 0 & \end{array}$

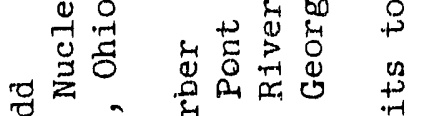

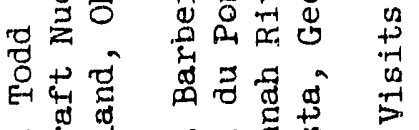

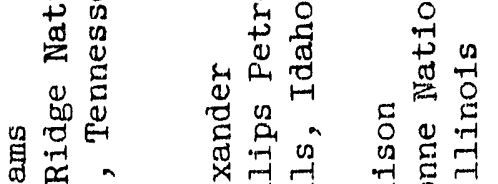

$\stackrel{\substack{n\\}}{\stackrel{n}{n}}$

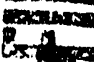

क्षे

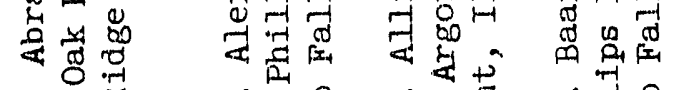

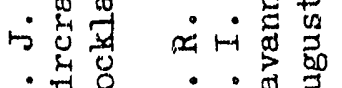

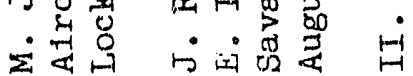

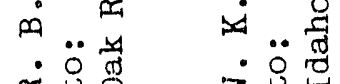

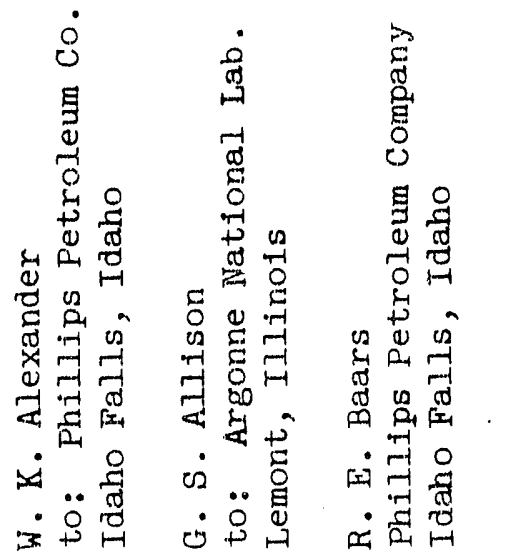




\section{!}
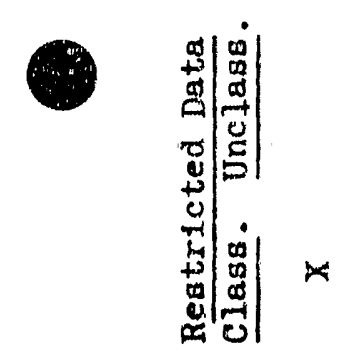

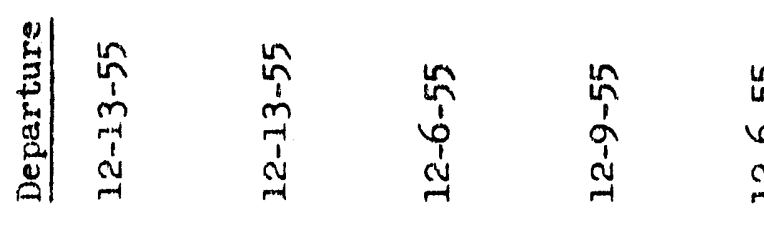

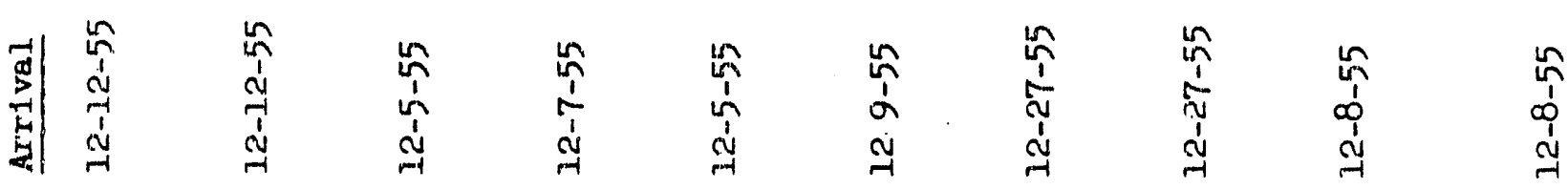

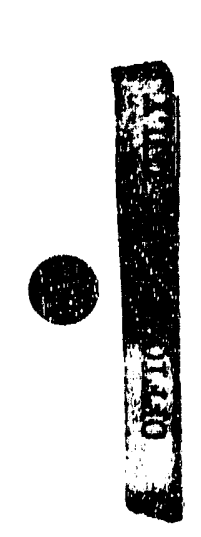

I

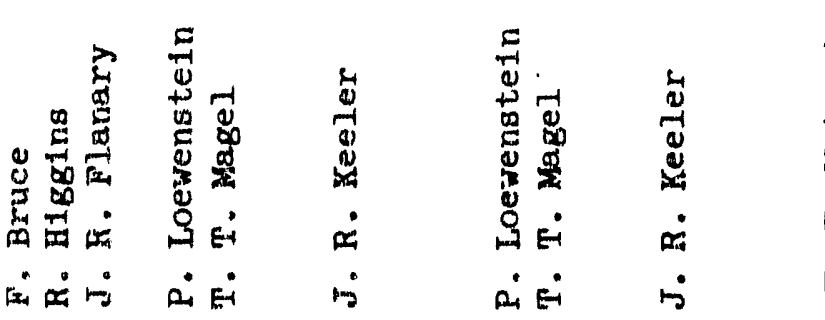

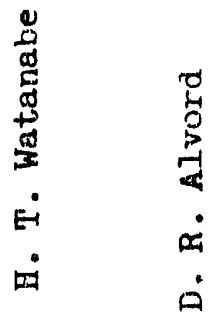

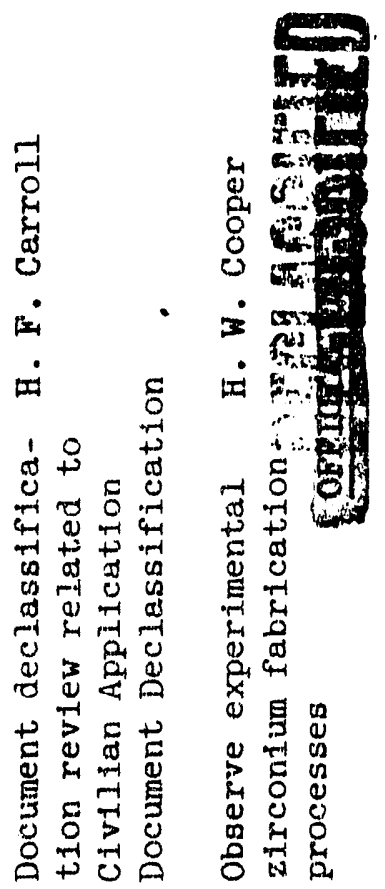

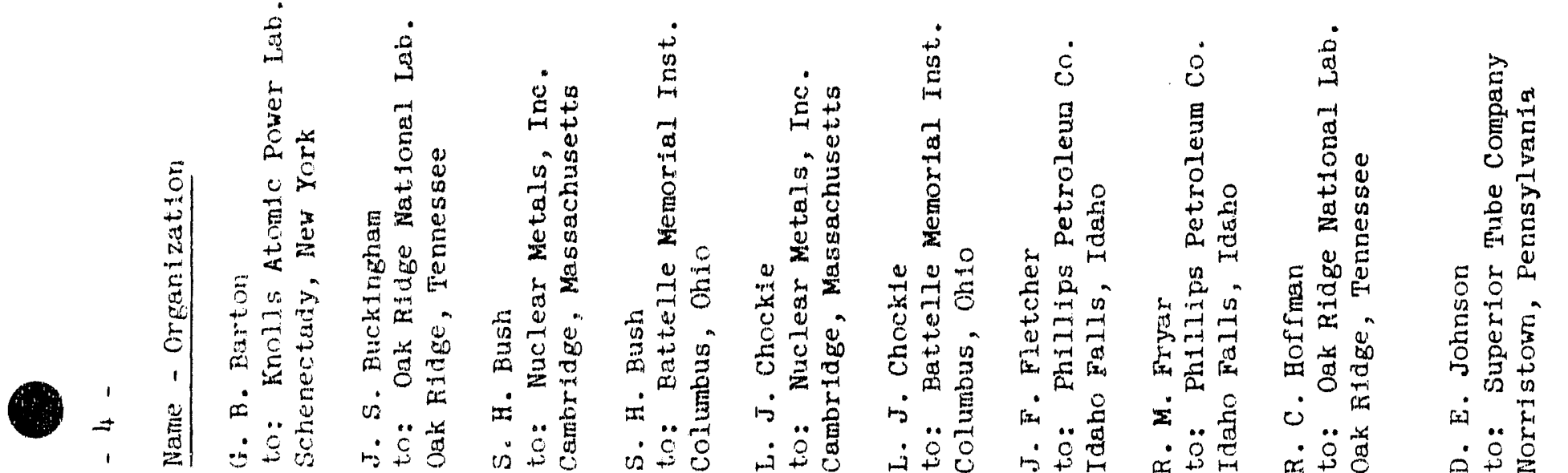


일

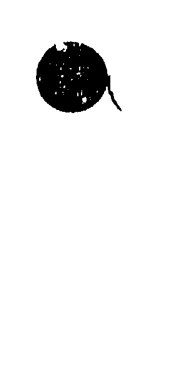

In . . . . .

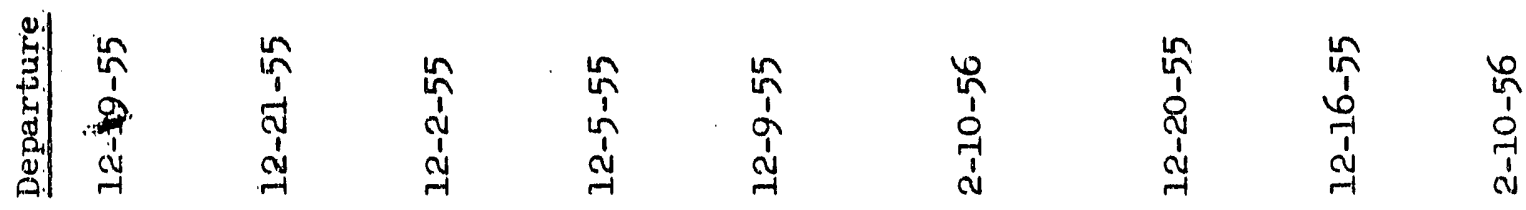

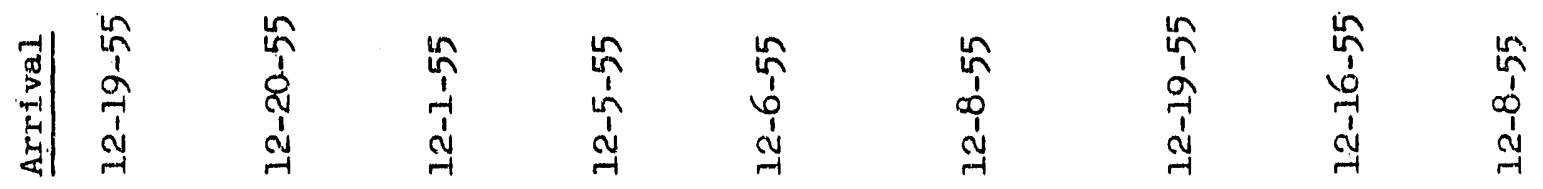

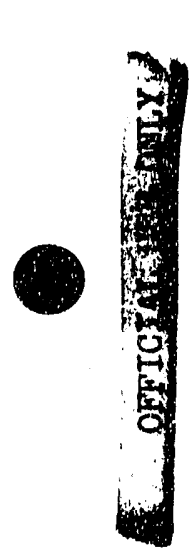

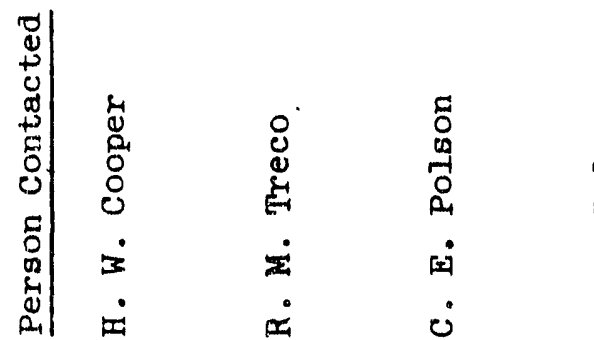

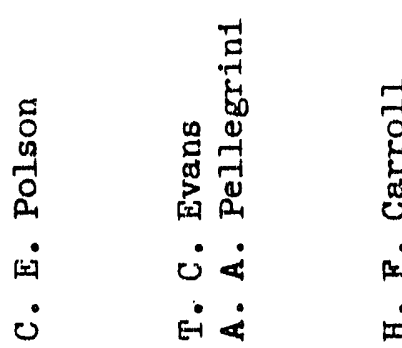

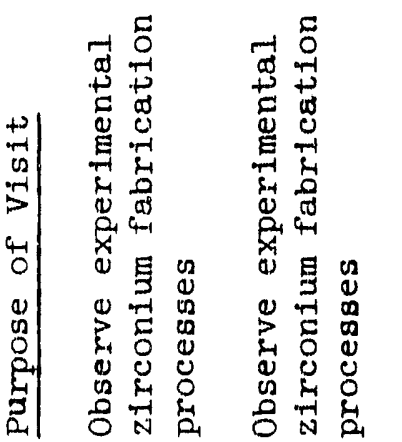

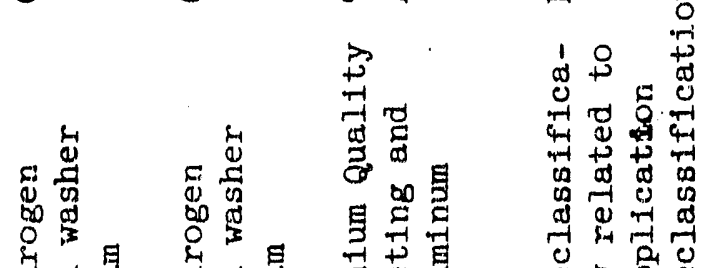

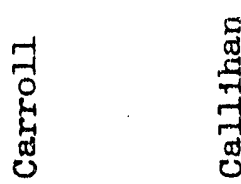

蛋

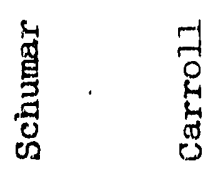

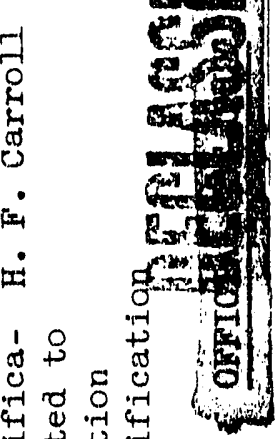

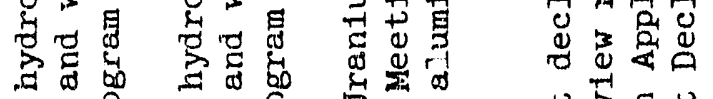

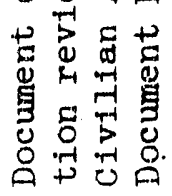

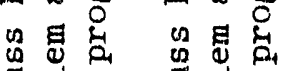

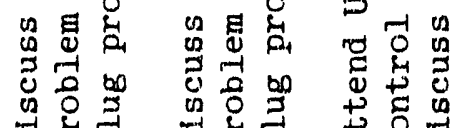

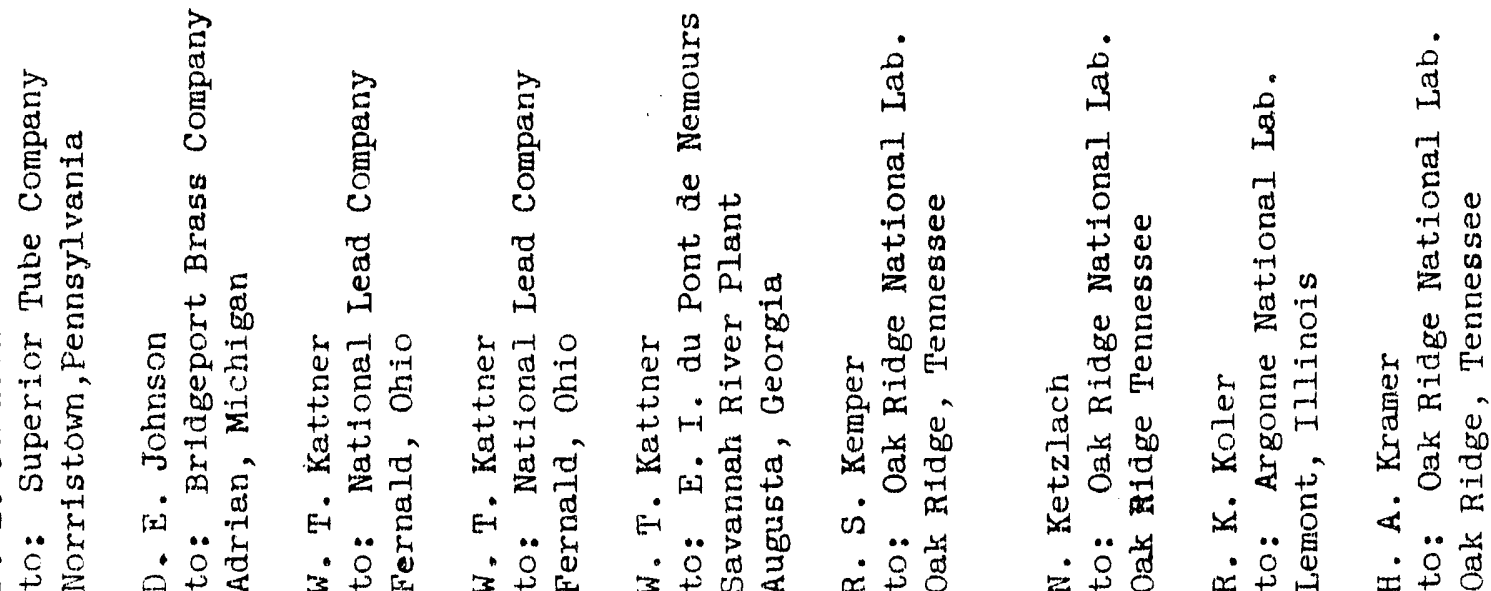


!

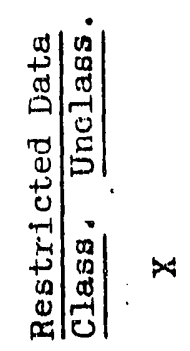

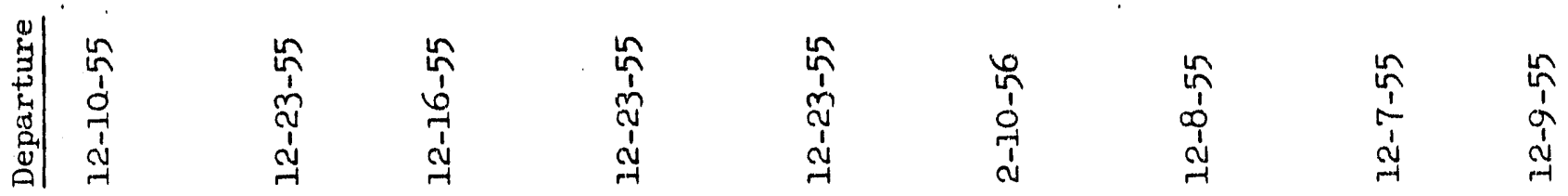

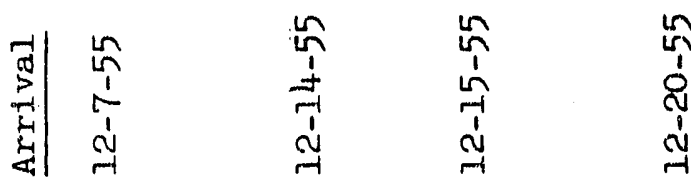

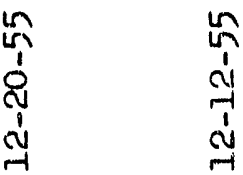

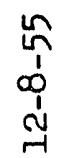

崩

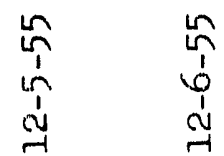

穿

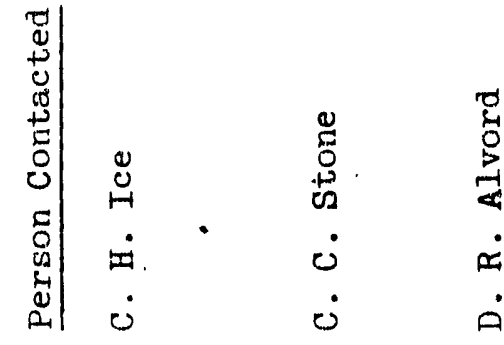

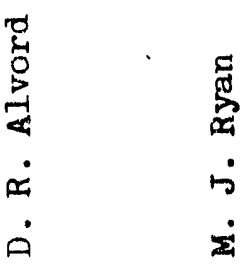

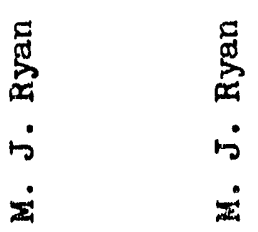

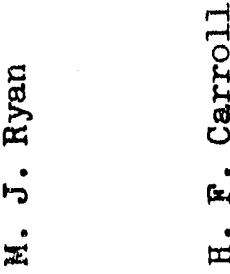

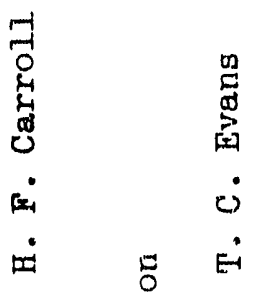

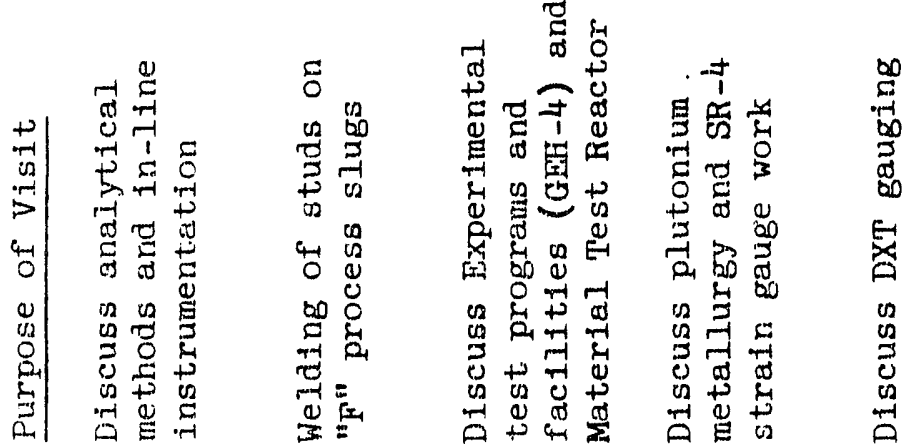

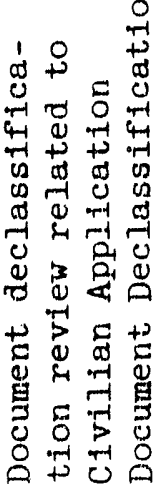

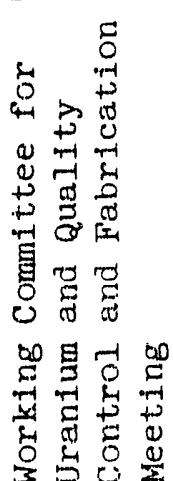

要

2

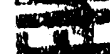

邹

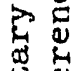
. i.

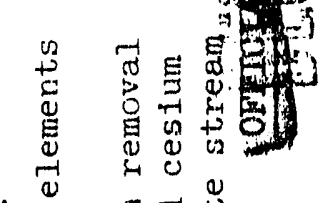

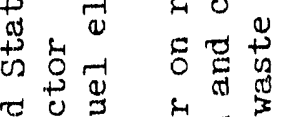

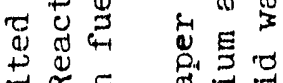

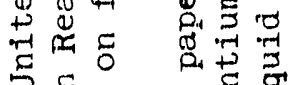
5 品 诺

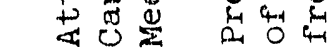

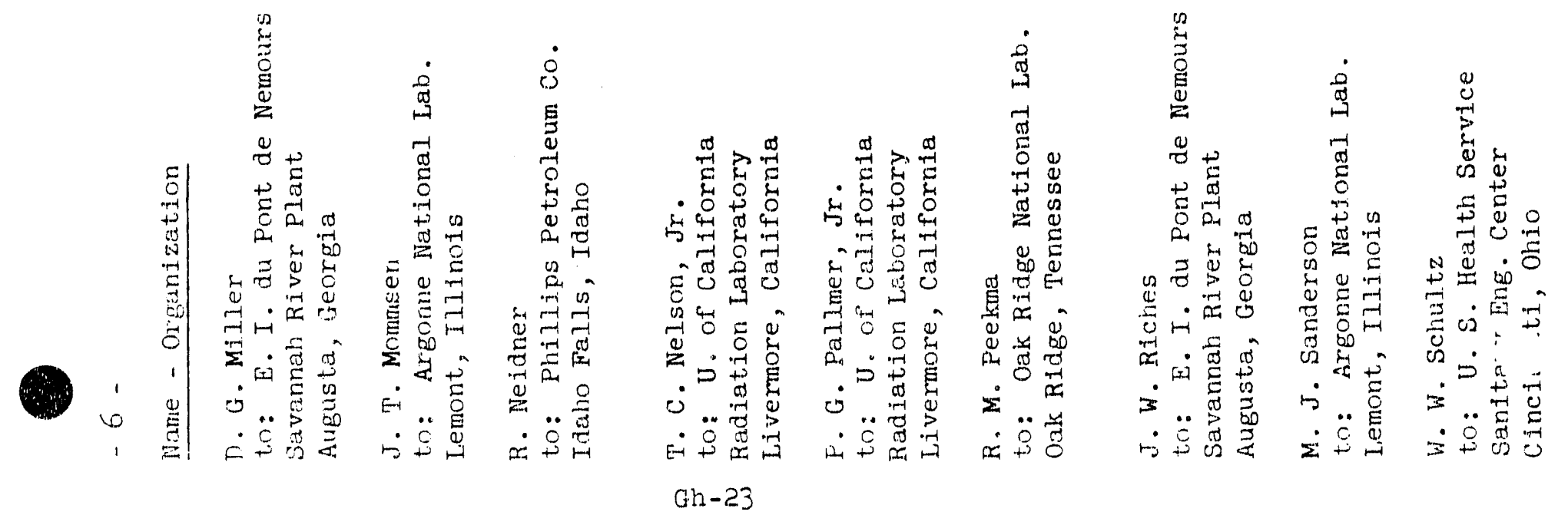


ํํำ

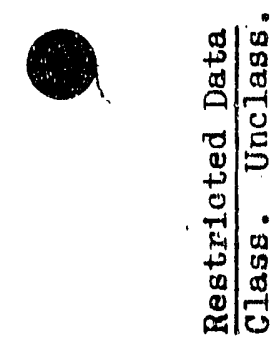

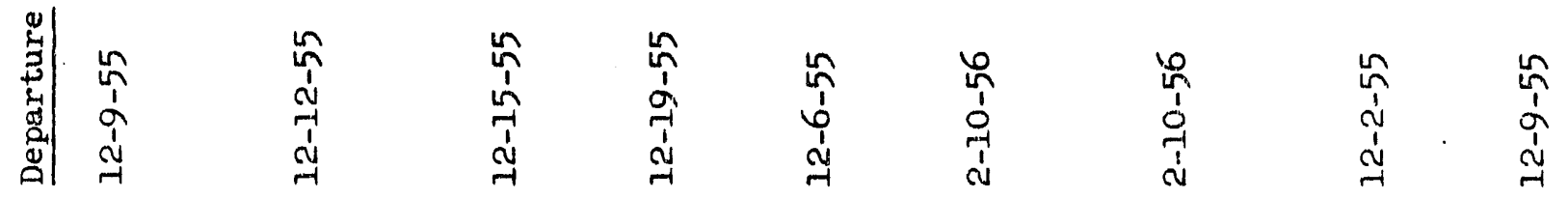

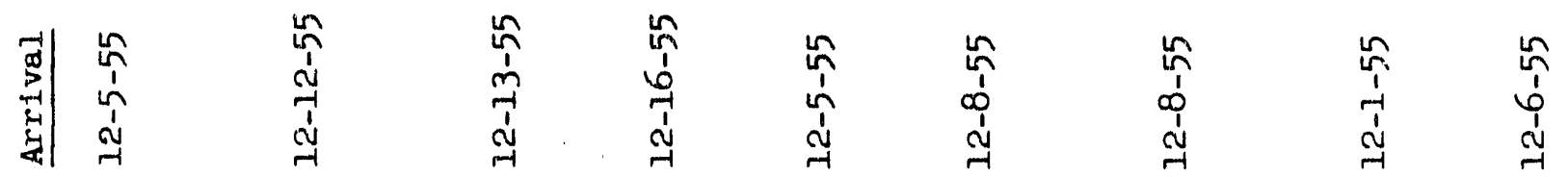

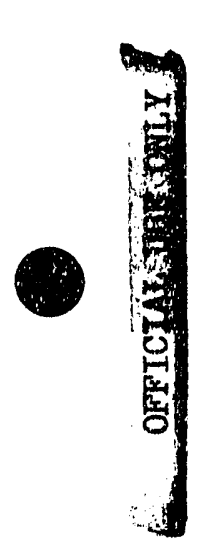

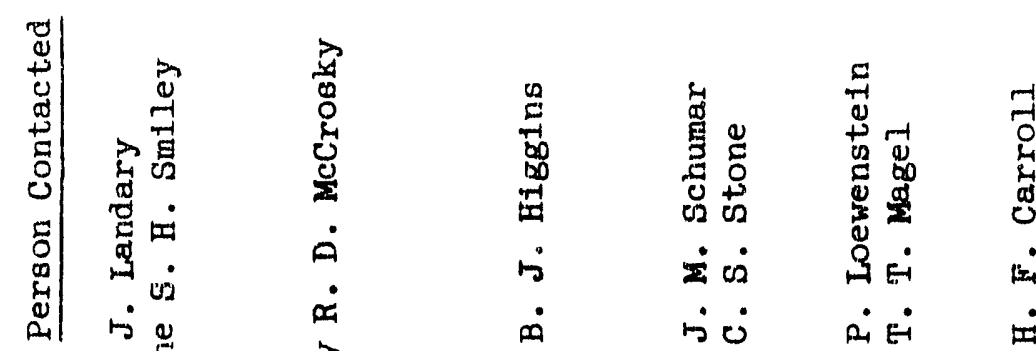

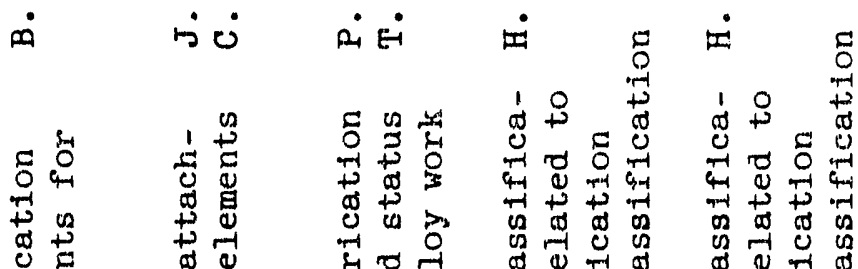

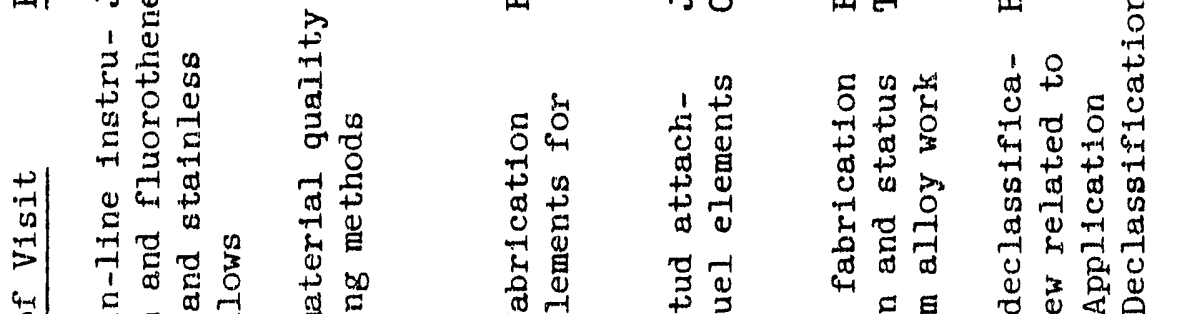

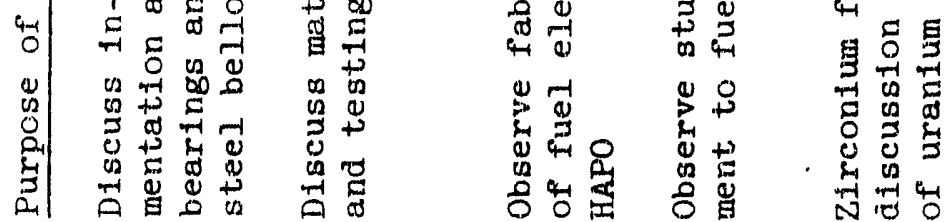

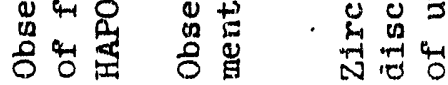

य员

विद वि

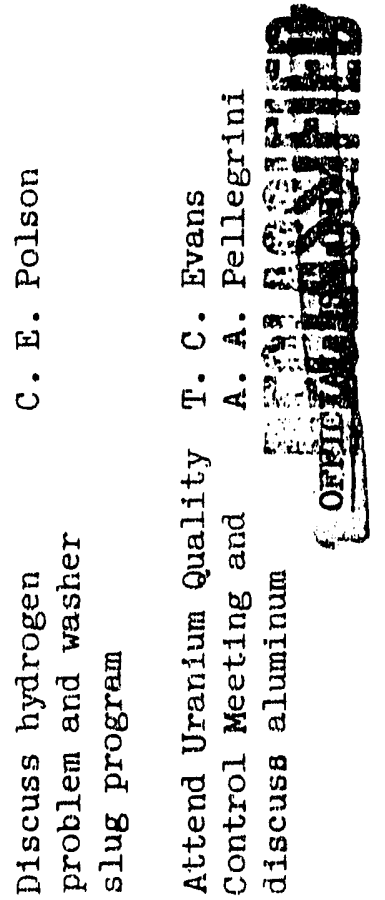

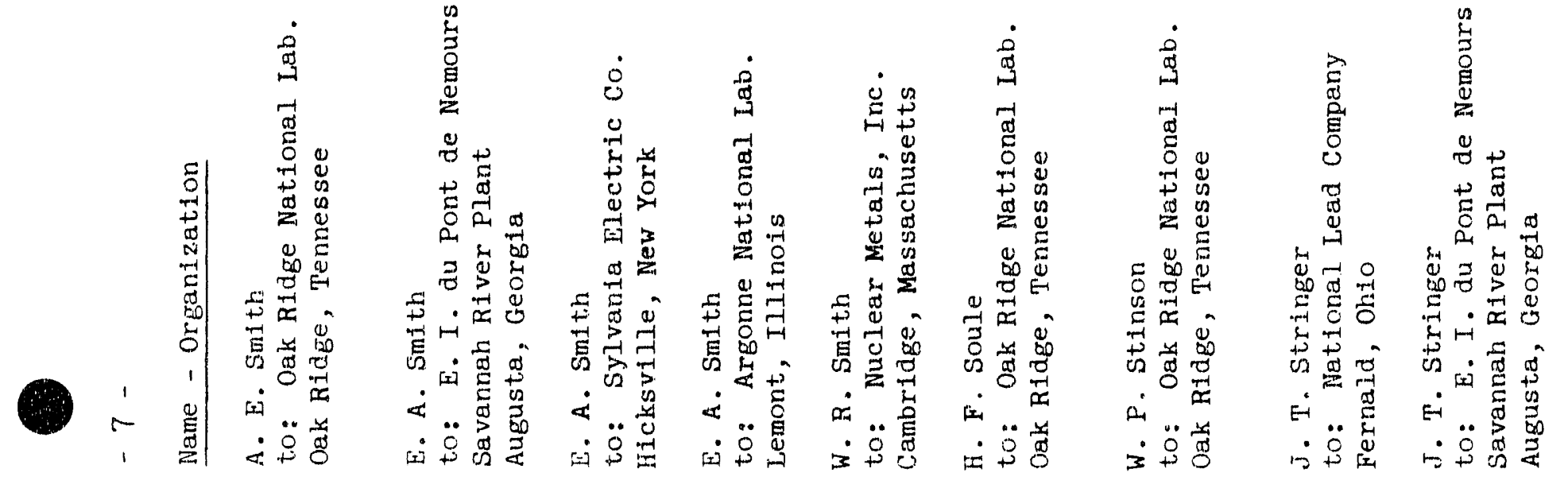


站

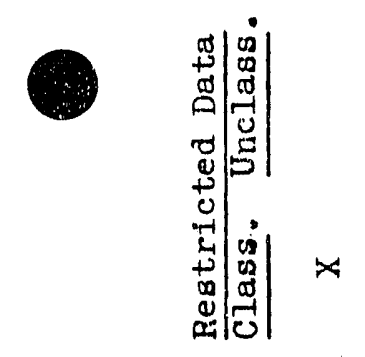

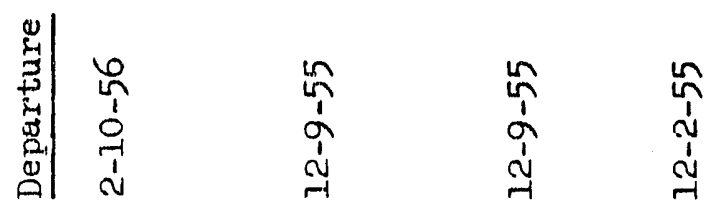

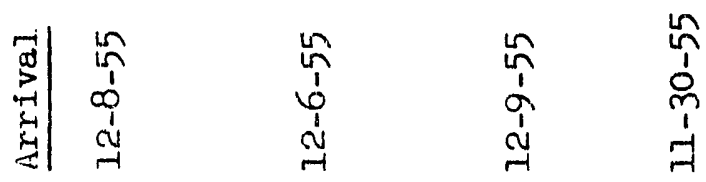

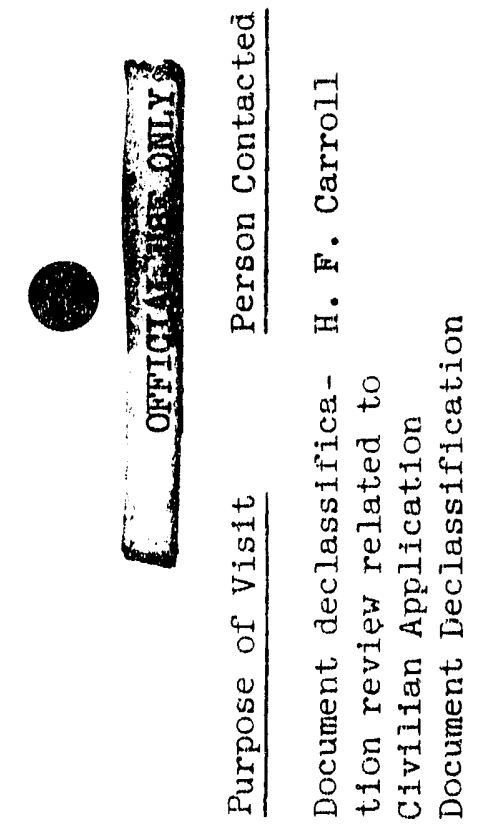

$\stackrel{\substack{n \\ \vdots}}{a}$

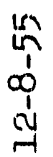

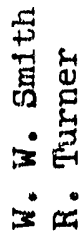

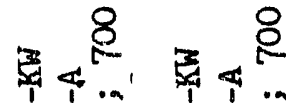

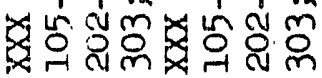

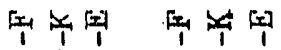

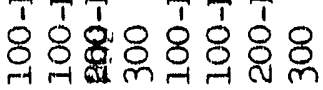

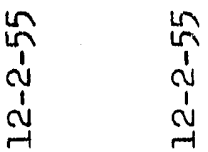

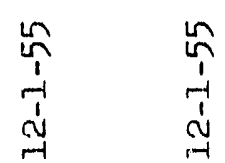

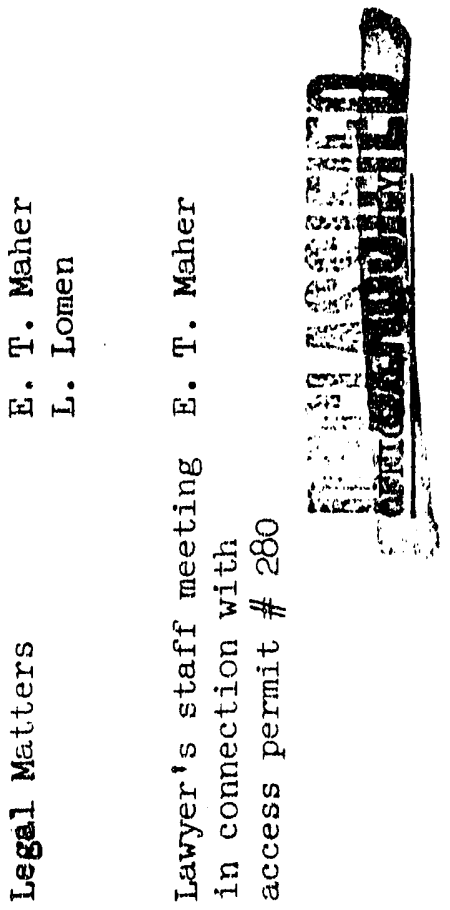

ร

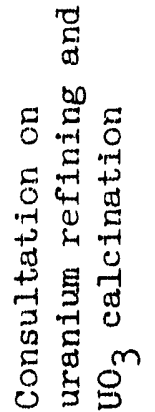

离

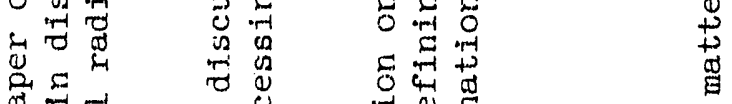

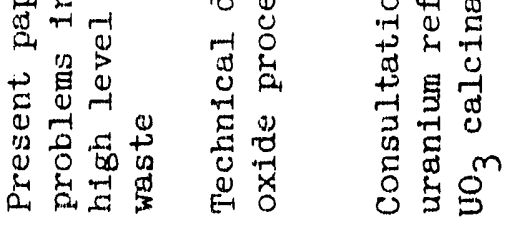

त्र $\sum_{T=1}^{0} 0$
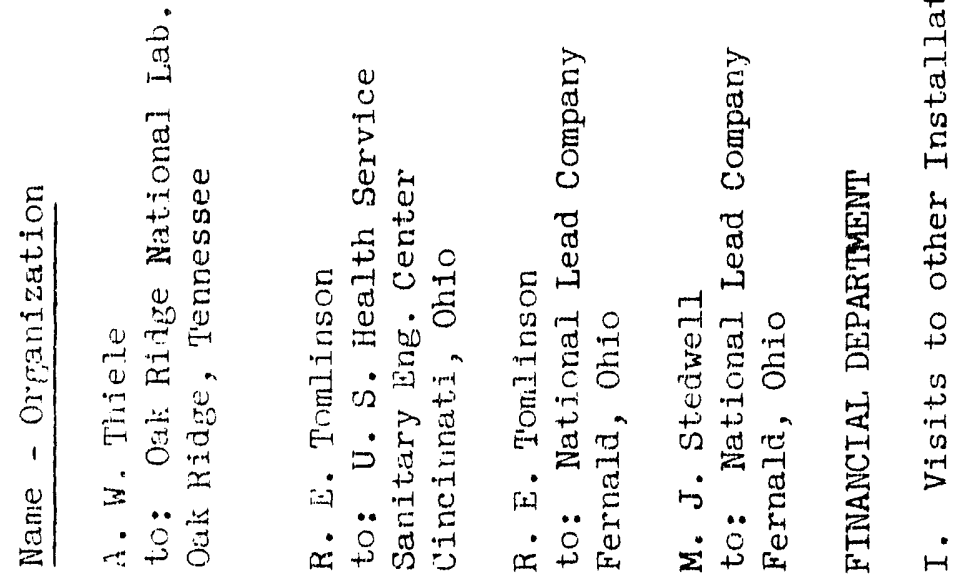

i

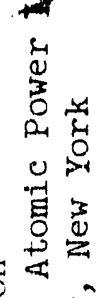

$\begin{array}{lll}0 & 2 \\ \text { in } & 02 & 2\end{array}$

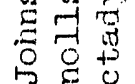

$\dot{4}$

$\Sigma$

$\ddot{\circ} \ddot{0}$

Gh-25 

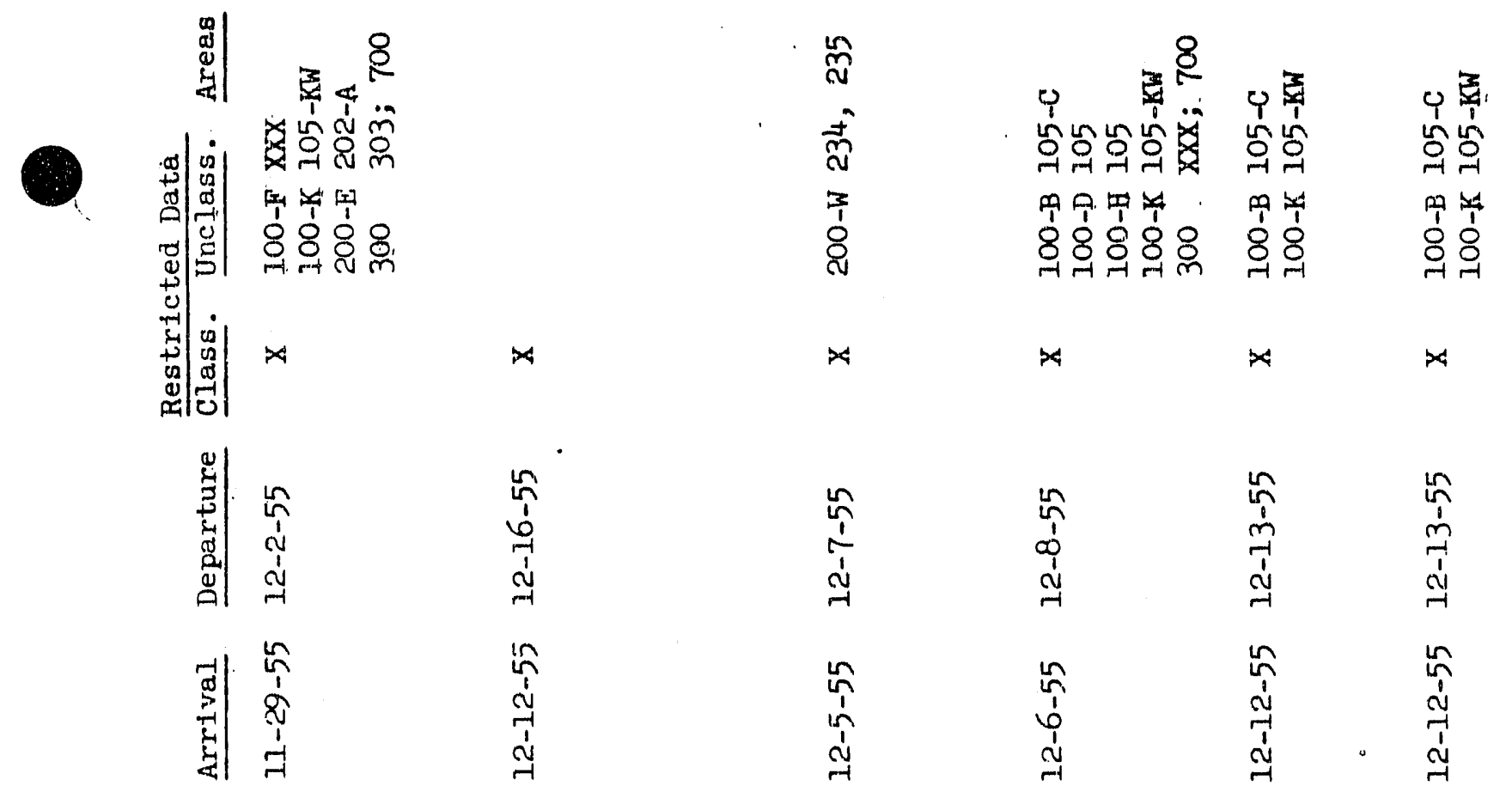

in
cे
ते
ஸे<smiles>O[AlH2]O[AlH2]</smiles>

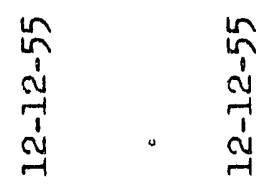
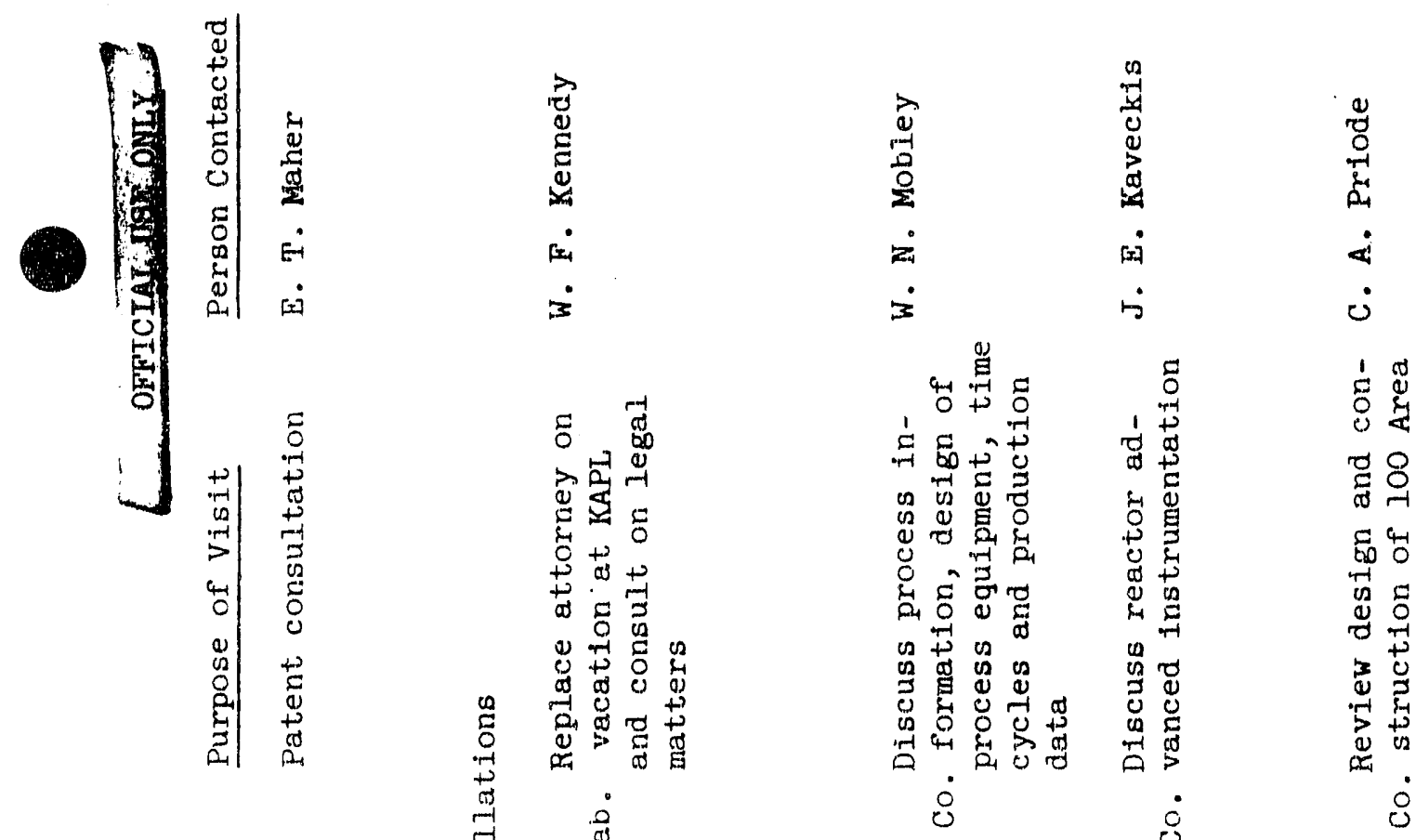

旃

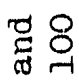
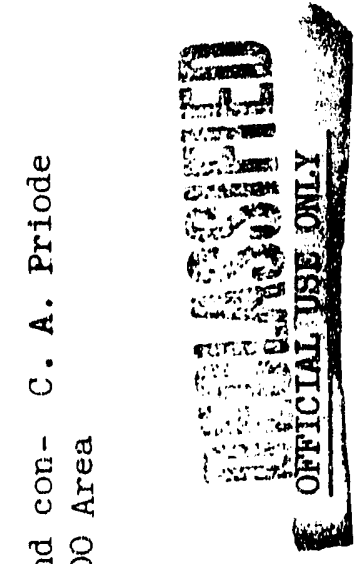

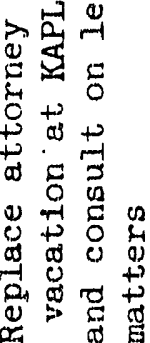

离
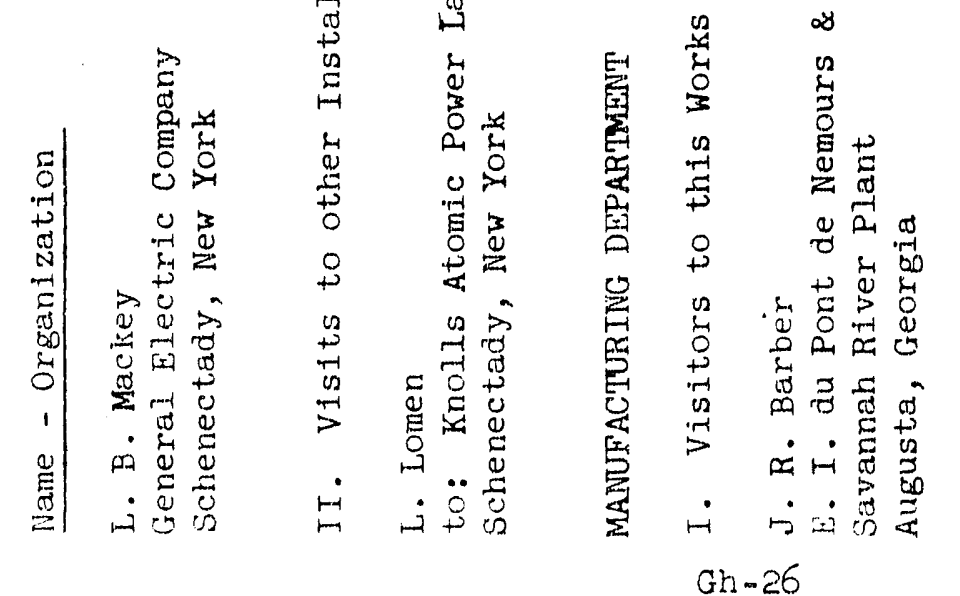

点岁落出。

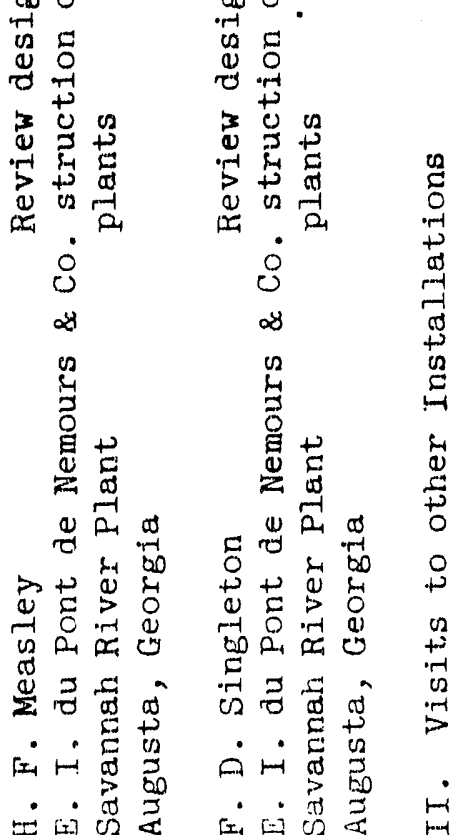


!

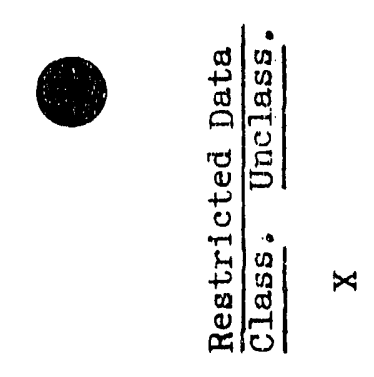

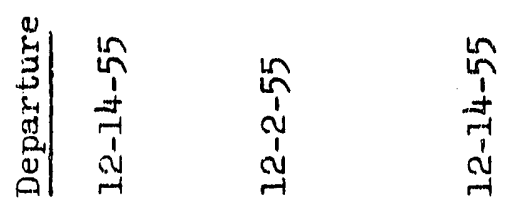

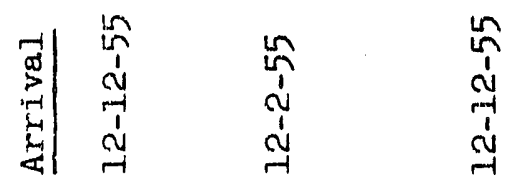

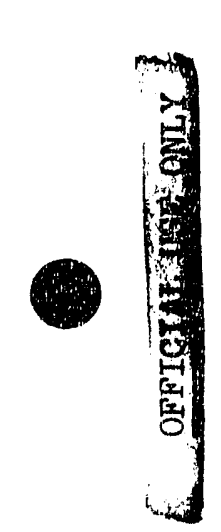

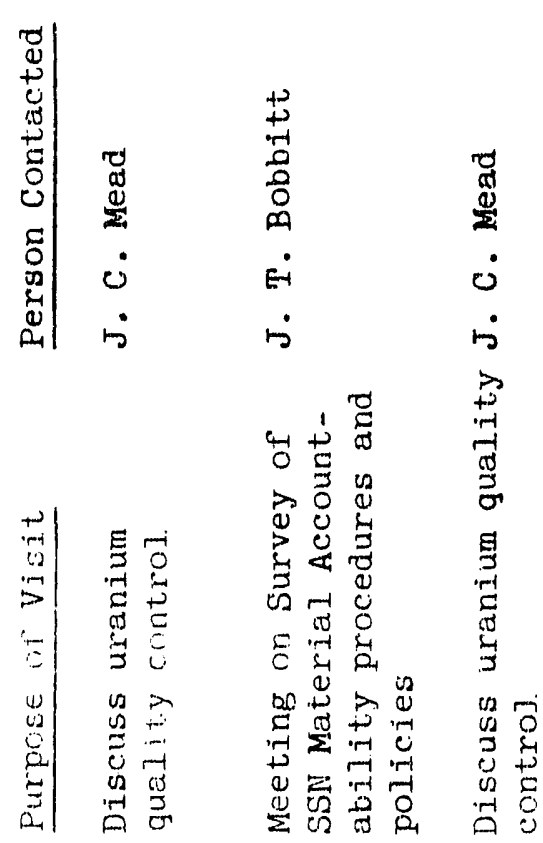

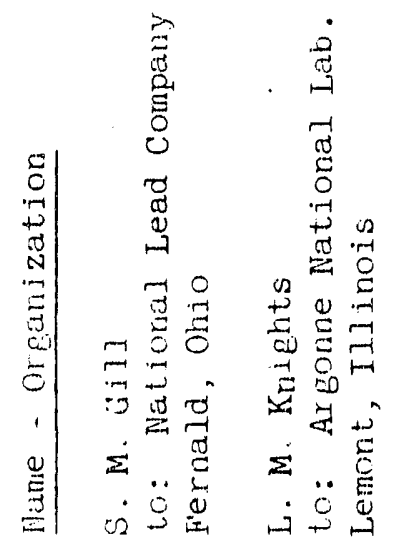

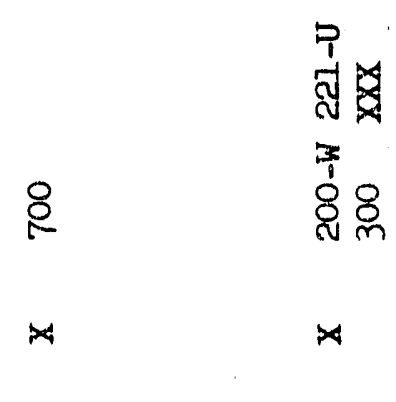

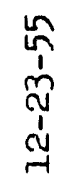

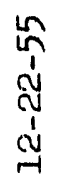

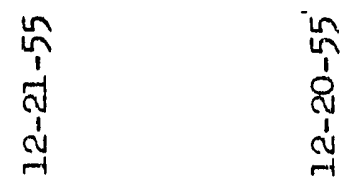

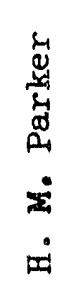

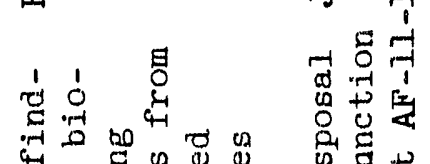

क्ष

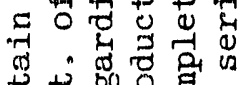

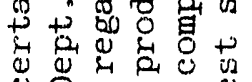

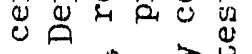

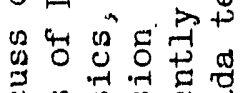

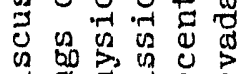

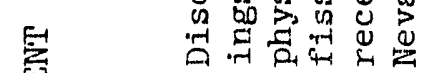

品

式点范

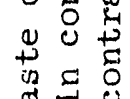

罂要

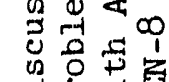

站

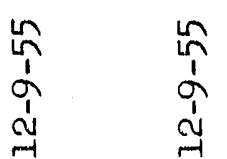

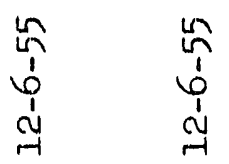

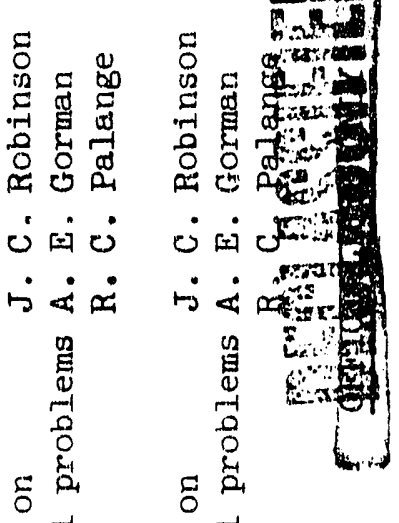

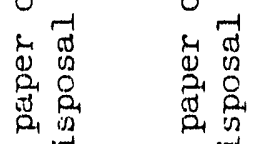

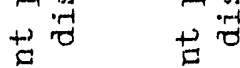

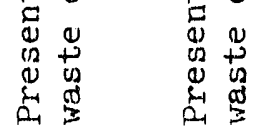

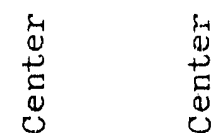

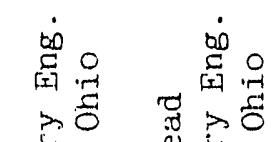

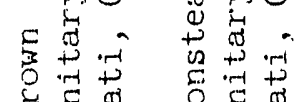

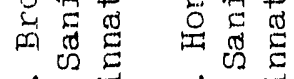

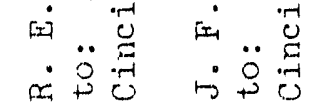




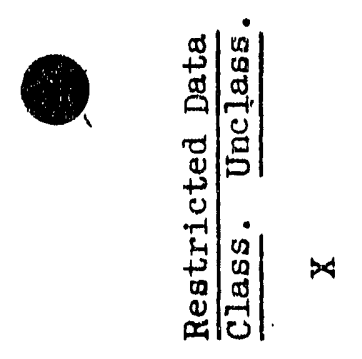

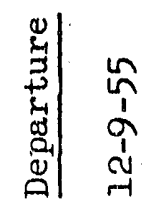

$\begin{array}{ll}n & n \\ 0 & 0 \\ 0 & 0 \\ 0 & 1 \\ 0 & 0 \\ 0 & 0\end{array}$
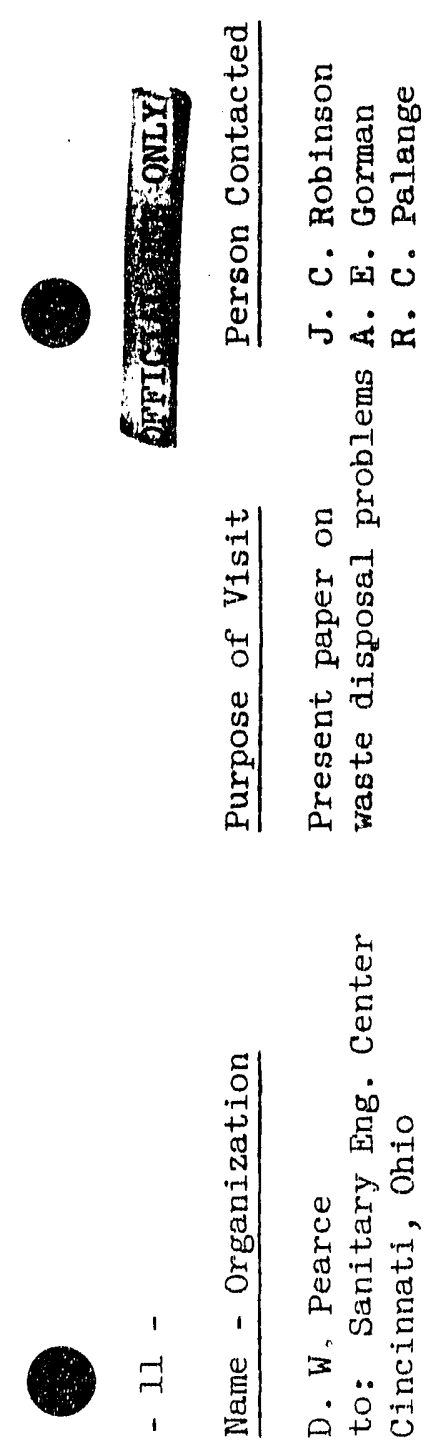


\section{RADIOLOGICAL SCIENCES DEPARTMENT}

DECEMBER

1955

\section{SUMMARY}

Twenty-six Informal, seven Class $I$, and two Class II radiation incidents were recorded. The Class II cases involved localized skin irradiation from particulate contamination on one employee and contaminated gloves on another. In "oth instances the dose and skin areas involved were such as to make the actual hazard small.

Emission of $I^{131}$ was IImited to a very satisfactory average of two curles per week.

Good progress was made in the critical study of irradiation effects on the intestine and in studies on the metabolism and toxicology of radioactive particles. Physical, radiochemical, and instrunentation investigations basic: to the development of an automatic effluent monitor also advanced satisfactorily.

A Radiological Defense Handbook was completed and. in process of being issued at month-end.

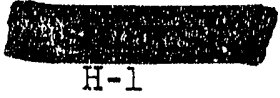


RADIOLOGICAL SCIENCES DEPARTMENIT

DECEMBERR _ $\quad 1955$

The month-end force of 426 included 34 supervisors, 100 engineers and scientists, 24 clerical, and 268 other personnel.

Number of Employees on Payroll

Beginning of Month 419

End of Month 426

Net increase 7

All persons engaged in hork that might reasonably be expected to result in inventions or discoveries advise that, to the best of their knowledge and belief, no inventions or discoverles were made in the course of their work during the period covered by this report except as listed below. Such persons further advise that, for the period therein covered by this report, notebook records, if any, kept in the course of their work have been examined for possible inventions or discoveries.

Name

C. M. Unruh

\section{Title of Invention}

Radiation Film

There were 35 radiation incidents, including 7 Class I and 2 Class II cases. The Class II cases 1nvolved localized exposure, estimated at 2.5 rads, from a radioactive particulate lodged on the face of an operator and hand exposure of 4 to 10 rads from contaminated gloves worn by an instrument technician.

Twenty-two new cases of plutonium deposition were confirmed during the month. Nineteen, however, involved a deposition of $\angle 0.5 \%$ of the MPL; the others were in the range 1\%-20\% of the MPL. It should be noted that the 22 cases were only confirmed during the month, the deposition having occurred at various times earlier in the year. This brings the total new cases confirmed this year to 36 . One new case of fission product deposition also was confirmed during the month.

Several tests being conducted by the Field Development Unit give promise of yielding improved protective apparel at reduced cost. A lead impregnated plastic dip glove if found sultable as a replacement for the molded neoprene hood glove at the 234-5 Bullding will permit about a $90 \%$ reduction in hand exposure.

The average weekly emission of $I^{131}$ from the separations plant stacks was about 2 curies; this was well within the target limit and about a factor of two lower than for the previous month. The average deposition on vegetation was found to be below the MPL at all locations.

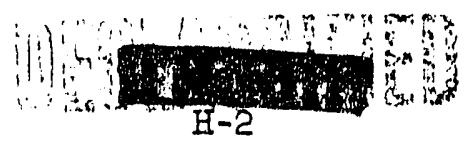


Radiological Sclences Department

A substantial increase in particle fallout, detected at all locations both on and off the project, was attributed to a mixture of fission products from nuclear detonation. Ground surveys were limited durlng the month by snow and cold weather. Surveys around 100-H Area indicated that the contamination deposited at this location in November had been signiflcantly reduced by decay and weathering action.

There was no significant change in the reactor effluent water activity. The total activity at the 100-K. Areas increased during the past three months with increased power levels, as expected. Various researches in support of the automatic isotope monitor for effluent analysis proceeded at a satisfactory pace. In addition to extension and refinement of analytical procedures in progress last month, new studies were initiated on the possibility for continuous removal of radiolsotopes frcm effluent sample streams by electro-migration through lon exchange mambranes.

In separations waste disposal, the status remained essentially unchanged from last month. Preliminary results showed exceptionally good scavenging in the first tankful of in-farm scavenged waste produced in 200-E Area. An appraisal of the possible environs hazard from mercury, used occasionally in slug dissolving, disclosed that the quant1ty released to ground at this time is insignificant with respect to pertinent limits quoted in the literature.

In the blological work, good progress was made in the critical study of irradiation effects on the intestine. Sufficient animals have now been irradiated to establish the median lethal dose, for lrradiation of the exteriorized gut, at 1600 to $1900 \mathrm{r}$. The technlque employed for in situ gut irradiation appears to be such as to make this same range applicable; a fact that will enhance the efficient prosecution of thls experiment.

The survey boat which sank at McNary Dam was damaged to only minor extent but sufficient to accentuate the need for extensive alteration and repair to the hull. Analysis of program need vs cost of rehabilitation presently indicates the advisability of excessing this large tug-type craft and possibly replacing it with a smaller inboard motor boat.

In brief review of the year's activities, protection performance as indicated by the several standard measurements previously employed was satisfactory. Figure I shows the total radiation incidents in the three categories: Informal, Class I, and Class II, compared to 1954.

\section{FIGURE I}

Radiation Incidents

\begin{tabular}{|lrr|}
\hline Category & 1954 & 1955 \\
\hline Informa. & 287 & 396 \\
Class I & 76 & 147 \\
Class II & 20 & 15 \\
\hline
\end{tabular}

SECRET

$\mathrm{H}-3$ 


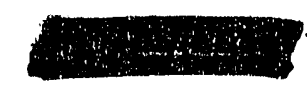

HW -40692

\section{Radiological Sciences Department}

At face value these figures would indicate a deterioration of radiation control standards in the field. However, closer examination indicates this not to be true. For example, the Class I incidents include for the first time this year all reported cases of fallure to wear personnel meters in Radiation zones. There is some evidence to support the opinion also that better surveillance and improved reporting of lacidents has taken place in this period. Such modifying factors coupled with start-up of additional facilities account for substantially all of the increase in numbers of incidents noted above.

It is slgalficant to note that none of the Class II incidents involved whole body exposure to external radiation, compared to 7 in 1954; whereas there were 13 partial body exposures in this category attributable to contamination. The need for improved control of work conducted in zones where, potentially or actually, high level contanination exists is thus indicated.

The most significant internal body depositions of plutonium of local origin were revealed during the year when two cases of deposition between $90 \%$ and $100 \%$ of the maximum permissible linit were confirmed. There are now 139 cases having positive evidence of plutonium deposition compared to 112 confirmed cases at the end of last year. Of these 59 have deposits in excess of $1 \%$ of the permissible limit, and 21 have deposits in excess of $10 \%$ of the permissible IIntt. None of the cases of local orlgin is known to have a deposit in excess of the lintt. As reported a year ago, an increasing number is to be expected as the result of "normal" accumulation as the plants continue to operate. Continuing close attention is being given this problem to ensure that necessary advance action will be taken in the event the trend indicates the need for further restriction on plutonium handing.

Overall exposure to external radiation was in general satisfactory. With but few exceptions exposures were well within bounds of the annual bogey of $3 \mathrm{r}$ (or equivalent for mixed radiations). Near year-end it became necessary to interchange personnel of the Reactor Monitoring organization with their counterpart in this department in order to maintain exposures within the planned annual lintt. As measured by the index for gamia radiation, the average annual exposure was $0.2 r$ as it was in 1954. Three percent of the exposed individuals exceeded I $r$, compared with 3.5 percent in 1954 , and 0.02 percent exceeded $3 \mathrm{r}$, compared with 0.14 percent in 1954 . The average of the 10 highest annual exposures was $3.4 \mathrm{r}^{*}$

In most segments of the department's protection of plant and personnel operations the work load increased significantly. Conventional factors, compared to 1954 , are tabulated in Figure 2 .

*Annual exposure data estimated, firm figures awalt compilation of data under way but not completed in time for this report.

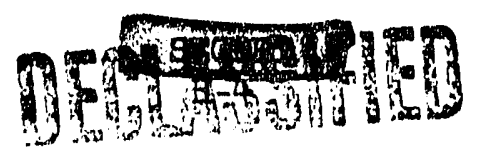


Radiological Sclences Department

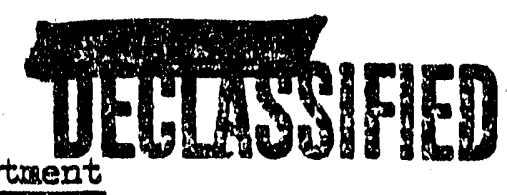

HW -40692

\section{FIGURE 2}

Work Load Fectors Compared With 1.954

\section{Iten}

Percent Increase

Radiation surveys

Gemma pocket chambers read

56

Slow neutron pocket chambers read

24

Beta-ganms 11 in badges

Fast neutron badges

Plutonium bloassays

Fission product bloessays

Urenium bloassays

Fixed and portable instrument callbrations

44

Laboratory samples

Counting roon samples

To cope with this increased work load the force assigned to the protection of plant and personnel functions in the department was increased 11.5 percent. Inproved efficiency in many of the operations offset signiflcantly additions to the force that would otherwlse have been necessary. This inproved utilization of manpower is reflected in many of the unlt cost indices maintained within the department. Comparison with 1954 cost performance for the major service activities is shown in Figures 3 through 6 . 
RADIOLOGICAL SCIENCES DEPARTMENTI

\section{FIGURE 3}

Unit Cost Trends

Personnel Meters Services

(Units in Dollars)
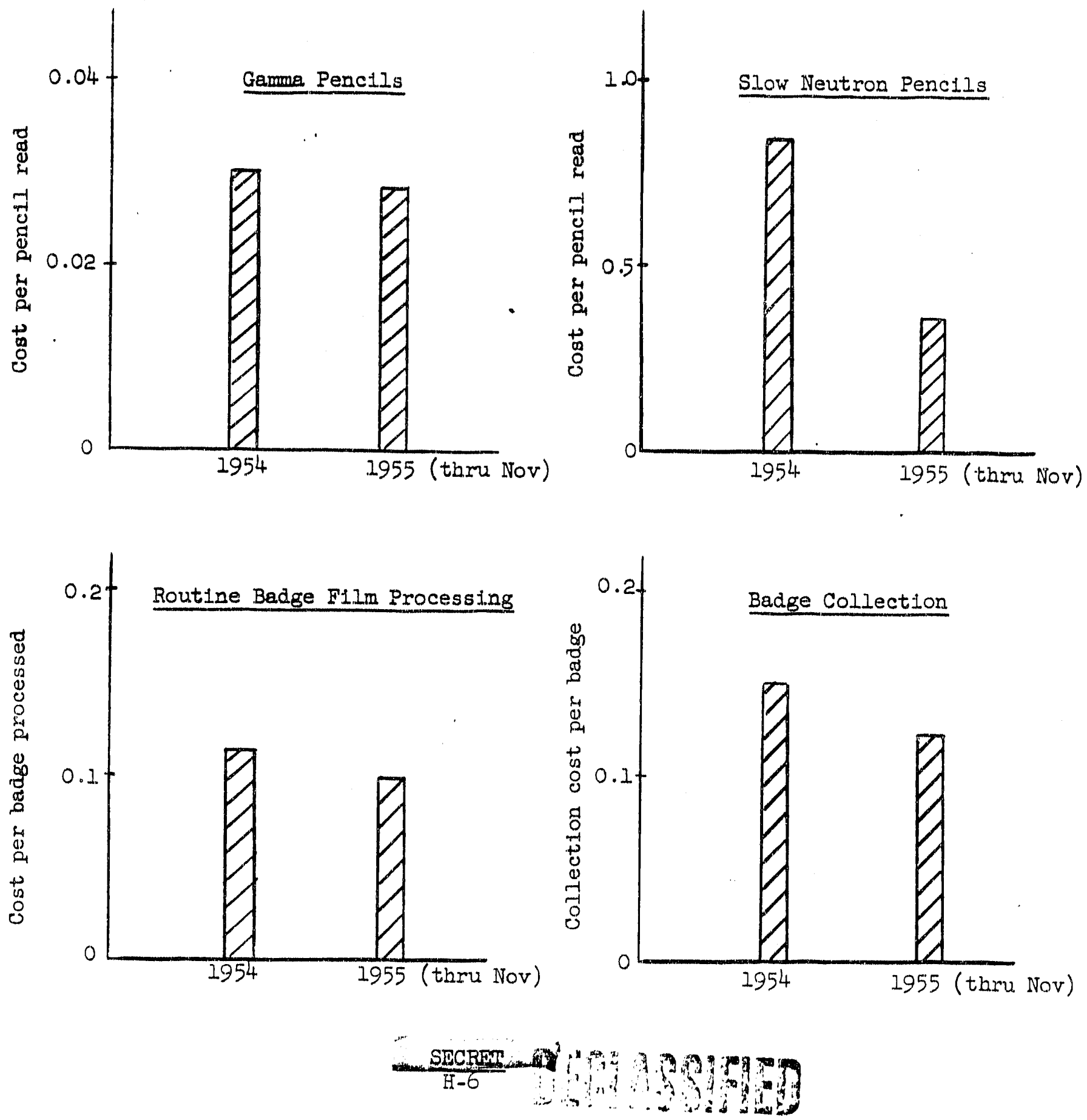


\section{RADIOLOGICAL SCIBNCES DEPARIMEANS}

FIGUTE 4

Unit Cost Trends

Measurements in Environs
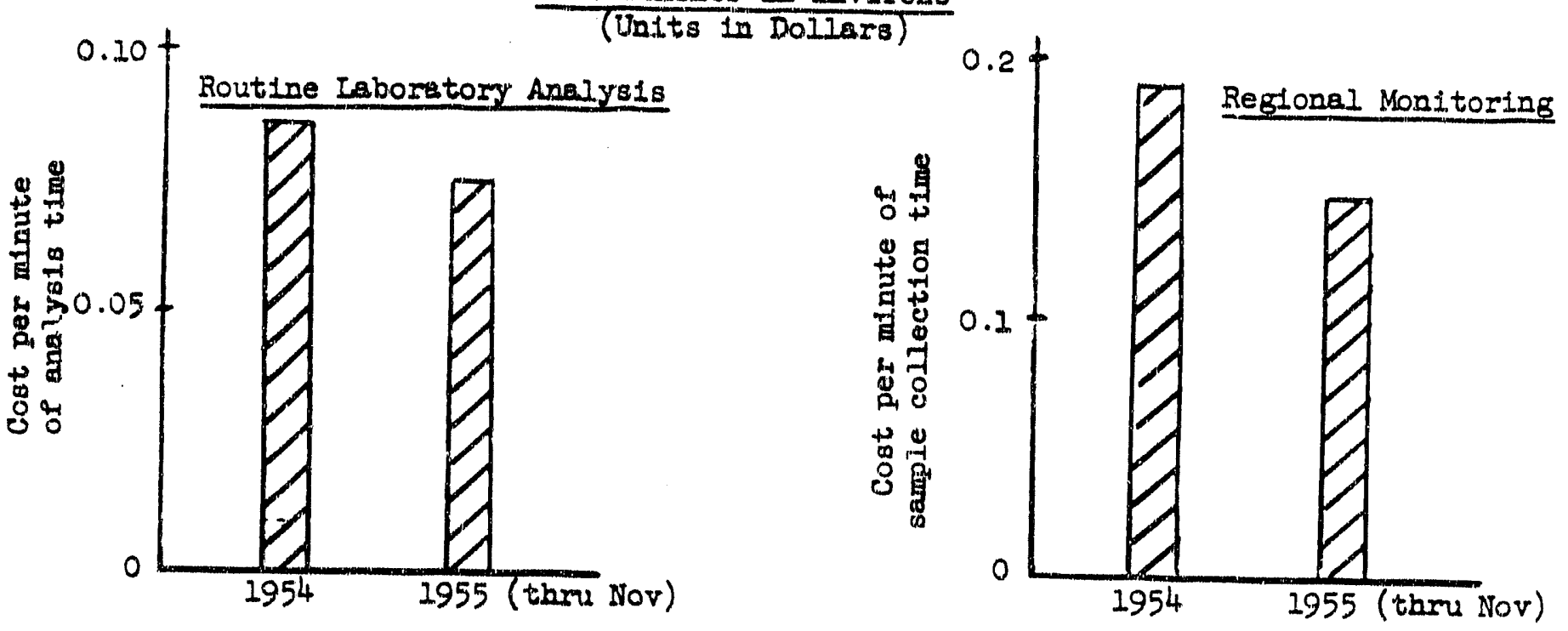

FICURE 5

Un1t Cost Trends

Bioassay

(Tnt's in Dollars)

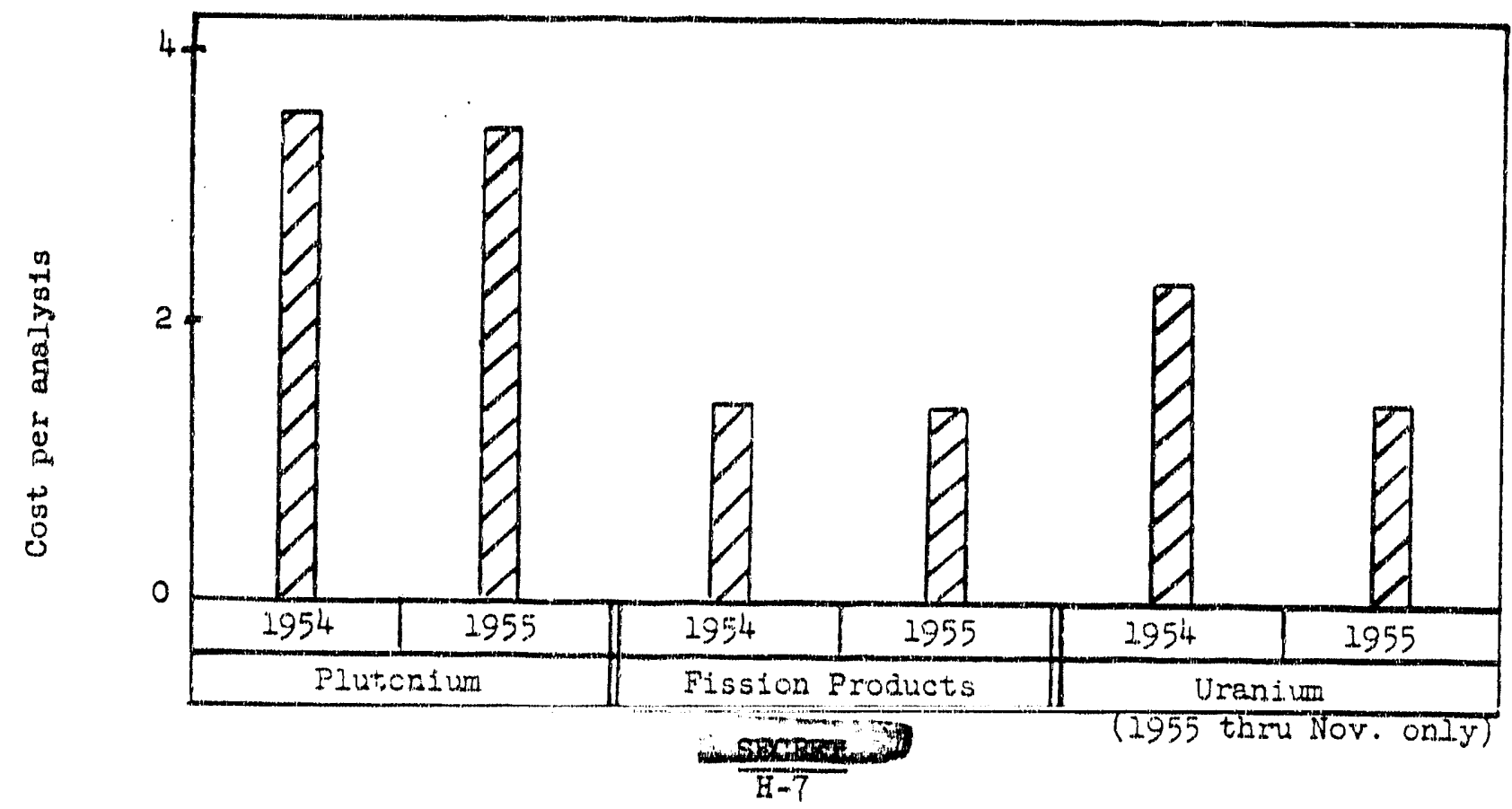




\section{RADIOLOGICAL SCIENCES DEPARTMEANT}

\section{FIGURE 6}

\section{Un1t Cost Trends}

Inst rument Calibrations

(Units in Dollars)

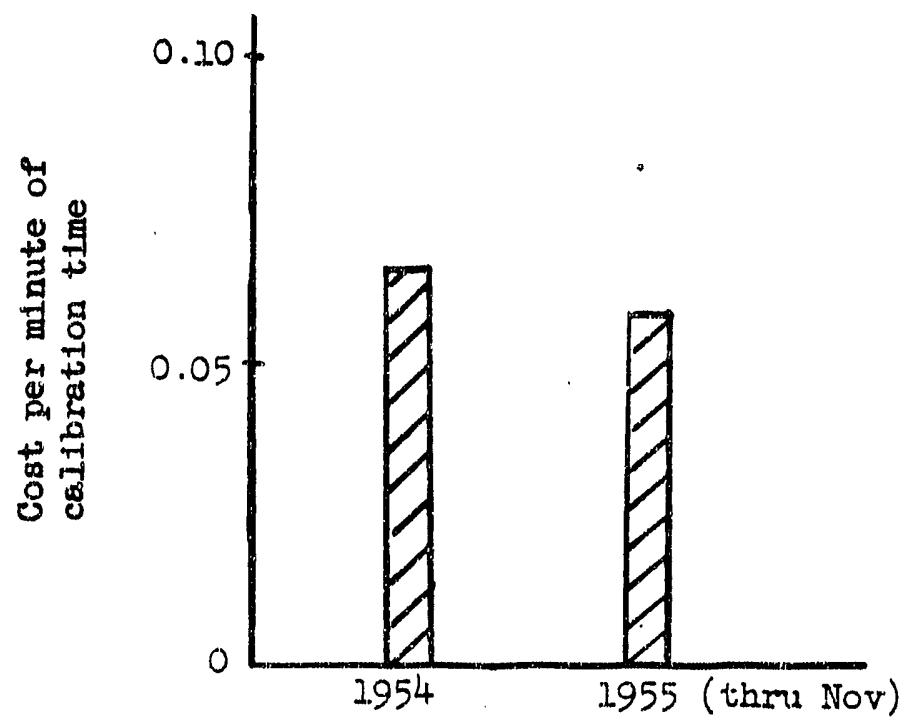

As to organization in general, there was considerable tightening up all along the line in the way of eliminating echelons and increasing span of control. Over the past two years the average span of control has almost doubled. One level of supervision eliminated in both Blology and Biophysics Sections during 1955 effected a reduction of four in the total number of supervisors. By year end there had been a $26 \%$ increase in the ratio of average number of employees supervised, and a $16 \%$ increase in the ratto of dollars of employee's salary per dollar supervisor's salary.

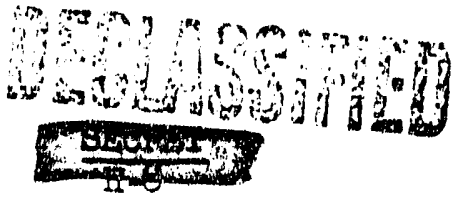




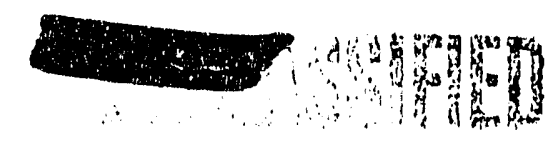

\section{Radiolog1cal Sclences Department}

Safety performance was less satisfactory, as measured by the injury Prequency index shown in Figure 7, though our objective of malntsining the frequency rate below the average for BAPO was achleved. No major or sub-major injury occurred.

\section{FIGURE 7}

\section{Injury Frequency Rate}

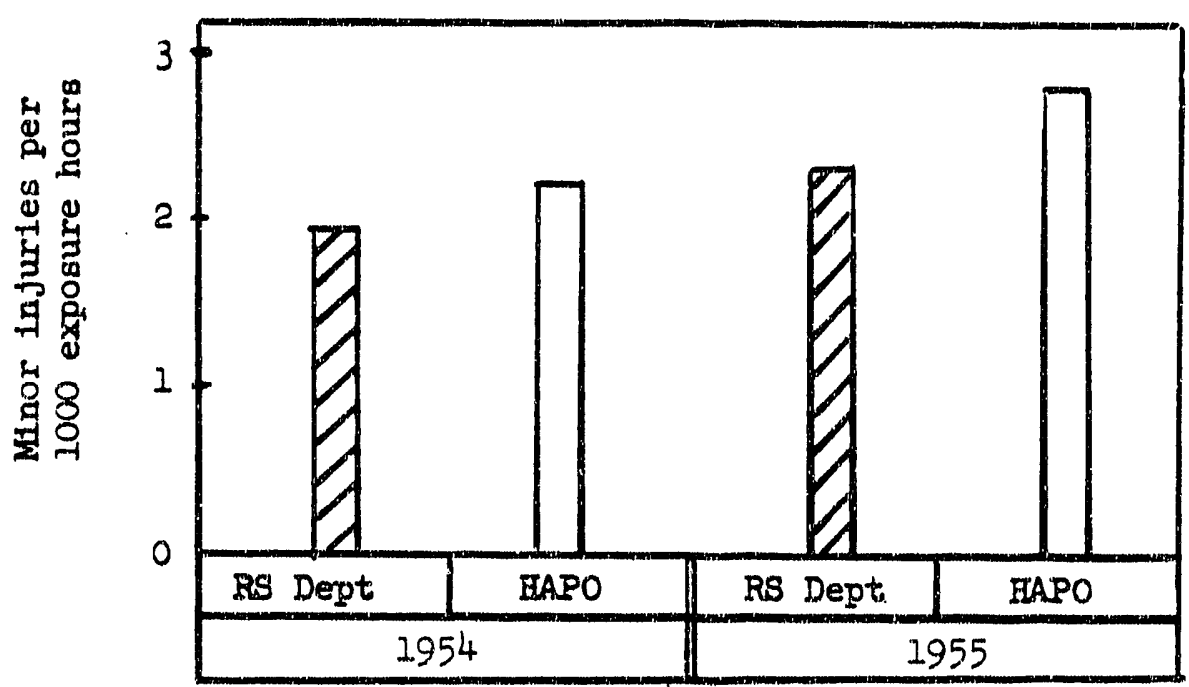

The efficlency of the organization was conslderably enhanced through a substantial improvement in employee separations rate and through maintaining the previous good record of presenteelsm, especially among male ermployees, as shown in Figures 8 and 9 , respectively.

\section{FIGURE 8}

\section{Separations Rate}

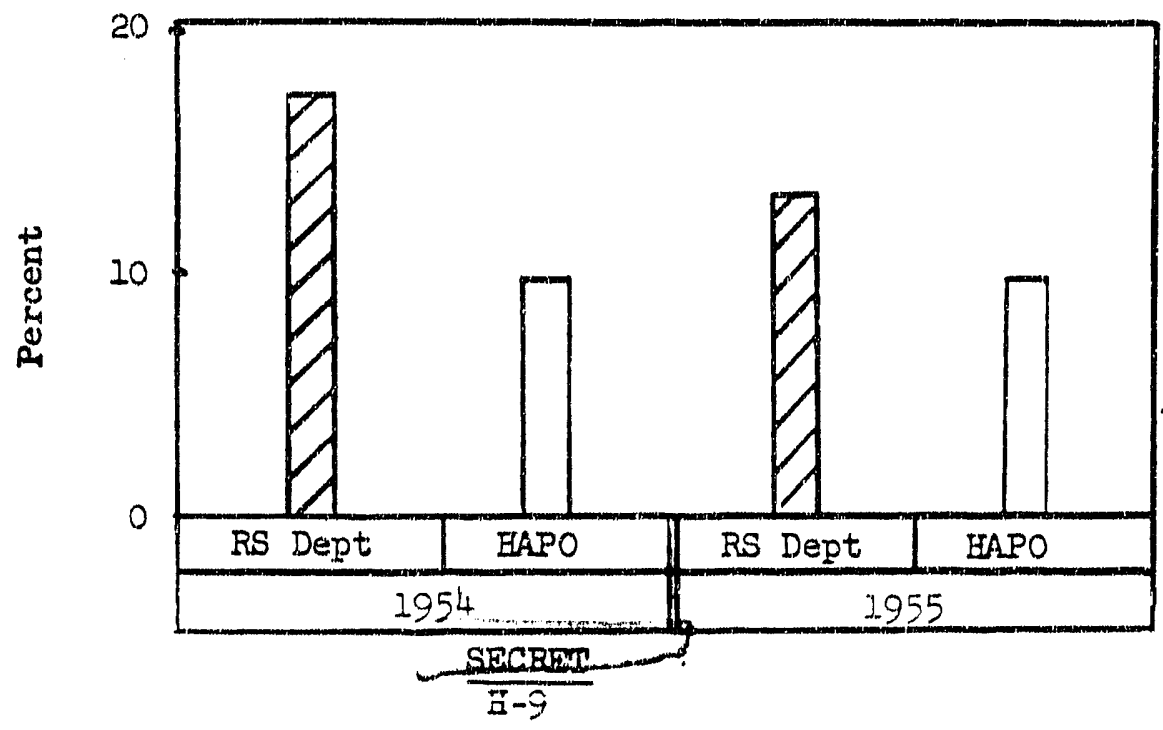


RADIOLOGICAL SCIENCES DEPARTMEMNT

\section{FIGURE 9}

Average Annual Absenteeism

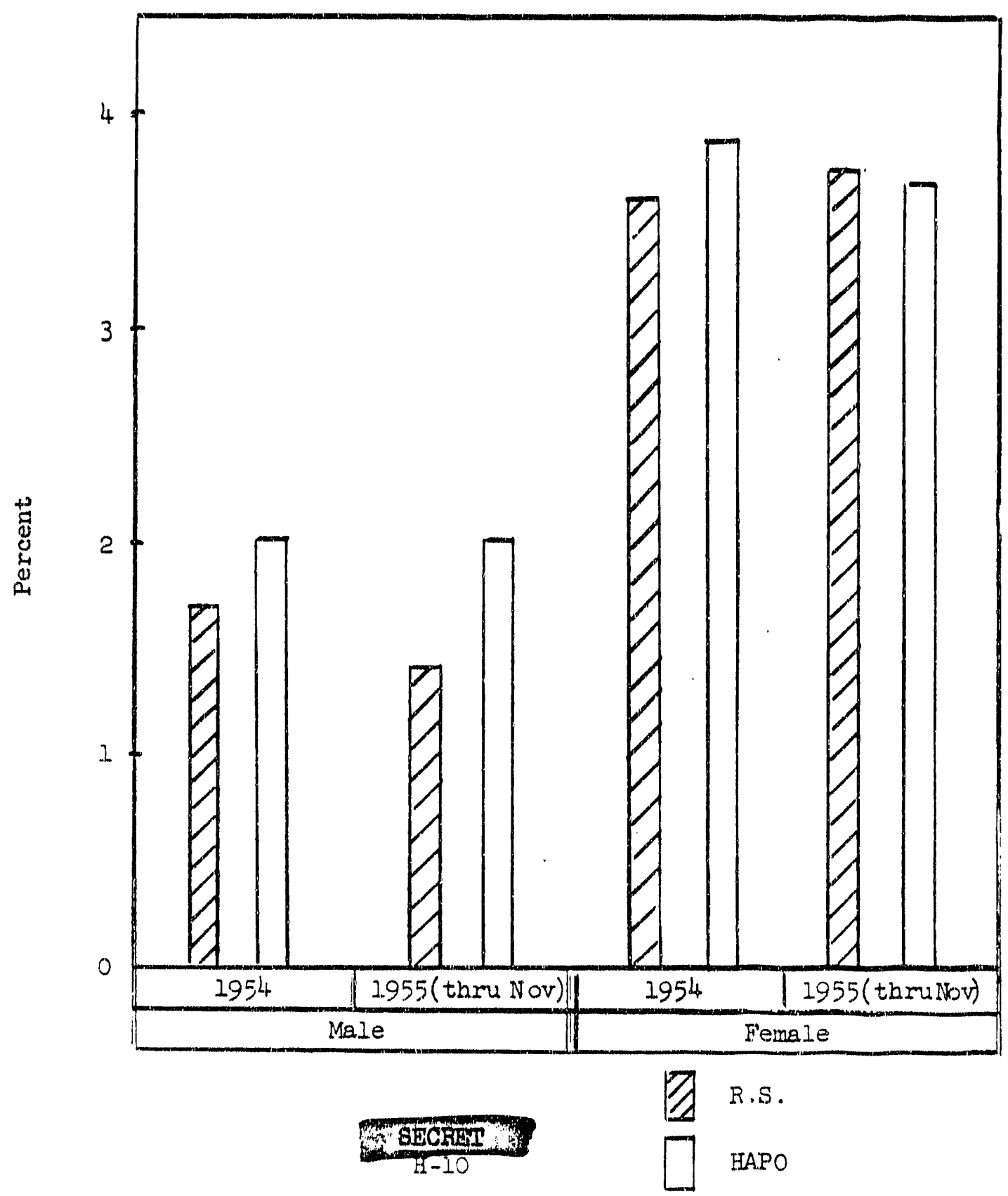




\section{Radiological Sciences Department}

Research and Development activities continued on problems arlsing principaliy from the various Hanford radioactive effluents and those problems related to physical measurement of radiation.

Continued emphasis has been given to the Columbia RIver contamination problem because of the predicted increase in river water activity assoclated with h1gher production levels and, more recently, expressions of concern at the Geneve Conference in regard to contanination of international bodies of water. Development of instrmentation capable of locating and accurately measuring internally deposited radiolsotopes in the human body bas been given high prlority as have resesrches on the increasingly 1mportant problem of establishing criteria for continued safe disposal of ilquid radioactive wastes to the separations plateau. Additional funds were requested from the Commission to permit acceleration of these investigations and at year end these topics were belng actively developed.

mix.michedmen

Acting Director, RADIOLOGICAL SCIENCES DEPARIMENT

MI Mickelson:kss

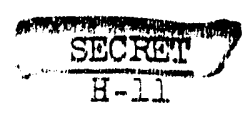




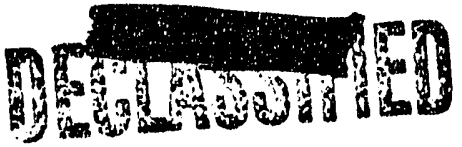

BW- 40692

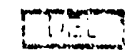

Radiological Sciences Department

\section{APEENDIX}

1. Condensed Exposure Records

\begin{tabular}{|l|c|c|c|}
\hline \multicolumn{1}{|c|}{ Type } & $\begin{array}{c}\text { Number } \\
\text { of Readings }\end{array}$ & $\begin{array}{c}\text { Potential } \\
\text { High Results }\end{array}$ & $\begin{array}{c}\text { Confirmed } \\
\text { High Results }\end{array}$ \\
\hline Pocket chambers - gamma & 306,932 & 40 & 0 \\
Pocket chambers - slow neutron & 1,720 & 9 & 0 \\
Film Badges - beta-gamm & 52,198 & 40 & 0 \\
Neutron film & 1,025 & 0 & 0 \\
\hline Pu Bloassay & 1,076 & 22 & 22 \\
F. P. bioassay & 1,260 & 8 & 3 \\
U biosssay & 464 & 11 & 0 \\
\hline Alpha hand counts & & & 0 \\
Beta hand counts & 52,733 & 0 & 0 \\
Thyrold counts & 67,894 & 0 & 0 \\
\hline
\end{tabular}


Rad1ologlcal Sclences Departinent

2. Reglonal Monitoring Records

\begin{tabular}{|c|c|c|c|}
\hline jemple Type and & $\begin{array}{c}\text { Act1vity } \\
\text { Type }\end{array}$ & $\begin{array}{c}\text { Average } \\
\text { Activity Density } \\
\mu c / m l\end{array}$ & $\begin{array}{l}\text { Trend* } \\
\text { Fector }\end{array}$ \\
\hline
\end{tabular}

Drinking Water and

Related Materials

Benton City Water Company Well

Richland, N. Richland, Benton C1ty Wells

100 Areas

200 Areas

Pasco, Kennewick, McNary Dam

Backrwash Solids - Pasco

Filter Plant

Backwash Liquids - Pasco

Filter Plant

Sand Filter - Pasco

Fliter Plant.

Anthracite Filter - Pasco

F1lter Plant

Other Waters and

Related Materials

300 Area Wells \#1 and \#3

300 Area Well \#4

Well \#4 measured as Jranium

Other Wells on the

Reservation

Columbia River - Hanford

Ferry

Columbla River - Below Reactors

Columbia River - Paterson to MaNery

Columbia River - Shore Mud

Raw Water - Operating Areas

Reactor Effluent Retention

Basins to River

Reactor Effluent Retention

Basins to River

I-13I In Farm Wastes to River

I-131 in Columbia, River Hantoord

300 Area Pond Inlet

$\begin{array}{lll}\text { alphe } & 1.2 \times 10^{-8} \\ \text { alpha } & (\mathrm{K} 0.5 \text { to } 1.2) \times 10^{-8} \\ \text { beta } & (1.6 \text { to } 3.6) \times 10^{-6} & - \\ \text { beta } & (0.53 \text { to } 2.1) \times 10^{-6} & - \\ \text { beta } & (<0.5 \text { to } 6.7) \times 10^{-7} & +2 \\ \text { beta } & 2.2 \times 10^{-2} / \mathrm{uc} / \mathrm{gm} & \ldots \\ \text { beta } & 2.7 \times 10^{-7} \\ \text { beta } & 2.8 \times 10^{-5} / \mathrm{uc} / \mathrm{gm} & \ldots \\ \text { beta } & 2.6 \times 10^{-5} / \mathrm{uc} / \mathrm{gm}\end{array}$

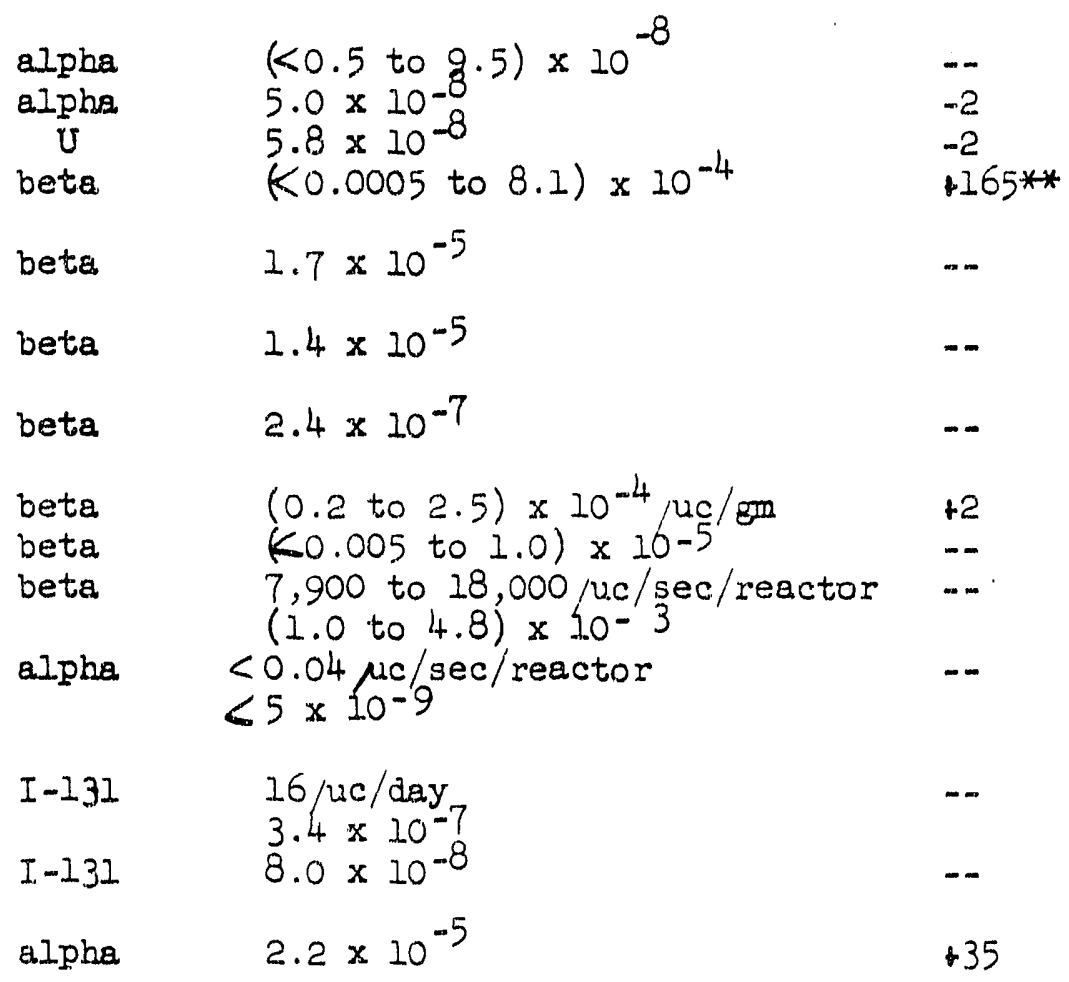




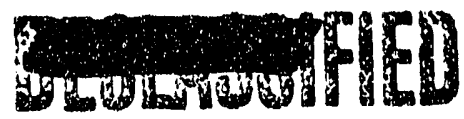

Radiological Sciences Department

\begin{tabular}{lccc} 
& Average & \\
Sample Type and Location & Activity & Activity Density & Trend* \\
\hline
\end{tabular}

Atmospheric Pollution

\begin{tabular}{|c|c|c|}
\hline $\begin{array}{l}\text { Gross Alpha Emitters } \\
\text { Gross Dose Rate - } \\
\text { Separations Areas }\end{array}$ & $\begin{array}{l}\text { a.pha } \\
\text { beta - } \\
\text { garma }\end{array}$ & $\begin{array}{l}<4.0 \times 10^{-15} \\
(0.53 \text { to } 3.9) \mathrm{mrad} / \text { day }\end{array}$ \\
\hline $\begin{array}{l}\text { Gross Dose Rate - } \\
\text { Residential Areas }\end{array}$ & beta - & $(0.35$ to 0.81$) \mathrm{mrad} /$ day \\
\hline $\begin{array}{l}\text { Active Particles - } \\
\text { Separations Areas }\end{array}$ & beta & $(0.16$ to 1.1$) \times 10^{-12}$ \\
\hline $\begin{array}{l}\text { I-13I Separations Areas } \\
\text { I-13I Separations Stacks }\end{array}$ & $\begin{array}{l}I-131 \\
I-\frac{1}{131}\end{array}$ & $\begin{array}{l}(K 4 \text { to } 9) \times 10^{-14} \\
0.30 \text { curie/day }\end{array}$ \\
\hline $\begin{array}{l}\text { Ruthenium - Separations } \\
\text { Stacks }\end{array}$ & $R u^{183-106}$ & $<0.01$ curle/day \\
\hline $\begin{array}{l}\text { Active Particles - Wash., } \\
\text { Idaho, Ore., Mont. }\end{array}$ & -- & 0.006 to $0.041 \mathrm{ptle} / \mathrm{m}^{3}$ \\
\hline $\begin{array}{l}\text { Active Particles - Project } \\
\text { Tritium (as oxides) - }\end{array}$ & $\bar{T}$ & $\begin{array}{l}0.001 \text { to } 0.060 \text { ptile } / \mathrm{m}^{3} \\
1.85 \text { curles } / \text { day }\end{array}$ \\
\hline ) & & \\
\hline
\end{tabular}

\section{Vegetation}

\begin{tabular}{|c|c|c|c|}
\hline $\begin{array}{l}\text { Environs of Separations } \\
\text { Areas }\end{array}$ & $I-13 I$ & (K3 to 6$) \times 10^{-6} / \mathrm{uc} / \mathrm{gm}$ & -2 \\
\hline Residential Areas & $I-131$ & $<3.0 \times 10^{-6} / \mathrm{uc} / \mathrm{sm}$ & -- \\
\hline $\begin{array}{l}\text { Eastern Washington and } \\
\text { Oregon }\end{array}$ & $I-131$ & $<3.0 \times 10^{-6 / 4 \mathrm{uc}^{\prime} \mathrm{gm}}$ & -- \\
\hline $\begin{array}{l}\text { Non-Volatile Beta Emitters } \\
\text { Wash. and Ore. }\end{array}$ & - beta & $(3.5$ to 7.2$) \times 10^{-5} / \mathrm{uc} / \mathrm{sm}$ & +2 \\
\hline $\begin{array}{l}\text { Alpha Emitters - } \\
\text { Separations Areas }\end{array}$ & alpha & $(0.22$ to 2.9$) \times 10^{-6} / \mathrm{uc} / \mathrm{gm}$ & +2 \\
\hline Alpha Emitters - 300 Area & alpha. & $3.8 \times 10^{-7} / \mu \mathrm{c} / \mathrm{gn}$ & -- \\
\hline \multicolumn{4}{|c|}{$\begin{array}{l}\text { * The trend factor shows the } n-f o l d \text { increase ( }+ \text { ) or decrease ( }- \text { ) from last month, } \\
\text { where values of } n \text { less than } 2 \text { will not be noted. }\end{array}$} \\
\hline
\end{tabular}




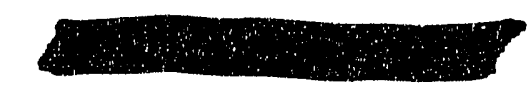

FDNANCTAL DERAREMMENII MONTLFTY RIMPORT DECEMMBER, 1955

The Commission and General Blectric reached an agreement in December as to the additional funds to be obligated to take care of operations through June 30, 1956, as well as those needed to complete projects currently in progress and to provide for FI 1956 projects. An amendment to the prime contract will provide for an increase of $\$ 36,000,000$ for HAPO and $\$ 19,500,000$ for KAPL, makding the total obligated to date $\$ 1,134,917,000$, of which $\$ 932,833,000$ will be HAPO's portion, and $\$ 202,084,000$ KAPL's portion.

In meetings with Radiological Sciences and ARC personnel it was determined that $\$ 13,000$ could be transferred from Biology Research to the Biophysics Research Program in FY 1956. This reduced the total additional funds requested for the Biophysics program.

Resumes of the following business reviews were completed and issued during December:

\section{Employee and Public Relations Department (excluding Cormunity and Health and Safety Sections)}

\section{Separations Section - Marrufacturing Department \\ Radiological Sciences Department}

Document HW-40608, entitled "Separations Section Essential Material Codes," was issued to revise and replace document HW-32730. The codes covered in this document are used to identify essential materials in consumption reports, thus preventing and possibility of compromising process flow sheets.

The mid-year budget review was completed on schedule and submitted to the AEC on December 9.

The first semester of the Business Training Program was concluded on December 17, with 36 students satisfactorily completing the course offered. These students will be eligible for the second semester's program.

At the request of the Hanford Operations Office of the AEC, several representatives of the Vitro Manufacturing Company and the AEC were conducted through the separations facilities. The purpose of the tour was to obtain background information on procedures, since the Vitro Company holds an AEC contract for the design of reactor-separations-fabrication plant cormplexes for use in foreign countries and one of the design objectives is to incorporate SS accountability controls which will reduce the possibility of diversion.

Notice of the AEC's program for the survey of SS materials for the calendar Jear 1956 was received December 8. This survey, No. 13, will include the verification of HAPO holdings of SS materials by type. A poxtion of this program is scheduled for the end of Jamary, and will continue at threemonths' intervals thereafter.

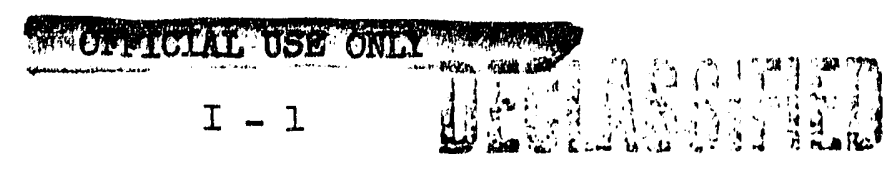


The adaption of numerous reports and procedures to the use of the 702 electronic data processing machine is contimaing. The conversion programs which are receiving priority at present include inventory controls, for the stores Sub-section; plant property records, for the Plant Accounting Section; and the exempt payroll, for the Personnel Accounting Section.

The first 702 processing of TBI ("trip beforo instability") linits, involving the calculation of the individual tube flows in all of the reactors, was carried out in November.

The anrmal physical inventories of stand-by material and motor vehicle and heavy mobile and construction equipment parts in the custody of the Stores Sub-Section was taken December $I_{4}$ and 15. The physical inventory of road materials in the custody of the Community and Transportation Sections was taken December 29.

The physical inventory of pile grade graphite in the custody of Stores SubSection was taken. December 27. Graphite is booked in the Special Materials inventory account, but was excluded when the other special materials were physically inventoried in August. An actual physical count of the graphite was not made since it was not considered desirable to move the material. Instead, the volume and wejght was calculated by the Field Survey Unit, Engineering Department, and test checks of the individual pallets of material was made by the Inventory Accounting Unit. Reconciliation of the survey to book values is in progress and a report covering results will be issued upon completion.

A study is being made to determine the most feasible method or methods to be used in distributing indirect construction costs incurred in connection with construction projects. The procedures involved and the effects produced by various methods of distribution are being analyzed in order to devise a system that will produce acceptable results from the standpoint of the property custodian as well as for accounting purposes.

Preparation of an annual AEC Fire Evaluation Report is in progress for complotion in January, 1956.

Information on the plant telephone system is being supplied to the Telephone Sub-section for its use in connection with evaluation of the plant telephone system.

An inventory of uninstalled equipment and operational spares of 300 Area. Manufacturing Department was started in December. Reconciliation of windowtype air conditioners was completed during the month, while reconciliation of ranges and refrigerators and establishment as cataloged plant continues.

A major effort is involved in the disposition of the equipment and materials to be removed under projects $C G-558$ and $C G-600$. Several million dollars worth of property is involved. One item, for example, $i$ is approximately 100 prums, motors and associated equipment, such as control panels, which will be moving into excess. The Property Management Unit is coordinating the planning for the orderly disposition of this property. The dollar value of the excess accounts can be expected to climb sharply as the full volume of this property begins to flow into the sales yard.

$$
I-2
$$


Twenty-setren appropriation requests totaling $\$ 560,990$ were investigated and processed during the month. Eighty-five requests for the disposal of property were investigated during the month.

Seven project proposals and one informal request representing an aggregate of \$1,031,700 were reviewod, approved and processed to the Comission during the month. After receipt and analysis of AEC directives and work authorities, twelve project authorizations were issued for a total of $\$ 1,794,850$.

The November "Summary of Disbursements," transmitted to the Commission through the Director of its Finance Division, showed net expenditures of $\$ 6,746,649$, summarized as follows:

Payrolls and payroll dechactions disbarsed

Materials (including orders placed on requirements contracts) and freight

Taxes and insurance

Subcontracts and agreements

Advances for traveling and living expense Miscellaneous

Gross Disbursements

\section{Less: Reverme}

Net Disbursements
$\$ 4458533$

2342142

110682

79387

70992

42078

$\$ 7 \quad 103 \quad 814$

357165

$\$ 746649$

Charges from BAPO against the overhead allowance in December were $\$ 7,849$, consisting of:

\begin{tabular}{lr} 
Conference expense (entextainment) & $\$ 2132$ \\
Expense in connection with transfer & \\
of employee to Washington, D. C., & \\
for position with AEC & 1590 \\
Travel and living expense variation & 1441 \\
Unreimbursed transfer expense & 413 \\
Unreimbursed travel and living expense & \\
$\begin{array}{l}\text { Special distribution of November, 1955 } \\
\text { issue of "General Electric Review" }\end{array}$ & 135 \\
$\begin{array}{l}\text { Cost of operating Company-owned } \\
\text { automobile }\end{array}$ & 76 \\
$\quad$ Total & $\$ 7849$ \\
\hline
\end{tabular}

Total attendance at meetings conducted by the Contract Reimbursements group to acquaint key personnel with the provisions of the proposed revised AEC.-COF prine contract exceeded 600 at the end of the month. Except for some employees of the Financial Department, for whom a meeting was held Jamary 5, and possible "wind-up" meetings for those unable to attend previous sessions, pre-signatory informational work had been completed on December 31. 
Detailed reports for the Financial Department appear on succeeding pages, as follows:

Sunmary of Cash Disbursements, Receipts and Advances

$I-5$

Auditing Section

$I-6$

Budgets and Measurements Section

$I-7$

Contract Cost Section

$I-8$ through I - 10

General Accounting Section

I - II through I - 19

Personnel Accounting Section

$I-20$ through I - 23

Procedures and Computing Section

I -24 through I - 29

Property Accounting Section

$I=30$ through I - 34

SS Accountability Section

I -35 through I -38

Personnol and Organization Statistics

$I=39$ through $I=40$ 
SUMMARI OF CASH DISEURSEMENMS,

RECEIPTS AND ADVANCES

A summary of cash disbursements and receipts (excluding advances of $\$ 7,200,000$ by the Atamic Bnergy Commission for December and $\$ 7,300,000$ for November) for the months of December and November, 1955, is shown below:

\section{Disbarsements}

Payrolls (not)

Materials and Freight

Payroll Taxes

Payments to Subcontractors

United States Savings Bonds

Pension Plan - Rmployees' Portion

Travel Advances to Employees

Group Insurance Premium

All Other

\begin{tabular}{|c|c|}
\hline December & November \\
\hline $\begin{array}{rr}\$ 3994267 \\
1634 & 551 \\
663 & 543 \\
632 & 992 \\
259 & 464 \\
171 & 263 \\
85 & 445 \\
10- \\
122023 \\
\end{array}$ & $\begin{array}{rrr}3479 & 023 \\
1868 & 654 \\
617 & 492 \\
552 & 875 \\
326 & 511 \\
& 0 \\
70 & 992 \\
3 & 178 \\
185 & 089 \\
\end{array}$ \\
\hline 7503548 & $7 \quad 103 \quad 814$ \\
\hline
\end{tabular}

\section{Receipts}

Rant .

Electricity

Hospital

Telephone

Sales to ARC Cost-type Contractors

Sundry Accounts Receivable

Refund of Travel Advances to Ermloyees

Bus Fares

Refunds from Vendors

Other

$$
\begin{array}{rr}
123435 & 110496 \\
72366 & 67.593 \\
55348 & 42177 \\
54183 & 57141 \\
41046 & 28465 \\
21647 & 26331 \\
11625 & 10041 \\
10012 & 9239 \\
4977 & 952 \\
4024 & 4730 \\
\hline 398663 & 357165 \\
\hline \$ 104885 & \$ 674649 \\
\hline
\end{array}
$$

\begin{tabular}{|c|c|}
\hline December & November \\
\hline $\begin{array}{r}\$ 2.538687 \\
20000 \\
\end{array}$ & $\begin{array}{r}\$ 2443572 \\
20000 \\
\end{array}$ \\
\hline$\$ 2558687$ & $\$ 2 \quad 463 \quad 572$ \\
\hline
\end{tabular}$$
\text { TotaI }
$$

Net Disbursements

Outstanding adrances as of Decenber 31, and November 30, 1955 were as follows:

Cash in Bank - Contract Accounts

Cash in Bank - Salary Accounts

$$
\text { Total }
$$


AUDITING SECTION

MONTHEY REPORT - DECEMBER 1955

At month-end reports were belng prepared for the following audits:

Telephone and Telegraph Administration

Overtime Administration

Fleld work was continued on the following audits:

Employment Administration and Practices

Management of Capital Assets

Reproduction and Engineering Files - Project Auxiliaries

Sub-Section

Motor Pool Operations

Product Cost

Classified Files

An audit of Accounts Receivable was started during the month.

Follow-ups were made to determine the extent of compliance with recomendations in reports of the followlag audits:

\author{
Stores Activities \\ Minor Construction Stores \\ Bank Account Reconciliations and Cash Controls \\ Good Neighbor Fund \\ Cost Accounting - Technology Cost
}

Three Information meetings for exempt employees were held during the month. Two meetings were also attended by non-exempt exployees; one included safety and security topics and the other a showing of the f1.lm, "Productivity: Key to Plenty".

During November the Auditing Section moved from the 703 Building to the Northwest corner of the 713 Building. During December the required partitions in the 713 Building were installed. The 14 auditors, formerly in one large office, are now in four small offices and working conditions are substantially improved. 


\section{General}

The first semester of the Business Training Program was successfully concluded on December 17. Th1rty-seven students were originally enrolled comprising four classes in Financial Analysis. One stident voluntarily dropped out prior to the mld-semester examination. The remaining thirtysix students satisfactorily met the requirements and will be irvited to continue with the Program next secester.

The sumary portion of the report "1955 at Hanford" was completed on schedule (December 22) and submitted to the Graphtes linit which holds responslbility for the completed work.

\section{Budgets}

The Midyear Eudget Review was completed on schedule and was submitted to HOO-AEC on December 9. Assistance is cont nulny to HOO-AEC on an informal basis to expedite their submission to washingion.

Durfing the morith, several contacts were made by BCO-AEC auditors with regard to their current audit of budgeting procedures. No critical observations are indicated at this time.

Schedule of due dates and buageting instructions for the FY 1358 and Revised FY 1957 budgets were prepired and sent :0 Cortract Cost Bection.

The Control Eudget, after five nontiss, remins withn $0.3 \%$ of aciual costs.

\section{Measurements}

Major efforts were devoted to completion of the annual report to the Ceneral Mnager. Transmittal was mede Decenter 28 with copies being sent by the Ceneral Manager to Vict President, Mccure. 
Employee and Public Relations Cost Unit

At the request of the Manager, Employee and Public Relations Department, a listIng of all facilities, utilities, and properties outside of Rickland proper (excluding plant areas) was prepared. Conmunity Section and Telephone subSection were the only organizations in this department responsible for such properties.

A varlance of approxdmately $\$ 36,000$ in net revenues exists between the budget prepared and subnjtted Ior Communty Section's operations by G.E. and a tentative I1gure established by the Atomf Energy Comission. The A.E.C. contemplated reductions in certain malntenance work whtch bave not as yet been definitely agreed to by all concerned. As soon as this question 1 s resolved we will either adjust our budget to conform, or furnisb Comunity Section management with monthly comparisons with respect to the A.E.C. Flgures as well as with our own budget.

Letters have been sent to other Washington cities asking for coples of their budgets for the coming year. Information thus recelved will be used in providing per capita cost comparisons in preparing the FY 1957 budget.

\section{Engineering Cost Unit}

Financial data in connection with business reviews has been compiled for the Design, Separations Technology and Pile Technology Sections. Formal reports covering the reviews of Separations Technology and Design sections were almost complete at the end of the month.

A quarterly report concerning research anc jevelorment costs and manpower will be 1ssued starting with the and quarter, FY 1956, for each research and developmert study pertaining to the Pile Technology and Separations Techrology Sections. This quarterly report will supplement the montbly cost report by presenting the major cost components for each study.

Effective with the week ending January 8, 1956, the standard liquidation rate of $\$ 50.00$ per engineering man-day for Design section will be increased to $\$ 54.00$ per engineering man-day. The increase in the standard rate has been caused by three primary factors: (I) present general salary increase and previous salary appra1sal increases; (2) an increase in the ratio of non-liquidators to ilquidators caused primarily by the transfer of several liquidating engineers to other General Electric installations. This causes a derrease in the man-days liquidated without a proportionate decrease in the cost per man-day; and (3) the cost of other services xequired by Design Sect1on have gradualiy increased. The direct services or charges to an end function or customer account are not reflected in this standard rate which includes only salarles and related overbeads for direct and indirect personnel.

Effectlve immediately, the costs incurred agr inst funds authorized to the Design Sectica for design of new construction projevis will be controlied through the use of design cost codes. These codes will replace the present design order controls now utilized. 


\section{Engineering Cost Ontt (Cont.)}

The upgrading program of Minor Construction Major Equipment is progressing satisfactorily. Of the 170 pieces received, twenty bave been assigned to Operations, 149 assigned to Minor Construction, and one water truck assigned to the A.E.C. equipment pool. Of the 149 pieces assigned to Minor Construction, 140 pieces have been placed in service and nine pleces are undergoing minor repair; this repair is belng delayed due to slow delivery of repair parts. Minor Construction has moved 136 pieces of old equipment to the Sales Yard and nine pieces are awalting Fidiological Sclences approval. The net book value of equipment transferred to the Sales Yard as of December 31, 1955, was $\$ 134,348$ (acquisition ralue $\$ 1,011,512$ and reserve $\$ 877,164)$.

On December 2, 1955, Mr. I. I. Bumett was made avallable to Procedures and Computing full time to assist in the planntag ard scheduling nesessary to plare Project Cost on IBM.

General and Consolidations Cost Untt

A meeting was held December 8, 1955 , with members of Gexeral Accounting, Procedures and Computing, and central Stores Sections in the attempt to clarify certain phases of the exment store order 1ssuss prosedure. Basic decisions were reached regauding responstblitty for vartous types ce correntions and adjustments which are experted to prorlie for a smoother prosedure.

The salary distrtbution form as it appears on the bark of weekly payroll time cards was revised and is suhsjuled for pleld ase dusing the later part of January. Included in the form revisior wlil ke a spare for standard overtime reason codes which will ultimately be used to provile a sompliation of overtime with standard reason by organizationa: compraert.

Considerable time bas been spert in straduling closing dates in order to meet A.E.C. deadilines as well. as to provide intormation to G.E. management at, earlier dates. Closer coordination between sos and omputing has been effective in eliminating delays, enabling us to meet estaclished jue dates. This bas been complicated by the recent holidsy weekeris.

Preparation of the Business Review for the Radiologtal Sicroes Department was completed and issued on Denember $=2,1355$.

Meetings were attended w th maragement of G.E. and A.E.C. to discuss the justiflcations for the proposed in rease of furds for the foon Reseam. Program. Due to some known terminations of sientists, it was determinea tiat, $\$ 13,000=0$ ald

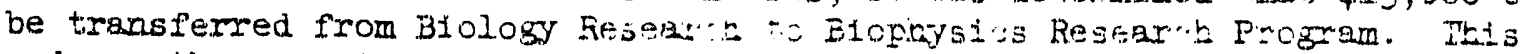

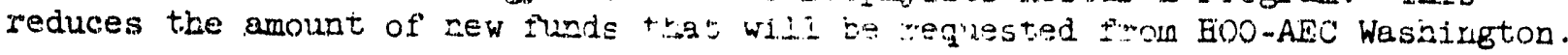

Manufacturing Cost Unit

By consolidating the equipment izems 1ato rajoz atagories during the month of November, it was possitie to iss:ie the Equipment, Not Ialluled in Construntion

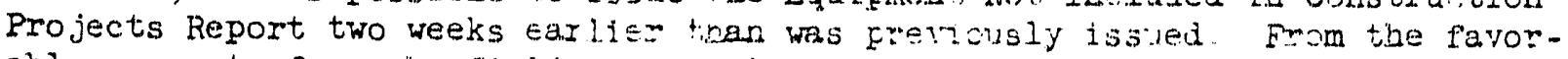
able comments from the fiela fersonel $1:$ afferars tinst trere is encugh detail to control costs on these aplipmert items. 
Menufecturing Cost Unit (Cont.)

Inttial information on personnel and equipment required for the FY 1957 budget: has been requested of area representatives in order to insure meeting required submission dates.

To further irprove the efflclency and cut down on the overtime required for the preparation of the 1958 and revlew of 1957 budgets for the Manufacturing Department, a peg board system will be used.

Month end physical 1nventories of essential materlals were witnessed at $100-\mathrm{K}$ and 200-E and W Areas on December 30, 1955. Reports are belng prepared on this activity.

A review of the essential materials used in the $\mathrm{BIPO}_{4}$ and TBP processes was made in an effort to determine the approximate excess of materials that will be left in inventory when these programs are completed. Since all TBP materials are usable in other processes, no excess is anticlpated. It is estimsted tisat $\mathrm{B}_{\mathrm{HO}} \mathrm{PO}_{4}$ excess materials will amount to approximately $\$ 68,000$ and these materials wlll be excessed as soon after the completion of this program as is practicable.

A new ledger control sheet was devised to be put into use in January to allow further use in the Manufacturing Cost Ledger of "cent-less accounting". This will also speed up posting operations and should save considerable time during month end closing.

A revlew of Maintepance Unit IME rates was made and rates were revised upward effective January 2, 1956. Reactor Section rates were increased from $100 \%$ to 105\% while Separations Section rates increased an average of $20 \%$. Separations section rates range from $120 \%$ to $150 \%$.

A spectal report on produstion and unit costs was prepared for the Manager of Manufacturing. This report included production and unit costs by plants for calendar years 1953, 1954, and 1955. Calendar year 1955 included 11 months actual with December estimated. A similar report was prepared Por the Manager of Finance covering colendar years 1954 and 1955, 1 sing 11 morths actual and the December bogey. 
GENERAL ACCOUNTING SECTION

MONIHIY REPORT-DECEMBER, 1955

\section{ACCOUNTIS PAYABLE UNIT}

The volume of vouchers processed during the month remained at an average level, 4,082 , amounting to $\$ 3,183,048$, being recorded. A recap of the overall work volume for the calendar year 1955 is listed below:

\author{
Vouchers recorded \\ Checks issued \\ Freight bills paid \\ Purchase orders recelved \\ Cash discount earned. \\ Nurnber of employees
}

\begin{tabular}{rrr}
1955 & Average per Month \\
\cline { 2 - 3 } 52162 & 4347 \\
32842 & 2737 \\
18457 & 1538 \\
27787 & 2315 \\
$\$ 87006$ & $\$ 7250$. \\
& & 23.6
\end{tabular}

Active contracts handled by Accounts Payable, excluding requirements contracts, numbered 41 and contract comitinents at month-end amounted to. $\$ 802,710$. Payments on these contracts during December were $\$ 83,963$, of which $\$ 18,898$ applied to contracts having no fixed comitments.

Included in the comitment figure of $\$ 802,710$ is $\$ 642,712$ applicable to the followling four contracts: International Business Machines Corporation, No. SO-2, \$279,862; The Lurmus Company, No. S0-5, \$223,330; and General. Chemical Division of Allied Chemical \& Dye Corporation, No. G-316 and No.G-346, $\$ 12,500$ and $\$ 127,020$, respectively.

Requirements contract orders placed during December numbered 13 in the amount of $\$ 499,572$ and comitments at month-end totaled $\$ 978,108$. Payments under requirements contracts for the month were $\$ 546,376$.

Following are statistics pertaining to Accounts Payable:

Accounts Payable:

Balance at beginning of month.

Vouchers entered

Cash receipts

Less: Vouchers Paid

Belance at end of month

Number of vouchers recorded

Number of checks issued

Number of freight bilis paid

Amount of freight bills paid

Number of purchase orders received.

Amount of purchase orders received

Amount of casn discount earned

\begin{tabular}{|c|c|}
\hline December & November \\
\hline $\begin{array}{r}500783 \\
3183048 \\
4 \quad 976 \\
\end{array}$ & $\begin{array}{rrr}\$ & 704 & 121 \\
3093938 \\
\end{array}$ \\
\hline $\begin{array}{rrr}3 & 688 & 807 \\
3 & 249 & 817 \\
\end{array}$ & $\begin{array}{lll}3 & 799 & 011 \\
3 & 298 & 228 \\
\end{array}$ \\
\hline$\$ 438990$ & $\$ 500783$ \\
\hline 4082 & 4294 \\
\hline 2496 & 2569 \\
\hline $\begin{array}{r}1683 \\
\$ 317676\end{array}$ & $\begin{array}{r}1 \\
150\end{array}$ \\
\hline $\begin{array}{r}\$ 317616 \\
2080\end{array}$ & 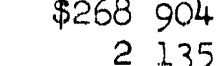 \\
\hline $\begin{array}{rrr}850 & 573 \\
\$ 9 & 1.14\end{array}$ & $\begin{array}{rr}\$ 1520109 \\
\$ 8502\end{array}$ \\
\hline
\end{tabular}


A reconciliation of telephone rent cards maintained by the Accounts Recelvable Unit and equipment records maintained by Telephone Unit was accomplished during the month of December. Two retroactive adjustments will be given subscribers due to discrepancies discovered during the course of the reconclilation. The overall results of the reconclilation indicated that extreme care has been exercised in the recording and malntenonce of the subject records.

In accordance with the routine established for controlling revenue from private bost moorage sites, 76 memorandum billings were issued to holders of permits on December 1 . These billings advised permit bolders that rentals for calendar year 1956 were due. As of December 31,40 permittees had remitted the amounts due, while 13 additlonal payments were received by January 5 .

As recommended in an audit of cash controls by GE's Auditing Section, new cash recelpt forms were obtained for use in accounting for valuables deposited with the admittance clerk by patients at Kadlec Hospital. The utilization of this special form will eliminate the use of the EAPO standard cash recelpt and maise the procedure conform to standard hospital practice. The valuables deposited are 1temized on the envelopes which contain them, and the receipt and the eavelope bear the same number.

With a letter dated December 15, 1955, the Comptroller of Federal Housing Administration, Washington, D.C., forwarded a United States Treasury check In the amount of $\$ 9,150$, representing land-use rental and municipal-type service charges on leases between General Electric Company and Bauer-Day, Inc., for the period from July 1, 1955 to September 30, 1955. As requested in this letter, a statement of charges for the period from October 1, 1955 to January 1, 1956, was sent to the FHA Comptroller.

An audit of all categories of Accounts Receivable was started during the month by personnel of GE's Auditing Section.

Eviction notices vere delivered on December 8 to 22 tenants occupying Government housias and seven dormitory tenants for nonpayment of November rent. Except for two dormitory tenants who vacated the premises, satisfactory arrangements or rent payments were recelved by Decenber 13 , the date specified in the eviction notices.

The gross accounts receivable balsuce at December 31 amounted to $\$ 319,399$, an Increase of $\$ 1,979$ over the November 30 balance. This change results from increases of $\$ 27,006$ and $\$ 5,329$, respectively, in the electricity and AEC Cost-type Contractors accounts, largely offset by decreases totaling $\$ 31,337$ in the other major recelvable accounts. Explanations of the more significant changes in balances are given below:

Electricity - Charges booked for electrical consumption was $\$ 99,990$, as compared With $\$ 67,371$ for November. This came about because meter routes comprising residences consuming electricity for beating purposes were read and billed during the month.

$$
I-12
$$


ACCOUNIS RECEIVABLE UNIT (Continued)

AEC Cost-type Contractors - A billing to the University of California Radiation Labaratory of $\$ 32,585$ accounts for the increased balance in this account. It is sigaificant to note that of the outstanding balance, $\$ 50,596$, in this account at December 31, only one account, amounting to $\$ 3,947$, is 90 days old, and two accounts, amounting to $\$ 275$, are 30 oays old. All other accounts represent current balances.

Kadlec Hospital. - The decrease reflected in this account results from reduced sales and an excellent collection experience. A decrease in the adult patient day census from 49.2 in November to 42.5 in December substantiates the reduction in billings.

Rent - Through accelerated effort a reduction amounting to $\$ 11,306$ was realized in delinquent commercial facilities rent. Payments for delinquent rentals were received from Bauer-Day Housing Project, Rizhland Village, Inc., and Kidwell Automotive Service. Except for the American Legion account, which is involved in a Federal reorganization case, continued collection efforts should reflect further reductions in this account.

Disconnect notices were mailed to 173 telephone subscribers and the service of 18 subscribers was suspended due to nonpayment of bills. During the month 385 delinquent notices and 96 final notices were mailed to electricity customers, while the service of four electricity customers was suspended due to nonpayment of bills.

Accounts receivable statistics are sumarized below:

\begin{tabular}{|c|c|c|c|c|c|}
\hline Account & $\begin{array}{l}\text { Balance } \\
11-30-55\end{array}$ & $\begin{array}{c}\text { Net } \\
\text { Charges }\end{array}$ & $\begin{array}{l}\text { Collec -. } \\
\text { tions } \\
\end{array}$ & $\begin{array}{r}\text { Balance } \\
12-31-55 \\
\end{array}$ & $\begin{array}{l}\text { Active } \\
\text { Accounts }\end{array}$ \\
\hline adlec Hospital & & & & & \\
\hline $\begin{array}{l}\text { Active } \\
\text { Collection Agencies }\end{array}$ & $\$ 95394$ & $\$ 44417$ & $\$ 61742$ & $\$ 78069$ & 1630 \\
\hline (88 accounts & 8077 & 303 & 18 & 8362 & \\
\hline Electrleity & 28628 & 99990 & 72984 & 55634 & 3950 \\
\hline Telephone & 33535 & 53312 & 55591 & 31256 & 6662 \\
\hline $\begin{array}{ll}\text { Sundry: } & \text { Active } \\
& \text { Collection Agencies }\end{array}$ & 36067 & 20478 & 21509 & 35036 & 399 \\
\hline (150 accounts $-a)$ & 6745 & 2125 & 2.20 & 8650 & \\
\hline AEC Cost-Type Contractors & 45267 & 46375 & 41046 & 50596 & 23 \\
\hline $\begin{array}{l}\text { Rents } \\
\text { Equipnent Sales to }\end{array}$ & 42811 & 380793 & 392811 & 30793 & 6733 \\
\hline Facilities ( 1 account) & 19544 & & 349 & 19195 & \\
\hline $\begin{array}{l}\text { Safety Shoes } \\
\text { Loans to Employees }\end{array}$ & 1062 & 2753 & $2 \longdiv { 4 7 4 }$ & 1341 & 302 \\
\hline (2 accounts) & 290 & 200 & 23 & 467 & \\
\hline Sub-Total & 317420 & $\$ 650746$ & $\$ 648 \quad 767$ & 319399 & 19699 \\
\hline Reserve for Bad Debte & $(34 \quad 12 \cdot 2)$ & & & $\left(\begin{array}{ll}35 & 081\end{array}\right)$ & \\
\hline General Ledger Balance & $\$ 283298$ & & & $\$ 284 \quad 318$ & \\
\hline
\end{tabular}

(a-Includes all utility and rental accounts. 


\section{ADAINISTRATIVE PLANIIING}

A total of 18 new or revised arganization and policy guides were distributed during December. Of these, five were instruction or policy guides and 13 were arganization guldes. In addition, seven OPGs were in the process of duplication ar distribution at the end of the month. The five instruction guldes are as follows:

08.2

"Telegraphic Messages"

This policy guide was revised to eliminate the requirement

that the telegram form must be signed by an exempt employee.

14.7

"Safety Shoe Parchase"

This policy guide was relssued to more clearly state HAPO policy with regard to safety shoes and to bring up-to-date the procedure for obtalning them.

14.11 "Reporting and Investigating Accidents"

This new instruction takes the place of Accident Prevention Bulletin A-I in describing the various types of injurles and accidents and requiring that they be reported and investigated.

15.1.3 "Security Clearances and Identification" This instruction was revised to incorporate some restrictions on the use of I clearances and to eliminate the spectal approval former ly required for entrance to the 303 Exclusion Area.

I5.4 "Non-Defense Information"

This new instruction outlines the conditions under which information may be marked "Official Use Only," "Strictly Private," ar with other designations limiting dissemination.

One Company Announcement was prepared which announced the establishment of an Operations Research and Synthesis Section and the appointment of Carl A. Bennett as 1 ts Manager.

A report was made sumarizing AEC transmittals received within HAPO during November.

A summary of organization and policy guides issued during November was sent to all section and department managers.

One OfPice Letter was processed: No. 216, Christmas Day and New Year's Day Hol.1days.

A total of 462 extra copies of OI Gs were distributed and one complete book compiled. 


\section{ADMINISTRATIVE PLANNIIGG (Continued)}

The following arganization and policy guides are currently being reviewed or revised:

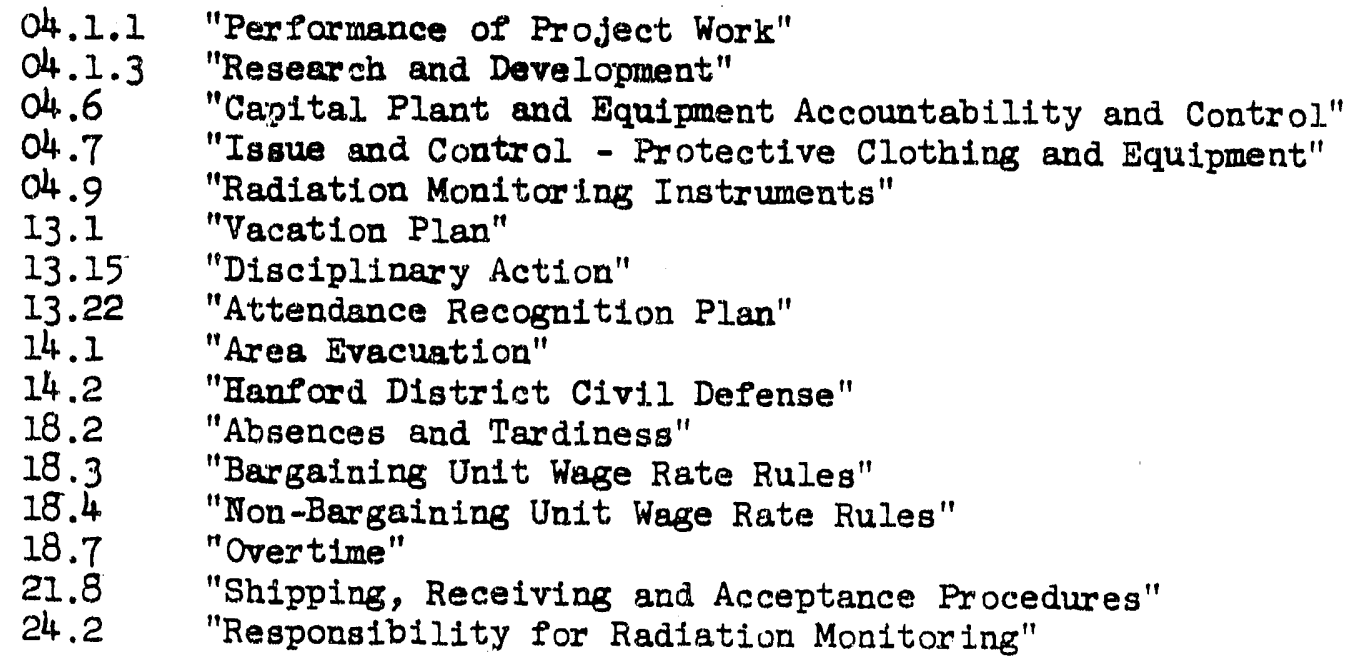

The following new organization and policy guides are being circulated for review and approval:

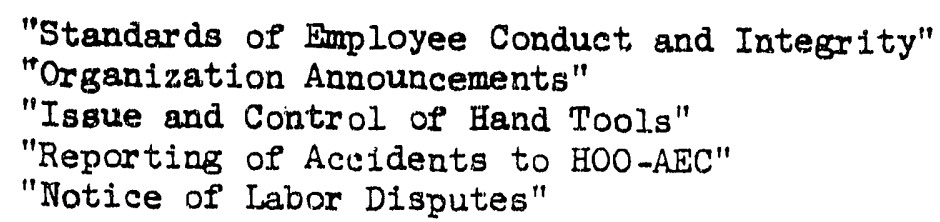

\section{CONIRACI REIMBURSEMENTS}

Total attendance at meetings conducted by the Contract Reimbursements. group to inform key personnel of the provisions of the proposed revised AEC-GE prime contract exceeded 600 at the end of December. Except for some employees of the Financial Department, for whom a meeting is saheduled for January 5, and possible "wind-up" meetings to cover those unable to be present at previous sessions, pre-signatory informational work has been completed.

A major assignment for the Contract Reimbursements group has been that of obtaining information and drafting letters for consideration of the joint AEC-GE working committee which has been charged with the responsibility of preparing documents to implement changes in operating procedures which wil] result when the revised prime contract goes into effect.

The Comission's approvals for reimbursement of expenditures for the following purposes were received in December:

Payment of expenses in connection with real estate transactions of $G E$ employees transferred to HAPO. (This brings current practices into line with those agreed upon between the $\mathrm{AEC}$ and $\mathrm{GE}$ for Appendix $B$ to the proposed revised prime contract.)

$$
I-15
$$


COMTRACT RETMBURSEMGEMS (Continued)

Settlement by The Travellers' Insurance Company of a sult (Traum vi. GE) In connection with automobile accident.

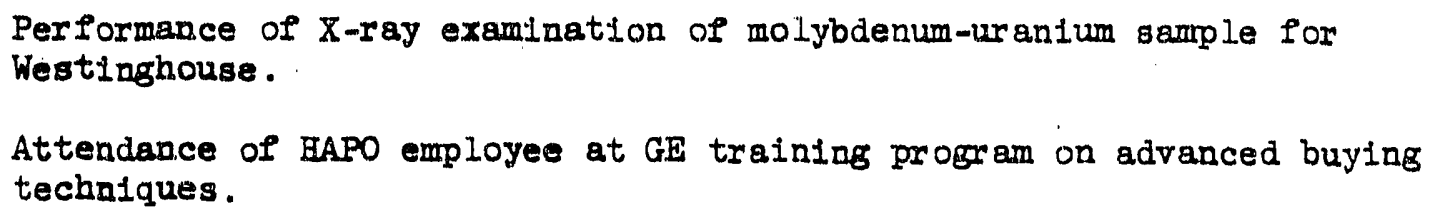

Rental of school facilities for employee meetings for the calendar year 1956.

Payment of moving expenses of HAPO employee transferred from New Jersey to Richland, originally authorized in 1948 but not effected at that time.

Costs not to exceed $\$ 16,000$ for appralsal of plant and community telephone system.

\section{Membership in American Society for Industrial Security ( $\$ 25.00$ per year).}

Feasibility program on magnetic multiple point protection control ("Assistance to Hanford" project).

The Camission also approved a new schedule of increased room rentals for Kadlec Hospital, which went into effect as of January 1, 1956. It declined to approve as reimbursable the proposed payment of college registration fees of $\$ 2.00$ per course for participants in the technician training program who wished to receive college credit for scholestic work completed in that program. It also declined to approve for reimbursement the living expenses of newly-hired employees of section manager or higher level and high caliber technical men, and of their families, while awaiting housing and the arrival of household goods.

Three reimbursement matters submitted to the AEC had not been settled at the end of December. These were (1) the expense involved in sending HAPO representatives to the General Electric Management Research and Developinent Institute at Crotonville, N. Y., for advanced management courses, (2) the cost of advertisements in local newspapers to publicize the advantages of working for General Electric at HAPO, and (3) the cost of periodical physical examinations for inspectors located in distant cities.

The November "Summary of Disbursements," transmitted to the Commission through the Director of Its Finance Division, showed net expenditures of $\$ 6,746,649$, sumarized on the following page. 


\section{CONIRACT REIMBURSEMEINTS (Continued)}

Payrolls and payroll deductions disbursed

Materials (including orders placed on requirements contracts) and freight

Taxes and insurance

Subcontracts and arreements

Advances for traveling and living expense

Miscellaneous

$$
\begin{array}{rrr}
\$ 4 \quad 458 & 533 \\
2 \quad 342 & 142 \\
110 & 682 \\
79 & 387 \\
70 & 992 \\
42 & 078 \\
\hline 7 \quad 103 \quad 814 \\
\quad 357 \quad 165 \\
\hline 6 \quad 746 \quad 649 \\
\hline \hline
\end{array}
$$

Gross Disbursements

Less: Revenue

Net Disbursements

Charges from HAPO against the overhead allowance in December were $\$ 7,849$, consisting of:

\section{Conference expense (entertainment)}

Expense in connection with transfer of employee to

$\$ 2132$

Washington, D.C., for position with AEC

Travel and living expense variation

Unreimbursed transfer expense

Unreimbursed travel and living expense

Special distribution of November, 1955 issue of

"General Electric Review"

Cost of operating company-owned automobile

2062

1590

1441

413

$\begin{array}{r}135 \\ 76 \\ \hline 7849 \\ \hline\end{array}$

The Contract Reimbursements group handled 16 inquiries relating to reimbursement problems during December, nine of which originated in departments other than Financial.

\section{GENERAL BOOKS UNIT}

The amount of additional funds required for operations through June 30, 1956 as well as those needed to complete projects currently in process and to provide Punds for FY.-1956 projects was agreed upon between HAPO and the Comission. An amendment to the prime contract will provide for total funds to be obligated in the amount af $\$ 1,134,917,000$, of whiwh $\$ 932,833,000$ will be obligated to EAPO and $\$ 202,084,000$ to KAPL. The ese totals represent an increase of $\$ 36,000,000$ in funds for HAPO and $\$ 19,500,000$ for KAPI.

During December a slimmary of cash expenditures for FY-1955 and estimated cash expenditures for FY-1956 and FY-1957, detailed by operating program, was furnished to F. W. Magulre of Schenectady for use in arriving at a "net sales billed" figure to be used in comparative statements for HAPO, KAPL and ANP which are being prepared at the request of $F$. $K$. McCune. 
Revision of the travel and living expense variation budget for FY-1956 is nearlag completion and will be reflected in the January 1956 report, "Sumonary of Travel and Living Expenses." The orlginal budget was based on the assumption that the new contract, which provides for a $\$ 10.00$ per diem allowance, would be signed and made effective September 1, 1955. The revisions to be incorporated in the January report will be based on a $\$ 9.00$ per diem rate for the full fiscal year and will be adjusted downward at such time as the new contract is sigaed and made effective.

Travel and living expenses reports processed in December totaled 310, representing a gross expenditure of $\$ 78,626$, as compared to 311 reports in November for a total of $\$ 77,210$. These may be classified as follows:

Travel and Living Brpenses

December November

BAPO Business

Billed to Others

Transfer Expense of Employee Assigned to AEC, Washington

Civilian Application Document Declassification Team (Undistributed Cost)

Travel Expense Not Reimbursable

Conference Expense

Cost of Company-owned Cars

Other

\begin{tabular}{rrr}
$\$ 69993$ & $\$ 66735$ \\
2416 & 8817 \\
2062 & $-0-$ \\
1534 & $-0-$ \\
413 & 77 \\
2132 & 1467 \\
76 & 4 \\
$-0-$ & $-\$ 77 \quad 120$ \\
\hline 78626 &
\end{tabular}

Other statistics for the month of December, along with the previous month's figures, are given on the following page.

$$
I-18
$$


GFIEERAL BOOKS UNIT (Continued)

\begin{tabular}{|c|c|c|}
\hline & December & November \\
\hline \multicolumn{3}{|l|}{ Adrances from AEC } \\
\hline $\begin{array}{l}\text { Balance at beginning of month } \\
\text { Advances recelved from } \mathrm{AEC} \\
\text { Other cash receipts }\end{array}$ & $\begin{array}{r}\$ 2463572 \\
7200000 \\
\quad 398663 \\
10062235\end{array}$ & 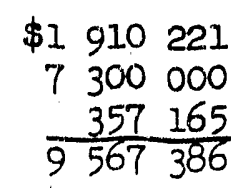 \\
\hline Less disbursements & 7503548 & 7103814 \\
\hline Balance at end of month & $\$ \underline{2558687}$ & $\$ 2463 \quad 572$ \\
\hline Adrances requested for subsequent month & $\$ 6050000$ & $\$ 7200000$ \\
\hline $\begin{array}{l}\text { Travel and Living Expenses } \\
\text { Travel Advances to employees } \\
\text { Balance at beginning of month } \\
\text { Advanced to employees }\end{array}$ & $\begin{array}{r}77332 \\
85445 \\
162777 \\
\end{array}$ & $\begin{array}{r}93501 \\
70992 \\
164 \quad 493 \\
\end{array}$ \\
\hline $\begin{array}{l}\text { Less: } \\
\text { Travel, living, and conference expenses } \\
\text { reported by employees } \\
\text { Cash refunded by employees }\end{array}$ & $\begin{array}{r}78626 \\
11625 \\
90 \quad 251 \\
\end{array}$ & $\begin{array}{rr}77 & 120 \\
10 & 041 \\
87 & 161 \\
\end{array}$ \\
\hline Balance at end of month & $\$ 72 \quad 526$ & $\$ 77 \quad 332$ \\
\hline $\begin{array}{l}\text { Outstanding Travel Advances to Bmployees } \\
\text { Current } \\
\text { Outstanding over } 30 \text { days }\end{array}$ & $\begin{array}{r}58815 \\
13 \quad 711 \\
\end{array}$ & $\begin{array}{r}\$ 62360 \\
14972 \\
\end{array}$ \\
\hline Total & $\$ 72526$ & $\$ 77 \quad 332$ \\
\hline Number of expense reports submitted by employees & 310 & \\
\hline
\end{tabular}


The practice of billing Labor Unions for expenses incurred in deducting membership dues from salary checks has been discontinued. The number of employees who had participated in the check off system Increased during 1955 by 292 to a total of 2,331 .

Pension refunds were made to exempt employees on December 6, 1955, and to nonexempt; employees on November 18, 1955. This refund was a result of the reduction in employee contribution rate as provided by the revised Pension Plan. The lower rate was to be effective August 15, 1955, but was not put into effect locally until after ratification of the Labor Agreements and receipt of refimursement authorization from the A. E. C.

Effective January 1, 1956, deductions from employee's salary checks for pension contrim butions will be at the rate of $1 \%$ until the employee has earned $\$ 4200$ subject to pension contributions during the year; thereafter, a rate of $4 \%$ will be applied to the excess over $\$ 4200$ of annual compensation subject to contributions. The method of contribution in effect prior to January 1 provided for deduct 1 on each pay period of $1 \%$ of earnings up to $\$ 80.5 .2$ per week, or $\$ 350$ per month; and $4 \%$ of the excess over this amount.

Office letter No. 216 was issued outlining the Plant clostag on Christraas and New Year's . days, and instructions for completing time cards for the weeks sontaining the holidays.

One new time recorder was installed in 760 bullding. At the present time, there are 47 time recorders in use in the 300,700 , and 1100 areas.

Reimbursement Authorization No. 254 was received from the Atcmid Energy Comission. This authorization revises Relmbursement Authorization No. 250 by liberalizing the policy to be applied. when absences occur prior to or after a holiday.

A new report entitled "Overiime Paid Report" was developed in sooperation with the Union Relations Section and Procedures and Compiding Section. This report will show the overtime hours paid accumulated for the year plus any carmyover from the previous year for each employee in the Maintenance groups. The purpose of the repurt, is to assist in an equitable distribution of overtime among employees. Accumulation of hours willi start with January 1, 1956, with the first report scheduied for issiae diring january.

The weekly time card format was revised and an order placsd for the revised cards. The revision was made to provide space for supervisors to indiade whetter personal illness absences are due to personal injury or hospitalization, and space to indicate overtime bours refused by the employee. Payments during personal iliness absences may be excluded from earnings for income tax purposes if certain condjtions are met. Refised overtime hours are necessary for preparation of a new cverture control report th elpervision explained above.

Questionaires were sent to all employees who had receiral a pursucal illnes: absence payment during 1955. The employees were asked to indicate if they were hospitalized during their absence, or if the abseace was the result of a personal-in,jury. This information is necessary to calculste earnings excludable for income tax purposes. The revised weekly time card will make this qusry unnecessary in the fintiure.

As of December 31, 1955, 168 Anrity Cartificates bave been allivered to employees who transferred from the duPont Company to the General Electr.; Company at; Hanford on September 1, 1946. These certificates are iesied hy the connoctacut General Life Insurance Company and are delivered to emplnyees on tie 15 th snnivgreary of their dupont hiring date. 
Personnel Accounting Section

Monthly Report - December 1955 (Continued)

Income taxes, and social security taxes where applicable, on the value of Safety Awards were deducted from salary checks of Conmulty Section employses. The Safety Awards were received by these employees during December.

A revised monthly salary check was designed and an order placed for the revised checks. The revision is part of the system being developed by Procedures and Payroll personne.l in conjuaction with the conversion of the Monthly Payroll preparation to IBM equipment. 
STATISTICS

Personnel Accounting Section

Number of HAPO Employees

Changes During Month

Employees on payroll at beginning of month

Additions and transfers in

Removals and transfers out

Transfers from weekly to monthly payroll

Transfers from monthly to weekly payroll

Employees on payroll at end of month \begin{tabular}{lll} 
Total & $\begin{array}{l}\text { Monthly } \\
\text { Payroll }\end{array}$ & $\begin{array}{l}\text { Weekly } \\
\text { Payroll }\end{array}$ \\
\hline
\end{tabular}

9353

100

(44)

2276

11

(6)

12

(1)
7077

89

$(38)$

(12)

$\underline{1117}$

9409

December

\section{Overtime Payments During Month Weekly Paid Employees Monthily Paid Employees Total}

\begin{tabular}{|c|c|}
\hline Vumber & \\
\hline$\frac{9022}{902}$ & $\$ \frac{A m o u n t}{174225}$ \\
\hline 429 & $32 \quad 236$ \\
\hline 9451 & $\$ 20046$ \\
\hline
\end{tabular}

December

$\$ \overline{833513}$

3239605

1391232

\$5 464350 a)
November

\begin{tabular}{ll} 
Number & $\begin{array}{c}\text { Ainount } \\
7495\end{array}$ \\
$\begin{array}{l}\$ 171707-b) \\
463\end{array}$ & 43576 \\
7958 & $\$ 215283$ \\
\hline
\end{tabular}

Gross Payroll Paid During Month
Engineering
Manufacturing
Other
$\quad$ Total

(a- Payments to weekly paid employees are for five weok periods.

(b- Payments to weekly naid employees are for four week ner lods.

\author{
Employee Benefit Plans \\ Participation in Benefit \\ Plans at Month Erd \\ Pension PJan \\ Insurance Plan \\ Personal coverage \\ Dependent coverage \\ U. S. Savings Eonds \\ Stock Bonus Plan \\ Savings Plan \\ Eoth Pians
}

$\frac{\text { Number Participating }}{\text { December }}$

$\frac{\text { Percent Pnticipation }}{\text { December }}$

$98.7 \%$

$93.6 \%$

3302

8245

3470

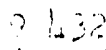

20.6

99.6

674.2

6705

5012

$1 \mathrm{OL}_{4}$

5000

1051

$5 \quad 487$

5.483

53.2
11.1
58.3

53.5

11.2

58.6 
Pension Plan

Number retired

Number who became eligible for participation

Number who applied for participation

Number who elected not to participate

Replies not received

Insurance Plan - Number of Claim Payments

Employee Ljfe Insurance

Employee accident arid health insurance

Dependent accident and health insurance

Total

Good Neghbor Fund

Number particfpating

Percent of participation

\begin{tabular}{rr} 
December & November \\
\cline { 2 - 2 } 7 & 2 \\
77 & 108 \\
75 & 106 \\
2 & 2 \\
- & -
\end{tabular}

Suggestion Awards

Number of awards

Total amount of awards

166

$\$ 4 \quad 150$

$\begin{array}{r}4 \\ 513 \\ 480 \\ \hline 997 \\ \hline\end{array}$

6589

$70.0 \%$

6568

$70.2 \%$

Preferential Rates

Number (eliminated) or added

(2)

Number currently in effect

533

(1)

535

Number of Military Allowance Payments 


\section{GEIERAL}

Payroll processiug for the 3-day Thanksgiving hollday week was completed in record time. Checks and earnings statements were completed by 3:00 p.m. Tuesday, November 22:

An improved SCRJPT system has been completed and is being used. The new system provides for automatic address modification, the assembly of profgrams which exceed the memory capacity of the 702, and improvements and additions to the subroutine library. For certiain types of problems, the address modification feature will reduce programing time by 15-20 percent.

The tralning program has proven extremely successful. In the last two months, five new groups of people have been trained in programing for the 702. Each group has been able to begin writing productive programs after two weeks of basic training.

Retro salary, retro accrual reversals and pension refunds were processed during the month of November. 100-D temperature maps were key-punched and verified, and 100-F temperature maps are being key-punched. Controls were set up on Property Accountabil1ty in the Scheduling Unit. On December lst, a trip was made to 100-B Area to consolidate data recelved for panellit reports.

Systems work has been started on exempt payroll conversion to the 702. This is the first system to be installed on the 702 in which the system will be designed specif1cally to take advantage of the logical ability of the 702 .

The Pirst 702 processing of TBI limits was carried out fin November. All reactors are included in the procedure, which has been set up on a weekly schedule.

\section{PROCEDURAL ANALYSIS}

Forms Control reviewed 429 orders during December covering 1,071,065 forms; 28 orders, amounting to 73,800 forms, were rejected; 71 new forms were designed; 12 forms were obsoleted.

The study of reports presently being prepared for the Monthly Payroll is completed, except for formallzation. A general Plow chart of conversion to EDPM was prepared End an estimate of conversion cost and hours of labor was sent to Personnel Accounting. A schedule of the approximate dates on which reports are due out of computing, which involves cleared operators only, has been provided for the information of Computins, Montbly Payroll, and Salary Administration.

Conversion of bond purehases to EDPM was completed in December, in time to permit release of the 604 computer frow rental as per schedule.

Weekly payroll EDPM procedures were revised to correct improper updating of year-todate hours vorked. A new routine was developed, programined and assembled to accouplish this adjustment and to provide acclirate permanent records. A routine to calculate extended hours of vacation pay for 1956 was developed, programed and key-punched during 
December. Changes to Pass 2 of Weekly Payroll were made to wake the year-end conversion which dropped year-to-date figures and no master records.

The loglc and program changes necessary to prepare a voucher roll for inclusion of year-to-date payments made before December 31, 1955, were completed.

A routine was developed and programmed to produce a card indicating participation in the varlous company benefit plans as of the end of 1955.

Flow charting and programing of preparation of W-2 forms was undertaken in December and is approximateliy $80 \%$ complete at month's end.

The conversion to EIPM of Stores Weekly Cost Report and Monthly Sunmary of Issues Report was completed during December. With the completion of Stores Monthly Cost Reports, now in the process of debugeing, the Stores conversion will be accomplished.

Durlng the month of December, the conversion of the Office Machine Monthly Sumary procedure to the 702 was completed and placed in production. The complete summarles for the montins of October and November were run in parallel to those run on the EAM equipment and successfully checked out. Following the normal cut-off date in December, the regular swary was accomplished, using EDPM equipment, including the updating of all master records and the production of the required seven monthly reports for personnel in Accounting, Office Machines and Stores.

The revision in the internal operating procedures of the section, 1.e., Control, Key Punch and operations, were essentially completed at month's end.

A special emergency report of the holdings of material from Classified files by the Yellow File was prepared on short notice. The report was required to assist in the AEC declassification review for release of information for use by private industry. The annual report of Research and Development type documents was prepared as of the elose of business December 30th. As a by-product of this report, a large volume of cards was edited and corrected for certain types of invalid conditions.

Testing of the principal pass of the Classified Files EDPM program is about $60 \%$ couplete and programing of all passes is $90 \%$ complete. Logic of all passes required for conversion is $100 \%$ complete. Logic and related work for the pass to update the main record file remains to be done, and while not necessary for conversion of the system, it is required to maintain the EDPM system.

Work was begun on the problem of complete conversion of Accounting routines to a machine basis. A study group, consisting of one representative each from Procedures and Computing, Contract Cost and Genersl Accounting, was appointed to pursue the problem. The study group submitted a progress report at the end of December as the initial step in the appraisal of this conversion.

The over-all logic for the programing of property accountability operations is $90 \%$ completed. Progress has been made in charting pass 1, which is a daily routine for updating master records and producing custodian control cards for new and revised records. A "type of entry" code has been devised for use in conjunction with the "operation" code to identify the required reporting categories of montbly activity. A listing of machine tool records showlng nomenclature, along with description codes, has provided a basis for clearing up errors and inconsistencles which inust be eliminated before the records will meet EDPM processing requirements. 
Procedures were revised for purchase order analysis. 407 and 101 panels and test decks were changed to conform to the change in purchase order number prefixes which became effective on December 1.

\section{RECORDS OPERATIONS}

Quantity of recorils received, processed and stored:

Employefe and Public Relations Department

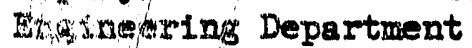

Finariclal Dapartment

Manufacturing Department

Radiologlcal Sclences Department

$\begin{array}{rrcc}42 & \text { Standard } & \text { Storage } & \text { Cartons } \\ 41 & " & " & " 1 \\ 182 & " & " & " \\ 89 & " & " & " \\ \frac{9}{363} & & & \end{array}$

Records Retention and D1sposal Schedule Number 222, "Manufacturing Radiation Monitoring Records", consisting of flfty ladividual records was developed and submitted for internal approvel. Records Retention and Disposal Schedule Nurnber 220, "Reactor Process Records", consisting of twenty-six individual records and Records Retration and Disposal Schedule Number 221, "Manufacturing Maintenance Records", consisting of thirty-four ladividual records were submitted to the Atomic Energy Comission for approval.

Forty-one reels of microfilm, consisting of 130,091 images, were completed during the month. A total of 245 reels consisting of 970,353 images have been completed by Recordak Corporation to date.

\section{NOMIORICAL ARALYSIS}

An analyst was transferred from the Procedural Analysis Unit to the Numerical Analysis Unit, effective December 1955.

Plans are being made for the conversion of Special Request Exposure calculations to the 702 . These calculations are made routinely to assist personnel in the Englneering Department in preparing reports on special materials submitted for irradiation in HAPO reactors. Exposure accounting will now be made on a slug-by. slug basis, rather tban on a tube-by-tube basis. In addition, the report format will be altered so that the 702 report can serve both as a final report to the irradiation requestor and as a woris sheet for entering new data manually.

Programatng of the Power \& Exposure Study ealculations has been completed. The program showld be running on a routine basis by the end of January. Correction curves for the reactor operating limits (TBI) calculations, now being run routinely, were fit and programed into the system.

As of month end, 76 temperature tapes have been recelved and 70 processed in connection with the KE experiment. The control panels for this job have been rewired for the 605 calculator, in order to make the 604 calculator available "or release. A sumary listing of each temperature map processed under the experinent was made for the Operations Research Section, which is undertaking an analysis of the experiment. Because the experiment will extend well into next year, plans have been made cor converting the calculations to the 702 . Preliminary analys is is almost completed. 
Neetings were held during the month with representatives of the Experimental Meteorology group to define further the five-year weather processing program. Cost estlmates were supplied to the customer. Samples of reports have been supplied and approved. The raw data is presently awalting transcription to magnetic tape, and will be sequence-checked to assure its complete consistency. The programing of this problem involves the preparation of many printed tables, and the MOV-TO technique developed in connection with commercial programing will be used extensively for this purpose.

Key punching has been completed on the Engineering Department blueprint file. Proof listings of some 22,000 cards will be made in the near future, and submitted to the customer for correction.

Machine processing of the attitude survey being conducted by the Manufacturing Department has been completed. A total of 1,087 questionnaires, each containing 47 questions to which one of five responses was possible, were tabulated on the 702 in a little over hale an hour. Further work in connection with a statistical evaluation of the results is contemplated.

Calculation of exponential pile cell characterlstics was completed during the month. Quantities calculated included infinite reactivity, conversion ratio, metal coefricient, and themal utilization. Some 920 cases were considered. An error in problem formulation was detected early in the run, and corrected.

Planning work on the three-dimensional pile control problem is approximatiy $2 / 3$ conplete. Of the three passes required to generate coefficients in the expansion for the flux, two have been tested and the third programed. An iterative process is used to obtain the coefficlents; the magnitude of this process is indicated by the estimate of 40 minutes 702 time per iteration. Some seven hours will be required to complete each case, several of which are being considered.

Work on the tabulation of neutron collision density functions is continuing. Prograns for the generation of certain kernel functions have been written and tested. These functions will be used as input to the main calculation, which is presently belag being programmed. In addition, a new generating function, based on a cosinesquared flur distribution, is to be calculated. This function will receive the same treatment as the cosine function now being considered.

Extensive 702 runs have been made recently on the calculation of the neutron diffulion properties of several different slug designs. Parameters studied included cell dimensions, cell wetness, and fuel snrichment. The continuing interest of various groups in this particular calculation (a request was recently received for the calculation of 68 cases) makes it desirable to modify the program to allow easier preparation of case data. This will be done as time allows.

Worls will be started in the near future on the calculation of the resonance escape probability of a dry gizphite-uranium lattice. The calculation involves the numenical integration of fuel rod blackness over all the pertinent uranium resonancus, some 18 in all, for varlous rod dlameters and neutron temperatures. The blackness, in turn, will involve extensive look-up in a table of intractable integrals, and the evaluation of Bessel functions for very large arguments. A number of new techniques must be developed to keep the calculator running time within reason.

$$
I-27
$$


Additionsl work has been requested on the calculation of slug surface temperature under conditions of loss of coolant. Two cases bave been completed, corresponding to hypothetical conditions at C-reactor. Four additional cases are awaiting processing. The method of solution consists of numerically solving the diffusion equation over one space variable and time. An analytic solution of the same problem bas recently been obtained, and will be programmed and run to check the previously obtained results.

Work is continuing on the calculation of thermal stresses in fuel elements of several different types. One case has been programed and is now being tested.

Work is continuing on the study of process tube corrosion. Temperature maps from $D$-resctor have been key-puached, and similar maps from $B, F$ and $B$ reactors are now being key-punched. The calculation will be made in two passes on the 702 . In the flist, data from $D$ and $F$ reoctors will be processed to yield the doubling temperature, 1.e., the temperature cise which doubles the rate of corrosion, and calculated corrosion compared to corrosion accurately measured in selected tubes. With this basic inpormation, tube wall thicknesses f.n D, B, F and E reactors will be computed. Prograrming for the first pass is $90 \%$ complete. The results of this study will be used in implementing a tube replacement program.

The first production run on average corrosion temperatures was made during the montb. In this calculation, an attempt was made to correlate the average corrosion temperature with the bulk outlet temperature. In the future, temperature data for their calculation will be selected from that being processed under the tube wall thickness program. Due to different input format, some programing ehanges must be de in the present program.

A table of sine functions and assoclated quantities was prepared. The table will be used in spectroscopy work in the development of new instruments.

Testing of changes and additions to the floating decimal subroutine library has been completed. One new feature, the index registers, has proved highly valuable in reducing programing time, and in one Instance has saved over 1000 high speed memory positions required for instructions.

\section{COMPUTING OPERATIONS}

This month, for the Plist time, non-motating, fulltime operators were assigned to the 702 EDPM. In connection with this program, effort was made to increase the operating efflclency of the machine and also to pay IBM for the extra shift usage of the machine. The use of overtime employees to man and operate the machine beyond the day shift was discontinued insofar as was possible.

Work was continued on the project of plumbers and pipe fitters for the construction contracts. A preliminary report was prepared and released. A new version of this report, including corrections and revisions, will be published in January.

A number of special programs vere written to prepare year-end reports on exempt and non-exempt payroll inforrnation.

For the first time, the office machine repair and accountability reports were prepared on the 702. Also, the November reports were run on the 702 as an after-thefact parallel to the November punched card operation.

$$
I-28
$$


The programs were completed, tested and the montbly stores inventory reports were prepared on the 702 for the eirst time. These reports have been prepared in the past using punched-card equipment combined with manual operation. This month punchedcard operations were suspended.

A number of personnel from other organizations in the plant have been temporarily loaned or assigned to work with this section to receive programing training, and some of these have been sufficiently trained to be able to perform minor programing tasks, while others are still in the basic training atage.

This month, for the first time, the 702 utillzation and billing reports were prepared on the 702 EDPM. The programs were writt in and tested to edit the time cards for improper data and lack of continuity, as well as the preparation of the utilization, extra shift rental calculation, and customer billing reports.

The weekly payroll for the short week following Christmas was prepared satisfactorily and the checks were delivered to payroll in adequate time for convenient distribution.

Work continues on completing the testing of the programs for the processing of work order cost distribution on the 702. An effort was made to accomplish the conversion from punched cards to EDPM during the month of December. This effort failed. The most likely cause for the fallure is simply the shortage of manpower assigned to the project. This is a direct reflection of the severe shortage of manpower in this section which began about last September.

During the month of December, the following non-routine assignments were completed for cuistomers:

$\begin{array}{lr}\text { Employee and Public Relations } & 5 \\ \text { Engineering } & 12 \\ \text { Financial } & 18 \\ \text { Manufacturing } & 6 \\ \text { Operations Research } & 3 \\ \text { Radiological Sclences } & 1 \\ & 45\end{array}$




\section{PROPIGRIY ACCOUNTIABIIITYY UNIT}

The annual Fire Evaluation Report 1s required by AEC January 27, 1956. This report atffers from previous reports in that it is necessary to indicate replacement value on all plant and equipment included therein. The application of a cost index furnished by AEC will be applied to each year's acquisition of facility in determining replacement values.

Special report on cost of plant telephone system is being compiled for Telephone Sub-Section for use in connection with their study for submission to AEC. A.ll related costs of this system, such as buildings, motor vehicles, office furniture and equipment, and maintenance equipment is included in the report.

To reduce time at peak perlods of the month, several meetings were held regarding the accumulating, compliing and issuing of the Cost Report on Changes in Plant and Equipment. Costs which do not change from morth to month are being completed prior to months closings with an ultimate savings of several hours work which normally was required between monthly closingis and the deadline for issuance of the report.

A reconciliation of Freon refrigerated window type air anditioners was completed and all of these items placed under the controi and iustody of office Equipment and transfer to Office Equipment account sompletsd.

Plans for inventory of uninstalled equifment utilized by to iephene Sub Sectior, including radio equipment, were fomalized and soheduled 5 start early in Jamuary. An inventory of 300 Area Metal Preparation Section uninstalied equip ment was started during the month and was 20 percent rrmpirted.

\section{CAPITALTZATION AND DEPRECIATION UNIT}

A study is being made to determine the most feasible methed on methols to be used in distributing indirest constmption cosss ineurred in nonnopton with construction projects. We are anelyring the proredures invive $i$ and the efi-

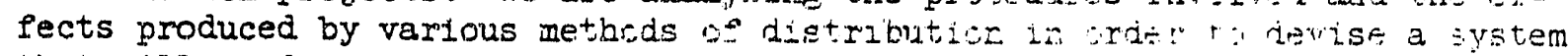
that will produce acceptable results from the standprant the propenty custodian, as well as for accounting purposes. This anaiy:s 5 ichld be com cluded during February.

A complete system of plant accounts has bean destop: or jupwase the one

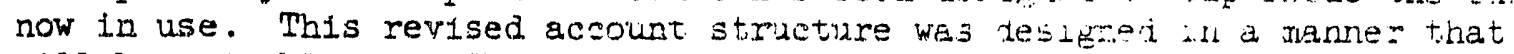

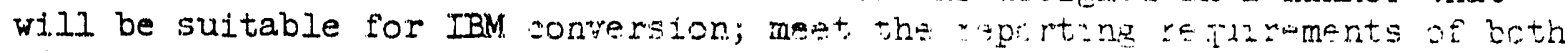
GE and AEC; provide a consistert depreazation base; and protude many of the classification problems that now exist. Whis revisiar it re incorpreated in our operating procedure shorily.

During the month of December a series of meetings was reid with Procedures and Computing personnel for the purpcse of evaluating gur present method of Comnodity Code Classification. As a resilt of these meetings, it was agreed tiat our current system is satiafantory, prowide 1 is in is istily applied,

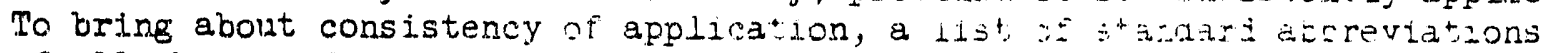

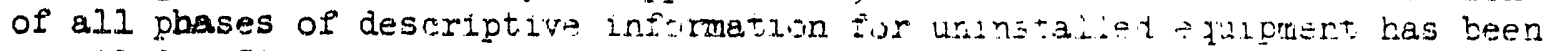
compiled. Standard abbreviations have been applied - mirhiat tosis and a revised coding key has been issided.

$$
I=30
$$




\section{CAPITALTZATION AXD DEPRECIATION UNII: (Continued)}

A summary of Plant and Equipment (by Production, Research, Community, Medical, and General Facilities) was completed for the General Managers Meeting at the request of W. H. Chamberlain. This covers the perlod December 3I, 1946 through December 31, 1957 by calendar years and includes an analysis of the major increases in each year.

\section{ITVERMPRY ACCOUNMIIIG UNIT}

The anmal physical inventory of motor vebicle and heavy mobile and construction equipment parts in the custody of Stores Subsestion, Manufacturing Department, was conducted on December 14 and 15, 1955. The reconciliation of physical to book value is in progress and a report covering results will be issued upon completion.

The physical inventory of pile grade graphite in the custody of Stores Sub Section was taken on December 27, 1955. Graphite is booked in the Special Materials inventory account but was exsluded when the other special materialz were physically inventorled in August. An astual phys was not made since $1 t$ was not considered desirable to move the material. Instead, the volume and welght was calculated by the Fisld Survey Unit, Englneering Department. Test checking of indrilual pallets of materiai was made by Inventory Accounting. Reconciliation of the survey to brok value is in progress and a report covering results will be issued upen soxplet.ton.

The annual physical inventory of road materials tra the custody of Transportation Section and Communtity Section was taken on De sember 29, 1955. Resonciiiation of physical to book value is in progres:s and a meport noveriag resizts will be is sued upon completion.

The physical count of stantity oxterials origneliy shedulad t.p be made on November 30 , 1955, but postponed zesaisas af aduerse veather crnditians was th romplished on Decomber 14. A repont novering rosuiss wili be inciuded with that for spare parts upon exmpleticn.

Preparatory work to effect gee transter of zffina machine rapair parts cos held

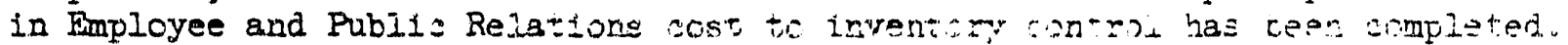
A caption has been estabistaed in gonera. euppizes infantory, ffoctive january 1. 1956, to refiect future activity cf this ma:eriai.

A meeting was held at the request of Auxiliary Operations and Plan: Protertisn Section personnel to disouss the advisability of pigcing bilik sulphura arid used at the 700 Area steam piant inder inventory controi. The a:li la a: prosent being purchased on a direct charge basis

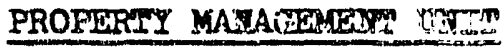

A major effort is Invilved in the disposition of the equipment and materials to be renoved under projects $C G-558$ and $c c^{-} 600$. Several milition doliars worth of property is involved. One item, for example, is approximately 200 pumps, motors and associated equipment such as cortrol panels whith will be moving into exsess. Disassembled somponents must be properiy marked hetore leavang ins tield and must be properiy identified ana stored apon axrire if toe saits yard. Large

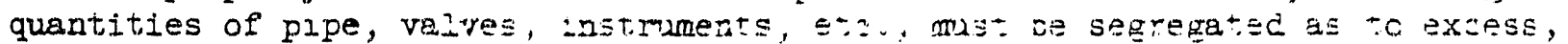

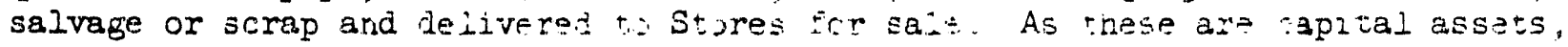
the equipment must also be idfntified and seatred fron the rapital ascounts. The Property Management Urit is acrilcating the Fidrang far ine order?y

$$
I-3 i
$$




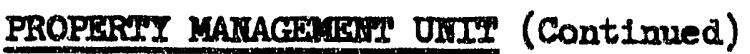

disposition of this property. A muber of meetings and field inspection trips have been held with interested activities. Contact engineers of the Reactor Section are preparing master control lists of itens to be removed. These lists will be given to the property control custodians who will prepare the necessary disposal documents. They will also be used by the Property Accountability Unit to scope the dollar value of the assets to be removed from the books. PreIiminary classification of the pxoperty as excess, salvage or scrap has been made by the Property Management Unit. Stores is preparing necessary storage areas to receive the property pending sale. Representatives of the Commission are currently screening other govermment agencies in advance of the removal of the major items to determine possible need for same in an attempt to minimize storage problems. The dollar value of the excess accounts can be expected to climb sharply as the full volume of this property begins to flow into the sales yard.

At the request of AEC the status of the emergency "Five Mile Transmission Iine" in standby Inventory was reviewed jointly by AEC Property Management, GS Property Management and the Electrical Utility Section. The re bas been some confusion as to the exact status of this inventory; specifically, as to the amount of equipment to be carried, the count of equipment surrentily on hand and whether the equipment was avallable for normal requirements on a five mile moximum and two mile minimum basis. Subsequent to this review AEC has requested by letter that:

a) The Electrical Utility Section review and establish Stock Adjustment Requests (SAR's) for this line on a five mile maximum and no minimum bssis. This would normaliy insure the tull fitre miles of line being avaliable in an emergency.

b) That items in this inventory subject to deterforation, such as wooden arms and poles, be periodicaily used to reet, routine requirements and replaced.

c) That any other withdrawals be subject to AEC authorization.

Twenty-seven appropriation requests totaling $\$ 5,60$, 990 were investigated and processed during the month. A precision spestrophotometer was located on site to $f 117$ a requirement to the Radiclogieal Sciences Department. A request for a trailer van was filled from equipment being held for the 2101 graphite facllity. A request for radiation instruments was withdrawn when a majority of the required instruments were located on the plant-site. A compressor was located for loan to Purex for elght months. Sevaral heaters were located to facilitate coal handling and water treatment in the 130 Areas. A turret lathe was located from AEC excess to Pill an appropriation request requirement.

Elghty-five requests for the disposel of property were investigated during the month and disposition instructions issued. It is of interest to note that during the current calendar year 1234 requests for the disposal of property have been processed compared with 794 requests for the prior year. 


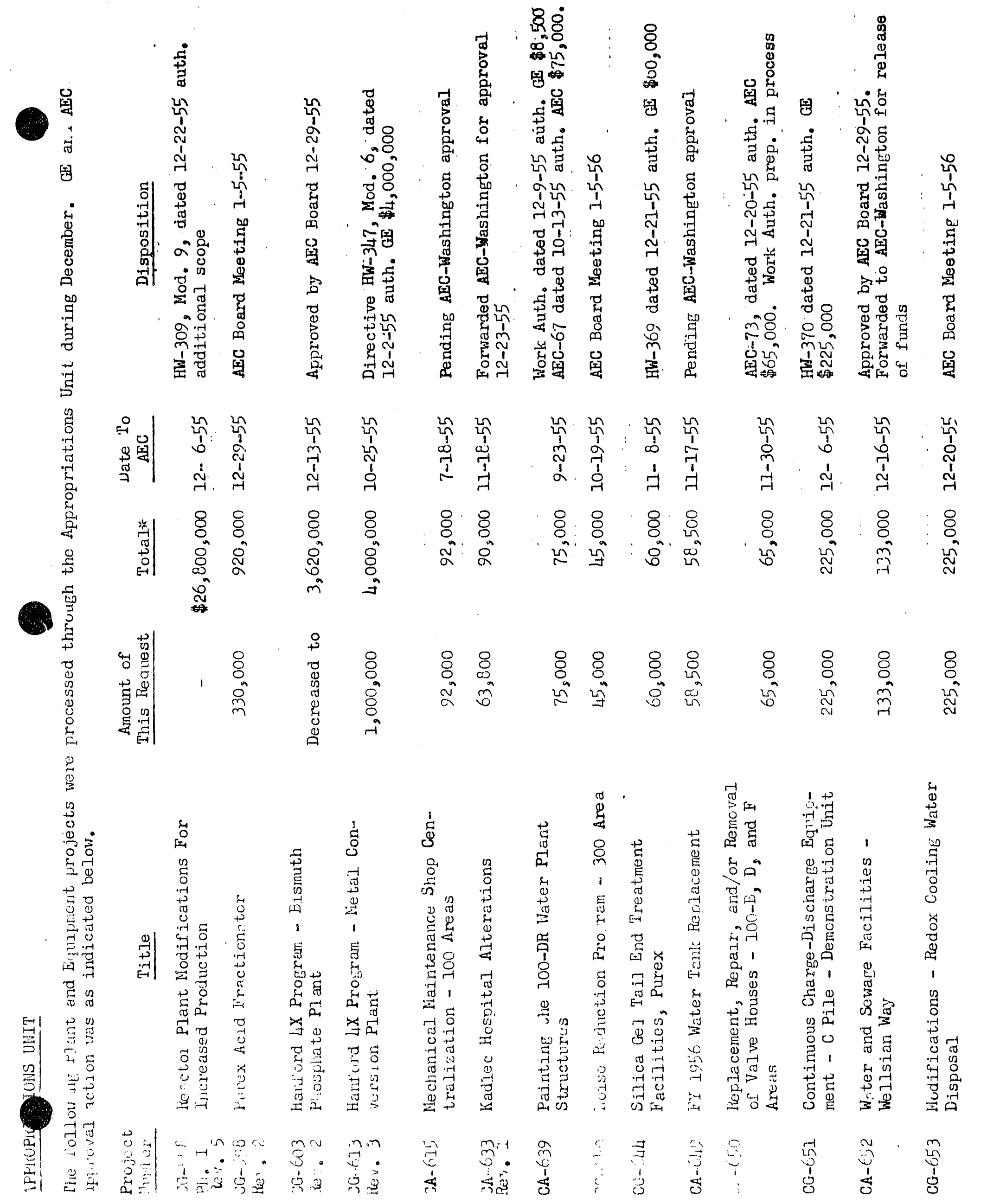


○

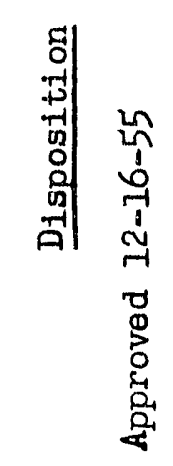

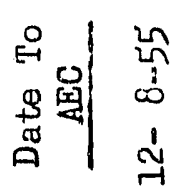

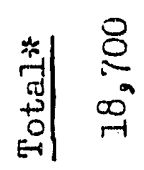

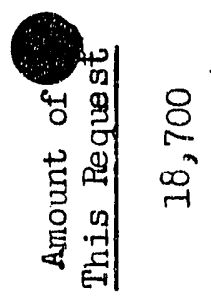

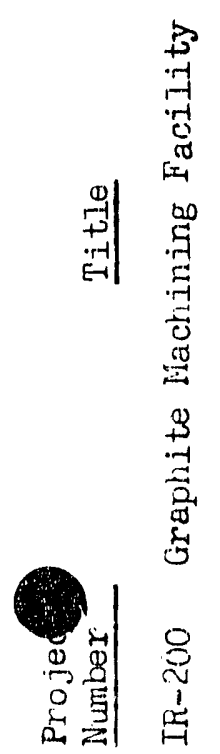


SS ACCOOMTABILTHY SECTION

MOWHELY REPOAT - DECAMARR, 1955

\section{Sumary}

Totice of A. B.C. Survey \#13 was recelved on December 8, 1955 covering the calendar year 1956. Th1s program will 1nclude the veriflcation of BAPO holdings by SS material type. A portion of this progran is achedulded for the end of January, 1956 and at three month latervis for the balance of the year.

At the request of the USAEC-Hanford Operations OPfice, several A.E.C. and Vitro Manufacturlag Company repredentatives vere conducted on a tour through the Separstion Section Plant. Accountablilty procedures were reviewed in detail. Vitro holds an A.E.C. contract for the desigr of Reactor-Separations-Fabrication Plant complexes for use in foreign countries. One of the design objectives is the incorporation of ss Accountablifty controls for the purpose of reducing the possibility of diversion. The purpose of the HAPO visit was to obtain background information on SS Accountability procedures at this site.

\section{Metal Preparation Area}

The major portion of the activities of this Unit were involved in activities which If specified, constituta classifled information. We have therefore directed our report to the types of activities rather than to the details for purposes of declassification.

\section{Inventory Reduction}

Due to change in production schedule an opporiunity for reduction in inventory holdings has developed. This Unit has directed its attention to the collection of data necesiary to complete the preparations for off-plant shipment at the earliest posible time. Specific contacts were made with the Engineering Department for the returi to Operations of the maximum portion of their holdings so that this material could be included in the shipwent. We have also contacted the Hanford Operations Office and they have agreed to make preliminary contacts for the purpose of developing a Receiver. Present jndications are that complete liauidation of holdings can be affected This applies to cnir spacitis material type.

2. During December we completed the statistical review of the factor welght for bare slugs and as a result the value in use will be reduced $0.01 \mathrm{Lb} / \mathrm{s} I u g$. The effect $w 11$ be to reduce the Material Underaccounted for as a function of throughput. No thange in the weight of accepted slugs-canned for transfer purposes to the Reactors is contemplated at the present time.

3. As the result of a request frow the USAEC-Hanford Operations Office, we are reviewing our method of determining "J" Slug shipping weights as reject returns to the fabrlcator. Preliminary reports indicate a substartial shipper-Variance.

4. A substantial reduction in the various types of corec slugs has been achieved thereby providi.1g a substantial reduction in account control. mils resulted from decisions by the Engineering Department which has been in the process of elaluating a large nurber of alternate forms. 
SS ACCOUNTABIIITY SECTION

MONTELY REPORT -DECEMER, 1955

\section{Reactor Area - SS Accountability UnIt}

During the course of A.I.C. Survey \#12, discrepancies developed between the observed physical inventories and the records of the SS Accountability Section. We were able to reconcile these differences by the establishment of errors of omisision in the custodians' inventories and were able to obtain corrected inventories from the custodians. Our ansiysis of the errors shows that the use of a location chart would bave prevented this situation which applied to more than one area.

He are currentl.y reviewing the custodian's problem and will make specific recommendations for improvewent in the present physical inventory proceuiures which are inadequate on the basis of current performance.

Up-to-the-present-time the deadilas date for reports fom pleld units has been the seventb working day of the new month. As a resilt of demonstrated abjlity to exceed these requirements the Unit is now reporting no later than the sixth working
day.

One of the recurring problems has been the question of hold-up under chute liners with the result we established special control accounts for this problem. The accounts are capable of verlfication at the time of liner repeir at which time recovery is affected. The chute liner in $D$ Reactor basin is now undergoing repair and it will be possible to adjust on the basis of recovery and also to establish a firm beginning inventory for this area.

Separations Area - SS Accountability Unit

\section{Sepcial Depleted "iranium}

Cold mase of this material continued in Purex. Waste losses have been very satisfactory and at least equal to Flow Chart values. The program has now continued to the point where the use of this material in preference to Norma Uianium shows a substantial saving. Final values wiil not be avaliable until January at the completion of the cold rins.

T Plant completed operations as of 12-31-55. A series of special runs will be made in which product will be incidental to the operation. A of i:-j-55, routine operation ceased.

Recuplex operations have now become routine. Of partioular intersst to the SS Accountability control problem is the al: important lact that the throughput exceeds the rate of generation.

Redox operation was intermpted for scheduled maintenano. In ant:cipation of the shutiown a substantial throughput was achieved. The shutdown was of particular interest to the SS Accountability control problem for Depleted Uranium in that it provides an opportunity to verify physical inventory value at the time of clean out. The results are not yet available but will provide a conclusive answer to the question of Redox contribution to the $\mathrm{UO}_{3}-\mathrm{MUF}$ problem.

Application of the SS Accounting Unit's Review recommendationi have been completed for Redox. A follow-up by the SS Accounting Unt is scheduief for February. Further activity in the fleld of Review recomendation applications have been conducted in the Isolation Blag., particularly, with respect to inventory reconciliation problews.

$$
I-36
$$


SS ACCOETMABIIITY SECTION

MONHELI REPORT-DECGETRER, 1955

Separations AreB - SS Accountability UnIt - cont'd.

We have completed an extensive review of the classification of all documents, lecie:s and reports. In addition to the review, we have taken all necessary action to cumply with the numerous Security requirements. Instructions have been issued to all clerical personnel covering security controls and have been explained and discussed in round trable weetings.

\section{SS Accounting Unit}

This Unt devoted considerable epfort to the review of the reconcliliation problems which developed during A.E.C. Surrey \#12 due to inventory omisalons by the custodians. As a result of the recomendations made by this unit, we were able to eliminate the problem.

A second review of the reports submitted by the field units for consolidation purpoaes shows a substantial iuprorement both as to subwission date of reports and with respect to accuracy. Current evaluation of the Monthly Consolidated Materia: Balance Report is bighly satisfactory.

In conjunction with the assignments to the SS Accounting Unit as described in the Section "Program - Organization and Integration," plan the scheduile Por" 1955 was melntained in satisfactory manner. A Plan for 1956 has been drawn up and aubmitted for review.

\section{SS Measurements Unit}

Extensive invesigation is being made into the depleted uranium MUF. To date, however only minor error has been disclosed. The intentories appear substantialiy correct, and analytical recoveries have not onanged signifloantiy. We have found a very high lacidence $\sigma_{i}^{-}$TBP Peed batches in October and partisulariy November whach contained solids whlle in 005-WR (the recelving tank just ahead of 004-WR the sampling tank). This may be assosiated wth a high bias in the ool samples, but there is no means of proving it one way or the other. A report HW -40534 bas been issued.

Purex eading lnventory, consisting entirei.y of highly deplet,ed uranium, was in.vestigated and its precislon estimated.

Purex has completed a study demonstrating that they can obtain reprisentative samples from their dissolver soiution tank.

The Purex Inventory Manual in rough draft is now $95 \%$ compiete.

Plutonlum MUF's for November were generally in good control. The only major discrepancy occurred across the Recuplex dissolvers in which the recoveries were only $60 \%$ of the book value of the charges. The entire production was in powders and sweepings which were at estimated vaiues.

A new system for control limit calculations which hiaj besn under development for several months is now in use. It has eliminated a posting step. simplified and standardized the a:tual calculations, and has improved and speeded up the date required from the SS Separations Unit. It is resulting in a substential savings in clerical time (est. 3 days per month), has eiminated a security probiem by

$$
\text { I }-37
$$


SS ACCOUTILABIITIYY SECPTON

MONYHLY REPOER - DECBYYIER, 1955

SS Measurements Unit - continued

eliminating the need for rough draft worksheets, and will a.ow earlier publication of the monthly control report. The system was suggested and developed by $R$. W. Doerr.

Our recondsendation that L-16 Tank (Redox) be moved into the extraction material bajance area was adopted. This change will simplify procedures and make some savings in sampling and andytical costs.

Accountablity procedures for the Radiological Sciences Department is completed. These procedures have been submitted to them for their concurrence. 
Personnel Changes During Month

Eingloyees at beginning of month

Additions and transfers in

Removals and transfers out

Employees at end of month

Current Prior

Mor th Month

Personnel by Unit at Month-Find

General

Auditing Section

$499 \quad 493$

$7 \quad 17$

$\frac{(4)}{502} \quad \frac{(17)}{499}$

Budgets and Measurements Section

$10 \quad 10$

$16 \quad 16$

$15 \quad 15$

Contract Cost Section

General and Consolidations Cost Unit

$17 \quad 11$

Ingineering Cost Unit

General

Design Cost

Project Cost

Techrical Cost

Employee and Public Relations Cost Unit General

Plant Activities Cost

Community Cost

Medical Cost

Manufacturing Cost

General

Financial Representatives

Budgets and Control

Reports and Records

Analysis and Studies

$\begin{array}{ll}3 & 3 \\ 9 & 9\end{array}$

$21 \quad 21$

11 II

22

$10 \quad 10$

$\begin{array}{ll}5 & 4\end{array}$

33

$2 \quad 2$

$13 \quad 23$

$18 \quad 28$

$16 \quad 3.5$

$\frac{4}{128} \quad \frac{4}{126}$

General Accounting Section

Accounts Payable Unit

Accounts Receivable Unit

General Books Unit

Administrative Planning

Contract Fleambursements

\begin{tabular}{rr}
24 & 24 \\
21 & 21 \\
16 & 17 \\
3 & 3 \\
6 & 6 \\
\hline 70 & 71 \\
\hline
\end{tabular}




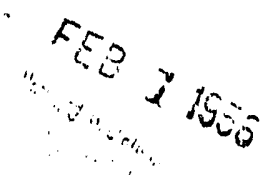

\begin{tabular}{|c|c|c|}
\hline & $\begin{array}{l}\text { Current } \\
\text { Month }\end{array}$ & $\begin{array}{l}\text { Prior } \\
\text { Month } \\
\end{array}$ \\
\hline $\begin{array}{l}\text { Personnel Accounting Section } \\
\text { Payroll Planning and Analysis Unit } \\
\text { Weekly Payroll Unit } \\
\text { Monthly Payroll Unit } \\
\text { Benefit Plans Accounting Unit } \\
\text { Payroll Reports Unit } \\
\text { Weekly Payroll Records Unit }\end{array}$ & $\begin{array}{r}7 \\
17 \\
12 \\
13 \\
8 \\
-7 \\
6\end{array}$ & $\begin{array}{r}6 \\
18 \\
12 \\
13 \\
7 \\
8 \\
64\end{array}$ \\
\hline $\begin{array}{l}\text { Procecures and Computing Section } \\
\text { Camputing Operations Unit } \\
\text { Numerical Analysis Unit } \\
\text { Procedural Analysis Unit } \\
\text { Scheculing Unit } \\
\text { Records Unit }\end{array}$ & $\begin{array}{r}25 \\
10 \\
\frac{114}{24} \\
8 \\
81 \\
\end{array}$ & $\begin{array}{r}24 \\
9 \\
25 \\
24 \\
8 \\
80 \\
\end{array}$ \\
\hline $\begin{array}{l}\text { Property Accounting Section } \\
\text { Appropriations Unit } \\
\text { Inventory Accounting Unit } \\
\text { Property Accountability Unit } \\
\text { Property Management Unit } \\
\text { Capitalization and Depreciation Unit }\end{array}$ & $\begin{array}{r}5 \\
12 \\
28 \\
4 \\
21 \\
70 \\
\end{array}$ & $\begin{array}{r}5 \\
12 \\
28 \\
4 \\
-21 \\
-70 \\
\end{array}$ \\
\hline $\begin{array}{l}\text { SS Accountability Section } \\
\text { Reacto Area - SS Accountability Unit } \\
\text { Separations Area - SS Accountability Unit } \\
\text { Metal Preparation Area - SS Accountability } \\
\text { Unit } \\
\text { SS Accounting Unit } \\
\text { SS Measurements Unit }\end{array}$ & $\begin{array}{r}4 \\
20 \\
8 \\
7 \\
7 \\
16\end{array}$ & $\begin{array}{r}7 \\
7 \\
8 \\
45\end{array}$ \\
\hline Rotational Trainees & $\frac{2}{502}$ & $\frac{2}{499}$ \\
\hline
\end{tabular}



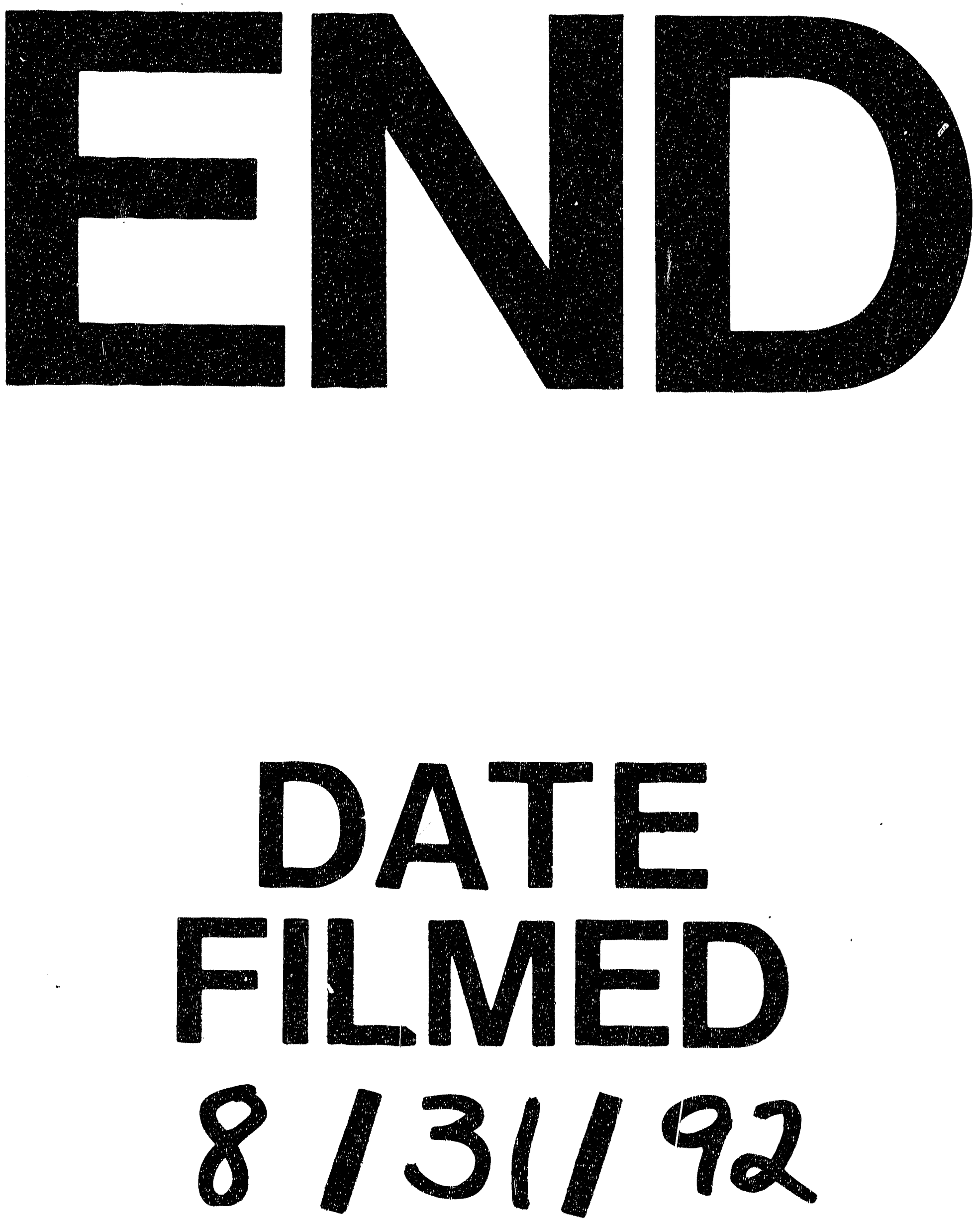
